\title{
Guide to the Materials for United States History in Canadian Archives
}

\author{
BY \\ DAVID W. PARKER
}

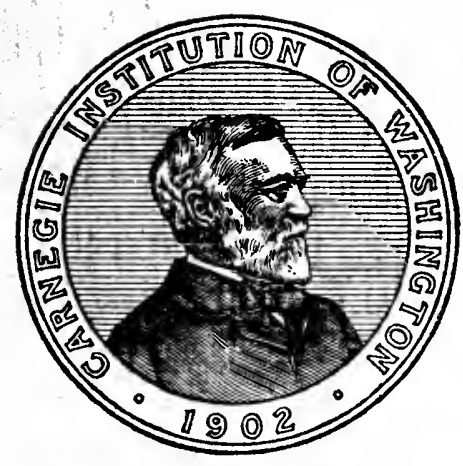

WASHINGTON, D. C.

Published by the Carnegie Institution of Washington 1913 
CNIIFRSITY OF PITTSBLRGH

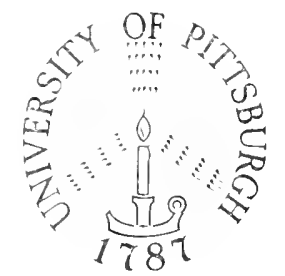

I. I B R A R Y 


. 



\title{
Guide to the Materials for United States History in Canadian Archives
}

\author{
$B Y$ \\ DAVID W. PARKER
}

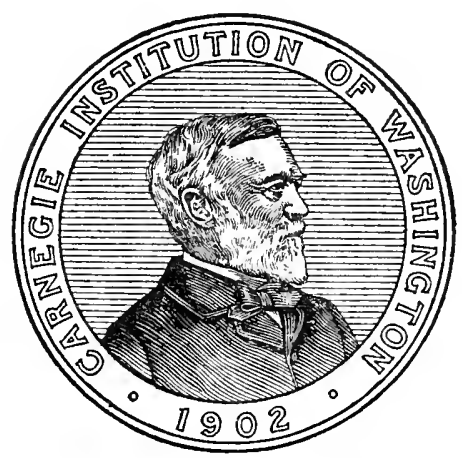

WASHINGTON, D. C.

Published by the Carnegie Institution of Washington 
CARNEGIE INSTITUTION OF WASHINGTON

Publication No. 172

Papers of the Department of Historical Research

J. Franklin Jameson, Editor

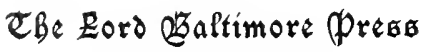

B.LTIMORE, MD., ర. S. A. 


\section{PREFACE.}

This volume is part of a series by means of which the Department of Historical Research in the Carnegie Institution of Washington is endeavoring to make better known to those who work in American history the materials for that history which are preserved in foreign archives. Guides to the materials in the archives of England, Spain, Italy, and Germany have already been published, a volume for Mexican archives is about to appear, and volumes for France and other countries will follow. The constant relations between Canada and the English colonies, or the United States, during two centuries of conflict and a hundred years of peace, across the longest international line, save one, that the world has ever known, have made it inevitable that the archives of Canada should abound in documents useful, and sometimes highly important, to the history of the United States. Probably few American students suspect the extent of that abundance. It is especially difficult to appreciate in the case of the Public Archives of Canada at Ottawa. That wonderful collection has increased by leaps and bounds, and few persons, even in Canada, are fully aware of the rich claims it has to their pride and admiration. In the effort to make its treasures better known to students one is inevitably hampered by this very rapidity of growth. Fresh accessions will quickly make one's manual out-of-date ; but the present need must nevertheless be met.

A large part of the Archives of the Dominion consists of transcripts from London and Paris. The originals of these transcripts are, it is true, dealt with in the books on London and Paris archives which Professor Andrews and Mr. Leland have been preparing for the Carnegie Institution of Washington. But Ottawa is nearer than London, and many an American student will find it most practicable to pursue his researches in Ottawa, aided by the calendars published by the Dominion Archives and by the present work, which in respect to the series of transcripts is framed to be the complement of the official calendars. The student finds excellent facilities given him at Ottawa, with the most appreciative liberality. It is also well worthy of note that the Archive establishment possesses a photostat, by means of which copies of its documents, which are mostly in modern and legible handwriting, can be readily and cheaply obtained.

The chief author of this book, Mr. David W. Parker, now on the staff of the Dominion Archives, spent eight months, in I9Io and I9I I, at Ottawa in the service of the Carnegie Institution of Washington, preparing the sections, on the Ottawa collections, which fill the major portion of the book. Subsequently he also prepared, by personal investigations at Halifax, Fredericton, and Toronto, the sections relative to the archives of Nova Scotia, New Bruns- 
wick, and Ontario, though in the latter case local conditions, resulting from a fire at the Parliament buildings and from the processes of reconstruction, made it impossible to present more than a sketch. A careful examination of Dr. Hannay's report to the Dominion Archivist on the archives of Prince Edward Island, in the volume at the Archives designated as M 580 (see p. I45), showed that the archives of that province contained no materials for United States history to warrant a visit to Charlottetown.

At Quebec the archives of the archbishopric were carefully examined in the summer of I9I I by the Reverend Professor Frederick J. Zwierlein, Ph. D., of St. Bernard's Seminary, Rochester, N. Y. But, for the section devoted to those archives, we are also indebted, in the very highest degree, to the kind assistance rendered by their custodian, Abbé Lionel St. George Lindsay. The civil archives of the province of Quebec, which Professor Zwierlein was unable to examine at the time of his visit, were searched in October, 1912, by Mr. Waldo G. Leland, of the staff of this department. The information presented respecting Morttreal is due to the kindness of Professor Charles E. Fryer, of McGill University.

For reports upon the archives of the provinces to the westward, not as a rule abundant in materials for United States history, it has been necessary to rely upon the kindness of local authorities. In the case of Manitoba, the information presented has been supplied by Mr. J. P. Robertson, Provincial Librarian at Winnipeg; in that of Alberta, by Miss Katherine Hughes of Edmonton; in that of Saskatchewan, by Mr. John A. Reid, Deputy Provincial Treasurer at Regina. The archives of British Columbia, more abundant for the purposes of this book, are not yet in condition for examination; the statement respecting them has been prepared by Mr. Leland, from such materials as were available at a distance. To the accounts respecting archives in the Dominion of Canada the kindness of Mr. G. F. R. Prowse of St. John's has enabled us to add a descriptive list of what the archives of the ancient colony of Newfoundland contain for the history of the United States.

Cordial thanks for their aid are tendered to all those who have been named; to the Right Honorable Sir Wilfrid Laurier, premier of Canada at the time when the preparation of this volume was begun, to several members of his ministry, and to Dr. Martin J. Griffin, C. M. G., Parliamentary Librarian at Ottawa; to His Grace the Archbishop of Quebec; to Harry Piers, Esquire, Deputy Keeper of Public Records in Nova Scotia; to the Provincial Secretary of Quebec and to Messieurs Eudore Evanturel and Philéas Gagnon, archivists to that government ; to Professor C. W. Alvord ; to Alexander Fraser, Esquire, Provincial Archivist of Ontario ; and to Dr. George H. Locke, chief librarian of the Toronto Public Library. But our chief expressions of gratitude are to be made to the Archivist of the Dominion of Canada, Dr. Arthur G. Doughty, C. M. G., whose encouragement and goodwill have attended the undertaking 
from its beginning, and who has rendered generous aid at every stage in the exploring of the great collection at Ottawa, so largely his creation.

The use of the noun American in the specific sense of an inhabitant of the United States, and of the adjective American in a corresponding sense, is open to obvious objections, which will be keenly felt by an "American " editor in proportion as he appreciates the greatness of the Canadian nation. But such a book so constantly requires the use either of these words, or of awkward circumlocutions, that no reader, it is hoped, will see in such employment of the terms anything savoring of arrogance or provincialism.

Delays incident to the treatment of the local archives have caused so much time to elapse since the preparation of Mr. Parker's account of the Dominion Archives, that a supplementary statement, intended to cover the main changes and accessions which have since occurred, has been drawn up by him and is inserted after the Table of Contents.

Washington, August 28, 1913. 



\section{TABLE OF CONTENTS.}

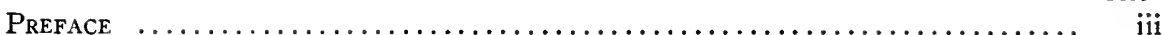

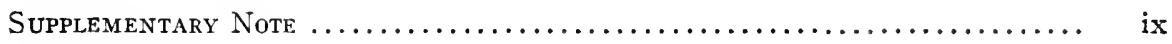

INTRODUCTION $\ldots \ldots \ldots \ldots \ldots \ldots \ldots \ldots \ldots \ldots \ldots \ldots \ldots \ldots \ldots \ldots \ldots \ldots \ldots \ldots \ldots$

Archives of the Dominion of Canada:

Series A: The Bouquet Collection $\ldots \ldots \ldots \ldots \ldots \ldots \ldots \ldots \ldots \ldots \ldots$ Io

Series B: The Haldimand Collection $\ldots \ldots \ldots \ldots \ldots \ldots \ldots \ldots \ldots \ldots \ldots \ldots$ I2

Series C: Military Papers ............................ I4

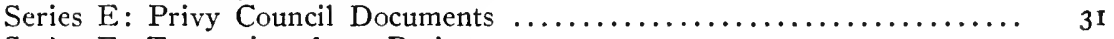

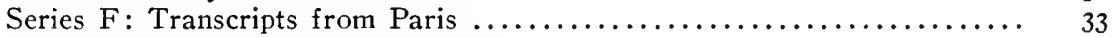

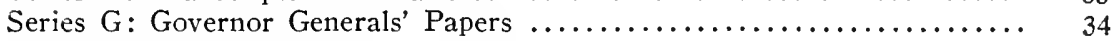

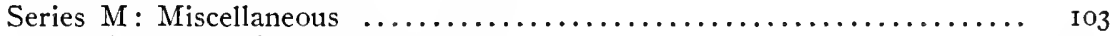

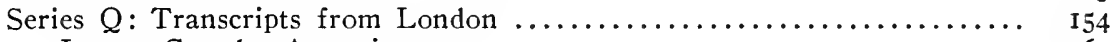

Lower Canada, Accessions ........................... I6o

Upper Canada, Accessions ......................... I66

Red Volumes of Despatches ....................... 174

Series S: Secretary of State's Papers ..................... I75

Miscellaneous Collections ............................ I 80

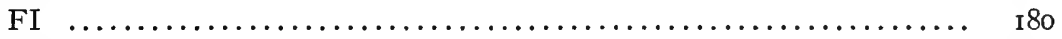

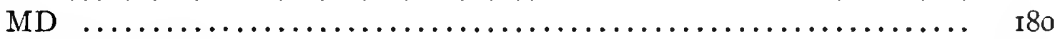

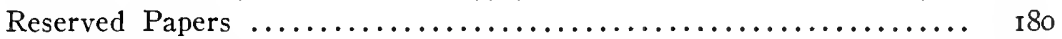

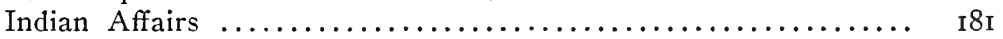

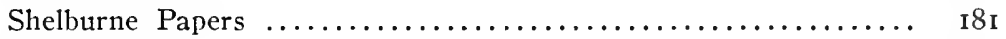

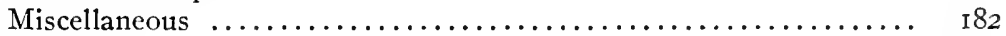

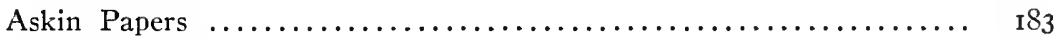

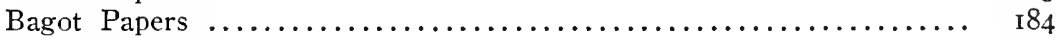

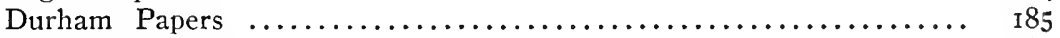

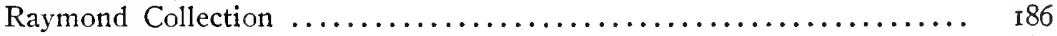

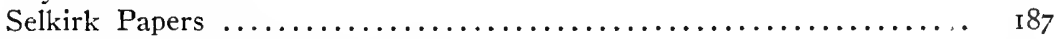

Department of the Secretary of State $\ldots \ldots \ldots \ldots \ldots \ldots \ldots \ldots \ldots \ldots \ldots$

Department of Indian Affairs .......................... I89

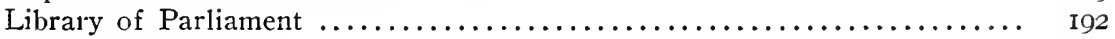

Archives of the Provinces . . . . . . . . . . . . . . . . . . . . . . 193

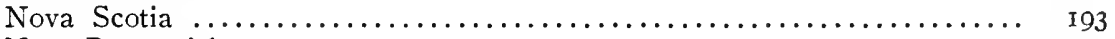

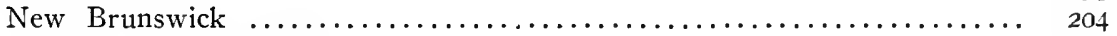

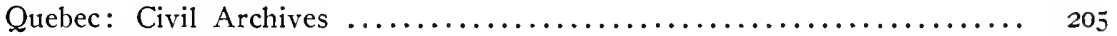

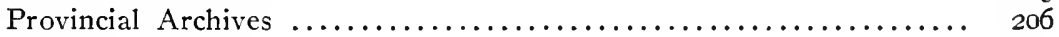

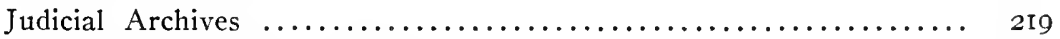

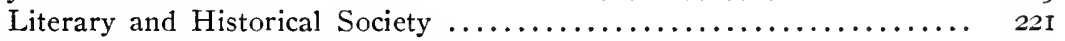

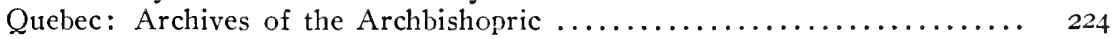

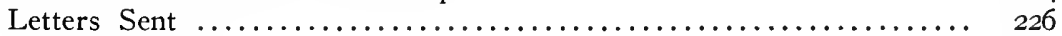

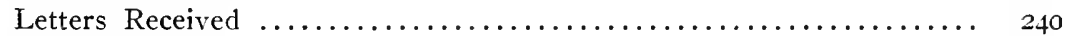

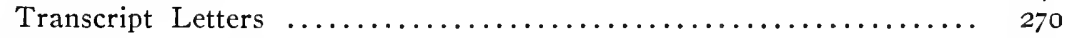

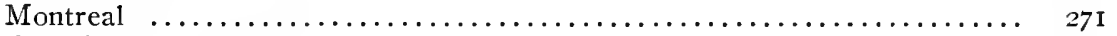

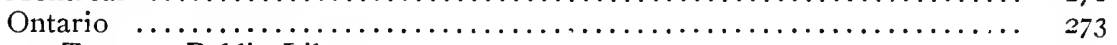

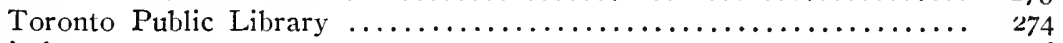

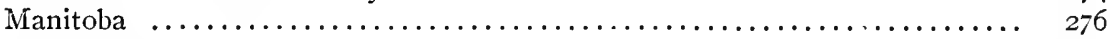

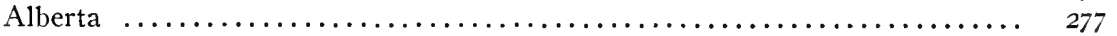

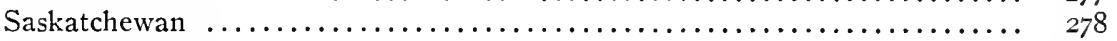

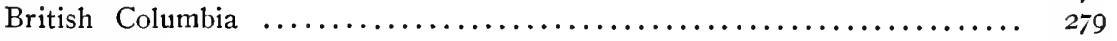

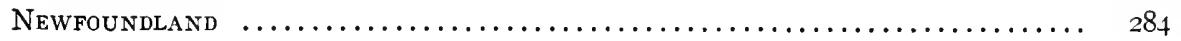





\section{SUPPLEMENTARY NOTE.}

\section{IMPORTANT ACCESSIONS TO THE DOMINION ARCHIVES.}

Howe Papers. This collection, which comprises both official and private papers of Joseph Howe ( I804-1873), was recently received from Mr. Sydenham Howe. It has not yet been arranged. Material for United States history falls into three groups. The first relates to the Fisheries Commission under the reciprocity treaty of 1854 , comprising several bundles and a few books containing correspondence of Mr. Perley, the British commissioner, and of Mr. Howe, his successor. These records cover the years I855-I866. Two large portfolios are filled with letters, accounts, and miscellaneous papers regarding the part taken by Howe in the cause cćlćbre of the Foreign Legion, I $855-1856$. One small portfolio of newspapers, pamphlets, and manuscripts deals with the Detroit Convention of 1865 .

With the above may also be classed the Johnson Papers. These contain many papers of Joseph Howe, which were loaned to Mr. George Johnson for the purpose of writing a biography of Howe. They relate to the same topics as the Howe Papers, and when arranged will probably be united with the latter.

Inglis Papers. Correspondence, journals, etc., of the Right Rev. Charles Inglis, D. D., rector of Trinity Church, New York, during the Revolution, and subsequently the first bishop of Nova Scotia. This collection at present consists of four volumes and three portfolios, copied from the originals in the possession of Archdeacon Armitage, Halifax, Nova Scotia. Only the first volume relates to the United States. This is a diary covering the period I776I79I, which details, often with comments, various events of the Revolution. The year 1782 is the last for which there are any items relating to American history.

Dubois Collection. This large collection, recently purchased from Abbé Nazaire Dubois, principal of the Jacques Cartier Normal School, Montreal, has not yet been inventoried. It contains a considerable number of papers of Lieutenant-Colonel Charles de Salaberry, many of which deal with the War of $\mathrm{i} 8 \mathrm{r} 2$.

Lawrence Collection. This mass of note books and original manuscripts was recently purchased from Mr. J. W. Lawrence, of St. John, New Brunswick. Loose papers have been placed in portfolios just as received, and will require further arrangement. A general description of the material bearing upon United States history, however, can be afforded at present. Seven portfolios are largely filled with original correspondence, drafts, reports, memoranda, books of field surveys in I796-I797, etc., relating to the Northeast Boundary. This material of course centres about the commissions appointed under the treaties of 1794 and 1814 . It ranges from I796 to about 1843 . A few separate sheets containing statistics of imports and exports of New Brunswick, I8I5-182r, and a letter-book of the collector and the comptroller of customs, Prince Edward Island, I789-I809, have some items on trade relations with the United States.

Foreign Office Miscellaneous, volume 511. Letters of Oswald, Strachey, Shelburne, Townshend, and miscellaneous diplomatic correspondence and papers, relating to the treaty negotiations of $\mathrm{I} 782-\mathrm{I} 783$. (Copy.) 
Shelburne. Copies of selected documents in volumes 66-69, inclusive, of the Shelburne manuscripts. These deal partly with military affairs at New York, the Revolution in general, and Loyalists. I $764-1783$. See the appendix to the fifth Report of the English Historical Manuscripts Commission, pp. 232-239.

History of the Society of Jesus in New France, book xiII., part vi., by Father Jogues. Occasionally refers to missions among tribes within the present limits of the United States. I6I6-I642. (In Latin. Copied from the original manuscript at Munich.) 255 pp. 


\section{INTRODUCTION.}

\section{HISTORY OF THE DOMINION ARCHIVES. ${ }^{3}$}

During the period of French rule in Canada there was no centralization of the various classes of public records. Governor, intendant, and bishop, the three chief functionaries in the colony, each had his respective archives. The religious orders had records of their own, while each clerk and notary was usually in charge of the documents the compilation of which was the chief aim of his official existence. In I73 I we find the intendant Hocquart writing to France as follows:

It has frequently been represented to me since my arrival in Canada, that the minutes of the notarial deeds, the registers of the Superior Council and of the Prévosté are exposed to risk from fire in the private houses of the clerks, where such minutes and registers are now deposited, and that the titles of all individuals in this colony might be destroyed. These representations appeared to me, my Lord, so important that I thought it my duty to acquaint you with them, and to propose to you, for the sake of public security, to have a fireproof building erected to contain all papers.

The estimate of the cost of erecting such a building proved larger than one would expect, and the recommendation does not seem to have yielded any positive result.

When the colony was conquered by the English due precautions were taken to retain in Canada all documents necessary for the government of the country. No less than seven articles of the capitulation of Montreal relate to the public archives. No mention was made of the papers of the religious bodies, which of course kept their records as before.

During the first generation of British rule a slight movement toward centralization became noticeable, and a few steps were taken to make public records more accessible. Among the several committees of investigation appointed by Lord Dorchester was one on the state of the archives of Quebec. ${ }^{3}$

${ }^{1}$ This brief account of the history of the archives is based largely upon the annual Canadian Archives Reports. It may readily be traced in considerable detail in the volume entitled Index to Reports of Canadian Archives from I872 to I908 (Ottawa, 1909). Reference may also be made to a paper by Mr. D. A. McArthur. read at the annual meeting of the American Historical Association in rgro, and printed in the Anmual Report of that society for the same year.

${ }^{2}$ Can. Arch. Rept., I904, app. D, p. 8I.

8 This committee was appointed December 27,1787 , began its sittings in July, I789, and in March, r790, submitted its report together with a copy of its journal of proceedings. The report was printed in English and French in a pamphlet entitled Ancient French Archives, etc. (Quebec, I79I, pp. 49+49). Further labors of this committee and some supplementary papers bring the record of archival investigation to I799. These papers, including the journal and report, are printed in cxtenso in Can. Arch. Rept., 1904, app. D. This investigation of course took no cognizance of religious archives. The chief present value of the report is that it constitutes an inventory of the principal mass of the archives of the French régime. These have always remained in $Q$ uebec and are now in the custody of the provincial government. 
This body obtained numerous inventories of records, which appear in its journals, and effected a few needed changes. Enquiries were made for any public documents of the French period which might be in the possession of private individuals. A subcommittee at Montreal aided the work.

At Quebec probably the largest part of the historic records was in the custody of the secretary and registrar of the province, and was kept in a vault in the bishop's palace. A few repairs served to make this also a fit repository for a large collection of French papers formerly in the custody of the clerk of the court of common pleas. By I799 apparently all civil records at the Jesuits' College had been removed to the bishop's palace.

At Montreal the archives were found to be for the most part in a vault in the court house. The ceiling was cracked, and the room could hold only a part of the papers, the remainder being in the office of the clerk of the court, who had charge of them. These files were largely composed of judicial records and notarial repertories.

Until I790 there was probably little at Three Rivers beyond the usual études of the notaries. In that year steps were taken to place in the custody of the clerk of common pleas at Three Rivers some miscellaneous records, mainly of a judicial character, which had been found in the Jesuits' College at Quebec.

At the beginning of the nineteenth century, then, Canadian archives were in a far better condition than might have been expected. Those of Lower Canada were largely in vaults, there were more or less detailed lists of their contents, they were classified in various ways, and those in common use were indexed. Upper Canada as yet had few records, and these were recent in date.

During the next fifty years there is comparatively little to chronicle. From fugitive papers in the Dominion Archives, from numerous lists of documents, and from occasional remarks in official correspondence we derive rather meagre information as to the location, amount, and administration of departmental archives. For the larger part of this time Montreal is especially prominent. Here for many years were the archives of the Indian Department. When the Johnson family came to Canada during the Revolution they brought with them numerous and valuable records of the administration of Indian affairs in New York and the northern department generally. These served as a nucleus, and to them were added others no less important, which until I8I5 contain much pertaining to the United States. Some of these early books and loose papers have apparently been lost.

At Montreal too were many papers of the great fur companies, and here occurred the destructive conflagration of the parliamentary buildings in I849 in which a large number of valuable records were lost.

While Upper Canada and Lower Canada were bound together by the Act of Union (I840-I867) the capital might fairly be called a peripatetic inconvenience. For the first four years legislators gathered at Kingston. Mon- 
treal next became their place of meeting until after the riot and fire caused by the Rebellion Losses Bill. Then Parliament "boarded around", as has been aptly said, at Toronto and Quebec, four years in each city. At length in 1858 Queen Victoria selected Ottawa as a permanent capital, and at last the various departmental archives secured a final abode.

In the meanwhile histories of Canada were being written without the necessary sources; Nova Scotia essayed to gather and to organize its public records; a few students copied a comparatively small number of documents in Paris; and the demands of scholars grew steadily more insistent. In I87I, as we are informed by the first Report on Canadian Archives, published in I872, " a petition was presented to the Parliament of the Dominion, setting forth that authors and literary enquirers were placed in a very disadvantageous position in this country, as compared with persons of the same class in Great Britain, France, and the United States, in consequence of being practically debarred from facilities of access to the public records, documents and official papers in manuscript, illustrative of the progress of society in Canada, and praying that steps be taken to have the Archives of Canada collected".

A favorable report was made upon this petition and an Archives Branch was estabiished and assigned to the Department of Agriculture. ${ }^{1}$ Mr. Douglas Brymner was appointed head of the branch with the title of Dominion Archivist, and held the position until his death in I902. His activities during this period of thirty years are evidenced by the well-known and valuable series of annual Reports on Canadian Archives. With scanty resources at his command, often harassed by politics, hampered by inadequate accommodations, he nevertheless accomplished much useful and creditable work and students of American history have been among the first to appreciate his services and to acknowledge their indebtedness to him.

The Dominion Archivist however had no archives, in the strict sense of that term, to administer. Except for about a thousand volumes (series C) from the office of the Military Secretary to the Commander of the Forces in Canada, transferred to the Archives Branch from Halifax in 1873 , there were no such transfers of records from the Dominion offices to the branch as were evidently contemplated in the petition already cited. Dr. Brymner accordingly devoted his efforts to examining provincial and other archives in Canada, and to making copies therefrom, and, more especially, to an exploitation of the archives of the two mother-countries, France and England. Thus in the thirty years of his incumbency he gathered together over 2000 volumes of documents, exclusive of the military archives from Halifax. This collection consisted mainly of transcripts of the Bouquet and Haldimand Papers (series A and B), in the British Museum, of transcripts of Colonial Office Correspondence, from the Public Record Office (series $Q$ and part of series

\footnotetext{
${ }^{1}$ This department was established in 1853 and has had under its control not only agricultural affairs, but such matters as the census, immigration, patents, copyright, etc.
} 
$\mathrm{M})$, and of transcripts from the Colonial Archives in Paris (series F), together with a certain number of original manuscripts obtained as gifts or by purchase, and transcripts of documents in Canadian provincial archives, notably those at Quebec (in series M). A considerable library of books and pamphlets on Canadian history as well as a collection of maps and plans was also built up. In his annual reports Dr. Brymner printed extensive calendars of documents copied or yet to be transcribed together with short series of documents accompanied by editorial comment and historical introductions. These reports contain much valuable material, a suitable index or guide to which is still a desideratum. Unfortunately certain sections of the reportsespecially the calendars-are marred by numerous misprints and other errors, due in main part to the inefficient assistance upon which the archivist was compelled to rely. ${ }^{1}$

The archives of the federal government, however, notwithstanding the activities of the Dominion Archivist, remained, as before the establishment of the Archives Branch, in the various departments and offices, subject to no general supervision, and suffering from neglect. A grave accident was necessary to call the attention of the government to this state of affairs. In I897 a fire broke out in Ottawa in what was known as the Western Block. Although the Archives Branch itself was untouched, there was a sufficient loss of departmental records to stir the government to action. A departmental commission was appointed to

report to the Treasury Board as to the state of the records in the several departments; how and where they are kept and their safety in case of fire; what papers or records might be destroyed and after what interval of time; and generally to report fully on the subjects referred to in this minute, and to make such suggestions as may seem to them best in the public interest in accordance with the terms of the Order in Council above quoted with the view to the adoption of a system for the safe keeping of the public records which are required to be preserved, and the periodical destruction of such papers and vouchers as may be deemed to be useless. ${ }^{2}$

These commissioners made their rounds, spending a few hours at each place, and, in 1898 , submitted their report. ${ }^{3}$ This examination disclosed-in the words of the commissioners- " a state of affairs which, in the opinion of the undersigned, calls for prompt and vigorous measures of reform". Not only were papers stored in damp basements and dusty attics, but there was no adequate protection against fire:

Thus records which united would form a collection of rare interest, are dispersed throughout the departments, where they lie in every stage of inse-

\footnotetext{
${ }^{1}$ See Dr. Brymner's own account of his work in Papers of the American Historical Association, III. 395-407.

${ }^{2}$ It should be noted that this examination was confined to the various departments. Parliamentary files and the valuable papers at Government House, Ottawa, were not inspected.

${ }^{3}$ See extracts printed in Can. Arch. Rept., 1904, pp. x, xi. The report was not published; a few copies were printed for individual use.
} 
curity, often unarranged and undescribed, suffering more or less from damp, their value sometimes unrecognized and their very existence, it may be, unknown. Nor is this surprising when it is borne in mind that until the fire of February last the care of records was not considered a matter of immediate concern.

Recent experience must have taught all persons, as it has greatly impressed the undersigned with the conviction, that the danger from fire to which the public records are exposed is a serious and ever present one.

On every hand the undersigned found that, owing to the lack of adequate protection, records and documents, valuable and otherwise, are not only constantly exposed to the risk of fire but are in themselves a source of danger. The wooden cupboards and pine shelving almost universally used in the departments are a constant menace, and the frequent utilization of the corridors for storage space is a practice fraught with peril. Thus the protection sought to be afforded by fireproof rooms and buildings is impaired by reason of the fittings being of combustible material.

Another quotation from this report shows some of the difficulties under which Dr. Brymner was laboring:

As regards the older papers of historic interest which form the archives of the country, the undersigned are unable to speak more favourably. It is true that there is a collection of valuable papers bearing on the early history of Canada in the Department of Agriculture, under the control of an official known as the Dominion Archivist, but this official, though being amply qualified for the post, has never been provided with facilities for its adequate administration, nor enjoyed anything beyond a casual and perfunctory recognition. The Department of the Secretary of State possesses a similar collection of papers under the immediate charge of an officer known as "The Keeper of Records". These two branches of the public service, though ostensibly devoted to the promotion of a common object, are not in any sense of the word auxiliary to each other. On the contrary, they are distinct, and even antagonistic. The commissioners, for instance, understand that for the purpose of bridging over breaks in the archives copies have been made in the libraries of European capitals, when the originals of these very documents were at the time in the custody of one or the other of the public departments. It is not too much to say that the rivalry existing between these offices has long been an obstacle to the attainment of the unity and responsibility essential to the introduction of a perfect system.

This Records Branch of the Department of the Secretary of State had its beginning in 1875 , when a mass of public documents long retained in the old Government House at Montreal was brought to Ottawa. From this nucleus had grown up a considerable collection, of which the most valuable papers were kept in the wooden attic.

The commissioners also pointed out that the salaries of the Keeper of Records and his clerks amounted to $\$ 4,400$ yearly; that the Dominion Archivist and his assistants were paid $\$ 3,570$; and that various other appropriations relating to old documents came to about $\$ 10,000$ more. The estimate of the commissioners, and clearly a moderate one, was that "the Government pays at least $\$ I 7,000$ a year, ostensibly for a service, the various branches of which, instead of co-operating with, tend to neutralize one another ". 
The principal recommendations of the commissioners with regard to the archives may properly be quoted at this place:

Having thus given their best consideration to the whole subject of the care and management of the public records, and realizing the manifold inefficiencies of the present methods and the need of a radical change therein, the undersigned are unanimously of opinion that no reform can be permanent or effective which does not provide for concentration and unity of control. They accordingly recommend that the older and more valuable documents, and particularly those enumerated in Appendix A to this report, be brought together in one place and committed to the custody of one person, under whose control and supervision they should be classified and arranged. To this end they recommend the erection of a suitable fireproof building to be known as the Record Office, which shall serve as a general repository for the archives above mentioned, where they could be convenient of access to students and other accredited persons, under rules to be laid down similar to those of the Public Record Office in England .... In the opinion of the undersigned the Minister of the Crown under whose supervision the Public Record Office is placed should be styled, as such, "The Keeper of the Records" and, following English precedent, the chief executive officer should be designated "The Deputy Keeper of the Records".

The papers referred to as "Appendix A", which in the opinion of the commissioners should be concentrated in a single office, were as follows:

I. Everything in the Archives Branch of the Department of Agriculture.

2. Everything in the Records Branch of the Department of the Secretary of State, other than departmental files and letter-books of later date than June 30, I867, lodged there for convenience.

3. Everything in the Privy Council Office of date anterior to July I, I867.

4. Correspondence of the Provincial Secretary of Canada in the Department of Finance, and elsewhere.

5. Papers in the Militia Department, or elsewhere, having reference to the War of I8I2 and the rebellion of I8 37 .

6. Documents bearing upon the early history of the Rideau and Welland canals, whether in the Department of Railways and Canals, or in the Department of the Interior or elsewhere.

7. Documents in the Department of Justice, or elsewhere, relating to the risings in the Northwest, and also those touching the Fenian raids.

8. Bound manuscript volumes containing reports of the Indian Commissioners at Albany and elsewhere, dating from I722, now in the Department of Indian Affairs, also the original surrenders from the various tribes.

9. Papers in the Department of Marine and Fisheries relating to the Behring Sea seal fisheries and other international questions, as the subjects to which they relate are disposed of.

These recommendations remained without effect until after the death of Dr. Brymner. In 1903 an order in Council, based in the main upon them, was passed. This order did not create an establishment like the Public Record Office, as recommended in the report, but the record office in the Department of the Secretary of State was merged in the Archives Branch, and the Dominion Archivist was given the additional title of Keeper of the Records. The order provided that the documents be "assembled in one place and put 
into the custody of one person, and so arranged and classified as to be easily accessible to all persons interested therein ", and further:

That it shall be the duty of the said Dominion Archivist and Keeper of the Records, under the direction of the Minister of Agriculture, to keep and preserve the archives of Canada and such other documents, records and data as may tend to promote a knowledge of the history of Canada and furnish a record of events of historical interest therein, and to that end and for the greater safety in their preservation and convenience in referring thereto, that the documents, records and papers mentioned and described in said appendix " A", hereinbefore referred to, and such others as may from time to time be determined by Your Excellency in Council, be collected from the several places in which they are now respectively deposited, and placed in the custody of the said Dominion Archivist and Keeper of the Records, who shall thereupon under the direction, as aforesaid, be the custodian thereof."

One grave defect of the report was thus remedied by the order in Council. Whereas the former had recommended the transfer only of certain groups of records from the departmental archives, thus tending to destroy the unity of those archives, a proceeding contrary to the principles of sound archive economy, the latter made the further provision that such other records as might from time to time be designated by the council should also be transferred-thus opening the way for a complete concentration of the archives, as circumstances should make such action expedient.

In May, I904, Dr. Arthur G. Doughty was appointed Dominion Archivist and Keeper of the Records, and in 1906 a separate building, fairly well adapted to its purpose, and capable of further enlargement, was erected on Sussex Street, near the Ottawa River, for the housing of the Archives.

In January, I9I2, the Public Archives Act transferred the Archives Branch from its somewhat anomalous position as a part of the Department of Agriculture to the control of the Privy Council, which in turn assigned it to the Department of the Secretary of State. At the same time the title of the establishment was changed to the Public Archives and the Dominion Archivist was given the rank of a deputy head of a department. The complete concentration of public records was still further provided for as well as the most extensive collection of other historical material, the terms of the act in this respect being as follows:

Sect. 6. The Public Archives shall consist of all such public records, documents and other historical material of every kind, nature and description as, under the provisions of this Act, or under the authority of any order in council made by virtue thereof, are placed under the care, custody and control of the Dominion Archivist.

Sect. 7. The Governor in Council may order and direct that any public records, documents or other historical material of any kind, nature, or description shall be taken from the custody of any department of the Government having control thereof and removed to the Archives Building in the city of Ottawa established for the purpose of containing such records, documents and material and placed under the care, custody and control of the Dominion Archivist.

${ }^{1}$ See Can. Arch. Rept., 1904, pp. xi, xii. 
2. The Governor in Council may order and direct that any other records, documents or historical material of any kind, nature or description acquired under the authority of the Minister shall be placed in the said Archives Building under the care, custody and control of the Dominion Archivist.

Sect. 8. The Dominion Archivist, under the direction of the Minister, may acquire for the Public Archives all such original records, documents, and other material as he deems necessary or desirable to secure therefor, or he may acquire copies thereof, and all such originals or copies so acquired shall form part of the Public Archives ....

With the appointment of Dr. Doughty in 1904 the Archives entered upon a period of remarkable expansion and increased activity. First of all came the concentration of departmental and Privy Council records contemplated in the report of 1898 . To these were added the most important of the records formerly kept at Government House as well as many additional military records from Halifax, the larger part of which had, as noted above, been transferred in I873. Thus the Archives Branch became for the first time a real depot of public archives. In the second place, it being recognized that the archives of France and England contain the necessary complement of the archives indigenous to Canada, the exploitation and copying of that material, which had been the principal work of Dr. Brymner, was continued and enlarged in scope. The force of copyists in both countries was increased and Mr. Henry P. Biggar was appointed European agent of the Archives Branch, with direct supervision of this work. Finally it was the intention of Dr. Doughty to make the Archives Branch the principal centre for the study of Canadian history. To this end, he instituted a systematic search for and examination of manuscript and archival sources of Canadian history throughout Canada and in other parts of the world. Through personal visits and correspondence and through the work of agents he located groups of documents in provincial, ecclesiastical, and other archives, semi-public depositories, and private hands, especially in Canada, the Mississippi Valley, England, and Scotland. The results of these investigations were published in the annual reports, and many important acquisitions were made through copying, or purchase, or by gift.

Thus the Public Archives has developed into an important national institution consisting of a depot of public records, supplemented by large collections of manuscripts and transcripts, a rapidly growing library, and a similarly increasing collection of maps and plans. At the present time (I9I2) there are in the establishment about 19,000 volumes of archives, transcripts, and manuscripts, for which 900,000 index cards have been prepared, 20,000 printed volumes and pamphlets, and 9000 maps.

It remains to mention three important steps taken towards ensuring a close relationship between the archives and historical scholarship. The first of these was the creation of the Historical Manuscripts Commission. This was effected by the order in Council of April I7, I907, which provided: 
That the members of the said commission shall be historical scholars of recognized attainments, whom the minister may deem it advisable to invite to take part in the task of shaping and of executing a systematic plan for the prosecution of all the activities that are carried out under the auspices of the Archives Branch.

The commission was reorganized in I9I2, and is now a larger and more representative body.

The second step, designed to establish closer relations between the universities and the Archives, was the establishment by the Dominion government of scholarships of the value of fifty dollars per month for students nominated by the several Canadian universities, who should spend a part of the vacation months in research work in the Archives.

Finally, the form of the annual reports was changed. Until Igo5 inclusive they had been volumes of miscellaneous documents, lists, statistics, calendars, and other material. Then the annual report was reduced to a brief statement of the activities and acquisitions of the archives during the year, and a separate series of documentary and kindred publications was established under the title of Publications of the Canadian Archives, thus providing in a more systematic way for the editing and printing of historical material, and the publication of calendars, catalogues, and other guides. Later reports contain some brief lists, calendars, and texts.

\section{CONDITIONS OF WORK}

Admission to the archives for historical purposes is readily granted without diplomatic or other formalities. The accommodations provided for investigators are far superior to those in European archives, there being small individual rooms set apart for this purpose, on the first floor, adjacent to the library. The usual hours are from 9 to 5 (on Saturdays 9 to I) with summer closing an hour earlier. There is a refreshing freedom from the multitude of troublesome restrictions that hamper work in the older and larger archives of Europe, and the student is made to feel that all the resources of the establishment are at his disposal. In spite of the large number of index cards thus far prepared (it is estimated that they will ultimately number over I $5,000,000$ ) the materials more likely to be used by American students have not yet, for the most part, been dealt with. Thus dependence must largely be placed on the present report, and on the annual archive reports. Although various series will probably receive a much-needed reclassification, key lists will be made which will enable volumes readily to be found, although called for by the shelf numbers as indicated hereinafter or in the annual reports.

In conclusion the compiler of this account of the Public Archives of Canada desires to make grateful acknowledgement to the Dominion Archivist in particular and also to the members of his staff for their valuable and indispensable aid. 


\section{ARCHIVES OF THE DOMINION OF CANADA.}

\section{SERIES A: THE BOUQUET COLLECTION.}

Henry Bouquet was a native of Switzerland and previous to the Seven Years' War had received a valuable military training in the Dutch and Sardinian armies. In 1756 he and his fellow-countryman Haldimand were selected to raise men for the Royal American Regiment. Henceforth the rest of his life was spent in America, where he took a prominent part in both the conflict with France and the struggle against Pontiac. He was subsequently transferred to Florida. and died at Pensacola in 1765.

Upon receiving news of this event, General Haldimand, as executor, took charge of all Bouquet's papers. Public correspondence and receipts to July, I759, as well as private papers, had before this time been accidentally destroyed by fire. In I 857 a copy of the remaining collection was presented to the British Museum by William Haldimand, General Haldimand's grandnephew. At the British Museum the series is designated as Additional Manuscripts 21661-21892. See Andrews and Davenport, Guide to the Manuscript Materials for the History of the United States, to I783, in the British Museum, ctc. (Washington, Carnegie Institution, I908), pp. I05-Io6.

About I887 the volumes in the British Museum were copied, and these recopies are now in the Dominion Archives, where they have been designated as series $\mathbf{A}$. The entire collection of 35 volumes is calendared in an appendix of 337 pages to the Report on Canadian Archives for I889. Various remarks on the series are given ibid., pp. xi and xxvii-xxxii.

The period covered in these volumes extends from I754 to I765. Very little material, however, is previous to I757. Correspondence with Amherst, Gage, Stanwix, Monckton, Loudoun, Forbes, and Washington makes up about three-fourths of the collection.

Centring, as it does, about the Seven Years' War in America and the Pontiac conspiracy, this material is of prime importance to American history. Besides the purely military events much light is thrown upon such topics as the attitude of the Pennsylvanian and Virginian legislatures toward the colonial struggle, and the measures they adopted, either voluntarily or as the result of external influences; the character, equipment, and behavior of the provincial troops; the parts taken by Governors Sharpe and Fauquier; and numerous similar matters, in all of which the Indian background appears in striking colors.

The greater part of the calendaring is fairly satisfactory, but there are many cases of inaccuracy and omission, as the following casual examples will show:

A 4. Amherst to Bouquet. Mar. 5, I759. The calendar states that Amherst had desired Governors Sharpe and Fauquier to meet him at Philadelphia, but omits the purpose of this request, which was "to settle the Indian affairs in the best manner we can". Other observations upon Indian matters a few lines beyond are bereft of their rightful meaning to the reader through this omission of the keystone, as it were, of the Indian section. An item of some importance is also unnoticed at the close of this letter, where Amherst 
urges that an attempt be made to surprise the enemy's posts " at the Salt Springs, Venango, or any other place that may offer".

Bouquet to Amherst. Mar. I3, I759. One who attempted to write history from the calendar without consulting the manuscript might be led into an inaccurate statement here, for the latter source shows that Bouquet's assertion was that possession of the Ohio could not be secured without Ioon to I 500 men and artillery at Pittsburgh, while in print the numbers are simply given as rooo. Bouquet also adds that no time should be lost in sending such a force, an item which the maker of the calendar neglected.

The letter from Amherst to Governor Sharpe, Feb. 9, I762, is treated by the calendar in these words: "To restore tranquillity in the old Provinces and in those newly acquired, His Majesty desires that each Province raise its quota of men to be in readiness for an early campaign." To show the full contents of this letter the following items must be added: Provincial forces to be victualled in the same manner and in the same proportions as the regulars, and supplied with arms and tents at the expense of the crown. Order respecting arms. Regular regiments in America will be completed by recruits raised in the several provinces over and above the provincial quotas.

Similarly in Bouquet's letter to Amherst, Mar. 30, 1762 , this paragraph is unnoticed: "I had orders likewise to give sparingly some powder and Lead to the Indians going to war to the southward which has been a constant practice on this Continent, but the Circumstances being Altered I beg the favour of your Orders on these two Articles, that I do not Exceed your Intentions."

A 7. Bouquet to Amherst. June 20, I764. Given in the calendar with this date, but in the manuscript volume as of June $2 \mathrm{I}$.

Bouquet to Gage. Dec. 22, I764. This is written from "Conegocheague near Fort Loudoun" instead of at Fort Loudoun, as given in the calendar. The preceding letter is headed "Conegocheague in Maryland".

Several letters in this series are duplicated and have been epitomized twice. A striking example of this is the one from Gage to Bouquet, May 20, I764, which appears in both $\mathbf{A} \mathbf{7}$ and $\mathbf{A} 8$. In the former it occupies seven lines of the calendar, in the latter thirty-seven.

On p. 7I another case of duplication is present, this time not unmixed with other faults. The first letter (Gage to Lieut. Potts) is plainly shown by the manuscript volume to be addressed to Bouquet, as are likewise the next four. Of the two dated Sept. I5, the first is a duplicate of the second, yet they are calendared one after the other, in twelve and eighteen lines respectively.

A 21. Bouquet to Gov. Penn. Nov. I5, I764. This should be given as similar to the letter to Governor Sharpe (instead of Governor Fauquier). As it now stands the reference is unintelligible.

Bouquet to Col. McNeill, and same to Col. Lewis, both Nov. I5, I764. It is stated in the calendar that the second letter is similar in terms to the first. In reality additional details are given about the Mingoes and Delawares, their prisoners, hostages, etc.

Such faults as the foregoing do not signify that the calendar is quite unreliable. Errors seem to occur for the most part in groups, and between such passages or groups a far better class of work will be found. Yet, taken as a whole, the calendar must be used with considerable caution. No annotations give warning of the large number of duplicates and copies which are scattered through the series. Also, as has been shown by sone of the foregoing examples, the treatment is not always uniform, and the space given to abstracts of similar documents is prone to vary. 


\section{SERIES B: THE HALDIMAND COLLECTION.}

Frederick Haldimand was born at Yverdun in the Pays de Vaud, Switzerland, in I7I8. At an early age he entered military life, and after serving in the Prussian army becane an officer in the Swiss guards at the Hague. In 1756 he and his friend Henry Bouquet joined the British army, and came to America with the object of raising the Royal American Regiment. In $175^{8}$ Haldimand became part of the force under Abercromby, and remained at the north during the rest of the war. Shortly after the capitulation of Montreal he received the command at Three Rivers, but a few years later was transferred to the southern district to succeed Bouquet, upon the latter's death in I765.

Haldimand remained in Florida until 1773, when he took charge of the British troops at New York. The next move was to Boston, where he went in I774 to aid Gage. In the following year Haldimand was recalled to England. In the middle of 1778 he returned to Canada as governor general, having received the appointment upon Carleton's resignation in I777. This position he filled until I $\% 86$. His death took place at Yverdun, Switzerland, in 1791 .

In I857 William Haldimand, grandnephew of General Haldimand, presented the latter's papers to the British Museum, where they now bear the designation Add. MSS. 2I66I-2I892. ${ }^{1} \quad$ About twenty-five years later Dr. Brymner, the Canadian archivist, had copies made of the volumes in the British Museum, and these copies now form a collection of 248 volumes in the Dominion Archives at Ottawa, where they are known as the Haldimand Papers, or series B.

This entire series was calendared by Dr. Brymner, and occupies a large portion of the Canadian Archives Reports for the years 1884-I889 inclusive. Some of these calendars have many comments upon certain portions of the documents. Several papers are also printed in full, notably General Haldimand's private diary, which appears with an English translation in the Report on Canadian Archives for I889.

Taking as an objective only those parts of the collection which relate to American history, we find the material antedating 1778 comparatively easy to classify. For the Seven Years' War there is Haldimand's correspondence with Amherst, Abercromby, and Gage, not to mention others of less importance. Letter-books of the Florida period, correspondence as commanderin-chief at New York, despatches to and from the colonial secretary, I773I775-these represent the larger part of that section.

Those portions of the series dealing with Haldimand's régime as governor general of Canada are even more important for American history, but this does not always appear at the first glance. Certain large subjects, such as negotiations with Vermont, correspondence with western posts, the Loyalists, Indian matters, etc., can easily be brought together and their relative importance discerned as parts of the entire series. Yet it is only by comparison and study of much scattered material that the full significance of such a mass in its bearing upon subjects which are less prominent and often not so well known, becomes apparent. Within the period I $778-1785$ may be found much interesting evidence upon the various plans for invading Canada; excitement caused by them and measures taken for defense; development and exploits of the secret service cmployed by both sides, including their methods and channels for conveying information; disaffection in Canada, and the "aid and comfort" given to the Americans during those years. These by no means exhaust the possibilities along such lines; they only serve as examples.

${ }^{1}$ See Andrews and Davenport, Guide, etc.. pp. I05-106. 
For the American scholar the calendar is on the whole better than that of the A series. Stated briefly, its faults are of the same nature as those displayed in the treatment of the Bouquet collection, but they occur less frequently. Most of them, also, are in the first hundred volumes. The succeeding volumes are not perfect, but they can be used with greater confidence.

In the appended examples of deficiencies in the calendar of the B series, none have been taken from that portion of it in the Report on Canadian Archives for I884. This is now out of print, and compared with later reports, is much more difficult to obtain. The thirteen volumes which it summarizes include Haldimand's correspondence with Amherst and Gage, I758-I777, and various other material upon the Seven Years' War, the Indians, and Quebec before I775. This part of the calendar may be readily estimated from the following examples of certain defects in other portions.

B 2-1. In the letter from Gage to Haldimand, dated Feb. 2, I764, there are two errors, and a neglect of some details of interest to Americans. The calendar reads, "Distribution of troops to the southward. Indians well disposed; some outrages by Creeks at the back of Virginia", etc. For this the manuscript shows the following: "The 9th Regt is posted at Augustine, Providence and Bermudas, the 35th at Pensacola, 34th at Mobile and the 22nd gone to occupy a Fort at the mouth of the Ohio with Forts Chartres and Haskia [Kaskaskia] in the Illinois country. The Savages are in appearance all well disposed in those Parts. The Creeks have lately committed some outrages on the Back of Carolina ", etc.

$B$ 15. Another combination of neglect and error may be seen in the letter of Aug. I3, I767, which the calendar states is from "Brigadier Haldimand to Lieutenant Home ". One sentence runs, "Cartel cannot be established but by arrangement made by General Gage". The full passage is this: "As to the Cartel Lieut. Home has agreed upon conditionally with the spanish commandant, is not in my power to ratify, nor is it in the power of the Civil Governor of this province to conclude a cartel; I am therefore to desire you to withdraw the engagements entered into on that subject, and to acquaint the spanish commandant therewith, as was agreed upon. I have acquainted Don Ulloa of this step and hope it will not lessen the harmony so advantageous to both nations, and so much recommended.

"As I am of opinion that a cartel wou'd be very advantageous to His Majesty's service, I have wrote upon that head to the commander in chief and expect in a short time to recieve orders thereon, which I hope will be satisfactory to both nations."

This was probably written to Capt. Disney instead of Lieut. Home, for the latter is mentioned several times in the third person, and the document is endorsed as follows:

"A Trewe copy of that given me by Captn Disney.

"Thomas Home Lieut. in the Royal N. B. Fuzeliers."

Finally, the letter is signed merely "Fredk. Haldimand".

In the same volume the document given as from Capt. Varlo to Brig. Haldimand, Aug. 22, 1768, proves to be unaddressed, and is signed by both Capt. Varlo and Lieut. Sampson.

B 17. Kirkman to Haldimand. Fort Bute, July I8, I768. This paragraph is unnoted in the calendar: "The carpenters as yet have not set to work on the Batteaus, we have neither sails, awnings, or cordage, for service."

B 18. Amherst's instructions to Monckton, Apr. 29, 1760, are shown by the manuscript to be only an extract. 
Amherst to Browning. Oct. 29, I763. In the summary of this letter the calendar omits any mention of the distress at Niagara for want of hay, and the "very essential point" of getting provisions to Fort Schlosser during the winter.

A letter of May 17,1765 , is given the heading "Alexander Fraser" in print. It should be Alexander Fraser to Lieutenant-Colonel Campbell. The calendar also neglects the fact that it is no. 4, and a copy. The succeeding letter is correctly addressed. In this volume the name of the addressee is often omitted in the calendar, when he is the commanding officer at Niagara, since the entire book relates to that post. This plan, however, is not followed consistently, so from the calendar alone one cannot be certain to whom at least half the letters were written.

Gage to Capt. Brown or the officer commanding at Niagara. Feb. 22, I768. This letter is summarized in the following terms: "Bad condition of the boats at Little Niagara. Man poisoned by a root. Senecas quiet but doubts their sincerity." In the first place Gage comments upon the men (instead of man) at Niagara who were poisoned, although no numbers are given. Secondly, he states that a fresh supply of boats will be sent from Montreal to Niagara in the spring. Thirdly, the officer is instructed to watch the Senecas and to be constantly upon his guard. These are somewhat minor items, it is true, but they are not far inferior in importance to those which appear in print, and to some students they may be the most interesting. In any case the total amount of information lost in the calendar of a series by such methods is considerable.

B 35. Haldimand to Dartmouth. (No. 8. Copy.) Nov. 3, I773. Settlement on the Ohio is noticed in the summary, but remarks upon that along the Wabash are overlooked.

B 5\%-2. Haldimand to Germain. July 8, I78I. The calendar speaks of negotiations with Gov. Chittenden and Ethan Allen. The manuscript shows that it was Ira instead of Ethan. Also this letter is "Most private".

B 97-1. De Peyster to Haldimand. Aug. 3I, I778. This important section is not represented in the text: "The Traders in that Country and many from this Post are Plundered, and the whole Country in the greatest Confusion being at a loss to know which route the Rebels will take next".

To return once more to general characteristics, such terms as "copy", "duplicate", "secret", "confidential", "private", and "extract" are unnoted in the summaries; nor are the numbers of despatches always given. Stated briefly, the calendar is for the most part satisfactory as to contents, but unsystematic in many respects, and neither scientifically made nor impartial. Certain subjects attracted its compiler more than others, and American affairs are apt to be among those to which less attention has been given.

A word of caution is necessary with regard to duplicates. Many of Haldimand's despatches to the colonial secretary are in duplicate in B, and also appear in the $\mathbf{Q}$ series. In the calendar of the latter a cross-reference is usually made to the same document in $\mathrm{B}$, but the system of checking these evidently was not perfect, and many escaped. As a result we sometimes have two different summaries of the same despatch in the B calendar and either a third summary or a reference in the calendar of $Q$.

\section{SERIES C: MILITARY PAPERS.}

The $\mathbf{C}$ series, military in origin, is composed of about $\mathrm{I} 875$ folio volumes and portfolios. With a few exceptions the dates are confined to the period 1785 I870. More than half of this collection was obtained from Halifax in I873, 
as a result of negotiations with the British War Office. This portion came in bundles, which were sorted, classified, and bound. ${ }^{1}$ It includes most of the material relating to the United States. About the year 1904, large additions were made in the form of letter-books, and a considerable quantity of loose papers have helped to enlarge the series since that date.

The collection is made up of numerous units, varying from one volume to nearly one hundred, which are either concerned with one subject, or, as in the case of most additions since I873, consist of sets of letter-books. In this respect it slightly resembles the $\mathbf{M}$ series, but, unlike the latter, the documents are ail of a military character.

For the student of United States history the War of 1812 furnishes the largest body of correspondence. Fenian raids, Indian affairs and the westward country, and the Civil War in the United States are each well represented, while scattered items from time to time relate to a great variety of topics.

An inventory of this series forms no. 2 of the Publications of the Canadian Archives. It was prepared by Lieut.-Col. Ernest A. Cruikshank, and appeared in I9Io. The body of the work comprises 295 pages, to which is added an index of 75 additional pages. Each volume or portfolio is taken up separately and is described in, upon the average, six or seven lines of print. The existence of this manual has made it unnecessary, in the following list, to say anything concerning any portions of the $\mathrm{C}$ series but those volumes which in some degree relate to United States history.

Every book in that part of the series classified by Dr. Brymner-which may be taken to include the first thousand numbers-is furnished with an index supposed to contain every name in the volume and the principal subjects, such as Indians, etc. In the case of several parts in common use, including volumes on the War of I8I2, each name has been indexed on a card, and these are filed in an adjacent room. The sets of letter-books added to the series within the last few years contain indexes of various kinds. A large proportion give the purport of each document, while others have only a more or less complete list of names.

0. H. Dearborn to Lieut.-Gen. Prevost. Has put in close confinement 23 British prisoners as hostages for the safe-keeping of the same number of U.S. infantry held in England as British subjects. Fort George, May 3I, I8I3. (Copy.)

14. This volume, labelled "Aliens", contains correspondence of various military and civil officials relative to the entry of suspected persons into Canada, passports, etc. The period covered is $1796-1816$, and the most important case is that of Louis C. Coulteulx. (I94 pp.)

29. Monthly return of forces at the several posts in Upper Canada. Sept. 25, 1792.

Lieut.-Col. McDonell to —_. Relative to Spaniards, information from Indians at Detroit, etc. Fort George, Feb. 19, I799. (Private.)

31. List of U. S. mercantile vessels navigating lakes Ontario, Erie, Huron, Michigan, and the St. Lawrence, and their capabilities for war purposes. [1848 ?] (Ff. I83-I86.)

37. Lieut.-Gen. Windham to the Secretary of War. Remarks on certain military matters, Ogdensburg as a Fenian centre, etc. Montreal, Mar. I2, 1869. (Copy.)

${ }^{1}$ For fuller details respecting these papers see Dr. Brymner's own account in the Can. Arch. Rept., I889, pp. xi-xiii. 
38. Hobart to Lieut.-Gen. Hunter. No. 5. Sends "Memorandum concerning a Canal projected by the American States from Albany to Lake Ontario; and a Canal between Lake Ontario and Montreal, by which the former would be rendered fruitless". Remarks. Downing Street, Feb. 4, I802. (Duplicate. Enclosure present.)

Gother Mann to Maj. Green. Remarks on the above "Memorandum ". Quebec, July I5, ISO2. (Letter to Hunter upon this subject on Aug. 3I.)

39. J. W. Clarke to Lieut.-Col. Addison (military secretary). Relative to passage of U. S. barges through the lock at Côteau du Lac, etc. Montreal, Apr. 2I, ISI8.

76. Col. Gother Mann to Lieut.-Gen. Hunter. "Some general observations on the Boundary between the British Provinces of Canada and New Brunswick and the United States of America". Quebec, Apr. 23, ISO2.

7\%. James McGill to Lieut.-Gen. Hunter. Various remarks respecting the treaty of I794. Montreal, Jan. 28, I804.

78. Gordon Drummond to Col. Baynes (adjutant-general). Relative to supplies for Fort Niagara and supplies and reinforcements for Michilimackinac. Kingston, Mar. 22, ISI4.

81. Edmund Head to Maj.-Gen. Home. Relative to allowing the U. S. vessel Jefferson Davis to pass through the Canadian canals to the Lakes. Toronto, June I4, I856. (Other documents on this matter precede and follow this letter.)

84-101. Claims for losses. ISI2-I870. Relate principally to the War of I812. Nearly all the claimants are Canadians. Occasionally, as in vols. 86 and 87 , there appear claims for losses at Plattsburg, Champlain, etc. In C 84 are returns of property lost at York, Apr. 27, I8I3. Several letters of Lieut.-Gen. Murray, Maj. Brock, Col. Butler, and others, in $\mathrm{C} 88$, relate to the retention of Bois Blanc Island by the Americans, and the restoration of posts. These were written in Apr. and May, I8I5.

Besides the above, a few memorials to Drummond recount the services of various persons. That of Oliver Barker (C 91, Pp. I 5I-I57) gives information of a few raids upon Vermont, and one of Thomas Otway Page ( C 95, pp. 83-86) recounts his exploits during the war. There are also a few scattered items respecting aid furnished the Canadian forces by persons in the U. S.

105-163. Commissariat. I788-I870. Materials relating directly to the U. S. are very few in these volumes. Nos. 116-120, however, contain much information upon supplies for Canadian troops and the movements of the latter during the War of I8I2.

107. "List of Invalid Loyalists victualled at William Henry agreeable to the latest Returns." Quebec, July 7, i8oo.

117. R. Sheaffe to Prevost. Commissariat matters along the Niagara and Erie frontier. Fort George, Jan. 6, I8I3.

148. F. Halkett to Col. Rowan. Relative to buying of cattle and hogs in the Midland district by Americans. Toronto, Mar. II, I839. (Another letter on this subject, Mar. 25.)

R. Routh (commissary-general) to same. Exportation of cattle to the U. S. Quebec, Apr. 2, I839. (Two enclosures.)

164. Lieut.-Col. Grant to James Green. Why U. S. deserters have not been given up. Fort George, May 2, ISo6. (Followed by letter of May 23 
upon this subject from Alexander Grant, president of the Council, U. C., to Col. B. F. Bowes.)

184. At the first of this volume are copies of two reports of committees of the executive council, dated Nov. 9, I865, respecting preparations against Fenian raids from the U. S. The remainder of the number covers the period Jan. I4, I867-Aug. 20, I870. It consists of correspondence of the governor general and other officers in Canada, both civil and military, with the secretary for the colonies and the secretary at war; Canadian correspondence between various officers, the military secretary, and the commander of the forces; miscellaneous correspondence, returns, and memoranda.

This material relates partly to rumors of Fenian invasion, partly to disposition and movement of troops on the frontier, etc., and partly to the second Fenian raid. One letter from Tom Reymond to the commander of the forces in Br. N. America, dated Corinne City (Utah), May 19, I870, offers 25 men "eager and ready to assist in defending the Supremacy of the British Empire from all its foes both native and foreign ". (234 pp.)

185. Jan. 3I-June I6, I866. ( 168 pp.) Correspondence of various military and civil officers in Canada with each other; their correspondence with the Colonial Office, the War Office, and the Admiralty; telegrams, memoranda, dispositions of forces, etc. This material deals with the Fenian raid of 1866.

186. Jan.-Dec. 26, I866. (I65 pp.) A continuation of the preceding volume. Nearly all of the correspondence is Canadian.

186 A. Jan.-Nov., I866. Telegrams to Lieut.-Gov. Gordon (New Brunswick) from Gov. Gen. Monck, Gen. Williams, Gen. Doyle, the British minister at Washington, the British consul at New York, and others, relative to the Fenian raid. There are over 500 of these telegrams. Nearly all the important ones are in cipher.

204. Memorial of Gwyn Owen Radford to Dalhousie, detailing his services in Canada since I792. Gives information on relations with Vermont, projects of French in the U. S., etc. Montreal, Feb. 22, I828.

228. Col. John Vincent to Maj.-Gen. Sheaffe. Artillery duel between U. S. vessels on the one side and the Royal George and Kingston batteries on the other. Remarks. Kingston, Nov. i I, I8I2. (Copy, followed by letter from Sheaffe to Prevost, Nov. I6, commenting upon this.)

230. Sherbrooke to Prevost. Remarks on various military matters. Halifax, Aug. IO, I8I3. (Private.)

231. District general order for an advance against the enemy the next day, by Lieut.-Col. Harvey. Niagara Falls, Aug. I, I8I4. (Copy.)

247-271. "Indian." I767-I857. Correspondence relating to the Indian Department. Most of it is between officials of the department and various civil and military officers. The earlier volumes and those covering the War of I8I2 are very valuable for the history of the U.S. This is local correspondence, and very little is duplicated in other series. Only a few documents are dated after 1845 .

247. June $20,1767-D e c .29$, I794. (37I pp.) At the first of this volume are copies of instructions to William Johnson from Shelburne, June 20, I 677 , and Hillsborough, June I I, I 768 , respecting settlement upon the Ohio by persons from Maryland and Virginia, and Indians matters. With these exceptions few documents of any value are before I793. 
There are numerous letters of Joseph Chew, secretary of the Indian Department, to Thomas Aston Coffin, assistant civil secretary to Lord Dorchester, and letters to Chew from Alexander McKee, Thomas Duggan, John Butler, Joseph Brant, Lieut.-Col. England, Lamothe, Capt. Doyle, and Thomas Talbot. Those of McKee and Duggan (Indian agents), England, and Brant are the most important. Many of McKee's were written at the Miamis. There are also letters of Maj. Littlehales, secretary to Lieut.-Gov. Simcoe, to Capt. Le Maistre, military secretary at Quebec, Lieut.-Gov. Simcoe to Lieut.-Gov. Clarke, England to Simcoe, England to Le Maistre, Gen. Chapin to Brant, and correspondence of Brant and Timothy Pickering.

Numerous speeches to the Indians, and minutes of Indian councils are also present, such as Wayne's speech to the Indians at Greenville, Jan. I4, I794, the council at Buffalo Creek, Apr. 21, I794, Wayne's speech to the Indians at Grand Glaize, Sept. 12, I794, Pickering's speech to the Indians, Oct. 25, I794, etc. The treaty between the Six Nations and the U. S., at "Konondauqua" (Canandaigua), Nov. I I, I794, brings this class of documents to an end.

This material is of great value for the relations of the Indians, British, and Americans in the West during this period, and gives much information respecting Wayne's expedition. One letter of McKee to Chew describes the battle of Fallen Timbers, and is accompanied by a rough sketch of the locality. News gained from scouts and from deserters is an important factor. A diary or report of Thomas Duggan on business in the Indian country, Sept. 28-Dec. 24, I793, deals with the Indians and with Wayne's movements.

A general order of Maj. John Buell, U. S. A., dated at the "Banks of the Miamis", Aug. 23, r794, congratulates the army upon its success against the Indians " aided by a body of the Militia of Detroit, and Countenanced by the British post and Garrison close on their rear", etc.

The letters from Chew to Coffin are originals; practically all the remaining documents in the volume are copies.

248. Jan. 5-Dec. 22, I795. (426 pp.) Except for the numerous and important letters of Joseph Chew to Thomas Aston Coffin, and a few to the latter from John Lees (storekeeper), there are few original documents in this volume. There are letters to Chew from Prideaux Selby, assistant secretary of Indian affairs, Joseph Brant, William Johnson Chew, Col. John Butler, Alexander MicKee, deputy superintendent of Indian affairs; communications between McKee and Edmund Burke, vicar-general of Upper Canada, and a small amount of miscellaneous correspondence.

Speeches at Indian councils by both British and Americans, and Indian treaties are numerous. This material relates to relations of the Indian tribes with both Canada and the U. S., treaties with the western Indians by the federal government, and with the Six Nations by New York.

249. Jan. 4-Nov. 21, I796. (422 pp.) Letters to Coffin from Chew and Lees continue in this number; but in the latter part Coffin's name is replaced by that of Capt. James Green, military secretary at Quebec. Letters to Chew are from McKee, William Johnson Chew, Prideaux Selby, Thomas Duggan, storekeeper at Michilimackinac, and Charles de Lorimier, interpreter. There are also communications from Chew 
to Green, correspondence of Col. England and Capt. Green, numerous speeches and Indian treaties, etc.

A copy of a letter from McKee to Dorchester, June 7, I796, relates to the administration of the Indian Department, and a copy of another letter from Thonas Gage to Capt. Stevenson, New York, Apr. 8, r768, gives instructions respecting Indians, treaties, and grants at Detroit. This material deals with the triangular relations of British, Indians, and Americans, treaties, and the delivery of the western posts.

250. Feb. 25-July 30, 1797. (586 pp.) This volume is largely composed of letters to Capt. James Green by Joseph Chew, Capt. Hector McLean, Maj. David Shank, Capt. William Wayne, John Lees, John Johnson, and Joseph Brant. There is also some riscellaneous correspondence, requisitions for the Indian Department, etc. This material is largely Canadian in character.

A general order, Detroit, July 15, I797, relates to both British and U. S. deserters. There is also a note from Gen. James Wilkinson to Capt. McLean, and letters between Maj. Shank and Robert Liston, British minister at Philadelphia, respecting the possession of Bois Blanc Island. Indian administration and land grants are the chief topics.

251. A continuation of material of no. 250 for the year I798. Consists of letters written to Capt. Green, miscellaneous correspondence, requisitions for the Indian Department, etc. Largely relates to administrative and military affairs. Very little respecting the U. S. (304 pp.)

252. Material covering the year I799, and similar in character to that in the two preceding volumes. Relates chiefly to Indian administration in Canada. A few letters from the West give information received through Mississippi traders. (39I pp.)

253. Jan. 6, I800-Nov. I2, I80I. (347 pp.) Correspondence and other papers, chiefly relating to Indian administration in Canada. References to the U. S. are only incidental.

254. Jan. 28, ISO2-Nov. 2, I804. (242 pp.) Material in this number is of the same general character as that in vol. 253. There are a few items on Indian migrations, U. S. deserters in Canada, and information from the Mississippi.

255. T. McKee to Col. [William] Claus (deputy superintendent of Indian affairs). Relative to remarks of Gov. Hull upon a rumored speech of an Ottawa chief. Amherstburg, Feb. I4, I808. (Copy. Two enclosures.)

Gore to Craig. Remarks upon Americans and western Indians. York, Mar. 4, 1808.

David Price to Prideaux Selby. Council at Buffalo Creek, and journey of certain Indians to Washington. Fort George, Apr. 21, I808. (Copy. Enclosed in letter of John Johnson to Lieut.-Col. Thornton, May I9.)

George Johnstone, president of the executive council of New Brunswick, to Craig. Believes the New Brunswick Indians are more attached to the U. S. than to Canada, etc. Fredericton, Dec. 22, I808.

256. Capt. Glegg to Col. Baynes, adjutant-general. Services of Robert Dickson among the western Indians. Observations upon sundry events in the West after the battle at Tippecanoe. York, Nov. I I, I8I2.

257. Jan. 2, I8I3-Dec. 29, I8I4. (384 pp.) In this volume are about fifteen letters relating to western Indians and the war. Nearly all of these are to Prevost and his military secretary. About half are from Robert Dickson, British agent for the western Indians; the others are from 
John Norton, Capt. Charles Roberts, James McGill, John Richardson, and William McGillivray. A draft of Dickson's instructions is present. There are also a few miscellaneous documents on general matters relating to Indians and the war.

258. Jan. I3, I8I5-May 25, I8I6. (542 pp.) At the first of this volume are a few letters from Robert Dickson at Prairie du Chien to Capt. Freer, military secretary at Quebec, respecting events in that quarter. A communication from Drummond to Prevost, York, Feb. 8, I8I5, deals with a plan to remove "the western Indians from the Shores of Lake Ontario to the Mississippi". The largest and most valuable part of the material relating to the U. S., however, is found in the letters of Lieut.-Col. McDonall. Nearly all of these were written from Drummond Island, and are of much value for relations with Americans in the West just after the war. There is a long account of Lieut.-Col. McKay's mission to the Mississippi in connection with Indian matters. The policy of the U.S. toward the western Indians, councils, speeches to Indians by both British and Americans, and the relations of Upper Canada with Michigan are other features of prominence. There are the proceedings of two British courts of inquiry, held to investigate charges by the Americans that certain British subjects had incited the western tribes against the U. S., etc.

Some miscellaneous correspondence also relates to the U. S. Stated briefly, about one-fourth of this volume is of much value for the relations of Canada and the $\mathrm{U}$. S. with regard to the westward country and the Indians therein during the period immediately following the treaty of Ghent.

260. Jan. I-Dec. 26, ISI6. (502 pp.) In this volume are several letters from Lieut.-Col. McDouall (at Drummond Island), and William Claus, deputy superintendent of Indian affairs, which relate to Indians of the western country, alleged encroachments of Americans on Indian lands, local disputes at Mackinac, amount of presents formerly given to Indians on the Mississippi, and charges that the Americans had broken article IX. of the treaty of Ghent. There are also a few Indian speeches at councils at Drummond Island, York, etc.

261. Charles Bagot to Sherbrooke. Sends copies of treaties between the $\mathrm{U}$. S. and several Indian tribes. Washington, Feb. 3, I8I7. (Enclosures in the National Intelligencer for Jan. I4, I6, and I8.)

William Claus to Lieut.-Col. Addison, military secretary at Quebec. Relative to U. S. prisoners among the Indians. York, Mar. IO, I8I7. (Letters of John Norton, Mar. I4, Lewis Johnston, June 8, and L. Givins, July 25, are upon the same topic.)

262. Maj.-Gen. Widdrington to Lieut.-Col. Addison. Reported Indian outrages near Chicago. Conduct of the U. S. toward Indians in the northwest, Americans moving westward, and the numbers of their vessels on the Detroit River. Kingston, May I6, i8I8. (Letter of William Claus, of June I5, recapitulates part of the above.)

265. Copy of the Indian cession at Fort Stanwix, Nov. 5, I768. (Ff. 217222.)

268. Extract of the "Charter of the Corporation for propagating the Gospel in New England and the parts adjacent in America", etc. (Ff. 205-208.)

278-282. Petitions, returns, correspondence, etc., relative to lands at Sorel, Quebec, I792-I845. The earlier records relate largely to Loyalists 
at William Henry (Sorel). In vol. 278 are numerous memorials and a few returns of Loyalists at that place.

363. The Northwest. I800-1845. (269 pp.) Several memorials of McTavish, McGillivray and Co., Forsyth, Richardson, and Co., miscellaneous correspondence, and a few despatches from the Colonial Office deal with the relations of the Northwest Co. and the U. S., chiefly with respect to duties upon furs. This material comes to an end about I8I5.

364. The Northwest. I855-1863. (379 pp.) At the beginning of this volume, I856-1857, is correspondence between the Colonial Office, the War Office, and the Hudson's Bay Co. respecting the establishment of a military garrison at Pembina by the U.S. A few scattered letters in the remainder of the volume throw some light upon mail and trade routes in the northwest, which passed through a part of the U. S.

370. Commodore G. W. Owen to Drummond. Observations on claims of the U. S. to Bois Blanc Island. Kingston, Oct. I5, I8I5. (Followed by instructions to Capt. T. W. Owen respecting surveys on the Lakes, and a confidential circular of Commodore Owen to captains of British vessels on the Lakes, on relations with the U. S.)

381-495. Ordnance and Engineers. I77I-I870. A few documents in the first two numbers of this sub-series relate to the state of British posts in the western country, before they were given up to the U. S., and also to provisions lent to U. S. commanders.

Vols. 386-389 cover the War of $\mathrm{I} 8 \mathrm{r} 2$. They contain material upon the state of Canadian posts, and a few held in the U. S., such as that at Burlington Heights.

In vol. 445 is a report of Capt. Vincent Briscoe to Colborne on the rebel position at Navy Island, dated Kingston, Jan. I6, I838.

A brief examination of several other volumes of this sub-series revealed nothing further relating to the U. S.

505. Petitions for relief. I 787 -I8I3. Not more than six are from Loyalists.

511. Abstracts of ordnance, ordnance stores, and ammunition issued at Detroit. Sept. 10, I793-Sept. I, 1794. (Show what proportion went to Fort Miami, pp. 156-161.)

608-615. "Rebellion. I837-1838." Local correspondence, chiefly military, respecting the rebellion. There are numerous letters on alleged hostile preparations in the U.S. to invade Canada, and defensive preparations are clearly brought out. The only raids actually described, however, are those at Windsor and at Prescott. Generally speaking, this material is of much less importance for the relations of Canada and the U. S. during this period than the records in series $Q$ and $G$.

608. Mar. 22, 1837-June 2, 1838. (269 pp.) Nearly half of this material from Feb., 1838 , relates to rumors of attacks from the U. S. upon Upper Canada, preparations for defense, hostile organizations across the border, the destruction of the Sir Robert Peel, and the Caroline affair. Most of the letters are to Colborne and the assistant military secretary at Toronto from Col. James Kerby, commanding on the Niagara frontier, Maj. Plomer Young, Capt. H. Reid, Col. Maitland, and several others.

There are also some miscellaneous letters, depositions, reports, and correspondence of Brig.-Gen. Winfield Scott and Col. Maitland, on complaints against U. S. troops. 
609. June I-June 20, I 838 . (225 pp.) About one-fourth of this volume is composed of miscellaneous military correspondence and letters written to officers, on shots fired at the U. S. steamboat Telegraph at Brockville, rumored preparations in the U. S. for attacks upon Upper Canada, piratical actions along the frontier, and relations along the border generally.

610. June 22-July I3, I838. (299 pp.) About twenty letters of various officers and their correspondents relate to rumors of intended aggressions from the U. S., movements of the insurgents in New York and Michigan, and piratical actions along the border. This material chiefly concerns Upper Canada. There are a few copies of letters from U. S. officers at Detroit.

611. June 30-Oct. 30, I838. (293 pp.) About twenty-five letters of various persons, chiefly nilitary officers, throw light upon agitation and plots of the rebels and their American sympathizers in the U. S., Canadian border defense, and the means taken to obtain information of any hostile movements.

612. Oct. 3I-Nov. 24, I838. (320 pp.) Nearly one-fourth of this volume deals with hostile preparations in Michigan, New York, and Ohio against Upper Canada. the restraining actions of U. S. army officers, and border raids. There are important letters of Lieut.-Gov. Arthur, Capt. Sandom, British commander on the Lakes, Col. Airey, Col. Dundas, and others respecting the attack at Prescott, numerous communications from persons at Detroit and Cleveland, some miscellaneous military correspondence, etc. A small part of this material relates to the Eastern Townships.

613. Dec. 4, I838-Jan. I, I839. (3I6 pp.) About twenty letters of Col. Airey, Col. Chichester, Col. Estcourt, Sir Allan McNab, Lieut.-Gov. Arthur, Capt. Sandom, and F. Baby relate to the raid at Windsor by persons from the U.S. A list of the prisoners is on p. I65.

614. Jan. 2-July I3, I839. (245 pp.) Several letters of Capt. Sandom relate to matters on the Lakes, and border piratical actions. A few scattered letters of various persons also give information upon the prisoners captured at Windsor, and the lessening of hostile feeling across the border.

615. July I0, I839-Sept. 24, I866. (286 pp.) In this volume a few scattered letters relate to fugitives from justice in the U. S., and rumors of projected attacks upon the Upper Canada frontier in I839 and 1842. There are very few documents of a later date than 1842 .

619. I. W. Clarke to Maj. James Green. News that the fever is much abated at Boston. As many as thirty a day had died of it, etc. Montreal, Oct. I 5, I798.

634. The first part of this volume, which covers the period I787-I869, is largely composed of petitions and letters of various Loyalists, respecting lands.

673-675. Relations with the U. S., I790-I844. These three volumes contain much miscellaneous material on diplomatic subjects analogous to that found in several portions of series $G$. The section is far from covering the field embraced in the heading, but it yields some important evidence supplementing that found chiefly in series $G$ and $Q$.

673. June I7, I790-Nov. I3, I8I5. (236 pp.) This volume is miscellaneous in character. Extradition matters and smuggling cases frequently 
occur. Relations with Vermont and French plots in the U. S. are the chief items in the nineties. A few letters of the British chargé d'affaires at Washington, scattered documents on various phases of the War of I8I2, Gother Mann's “ Memoranda and Conjectures, relative to part of the Boundaries between Lower Canada and New Brunswick and the United States of America ", Oct. 28, I799, and instructions from the Secretary of the U. S. Navy to Capts. Evans and Lawrence of the Chesapeake are items of prominence.

674. Jan. 5, I8I6-Dec. I8, I8I9. (244 pp.) Correspondence of the British minister at Washington with the U. S. Secretary of State forms about three-fourths of this volume. Despatches from the former to Sir Gordon Drummond and Sir John Sherbrooke are next in point of bulk. There are also a few despatches from Lord Bathurst to the governor general of Canada. Enclosures are present in many instances.

The subjects, in the relative order of space devoted to them, are as follows:

Negotiations respecting naval armaments on the Lakes.

Alleged enlistment of British deserters in the U. S. army.

The use of Canadian fisheries by Americans.

Various proceedings relative to articles IV., V., VI., and VII. of the treaty of Ghent.

Sundry alleged outrages, such as the exercise of the right of search.

Correspondence of Canadian officials with U. S. authorities.

The plaster of Paris trade.

Conduct of American residents at St. Regis.

At p. 33 is a statement of the U. S. force at Sackett's Harbor, May I, I8I6.

675. Apr.7, I820-Sept. I6, I844. (273 pp.) A few pages at the first of this volume continue the same kind of correspondence as that found in C 674, respecting British deserters in the U.S.

In the remainder of the volume several letters between various British officials in Canada and in England relate to the Northeast Boundary dispute. Most of these were written in 1828 . A few documents on articles VI. and VII. of the treaty of Ghent, numerous British claims arising from the evacuation of Drummond Island, and miscellaneous correspondence on topics of small import complete the book.

676-695. Records of the War of I812. These constitute one of the most important parts of the $\mathbf{C}$ series. They may be divided into certain sections. The first and most important, consisting of vols. 676-688 inclusive, comprises the greatest part of the military correspondence for I8I2-I8I5. Letters of the various British officers, secret intelligence, returns, communications from the Horse Guards, news of Indian affairs, and despatches from Lord Bathurst are the chief fixed constituents of these volumes.

Next in order come numbers $688 \mathrm{~A}-688 \mathrm{E}$ inclusive, which are largely of a miscellaneous character, containing here and there important letters and returns, and likewise a few despatches from Downing Street. The dates cover practically the same period as the preceding section.

Vols, 689-694 inclusive relate to prisoners taken on both sides. Correspondence, returns, statements, and conventions for the exchange of prisoners are the chief items. The letters are from military officers of both nations, agents employed in this branch of the service, and numerous persons in civil life. Returns are either of prisoners cap- 
tured at different places or of those confined in certain localities. Statements are usually by the prisoners themselves, and relate to the circumstances of their services and capture or to the treatment accorded them in captivity.

Taken as a unit this material is important for the life of prisoners on both sides, their situation, numbers, paroles, exchanges, retaliatory treatment, and the large subject of diplomatic relations upon the whole question. Despatches from Lord Bathurst continue in this section.

Vols. $694 \mathrm{~A}$ and $694 \mathrm{~B}$ are general entry books of prisoners of war at Quebec, containing I990 numbers, with the name of each, his rank, birthplace, age, stature, color of eyes and hair, details of discharge, exchange, when and where captured, etc.

Vol. 695 relates to prize money.

676. Mar. 8, I8o6-July 29, I8I2. (246 pp.) Nearly one-half of the volume deals with diplonacy and military preparations before the war. Despatches from the British minister at Washington and the colonial secretary to the governor general, and letters of Maj.-Gen. Brock and the lieutenant-governor of Nova Scotia are the most important.

With the opening of the war communications from Halifax become fewer, and nearly all the material deals with affairs along the western frontier of Canada. Several letters from Brock to Prevost form the largest item.

Next come those received by Brock from his officers-Lieut.-Col. St. George (Malden and Amherstburg), Capt. Roberts (St. Josephs and Mackinac), and Col. Procter (Amherstburg). Among miscellaneous correspondence may be mentioned letters between Brig.-Gen. Hull (U. S. A.) and Lieut.-Col. St. George, the former and Secretary Eustis, and a few communications to Prevost, etc., from Matthew Elliott and William Claus of the Indian Department.

Apart from correspondence, documents in this volume of interest to Americans are a return of ordnance, ammunition, and stores captured at Mackinac by Capt. Roberts, a monthly return of the garrison under Lieut. Hanks (U. S. A.) for June, I8I2, a copy of the capitulation of the garrison, July I7, I8I2, temporary regulations respecting alien $\mathrm{U}$. S. subjects desirous of coming into the district of Montreal for a limited time, and notes of the Baron de Diemar on his journey through New York.

677. Aug. 4-Dec. 26, I812. (296 pp.) Brock's letters, most of which were addressed to Prevost, are the most important feature of this number. Penned at various places, they take up both general matters and particular events of the war. Letters of each of the following persons deal with engagements or the situation at the frontier: Maj.-Gen. Sheaffe (Fort George, York, and Chippewa), Col. Procter (Detroit and Amherstburg), Maj.-Gen. de Rottenburg (Blairfindy Camp and Chambly), Maj. Muir (Old Delaware Town, Sandusky, etc.), Lieut.Col. Myers (Fort George), Capt. Roberts (Michilimackinac), Lieut. Dewar (Amherstburg), Maj. Heathcote (Point Frederick), Judge A. B. Woodward (Michigan), Matthew Elliott, Lieut.-Col. Pearson (Prescott), Lient.-Col. Bisshopp (Frenchman's Creek), and Sir John Sherbrooke (Halifax).

There are also letters from Dearborn to Prevost concerning the armistice, a detailed report of Col. Baynes (adjutant-general) on his mission to Albany, a communication from Hull to Prevost relative to Capt. 
Brown's party with the flag of truce, a copy of the armistice between Sheaffe and Van Rensselaer, and the observations of Toussaint Pothier on the capture of Michilimackinac and its condition when he left it.

The letters of Maj. Muir deal with the British expedition against Fort Wayne, while Judge Woodward's correspondence with Col. Procter relates to prisoners taken by the Indians at the capture of Fort Dearborn. A few despatches from Bathurst to Prevost are also present.

678. Jan. 7-May 3I, I8I3. (357 pp.) The material in this volume relates chiefly to the battle at the river Raisin, Procter's attempt at the Miamis (May 5), the American raid upon Elizabethtown (Brockville), the British rejoinder at Ogdensburg, and the capture of York and Fort George. Accounts of all these are present, written by the British officers concerned; also several returns of men killed, wounded, prisoners taken, etc.

Besides accounts of the action at the Raisin, Harrison's instructions to D. McRechan on his mission respecting the wounded, and Judge Woodward's letter to Monroe criticizing the strategy of the commander of the U. S. forces are present as copies.

Communications from Lord Bathurst, Lieut.-Col. Gubbins (Fredericton), Capt. Roberts (Michilimackinac), Liett.-Col. Bisshopp (Fort Erie), Maj.-Gen. de Rottenburg (Montreal), Maj. Chambers (Amherstburg), Sir John Sherbrooke (Halifax), and N. Boilven (U. S. Indian agent, Portage des Sioux) contain items relating to the U. S. Apart from returns, the miscellaneous documents include resolutions of U. S. citizens of Detroit, protesting against Col. Procter's orders to leave the territory, conditions proposed as the basis of a convention between the citizens of Detroit and Col. Procter, the capitulation of York, and an agreement for exchange of prisoners between Col. Procter and Brig.-Gen. Harrison.

679. June 2-Aug. 3I, I8I3. (522 pp.) The numerous letters of military officers contained within this volume furnish accounts more or less detailed of the situation from Isle aux Noix to Michilimackinac for the above period.

The principal events described are the fall of Fort George, the fight at Stoney Creek and the subsequent retreat of the Americans, the affair at Beaver Dam, British raids upon Plattsburg, Fort Schlosser, and Black Rock, Procter's unsuccessful attempt against Fort Stephenson, the capture of the U. S. vessels Growler and Eagle, the landing of U. S. troops at York, and British preparations for attacks upon forts Niagara and George. General returns of forces, both land and naval, and numbers of killed, wounded, prisoners taken, etc., are present.

The chief correspondents on the above events are Maj.-Gens. Sheaffe and de Rottenburg, Brig.-Gens. Vincent and Procter, Lieut.-Cols. Harvey, Evans, Boerstler (U. S. A.), Bisshopp, Clark, and Murray, Majors Taylor and Holcroft, Capt. Cuvillier and Lieut. Fitzgibbon. One letter of Sir Sidney Beckwith gives a few details on the British expedition up the Potomac.

680. Sept. I-Oct. 3 I, I8I3. (367 pp.) Correspondence in this number deals with minor operations on Lake Champlain, the state of the British centre division under de Rottenburg, naval manœuvring on lakes Erie and Ontario, Procter's defeat at Moraviantown and the subsequent situation at Michilimackinac, and the battle of Chateauguay. 
Accounts of Perry's victory on Lake Erie are meagre and second-hand. Returns are rare. Material upon the situation of the various British forces with respect to supplies of every kind is abundant.

The principal correspondents upon the above topics are Maj.-Gens. de Rottenburg, Procter, and Tincent, and Capt. Bullock.

A few documents dated ISI4 on Procter's part at Moraviantown are included, and at the end of the volume is a misdated letter of Heriot, commenting upon the war up to Oct., I 8 I4.

681. Oct. 28-Dec. 30, I 8 I3. (346 pp.) The miscellaneous military correspondence in this volume relates chiefly to movements of the U. S. forces under Wilkinson and Hampton, operations on the Niagara frontier, and the state of affairs about Michilinackinac.

The letters are written by various British officers concerned in these events. Descriptions and a sketch of the engagement at Chrysler's farm, and Wilkinson's proclamation of Nov. 6 to the inhabitants of Canada are prominent features. British plans for attacks upon Buffalo and Black Rock are near the end of the volume.

682. Jan. 2-Mar. 3I, ISI4. (292 pp.) About one-third of this number is composed of letters respecting the capture of Black Rock and Buffalo, plans for destroying U. S. vessels on Lake Erie, the battle of Lacolle, British defense of the Niagara frontier, and skirmishes on the line of the river Thames. The remainder of the volume is largely filled with material on the state of the British forces, supplies, etc.

Lieut.-Gen. Drummond, Maj.-Gen. Riall, Lieut.-Cols. Harvey and Williams are the principal writers on subjects of interest to Americans. A few letters between Wilkinson and Prevost are concerned with flags of truce and the conduct of certain U. S. militia.

683. Apr. 2-June 30, I8I4. (3I5 pp.) Operations on and about Lake Ontario furnish the chief points of interest in this number. As in the preceding volume, Drummond's letters are the most important. Full details of a plan to attack Sackett's Harbor are given, as well as accounts of the capture of Oswego, a British repulse at Sandy Creek, and the American raid at Dover.

Naval movements on Lake Ontario, and secret intelligence, largely on the progress of ship-building at Sackett's Harbor, are prominent features. There are some returns, and statements of the U. S. naval force on Lake Erie, May I4, and of British vessels on Lake Ontario, June 2 .

A few communications of Capt. Pring deal with affairs on Lake Champlain, while one from Lieut.-Col. McDouall at Michilimackinac relates to the western country.

Letters of Monroe, Brig.-Gen. Macomb, U.S. A., Col. Pinckney, U. S. A., Prevost, and Adj.-Gen. Baynes deal at length with the proposed armistice. A draft of the latter is included. A report of Lieut.-Col. Nichol gives reasons why the Britisli should not attempt to obtain a naval superiority on lakes Ontario and Huron during the season.

684. Apr. 28-July 3I, ISI4. (25I pp.) Material upon the surrender of Moose Island, the battles of Chippawa and Lundy's Lane, secret intelligence, and British measures of retaliation in consequence of alleged outrages by U. S. troops fill nearly two-thirds of this volume. The principal writers are Lient.-Gen. Drummond, Maj.-Gen. Riall, and Vice-Adm. Cochrane. 
Apart from correspondence the formal documents on the surrender of Moose Island, and Vice-Adm. Cochrane's instructions of July i 8 to ships under his command respecting retaliatory measures against the coast of the U. S. deserve special mention.

685. Aug. I-Sept. 28, I8I4. (295 pp.) At least half of this book is composed of Drummond's letters, written before Fort Erie. A sketch of the sortie of Sept. I7 is included. Most of the remainder relates to British operations in Maine, the capture of Fort McKay, and events about Michilimackinac, including an account of the seizure of the U. S. vessels Tigress and the Scorpion. The chief correspondents on these events are Sir John Sherbrooke, Lieut.-Col. McDouall, and Capt. McKay.

Material on the attack at Black Rock precedes that on the siege of Fort Erie.

686. Oct. 2-Dec. 3I, I8I4. (263 pp.) Events on the Niagara frontier, the skirmish at Cook's Mills, Brig.-Gen. MacArthur's raid from Detroit, and secret intelligence from various quarters are the chief components of this volume. Lieut.-Gen. Drummond, Maj.-Gen. de Watteville, Col. Myers, and Lieut.-Col. Harvey are the principal writers.

687. Jan. 2-Apr. 24, I8I5. (232 pp.) The bulk of this volume is composed of material upon the movements of U. S. forces, secret intelligence on various matters, relations with Vermont and New Hampshire, ratification of the treaty of Ghent, and the restoration of posts. The correspondence is of a miscellaneous nature. Letters of Drummond are the most important for military affairs, and those of Monroe and the British chargé d'affaires at Washington for the diplomatic side.

688. Mar. I7-Dec. IO, I8I5. (253 pp.) The contents of this number relate almost exclusively to the mutual restoration of posts and to Indian matters in the western country. Diplomatic negotiations, as well as military correspondence, upon the former topic run parallel with the problem of readjusting the relations of both sides with the various Indian tribes.

The chief writers are Lieut.-Col. McDouall (Michilimackinac), Anthony St. John Baker (British chargé d'affaires at Washington), James Monroe, Lieut.-Gen. Murray, Maj.-Gen. Robinson, and Col. Butler, U. S. A. (Detroit).

688 A. Oct. 9, I8I I-Aug. 25, I8I2. (239 pp.) Several letters of Capt. Roberts (Michilimackinac) and one of Capt. Heald (Chicago) deal with the situation in the West. A long communication from [Judge] A. B. Woodward to Col. Henry Procter relates to religion and laws in Michigan under British rule, describes the civil government and geographical features of the territory, and encloses a detailed census signed by Reuben Attwater.

A few letters of officers at Amherstburg and elsewhere relate to details of the war. There are returns of the garrison at Michilimackinac under Lieut. Hanks, June, I8I2, of ordnance and stores taken at Detroit, Aug. I6, I8I2, and of provisions found at the Miamis. At p. 46 is the commission of Wadsworth Phillips as captain of militia in Oneida County, New York.

688 B. Aug. 26-Dec. 3I, I8I2. (206 pp.) A few letters from Col. Procter at Detroit relate to affairs in that quarter. Some communications of Col. Baynes, Maj.-Gen. Sheaffe, and Maj.-Gen. Van Rensselaer deal 
with the armistice, while those of Brig.-Gen. Smyth are upon the exchange of prisoners. The volume contains a general return of prisoners taken at Detroit, Aug. I6, I8I2, and several documents on the attitude toward U. S. citizens in Canada.

688 C. Jan. I4-Dec. 27 , ISI3. ( I 57 pp.) This volume is largely filled with claims for losses and with miscellaneous correspondence, little of which has any direct relation to the U. S. A letter of Brigade-Major McLean (Sandwich) furnishes information as to Harrison's position at the Miamis, and there is a printed general order of Dec. I2 respecting U. S. soldiers, prisoners of war, sent to England to be tried as criminals, and the retaliatory measures adopted as a consequence.

$688 \mathrm{E}$. At the end of this portfolio of miscellaneous documents are copies of the following:

A few communications from Adm. Sir J. B. Warren to Prevost, on naval affairs. I8I2.

The British minister at Washington to Sir R. S. Milnes, respecting importation of cattle from Canada to the U. S., and rumors of hostile preparations. Nov. 24, I804.

James Monroe to Sir J. B. Warren, discussing British proposals for a cessation of hostilities. Oct. 27, I8 12.

Anthony St. John Baker (British chargé d'affaires at Washington) to Prevost, on diplomatic matters and the general situation at Washington. Aug. Io and 24, I8I2.

696-699. These four volumes, covering the period of the Civil War, contain official correspondence and miscellaneous documents relating to military preparations for defense in case of attack, rumors of raids, and crimping.

722. Sir John Sherbrooke to Sir George Prevost. Escape of the Belvidera from three U. S. vessels. Halifax, June 23, I8r2.

722 A-742. Records of the Provincial Marine, I776-I845. The first two volumes have occasional references to Detroit, while numbers 728-733 inclusive contain scattered documents on the War of $\mathrm{r} 8 \mathrm{I} 2$. These consist of a few letters of Capt. Pring, Sir Gordon Drummond, and Sir James Yeo, and some returns or estimates of British and U. S. naval forces.

824. Sir John Sherbrooke to Noah Freer (military secretary to Sir George Prevost). Sends letter with enclosures respecting the capture of the Samuel and Sarah transport by the U. S. frigate Essex. Halifax, July 27, I812. (Enclosures present.)

834. Sir John Sherbrooke to Noah Freer. Defense of the Somers transport against a U. S. schooner. Halifax, Apr. I9, ISI4. (Duplicate.)

1168-1194 B. General orders. JSII-IS7o. Vols. 1168-1173 inclusive cover the War of I8r2. Very few items are of interest to Americans.

1197. General orders. New York, Sept. 25, I764-Aug. 12, I772. A few letters of Lord Dartmouth and Lord Barrington, I773-I775, relate principally to the West Indies.

This order book of Gage, comprising IO7 pp., was copied from the original in the possession of M. de Léry McDonald, of Montreal.

1198-1199. Garrison orders. Quebec, Sept. I7, I775-June I, I776. (Copies.)

1201. Garrison orders and proceedings at Fort Niagara, Nov. I 5, I8 I 2-May I2, I8I3, and Oct. IO-Dec. I6, I8I3. There is also a list of British prisoners taken at the capture of Fort George, May 27, I8I3. 
$1203 \frac{1}{2}-1203 \frac{1}{2} \mathrm{~S}$. Orderly books of various dates. Numbers $1203 \frac{1}{2}, 1203 \frac{1}{2} \mathrm{~A}$, $1203 \frac{1}{2} \mathrm{~B}, 1203 \frac{1}{2}$ E-1203 $\frac{1}{2} \mathrm{~S}$ inclusive-with the single exception of $1203 \frac{1}{2} \mathrm{P}$-contain garrison and militia orders, 1812-18I5. Vol. $1203 \frac{1}{2}$ AA has orders of the King's Royal Regiment of New York, May 14, I779-Aug. I, I780.

1205-1275. A sub-series of letter-books labelled "Old Correspondence", at one time kept in the office of the governor general's military secretary, at Montreal. These volumes extend from 1795 to 1847 , and are composed of letters from the governor or the military secretary to various military and civil officials in Canada and England. Vols. 1230, 1240,1247 , and 1263 consist of despatches on military affairs from the governor general to the colonial secretary. Apr., I8I5-Aug., I828. These may be found in the $Q$ series and are left unnoted on that account.

1218. Prevost to the Duke of York. Account of the capture of Detroit, and of previous operations in the west. Montreal, Aug. 28, I8I2.

Same to Maj.-Gen. de Rottenburg. Instructions on the employment of Indians. Montreal, Sept. 9, I8I2.

Same to the Duke of York. Various remarks on the progress of the war. Montreal, Oct. I7 and 22, I8r2.

1220. Oct. I7, I8I2-June 30, I8I3. (420 pp.) Letters from Sir George Prevost and the military secretary to Lord Bathurst, Maj.-Gens. de Rottenburg, Sheaffe, and Dearborn, the Duke of York, Col. Baynes, etc. Several give information on Dearborn's army, Procter's defeat of Winchester, and prisoners.

1221. July, I8I3-Dec. 3I, I83I. This letter-book is a continuation of the preceding one. The letters are to various military officers. Important communications relating to the war are duplicated in the $Q$ series.

1222. Nov. 4, I8I 3-Jan. 3, I8I5. (246 pp.) Letter-book containing letters from Sir George Prevost and the military secretary to Lieut.-Gen. Drummond.

The correspondence consists chiefly of comments upon military plans, and instructions.

1225. This letter-book consists of two parts. All of the letters are by Sir George Prevost or the military secretary. Those in the first part, which consists of 64 pp., extend from Feb. I7, I8I4, to Feb. I3, I8I5. They are mainly addressed to Maj. Melville, Thomas Barclay, Maj.Gens. Wilkinson, Macomb, and Izard, James Monroe, and Col. Baynes, and relate to prisoners of war, their exchange, etc., and to a proposed armistice.

The second part is composed of $3^{8}$ pp. of letters to Sir James Yeo, Jan. 3 , I8I4-Jan. 30, I815. These deal with naval matters upon the Great Lakes, and the Plattsburg expedition.

1227. Jan. 2, I814-Apr. 3, I815. (I90 pp.) In this letter-book are several letters from Sir George Prevost to the Duke of York and Maj.-Gen. Torrens (Horse Guards), giving accounts of the skirmish at Lacolle, fighting on the Niagara frontier, and Prevost's Plattsburg campaign.

1234. Lieut.-Col. Harvey to Lieut.-Gen. Murray. Instructions as to the restoration of posts to the U. S. Quebec, Apr. 6, I815. (One enclosure, letter of May 24, relates to the same topic.)

Lieut.-Gen. Drummond to Lieut.-Gen. Murray. Importation of provisions into Upper Canada from the U. S. should be allowed. Quebec, Apr. 29, I815. 
Same to Maj.-Gen. Robinson. Remarks on conduct of U. S. commanders at Amherstburg and Detroit, and the restoration of posts. Quebec, July I, I8I 5. (Letter of July 29 is upon the last topic.)

Same to same. Instructions to investigate charges from Washington that recent Indian aggressions in the U. S. were instigated by British agents. Quebec, Aug. I, I8I5. (Letter of Aug. 29 relates to the same topic.)

1236. Apr. 4, I8I5-Apr. IO, I8I6. (66 pp.) This letter-book contains despatches from Lieut.-Gen. Drummond to Anthony St. John Baker, British chargé at Washington. The greatest part of this correspondence is concerned with the restoration of posts. Other topics are the alleged instigation of western Indians to acts of hostility against the U. S., enlistment of British deserters in the U. S. army, the possession of Bois Blanc Island, the purchase by New York of islands in the Niagara River belonging to the Indians, the conduct of the U. S. commander at Detroit, and a few minor subjects, such as the detention of boats, thefts, etc.

1242. T. F. Addison, nilitary secretary, to Maj.-Gen. Wilson. Instructions to prevent interference of British officers with $U$. S. vessels on the Lakes. Quebec, Nov. I9, I8I6.

Same to Maj.-Gen. Widdrington. Orders for Col. Evans not to interfere with the Americans at Bois Blanc Island.

1244. July I5, I8I6-July I4, I8I8. (I3 pp.) Despatches from Sir John Sherbrooke to the British minister at Washington.

The subjects are the restoration of islands in Passamaquoddy Bay to the U. S., various Indian matters, and negotiations respecting the fisheries. Replies to these communications may be found in M 157.

1246. T. F. Addison to Maj.-Gen. Smyth. News respecting negotiations on the fisheries. Quebec, Sept. 21, I8I6. (Confidential.)

Sir John Sherbrooke to the Earl of Dalhousie. Moose, Dudley, and Frederick islands to be handed over to the U. S. Quebec, May 27, I8IS.

1254. Maitland to the British chargé d'affaires at Washington. Alleged inducements held out by Americans to British soldiers to desert. Quebec, Aug. I8, I8I9. (Two enclosures.)

1272. Sept. 22, I837-Aug. 29. I838. (I 57 pp.) Letters from Sir John Colborne to the British minister at Washington, Sir Colin Campbell, Col. Foster, Gov. Marcy, Sir F. B. Head, Lord Glenelg, Brig.-Gen. Wool, U. S. A., Lord Fitzroy Somerset, etc. This material deals with the Canadian rebellion, incursions from the U. S., and diplomatic correspondence connected with the same.

1278. Colborne to Lord Fitzroy Somerset (military secretary to the commander-in-chief). News of efforts of the U. S. authorities relative to manifestations against the Canadian frontier. Quebec, June 26, I83S. (A private and confidential letter of Oct. 20 deals with the same topic.)

1671. This unpaged portfolio contains correspondence of British officers at Halifax with the WVar Office, telegrams of the general officer in command at Halifax, and reports. All of this material relates to movements of troops in Canada, frontier defense, etc., in I86I and I862, as a result of the Trent affair.

1672. This large portfolio is composed of telegrams and correspondence on the Fenian raids of 1866 and 1870 . Telegrams are numerous, and 
relate chiefly to the events of I866. Correspondence is largely of a local character. There are important letters from officers at St. Armand, Fort Erie, I866, and Eccles Hill, i870.

1703. About $25 \mathrm{pp}$. of this volume are filled with records of the militia of Essex County, Upper Canada, I787-I794. Most of these are lists of militia and of inhabitants. Much of this material relates to Detroit and the surrounding country.

1705-1712. Freer papers. I786-I868. With a few exceptions these volumes are composed of the papers of Capt. Noah Freer, military secretary to Gov.-Gen. Prevost. Numerous returns-largely of Canadian militiaand correspondence form the bulk of the set. Besides items relating directly to the U.S. there are several papers showing the state of British forces in Canada, prisoners taken, fortifications, etc., at various times during the War of 1812 .

1705. At p. Io begins a fifty-page statement concerning Upper Canada, dated I800. A large portion of it is devoted to a discussion of relations with the U.S. over the western posts, the Indians, and various notes upon Niagara, Michilimackinac, St. Joseph, etc.

Extracts from the report of Capt. Hughes, of Dec. I6, I808, on the roads of communication from the district of Montreal to New York and Vermont.

1707. Draft of an armistice. n. d. [I8I2].

Statement of the U. S. army at Champlain. Nov. 20, 1812.

E. B. Brenton to Freer. Account of the British attack upon Sackett's Harbor. Kingston, May 30, I8I3.

1708. "A List of Non Commissioned Officers American Prisoners of War, confined on Board of Prison Ships." Oct. 2I, I8I3.

A list of U. S. officers on parole at Beauport. Oct. 2I, I8I3.

Return of U. S. prisoners of war in Montreal. Dec. I, I8I3.

1709. Unsigned, undated account of Wilkinson's army at the French Mills. (I8I4.)

Prevost's proclamation to U. S. citizens. Champlain, Sept. I, I8I4.

Comparative statement of the flotillas on Lake Champlain. Sept. II, I8I4.

Capt. Anderson to Lieut.-Col. McDouall. Account of the recent fight at Fort McKay, and the general situation there. Fort McKay, Sept. I4, I8I4.

1713. Orderly book. Quebec, Sept. I7, I775-June 1, 1776. (135 pp.)

\section{SERIES E: PRIVY COUNCIL DOCUMENTS.}

In 1907 there came to the Archives from the Privy Council office at Ottawa loose papers which ultimately filled more than seven hundred portfolios, and over three hundred original bound volumes of varying size and importance. The entire collection centres about the "State Books". This name is applied to about one hundred and ten bulky folio volumes containing original minutes of the legislative or executive councils of Upper Canada and Lower Canada from August, 1764 , to the confederation of $1867 .^{1}$ Elaborate indexes are in separate volumes.

${ }^{1}$ Quebec had only a legislative council until after the Quebec Act. The minutes of the privy council (or executive council) of Quebec begin in August, I776, and those of the legislative council extend to the close of April, I79I. 
The minutes relating to each province are for the most part kept in separate series. These records are again subdivided into minutes of the council on crown lands and minutes of the council on state affairs. This distinction is preserved in series of "Land Books" and "State Books" for each province.

Council minutes on crown lands are of interest to Americans only so far as they relate to Loyalists. Books " B" " C", and " $\mathrm{F}$ " are missing for Lower Canada " D", June I5, I795-March 22, I800, and " $E$ " are present. A volume labelled "Quebec Land Book" covers the period February I7, 1787December 24, I79I, and has many items relating to Quebec, although the greater portion is concerned with early land grants in Upper Canada. Therefore part of the records on Loyalists in Lower Canada must be sought in files of petitions and correspondence and in series $Q$.

Council minutes on state affairs contain many items relating to the United States, but on the other hand practically everything bearing on international relations was copied and sent in the form of enclosures in despatches from the governors general to the Colonial Office. Such items, therefore, will be found in series $G$ and $Q$.

In addition to the State Books themselves there is a large quantity of loose papers which belongs to them. Petitions and correspondence on land matters and state affairs, documents of land commissioners, land certificates, etc., for Upper Canada fill about seven hundred portfolios. Nearly all of these are upon land matters. Petitions and accompanying correspondence are arranged alphabetically and chronologically, and cover the period r789-1867. Thirty portfolios contain land grants arranged alphabetically by townships; these bear dates subsequent to Loyalist immigration. ${ }^{2}$

Eighty-six large portfolios bear the title "Orders in Council". One number extends from I788 to I8I7; the remainder cover the period I84I-I867. They are largely composed of comnittee reports.

Seventy-five large portfolios of "Proceedings in Council" fall within the years I84I-I866, and consist chiefly of correspondence.

Eleven large portfolios of rough Council minutes, reports, etc., extend from 1788 to 1840 , but are very incomplete.

About thirty small portfolios contain English despatches referred to the executive council, I844-I867. These are duplicates of some in series G.

Sixteen large portfolios are filled with muster-rolls, pay-lists, and general accounts of Canadian militia, I8I2-I8I5. There is no record showing how these anomalous papers came to be embodied with the others.

About 200 miscellaneous volumes complete the list of material received from the Privy Council office. These are principally letter-books of various kinds, land records, rough Council minutes, etc. A few contain copies of despatches or correspondence of civil secretaries, duplicating-and in a few cases supplementing-certain parts of series $\mathbf{G}$ and $\mathbf{Q}$. These volumes were placed upon the shelves without any attempt at arrangement. The three noted below have been listed in the order in which they now stand, and under the original numbers which in most cases are burned on the backs of the volumes.

33. Dec. 22, I838-Apr. 25, I839. (I 58 pp.) Letter-book of John Macaulay, secretary to the governor. Letters to various persons, several of which relate to actions of Canadian rebels and their sympathizers in the U.S. Emphasis is placed upon the situation at Cleveland, Sarnia, and Oswego.

No number. Detroit quit-rents. I770-I 78 I. Lists of names.

${ }^{1}$ For land papers of Lower Canada, and others belonging to Upper Canada, see series $\mathbf{S}$. 
163. United Empire Loyalist list. (Residence, descendants, etc. Contains the same names as $\mathbf{M} \mathbf{1 8 5}$, but they supplement each other as to details.)

SERIES F: TRANSCRIPTS FROM PARIS.

This series is composed of documents copied from French archives, and therefore relates to the French period of Canadian history. All of these records which concern the United States are treated in W. G. Leland's forthcoming Guide to the Materials for American History in the Archives of Paris. The object of the following report is to indicate briefly what has been accomplished in France by agents of the Dominion Archives and the amount of copying to the present time (I9I2).

In 1873 the Abbé Hospice Verreau was appointed to investigate the sources of Canadian history in Europe. Being linited as to time he hastily glanced over certain records at the Bibliothèque Nationale, the Archives Nationales, the Ministry of Marine (which then contained the Archives des Colonies), summarized a few volumes at the Ministry of Foreign Affairs, and also visited some of the departmental archives.

In I883 Joseph Marmette resumed this work at Paris. The results are published in the Canadian Archives Reports for I883, I885, I886, and I887. With him began the exploitation of the riches of the Archives des Colonies. Other archival depositories were examined, but little was done in a systematic way with regard to them.

The Report for 1883 has a synopsis of a few volumes at the Ministry of Foreign Affairs, and those for 1885 , I886, and 1887 contain analyses of the greater portion of series $\mathrm{C}^{\mathbf{1 1}}$ (correspondence received from Canada) of the Archives des Colonies. These may be called calendars, but calendars of a peculiar kind. They are unsystematic, replete with inaccuracies, and the space given to the summary of any document depends rather on interest or caprice than on any settled plan of impartial analysis. As a matter of fact these summaries were probably made with two ends in view : to arouse interest in the documents, and to afford a guide for copyists.

In I898 Edouard Richard was appointed as Marmette's successor at Paris. He devoted his time even more exclusively to the Archives des Colonies. His work appears in a special Archives Report for 1899, in the Report for I904, appendix $\mathrm{K}$, and in that for I905, part vr. It consists of summaries of documents relating to Canadian history in some parts of series $C^{11}$ unfinished by Marmette, and of 189 volumes of series B (letters sent to Canada). This calendaring, though somewhat erratic, and emphasizing especially Acadian matters, is much fuller than that of Marmette.

Since the appointment of $\mathrm{Mr}$. H. P. Biggar as agent of the Dominion Archives in Europe further research in series already treated by Marmette and Richard has revealed many documents relating to Canadian history which had been overlooked by those investigators. ${ }^{1}$

The volumes copied may be indicated as follows:

\section{Archives des Colonies.}

Series B. Lettres envoyées. Vols. 1-189 calendared by Richard. Copies of vols. 1-67 inclusive are at the Archives.

Series C $C^{11}$. Correspondance Générale, in several sub-series: "Canada ", I24 volumes and 2 cartons. Analyzed by Marmette in Reports for 1885, I886, and I887. Entirely copied.

\footnotetext{
${ }^{1}$ For a fuller statement of the work done in France by the various agents of the Dominion Archives, and of the volumes copied, see J.-E. Roy, Rapport sur les Archives de France relatives à l'Histoire du Canada (Ottawa, IgI I), passim.
} 
"Acadie", Io volumes. Analyzed by Marmette in the Report for 1887. Copied.

"Règlements des Limites", etc., I6 volumes. Analyzed by Marmette in the Report for I887. Copied.

"Ile Royale", 38 volumes. Analyzed by Marmette in the Report for I 887. Copied.

"Ile Royale et Terreneuve." A continuation of the preceding sub-series, but under new numbers. Vols. 8-10 were analyzed in the Report for I887, and have been copied.

"Terreneuve", 7 volumes. Analyzed in the Report for I887. Copied.

Raudot-Pontchartrain correspondence, etc., I2 volumes. Analyzed in the Report for I899. Copied.

Series $C^{13}$. This series relating to Louisiana is composed of 54 registers and I carton. Three numbers are analyzed in the Report for I 899 .

Series $D^{2}$ (military). Numbers 2, 3, 4, 17, 18, 43, 44, 49, 52, 53, 58, 59, 222 are mentioned or analyzed in the Report for IS99, and have been copied.

Series $\mathrm{F}^{2}$. Missions Religieuses (vols. 2 and 3 ) are analyzed in the Report for IS99, and have been copied.

Series $F^{3}$. Collection Moreau de St. Méry. Vols. 2-16, 24, 25, 50, 51 are calendared in the Reports for I899 and I905, and, with the exception of vol. 25, have been copied.

Series G. Vols. 406-411, 458, 460, 461, 464-467, 482-493 of sub-series $G^{1}$ (judicial records) have been copied. Nearly all of these were pointed out by Richard in the Reports for I899 and 1905 .

\section{Archives Nationales.}

Marmette (I883) summarizes certain documents in series E(arrêts du Conseil d'État). Numbers $3492-3495$ of series $F^{15}$ have been copied; also series K, no. 1232, series M, nos. 200 and 204 and series MM, no. 493.

\section{Ministry of Foreign Affairs.}

Vols. 4-11, 17, 20 of "Mémoires et Documents", series "Amérique", have been copied, as well as vols. 1-11 of "Correspondance Politique", series "Etats-Unis" and 35, 36, 41, 43, 44, 45, 63 of "Angleterre"; see Can. Arch. Rept., I9I2, apps. D, L.

\section{Bibliothèque Nationale.}

Selected documents have been copied from the following volumes of Manuscrits Français (Ancien fonds) , 4569, 4826, 4925, 5085, 5503, 5644, 5653, 5682, $6349,6453,6569,6800,7516,7800,8022,8027,8028,8036,8038,8973,8974$, $8989,9097,9557,9773,10207,10569,11248,11319,11321,11332,11340$, $11342,11735,12081-12085$.

One sub-series in F, consisting of official correspondence of governors and intendants of Canada and beginning in 1637 , was copied from the Faribault Collection possessed by the Literary and Historical Society of Quebec.

A considerable force of copyists is still at work at Paris, and the data here given are to be understood as representing only the present state of a somewhat rapidly increasing total.

\section{SERIES G: GOVERNOR GENERAL'S PAPERS.}

This series of original despatches was obtained in part from the governor general in 1904, in part from the department of the secretary of state. From the viewpoint of either Canadian or United States history these documents 
form what is perhaps the most important collection at the Archives. The following is an analysis of the series. Numbers 1-267, 274-316, and 342-359 are original despatches in portfolios which will average about 350 pages each (with the exception of $2 \% 4-309$, which are bound in volumes). These came from the governor general. The remainder of the analyzed portion consists of letter-books, most of which came from the department of the secretary of state.

1-51. Despatches from the colonial secretary to the governor of Lower Canada. I787-Feb., I84I.

52. Drafts of despatches from Sir J. H. Craig to the colonial secretary. 1807.

53-95. Despatches from the colonial secretary to the lieutenant-governor of Upper Canada. I796-I84r.

96-107. Enclosures of despatches from the lieutenant-governor of Upper Canada to the colonial secretary. Apr., I838-Feb., I84I.

108-180. Despatches from the colonial secretary to the governor general. Mar., I84I-Dec., I867.

181-183. Instructions to various governors. I79I-I 843 .

183 A. Drafts of letters to Lord Bathurst. I8I2-I820.

184-221. Drafts of despatches to the colonial secretary from the governor general. I8 35, I 838, I839, I840, I84I, and Jan., I842-I867.

222-239. Despatches from the British minister at Washington to governors and lieutenant-governors of Canada. I8I5-I868.

240, 248. Drafts of letters from the governors general to lieutenant-governors and others. I839-1855, I860-I866.

241,249 . Drafts of letters from the governor general's secretary to various persons. I840-1842, I844, I845, I848, I860-I866.

242. English parliamentary papers on Canadian matters. I853-1867. (Printed.)

243-247. Drafts to the colonial secretary on various subjects. I832-I85I.

250-252. Despatches from Sir George Arthur to Lord Sydenham. Oct., I839-Mar., I84I.

253-254. Indexes of despatches from the colonial secretary to the lieutenantgovernor of Nova Scotia. I855-July, I867.

255. Index of despatches from the lieutenant-governor of Nova Scotia to the colonial secretary. I855-Aug., I867.

256. Despatches to liettenant-governors of Nova Scotia and others. I839I867. (Miscellaneous correspondence, some of it being with Downing Street.)

257-262. Despatches from the lieutenant-governor of New Brunswick to the governor general. July, I838-1847.

263-266. Drafts of letters from the Emigrant Office to the chief secretary (civil secretary of the governor general). I840-1845.

267. Drafts of letters from the chief secretary to the Emigrant Office. Jan., I84I-Aug., I843.

268-271. Letter-books of despatches from lieutenant-governors of New Brunswick, Nova Scotia, Upper Canada, and the British minister at Washington to the governor general. Aug., I840-Oct., I842.

272. Various documents relating to Nova Scotia, Upper Canada, and Prince Edward Island. I82I.

273. Register of despatches (sent to the lieutenant-governor of Prince Edward Island) in the office of the colonial secretary. June, I77IOct., 1868. 
274-315. Despatches from the colonial secretary to the lieutenant-governor of Prince Edward Island. I77I-July, I873. (Folders 293-300 also have interprovincial despatches, and nos. 293-297 despatches from the British minister at Washington.)

316. Drafts of despatches to and from the colonial secretary, the governor general, and lieutenant-governors. (Prince Edward Island.) I826I873.

317-329. Despatches from the lieutenant-governor of Prince Edward Island to the colonial secretary. I8I3-Aug., I873.

330-335. Schedules of despatches and acknowledgments of parliamentary publications (Prince Edward Island). I85I-I873 and I868-I873.

336. Despatches from the governor general to the lieutenant-governor of Prince Edward Island. I859-May, I867.

337. Despatches from the lieutenant-governors of New Brunswick and Nova Scotia to those of Prince Edward Island. I859-June, I867.

338. Letters to Lieut.-Gov. Dundas. I855-IS68.

339. Despatches from the governor of Newfoundland and from the British minister at Washington to the lieutenant-governor of Prince Edward Island. I858-I868.

340-341. Imperial orders in Council relating to Prince Edward Island. I769I 846.

342-346. Despatches from the colonial secretary to the governor of Vancouver Island. I846-1867.

347-359. Despatches from the colonial secretary to the governor of British Columbia. I858-I871.

360-362. Despatches from the governor of Vancouver Island to the colonial secretary. Oct., 1858-Apr., I864.

363-365. Despatches from the governor of British Columbia to the colonial secretary. Apr., I864-July, I87I.

\section{LETTER-BOOKS. ${ }^{1}$}

366. Correspondence of the lieutenant-governor of Upper Canada and of his secretary. Dec., I837-Mar., I838.

367-368. Registers of the private secretary's correspondence. I844-I846, I 828-I 829 .

369-373. Despatches from lieutenant-governors and administrators of Upper Canada to the Treasury. I796-I 834 .

374. President Grant's (Upper Canada) Canadian correspondence. Sept. 24, ISO5-Sept. 3, ISo6.

375. Letters of the civil secretary and of the Indian Department, Upper Canada. Sept. 2, ISo6-Oct. 5, I8I6.

376. Letters from the Treasury to Lieut.-Gov. Hunter. Dec., I799-Dec., ISO4.

37\%-408 C. Despatches from the governor of Lower Canada to the colonial secretary. I8I $5-J u n e 2 \%, 186 \%$.

409. Letter-book of Lord Dorchester. Aug., I $788-J u l y$, I 79 I.

410-4.18. Letter-books of various governors, lieutenant-governors, etc., of Lower Canada. I805-1839. (A few gaps.)

419-421. Despatches of the lieutenant-governor of Upper Canada to the governor general. Aug. 21, 1818-Dec. 24, I840.

\footnotetext{
${ }^{1}$ Practically all the letter-books containing material on United States history have chronological indexes showing the purport of the documents.
} 
422. Despatches to and from various persons, including some from the British minister at Washington to Gov. Gen. Thomson.

423. Despatches from the governor general to lieutenant-governors in $\mathrm{Br}$. N. America. Nov. I, I839-Sept. 7, I842.

424-461. Letter-books of the governor general's civil secretary. Mar., I794I867. (Name index only.)

462. Letter-book of the civil secretary and the attorney general of Lower Canada. Apr. 9, I808-Jan. I6, I809.

463. Letter-book of the governor's military secretary. Jan. II, I842-Mar. $29, \mathrm{I} 843$.

464-465. Letter-books of the governor's private secretary. June I, I844Dec. 5, I 845 .

466-497. Despatches from the lieutenant-governor of Upper Canada to the colonial secretary. July 24, I799-Feb. I9, I84I.

498-504. Abstract and classification of despatches from the lieutenant-governor of Upper Canada to the colonial secretary. Jan. 6, I820-Dec., I839.

505. Index to despatches of the colonial secretary. I840-I84I.

506. Index of despatches from the colonial secretary to the governor, etc., of Lower Canada. I786-1839.

507-533. Despatches from the colonial secretary to the governor of Lower Canada (to the governor general after the union). Jan., I8I 5-Apr., 1855 .

534. List of despatches from the colonial secretary to Sir James Kempt. July I2, I838-Aug. I, I840.

535. List of despatches from Sir James Kempt to the colonial secretary. Sept., I828-July, I831.

536. Addresses to C. P. Thomson. I839-1840.

537. Despatches from the British minister at Washington to the lieutenantgovernor of Upper Canada. I799-I807.

538. Despatches from the lieutenant-governor of Upper Canada to the British minister at Washington. Mar. 2, 1839-Feb. 6, I84I.

539. Despatches from the colonial secretary to the governor, etc., of Lower Canada. July I7, I793-Mar. 5, I806.

It will be seen from the above that this series comprises a fairly complete collection of despatches between the colonial secretaries and the governors, lieutenant-governors, and administrators of Canada from I800 to I867. A few original despatches anterior to 1800 are present, and there are some gaps in the sub-series of letter-books of despatches from Upper Canada and Lower Canada. These last despatches may be found almost complete in the $\mathbf{Q}$ series for the dates it covers: but despatches from England-with the exception of the sub-series copied later-only extend in full series to about I8I2 in $Q$, and from that point are very few in number until the last part of the series. ${ }^{1}$

A fragmentary series of duplicate despatches and enclosures from governors, etc., in Canada to the colonial secretaries is a recent acquisition of the Archives. These records partially duplicate certain portions of $\mathbf{Q}$, and have practically the same value as originals. Eleven portfolios cover the period I77I-I80o and twenty-five volumes that of I813-I840 for Lower Canada; for Upper Canada (and the united province from I84I) despatches of the years

\footnotetext{
${ }^{1}$ Despatches from England which are in $Q$ are, moreover, either drafts or duplicates. For a fuller description of the character of $\mathbf{Q}$, see the introduction to that series.
} 
I79I-I800 are included in one portfolio, and those for I8I6-I824, I827-I847 in twenty volumes. An examination of several numbers showed that many despatches are missing, and that occasionally the arrangement varies somewhat from that of $Q$.

Special collections, such as the Bagot Papers in series $\mathbf{M}$, and the Haldimand Papers, contain numerous despatches.

In the face of such variance and duplication it will be necessary to keep two facts constantly in mind. First, none of these series is entirely complete. Despatches in G are frequently missing, as the numbers show. Deficiencies in $Q$ have been noted above and in the special treatment of that series. Neither is the later sub-series of despatches in $Q$ complete, and dates, etc., are occasionally at variance between it and $G$. Secondly, a despatch may often be found in several places: those from Haldinand to Germain appear twice in series $B$, once in series $Q$, and also in the duplicate despatches; those of Bagot may be found in the Bagot Papers, in various parts of $G$, and among duplicate despatches; communications from the colonial secretary to Lord Gosford appear twice in $\mathrm{G}$ and twice in Q, while the latter's replies are also in each of these series as well as in the duplicate despatches.

In view of the foregoing it became necessary to adopt for the present manual a definite plan of attack. All original despatches in $\mathrm{G}$ have been checked from the printed calendar of $Q$, and only those papers listed which did not appear in the latter; the letter-books were also checked from both $Q$ and other parts of $G$ wherever necessary, and despatches concerning the United States in any way, which had not been found elsewhere, were noted.

In the case of $Q$ the nncalendared part was checked by $G$, and only those items listed which are missing from the latter; while for the recent sub-series of despatches in $Q$ the only ones noted were those which are neither in $G$ nor in the calendar of $Q$. Thus in every case $G$ was used as a basis whenever possible.

When we come to the Maritime Provinces-Nova Scotia, New Brunswick, and Prince Edward Island-the problem is much simpler. In $\mathrm{G}$ are original despatches from the colonial secretary to the lieutenant-governor of Prince Edward Island, I77I-I873, and letter-books of replies, I8I3-I873; but no similar materials for Nova Scotia or New Brunswicl. Copies of state papers of all the Maritime Provinces for various periods are in series $\mathbf{M}(q . v$.$) .$ They are similar in character to series $Q$.

Despatches for British Columbia (including Vancouver) are in $\mathrm{G}$ alone. A few scattered items exist in $\mathbf{M}$, but they are lacking in continuity.

About I 40 unnumbered portfolios came from the office of the governor general's secretary, and contain correspondence addressed to that official. For the most part these files extend from I84I to I865. 'The covers are marked "G", but sometimes these documents are referred to as series GS. An examination of a few portfolios showed nothing relating to the United States.

G 1. Grenville to the governor of Quebcc. Sends copy of order in Council of May 20, I 999 , on the importation of provisions from the U. S. into Quebec and the countries bordering on the Gulf of St. Lawrence. Whitehall, June 6, I-89. (Circular. Enclosure present.)

Same to same. Sends order in Council of Mar. I3, allowing conditional importation into Newfoundland from the U. S. for the ensuing season only, of bread, flour, and corn. Whitehall, June 6, I789. (Circular. Enclosure present.)

3. Castlereagh to Craig. Sends order in Council of May Is declaring that information of the order in Council of Nov. I I, I807, shall be 
held to have been received in all places in N. and S. America between ten and thirty degrees of north latitude by Feb. Io, I808. Downing Street, May 2I, I808. (Circular. Enclosure present.)

4. Liverpool to Prevost. Sends documents on the injury to direct trade between England and the British N. American colonies by the introduction of East India and other foreign commodities from the U. S. into those colonies. Instructions. Apr. 6, I8I I. (Enclosed are three letters and one memorial from merchants. Similar letter to Craig, in same volume, and one to Lieut.-Gov. Gore in G 56.)

5. Peel to Prevost. Sends order in Council of June 23. June 25, I8I2. (Circular. Enclosure present.)

Bathurst to Prevost. Sends order in Council of July $3 \mathrm{I}$, respecting American ships, etc. Aug. I, I8I2. (Circular. Enclosure present.)

Same to same. Sends order in Council on general reprisals against the U. S. Oct. I3, I8I2. (Printed circular. Enclosure present. Similar letter to Brock, followed by authorizations to issue letters of marque.)

Same to same. Sends documents on returns of American property captured at foreign stations. Nov. 24, I812. (Circular. Three enclosures.)

6. Bathurst to Prevost. No. 3I. Sends report from Committee of Council for Trade and Foreign Plantations on bill passed by the legislature of Lower Canadla, respecting duties during the war. June 9, 18i3. (Duplicate. Report in place.)

Same to same. No. 48 . Believes that the same spirit of emigration that in recent years has drawn so many of the Scottish peasantry to the U. S. still prevails in the Highlands. Proposes to divert them to Canada. Oct. 29, I813. (Copy.)

Same to same. No. 62. Remarks on the confinement of certain prisoners and the attitude of the Americans toward such a course. Mar. 5, I8I4. (Copy.)

Same to same. No. 79. Favors land grants along the frontier to men of certain regiments. Would serve as a protection and barrier. Sept. I5. I8I4. (Duplicate.)

7. Bathurst to Drummond. Remarks on emigration to Canada and the U. S. June 13, I815. (Duplicate.)

Same to same. Emigration to Canada and the U. S., steps to protect Upper Canada from future American invasion, etc. July I2, I8I5.

Same to same. Remarks on the restoration of Michilimackinac, the boundary, Indians, etc. Oct. IO, I8I5.

Same to same. Latter's regulations for renewing commercial intercourse between Canada and the U. S. have been approved. Nov. I5, 18I5. (One enclosure.)

Same to Maj.-Gen. Wilson. Orders to leave the frontier between Montreal and Lake Champlain " as much as possible in a state of nature". Nov. I6, I8I5.

8. Bathurst to the officer administering the government of Canada. Military officers to be warned against political correspondence with civil or military authorities of the U. S. without the approval of the governor. Mar. 3, 18i6. (Duplicate.)

Same to Drunmond. No settlement to be made at present at any place likely to become an object of dispute by the British and the U. S. governments. May 31, I816.

Same to Sherbrooke. No. 6. Relative to leaving in a state of nature that 
part of the frontier between Lake Champlain and Montreal. Instructions on settlements already effected. July I, I\&I6.

Same to same. No. 8. Instructions on commercial relations with the U. S. July 4, I8I6.

Same to same. Conduct of the U. S. toward the Indians. Oct. 3I, I8I6. (Private.)

9. Bathurst to Sherbrooke. No. 67. Defense and the Canadian and U. S. militia. Feb. 5, I8I7.

Same to same. No. 94. Sends instructions respecting American vessels fishing on the coasts of the British provinces in N. America. May I3, I8I7. (Duplicate. Enclosure present.)

Same to same. No. I I4. Remarks on commercial regulations, etc. July 5, x 8 I 7 .

Same to same. No. I21. Commercial regulations. Aug. 13, I8I7. (One enclosure.)

10. Bathurst to Sherbrooke. No. I48. Orders to give due facility to the re-establishment of an American settlement upon the Columbia River. Feb. 6, I8r8. (One enclosure.)

Same to Richmond. It is reported that Lake Erie can be so lowered as to render the projected canal useless. Orders to ascertain if this be true. Oct. I5, I8IS. (Confidential. One enclosure.)

Same to same. No. 22. Commercial relations between Quebec and the U. S. Apr. 7, I8Ig. (Two enclosures.)

11. Bathurst to Dalhousie. Instructions on the importation of corn, meal, or flour, from the U. S. into Canada. June I4, I82O.

Same to same. Frontier townships between Montreal and Lake Champlain can now be settled. Aug. 8, I82I.

12. Bathurst to Dalhousie. Relative to claim made by the U. S. to Carleton Island. Jan. I2, I822.

Same to same. Remarks on navigation through the Long Sault Islands, arbitration, etc. Mar. 12, I823. (Private.)

Same to same. Sends documents relative to survey of part of the St. Lawrence. Mar. I4, I823. (Two enclosures, pertaining to the boundary question.)

Same to same. Sends order in Council of July 2I, respecting duties on American vessels and cargoes. July 3r, is23. (Circular. Enclosure present.)

Same to same. Sends documents urging change in duty upon leather exported from the U. S. into Lower Canada. Dec. 24, I823. (Three enclosures.)

13. Bathurst to Dalhousie. Has sent to the Secretary of State for Foreign Affairs documents respecting the U. S. claim to free navigation of the St. Lawrence. Aug. 27, I824.

Same to Burton. Certain islands in the St. Lawrence to be evacuated in compliance with the decision of the commissioners. Oct. I8, I824. (Two enclosures.)

16. Bathurst to Dalhousie. Relative to importation and warehousing of American flour for exportation to the West Indies. Mar. 2I, I827. (Two enclosures. Ariother letter on the same subject, with several enclosures, on Apr. 28.)

Goderich to same. Remarks on proposed road from the St. Lawrence to the frontier of New Brunswick, as affected by the boundary dispute. July I4, I827. (Private and confidential.) 
Huskisson to same. Remarks on the Northeastern Boundary. Orders to have a survey of part of the country. Oct. 5, 1827. (Confidential.)

17. Murray to Dalhousie. No. I3. Remarks and instructions as to islands in the St. Lawrence and lakes Ontario, Erie, and Huron awarded to either country by the commissioners under the sixth article of the treaty of Ghent. July $3 \mathrm{I}, 1828$. (Several enclosures.)

19. Murray to Kempt. No. 79. Approves of latter's conduct in extradition matter. Oct. 5, I829.

20. Murray to Kempt. Sends first statement of Great Britain of the disputed points under the fifth article of the treaty of Ghent. Remarks. Apr. 8, i83o. (Confidential. Enclosure missing. Two letters of same date upon this subject.)

21. Murray to Aylmer. Sends order in Council of Nov. 5, on opening of English ports to U. S. vessels. Remarks. Nov. IO, I830. (Circular. Five enclosures. Also in G 280.)

Goderich to Aylmer. Relative to the protective duties to be established on opening of intercourse with the U. S. Dec. 8, 1830. (Circular. Also in G 280.)

22. Goderich to Aylmer. No. I8. Sends decision of the King of the Netherlands upon the boundary question and Preble's protest against it. Remarks. Jan. 27, I83I. (Enclosures present.)

Same to same. Sends copy of a confidential letter to Sir James Kempt upon the U. S. boundary question, and a copy of his reply. Jan. 27, I831. (Confidential. Enclosures present.)

Same to same. Sends draft of bill respecting trade relations with the U. S. Remarks. Feb. 9, I83I. (Draft present. Similar letter to Colborne in $\mathrm{G} \mathrm{67.)}$

23. Goderich to Aylmer. No. 68. Sends despatches with enclosures, showing the views of government on recent relations between New Brunswick and Maine. Remarks. Nov. 5, I831. (Two enclosures, containing in all eight letters.)

25. Howick to Aylmer. Sends documents on the rejection by the U. S. Senate of the award of the King of the Netherlands on the boundary question. Remarks. Sept. 22, I832. (Three letters enclosed.)

27. Stanley to Aylmer. Sends correspondence relating to recent encroachments made by Maine on New Brunswick. Instructions. Feb. 28, I834. (Copy. Confidential. Six enclosures.)

30. Glenelg to Gosford. No. 3I. Remarks at length upon certain proceedings of New Hampshire in the disputed Indian Stream territory. Instructions. Dec. I2, I835.

31. Glenelg to Gosford. No. 97. Sends correspondence and memorial on the admission of U. S. reprints of English works into the Canadas. June 25, I836. (Enclosures present.)

34. Glenelg to Gosford. No. 219. Sends correspondence relating to the U. S. protest against further progress of the Quebec and St. Andrews railroad. June 8, I837. (Enclosures present. Separate despatch of same date also relates to this subject.)

38. Glenelg to Colborne. No. 7. Relative to importation of arms into Canada through the U. S. Jan. 6, I838. (One enclosure.)

Same to same. No. I8. Brief remarks on defeat of insurgents entering Canada from Swanton, Vermont, by the Missisquoi Volunteers. Jan. 30,1838 . 
Same to same. News of band of Canadians and Americans under Mackenzie at Navy Island. Instructions. Jan. 30, I 838 . (Separate.)

Same to same. No. I9. Sends letter on secret committees said to have been established in various places to aid Canadian insurgents. Feb. 4, I838. (Enclosure present.)

Same to same. No. 2I. Tarious remarks on part taken in the rebellion by U. S. citizens and the attitude of that government. Feb. 6, I838.

Same to same. No. 30 . Increase in military force in Canada as result of "the proceedings of certain citizens of the States bordering on H. M. Canadian Possessions". Feb. 22, I838.

Same to same. No. 3I. Approves steps taken to regain possession of Navy Island. Feb. 22, I 838 .

Same to same. No. 44. Remarks on assistance to insurgents of Lower Canada by citizens of New York and the attitude of the U. S. government toward the rebellion. Instructions. Mar. I4, I838. (No. 47, of Mar. I7, also relates to this topic.)

Same to Durham. No. 2I. News of recent attempts by U. S. citizens to invade Canada. Instructions. Apr. 21, I838. (Duplicate.)

Same to same. No. 26. Approves of Sir John Colborne's conduct toward some Canadian refugees in the U.S. Apr. 27, I838. (Duplicate.)

39. Glenelg to Durham. No. 49. Remarks on Aaron Vail's mission to Canada on behalf of $\mathrm{U}$. S. citizens who may be imprisoned there as a result of the late troubles. May 29, I838. (Duplicate. Similar letter to Arthur in G 85.)

Same to same. No. 56. Sends letter on Canadian affairs, addressed to Durham by the British consul at New York. June 3, I838. (Enclosure makes several comparisons.)

Same to same. Sends despatch from the British minister at Washington upon the state of the U. S. navy. July 4, I 838 . (Confidential. Enclosure present as a report with several enclosures.)

Same to same. No. 66. Remarks on destruction of the British steamboat Sir Robert Pecl by an armed party from the U. S. July I2, I838. (Duplicate.)

Same to same. No.67. Remarks on measures for the protection of the frontier. July I 3,1838 . (Duplicate.)

Same to same. No. 75. Remarks on attitude of the U. S. government toward American citizens aiding in the Canadian rebellion, and on the agreement of I8I7 as to British and U. S. forces on the Lakes. July 20, I838. (Duplicate. Two enclosures on latter topic. Similar letter to Lieut.-Gov. Arthur on the second topic is in G 83.)

40. Glenelg to Durham. Sends letter from the English consul at Portland, on the proposed erection of certain military works in Maine. Aug. 3I, I838. (Confidential. Duplicate. Enclosure present.)

Same to same. No. I20. Approves latter's measures respecting an outrage by a U. S. fishing schooner upon a British vessel wrecked off the coast of Prince Edward Island. Oct. 2 I, I838.

Same to same. News from the U. S. government, through the British minister at Washington, of preparations on the U. S. frontier for an attack upon Canada. Remarks. Oct. 26, 1838 . (Confidential.)

41. Glenelg to Colborne. No. 6. Further information of and remarks on preparations on the U. S. frontier for an attack on Canada. Nov. 24, I 838 . 
Same to same. No. I2. Remarks on news of invasion of Upper Canada near Prescott by persons from the U. S. bank of the St. Lawrence and their defeat. Dec. 10, 1838 .

Same to same. No. I9. Approves of arrangements for defending the Canadas against internal and external dangers. Dec. 14, 1838 .

Same to same. Remarks at length upon the agreement of 1817 , border incursions, and the line of conduct to be followed regarding these. Dec. 14, I838. (Confidential.)

42. Normanby to Colborne. Disapproval of correspondence of the British consul at New York with Papineat1. Feb. 26, I839. (Confidential. Similar letter to Lieut.-Gov. Arthur in G 91.)

Same to same. No. 2I. Approves of latter's measures to meet the recent proceedings of Maine with respect to the disputed territory. Apr. 15, I839.

Same to same. No. 24. Sends letters on points connected with the U.S. boundary dispute, upon which Lord Palmerston desires information. Apr. I8, I839. (Two enclosures.)

Same to same. No. 27. Sends documents on outrage by U. S. fishing schooner on the British vessel Sir Archibald Campbell. Apr. 23, I839. (Two enclosures.)

Same to same. No. 32. Brief remarks on arrangements with Maine, and continued outrages on the Missisquoi frontier. May 6, I839.

Same to same. Sends grounds of decisions on claims by Americans for slaves brought to the Bahamas, etc., in U. S. ships, and there seized by English officers. May 25, I839. (Circular. Enclosures present. Also in $\mathrm{G} 285$.)

43. Normanby to Colborne. Sends letter on appointment of persons to survey disputed territory, with a view to settlement of the Northeast Boundary. July 9, I839. (Separate. Duplicate. Enclosure present.)

Russell to Thomson. No. 9. Sends despatch from Palmerston to the British minister at Washington on the seizure of the American schooner G. S. Weeks by customs officers at Brockville, etc. Sept. 20, 1839. (Enclosure present. Similar communication to Lieut.-Gov. Arthur in G 94.)

44. Russell to Thomson. No. 3I. Sends despatch and enclosures from the lieutenant-governor of Upper Canada on its finances. Oct. 3I, I839. (Enclosed are long reports by Sir George Arthur and Lieut.-Col. Philpotts, which urge improvement of the Welland Canal, especially in view of the rapid growth of the American West, etc. Extracts of U.S. letters given.)

45. Russell to Thomson. No. 36. Sends document on seizure of the U. S. schooner G.S. Weeks. Nov. I I, I839. (Enclosure present. Similar letter to Lieut.-Gov. Arthur in G 94.)

Same to same. Orders for military forces to be restationed on the left bank of the St. John and in the Madawaska settlement. Dec. 4, I839. (Private.)

Same to Jackson. No. I. Relative to military occupation of disputed territory in New Brunswick. Dec. 27, 1839. (Enclosed is a copy of a despatch from Lord John Russell to Lieut.-Gov. Harvey.)

46. Russell to Thomson. Views of the governor of Maine upon British occupation of the disputed territory. Attitude of the English government. Troops to remain. Feb. 6, 1840. (Confidential. One enclosure.) 
Same to same. Comments on agreement between Lieut.-Gov. Harvey and Gov. Fairfield, of Mar. 23, 1839. Instructions. Feb. 6, 1840. (Separate.)

Same to same. Comments at length upon infractions of late agreement between New Brunswick and Maine. Instructions to conclude a new arrangement, if possible, etc. Feb. I9, I840. (Confidential.)

Same to same. Sends copy of despatch from Lord Palmerston to Fox at IVashington, upon the boundary. Other arrangements. Feb. I9, I840. (Confidential and separate. Four enclosures.)

Same to Jackson. No. 6 . Acknowledges receipt of despatches on the boundary dispute. Feb. 19, I840.

Same to same. No. 8. Approves latter's measures regarding the boundary dispute. Mar. II, I 840.

Same to Thomson. No. 88. Is gratified at Lieut. Jones's account of altered feeling in the U. S. regarding the invasion of Canada. Mar. $20,1840$.

47. Russell to Thomson. No. II5. Approves of latter's course regarding the Northeast Boundary. Apr. 23, I840.

Same to same. Remarks on provisional arrangement, report, etc., regarding the Northeast Boundary. Apr. 29, I840. (Confidential.)

48. Russell to Thomson. Instructions regarding the disputed territory. June I3, I840. (Confidential.)

Same to same. Is glad to learn that few emigrants to Canada pass into the U.S. June I9, I840. (Separate.)

Same to same. No. I58. Remarks on charge that British authorities were enticing Indians of the western states to come into Canada, etc. June 22, I840. (One enclosure.)

Same to same. No. I78. Sends instructions given to certain surveyors in the disputed territory. July 8, I840. (Enclosure present.)

Same to same. No. Ig6. Sends correspondence relative to duty on wheat grown in Upper Canada and exported to the U. S. Desires opinion. Aug. 6, I840. (Enclosure in place.)

Same to same. No. 200. Relative to a provisional agreement for the exercise of control within the disputed territory. Aug. I2, I840.

Same to same. No. 208. Comments on latter's trip to New Brunswick, etc. Aug. 24, 1840.

49. Russell to Sydenham. No. 220. Relative to claim of James Crooks against the U. S. for the seizure of his vessel on Lake Ontario before the declaration of war in I812. Sept. 7, I840. (One enclosure.)

Same to same. No. 23I. Sends copies of diplomatic correspondence, showing the progress in negotiations over the Northeast Boundary. Sept. 20, 1840. (Four enclosures.)

Same to same. No. 233. Remarks and instructions regarding the disputed territory. Sept. 28, I840.

Same to same. No. 248. Remarks on plan to grant land to immigrants upon arrival to prevent their passing to the U.S. Oct. $27,1840$.

50. Russell to Sydenham. No. 272. Remarks on military measures to protect the Madawaska settlement against Maine aggressions. Dec. I9, I 840 .

Same to same. No. 276. Sends letter giving Palmerston's opinion on best attitude to be taken towards Maine aggressions. Dec. 30, I840. (Enclosure present.) 
51. Russell to Sydenham. No. 285. Orders to investigate charge of outrage upon U. S. citizens at Chippewa by British negro soldiers there. Jan. I6, I84I. (Three enclosures.)

Same to same. Sends copy of despatch recalling Lieut.-Gov. Harvey because of his actions upon the boundary question. Jan. 25, I84I. (Confidential. Enclosure present.)

Same to same. No. 288. Sends suggestions from Thomas Morgan on the settlement of the boundary dispute. Jan. 25, I84I. (Enclosure present.)

Same to same. No. 296. Presents should be continued "to such of the Indians who formerly received them on visiting Upper Canada annually from the United States, as may now become resident within the British Territory".

Same to same. No. 317. Approves course in regard to block-houses at the disputed territory. Feb. 27, I84I.

53. Portland to Simcoe. Sends explanatory article to treaty of amity, commerce, and navigation, with the U. S. Whitehall, July 7, 1796. (Enclosure present.)

Same to Russell. Comments and instructions chiefly on Indian matters. Whitehall, June 7, I798. (Most secret. Also in Q 284, p. I26. Four enclosures present in G.)

Same to same. No. 9. Instructions to grant 13,400 acres in Upper Canada to Benedict Arnold. Whitehall, June I2, I798. (Enclosed memorial of Arnold is for 1 5,800 acres.)

54. Hobart to Hunter. No. 5. Downing Street, Feb. 4, I8O2. (Calendared in Q 292, p. 9. Enclosures present in $\mathrm{G} 5$ and also in Q 293 A.)

56. Bathurst to Brock. Sends order in Council of July 3I. Aug. I, I8I2. (Circular. Enclosure present.)

57. Bathurst to Sheaffe. No. 5. Remarks on zeal of the legislature, defense, etc. June 8, I8I3. (Duplicate.)

Same to same. No. 7. Remarks on "disaster at York", etc. July ıo, I8I3.

Same to Drummond. Instructions to maintain " an ascendancy on the Lakes more particularly on Lake Ontario”, etc. Jan. IO, I8I 5.

58. Bathurst to Gore. Impropriety of late correspondence between military posts in Upper Canada and U. S. civil authorities. Mar. I3, I8I6.

Same to same. Approves of latter's opinion on sending presents to Indians in the U. S. July I3, I8I6.

Same to same. U. S. complaint of interference with vessels on the Lakes by British officers. Orders to stop any such actions. Sept. 9, I816. (Two letters upon the same topic.)

Same to same. Relative to British subjects lately arrived in the U. S., who wish to proceed to Canada as settlers. Jan. Io, I8I7.

Same to same. The English consul at New York has been instructed not to encourage any persons to proceed as settlers to Upper Canada. July 30, I8I7. (Duplicate.)

Same to Smith. Remarks and instructions on resolution of the assembly relating to the right of U. S. citizens to hold lands in the province. Nov. 30, I8I7.

59. Bathurst to Smith. Relative to settlers from the U.S. May I3, I8I8.

Goulburn to Hillier. Relative to a settlement of fugitive slaves from the U. S. Sept. 26, I8I9. (Private. Wrongly calendared in Q 326, p. II7, as Hillier to Goulburn.) 
60. Bathurst to Maitland. Receipt of legislative address upon the boundary at Barnhart's Island and U. S. claim to free navigation of the St. Lawrence to the ocean. May 8, I824.

Same to same. Instructions on case of Barnabas Bidwell, a citizen of the $\mathrm{U}$. S. who was elected to the assembly of Upper Canada. Nov. 30, I824.

61. Bathurst to Maitland. Remarks and instructions as to the status of U. S. settlers in Upper Canada. July 22, I825.

Same to same. Remarks on the boundary at "Burnhart's Island". July 28,1825 .

Same to same. Remarks on bill regulating trade between Upper Canada and the U. S. July 30 , I 825 .

Charles R. Vaughan to same. Case of John Macdonell. Washington, Nov. 12, I825. (Three enclosures.)

62. Bathurst to Maitland. Adverse decision on assembly memorial for encouragement of immigration from the U. S. June Io, I826.

Horton to same. Sends copies of circulars to governors of West Indies and Newfoundland. Aug. Ir, I826. (Enclosures relate to maritime trade, especially with the U. S. Also in G 279.)

Bathurst to same. Sends act which prevents U. S. citizens settled in Upper Canada, whether born before or after $17 S_{3}$. from becoming members of the assembly. Remarks at length upon aliens and naturalization. Aug. 3 T, 1826. (Act missing.)

Horton to same. Sends private letter with remarks. Oct. 7, r826. (Enclosure speaks of numbers and influence of U. S. settlers in Upper Canada, Methodist preachers from the U. S., etc.)

Bathurst to same. Further remarks on the Alien Bill. Nov. 24, I826. (Bill enclosed.)

63. Bathurst to Maitland. Remarks on importation of U. S. flour for export to the West Indies, duties, etc. Mar. 31, I827. (Two enclosures.)

Same to same. Disallowance of certain bill as contrary to recent acts of Parliament on intercourse with the U. S. Apr. 2, 1\$27.

Same to same. Importation and warehousing of U. S. flour for exportation to the West Indies. Apr. 28, 1827. (One enclosure.)

Huskisson to same. Transmits order in Council of July I6, on colonial trade with foreign countries, and comments at length upon it. Sept. 8, 1827. (Circular. Enclosure present.)

Horton to same. Certain postal arrangements. Oct. 5, I827. (Three enclosures.)

66. Murray to Colborne. No. 8r. Cannot grant assembly's request to lower the duty on U. S. spirits. Oct. $28,1830$.

67. Goderich to Colborne. No. 22. Instructions as to duty on U. S. produce conveyed through the Welland Canal. Apr. 26, I83I. (One enclosure.)

69. Goderich to Colborne. Remarks on the foreign interest growing up in Upper Canada through the settlement of Americans there. Policy to be pursued. Jan. ro, I832. (Confidential.)

Same to same. No. IOI. Purchase of complete verified copy of maps of survey of the boundary between the U. S. and Upper Canada under the treaty of Ghent is authorized. Nov. 6 , I 832 .

70. Stanley to Colborne. No. I3. Assembly's request for discrimination in favor of U. S. cotton and tobacco imported into Great Britain via Montreal and Quebec cannot be granted. June 25, I833. 
72. Rice to Colborne. No. 43. Sends letter on settlement of colored persons at Wilberforce. Oct. 30, I834. (Enclosure states that they emigrated from Ohio as result of harsh measures in I829.)

Aberdeen to same. No. 3. Remarks on assembly's address on naturalization of aliens in Upper Canada. Dec. 26, I834.

Same to same. Why government has been reluctant to naturalize U. S. settlers in Upper Canada. Dec. 26, I834. (Private.)

78. Glenelg to Head. No. I24. Remarks on body of U. S. adventurers at St. Mary's under "General Dickson Commander in Chief of the Indian Liberating Army". Thinks their object is the Red River settlement. Dec. 30, 1836. (About ten enclosures, giving many details.)

80. Glenelg to Head. No. I65. Assembly's address on trade with the U. S. has been received and referred. Apr. 19, 1837.

Same to same. No. I8o. Transmits answer of Committee of Privy Council for Trade and Plantations to assembly's address respecting duties on American imports. May IO, I837. (Enclosure present.)

83. Glenelg to Head. No. 255. Remarks on case of fugitive slave demanded by Kentucky. Dec. 4, I837.

84. Glenelg to Arthur. No. I7. Remarks on Americans and insurgents on Navy Island, attitude of the U. S. government, etc. Feb. 6, I838.

Same to same. No. 24. Relative to forces at Navy Island. Feb. 20, I 838 .

Same to same. Remarks upon case of the Caroline. Sends copy of legal report to Lord Palmerston. Feb. 22, 1838. (Private and confidential. Enclosure present.)

Same to same. No. 38 . Sends legal opinion regarding fugitive slaves from the U.S. denianded on pretext of being fugitives from justice. Mar. 9, I838. (Enclosure present.)

Same to same. Conduct of Col. McNab and Capt. Drew in destruction of the Caroline. Mar. I4, I838. (Confidential.)

Same to same. No. 4I. Proceedings of the U. S. government and feeling of its citizens in regard to recent events in Canada. Mar. I4, I838.

Same to same. No. 44. Comments on dispersion of U. S. sympathizers on the frontier and the language of Sir Francis Head respecting the U. S. Mar. I7, I 838 .

85. Glenelg to Arthur. No. 57. Further remarks on Sir Francis Head's violent language and extreme attitude toward the U. S. Apr. I4, 1838 .

Same to same. No. 59. Remarks on defeat of insurgents who had attempted an invasion from the U. S. Apr. 20, I838.

Same to same. Sends memorandum of instances in which the U. S. government has pursued enemies or alleged criminals on foreign territory. May 9, I838. (Confidential. Printed enclosure present.)

Same to same. No. 7o. Is gratified at news of quiet on the frontier and good understanding with New York. May 22, 1838.

Same to same. No. 82. Relative to U. S. citizens who were captured with the schooner Amn. May 30, I838.

Same to same. No. 85. Comments respecting assembly's address on recent attempts at invasion by Americans and future protection. May 31,1838 .

86. Glenelg to Arthur. No. 87. Comments on latter's proposals and apprehension of another attack on the western frontier by persons from the U. S. June I, I838. 
Same to sane. No. 92. Sends opinion of law-officers of the crown on mode of dealing with foreigners concerned in the late insurrection. June 6, I838. (Enclosure present.)

Same to same. No. 94. Relative to command of flotilla on the Lakes, in order to prevent any collision with U. S. citizens. June I I, I838.

Same to same. No. Ioo. Sends opinion of law-officers on case of Thomas J. Sutherland, an American charged with aiding in the late rebellion. Remarks. June 22, IS38. (Duplicate. Enclosure present.)

Same to same. No. I02. Adverse comments on act of the Upper Canada legislature to protect the province against aggressions from subjects of foreign countries at peace with Her Majesty. June 23, I838.

Same to same. No. Io4. Sends opinion of law-officers respecting Americans captured with the Amm and at Pointe Pelee Island. June 29, I838. (Enclosure present.)

Same to same. No. III. Discussion of mode of punishing Americans taken in the late rebellion. July I2, I838.

Same to same. No. II2. Case of Francis Dawson, a British subject, imprisoned by Americans on charge of being concerned in the destruction of the Caroline. Matter to be dropped. July I3, I 838 .

Same to same. No. I 5. Relative to destruction of the Sir Robert Peel by persons from the U. S. shore, etc. July i 8, I 838 .

Same to same. No. I22. Remarks on steps taken by the U. S. to deter from invasions of Canada. July 3 I, I 838 .

87. Glenelg to Arthur. No. I25. Approves of latter's measures to prevent the circulation in Upper Canada of newspapers published in the U. S. by Mackenzie and his associates. Aug. 16,1838 .

Same to same. No. I29. Renarks at length upon frontier invasions, punishment of captured Americans, and defense. Aug. 22, I838. (Legal opinion enclosed. Confidential letter of same date also discusses mode of punishing captured Americans.)

Same to same. No. I38. Sends legal opinion on question whether American prisoners taken on the Amn and at Pointe Pelee Island can be tried for high treason. Sept. 3, I838. (Enclosure present.)

Same to same. No. I39. Remarks on Vail's mission. Sept. 4, I838.

Same to same. No. I45. Further remarks on local act to protect the province against invasion, etc. Sept. I2, I838. (Same topic touched upon in no. I46 of Sept. I9.)

Same to same. No. I60. Sends further report on legal nature of the offense committed by Americans in invading Canada. Oct. 26, I 838 . (Enclosure present.)

88. Glenelg to Arthur. Sends copies of letter from the under-secretary, and note from the U. S. minister, demanding redress for the destruction of the Caroline. Instructions to obtain information and evidence. Oct. Io, I838. (Confidential. The enclosures are present, together with a long memorandum on the case. Stevenson's note to Palmerston is accompanied by several bulky enclosures. Altogether, the documents in this case fill one large folder, and comprise numerous letters, extracts, depositions, etc. G 89 contains duplicates or copies of $\mathrm{G} 88$.

90. Glenelg to Arthur. No. I66. Relative to proceedings of U. S. authorities against certain British subjects in connection with the Caroline affair. Diplomatic steps taken. Nov. I5, I838. (No. I67, of Nov. I6, touches upon apprehended attack upon Upper Canada from the U. S.) 
Same to same. No. ISo. Remarks on hostile movements from the U. S. border, approval of measures taken, etc. Dec. I3, I838.

91. In this folder among the others are fourteen despatches touching on American affairs. All are from Glenelg and Normanby to Lieut.-Gov. Arthur, and range from Jan. 3 to Mar. 30, I839. The chief topics are the raids at Prescott and near Windsor, sentences imposed by courts-martial upon prisoners taken in these attacks, and claims for property destroyed.

Three letters treat respectively of the Caroline, prosecution in Upper Canada of Howland Hastings for assault on a British subject at Detroit, and the case of W. P. Smith, formerly assistant state geologist of Michigan, who claimed to have lost that position because of his attempts to hinder U. S. attacks upon Canada in I837.

92. Normanby to Arthur. No. 23. Relative to intentions to pardon younger and less guilty of the American prisoners. Apr. 8, I839.

Same to same. No. 26. Remarks on Gov. Mason's attitude toward prosecution of Hastings. Apr. 12, I839.

Same to same. No. 32 . Approves of liberation of seven prisoners captured in the Ann in I838. Apr. 20, I839.

Same to same. No. 4I. Comments on latter's report of continued excitement across the border and "general expectation and desire for war". Arrangement respecting disputed territory. May 7, I839.

Same to same. No. 46. Sends report from Lords of the Treasury regarding export of live stock to the U. S. May I6, I839. (Enclosure present.)

Same to same. No. 48. Remarks on disposal of younger American prisoners, continued enmity against Upper Canada evinced by citizens of Ohio and Michigan, and the Northeast Boundary. May I8, I839.

Same to same. No. 7o. Relative to claims for losses through U. S. raids. June 27,1839 .

93. Normanby to Arthur. No. 79. Relative to summary execution of four prisoners near Sandwich, by Col. Prince. July $7,1839$.

Same to same. No. 8I. Remarks on liberated American prisoners, etc. July 9, I839.

Same to same. No. 87. Approval of latter's measures respecting certain border outrages. July 30, I839.

Same to same. No. 89 . Comments on fears of invasion from the U. S. on July 4, etc. Aug. I, I839.

Same to same. No. 90. Reply to address of fugitive slaves now resident in Canada. Aug. 2, I839.

Same to same. No. 97. Substance of Lord Palmerston's opinion regarding claims against the U.S. for property destroyed in late attacks upon the Canadian frontier. Aug. 25, I839.

94. Russell to Arthur. No. I4. Relative to occurrence at Brockville between the schooner Montreal and the U. S. steamboat St. Lawrence. Oct. 2, I839.

Same to same. No. 29. Relative to extradition arrangements. Oct. 25, I 839 .

Same to same. No. 30. Comments on recommendation of the legislative council that a police force should be stationed on the Niagara frontier during the winter, as a protection against U. S. attacks. Oct. 26, I839. (No. 33, of Oct. 28 , deals further with this topic.) 
95. Russell to Arthur. No. 6r. Sends copies of diplomatic letters on the vessel United States, fired on at Brockville. Jan. 26, I840. (Two enclosures.)

Same to same. No. 62. Extradition matter. Jan. 27, 1840. (Three enclosures.)

Same to same. No. 60. Remarks on measure to protect the western frontier. Jan. 29, I840.

Same to same. No. 66. Sends documents on case of the St. Larurence, fired upon at Brockville. Feb. I4, I84O. (Enclosures present.)

Same to same. No. 89. Remarks on numbers of Indians coming from the U. S., and upon charge that they were enticed by British authorities. June 22, I840.

Same to same. No. I03. Relative to project for removing free blacks in Upper Canada to Trinidad. July 22, I840.

96. Col. Foster to Lieut.-Gov. Arthur. Account of " Patriot" organizations in certain parts of the U.S. Gives their supposed intentions against Canada, with statistics. Toronto, May 28, I838. (Enclosure in Arthur's no. 2 I to the colonial secretary, May 30, I 838 .)

98. George Whitehead to John Macauley. Rescue of prisoner Wilson by body of armed men from Norwich. Burford, June 29. I838. (With it are minutes of Council of July 1, upon news of intended attack from the U. S. In Arthur's no. 33 to the colonial secretary, July I, I838.)

100. J. Buchanan to John Macauley. Information on plots in the U.S. against Canada. New York, Feb. 9, I839. (Copy, followed by copy of reply, dated Toronto, Feb. I9, I839. Enclosures in a private despatch from Arthur to the colonial secretary, Feb. 2I, I839, which does not seem to be in Q.)

101. John C. Hugunin, master of the Stephen Girard, to Col. Foster. Relative to attack upon the Stephen Girard in the Welland Canal. Oswego, May 8, I839. (Enclosed in Arthur's no. 99 to the colonial secretary, May 7, I839. Evidently put in after the despatch was written.)

102. Unsigned and unaddressed extract of a letter giving warning that attacks upon Canada from the U. S. border may take place upon July 4. New York, June 22, I839. (Not endorsed.)

103. R. A. Tucker, provincial secretary, to J. C. Spencer, secretary of state, Albany. Extradition matter. Toronto, July 6, I8 39. (One of three letters not found in Q, on extradition with New York. Enclosure in Arthur's no. I65 to the colonial secretary, July 27, I839.)

104. Statement of Lieut. Jones, on political conditions along the U. S. border. Drummondsville, Oct. I2, I839. (Incomplete in Q 420 , pt. I., pp. 88 et seq. Enclosure in Arthur's confidential despatch to the colonial secretary, Oct. I5, I839.)

Printed resolutions adopted at a patriot meeting in Onondaga County, Jan. 26, I839. (Enclosure in Arthur's confidential despatch to the colonial secretary, Oct. I5, I839.)

108. Russell to Sydenham. Sends papers on the case of McLeod. Downing Street, Mar. 3, I84 I. (Most confidential. Enclosed are about IoO pp. of diplomatic correspondence with the U. S., legal opinions, etc., respecting Alexander McLeod, late deputy sheriff of the Niagara District, now imprisoned at Lockport on charges of murder and arson, connected with the burning of the Caroline. Despatches no. $32 \mathrm{I}$ of Mar. 8, no. 335 of Mar. I8, and a confidential one of Mar. 25 all relate to McLeod.) 
Same to same. No. 329. Sends copies of correspondence between that office and the Foreign Office, on proposed convention between the U.S. and Great Britain for mutual surrender of criminals and military deserters. Mar. I3, I84I. (Enclosures present, including drafts of convention.)

Same to same. No. 349. Relative to proposals for twenty gunboats on the Lakes. Mar. 30, I84I. (Two enclosures.)

109. Russell to Sydenham. No. 380 . Sends Capt. Sandom's report on importance of enlarging the locks of the Welland Canal. May 2I, I84I. (Enclosure touches on numbers of American and Canadian vessels on the Lakes, the harbors, and defense.)

Same to same. Sends letter containing suggestions as to the mode of dealing with the U. S., and on the use of negro troops in case of a war with it. May 24, I84I. (Confidential. Enclosure present.)

Same to same. No. 384. News from the British consul in Maine that they intend to cut a canal between the Aligash and the Penobscot. May 27, I84I. (Three enclosures.)

Same to same. Sends correspondence between the U. S. government and the British minister at Washington on the demand for McLeod's liberation. May 28, I84I. (Confidential. Enclosure present.)

110. June 26 -Sept. 30 , I840. In this folder are fourteen despatches relating to U. S. interests, from secretaries Russell and Stanley to Sydenham or the officer administering the government of Canada. Several are confidential.

Six relate to the Northeast Boundary question, and are accompanied by bulky enclosures of diplomatic correspondence, drafts of conventions, etc. Three others give further instructions with regard to the McLeod case; two treat of rumored American plans for frontier attacks; while the Caroline, the Sir Robert Peel, and the criminal Kelly, arrested by Lieut. McClure withir American territory, have each a despatch devoted to them.

111. Stanley to Bagot. No. 2. General instructions. Oct. 8, I84I. (Touches upon relations with the U.S.)

Same to same. No. 4. Sends diplomatic correspondence on the disputed territory and the proceedings of the U.S. government regarding its provisional occupation. Oct. I5, I84I. (Enclosure present.)

Same to same. Sends despatches from the Foreign Office on McLeod's case. Oct. I5, I84I. (Confidential. Enclosure present. Other despatches in this folder on McLeod's case are dated Nov. 2, 5, and 25.)

Same to same. No. 8. Comments on continued spirit of hostility along the U. S. border and upon the arrest of Groghan. Orders for his immediate release. Oct. 20, I84I.

Same to Jackson. No. 3. Approval of measures with regard to unrest on the U. S. frontier, etc. Nov. I, I84I.

Same to same. Sends anonymous letter denouncing certain persons in Canada as members of secret societies (Hunters' Lodges) on the U. S. border. Nov. 3, I84I. (Confidential. Enclosure present.)

Same to same. No. 5. Transmits diplomatic correspondence on negotiations over the disputed territory. Nov. 9, IS4I. (Enclosure present. Similar communication to Bagot as no. 2I.)

112. Stanley to Bagot. No. 99. Power of Canadian government to grant ferry rights over frontier rivers must be settled by treaty. Mar. I6, 1842. (Enclosed is opinion of law-officers of the crown.) 
113. Stanley to Bagot. No. I37. Remarks on customs act. Apr. 30, I842.

Same to same. No. 153. Receipt of petition from the Home District for the imposition of the foreign duty upon U. S. corn imported into Canada, etc. May 29, I842.

Same to same. No. I77. Relative to extradition of James Gallagher from New York. June 21, 1842. (Three enclosures.)

114. Stanley to Bagot. No. 194. Transmits correspondence, chiefly between Aberdeen and Ashburton, on a clause which Webster proposed to insert in the treaty, on the mutual surrender of criminals. July 7, 1842. (Enclosure present.)

Same to same. No. 213. Instructions on extradition matter. July 30, 1842.

Same to same. No. 227. Transmits an act regulating the trade of British possessions abroad, and remarks upon it at length. Aug. I7, 1842. (Enclosure present.)

Same to same. Receipt of Comeau's report as to state of feeling on the U. S. frontier, etc. Aug. 24, I842. (Confidential.)

115. Stanley to Bagot. No. 267. Treaty with the U. S. has been ratified. Nov. 3, 1842 .

Same to same. No. 287. Sends correspondence between the governor of the Canada Co. and an under-secretary of state on proposal to have an agent at New York to induce British subjects arriving there to settle in Br. N. America. Nov. 28, 1842. (Enclosure present.)

116. Stanley to Bagot. No. 3I9. Sends correspondence between the Foreign Office and Brown of Cleveland, Ohio, regarding proceedings of persons there "inimical to the peace of Canada". Jan. 3I, I843. (Enclosure present.)

Same to same. No. 324. Sends correspondence between that office, the Admiralty, and the Foreign Office respecting reduction of British naval force on the Lakes to the amount agreed upon with the U. S. in ISI7. Feb. I8, I843. (Enclosure present.)

Same to Metcalfe. Appointment of Lieut.-Col. Estcourt to survey the boundary under the treaty of IVashington. Apr. 3, I843. (Circular.)

117. Stanley to Metcalfe. No. 44. Duty imposed at Boston upon instruments for Toronto observatory has been refunded. June $7,18_{43}$. (Three enclosures.)

Same to same. No. 59. Measures to be taken to prevent the evasion of duty on U. S. wheat partly manufactured into flour and imported into Canada. July I2, I843. (No. 60, of July I 3 , is also upon this topic.)

Same to same. No. 65. Remarks on Canadian bill to impose a duty on imported wheat. Jully I8, I843.

118. Same to same. No.9. Answers query regarding the boundary from the St. Lawrence to Lake Champlain, under the treaty of Washington. Sept. I8, I843.

Same to same. No. 92. The government does not care to purchase David Thompson's maps of the Oregon territory. Sept. I8, I843. (Copies of letters enclosed, including three from Thompsont.)

Same to same. No. I24. No reply has come from Washington on clain for destruction of the Sir Robert Pecl. Nov. I8, 1843. (Two enclosures.)

Same to same. No. I26. Transmits act for giving effect to the tenth article of the treaty of Washington. Instructions. Nov. 21, I843. (Enclosure present.) 
119. Stanley to Metcalfe. No. I67. Pardon of David Allen of New York, a prisoner in Van Diemen's Land, upon request of the American minister. Feb. 23, I844.

Same to same. Information of much smuggling of wheat from the U.S. into Canada. Instructions. Mar. 2, I844. (Confidential.)

Same to same. News of infraction of the agreement of I8I7 by the U.S. Instructions to investigate. Mar. 4, I844. (Private. Two enclosures.)

Same to same. No. 196. Comments on extradition cases. Apr. 3, 1844. (Legal opinion enclosed.)

Same to same. No. 207. Ten U. S. convicts in Van Diemen's Land will be pardoned on application of the U. S. minister. May 2, I 844 .

Same to same. No. 213. Sends correspondence between the British minister at Washington and the U. S. government on the seizure and release of two Canadian vessels by the customs officers at Genesee and Rochester. May 6, i844. (Enclosure present.)

Same to same. No. 230. Pardon will be granted to certain U. S. convicts in Van Diemen's Land. June I, I844.

Same to same. No. 239. Extradition matters. June I8, I844.

Same to same. No. 245. Certain U. S. convicts in Van Diemen's Land will be pardoned. June 25, I844.

120. Stanley to Bagot. No. 257. Pardon will be granted to U. S. convict in Van Diemen's Land. July 15, I844. (Similar letter, Nov. I4.)

Same to same. No. 286. Comments upon Canadian acts imposing duties upon agricultural produce and live stock imported from the U. S. Sept. 26, 1844. (One enclosure.)

Same to same. No. 320. News of a projected railroad from Portland to Montreal. Asks for opinion. Dec. I8, I844. (Two enclosures.)

121. Stanley to Metcalfe. Receipt of despatch and reports on U. S. naval force upon the Lakes. Jan. 4, I845. (Military. Separate.)

Same to same. No. 333. Why no damages can be obtained for the destruction of the Sir Robert Peel. Jan. 24, 1845 .

Same to same. No. 338 . Pardons granted to certain U. S. convicts in Van Diemen's Land. Jan. 29, I845. (Other letters of this nature on Feb. 23 and Mar. 28.)

Same to same. No. 353. Arrangement concluded with the PostmasterGeneral of the U. S. for the conveyance of mail through that country to and from England. Instructions. Mar. 2, I845.

Same to same. No. 362. Sends letter and enclosure from the Foreign Office regarding the proposed Portland-Montreal railway. Apr. 3, I845. (Enclosure present.)

Same to same. No. 402. Permission granted to Lieut.-Col. Kearney, of the U. S. army, to determine the position of certain points on the British shores of the Lakes, in connection with a hydrographical survey. July 23, I845. (Correspondence on the subject is enclosed.)

Same to same. No. 416. Sends extract of letter from the Archbishop of Canterbury relative to a closer union between the Protestant Episcopal churches in England and the U. S. Aug. I9, I845. (Enclosure present.)

122. Stanley to Metcalfe. No. 472. Relative to U. S. duty on wheat imported from Canada. Dec. 6,1845 .

123. Gladstone to Catheart. No. I7. Remarks on differential duties, trade routes, etc. Feb. 3, I846. 
Same to same. No. 19. Remarks on Canadian law imposing duty on U. S. wheat. Feb. 3, I $\$ 46$.

Same to same. No. 32. Remarks at length upon protection for Canada's grain and timber trade against the western states, under the proposed changes in the imperial tariff. Mar. $3,1846$.

Same to same. No. 45. Remarks on Canadian trade. Mar. 3I, I846. (Two enclosures, touching upon the influence of the Erie Canal, etc.)

124. Gladstone to Cathcart. No. 48. Comments and instructions as to local duty on imported grain. Apr. I, I846.

Same to same. Military no. I6. Relative to sending a detachment of troops to Fort Garry. May 4, 1846. (Four enclosures, one of which states the measure was rendered necessary by the tampering of Americans with the inalf-breeds.)

125. Gladstone to Cathcart. No. 83. In reply to the assembly's address on proposed change in the corn and timber duties. June 3, I846. (Part of it relates to the U. S.)

Same to same. No. 94. Encloses diplomatic correspondence showing the efforts " to establish an equality of Trade between the Dominions of the Republic, and the British North American Colonies". June 27, I846. (Enclosure present.)

Grey to same. No. 4. Sends printed copy of treaty to settle the Oregon boundary. July 25, I846. (Enclosure present.)

Same to same. No. I4. Sends diplomatic correspondence relative to desired equality of trade between the U. S. and the Br. N. American colonies. Aug. I I, I846. (Enclosure present.)

126. Grey to Cathcart. No. 46. Remarks upon local customs act imposing a discriminating duty upon certain leather articles from the U.S. Nov. 2. 1846.

127. Grey to Elgin. No. 38. Permission for U. S. vessels to pass from Fort Covington on the Salmon River down the St. Lawrence to Sorel. and thence up the Richelieu to Lake Champlain. Comments. Mar. I9, 1847. (Several enclosures including opinion of the Committee of the Privy Council for Trade and Plantations, and a memorandum prepared at the Board of Trade. on the navigation of the St. Lawrence.)

128. Grey to Elgin. No. 58. Sends letter from London merchants respecting duty on U. S. flour imported into Canada. Remarks. Apr. I9, I847. (Enclosure present.)

Sane to same. No. 9r. Relative to attempts to obtain equality of trade between the U. S. and Br. N. America. Inne 22, IS47. (Five enclosures, consisting of diplomatic correspondence and memoranda.)

130. Grey to Elgin. No. r69. Relative to complaint by Montreal board of trade of stoppage of their letters to Boston by the U. S. authorities. Feb. 12, I848. (Several enclosures.)

Same to same. No. IzS. Relative to seizure of a British subject in Canada by U. S. citizens and his imprisonment at Worcester. Mar. I0, I848. (One enclosure. No. 91, of Apr. 6, deals with the same topic.)

Same to same. No. I84. Permission for two U. S. revenue vessels on the Lakes to pass through the St. Lawrence. Mar. 24, I848. (One enclosure.)

Same to same. Relative to arrest of British colored subjects in Alabama. Apr. 26, 1848. (Circular.) 
131. Grey to Elgin. No. 223. Relative to equality of trade between the U.S. and Canada. June I, I848. (Three enclosures. No. 229, of June 9, with two enclosures, treats of the same subject.)

Same to same. No. 242. Relative to tariff relations between the U. S. and Canada, etc. June 30,1842 .

Same to same. No. 243. Wishes investigation made in case of Orlando Ware, arrested at Oswego for violation of revenue laws of the U. S. July I, I 848 .

132. Grey to Elgin. No. 262. Relative to free trade between Canada and the U. S. as regards certain articles. Aug. IO, I848. (One enclosure.)

Same to same. No. 266. Remarks on New Brunswick's desire for free trade with the U. S. on certain lines. Aug. I8, I848.

Same to same. No. 267. Transmits note with enclosures on extradition matters. Aug. 24, I848. (Enclosure present.)

Same to same. No. 277. Relative to memorial from Missisquoi on proposed erection of a bridge across Lake Champlain near Rouse's Point, within the U. S. Sept. I3, I848. (Enclosed is a despatch from the chargé d'affaires at Washington to Palmerston upon this subject.)

Same to same. Approves latter's views and precautionary measures for repelling any attempted aggressions from U.S. sympathizers with the Irish rebels. Oct. 5, I848. (Confidential.)

Same to same. No. 289. Relative to replacement of a disturbed boundary post. Oct. 24,1848 .

Same to same. No. 290. Two U. S. schooners allowed to pass through the St. Lawrence to the Lakes. Oct. 24, I848.

Same to same. No. 303. Views of government on free trade of natural productions between Canada and the U. S. Dec. 21, I848.

Same to same. No. 304. Sends despatch from the chargé d'affaires at Washington with reply of the U. S. Postmaster-General respecting arrest of Canadian express agent at Oswego. Dec. 22, I848. (Enclosure present.)

133. Grey to Elgin. No. 3II. Relative to passage of two U. S. vessels through the St. Lawrence. Jan. I2, I849.

Same to same. No. 342. Sends further diplomatic correspondence on check to navigation between Missisquoi Bay and the Richelieu River by the projected bridge across Lake Champlain. Mar. 28, I849. (Enclosure present.)

Same to same. No. 343. Sends despatches reporting failure of bill in Congress to establish reciprocal free trade with Canada. Mar. 3I, I849. (Enclosures present.)

Same to same. No. 352. Sends letter. Apr. 20, I849. (Enclosure gives instructions about transmission of mails between the United Kingdom and Canada through the U.S.)

Same to same. Sends diplomatic despatches stating the President's private intimation to the British representative that in the event of any hostility toward Canada on the frontier he would instantly send a force sufficient to prevent any aggression. Apr. 27, I849. (Confidential. Two enclosures.)

Same to same. No. 354. Sends diplomatic despatches regarding an equality of trade between Canada and New Brunswick and the U. S. Apr. 28, 1849. (Enclosures present.) 
134. Grey to Elgin. No. 363. Relative to rates of postage to be charged on letters between the U.S. and the Br. N. American provinces. May I2, IS49. (Four enclosures.)

Same to same. Word received that Gen. Taylor, in the event of disturbances in Canada, will collect sufficient force to keep order on the U. S. frontier. May I8, I849. (Confidential. Enclosed is a despatch to Palmerston from the British representative at Washington.)

Same to same. No. 4or. Relative to passage of U. S. vessels through the St. Lawrence. Aug. I, I849. (Two enclosures.)

Same to same. Will try to obtain reciprocal free trade between the U.S. and the N. American provinces. Aug. I6, I849. (Confidential.)

135. Grey to Elgin. No. 4I5. Relative to appointment of Israel D. Andrews as U. S. consul general for Canada and New Brunswick. Sept. 8, I849. (Copy of reply follows.)

Same to same. No. 4I6. Relative to passage of U. S. vessel from the Lakes to the Atlantic. Sept. 8, I849. (Correspondence with the Treasury is enclosed.)

Same to same. Military no. 64. Instructions relative to seizure of the steamer Canada by U.S. authorities. Oct. 20, I849.

Same to same. Sends instructions given to Sir Henry Bulwer, on commercial intercourse between the U. S. and Br. N. America. Nov. I7, I849. (Confidential. Enclosure present.)

136. Grey to Elgin. No. 448. Remarks on address to the people of Canada by certain citizens, urging annexation to the U. S. Instructions. Jan. 9, 1850.

Same to same. No. 449. The government is anxious to conclude an arrangement for free trade in agricultural products between the U.S. and Canada. Jan. 9, I850. (In reply to memorial from the Gore district.)

Same to same. No. 453. Relative to extradition between Canada and the U. S. Jan. 23. I850. (Order in Council enclosed.)

Same to same. No. 454. Sends copy of despatch to the lieutenantgovernor of Prince Edward Island, on commercial relations between the U. S. and Br. N. America. Jan. 24. I850. (Enclosure present.)

Same to same. No. 46I. Relative to request to allow a U. S. vessel to pass through the St. Lawrence. Feb. 6, I850. (Three enclosures.)

Same to same. No. 472. Transmits letter with enclosures from the Foreign Office, showing that the U. S. wishes to obtain Horse Shoe Reef, at the outlet of Lake Erie, in order to build a lighthouse there. An alternative proposition. Wishes question brought before the Council. Mar. 7, I $8_{50}$. (Enclosure present.)

Same to same. No. 478. Further proceedings anent Horse Shoe Reef. Congress has made an appropriation in the belief that the spot was U. S. territory. Mar. I9, I 850. (Three enclosures.)

Same to same. No. 48I. Sends correspondence between the department and the Foreign Office regarding Senator Douglas's bill for establishing reciprocity with Canada. Apr. 4, i850. (Enclosure present.)

Same to same. No. 486 . Sends further letter from the U. S. minister on the erection of a lighthouse on Horse Shoe Reef. May I, I850. (Enclosure present.)

Same to same. No. 492. Sends documents from New Brunswick on $\mathrm{U}$. S. registration of British-built ships, the coasting-trade, etc. Remarks. Alay I I, I85o. (Two enclosures.) 
Same to same. No. 493. Sends further letter with enclosures from the Foreign Office regarding the bill in the U. S. Senate for reciprocity with Canada. May 15, I850. (Enclosure present.)

Same to same. No. 498. Sends despatch from the minister at Washington, reporting progress of the reciprocity bill. June 7,1850 . (Enclosure present.)

137. Grey to Elgin. Relative to loading and unloading of vessels from $\mathrm{Br}$. N. America in U. S. ports. Nov. 9, I85o. (Circular. Also in G 292.)

Same to same. No. 540. Sends protocol signed by Lord Palmerston and Lawrence, on the cession of Horse Shoe Reef. Dec. 16, I850. (Enclosure present.)

138. Grey to Elgin. No. 559. Word received that the President of the U.S. has approved measures taken by Lawrence regarding Horse Shoe Reef, as set forth in the protocol. Feb. 24, I85I.

Same to same. No. 572. Sends correspondence between the department and the Treasury on permission granted by the Canadian government to the U. S. brigantine Minnesota to pass with copper ore from Lake Superior to the Atlantic. Remarks. Desires a report. Mar. I8, I85I. (Enclosure present.)

Same to same. No. 58I. Desires investigation of report that authorities of the Quebec Marine and Emigrant Hospital dismiss sailors upon the approach of winter, and send them, uncured, to New York and other American ports. Apr. 12, I851. (Several enclosures.)

Same to same. No.602. Transmits despatch and enclosure from the consul at New York, on proposed bridge across Lake Champlain at Rouse's Point. May 3I, 185I. (Enclosure present.)

139. Grey to Elgin. Military no. Io7. Sends letter and enclosures on question of power under the 46th section of the Mutiny Act of arresting deserters from the army, found on board U. S. vessels in Canadian ports. Remarks. Sept. I2, I85I. (Enclosure present.)

Same to same. No. 643. Remarks on permission by the Canadian government to certain U. S. vessels to navigate the St. Lawrence. Sept. 22,1851 .

Same to same. No. 649. Gratification at account of latter's visit to Boston in connection with celebrating the completion of the railway connecting Canada with New England. Oct. I7, I85I.

141. Pakington to Elgin. No. I7. Question of opening the St. Lawrence to U. S. ships has been referred to the Foreign Office. May I, I852.

Same to same. No. 23. Decision not to allow navigation of the St. Lawrence by U. S. shipping until the U. S. grants some equivalent. May I4, I852.

Same to same. No. 32. Small naval force will be sent to compel the observance of the fisheries convention of I818. May 27, I852.

Same to same. No. 40. Reiterates decision regarding American ships in the St. Lawrence. June 30, I852. (Two enclosures.)

142. Pakington to Elgin. No. 56. Sends copy of instructions to the Lords Commissioners of the Admiralty on protection of the fisheries in $\mathrm{Br}$. N. America. Aug. I9, 1852. (Enclosure present.)

Same to same. Desires returns of all vessels seized for breaches of the convention of I818. Sept. II, 1852. (Confidential. Enclosed are printed return of U. S. vessels seized and prosecuted at the court of vice-admiralty at Halifax for fishing or preparing to fish in British 
waters, ISO7-I8I2, and number seized for violation of the convention of I8IS, with dates of seizure and condemnation or restoration.)

Same to same. No. 75. Sends opinion of law-officers upon questions raised in memorandum of Vice-Adm. Seymour on the convention of ISIS. Oct. 19, IS52. (Both opinion and memorandum enclosed. Also in $\mathrm{G} 294$. .)

Same to same. Since negotiations with the U.S. on reciprocity are about to begin, it is desired that the legislatures of Br. N. America take no measures respecting fisheries, etc., which might prove a hindrance to diplomacy. Oct. 30, I852. (Confidential. Draft of reply within.)

Same to same. No. 94. Instructions to carry out enclosed suggestions of Vice-Adm. Seymour, respecting the fisheries. Dec. 7, 1852. (Enclosure present.)

143. Newcastle to Elgin. Sends copy of instructions to the Lords Commissioners of the Admiralty on protection to the fisheries in $\mathrm{Br}$. N. America during the ensuing season. Mar. 28, I853. (Confidential. Enclosure present.)

144. Newcastle to Elgin. No. 46. Sends compilation to be verified. July 22, I853. (Enclosed is a printed document entitled Regulations or Laws now in force in the undermentioncd colonies, with reference to the Fisheries, and especially in connection with the Convention with the United States of 2oth October I8I8, and the Statute 59 Geo. III. Cap. 38. Ncwfound!and, New Brunswick, Prince Edward Island, Canada, Noria Scotia.)

Same to the officer administering the government of Canada. Sends opinion of law-officers on question whether a vice-admiralty court in one province can take cognizance of a seizure on the coast of another province for a breach of the convention of I8I8. Nov. 9, I853. (Circular.)

145. Peel to Elgin. Sends despatch from the governor of Jamaica, on obtaining as laborers for that island refugee slaves from the U. S., now settled in Canada. Mar. 30, I854. (Enclosure present.)

146. July 25-Dec. 4, I834. In this folder eleven of the despatches from Grey to Elgin deal with topics affecting American interests. Two of the letters deal with 11avigation of the St. Lawrence by U. S. vessels, while the remainder are concerned with ratifications of the reciprocity treaty and especially with the rights and privileges of U. S. and British fishermen before the treaty came into full operation. The instructions to Elgin (Aug. 24) and the demands of Nova Scotia and Prince Edward Island to be allowed full and immediate enjoyment of treaty privileges are typical examples. About half of the despatches contain important enclosures of copies of diplomatic correspondence.

147. Grey to Head. No. 5. Sends despatch with enclosures from the minister at Washington, reporting that the U. S. had agreed to admit products of Nova Scotia on terms similar to those granted to the other N. American provinces. Jan. 6, i855. (Enclosure present.)

Herbert to same. No. 7. Sends act to carry into effect the recent reciprocity treaty. Instructions. Feb. 24, I855. (Enclosure missing here, but is present in G 297.)

Grey to same. No. I. Relative to proclamation of act to carry treaty into effect. Mar. 2, I855. (One enclosure.)

Same to same. No. 5. Sends letter enclosing despatch from the British consul at Norfolk, relative to the future practice in $\mathrm{Br}$. N. American 
ports of requiring invoices from vessels from U. S. ports. Mar. 9, 1855. (Enclosures present.)

Same to same. No. 24. Relative to proposal of Lewis E. Grant of New York to raise a number of men in the U. S. for the British army. Apr. 27, 1855 .

Russell to same. No. I9. In reply to memorial of the council of the Quebec board of trade for the appointment of an agent to represent and protect in the U.S. the commercial interests of the Br. N. American provinces. May 25, I855.

Same to same. Sends despatch with enclosures from Sir Gaspard Le Marchant. May 25, I855. (Confidential. Enclosures relate to Joseph Howe's mission to the U. S. to recruit men for the Foreign Legion, and include a copy of his long report.)

148. Russell to Head. No. 24. Approval of latter's course regarding communications addressed to him by Howe from the U. S. June 2, I855. (No. 25 acknowledges the receipt of a despatch relating to Howe.)

Same to same. No. 37. Sends copy of despatch to Lieut.-Gov. Le Marchant. June 22, I855. (Enclosure states that recruiting in the U. S. for the Foreign Legion has been unsuccessful and is to be stopped, etc.)

Same to same. No. 44. Relative to the appointment of Israel D. Andrews as consul general for the U. S. in Br. N. America. July 6, I855. (One enclosure.)

Same to same. No. 46. Relative to recruitment in Canada of foreigners (Germans) from the U. S. July 6, 1855 .

Molesworth to same. No. II. Sends extract of despatch from the British consul at Norfolk, on trade between Virginia and Br. N. America. Remarks. Aut. 3, 1855. (Enclosure present.)

Same to same. Remonstrance of the U. S. ninister at London against enlistment of troops within the U.S. Aug. IO, I855. (Confidential. Two enclosures, both missing.)

149. Molesworth to Head. No. 27. Wishes to know if the two depots at Niagara for enlisting recruits from the U. S. have been closed. Sept. I, I855. (Draft of reply and another letter upon this topic are within.)

Same to same. No. 46. Sends opinion of law-officers regarding observance by $U$. S. fishermen of local laws and regulations of the Br. N. American provinces; also despatch from the minister at Washington on Sec. Marcy's circular of July I2 to the collectors of customs. Oct. 19, I 855. (Duplicate. Enclosures present. Also in G 297.)

Labouchere to Head. No. 9. Relative to memorial of Montreal board of trade regarding a consul general in the U. S. Dec. I2, I855.

150. Labouchere to Head. No. 20. Sends letter and enclosures from Lawrence of Boston on assistance given by I. D. Andrews in promoting reciprocity between the U. S. and Br. N. America. Jan. 8, I856. (Enclosure present.)

151. Labouchere to Head. No. II3. Various remarks relative to the reciprocity treaty of 1854 . July 15,1856 . (Similar letter to Daly in G 298.)

Same to same. No. I29. Sends circular of instructions from Sec. Marcy to U. S. collectors of custons relative to the fisheries. Aug. $15,1856$. (Enclosure present. Also in G 298.)

153. Labouchere to Head. No. 2. Extradition matter. Jan. 2, I857.

Same to same. Sends recent law of South Carolina regarding colored 
persons on board vessels arriving within the limits of that state. Feb. 23, I857. (Circular. Enclosure present.)

Same to same. No. 44. Extradition matter. Apr. 7, I857. (One enclosure.)

Same to same. No. 49. Americans have no right to fish on the British side of lakes Huron and Superior. Apr. 16, I857. (Copy of Head's despatch on this topic is enclosed.)

Same to same. No. 5I. Remarks relative to the U. S. boundary from the Lakes to the Red River settlement. Apr. I8, I857.

154. Labouchere to Head. No. 59. Sends correspondence between the department and the Foreign Office on the continuation of the international boundary along the 49th parallel from the Gulf of Georgia to the Rockies. May I, I857. (Enclosure present.)

Same to same. No. 74. Sends letter and enclosures from the Foreign Office on the desire of the Toronto board of trade to obtain the help of the Chicago board in procuring an extension of the reciprocity treaty. May 25, 1857. (Enclosure present.)

Same to same. No. Sr. Relative to a portion of the international boundary said to lack accurate definition. June $6, \mathrm{I} 857$.

Same to the officer administering the government of Canada. No. I8. Sends letter and enclosures from the Foreign Office on repeal of present navigation laws on inland shipping in Br. N. America. Aug. 4, I857. (Enclosure present.)

155. Labouchere to Head. No. 58. Relative to seizure of the vessel Julia Smith or Maseppa within British waters by U. S. authorities. Dec. 8, 1857. (Five diplomatic and legal enclosures.)

156. Labouchere to Head. No. r4. Sends correspondence with the Hudson's Bay Co. and instructions to the governor of Vancouver's Island in the event of a Mormon immigration. Feb. 4, I858. (Enclosures present.)

Same to same. No. 25. Sends despatch from the minister at Washington relative to a migration of Mormons to the Hudson's Bay territory. Feb. 25, 1858. (Enclosure present.)

Stanley to same. No. 5. Sends despatch from the minister at Washington on the projected transcontinental U. S. railroad. Mar. 5, I858. (Enclosure present.)

Same to same. No. 9. Sends despatch from the minister at Washington, with enclosure, on survey of the Oregon international boundary. Mar. I2, I858. (Enclosure present.)

Same to same. No. 26. Sends despatch from the minister at Washington with memorial from Wisconsin favoring the construction of a railroad from the head of Lake Superior to Puget Sound. Apr. 9, 1858. (Enclosure present.)

Same to same. No. 32. No complaint can be made to the U. S. regarding the seizure of the Julia Smith or Mazcppa. Apr. 20, I 858 .

15\%. Stanley to Head. No. 39. Sends correspondence between the department and Hamilton Merritt on means of improving the trade of Canada. May I, I858. (Enclosure touches U. S. interests both by land and by sea.)

Same to same. No. 44. Sends two despatches with enclosures from the minister at Washington on the arrest of two Germans at Buffalo on a charge of recruiting for Her Majesty's service. May I4, I858. (Enclosures present.) 
Same to same. No. 46. Relative to postal communication between England, Canada, and the U. S. May 15, I858. (One enclosure.)

Same to same. No. 50. Sends diplomatic correspondence on levy of import duty on hay and hops brought into the U. S. from Canada. May 22, I858. (Enclosure present. Another letter, with enclosures, on this subject on June 8.)

Lytton to same. No. 2I. Sends letter from the Lords of Trade with extracts from a report by the British consul at Chicago on the trade of that place for 1857. July 7, 1858 . (Enclosure present.)

Same to same. No. 37. Sends letter from the General Post-Office relative to mails between England, Canada, and the U. S. Aug. 10, I858. (Enclosure present.)

Same to same. No. 4o. Sends despatch from the minister at Washington relating to six new U. S. revenue cutters for the Lakes. Aug. I7, 1858. (Enclosure present.)

Same to same. No. 42. Sends two despatches from the minister at Washington relative to revision and extension of the reciprocity treaty of 1854. Aug. I8, I858. (Enclosures present.)

158. Lytton to Head. No. 5I. Sends further despatch from the minister at Washington on additional U. S. revenue cutters on the Lakes. Sept. 2, I858. (Enclosure present.)

Same to same. Sends two letters from the Foreign Office. Sept. I8, I858. (Confidential. Enclosures relate to survey of rivers in Maine, Nova Scotia, etc., by British and U. S. commissioners.)

Same to same. Sends legal opinion on right of the supreme court of New South Wales to exercise jurisdiction in regard to certain complaints made by a seaman of a U. S. merchant ship against the captain. Oct. I4, 1858. (Circular. Enclosure present.)

Same to same. No. 72. Wiggin succeeds Cushman as U. S. commissioner for the settlement of fishery questions under the reciprocity treaty. Oct. I5, I858.

Same to same. No. 88. Postal arrangements between Great Britain, the U. S., and Canada. Nov. 26, I858. (Seven enclosures.)

Same to same. No. IO4. Sends letter from the Postmaster General on conveyance of mails between Great Britain and the U. S. by Canadian packets. Dec. 23, 1858. (Copy. Four enclosures present.)

159. Lytton to Head. No. 3. Receipt of letter from William Rees on necessity of purchasing from the U. S. the angular tract north of the St. John River as a preliminary to an intercolonial railway. Jan. I, I859.

Same to same. No. 9. Sends letter from the Board of Trade enclosing a despatch from the British consul at Chicago, on relief for British seamen in distress in U. S. ports on inland lakes. Jan. I4, I859. (Enclosure present.)

Same to same. No. I4. Sends letter from the Foreign Office, with enclosure, on a murder of a British subject in Canadian waters by a U. S. officer. Jan. 25, I859. (Enclosure present. Nos. 28, 35, 40, 46, 48 , and 59 deal further with this topic, and contain several enclosures on demands for extradition of the officer in question. The last number is dated Apr. 23.)

Same to same. No. 22. Sends further letter from the Board of Trade with despatch from the British consul at Buffalo, on relief for suffering British seamen on American vessels. Desires opinion. Feb. 7, I859. (Enclosure present.) 
Same to same. Sends report on question whether the exclusion of foreign shipping from the U. S. coasting-trade extended also to carriage of passengers from one port to another in the U. S. Feb. 10, 1859. (Confidential. Copy. Two enclosures.)

Same to same. No. 24. Sends letter from the Foreign Office with despatch from the minister at Washington on designs of disaffected Irish in Canada and the U. S. Feb. I I, I859. (Enclosures present.)

Same to same. No. 29. Remarlis on attempts to induce colored persons in Canada to emigrate to Jamaica. Feb. I I, I859. (One enclosure.)

Same to same. No. 49. The U. S. have no present intention of abrogating the reciprocity treaty. Mar. 31, i 859. (One enclosure.)

Carnarvon to same. No. 54. Sends correspondence between the department and the Treasury on proposal of the North Western Navigation and Railway Co. of Canada to convey mails through Canada and British Columbia to the Pacific. Apr. I3, 1859. (Enclosures give a good deal of information on U. S. mail routes and carriage.)

Same to same. No. 56. Relative to duty upon Canadian produce shipped from U. S. ports into Great Britain. Apr. I 5, I859.

160. Carnarvon to Head. No. 82. Sends further letter from the Foreign Office, with despatch from the minister at Washington, on extradition of U. S. officer charged with shooting British subject in Canadian waters. June 14, I859. (Enclosure present. No. 84, of June 23, is also concerned with this topic, as are also nos. I7 and 25, of Aug. I and 20, from Newcastle.)

Newcastle to same. Relative to laws of the Southern States with regard to free negroes landing at their ports. July 23, I850. (Circular. Two enclosures.)

Same to same. No. 20. Sends despatch from the governor of British Guiana against the introduction into that colony of free negroes from Canada. Aus. 6. 1859. (Enclosure present.)

161. Newcastle to Head. No. 32. Relative to legislative address regarding duty on certain Canadian products shipped into Great Britain from a U. S. port. Sept. 5. I859. (Two enclosures. No. 69, of Dec. 17, with enclosures, deals with the same topic.)

Same to same. No. 67. Relative to threatened encroachment on Canadian territory by subordinate U. S. officers. Dec. 5, I859.

162. Newcastle to Head. No. 8. Sends report and memorandum from the Lords of Trade on import duties levied in Canada upon certain British manufactures. Jan. 31. I860. (Enclosures make comparisons with U. S. duties and trade.)

164. Russell to Head. No. IO2. Orders to deliver up fugitive from justice from Missouri. Oct. 27. 1860. (Inmmediate.)

Newcastle to same. No. I24. Sends letter to Lord John Russell from Perley reporting his proceclings as fishery commissioner (under the reciprocity treaty) during the past season. Dec. 22, I860.

165. Newcastle to the officer administering the government of Canada. No. I30. Comments on agitation in the U. S. over the reciprocity treaty. Jan. I, I86 I. (Two enclosures.)

Same to same. Remarks on case of Anderson, a fugitive slave. Jan. 9, I86 I. (Nos. I.34, I35, I 55, I 56, I75, and I 79 are all on the same topic.)

Same to same. Relative to certificates now given at Charleston, S. C., to vessels clearing for British ports. Jan. 26, i86I. (Circular. Enclosures missing.) 
Same to Head. No. I43. Remarks on award of fisheries commissioners under the treaty of June, I 854 . Feb. Io, I86I.

Same to same. No. I68. Hamlin to succeed Hubbard as U. S. commissioner under the reciprocity treaty of i854. Apr. 23, I86r.

Same to same. Sends the queen's proclamation of neutrality during hostilities in the U.S. May I6, I86 I. (Circular. Enclosure missing. Papers of this nature were always published in the Gazette.)

Same to same. No. Ig6. Approves latter's course in refusing to sell or lend arms to New York or the U. S. May 26, I86 г.

Same to same. No. ig9. Sends despatch from Lord John Russell to Lord Lyons on secrel agents stated to have been sent to Canada by the U. S. government. June I, I86r. (Enclosure present.)

Same to same. No. 20o. Approval of latter's answer to application from the governor of Massachusetts to detain the steamer Peerless, and of his precautions to guard the canals. June I, I86I.

Same to same. No. 20I. Relative to visit at Quebec of Ashmun. agent of the U.S. Instructions to "continue quietly to discourage all missions whether from the United States or from the Southern Confederacy". June I, I86I.

Same to same. Neither party in the states is to be allowed to carry prizes into British ports. June r, I86r. (Circular.)

Same to same. No. 204 . Relative to resolution of the assembly of Prince Edward Island, expressing regret at hostilities in the states. June I 5. I86I. (Eight enclosures.)

Same to same. No. 2 IO. Approves latter's course in calling public attention to laws relating to enlistment. without leave, of British subjects for foreign service. June 27, I86r.

Same to same. No. 2I I. Approves latter's answer to Messrs. Redpath relative to cargoes owned by British subjects in U. S. vessels. June 27, 1861.

166. Newcastle to Head. No. 213. Sends London Gavette containing approval of the appointment of Joshua R. Giddings as U. S. consul general for Br. N. America. July 2, I86r. (Enclosure present.)

Same to same. No. 225. Remarks on protecting the canals from injury by citizens of the U. S. July 18, I861.

Same to same. No. 23I. Sends letter from the Foreign Office enclosing despatch from the minister at Washington on the secret agent sent into Canada by the U. S. July 30, r86r. (Enclosure present.)

Same to same. No. I 35. Sends despatch from the British consul at New Orleans. Aug. 6, 1861. (Enclosure on distress of Canadian subjects in that region largely as a result of the war, and measures for their relief.)

Same to Monck. No. 3. Approves magistrate's act in ordering the discharge of five deserters from the U. S. army. Nov. Io, I86r.

Same to same. Transmits cipher for communication with the British minister at Washington with more security. Instructions. Nov. 15, I861. (Secret. Cipher missing.)

Same to same. No. 6. Sends despatch from Seward on attempt made at Hamilton to recruit for the U. S. army. Nov. 22, 1861. (Seward's despatch contains a letter to him from Simon Cameron upon this topic.)

Same to same. No. 9. Military preparations for the defense of Canada 
as the result of the Trent affair. Dec. 4, I86I. (Duplicate. With it is a draft of the reply.)

Same to same. No. 12. Relative to accommodation of troops for defense "At a moment when a rupture with the United States appears to be imminent". Dec. 7, I86r.

Same to same. Arrangements regarding passports for British subjects embarking from U. S. ports. Dec. 27, 1861. (Circular.)

167. Newcastle to Monck. No. 39. Sends extract of despatch from the minister at Washington on proceedings in the House of Representatives on defense of the Great Lakes and rivers. Jan. 4, I862. (Enclosure present.)

Same to same. No. 40. Remarks on appointment of U. S. consular agents for Quebec and Gaspé Basin. Jan. 4, I862.

Same to same. Instructions to maintain neutrality with regard to time of allowing ships of the belligerent parties to leave port. Jan. I6, 1862. (Circular.)

Same to same. Sends rules to be observed regarding the contest in the states. Feb. I, I862. (Circular. Enclosure present.)

Same to same. No. 53. Remarks on the question of sending troops or military stores for British provinces through the U. S. Feb. 8, I862.

Same to same. No. 73. News that vessels are being built at Ogdensburg, Oswego, and Buffalo, apparently intended as gunboats on the Lakes. Instructions. Mar. 15, 1862. (Two enclosures.)

Same to same. No. 99. Remarlis respecting the numerous consular appointments in Canada recently made by the U.S. Apr. 28, I862. (Copy.)

Same to same. No. Io3. Receipt of despatch respecting the action of Congress with regard to the establishment of naval depots on the Lakes. Apr. 28, 1862.

Same to same. No. II5. Sends letter from the Hudson's Bay Co. on the state of the Saskatchewan and Red River territory. May IO, I862. (Enclosure speaks of American traders, and the fear of an influx of squatters and gold hunters from the U. S.)

Same to same. No. I I . Relative to the question of appointing a British consul at Detroit. May 21, I862. (Three enclosures.)

Same to same. Sends despatch from the British consul at Buffalo on the reciprocity treaty. May 26, 1862. (Confidential. Enclosure consists of several despatches and extracts.)

168. Newcastle to Monck. No. I23. Has laid before the queen the petition of the Quebec board of trade on U. S. registry of colonial shipping and participation in the $\mathrm{U}$. S. coasting-trade in the event of any changes in the reciprocity treaty. June $3,1862$.

Same to same. No. I34. Sends note from the minister at Washington to Seward and the latter's reply on the claim of John G. Shaver because of his imprisonment in the U.S. June 28, I862. (Enclosures present.)

Same to same. Intention of the U. S. government to issue letters of marque. Aug. I, I862. (Circular.)

Same to same. No. I63. Comments at length upon the rejection of the militia bill and the need of measures for defense in case of unfriendly relations with the U.S. Aug. 2I, I862. (Copy.) 
Same to same. No. I70. No land in San Juan Island may be sold while the question of ownership is unsettled, nor may British subjects settle there at their own risk. Sept. 24, I862. (One enclosure.)

169. Newcastle to Monck. No. II. Sends despatch with enclosure from the minister at Washington showing that the U.S. is willing to reconsider the case of John Shaver. Jan. 3I, I863. (Enclosure present.)

Same to same. Sends letter respecting the power of colonial laws over U. S. subjects fishing in British waters. Feb. 2, I863. (Confidential. Enclosure present.)

Same to same. No. 34. Sends despatch and enclosure from the minister at Washington on rejection by the House of a bill to enlarge the New York and Erie Canal. Mar. 24, 1863. (Enclosure present.)

Same to same. No. 58. Relative to delegation appointed by the Illinois legislature to urge enlargement of the Canadian canals. May 23, I863.

Same to same. No. 65. No objection to appointment of J. R. Giddings as consul general for the U. S. in Br. N. America. June 26, 1863 .

170. Newcastle to Monck. Sends treaty between Great Britain and the U. S. for the suppression of the African slave-trade, and an additional article thereto. July Io, I863. (Circular. Enclosures present.)

Same to same. No. 73. Sends correspondence between the department and the Foreign Office on desire of the U.S. to pursue hostile Indians taking refuge on the British side of the frontier. July IO, I863. (Enclosure present.)

Same to same. No. 78 . Relative to arrest by Canadian constables of two fugitives from justice at Port Huron. July 24, I863.

Same to same. No. 83. Sends circular addressed to governors of the West Indian colonies on issue of coal to war vessels of the belligerents. July 3I, I863. (Enclosure present.)

Same to same. No. 97. Sends memorials from the corporations of Stockton and Sheffield and one from the inhabitants of Sheffield, and his replies thereto, respecting a navigable water connection between Montreal and Lake Huron. Sept. II, I863. (Enclosures relate to increase of surplus products in the northwestern states, etc.)

Same to same. Transmits act to carry into effect the additional article to the treaty for suppressing the African slave-trade. Sept. 22, I863. (Circular. Enclosure present.)

Same to same. No. II2. Sends memorial from the town council of Leeds, and his reply, regarding a canal between Lake Huron and the Ottawa River. Oct. 21, 1863. (Enclosure similar to those in no. 97.)

Same to same. No. I28. Approves measures taken to prevent a band of Confederate refugees in Canada from invading the U.S. Dec. Io, I863.

Same to same. No. 133. Sends extract of despatch from the consul at Buffalo, showing the favor with which that place regards measures to prevent invasion of the U. S. by Confederate refugees. Dec. I8, I863. (Enclosure present.)

171. Newcastle to Monck. No. I. Course to be pursued regarding applications for the British registration of foreign-built vessels, purchased by British subjects, lying in foreign ports. Jan. 9, I864. (Two enclosures.)

Same to same. Salutes from Confederate vessels of war to be declined. Jan. I I, I864. (Circular.) 
Same to same. No. 5. Remarks on erection of works on the U. S. lakes with a view to defense from invasion from Canada. Jan. I6, I864.

Same to same. No. 7. Wishes to know if recruiting for the U. S. army is going on in Canada. Jan. I6, I864.

Same to same. No. I4. Sends despatch with enclosure from the minister at Washington on movement for abrogating the agreement of I 8 I7 respecting armed vessels on the Lakes. Feb. 4, I864. (Enclosure present.)

Same to same. No. 15. Sends despatch from the minister at Washington reporting the introduction of a resolution in the Senate, calling upon the President to give notice of the abrogation of the reciprocity treaty of I $_{54}$. Feb. 4, I 864 . (Enclosure present.)

Same to same. No. 2I. Sends despatch from C. F. Adams, with enclosure, on attempt to invade the U. S. from Canada. Mar. I, I864. (Enclosure present.)

Same to same. No. 29. Desires report on arrest of the consul general of the U. S. at Montreal. Mar. 22, I864.

Same to same. No. 30 . Relative to probable abrogation of the reciprocity treaty by the U.S. Mar. 24, I864. (Copy.)

Cardwell to same. No. 8. Relative to report of equipment of two schooners on the British shore of Lake Erie, to be used against the U. S., etc. Apr. 23, I864.

172. Cardwell to Monck. Instructions on treatment of prizes captured by Federal or Confederate cruisers, brought within British waters. June 2. I864. (Circular.)

Same to same. No. 23. Relative to the construction at Buffalo of an armed vessel by the U.S. June 4, I864. (Five enclosures.)

Same to same. No. 26. Relative to importation of anthracite coal into Canada from the U. S. June Io, I864. (No.6o, of Sept. I, also deals with this subject, as does no. 7I, of Sept. 27.)

Same to same. Course to be taken with regard to belligerent cruisers. July 5. I864. (Circular. One enclosure.)

Same to same. No. 37. No violation of territorial rights by the U. S. authorities in the case of Peter Needham. July 7, 1864.

Same to same. No. 44. "Earl Russell concurs with you as to the expediency of disconraging the practice by which the subordinate officers of the two govermments aid each other in the arrest of criminals without complying with the Regular forms of Law." July 23, I864.

Same to same. No. 45. Sends despatch from the minister at Washington on an act passed by Congress to regulate the foreign coastingtrade. July 23, I864. (Enclosure present.)

Same to same. No. 49. Appointment of John F. Potter as U. S. consul general for Br. N. America has been approved. July 27, I864.

Same to same. No. 56 . Remarks on case of two Americans captured on U. S. soil and tried in Canada, etc. Aug. 22, I864.

Same to same. Sends tables showing decrease in resin and turpentine imported into Great Britain since the stoppage of the supply from the Southern States. Aug. 26, I 864. (Circular. Enclosure missing here, but is present in G 306.)

Same to same. To allow no Federal or Confederate vessel of war to be brought into British ports in order to be dismantled or sold. Sept. I6, 1864. (Circular.) 
Same to same. No. 72. Remarks on case of the Rev. T. M. Kinnaird, an American-born person of color, naturalized in Canada, who was lately imprisoned and fined in Delaware under the laws of that state. Sept. 27, 1864. (Schedule of correspondence enclosed.)

Same to same. No. 74. Receipt of despatches on attempts to recruit in Canada for the U. S. army. Sept. 29, I864.

Same to same. No. 77. Sends regulations issued by the superintendent of immigration at New York respecting contracts made in foreign countries with emigrants. Oct. IO, 1864. (Enclosure present.)

Same to same. Information on mail and telegraph facilities from California to British Columbia. Oct. 29, I864. (Circular.)

Same to same. No. 83. Sends letter from the Foreign Office with enclosure on recruiting in Canada for the U. S. army. Nov. I, I864. (Enclosure present.)

Same to same. No. 88. Relative to conviction of two persons engaged in enticing British subjects into the U. S. army. Nov. IO, I864.

Same to same. Instructions on supply of coal to war vessels of the belligerents. Nov. 15, 1864. (Circular. Two enclosures.)

Same to same. No. 94. Comments upon actions of Confederates in Canada. Dec. 3, i864. (Copy. Copy of Monck's reply follows.)

Same to same. No. 95. Relative to crimping at Quebec for the U. S. service. Dec. 5, I864. (One enclosure.)

Same to same. No. II 2 . Sends papers received at the Foreign Office from C. F. Adams on Confederate organizations in Canada and the St. Albans raid. Comments. Dec. 3I, 1864. (Copy. Enclosures present.)

173. Jan. 5-May 26, I865. In this folder twenty-three of the despatches and circulars relate to American history. They are all from the Colonial Office to Viscount Monck.

The chief topics discussed are border raids, principally from Canada into the U. S., their prevention and results, and the abrogation of the treaties of 1817 and 1854 , with regard to naval forces upon the Lakes and reciprocity. Two despatches show the measures taken both in Canada and in Great Britain to express the sentiments felt with regard to the assassination of President Lincoln. Circulars on neutrality, the stringent passport regulations of the U. S., U. S. navy-yards on the Lakes, the alleged manufacture of Greek fire in Canada, and proposals in Congress for a canal around Niagara Falls are other subjects mentioned in single despatches.

As in other cases, many numbers contain important enclosures.

174. Cardwell to Monck. Sends letter from Earl Russell announcing that government recognizes that peace has been restored in the territory of the U. S., and giving instructions respecting Confederate cruisers in British waters. June 3, I865. (Circular. Enclosure present. Two circulars of July 5 and Sept. 7 , with enclosures, deal with the case of the Shenandoah, while another of Oct. I8 declares that all restrictive measures on vessels of war of the U.S. are now to be considered at an end.)

Same to same. No. Io2. Sends letter from the Foreign Office with enclosure respecting the Kate Carleton, a vessel captured for breach of blockade while sailing with a British register, though belonging to an American. June 22, I865. (Enclosure present.) 
Same to same. No. I05. Sends despatch from Sir F. Bruce enclosing correspondence with the U.S. government on the fishery commission. June 24, I865. (Enclosure present.)

Same to same. No. I06. Remarks on indictments of certain persons charged with conspiring in Canada against the U. S. June 28 , 1865.

Same to same. No. I07. Relative to a U. S. Senate report of Mar. I, 1865, touching on treatment of Indians in Br. N. America. June 29, 1865 .

Same to same. No. I Io. Sends circular issued by the U. S. Treasury, removing all restrictions on the exportation of anthracite coal. July $\mathbf{I}$, 1865. (Enclosure present.)

Same to same. No. I I9. Remarks on case of Dr. Blackburn, charged with having conspired to send infected clothing into the U. S. July 22,1865 .

Same to same. No. 164. Extradition matter. Dec. 4, I865. (One enclosure.)

Same to same. No. I73. Information on U. S. rights to navigate the St. Lawrence and the Welland and Rideau canals, and British rights to navigate Lake Michigan. Dec. 29, I865.

175. Cardwell to Monck. Sends report of law-officers upon the case of the steamer Gcorgiana. Jan. 20, I866. (Confidential. Copy. Enclosure present.)

Same to same. Actual termination of the reciprocity treaty with the U. S. Remarks and instructions regarding the fisheries. Mar. 3, I866. (Confidential. No. 2I, of Mar. Io, also deals with the rights of U. S. fishermen, as does likewise no. 24, of Mar. Io.)

Same to same. No. 33. Relative to calling out Canadian militia in consequence of a threatened Fenian raid. Mar. 3I, I866.

Same to same. No. 38. Sends letter from the Foreign Office with enclosure reporting steps taken by the fishery boundary commissioners at Washington, as a result of the abrogation of the reciprocity treaty. Apr. 14, r866. (Enclosure present.)

Same to same. Sends instructions issued for the officers of the British navy employed in the protection of $\mathrm{Br}$. N. American fisheries during the present year. Apr. I4, r866. (Confidential. Two other enclosures besides the printed one mentioned.)

Same to same. Relative to placing a naval force on the Lakes to protect Canada from Fenian attacks. Apr. 28, 1866. (Confidential. Copy. One enclosure.)

Same to same. Sends memorandum on the fishery question by [C. F.] Adams and instructions from the Foreign Office to Sir F. Bruce upon that subject. Nay i2, i866. (Confidential. Enclosures present.)

Same to same. Unwillingness of the Nova Scotia executive to issue licenses to U. S. fishermen for the current year. May 26, I866. (Confidential. Copy. Despatch to the lieutenant-governor of Nova Scotia is enclosed.)

176. Cardwell to Monck. No. 55. Relative to the appointment of additional consular officers of the U. S. in Canada. June I6, I866. (Copy.)

Same to same. No. 56. Receipt of despatch giving information of Fenian raid at Fort Erie. June I6, I866. (Other despatches on this raid, measures to prevent a recurrence, etc., are nos. $62,63,67,71,72$, and from Carnarvon, nos. 4 and 7.) 
Same to same. No. 66. Approves measures with regard to granting licenses to U. S. fishermen. June 23, I866.

Carnarvon to same. No. I9. Sends letter with enclosures from the Board of Admiralty on protection of fisheries in Br. N. America. Aug. 4, I866. (Enclosure present.)

Same to same. No. 2I. Sends copy of correspondence between the department and the Foreign Office on the temporary increase of the British naval force on the Lakes. Aug. 4, I866. (Enclosure present.)

177. Carnarvon to Monck. No. 49. Relative to additional British gunboats on the Lakes. Sept. Io, I 866.

Same to same. No. 62. Remarks on practice of U. S. fishermen in British waters of using set lines. Diplomatic matters. Sept. 24, I866. (Copy.)

Same to same. No. 85. Relative to disposition of the naval force in the St. Lawrence and on the Lakes during the winter. Oct. 29, I866. (Five enclosures, some of which refer to protection against any $\mathrm{Fe}$ nian attempts from the U. S.)

Same to same. No. IOI. Relative to measures with regard to certain Fenian prisoners. Nov. 23, 1866. (Copy. No. I08, of Nov. 24, deals at length with this subject.)

Same to same. No. I 6 . Relative to jurisdiction of Great Britain and the U. S. upon the Lakes. Dec. I, I866. (One enclosure.)

Same to same. No. I20. Open sale of muskets at Eastport, Maine. Dec. 22, I866. (Four enclosures.)

178. Carnarvon to Michel. No. I43. Is against the creation of a permanent British naval force on the Lakes. Mar. 2, I867. (Six enclosures.)

Buckingham to the officer administering the government of Canada. No. I7. Relative to the naval force to be maintained on the Lakes, etc. Apr. 5, I867. (No. 21, of Apr. 27, is also upon this subject.)

179. Convention between the General Post-Office of Great Britain and that of the U.S. London, June I8, I867. (Printed.)

Buckingham to Monck. No. 49. Comments on increased fee on fishing licenses by Prince Edward Island. July 6, I867. (One enclosure.)

Same to same. No. 6I. Relative to a private claim to compensation for damages to property in New Brunswick by Fenians in I866. July 26, 1867. (Three enclosures.)

Same to same. No. 8I. Sends report of the Postmaster General regarding postage rates upon letters and papers sent between Great Britain and Br. N. America via the U. S. Aug. 24, I867. (Enclosure present.)

180. Buckingham to Monck. No. 85. Various remarks on the fisheries. Sept. 3, 1867. (One enclosure.)

Same to same. No. II3. Sends correspondence regarding differential duties on breadstuffs imported into Prince Edward Island. Nov. I4, I867. (Enclosure present.)

184. Mar. 29, I838-May I8, I839. “Extracts from Sir George Arthur's Despatches to the Secretary of State, having reference to the State of public feeling within and without the Province." (Compilation of I94 pp.)

Colborne to Normanby. Raid at Barnston by a band from the U. S. State of feeling on the frontier. Montreal, July 28, 1839. (Confidential. Duplicate. Two enclosures on the Barnston raid.)

Arthur to same. No. I76. Account of sundry border raids and out- 
rages, state of feeling, etc. Toronto, Aug. 21, I839. (Copy. About a dozen enclosures on border occurrences.)

Same to same. No. I9I. Various remarks on border aggressions, rumors of plots, etc. Toronto, Sept. I7, I839. (Copy. The confidential despatch of Sept. 27 deals with the same general topics, and contains numerous enclosures, including correspondence with the minister at Washington, making a total of about $\mathrm{r} 40 \mathrm{pp}$.)

Same to same. Remarks at length upon "Patriot" proceedings on the U. S. frontier, and the aspect of affairs generally in Upper Canada. Toronto, Oct. I5, I839. (Confidential. Copy. Seven enclosures, making about 275 pp. in all.)

Same to Russell. Proceedings with regard to rumors of Gen. Scott's good understanding with the patriots. Toronto, Oct. 22, I839. (Confidential. Copy. Three enclosures, of which two are copies of Gen. Scott's letters.)

184 A. Petition to the queen from the Upper Canada assembly on the Canada Trade Act and its effects on the export of wheat to the U. S., etc. Feb. 4, I840. (Another petition, of Dec. 24, I839, asks that tea may be imported from the U. S. upon payment of a certain duty.)

Documents forming enclosure no. 2 to Arthur's despatch no. 94, Jan. 25. I841. (Twenty-seven numbers on the case of Alexander McLeod. Some are originals, some copies, while others are drafts. Also in Q 431, pt. I.)

Enclosure no. 3 in $i d$, being the original deposition of Samuel Wood, an American prisoner at Toronto, detailing at length various proceedings of Americans and patriots on the frontier, the Caroline affair, etc. (Copy in Q 431, pt. I.)

185. [Bagot] to Stanley. No. 17. Sends remainder of returns from the chief emigration agent. [Kingston], Jan. 26, I842. (Draft. Enclosure present, showing number who went from Canada West to the U. S. Letter evidently written before the return was compiled, as the latter is dated Feb. I.)

Same to same. No. 34. Remarks on immigration, including that from the U. S., and emigration to that country. Kingston, Feb. I7, I 842 . (Enclosed is report from the medical superintendent, remarking on the New York head tax, etc.)

187. [Bagot] to Stanley. No. I Io. Relative to the establishment of fisheries on Lake Huron. [Kingston], May 23, I842. (Three enclosures.)

187 A. Draft to Capt. Sandom, reporting intended attack of the patriots upon the British vessels on Lake Erie. Kingston, Jan. 4, I842.

[Murdock] to D[avid] Thompson. Acknowledges receipt of papers on the Oregon territory. Mar. 5, i842. (Marginal memoranda.)

Draft to Capt. B. Taylor, asking for copies of military charts of the country bordering on $45^{\circ} \mathrm{N}$. latitude, which are desired by Lord Ashburton. May $4, \mathrm{I}_{42}$.

Draft to William H. Seward. Extradition matter. May 27, 1842.

Draft to Capt. Taylor. Relative to rumor of projected attack upon the western frontier of the province from the U.S. June 9, I842. (Confidential.)

Draft to W. H. Seward. Extradition matter. Quebec, July 4, I842.

[Murdock] to R. D. Jackson. Relative to rumors of projected attack from the U. S. upon the western frontier of the province. July 22, I842. 
188 A. Draft to Lieut.-Col. Ermatinger. Asks for information on certain fugitives from justice from the U. S. Aug. 25, I842. (Immediate.)

Draft to Judge McLean. Remarks on latter's suggestions for regaining the Long Sault Islands and Barnhart's Island from the U. S. Sept. 7, 1842.

189. [Bagot] to Stanley. No. 35. Sends further documents on the bill imposing a duty on U. S. wheat. [Kingston], Feb. 24, I843. Two enclosures. Draft of no. 43, Mar. 20, with two enclosures, is upon the same topic.)

190. M[etcalfe] to Stanley. No. 46. Sends letter from David Thompson upon the Oregon territory. June 23, I843. (Enclosure present.)

[Metcalfe] to Stanley. No. 78. Sends reports on immigration. [Kingston], Sept. 4, I843. (One enclosure, giving numbers arriving at certain agencies from the U.S.)

192. [Metcalfe] to Stanley. No. 8. Extradition matters. [Kingston], Jan. I0, I844. (Several depositions, etc., enclosed. No. 21, with two enclosures, deals with another extradition case.)

193. Metcalfe to Stanley. No. 66. Sends report on the U. S. naval force on the Lakes. Comments. Kingston, Apr. I8, I844. (Copy. Report present.)

194. [Metcalfe] to Stanley. No. 320. Submits memorandum on duty on U. S. ashes imported into the province. [Montreal], July 24, I845. (Enclosure present.)

G[eorge] Simpson to Metcalfe. Details of and comments upon journey of Messrs. Warre and Vavasour " to acquire a knowledge of the character and resources of the country situated between the Sault de Ste Marie and the shores of the Pacific, and of the practicability of forming military stations therein and conveying troops thither, with a view, should it hereafter become necessary, to the occupation thereof for military purposes". Michipicoten, July 9, I845. (Confidential. Three enclosures, including a letter from Simpson to Warre and Vavasour on U. S. frontier posts, their journey, labor, water communication, etc., and another from the same to Peter Skene Ogden. Endorsement says copy of the above was sent to Stanley, July 26, I845.)

196. [Cathcart] to Gladstone. No. Ior. Sends petition from the Hamilton board of trade asking that Canadian produce may be shipped to Great Britain from U. S. ports on the same terms as from Canadian ports. [Montreal], July 27, 1846. (Enclosure present.)

197. [Elgin] to Grey. No. I6. Transmits memorial of the Montreal board of trade. [Montreal], Mar. 24, I847. (Enclosure treats of western trade, etc.)

198. [Elgin] to Grey. No. I3. The U. S. wish to bring two vessels through the Welland Canal, etc. [Montreal], Feb. I6, I848. (Four enclosures.)

204. [Elgin] to Newcastle. No. 9. Relative to Nova Scotian interests in the reciprocity treaty with the U. S. [Quebec], June I7, I854. (Memorandum enclosed.)

Same to Grey. No.64. Transmits the Blue Book for 1853, with public accounts and tables of trade and navigation. Remarks at length upon the reciprocity treaty, trade with the U. S., etc. Quebec, Dec. I8, I854. (Copy, totalling I I pp.)

205. [Head] to Russell. No. 28. Sends papers on proposed establishment of a British consul at Chicago. Remarks. Quebec, Apr. 6, 1855 . 6 (Five enclosures.) 
Same to same. No. 38. Sends memorial of the Quebec board of trade for the appointment of a consul general for $\mathrm{Br}$. N. America to the U. S. Quebec, Apr. 27, I855. (Enclosure present.)

Same to same. No. 58. Relative to enlistment of persons from the U.S. for the Foreign Legion. Quebec, May 23, I855. (Four enclosures. No. 73, a copy with four enclosures, also contains information on this subject.)

Same to Grey. No. I44. Relative to the postal arrangement of I849 with the U. S. Quebec, Nov. Io, IS55. (Two enclosures.)

Same to same. No. 145. Sends memorial of the Montreal board of trade for the appointment of Archibald as consul general to the U. S., for Br. N. America. Toronto, Nov. I6, I855. (Enclosure present.)

206. [Head] to Labonchere. No. 86. Legal view that U. S. government vessels have no right to free navigation of the St. Lawrence and its canals. Case of the Jefferson Davis. Toronto, June 14, 1856. (Four enclosures.)

Same to same. Remarks on union, the U. S. boundary, Hudson's Bay territory, policy of the U. S., etc. Toronto, Sept. 3, 1856 . (Private and confidential. Copy.)

207. Head to Labouchere. No. 9. Transmits Council minute. Toronto, Jan. I7, I857. (Copy. Enclosure urges the importance of fixing the Northwestern Boundary, etc.)

Same to same. No. 8. Transmits the Blue Book for I855. Remarks upon such topics as the working of the reciprocity treaty, comparative prices of land in Canada and Michigan, commerce of the Ottawa valley with the west, etc. Toronto, Jan. I7, IS57. ('Total of about 60 pp.)

Same to same. No. 23. Sends Draper's instructions relative to the Hudson's Bay territory. Toronto. Feb. I7, is57. (Enclosure touches on the importance of securing the northwest against the sudden American immigration, etc.)

Same to same. No. 24. Relative to right of Americans to fish in lakes Huron and Superior. [Toronto], Feb. I8, i857. (One enclosure.)

Same to same. Believes the boundary west of Lake Superior should be ascertained and marked with as little delay as possible. n. p., n. d. (Copy.)

209. Head to Lytton. No. I54. Sends memorial to him (Head) from the Cleveland board of trade, and minute of the executive council, both on the murder of Jones by U. S. deputy marshal Tyler. Toronto, Dec. I3. I858. (Enclosures present.)

212. Head to Newcastle. No. 76 . Relative to defense of Canada in the event of hostilities with the U. S. Quebec, Sept. 23, i86r. (Copy. Two enclosures.)

[Monck] to same. No. 8. Case of John Shaver, a British subject, confined at Boston as a prisoner of war. [Quebec], Nov. 9, I86r. (Three enclosures.)

213. [Monck] to Newcastle. No. I64. Believes there is no commercial need for a U. S. consul at Salmon Bay. [Quebec], Dec. I I, i862. (One enclosure.)

214. [Monck] to Newcastle. No. i I5. Relative to the registration of foreignbuilt ships, purchased by British subjects, lying in foreign (especially U.S.) ports. [Quebec], Dec. 2, 1863. (Two enclosures.)

215. [Monck] to Newcastle. No. 6r. Comments on charges of the Rev. Mr. Walshe that Canada had aided the Federals. [Quebec], Apr. I9, 186.4. (With it is a letter from Walshe to Newcastle.) 
216. Copies of two reports of committees of the executive council on steps taken to prevent raids upon the U. S. frontier from Canada. Dec. I6, I864. (Enclosures in a despatch from Monck to Cardwell, no. I99, Dec. I7, I864, which is missing here, but may be found in the letterbook.)

217. [Monck] to Cardwell. No. 30. Sends despatch. [Quebec], Jan. 26, I865. (Enclosure is from Burnley at Washington, with note from Seward respecting measures taken by Monck with regard to the alleged manufacture of Greek fire by Confederates in Canada.)

Same to same. No. 62. Sends telegram received from Burnley and his reply. [Quebec], Feb. 25, i 865. (Enclosures relate to the St. Albans raid.)

Same to same. No. 63. Sends correspondence with Burnley on the steamer Georgiana. [Quebec], Feb. 28, I865. (Only Monck's despatch to Burnley is present.)

Same to same. No. 84. Sends minute of the executive council respecting the U. S. naval force on the Lakes. [Quebec], Mar. 24, I865. (Enclosure present.)

Same to same. No. 99. Relative to trial of St. Albans raiders. [Quebec], Apr. 8, i865. (One enclosure.)

Same to same. No. Io8. Sends report on alleged organizations in western Canada for the purpose of making raids upon the U. S. [Quebec], Apr. 22, 1865. (Enclosure present.)

218. Monck to Cardwell. No. I 6 . Relative to two vessels built at Montreal, and suspected of being intended for the Confederacy. Quebec, May Io, I865. (Two enclosures.)

Same to same. No. I28. Case of Dr. Blackburn, charged with having conspired to send infected clothing into the U. S. Quebec, June 2, I865. (One enclosure.)

Michel to same. No. I I. St. Albans raiders. Montreal, Oct. 27, I 865. (Two enclosures.)

219. [Monck] to Cardwell. No. 23. Sends report of the commissioner of crown lands on the Canadian fisheries act of 1865. [Montreal], Apr. 2, I866. (Enclosure present.)

Same to same. No. 52. Sends copy of his despatch to the minister at Washington on the President's proclamation regarding the Fenian organization. [Ottawa], June I3, I866. (Enclosure present.)

Same to same. No. 78 . Need of larger naval force on the Lakes. [Ottawa], July Io, I866. (Enclosed is return of armed vessels kept on the Lakes by the U. S.)

Same to same. No. 8o. Sends report of executive council on injurious mode of deep-sea fishing practised by U. S. fishermen. [Ottawa], July I2, I866. (Enclosure present.)

221. [Monck] to Buckingham. No. 90. Extradition matter. [Ottawa], Nov. 23, 1867.

222-239. These eighteen folders of varying size form a sub-series of despatches from the British ministers at Washington to the governors, lieutenant-governors, administrators, and governors general of Upper and Lower Canada and of Canada, from I 8 I 5 to I868, with the exception of a gap covering Aug., I842-Jan., I861. Their contents may be described as follows:

222. In this folder of about I6o pp. the first item is a copy of a letter from Monroe to Sir John Warren, Oct. 27, I8I2, on negotiations for a cessation of hostilities between the U. S. and Great Britain. 
The remainder is composed of despatches from the British minister at Washington to the governor at Quebec, the dates ranging from I8I5 to I 830 .

The chief subjects are the American acts of Apr. i8, I8I8, May I5, I820, and Mar. I, I823, respecting navigation; trade between Lower Canada and the U. S. ; and Indian matters, such as trading licenses and restrictions on trade of British subjects with Indians in the U. S. One despatch of I 822 treats of disastrous overflows in Vermont, caused by a dam at the outlet of Lake Memphremagog. There are numerous but not bulky enclosures of acts of Congress, official circulars, etc., and sometimes of letters.

223. Apr. I4, I83I-Oct. I, I835. (325 pp.) This folder contains despatches to the governors, Aylmer and Gosford.

The objection of the U. S. to the levy of certain duties upon American vessels at Kingston, York, St. Johns, etc., and the actions of American authorities in the Indian Stream settlement are the principal subjects. There are numerous enclosures on Canadian deserters in the U. S.; the survey of Sherbrooke County (Quebec), the boundary between it and the $U$. S., and a request for documents touching upon the OhioMichigan boundary ( 1835 ) are among the other topics.

It may also be mentioned once for all that in every folder of despatches from Washington there are several items on extradition cases.

224. Jan. 6, I836-Dec. $7, \mathrm{IS}_{3} 8$. (325 pp.) The contents of this folder fall conveniently into two sections. The first has important despatches on the Indian Stream territory, the attitude of the governor of New Hampshire, enclosures on the late outrages, etc. Complaints on encroachments of $\mathrm{U}$. S. fishermen in the Gulf of St. Lawrence and a confidential despatch on the projected railroad between Quebec and St. Andrews bring this division to a close.

The second part may be said to begin with an important confidential despatch of Dec. 18,1837 , giving the measures taken both by the minister and by the American government to prevent any offensive measures against Canada from the American frontier, the President's attitude, and numerous details about American frontier excitement, the chief localities where it is found, etc.

The remaining part of the folder is entirely composed of cognate material, showing the frontier excitement of the time and the diplomatic side of the question. As examples may be cited two despatches, one giving correspondence with the State Department upon the Caroline affair, and the other conveying intelligence obtained from various U. S. customs collectors of frontier organizations and plots to invade Canada. Yet another relates to the British naval force upon the Lakes.

The despatches are addressed to Gosford and Colborne.

225. Jan. I-Nov. 3, I839. (455 pp.) About a third of this folder is taken up with the Northeast Boundary question, on which there are several long and important enclosures of diplomatic correspondence. Warnings of intended attacks upon the Canadian frontier are continued. Single despatches deal with the arrest in Michigan of Howland Hastings, a British subject. Americans imprisoned in Canada, and the schooner G.S. IV ceks.

Another communication, with enclosures, deals with the imprudent negotiations of Buchanan (British consul at New York) with Papineau. 
A report on alleged Russian plots in the U. S. against Canada is also present.

Many of the despatches are confidential, as was likewise the case with G 224 .

The addressees are Colborne, Arthur, Harvey (New Brunswick), and Thomson. About I 50 pp. are composed of duplicates.

226. Jan. 23-Dec. 27, 1840 . (58I pp.) With the exception of two despatches upon the case of Alexander McLeod, one on extradition negotiations, and one respecting damages claimed for the destruction of the Sir Robert Pecl, this folder is entirely filled with material upon the Northeast Boundary. Many of the despatches are confidential, and nearly all have long enclosures of diplomatic correspondence, some of which is with the Department of State, and some with the British Foreign Office. The persons addressed are Thomson and Arthur.

227. Jan. 2-Oct. 26, I84I. ( $\mathrm{Ca} .600$ pp.) About half the material in this folder relates to the trial of Alexander MIcLeod, especially with regard to its diplomatic bearings, showing how acute the situation became, and how narrowly war was averted.

There are also a good many despatches upon the Northeast Boundary question. The remaining ones touch the following matters : port regulations upon a U. S. vessel at Kingston, rumors of attack upon British vessels on the Lakes, the Caroline, Oregon, information from Webster of renewed designs upon Canada, and the arrest of James Groghan in Vermont by British officers.

The addressees are Sydenham, Arthur, and Jackson.

228. Fox to Bagot. No. 2. Sends correspondence with the Foreign Office on the British naval force on the Lakes and the agreement of I8I7. Washington, Apr. 20, I842. (Enclosure present.)

Same to same. No. 3. Sends copies and extracts from reports of U. S. private agents respecting the "patriot" associations on the frontier. Washington, Apr. 20, 1842 . (Confidential. Twenty enclosures.)

Memorandum for reply to Lord Ashburton's letter on extradition arrangements with the U. S. [Washington], May 2, I842.

Ashburton to Bagot. Extradition matter. Washington, July 26, I842.

Same to same. Has signed treaty for the settlement of the Northeast Boundary, the suppression of the slave-trade, and the extradition of certain criminals. Remarks. Washington, Aug. I5, I842. (Enclosed are copies of a long despatch from Ashburton to Aberdeen, Aug. 9, and of a correspondence with Webster.)

229. Jan. $3 \mathrm{I}-$ Nov. 28 , I $86 \mathrm{I}$. (I65 pp.) In this folder there is no subject of especial prominence, but from one to three despatches touch upon each. Following is a list of the topics:

Internal navigation regulations.

The recent $\mathrm{U}$. S. tariff act.

Applications to the Canadian government for arms for Massachusetts and Illinois.

British vessel suspected of being sold to the Confederacy.

Ashmun's mission to Canada.

Minor British subjects in the U. S. army.

Registry papers of vessels entering U. S. ports.

Recruiting in Canada for the Union army and pursuit of American deserters into that country.

Case of John G. Shaver. 
Alteration in U. S. passport regulations.

The despatches are addressed to W. F. Williams, E. IV. Head, and Monck.

230. Jan. I3-Dec. 24, I862. (IS7 pp.) The most prominent subject is the discharge of British minor subjects from the U. S. army. There are from one to three despatches, often with enclosures, dealing with each of the following:

Passage of British troops and stores through the U. S. on their way to Canada.

Passport regulations.

$\mathrm{U}$. S. harbor and river defense, and naval depots on the Lakes.

The reciprocity treaty.

Proposals to enlarge the Erie and Oswego canals.

Conduct of U. S. authorities on the frontier toward Canadians, and the irritation caused thereby.

The despatches are all addressed to Monck.

231. Jan. 5-Dec. 26, I863. (372 pp.) The contents of this folder are of a somewhat miscellaneous nature, and nearly half the space is occupied with material of a routine character, such as extradition cases. There are several despatches on projects of Confederate refugees in Canada, and others on a survey of the U. S. shore of the Lakes, with a view to temporary defenses against border irruptions. Other important topics are the violations of frontier territory by both British and American officers, and the desire of the U. S. that their troops might pursue into Canada hostile Indians taking refuge there. Among matters of less import are outrages of the Sioux in Minnesota, the blockade of Galveston, complaints relative to the British vice-consulate at Oswego, discharge of British minors from the U. S. navy, and plans formed in Massachusetts to obtain men in Canada for the U. S. army.

All of the despatches are addressed to Monck. Enclosures are numerous and sometimes bulky.

232. Jan. I3-June 30, I864. (3I9 pp.) Cases of American and British subjects taken from their own country by citizens or officers of the other, make up a large part of this folder.

Next in importance come Confederate refugees, and U. S. prohibition of the export of live stock and anthracite coal into Canada.

Subjects upon which less material is found are Sioux refugees in Canada, and a proposed pursuit of them into the Hudson's Bay territory, recruits for the U. S. army from British provinces, alleged Confederate vessels in British waters, the reciprocity treaty, and the building of a U. S. gunboat at Buffalo.

Besides the despatches (with their numerous enclosures) addressed to Monck, there are also a few drafts or copies of notes from him to Lyons.

233. July 5-Oct. 3r, r86r. (346 pp.) In this folder the three principal subjects are the alleged illegal imprisonment of two Canadians in Michigan, the question of importing anthracite coal from the U. S. into Canada, and recruiting of British subjects for the U. S. army. These fill about half of the folder.

Topics on which the correspondence is smaller are, projects of Confederate refugees in Canada, intention to increase the U. S. observing force on the Lakes, building of a $U$. S. revenue cutter at Buffalo, and 
compulsory enlistment of an alleged British subject in the Confederate ranks.

As in the previous folder, a few drafts and copies from Monck to Lyons are found among despatches to the former.

234. Besides extradition cases and the arrest of deserters, which take up a large portion of this folder, the miscellaneous topics therein may be grouped in the following manner, in the relative order of the amount of material bearing on them:

Confederate schemes in Canada including the reported manufacture of Greek fire.

The Georgiana, suspected of employment in the Confederate service.

Complaints from Michigan of the exposed nature of part of the frontier with regard to Confederate attacks.

The St. Albans raid.

Intercepted correspondence from persons in Canada. (Bulky enclosure.)

British ninors in the U. S. army.

Two vessels building at Montreal under conditions that looked suspicious to American authorities.

An alleged organization in Halifax for seizing U. S. ships on the Lakes, etc.

Several drafts from Monck to Lyons are present. The despatches to Monck cover the months of November and December, I864. (234 pp.)

235. The contents of this folder of 2 IO pp. are almost the same in character as those of the previous number, as can be perceived from the following list :

Plots in Canada against the U. S., and their prevention, including the alleged manufacture of Greek fire.

The Georgiana.

British minors in the U.S. army.

Vessels building at Montreal, and suspicions as to their purpose.

Apprehended marauding expedition from the U. S. into Canada.

Alleged organization in Nova Scotia, hostile to the U. S.

Mode of U. S. customs officers in dealing with articles exported inland from Canada into the U. S.

Passport regulations.

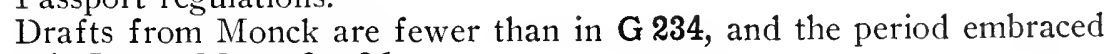
is Jan. I-Mar. 28, I 865.

236. Apr. 3-Dec. 30, I865. (282 pp.) Besides the usual complement of extradition cases the topic on which there is most material in this folder is the assassination of Lincoln. Drafts from Monck to the minister at Washington, and resolutions adopted by various Canadian bodies make nearly one-fourth of the folder.

Other subjects are the export of arms, ammunition, live stock, and anthracite coal from the U. S., mode of dealing with articles exported inland from Canada to the U.S., an alleged Confederate organization at Arnprior, and reward offered for the capture of persons attacking the U. S. from neutral soil.

With the exception of drafts, the despatches are to Monck and Michel. 237. At least half of these $248 \mathrm{pp}$. are taken up with extradition cases. Leaving these aside, the most prominent topic is the Fenian raid, especially its aftermath of prisoners. There are also several documents on violations of territory by officers of both countries in pursuing deserters and 
criminals. Single despatches, usually with enclosures, relate to the desire of the U.S. to appoint a consul at Hamilton, mutual aid given by frontier minor officers in the capture of criminals, the reciprocity treaty, Morrill's bill in Congress on trade relations with Br. N. America, a proposal of the American government for a reduction of the duty on fish in return for fishing privileges under a tonnage duty, and alleged demoralization of Indians on the Upper Missouri through sale of whiskey by British subjects.

The despatches are addressed to Michel and Monck, and cover I866.

238. Jan. I4-Dec. 26,1867 . (90 pp.) Nearly all of this folder is filled with material on extradition cases. Two despatches relate to violations of territory by officers in the pursuit of criminals, and another requests information relative to a Canadian passport for John Watson, which was found in the possession of John H. Surratt, charged with the murder of Lincoln. Intelligence of a contemplated Fenian attack upon Canada is also conveyed through the British acting vice-consul at Chicago.

The despatches are to the same persons addressed in the preceding folder.

239. Jan. I6-Dec. IO, I868. (3I 3 pp.) As in preceding numbers, extradition cases and abduction of criminals from foreign territory take up a good deal of space. From one to three despatches relate to each of the following:

State of feeling in Nova Scotia with regard to a union with the U. S.

Instructions to special inspectors of U. S. customs at Montreal.

Duties on British or Canadian shipping in U. S. ports.

Protection of U.S. fishing vessels in Canadian waters.

Trade between the U. S. and Canada.

Desire of British anthorities that, in relation to Fenian movements, their ressels with stores, etc., might pass through a part of Lake Champlain without delay from U. S. customs officials.

Prohibition against bringing horned cattle from the U. S. by reason of contagious disease then prevalent there.

Request from Vermont for the protection of shad and whitefish in the Canadian portion of Lake Champlain.

The despatches are addressed to Monck and Young. A few drafts from these to the British minister are also present.

240. The material on U. S. history in this folder may be classified under three heads.

(I) Drafts of about twenty-five despatches from the governors general to the lieutenant-governors of New Brunswick, largely relating to proceedings in the disputed territory and the boundary question generally. Sept., I84I-Aug., I85I.

(2) Drafts from the governors general to sundry state governors, but chiefly to the British minister at Washington. Extradition cases bulk very large here, but there is some material on the state of feeling and "patriot" organization, and quite a little upon such cases as those of McLeod and Groghan. These compose a section of about I25 pp. and extend from Aug. 8, I841, to Dec. I5, I845.

(3) Miscellaneous drafts and copies, of which the most important are a few addressed to Lord Ashburton on the boundary question and the other objects of the treaty. $1840-185^{\circ}$.

241. [The governor general's secretary] to the British consul at Portland. Relative to rumored project for a canal between the Aligash and the Penobscot. June 24, I84I. (Draft.) 
244. Nov., I844-Sept., I849. (225 pp.) This entire folder is filled with material respecting steamers on the Lakes. Most of these could be used as war steamers if necessary. There is little on the U. S. naval force. Most of the documents are drafts to the colonial secretary.

245. Russell to Sydenham. No. 303. Relative to project for the emigration of colored persons from Upper Canada to Trinidad. Downing Street, Feb. 3, r84I. (Several enclosures. One of seven despatches from the Colonial Office and drafts to it on colored emigration from Canada, ranging from the above date to Oct. $3 \mathrm{I}, \mathrm{i} 843$.)

246. May I2, I848-Jan. I4, I849. About sixty pages of this folder are composed of copies of despatches from the governor general to the colonial secretary, with enclosures, on a change in the navigation laws, as affecting the trade of the St. Lawrence. The admission of American shipping was the chief desire.

248. Sept. I, I860-Nov. I4, 1866. (246 pp.) Among the miscellaneous drafts from the governors general which, with their enclosures, make up this folder, there are at least fifty to the British minister at Washington. They are largely concerned with extradition and kidnapping cases, but there is also material relating to the pursuit of deserters into Canada by U. S. soldiers, proposal for the erection of block-houses on the Welland Canal, stoppage of live stock at the frontier, passport regulations, vessels fitting out on Lake Erie, and Fenian plans.

249. Sept. I-Dec. 3I, I861. (235 pp.) In this folder of miscellaneous drafts from the civil secretary there is a small amount of material on extradition cases, deserters, recruiting in Canada for the U. S. army, Fenians, etc. The period covered extends from Sept., I861, to the end of I866, but the American material is mostly between I862 and the latter date.

250. Arthur to Thomson. No. 2. Remarks on decline of the "patriot" cause on the American frontier, and upon use of Gen. Scott's name by the insurgents. Montreal, Oct. 26, I839.

Same to same. Remarks on frontier feeling, etc., and the militia required for defense. Toronto, Jan. 22, I840. (Other despatches on the militia force are also present.)

251. Arthur to Thomson. Remarks on the importation of tea through the U. S., etc. Toronto, Aug. 24, I840.

Same to Sydenham. Account of actions of British colored soldiers toward U. S. party at Chippewa. Toronto, Oct. 23, I840.

Same to same. Immigration of Indians from the U. S., and attempts of the authorities there to induce them to settle beyond the Mississippi. Toronto, Oct. 24, I840. (Seven enclosures. Letter of Nov. 3, with three enclosures, deals with the same topic.)

Same to same. Remarks on provincial act on the punishment of foreigners invading Canada from a friendly state. Toronto, Dec. 7, I840. (Two legal opinions enclosed.)

Same to same. Relative to passage of American vessels through the Welland Canal. Toronto, Dec. 8, ז840. (Five enclosures.)

252. Jan. I4-Feb. 4, I 84 I. (424 pp.) About 275 pp. of this folder are composed of five despatches, with enclosures, from Arthur to Sydenham, on the case of Alexander McLeod. It will be readily perceived that the enclosures are both numerous and bulky.

Besides the above, one despatch of Feb. 26 deals with a complaint that the collector of customs at Kingston had refused clearance to a U. S. vessel. 
256. John F. Crampton to the lieutenant-governor of Nova Scotia. Remarks and suggestions on protection of the fisheries. Washington, July 20, I852. (Confidential. A few printed enclosures.)

Joseph Howe to Mulgrave. Arrest of citizens of Nova Scotia in the U. S. Halifax, Sept. I7, I86i. (Copy.)

257. July 2I, I838-Mar. 3I, I840. (374 pp.) Fully three-fourths of this folder is composed of despatches from Sir John Harvey, lieutenantgovernor of New Brunswick, to Poulett Thomson and Sir R. D. Jackson.

The disputed territory is practically the sole topic under discussion. Enclosures are very numerous, and are in the nature of copies of correspondence with the colonial secretary and with the British minister at Washington, reports, legislative documents, etc.

There is nothing touching American interests before Nov. 6, I839.

258. Apr. I-Dec. 3I, I 840 . Despatches from Sir John Harvey to the governor general, with regard to the disputed territory, are continued in this folder. In fact there are about 300 pages on this subject.

There is a good deal of correspondence with the British minister at Washington among the enclosures, as are also reports from the warden of the territory, giving notice of measures taken by U. S. agents, such as surveys, attempt to take a census, etc. The extent and population of the Madawaska settlement is treated at length. In one of the despatches is a sketch of part of the St. John River from the Madawaska River upwards, as far as inhabited in Oct., I839, showing the various settlements.

259. Jan. I I-July 27 , I $84 \mathrm{I}$. (338 pp.) In this folder fully three-fourths of the despatches to Sydenham from Harvey and Colebrooke relate to the Madawaska settlement. As in the preceding numbers on this subject, enclosures are numerous, and the material is of the same general nature. Jurisdiction, Maine aggressions, powers of the British warden, and Sir John Harvey's defense of his measures, are among the prominent topics. One of the enclosures is a plan of the Madawaska settlement, May, I 84 I.

260. Aug. 2-Dec. 4, I84I. (335 pp.) Nearly all of this folder is composed of material bearing on the disputed territory and negotiations for the settlement of the Northeast Boundary. Described in general terms, the contents may be said to be nearly similar in character to those of the numbers immediately preceding. Looked at more in detail, subjects of special prominence are the American armed force at the Fish River, Maine aggressions, tax on the Madawaska settlement by New Brunswick, a new northern line run by U. S. surveyors, and negotiations by provincial and state authorities for a conventional line.

A few of the documents treat of the boundary question as a part of American politics. Among the enclosures is a printed map, dated July, I840, of ancient Nova Scotia, and illustrative of the boundaries of Massachusetts Bay according to the charter of William and Mary.

The despatches are from Colebrooke to Sydenham and Jackson.

261. Jan.-Dec, I842. (400 pp.) In this folder, which continues the despatches from Colebrooke to the governor general, the chief points of interest are those transmitting the former's correspondence with Ashburton, and reports from the warden of the disputed territory. About two-thirds of the folder is occupied by these. Besides treaty negotiations, reports, etc., there is material on such topics as military roads 
in the Madawaska settlement, timber cutting with the permission of Maine, and various suggestions from Colebrooke, with a view to settling the dispute. One of the enclosures is a manuscript map from the crown lands department, dated Oct. 2I, I84I, which depicts the entire region, with certain lines.

262. Colebrooke to Metcalfe. Sends copies of four of his despatches to the Colonial Office. Fredericton, May i8, i843. (Enclosures, with several sub-enclosures, relate to complaints from Maine regarding the Disputed Territory Fund, and alleged violations of territory in the arrest of certain persons. Total, about I $30 \mathrm{pp}$.)

Same to Cathcart. Sends joint resolutions of the New Brunswick legislature, placing $£$ Io,00O at the disposal of the crown in the event of hostilities with the U. S. Fredericton, Apr. 20, I846. (Confidential. Enclosure present.)

263-266. I840-1845. These four folders contain letters and reports from various officials in the emigrant office to the chief secretary (civil secretary). Reports from the agent at Kingston often give statistics of emigration from the province to the U. S., and of the influx from that country. The annual reports of the chief agent at Quebec also have figures on these topics. In many cases they are only estimated in round numbers. Nearly all of this material on American interests is statistical in character. The chief exception is a portion of the chief agent's report of Dec. 3I, I842 (G 264), where the economic situation in the U. S. is dealt with, and where it is stated that laborers had little prospect of obtaining employment if they passed from Canada across the American frontier, owing to the depression still remaining there as a result of the financial crisis of 1837 .

268. Aug. 29-Dec. 24, 1840. Material relating to American interests is in this letter-book in the form of despatches to the governor general from Sir John Harvey, Sir George Arthur, Sir Richard Jackson, and Henry S. Fox. They are merely copies of documents already described in various folders of earlier number. Despatches from Harvey are occupied with the disputed territory; those from Arthur include material on Indian emigration from the U. S., actions of British colored soldiers at Chippewa toward a U. S. party, and passage of foreign vessels through the Welland Canal; two letters from Jackson bear on the disputed territory and frontier raids in Lower Canada; while those from the minister at Washington deal with the Northeast Boundary question and arrangements for the mutual surrender of fugitives from justice.

269. Dec., I840-Mar. 27, I84I. This letter-book continues the correspondence of the previous number. The contents are largely, if not entirely, duplicates of material already dealt with. Besides their continuation of proceedings in the Madawaska region, one of Harvey's despatches deals with the McLeod case, which also forms the subject of five messages from Arthur. Jackson contributes two lengthy communications on frontier defense, while of the six despatches from Fox, four are on McLeod, and the remainder on port regulations and the disputed territory.

270. 1841. Despatches in this volume from the lieutenant-governors of New Brunswick are practically all copies of those in G 259 and 260 . In these last, enclosures are much nore complete, as not all are copied in the letter-books. 
Communications from the British minister at Washington centre about the cases of McLeod and Groghan, the disputed territory, and frontier raids.

Among miscellaneous letters, some from Gov. Seward deal with extradition cases, one from Vice-Adm. Sir T. Harvey relates to the McLeod case, another from Sir R. D. Jackson touches the arrival of U. S. troops at the St. Joln River, and two from James Renwick, New York, are upon the U. S. commission for exploring the Northeast Boundary.

271. Despatches from Sir William Colebrooke to the governor general in this letter-book are upon the disputed territory and his correspondence with Lord Ashburton. Six letters from Henry S. Fox deal with extradition matters, naval force on the Lakes, and proceedings of "patriots" and their sympathizers on the frontier.

Among miscellaneous communications are a few on extradition matters from Gov. Seward.

Fox's despatches extend from Jan. 4 to Apr. 20, I842, those of Colebrooke from Jan. I5 to Sept. 7 of the same year.

274. Address to the king by the Lords and Commons and reply thereto. London, Feb. 9, I775. (Printed.)

Germain to Gen. Stowe. Relative to defense of the island of St. John [P. E. I.] against the disaffected inhabitants of Nova Scotia and rebel privateers. Whitehall, Aug. I8, I777.

No. I2552 of the London Gasctte, containing an act on commercial relations of England with the U. S.

H. C. Litchfield to Lieut.-Gov. Fanning. Relative to commission to investigate losses of persons who have suffered in consequence of the cession of East Florida to Spain. Florida Office, Southampton Buildings, Aug. IO, I786. (Two enclosures.)

Sydney to the lieutenant-governor of St. John. Sends act on trade between British dominions and the U.S. Remarks. Whitehall, Apr. 6, I,87. (Enclosure missing.)

Same to same. Requests information on distilleries, importation of rum from the U. S., West Indian interests, etc. Whitehall, May 28, I787. (Circular. One enclosure.)

Same to same. Detailed instructions to keep watch of other powers on the continent, their military movements, etc. Whitehall, Sept. 2I, I 87. (Secret circular.)

No. 12976 of the London Gazette, containing act on trade with the U. S. Sydney to Lieut.-Gov. Fanning. Relative to importation of bread, flour, and corn from the U.S. Whitehall, May 6, I789. (Circular. Circular of June 6 deals with the same topic.)

277. Bathurst to the officer administering the government of Prince Edward Island. Orders to detain vessels of the U. S. Downing Street, Aug. I, I8I2. (Duplicate circular.)

Goulburn to same. Sends declaration on the causes and origin of the war with the U. S. Downing Street, Jan. II, I8I3. (Circular. Enclosure present.)

Bathurst to same. No. I I. Relative to passage of U. S. subjects from Great Britain to the U. S. via ports in Br. N. America. Downing Street, Aug. 26, ISI4.

278. Bathurst to Smith. Relative to convention with the U. S. regarding the fisheries. Downing Street, Apr. 7, I8I9. 
Same to same. Sends order in Council imposing certain duties on U. S. vessels and cargoes entering British ports in N. America and the West Indies. Downing Street, July 31, I823. (Enclosure present.)

284. Glenelg to Fitz Roy. No. 74. Relative to outrage by U. S. fishing schooner upon the British vessel Sir Archibald Campbell. Downing Street, Nov. 5, I838. (Legal report to Palmerston on this case was sent by Normanby, Apr. 23, I839, and is in G 285.)

288. Stanley to Huntley. No. 72 . In reply to legislative address to the queen for an armed vessel to protect the fisheries from the Americans. Downing Street, May 31, I843.

Same to same. No. 88. Instructions on extradition arrangements with the U. S. Downing Street, Nov. 2I, I843. (Printed imperial act of Aug. 22, I843, follows.)

292. Grey to Donald Campbell. Relative to Sir Henry Bulwer's instructions to negotiate with the U.S. with a view to improving the commercial relations between that country and the Br. N. American provinces. Downing Street, Nov. I7, I849. (Confidential.)

Same to same. No. 9I. Relative to legislative address from Prince Edward Island to the queen, suggesting a suspension of treaty between Great Britain and the U. S. regulating the fisheries around the island. Downing Street, Nov. 26, I849.

Same to same. No. 96. Relative to the fisheries of the island and its commercial relations with the U. S. Downing Street, Jan. I5, I850.

Edmund Grattan, British consul at Boston, to same. In reply to certain queries on the U.S. fishery laws and regulations.

293. John F. Crampton to Bannerman. Relative to U. S. shipping in Prince Edward Island ports. Washington, Aug. 27, 1851. (Four enclosures.)

294. Pakington to Bannerman. No. 4. Remarks on protection of the Br. N. American fisheries. Downing Street, May 27, I852. (No. I6, of Aug. I9, relates to the same topic.)

John F. Crampton to same. Sends letter from Webster on recent measures to protect British fisheries. Remarks. Washington, July 20, I852. (Confidential. Two enclosures.)

Colin Campbell to same. Flocking of U. S. vessels to Prince Edward Island. H. M. S. Devastation, Charlottetown, Sept. I6, I8 [52].

Colin Campbell to Vice-Adm. Seymour. Reports at length his observations while engaged in the protection of $\mathrm{Br}$. N. American fisheries. H. M. S. Devastation, Halifax, Nov. IO, I852. (Followed by letter giving extract of suggestions by Vice-Adm. Seymour for the protection of the fisheries.)

295. Newcastle to Bannerman. No. 28. Remarks on rumored intention of U. S. fishing vessels to go armed. Downing Street, Sept. 9, I853.

Same to same. No. 37. Relative to power of the vice-admiralty court in Prince Edward Island to try a U. S. vessel seized for breach of the treaty of I8I8. Downing Street, Nov. 9, I853.

Vice-Adm. Seymour to same. Intelligence that U. S. fishing vessels are arming themselves to go to the fishing grounds. Halifax, July 4, 1853 . (Confidential. Letter of July I $_{2}$ is on the entrance of U. S. fishing vessels into British harbors.)

296. May 3-Dec. 3I, I854. In this volume about sixteen despatches, some of them with copies of correspondence of the U.S. government with the minister at Washington, relate to the reciprocity treaty of 1854 . The 
chief points of interest are the rights and privileges of British and U. S. fishermen before the treaty came into full operation.

Nearly all these despatches to the lieutenant-governor of Prince Edward Island are from the Colonial Office and from the minister at Washington. A few, however, are intercolonial.

297. Grey to Daly. No. 29. Sends further correspondence between the Foreign Office and the minister at Washington on giving effect to the reciprocity treaty. Downing Street, Jan. 6, I855. (Enclosure present.)

Crampton to same. Sends bill (S. 560) to include Prince Edward Island in arrangements for giving effect to the reciprocity treaty. Washington. Jan. 29, I855. (Bill enclosed. Five other brief despatches from the minister at WVashington deal with the progress of such measures.)

303. Newcastle to Dundas. No. 7I. No arms or ammunition to be sold, given, or lent to either Federals or Confederates. Downing Street, May 29, I 86 .

306. Cardwell to Dundas. No. I4. Sends letter from the Foreign Office, enclosing despatches from the minister at Washington on the restrictions imposed by the U. S. on trade between New York and the British colonies. Downing Street, July I I, is64. (Enclosures follow.)

Same to same. No. Is. Protest has again been made to the U. S. against restrictions on trade between New York and the British colonies. Downing Street, Sept. 19, I864.

30\%. Cardwell to Dundas. No. 5. Sends note from Seward on alleged organization at Halifax for predatory attacks on the northern states. Downing Street, Feb. 4, I865. (Enclosure follows.)

309. Buckingham to Dundas. No. I7. Relative to increased fee for licenses to U.S. fishermen. Downing Street, July 6, i867.

310. Puckingham to Dundas. Necessity for vessels bound for the U. S. to have full manifests of cargo. Downing Street, Feb. 6, I868. (Circular. Printed enclosure present.)

Same to same. U. S. navy regulations prohibit a vessel from saluting when it mounts less than ten guns. Downing Street, Apr. 22, I868. (Circular.)

Same to same. No. 24. Relative to fee for licenses to U. S. fishermen. Downing Street, May 9. I 868.

Same to same. No. 40. Approves measures with regard to resolutions in Congress on free trade between the U. S. and Prince Edward Island. Downing Street. Sept. 30, IS68. (No.4I also treats of this topic.)

311. Granville to the officer administering the government of Prince Edward Island. No. S. Remarks on visit of committee of the U. S. House of Representatives to the colony. Downing Street, Feb. 13, I869. (No. I3. Nar. I3, also deals with this topic.)

Same to same. Relative to the frequent arrival at Savannah of British ressels with unlawful manifests. Downing Street, Apr. I, I869. (Circular, with printed enclosure.)

Same to same. No. 24. Remarks on legislative resolutions of Prince Edward Island on reciprocity of trade between that colony and the U. S. Downing Street, June I, I869.

312. Granville to the officer administering the government of Prince Edward Island. No. Io. Relative to a conference of E. W. Howlan with the British minister at Washington with regard to reciprocity and the fisheries. Downing Street, Nar. I5, is 70. 
Same to same. No. I6. In future all diplomatic communications between the U. S. and Br. N. America are to pass through the hands of the governor general of Canada. Downing Street, June 8, I870.

Kimberley to same. Sends order in Council declaring the making of a convention with the U. S. under the Naturalization Act, I870. Downing Street, Aug. 27, I870. (Circular. Enclosure present.)

Same to same. No. 32. Comments on certain regulations of Prince Edward Island with regard to U. S. fishermen. Downing Street, Oct. 20, I870. (No. 39, of Dec. I7, is upon the same line.)

313. Kimberley to Robinson. No. I. Relative to case of the U. S. fishing schooner Clara F. Friend. Downing Street, Jan. 2, I87 I.

Same to same. No. 22. Sends copies of diplomatic correspondence, protocols, etc., on the treaty signed at Washington, May 8. Remarks. Downing Street, June I7, I87 I. (Five enclosures.)

Same to same. No. 23. Sends correspondence with the Admiralty upon the late treaty and the protection of the fisheries. Downing Street, June 28 , I87I. (Enclosure present. No. 25, of July 6, deals with the same topic.)

Same to same. No. 32. Relative to provisional arrangements with regard to U. S. fishermen in Prince Edward Island waters. Downing Street, Sept. 3, i871. (No. 34, of Sept. 5, also deals with this topic.)

Same to same. No. 48. Remarks on question of refund of duties collected in the U. S. on fish-oil and fish exported from Prince Edward Island during the fishing season. Downing Street, Dec. 30, I87 I.

314. Kimberley to Robinson. No. 27. U. S. fishermen will not be allowed to fish in Prince Edward Island waters during the present season. Downing Street, Aug. 5, I872. (Two enclosures.)

Same to same. Sends imperial act to carry into effect the treaty of Washington. Downing Street, Aug. I3, I872. (Circular. Enclosure present.)

Same to same. No. 30. Sends letter from the Foreign Office and despatch from the minister at Washington, with enclosures, on admission of U.S. fishermen to Prince Edward Island waters during the present season, and refund of duties on fish and fish-oil imported last year into the U. S. from Prince Edward Island. Downing Street, Aug. I3, I872. (Enclosures present.)

315. Kimberley to Robinson. No. 4. Remarks on the Canadian fisheries bill in the U.S. Congress, and the admission of American fishermen to British waters. Downing Street, Mar. 7, 1873 .

Same to same. No. I7. Sends letter from the Foreign Office regarding the protocol on the treaty of Washington. Downing Street, May 6, I873. (Enclosure present.)

Same to same. No. 32. Sends printed protocol signed by Thornton and Fish on date when certain articles of the late treaty should come into operation. Downing Street, June 30, I873. (Enclosure present.)

317. Smith to Bathurst. No. 25. Various remarks regarding the boundary between the U. S. and Canada, etc. Charlottetown, June I, I8r4.

Same to same. No. 34. Relative to Americans arriving from Europe with a view to passing into the U. S. Charlottetown, Nov. I5, I8I4.

Same to Goulburn. News that Jan. and Feb. mails were captured by a U. S. privateer. Charlottetown, June I, I8I5.

318. Smith to Bathurst. No. I67. Relative to emigration to the U. S. by way of the British colonies. Charlottetown, Sept. I2, I8I8. 
322 A. Huntley to Stanley. No. 8o. Sends legislative address on protection of the fisheries against the Americans. Remarks. Government House [Charlottetown], Apr. I7, I843. (Enclosure not copied.)

323. Campbell to Grey. No. 27. Remarks on legislative address for relaxation of treaty with the U. S. relative to the fisheries. Government House, June I2, I 849 .

Same to same. No. $5 \mathrm{I}$. Various remarks upon the question of free trade with the U. S. Government House, Sept. 21, IS49. (No. I3, of Feb. I8, I850, deals further with this topic.)

324. Apr. 26, I85I-Dec. 30, I 854 . (422 pp.) In this letter-book between 25 and 30 despatches from the lieutenant-governor of Prince Edward Island to the Colonial Office relate to various questions connected with the fisheries, the participation of Americans, regulations, the treaty of I854, etc.

325. Daly to Russell. No. I6. Completion of arrangements for giving effect to the reciprocity treaty has given universal satisfaction in the colony. Government House, Apr. IO, I855.

326. Dundas to Newcastle. No. 84. Comments on certain local act relating to U. S. fishermen. Government House, Sept. I6, I86 .

327. Dundas to Cardweli. No. 46. Measures taken and sentiment in Prince Edward Island on receipt of news of Lincoln's assassination. Government House, Nay 26, i 865.

Same to same. No. 23. Remarks on termination of the right of all persons other than British subjects to use the inshore fisheries of the province. Government House, Mar. 7, I866.

Same to Buckingham. No. 54. Issue of fishing licenses to Americans for the current year. Government House, May 31, I867. (No. 73, of July $3 \mathrm{I}$, deals with the increased fee on such licenses.)

Same to same. No. 74. Remarks on practice of many American vessels in fishing without licenses. Government House, Aug. I4, I867.

Same to same. No. 77. Comments on act exempting from duty Canadian corn and breadstuffs imported through the U. S., via Portland. Government House, Sept. IO, I867.

Same to same. No. I3. Remarks at length, with statistics, on trade with the U. S. under the late reciprocity treaty. Government House, Feb. 7. I 868 .

328. Dundas to Buckingham. No. 64. Gives specimen of license issued to U. S. fishermen; also fee and notice of places where licenses may be obtained. Government House, May 28, is68. (Two enclosures. Further discussion of fishing licenses in No. 68, of June I7.)

Same to same. No. 83. Relative to reciprocity with the U. S. Government House, July 29, i868. (One enclosure. Continued in no. 90, of Aug. 27. No. 38, of Apr. 29, I869, is also on this topic.)

Same to same. No. 95. Account of visit of committee of the U. S. House of Representatives to Prince Edward Island, in the interests of trade. Government House, Sept. 21, I868. (Several printed clippings follow.)

Hodgson to Kimberley. No. 58. Remarks at length upon certain customary privileges to U. S. fishermen. Government House, Sept. 7, I 870 .

Robinson to same. No. I5. Remarks on question of U. S. fishing vessels obtaining supplies in Prince Edward Island ports. Government House, Nov. 22, I870. 
Same to same. No. 16. Case of the U. S. schooner Clara F. Friend. Government House, Nov. 25, I87o. (No. I7 is also upon this subject.)

Same to same. No. 55. The treaty of Washington, and the admission of Americans to inshore fisheries. Government House, July I2, I87I. (No. 59 deals further with the latter question, while nos. 72, I87 I, and 5 , I872, relate to refund of duty on fish and fish-oil imported into the U. S. from Prince Edward Island.)

329. Robinson to Kimberley. No. I2. Prince Edward Island is disposed to act in concert with Canada in the matter of the fisheries. Government House, Apr. 2, I873.

336. Head to Daly. Sends report of committee of the Executive Council, on the reciprocity treaty with the U. S. Toronto, Feb. I9, I859. (Enclosure follows.)

Monck to Dundas. Relative to negotiations for a renewal of the reciprocity treaty with the U.S. Quebec, July I5, I 865. (One enclosure. Letter of Aug. I4 deals with the same topic, as does also telegram of Dec. 28. Latter followed by two other telegrams.)

Same to same. Relative to termination of the right of Americans to use the inshore fisheries of Canada after Mar. I7. Montreal, Feb. 20, I866.

Same to same. Sends letter. Montreal, Mar. 12, I866. (Enclosure relates to rumors of Fenian plots.)

Same to same. Relative to granting licenses to U. S. fishermen. Ottawa, June I4, I866. (Three enclosures.)

337. MacDonnell to Dundas. Relative to co-operation in negotiations for a renewal of the reciprocity treaty with the U.S. Halifax, June 5, I865.

Williams to the lieutenant-governor of Prince Edward Island. Sends proclamation on termination of rights of Americans as to inshore fisheries. Halifax, Mar. 23, I866. (Enclosure present.)

Same to same. Relative to joint action for protecting the fisheries. Halifax, May 25, I866. (One enclosure.)

Same to same. Relative to issue of licenses to U. S. fishermen. Halifax, July 20, I866. (Proclamation enclosed.)

Gordon to same. Sends proclamation relating to expiration of the reciprocity treaty with the U. S. Fredericton, Mar. I2, I866. (Enclosure follows.)

Doyle to same. Change in fee for licenses to U. S. fishermen. Fredericton, June Io, 1867 .

339. The first part of this volume is composed of despatches to Lieut.-Gov. Dundas from the lieutenant-governor of Newfoundland, of which three (Mar. 21 and July IO, I866, and July 22, I867) relate to U. S. fishermen.

There are also despatches to the lieutenant-governor of Prince Edward Island from the British minister at Washington. These are chiefly concerned with such topics as resolutions of the legislature of Prince Edward Island on the war, discharge of British subjects from the U. S. army, the blockade of Galveston, bonds exacted by U. S. customs authorities on shipments to Prince Edward Island, passport regulations, etc. These cover the period from May 28 , I860 to July 2 I, I866.

340. Order in Council, giving report touching on Loyalist settlement in Prince Edward Island. London, Apr. 16, I794.

342. Pakington to Douglas. No. 5. Relative to American adventurers at Queen Charlotte Islands, etc. Downing Street, Sept. 27, 1852. (Three enclosures.) 
Newcastle to same. No. I2. Relative to U. S. fishing rights, their trade with Indians, etc. Downing Street, Oct. 22, 1853 .

Grey to same. No. 4. Authorizes latter to continue to treat islands in the "Canal de Arro" as part of the British dominions. Downing Street, Sept. 2I, J854.

Same to same. No. 8. It was not found practicable to extend the reciprocity treaty to the possessions of the two countries on the Pacific. Downing Street, Dec. I8, I854.

Molesworth to same. No. 2. Remarks on the Canal de Haro, etc. Downing Street, Aug. I3, IS55.

Grey to same. No. 5. Possibility of extension of the reciprocity treaty to Vancouver Island. Downing Street, Nov. I2, I 855 .

Labouchere to same. No. 3. Approves steps to aid U. S. troops against Indians in Oregon. Downing Street, Jan. 26, $18_{5} 6$. (Nos. 4 and $I_{5}$ are on the same topic.)

Same to same. No. I2. Sends correspondence with Swanston of San Francisco. Downing Street, July 8, I 856 . (Enclosure touches upon Indian war against the U. S., aid given the latter by the Hudson's Bay Co., etc.)

Same to same. No. I. Appointment of British commissioners to mark a portion of the Northwest Boundary. Downing Street, Jan. 2, I 857 .

Same to same. No. 2. Approves latter's course with regard to request from the commander of the Massachusetts for aid in arresting Indian murderers. Downing Street, Jan. 7, I857.

Same to same. No. 8. Approves latter's refusal to allow Americans to land Indian prisoners. Downing Street, Apr. 8, I857. (No. 9 is on refusal to allow the arrest in British territory of deserters from the U.S. army.)

Same to same. No. 2. Relative to attacks upon U. S. citizens by Indian tribes. Downing Street, Jan. 8, I858.

Same to same. No. 4. Instructions in case of a Mormon emigration from Utah to British territory. Downing Street, Feb. I, I858. (Several short enclosures.)

Lytton to same. No. 2. Instructions on dealing with influx of U. S. miners, navigation rights, etc. Downing Street, July I, I $8_{5} 8$.

Same to same. No.3. Approves refusal to deliver up deserters from the U. S. army. Downing Street, July I6, I 858 .

Same to same. No. 4. Americans must take out a license to navigate Fraser River, etc. Downing Street, July I6, I858.

343. Newcastle to Douglas. No. 4. Commercial matters. Downing Street, July 22, I859. (Enclosure touches on trade relations with California and the bonding system there. No. 9, of Sept. 3, relates to the latter subject.)

Same to same. No. I6. Approves answer to Gen. Harney on the occupation of San Juan Island by U. S. troops. Downing Street, Oct. 20, I859. (Nos. IS, I9, 22, 25, of I859, and 4 and 29, of I860, also relate to the U. S. occupation of San Juan Island.)

Fortescue to same. No. 35. Sends despatch, with enclosures, from the chargé d'affaires at Washington regarding the substitution of military for civil jurisdiction in San Juan Island. Downing Street, Sept. I6, i860. (Enclosures present.)

Same to same. No. 43. Removal of Gen. Harney from command in Oregon. Downing Street, Dec. 22, I860. 
Same to same. No. 68. British troops to be stationed on San Juan whether the U. S. withdraw theirs or not. Downing Street, Aug. 24, I861. (One enclosure.)

344. Newcastle to Douglas. No. 15. Sends despatch from Lord Lyons, with enclosures, on alleged attempts to fit out a Confederate privateer at Victoria. Downing Street, May 8, I863. (Enclosures present.)

Same to same. No. 20. Assurance (through Seward) that the rumor of preparations in California against British territory is groundless. Downing Street, May I9, I863. (One enclosure.)

345. Cardwell to Kennedy. No. 3. Instructions on neutrality. Downing Street, Apr. 30, r864. (One enclosure.)

Same to same. No. 8. Why exclusive rights should not be granted to a company for constructing a telegraph line from San Francisco. Downing Street, June I, I864. (No. 9 deals with the same topic.)

Same to same. No. 7o. Relative to fines levied on British steamer at Port Angeles. Downing Street, Dec. 23, I864.

346. Cardwell to Kennedy. No. 62. Relative to detention of the Shenandoah. Downing Street, Oct. 25, 1865 .

Same to same. No. 63. Comments on actions of Washington Territory officials in the case of the Maria. Downing Street, Oct. 26, I865.

Same to same. No. 26. Is gratified at news of completion of the electric cable between Vancouver Island and Washington Territory. Downing Street, June 2I, I866.

347. Undated statement of W. McGillivray, "relative to the Columbia River and adjoining territory on the western coast of North America".

Lytton to Douglas. No. I7. Sends correspondence. Downing Street, Sept. 2, I858. (Enclosure touches upon desire of the Pacific Mail Steam Ship Co. to establish regular communications between California and British possessions north of the 49th parallel, etc.)

Same to same. No. 28. Sends correspondence with the Foreign Office on repayment of a loan made in 1856 by Gov. Douglas to Gov. Stevens of Washington Territory. Downing Street, Oct. 9, 1858. (Enclosure present. No. 59, of Dec. 29, deals further with this subject.)

Same to same. No. 43. Sends information on the mining laws of California. Downing Street, Nov. 16, 1858. (Enclosure present.)

348. Lytton to Douglas. No. 25. Sends despatch from the minister at Washington regarding Nugent's report and the rights of foreign miners in British Columbia. Downing Street, Feb. 21, I859. (Enclosure present.)

Same to same. No. 3I. Sends letter from the Treasury defining the rates at which U. S. gold coins should be issued to British troops. Downing Street, Mar. I4, I859. (Enclosure present.)

Same to same. No. 42. Relative to advance of money to the governor of Washington Territory. Downing Street, Apr. 2, 1859. (No. 55, with diplomatic enclosures, deals with the same topic.)

Carnarvon to same. No. 56. Relative to postal service between San Francisco and British Columbia. Downing Street, Apr. 28, I859.

Same to same. No. 58. Sends correspondence with the Foreign Office on U.S. attempts to survey and occupy the island of San Juan. Downing Street, Apr. 30, I859. (Enclosure present.)

349. Carnarvon to Lytton. No. 69. Sends further despatch from the minister at Washington on repayment of sum lent to Washington Territory in 1856 . Downing Street, May 22, 1859 . (Enclosure present.) 
Same to same. No. 77. Sends letter with enclosures from the Foreign Office respecting Americans in San Juan Island. Downing Street, June IO, I859. (Enclosure present.)

Newcastle to same. No. 3. Remarks on practices of certain U. S. owners of steamboats running on the Fraser River. Downing Street, June 30, I859. (Legal opinion enclosed.)

Same to same. No. 13. Relative to mail service between British Columbia and San Francisco. Downing Street, Aug. 29, I859.

350. Newcastle to Douglas. No. I3. Sends instructions to Lieut.-Col. Hawkins as British commissioner for marking the land boundary between British territory and the U.S. west of the Rockies. Downing Street, Mar. I2, I860. (Enclosure present.)

351. Newcastle to Douglas. No. 97. News that the U. S. House of Representatives lias adopted a resolution to inquire into the expediency of fortifying the mouth of Columbia River and Puget Sound. Downing Street, Jan. 7, I862.

Same to same. No. I28. Relative to direct postal communication with San Francisco. Downing Street, June 7, I862.

352. Cardwell to Seymour. No. 7. Comments upon local ordinance to encourage the construction of a telegraph line to connect British Columbia with the American telegraph lines. Downing Street, June I, I864.

Same to same. No. 5I. Sends despatch from the British chargé d'affaires at St. Petersburg relative to the proposed construction of a telegraph line across British Columbia in connection with Russia and the U. S. Downing Street, Dec. I, I864. (Enclosure present.)

353. Cardwell to Seymour. No. 9. Receipt of despatch reporting progress of telegraph line across British territory in connection with Russia and the U.S. Downing Street, Feb. 24, I865.

355. Carnarvon to Seymour. No.5. Sends despatch from the acting British consul general at Honolulu, on the establishment of steam communication between San Francisco and Hongkong. Downing Street, Jan. IO, I867. (Enclosure present.)

Buckingham to same. No. I2. Relative to relations between the two parties on San Juan Island. Downing Street, Mar. 28, I867.

Same to same. No. 97. Relative to cessation of regular communication between British Columbia and San Francisco. Downing Street, Dec. I4, I867.

Same to same. No. IOI. Instructions on certain points connected with the Alaska purchase. Downing Street, Dec. 28, I867.

357. Granville to Seymour. No. I6. Sends correspondence with the Postmaster General of the U. S. on division of postage on letters passing between British Columbia and the U. S. Downing Street, Feb. 26, I869. (Enclosure present.)

Same to same. No. 35. Sends correspondence received from the Foreign Office on alleged encroachments of agents of the Hudson's Bay Co. on the territory and trade of Alaska. Downing Street, May I9, I869. (Enclosure present.)

360. Douglas to Lytton. No. 54. Relative to money lent to Washington Territory. Victoria, Dec. $27,1858$.

Same to same. No. 64. Relative to Nugent, late special agent of the U. S., etc. Victoria, Jan. 5, I859. 
Same to same. No. 65. Remarks on admission of members of the American bar to the courts of British Columbia. Victoria, Jan. 6, I859.

Same to same. No. 6. Proceedings of certain Americans with regard to the island of San Juan. Victoria, Feb. I9, I859.

Same to same. No. 137. Oppressive actions of certain U. S. steamboats running on Fraser River. Victoria, Apr. 12, 1859.

362. Douglas to Newcastle. No. I4. Remarks on ordinance to encourage the construction of telegraph lines connecting British Columbia with the telegraph lines of the U. S., etc. New Westminster, Apr. 4, I864.

363. Birch to [Cardwel1]. No. I7. Remarks on commerce, duties charged in Washington Territory, etc. New Westminster, Mar. 3, 1866.

Same to Carnarvon. No. 72. Sends Blue Book for 1865. Remarks on trade, etc. New Westminster, Oct. 3I, I866.

Seymour to same. No. 6o. Remarks on refusal of the U. S. steamers to carry the mails between British Columbia and San Francisco. New Westminster, Apr. IO, I867.

Same to Buckingham. No. I47. Remarks on his correspondence with Col. Scott and Maj. Hoyt of the U. S. army. New Westminster, Nov. 22, 1867 .

364. Seymour to Granville. No. 39. Relative to sentiment toward reciprocity with the U. S. Victoria, Mar. I7, I869.

365. Musgrave to Granville. No. 36. Remarks on dispute over San Juan Island and its value. [Victoria], Apr. 22, I87o.

Same to same. No. 16. Remarks on Northwest Boundary with the U. S., fisheries, etc, [Victoria], Feb. 22, I87I.

366. Dec. I8, I837-Jan. I6, I838. (I 18 pp.) In this letter-book about twenty documents relate to the insurgents and their U.S. sympathizers in New York, feeling in Michigan, etc. The larger part of these letters are from Sir F. B. Head to Sir John Colborne and to the minister at Washington.

374. Alexander Grant to Col. Bowes. Lack of authority to arrest deserters from the U. S. service. York, May 23, i806. (One enclosure.)

375. General return of persons owning land in Upper Canada, who have fled to the U. S. from the district of Newcastle since July I, I8I2. Haldimand, Nov. 29, I8I4. (Similar returns for other districts.)

395. Thomson to Russell. No. 97. Ill-treatment of Labrador fishermen by Americans and French. Montreal, Apr. 30, 1840. (Further details in Q 271, pt. II., p. 427.)

396. Thomson to Henry S. Fox. Need of re-enactment of the U. S. neutrality law. Toronto, Dec. 2, I839.

398. July 3, I840-Sept. 22, I84I. In this volume thirteen despatches in I84I relate to American interests. Of these, four are upon the McLeod case, four others deal with the disputed territory and proceedings of the Maine legislature, while single letters are concerned about grain trade with the U. S., duties upon agricultural produce, rumor of a projected canal between the Aligash and Penobscot, proposed convention with the U.S. for the mutual surrender of criminals and deserters, and news of proceedings of Canadian refugees and American sympathizers on the frontier.

The despatches are from Sydenham to Russell. (For the despatches of I840 see Q.) 
401. Jackson to Stanley. No. 8. Remarks at length upon the Northeast Boundary question and relations with the U. S. with regard to this and the McLeod case. Kingston, Sept. 27, I84I.

Same to same. No. I5. Comments on the substitution of U. S. troops in place of the irregular force formerly kept in the disputed territory by Maine. Kingston, Oct. 4, I84I.

Same to same. No.23. Activity of Canadian refugees and U. S. sympathizers along the frontier. Violation of Vermont territory by British subjects on the Missisquoi frontier. Kingston, Oct. I2, I84I.

Same to same. No. 32. Believes that persons in the U. S. who plan to attack Canada are few in number and desperate in circumstances, etc. Kingston, Oct. 26, I84I.

Same to same. No. $3^{6}$. Present condition of the province, and general relations with the U. S. Quebec, Nov. I7, I84I.

Same to same. No. 53. Remarks on fires on the Odelltown frontier, which were probably due to Americans. Strong feeling on the Canadian frontier. Kingston, Dec. 20, I84I.

402. H. S. Fox to Jackson. No. 2I. Relates an interview with the President, who declared his intention of preventing him (Fox) from leaving the U. S. in the event of McLeod's conviction, and that he would even detain him forcibly if it became necessary. Washington, Oct. 2, I84I. (Secret and confidential.)

Jackson to Stanley. Remarks at length upon relations with the U. S. as affected by the pending trial of McLeod, the possible withdrawal of Fox from Washington, etc. Kingston, Oct. I I, I84I. (Confidential.)

Same to H. S. Fox. In reply to latter's secret and confidential despatch of Oct. 2. Kingston, Oct. I6, I841.

404. Bagot to Stanley. No. Io. Case of Nelson Hackett, an escaped slave from Arkansas, demanded by Michigan on a charge of robbery. Kingston, Jan. 20, I842. (Council report follows.)

Same to same. No. I2. Relative to ferries over rivers dividing British territory from that of the U.S. Kingston, Jan. 21, I842. (Followed by extracts from Council reports.)

Same to same. No. 32. Smuggling of tea from the U. S. Urges that importation may be allowed upon payment of a duty. Kingston, Feb. I6, I842.

Same to same. No. 38 . Various remarks on fisheries of the Lakes. Kingston, Feb. I9, $18_{42}$.

Same to same. No. 52. Various comments relative to the Northeast and Northwest Boundaries. Kingston, Mar. 4, I 842.

Same to same. No. 6r. Observations on the second arrest, at Lockport, of Hogan, on the charge of being concerned in the destruction of the Caroline. Kingston, Mar. I4, I842. (Four enclosures.)

Same to same. No. 87. Feeling in New York with regard to the Hogan case, etc. Kingston, Apr. 19, I842. (Letter of Hogan follows.)

405. Bagot to Stanley. No. I Io. The Lake Huron fisheries, and U. S. duty on Canadian fish. Montreal, May 23, I842.

Same to same. No. I2I. Sends letter from Gov. Seward on an extradition case. Montreal, May 28, I842. (Enclosure follows. Nos. I45 and ${ } S_{5}$ also deal with extradition matters.)

Same to same. No. I54. Report of an agent sent to Buffalo discredits 
the rumors of intended attacks upon the frontier. Quebec, July I7, 1842 .

Same to same. No. 19. Remarks on Canadian bill to impose a duty on the importation of U. S. wheat and flour. Kingston, Jan. 27, I843.

406. Metcalfe to Stanley. No. 64. Question of the international boundary between the St. Lawrence and Lake Champlain. Disputes of Canadian and American Indians. Sends letter of David Thompson to his private secretary. Kingston, July 30, I843. (Enclosure follows.)

Same to same. No. 66. Sends letter of David Thompson regarding the Oregon territory. Kingston, Aug. I, 1843. (Enclosure follows.)

Same to same. No. I3I. Comments upon act to impose duties on agricultural produce and live stock imported into Canada. Nov. 21, I843. (A further account of the effects of this act is in no. 27I of May 9, I845.)

Same to same. No. I48. Observations on question of emigration of colored persons from Upper Canada to the West Indies. Kingston, Dec. 17,1843 .

Same to same. No. 29. Shipping, and trade relations with the U. S. Kingston, Feb. 3, I844.

Same to same. No. 66. Observations upon the U. S. naval force on the Lakes, its superiority over the British, etc. Kingston, Apr. I8, I844. (Separate military despatch of Dec. 9 is upon the same subject.)

Same to same. No. 88. Will strictly adhere to the tenth article of the treaty of Washington in the future, etc. Kingston, May I2, I844.

Same to same. No. 270. Relative to U. S. drawback law. Montreal, May 8, 1845 .

Cathcart to Gladstone. No. 7. Effects of the Corn Laws upon Canadian trade, how certain changes would divert shipping through the New York canals, etc. Montreal, Jan. 28, I846.

Same to same. Relative to rumors of plans in Tennessee and New York for attacking Canada. Montreal, Feb. 25, 1846.

407. Mar. 7, I846-May 28, I85 I. In this volume the despatches of both Cathcart and Elgin-especially those of the latter-show the distress of Canada during the first years of British free trade. Many letters tell how competition of British shipping with the lower rates of the Erie Canal, etc., became almost impossible. Reciprocity with the U. S. became an urgent issue, and a strong feeling in favor of annexation was openly manifested. One member was elected to the Canadian parliament as an avowed annexationist.

About twenty despatches to the colonial secretary deal with Canadian and U. S. trade, its routes, the free admission of U. S. vessels to the St. Lawrence and the Canadian canals, reciprocity, and the annexation sentiment. Minor topics are the seizure or kidnapping of British subjects and their imprisonment in the U. S., stoppage of letters of the Montreal board of trade on their way to Boston, a proposed bridge across Lake Champlain, Elgin's treatment in the U. S., extradition matters, etc. A rather long despatch from Elgin deals with Fenian agitation in the U. S., especially in New York, and a fear is expressed that wandering soldiers of the Mexican War may join the movement. 407 A. June I6, I85I-Dec. 29, I856. The chief American interest in this volume centres about commercial matters and reciprocity. Whether the navigation of the St. Lawrence should be opened to vessels of the U.S., the commercial policy of Canada toward that country just before 
I854, etc., are illustrative topics in this line. Among subjects of a more or less different nature are the following:

Elgin's trip to Boston, the friendliness displayed, and his impressions.

Detailed remarks on the Canadian Blue Books for I85I and I852 showing trade with the U. S., etc.

Plans for sending colored refugees to Jamaica.

Proposed establishment of a British consul at Chicago.

Enlistment for the Foreign Legion.

The foregoing survey represents about twenty despatches, all of which are addressed to the Colonial Office by Elgin and Head.

408. Jan. 2, 1857-Oct. 24, 186I. This number falls behind the two previous volumes in regard to the amount of material on American history; there is also a larger variety of subjects. From one to three despatches relate to each of the following:

The annual Blue Books.

Detailed comments on the workings of the reciprocity treaty.

Seizure of the Mazeppa or Julia Smith, at Detroit.

Shipment of Canadian produce to Great Britain via Portland.

Right of Americans to fish in the British waters of Lake Huron.

Outrage by a U. S. officer.

Lake trade.

Encroachments of the U. S. on Pigeon River.

U. S. armed cutters on the Lakes.

Estimates for U. S. defense.

Case of the steamer Peerless.

Applications to Canadian authorities for arms for the U.S.

Recruiting for the Federal army in Canada.

Attempts of U. S. soldiers to arrest deserters on Canadian soil.

British subjects in the U. S. army.

The despatches are addressed to the Colonial Office by Head, Eyre, and Williams.

408 A. Monck to Newcastle. No. 8. Arrest and detention of J. G. Shaver, of Belleville, by U. S. authorities. Quebec, Nov. 9, r86r. (Several other despatches upon Shaver's case in this volume.)

Same to same. No. 9. Relative to U. S. passport regulations. Quebec, Jan. I3, I862.

Same to same. No. 60 . Relative to rumor of construction of vessels at Ogdensburg. Q1iebec, Mar. 29, i862. (No. 68 deals with the same topic.)

Same to same. No. II3. Plans of Confederate refugees in Canada. Quebec, Nov. 19, I863.

408 B. Jan. I, I864-July 4, I866. American material is much more plentiful in this volume than in the two preceding it, but there is no single outstanding topic. About one-tenth of the despatches relate to American interests. The subjects, in an approximate order of the amount of space given to each, may be grouped as follows:

Confederate refugees in Canada, their plots against the U. S., and the steps taken by British authorities to discover and frustrate them.

The St. Albans raid.

Cases of kidnapping, arrest, and violations of territory by officers and citizens of both countries.

Prohibition of the export of live stock and anthracite coal from the U.S. into Canada. 
Recruiting in Canada for the U. S. army, and attempts to arrest deserters from the latter, who had fled across the border.

Alleged breaches of neutrality by Canada.

The reciprocity treaty, and its termination.

Suspected vessels, their building, or movements in Canadian waters.

Arrest of the U. S. consul general at Montreal.

A more detailed list of subjects will be found in G 171-176, where despatches in G $408 \mathrm{~B}$ are answered from Downing Street. All of the despatches are from Monck and Michel to the Colonial Office.

408 C. July 9, I866-Ju11e 26, I867. By far the most outstanding subject in this volume, connected with American history, is the Fenian raid. There is much material on trials of the prisoners, some of which tends to show that international relations had a certain amount of influence upon the sentences imposed. A good deal of attention is paid to the British naval force on the Lakes, as a deterrent to future actions of a hostile nature. Several despatches give intelligence of Fenian plotting after the raid of 1866 .

Subjects of minor importance are the arrest of a Canadian deserter on U. S. soil, and firing upon Fort Erie on the Fourth of July.

These despatches are from Monck and Michel to the Colonial Office.

409. Dorchester's order to allow the importation of salted provisions, wampum, etc., from the neighboring states, until Aug., I789. Mar. 2, I789.

[Dorchester] to the officer commanding at Detroit. Instructions for laying out the township of George Town. Quebec, May 15, I783.

Appointment of additional persons to the board "for the more easy accommodation of loyalists", etc. Quebec, July 22, I789.

[Dorchester] to Sir Jolnn Johnson. Detailed instructions to investigate all causes of dissatisfaction and uneasiness among the settlers in the western country. Quebec, June I7, I790. (Two letters of same date.)

Authorization to continue the land boards, "for the ease and accommodation of loyalists", etc., from May I to June I. Quebec, Mar. 3, I79I. (Circular. Three letters on this subject on above date.)

410. Thomas Dunn to the minister at Washington. Sends memorial of merchants of Lower Canada, engaged in Indian trade in the U. S., and proclamation of the superintendent of Indian affairs for the territory of Louisiana, prohibiting subjects of foreign powers from trade with the Indians, etc. Quebec, Nov. I5, I805. (Enclosures follow. Other letters to same upon this subject were written Nov. 25, and Mar. I I, I 806.)

Same to the British consul general at New York. Sends extract. Quebec, Sept. 9, I806. (Enclosure deals with British sailors in U. S. ships. Similar communication to Adm. Berkeley.)

Same to the minister at Washington. Relative to trade with U. S. Indians, etc. Quebec, Apr. 23, I807. (One enclosure.)

Same to Sir John Johnson. Relations between Great Britain and the U. S., etc. Quebec, July 3I, I807.

411. J. H. Craig to the minister at Washington. Views of Montreal merchants engaged in trade with western Indians, regarding non-importation and embargo measures of Congress. Quebec, Mar. 8, i8o8.

Same to same. Comments on Montreal traders and a recent occurrence at Niagara. Quebec, June 2, I808.

Same to same. Relative to Indian trade.

Same to Gov. Tichenor. Has not power to grant latter's request. Montreal, July 12, I809. 
Same to the minister at Washington. Relative to trade in the West. Quebec, Sept. 27, [1809].

412. Prevost to the minister at Washington. Relative to counterfeiting in Canada of U. S. bilis. Quebec, Apr. 23, I8I2.

Same to Sir John Warren. Information as to construction of ships at Kingston, etc. Quebec, Jan. 4, I8I4.

413. John Wilson to the minister at Washington. Sends, in compliance with request of the U. S. government, a descriptive list of American prisoners of war who died at Quebec during the late hostilities. Quebec, May 22, I8I6. (Enclosure not copied.)

Same to same. Relative to regulations on trade of British subjects with U. S. Indians. Quebec, June 29, I8I6.

414. Richmond to the minister at Washington. Relative to emigration of British subjects in the U. S. to Canada. Quebec, Feb. I3, I8I9.

Same to same. Necessity of employing a ship of war on Lake Erie. Quebec, Apr. 23, I8I9.

Instructions to the preventive officer at Stanstead on goods imported from the U. S. Quebec, July 23, I82I.

Dalhousie to the governor of Vermont. Extradition case. Quebec, Oct. 26, I82I. (Similar letter to the governor of New York.)

Same to the minister at Washington. Relative to a seizure by the collector of customs at Carleton Island. Quebec, Dec. IS, is2 I.

Same to Gov. Skinner. Remarks on alleged obstruction of the outlet of Lake Memphremagog. Quebec, June i7, r822.

Same to same. Vague letter stating Dalhousie's unwillingness to take any further measures in the case. Quebec, Nov. I8, I822.

Same to the minister at Washington. Information respecting the boy Peter Hoffman. Quebec, Feb. 26, I823.

Same to same. Cannot give certificate required by the U. S. government. Quebec, June 21, I823.

Same to same. Remarks on alleged outrages on U. S. fur-traders by western Indians. Quebec, Sept. Io, I823.

Same to the governor of Connecticut. Alleged kidnapping and imprisonment of a British subject. Quebec, Nov. I2, I\$23.

Same to the governors of Vermont and New York. Desires arrest of certain robbers. Quebec, Oct. 5, I824.

415. Aylmer to the governor of Vermont. Extradition case. Quebec, Jan. I3. IS3I. (Several other letters on extradition matters in this volume addressed to various U. S. governors.)

Same to the chargé d'affaires at Washington. Relative to deserters from the army, supposed to be in the U. S. Quebec, May 23, I832. (Several enclosures. Letter of Aug. 7 deals with the same topic.)

Same to the governor of Vermont. Relative to a rise in Lake Champlain, caused by the construction of a bridge at St. Johns. Quebec, June 27, I833. (Further letter on this topic, Aug. I3.)

Same to same. Remarks on overflow of Lake Memphremagog in Vermont. Quebec, July I8, I833. (Further letters on this topic on Oct. 25, and on Apr. I4, I835.)

Same to the minister at Washington. Remarks on boundary, land in Sherbrooke County, etc. Sorel, Oct. 7, I834.

Same to same. Exercise of judicial authority by New Hampshire in the Indian Stream settlement. Quebec, Apr. 6, I835. (Despatch of Sept. 5 is upon the same topic.) 
Gosford to same. Comments on duties upon U. S. vessels at Côteau du Lac. Quebec, Sept. 21, I835.

Same to Vice-Adm. Cockburn. Complaints against U. S. fishermen in the St. Lawrence. [Quebec], Dec. 26, I835.

Same to the chargé d'affaires at Washington. Details of outrage upon British subjects within the province, by an armed body from New Hampshire. Quebec, Feb. 6, I 836 . (Further despatch upon this topic dated Aug. 8.)

Same to the minister at Washington. Remarks on protest of the U. S. against the construction of a railroad between Quebec and St. Andrews. Quebec, Apr. 26, 1837.

Same to same. Account of various attacks upon the Canadian frontier by bands from the U. S. Montreal, Mar. 6 , IS38.

Same to same. Continuance of attacks from the U.S. Montreal, Mar. 9, 1838 .

Same to same. Apprehension felt on the frontier of Lower Canada. Montreal, Mar. 28, 1838.

Colborne to Sir Colin Campbell. Danger of attack from the western frontier, the feeling there, etc. Nov., I838.

Same to Maj.-Gen. Eustace [Eustis], U. S. A. Raid on the Missisquoi frontier. Dec., 1838. (Letter to the minister at Washington on this subject, Jan. I, I839.)

416. [Dorchester] to Lieut.-Gov. Parr. No. 19. Various remarks on trade, fisheries, and vessels of the U. S. at Canso, etc. Quebec, Oct. 3, I789.

Same to same and others. Instructions to stop illicit trade by Americans proceeding by means of counterfeit certificates of British plantation registry. Quebec, Apr. 7, I790. (One enclosure.)

417. Dalhousie to the governor of Vermont. Extradition case. Quebec, Nov. 2, 1827. (One of several despatches in this volume, to various persons, on extradition matters.)

Same to the minister at Washington. Remarks on the Northeast Boundary question and the need of better extradition arrangements. Quebec, May 30,1828 .

Kempt to the governor of Vermont. Relative to overflow of Lake Memphremagog. Quebec, Feb. 7, i83o. (Letters of May 3I and Sept. 6 deal with the same subject.)

418. Jan., I839-Jan., I844. This letter-book contains despatches from governors and administrators to lieutenant-governors, the British minister at Washington, etc. Nearly all-perhaps quite all—of the despatches are in previous volumes or folders of $\mathrm{G}$, and have there been treated at greater length.

The chief point of interest is the proceedings in the disputed territory, and the principal despatches are addressed to Lieut.-Gov. Harvey and to Henry S. Fox.

Next in importance come incidents connected with the aftermath of the Canadian rebellion of $1837-1838$. Frontier raids, efforts of rebels and their sympathizers in the U. S., the McLeod case, and other similar topics, are dealt with at more or less length.

Besides the foregoing, there are several minor subjects, such as the exportation of cattle to the U. S., lighthouses, extradition cases, etc.

419. Maitland to the minister at Washington. Why Carleton Island is to be considered British territory. York, Feb. I6, I822. (One enclosure.) Same to Gov. Cass. Remarks on extradition arrangements. Queens- 
town, Aug. 20, 1824. (Many other despatches to various persons upon extradition arrangements and cases are in the same volume.)

Same to Lieut.-Gov. Douglas. Comments at length upon settlers in British territory and their status. York, Apr. 3, 1826.

Same to the minister at Washington. Remarks on proclamation of the President of the U. S. with regard to trade with British colonies. York, Apr. 23, I827.

Colborne to Bankhead, Washington. Relative to duties levied upon American vessels in Canadian ports. York, Nov. 29, I83I. (Another letter on a similar query was written Aug. 20, I833.)

Same to the minister at Washington. Relative to certain commercial duties. Toronto, Mar. 27, I834.

420. Oct. 27 , I837-Aug. 2 I, I839. (248 pp.) At least three-fourths of this volume is composed of material relating to American history. Despatches touching upon relations with the $\mathrm{U}$. S. during the period are from Lieut.-Govs. Head and Arthur to Sir John Colborne, the British minister at Washington, and various officers in the American army. Every hostile act is discussed, many comments are made upon the state of feeling along the border, and prominent events, such as the various raids and the destruction of the Caroline, are usually treated with much detail. In brief, this is a very important volume of sources upon the U. S. attitude toward the rebellion in Upper Canada.

421. June 9, I838-Dec. 24, I840. (256 pp.) This letter-book is complementary to the preceding one. It contains despatches from Lieut.-Gov. Arthur to Govs.-Gen. Durham and Sydenham, and to Sir John Colborne.

The largest part of the material on relations with the U. S. is to be found in the twenty-five despatches to Durham. Some of these are entirely upon various attacks against the western frontier of Upper Canada, and nearly every one contains some intelligence regarding hostile acts or prevailing sentiment with regard to them, along the border. Much attention is also given to measures taken by the American authorities, and the treatment and trials of prisoners captured in these frontier raids. These despatches range from June 9 to Oct. 24,1838 . (96 pp.)

Despatches to Lord Sydenham and to Sir John Colborne contain much less information upon such matters. Mention is made, however, of other topics of interest to Americans, such as the cattle trade between Upper Canada and New York, emigration of Indians from the U. S. to Canada, increase of colored persons in the western district, etc.

422. Probably all letters in this volume relating in any way to the U. S. have been previously listed, in the form of originals or copies, in other numbers of this series. All despatches are addressed to the governor general, and may be classified as follows:

From Lieut.-Gov. Harvey. The disputed territory. Jan. 28-Aug. 27, I 840 .

From Lieut.-Gov. Arthur. Nothing on the U. S. Apr. 9-Aug. 24, I840. From Sir Richard Jackson.

One despatch on military arrangements in the disputed territory. Jan. 3 I, I840.

From the British minister at Washington. Seven letters respecting the Northeast Boundary. Jan. 23-May 23, I840.

From Lieut.-Gov. Campbell. The disputed territory, etc. Nov. I6, I839-June 25 , I840. 
423. This volume contains despatches from the governors general to the lieutenant-governors, the commander of the forces in Canada, the British minister at Washington, and various other persons.

Communications to the lieutenant-governors of New Brunswick are almost entirely concerned with the disputed territory. Those to Sir Richard Jackson are upon the same topic, and cover practically the same dates. Oct. I9, I839-Aug. 27, I842.

Despatches to the minister at Washington have for their most prominent topic the Northeast Boundary question. Those of less importance are the McLeod case, Grogan's arrest, frontier outrages, Buchanan's relations with Papineau, U. S. neutrality law, and extradition matters. The dates are Nov. I2, I839-May 4, I842.

Some of the miscellaneous correspondence relates to subjects included in the preceding paragraph, and a few despatches to Lieut.-Gov. Arthur comment upon frontier raids.

424. T. A. Coffin to J. McGill. Relative to importation of potash by certain Americans. Quebec, June 29, I795.

426. Coffin to James McGill and John Richardson. Relative to seizure of property in the Mississippi. Quebec, Sept. 28, I795.

Same to John Lees. Remarks on persons coming from the U. S. to buy powder, etc. Nov. 22, 1795. (Letters on same topic to P. Conroy and to J. W. Clarke.)

Same to P. Conroy. Export of furs to the U. S. June 16, I796.

Ryland to J. McGill. Relative to survey of part of the Mississippi. Jan. 26,1797 .

Same to John Richardson. Remarks on suspicious characters coming from the U. S., etc. July IO, I797. (Letter on same topic to William Lindsay.)

427. Samuel Gale to Messrs. Forsyth, Richardson, J. McGill, and A. McGill. Relative to treatment of François Bisson by the U. S. garrison of Michilimackinac. Dec. IO, I798.

428. R [yland] to J. Marshall. Extradition matters. Dec. 25, 1800.

430. Ryland to William Lindsay, St. Johns. Remarks on increasing intercourse with the U. S., and the prevalence of smuggling. Mar. II, I805.

432. Ryland to Porter, Haverhill, New Hampshire. Remarks on proposal to open a turnpike road from Boston and New York to Montreal. Feb. $27,1806$.

Same to Col. Bowes. Information from the minister at Washington on relations between Great Britain and the U. S. Mar. 8, I806.

Same to G. McBeath. Entrance of U. S. sleighs without examination at St. Johns. Apr. 21, I806. (Letter of May 5 on the same subject.)

Same to William Smith. Receipt of documents on boundary line of 1772 between the province and New York. Dec. 2, I806.

Same to Col. Sir John Johnson and to others in various townships. Instructions to prepare, in the present state of relations with the U.S., to take up arms for defense upon short notice. July 30, I807. (Confidential. Letter to Col. Baby, of Aug. I9, on the state of the militia.)

434. Ryland to the collector of customs at St. Johns. Instructions as to smuggling from the U.S. Aug. 25, I808.

Same to Henry Cull. Orders to watch for any military preparations about Burlington, Vermont. Dec. 5, 1808. 
436. L. Foy to the magistrates of Montreal. Remarks and instructions on disputes between Canadian and U. S. carters. June 4, I8I I.

437. Foy to Sir John Johnson. Information is desired of the general meeting of Indians within the U. S. lines. Aug. 23, I8I I.

439. Ryland to S. R. Miller. Relative to the exportation of certain goods to the U. S. July 20, I8I2. (Another letter on this topic to James McGill, on July 23.)

A. W. Cochran to the collector of customs at St. Johns. Relative to a renewal of commercial relations with the U. S. Mar. 27, I8I 5.

440. Robert Loring to the attorney general. Wishes to know whether trade with the U. S., through St. Johns, is legal or not. Apr. 20, I8I5.

Same to Alexander IVilson. Relative to commercial regulations. June I7, I8I5. (Similar letter to James Milne.)

Same to same. Remarks on regulations affecting American boats. July 2 I, I8I 5 .

441. Robert Loring to the collector of customs at St. Johns. Instructions as to prevention of smuggling from the U. S. by vessels on Lake Champlain.

442. Robert Loring to H. W. Ryland. Regulation of trade between the province and the U. S. Feb. 29, I8I6. (Letter on the same subject to George Pyke and Alexis Carron, Mar. 7.)

Same to the collector of customs at St. Johns. Orders to notify U. S. traders of approaching expiration of provincial act regulating commercial intercourse with the U. S. Mar. I9, I8I6.

Same to H. W. Ryland. Relative to regulations on trade with the U. S. Mar. 20, I8I6. (Circular to collectors on this subject, Mar. 22.)

Same to the attorney general. Instructions relative to regulations for trade with the U.S. Apr. I6, I8I6.

444. July I2, I8I6-Jan. 23, I8I8. In this volume about a dozen letters from the civil secretary to various persons relate to regulations on inland trade with the U. S. Most of these deal with requests for permission to import certain articles, usually by way of St. Johns. Many other letters are upon seizures of goods, and show the prevalence of smuggling.

445. Cochran to William McGillivray. Requests that due facility be given to the reoccupation by the $\mathrm{U}$. S. of the settlements on the Columbia River held by the Americans before the late war. May 28, I8I8.

446. J. Ready to the chief justice. Relative to land or inland trade of the province with the U.S. May 27, I8Ig.

Same to the collector and comptroller of customs, St. Johns. Instructions regarding vessels exporting goods to the U. S. June 7, I8I9.

451. A. W. Cochran to Sir F. Burton. Remarks on establishment of a port of entry at La Prairie in order to lessen smuggling, etc. July I3, I822.

452. Cochran to the police magistrates of Montreal. Remarks on kidnapping of a British citizen by Americans. Oct. I8, I823.

453. Cochran to the attorney general. Desires information on certain points in connection with seizure of a British subject by Americans and his conveyance to the U. S. Mar. 20, I824. (Another letter on this case to Calvin May, Mar. 3o, I824.)

454. Cochran to Gillespie, Moffatt and Co. Information on regulations concerning the importation of certain goods into the province from the U. S. Apr. $27,1826$. 
Same to the attorney general. Requests opinion on certain commercial regulations. Apr. 27, 1826 .

456. Cochran to the attorney general. Requests opinion on act granting privileges to U. S. fishermen. Aug. 17, r827.

459. Murdoch to the British consul at Portland. Further information desired on rumored project of canal to connect the Aligash and the Penobscot. Kingston, June 24, I $84 \mathrm{I}$.

Same to Capt. A. McDonald. Instructions respecting rumors of emissaries from the U. S. among the disaffected in the province. Aug. 3I, I84I.

460. Murdoch to J. Sheridan Hogan. Advises latter not to expose himself to further opportunities for arrest in the U. S. Kingston, Mar. I3, I842.

Same to Capt. Taylor. Instructions with regard to rumored plans for attacking the western frontier from the U. S. June 9, I842. (Confidential.)

460 A. R. W. Rawson to Lieut.-Col. Napier. Any attempts by U. S. authorities to exercise jurisdiction within British territory are to be firmly resisted. Aug. 5, 1843.

460 B. R. W. Rawson to S. P. Jarvis. Relative to emigration of Indians from the U. S. to the St. Clair frontier, etc. Dec. 21, I843.

J. W. Higginson to the provincial secretary. Remarks on interest of U. S. merchants and captains of vessels regarding the Canada corn bill. Instructions. Mar. 28, 1844 .

Same to P. B. de Blaquière. Relative to illicit importation of U. S. wheat. May i3, I844.

Same to Capt. Fowell. Report is desired on the amount and condition of the U.S. naval force on the Lakes. Oct. 25, I844. (Confidential.)

Same to Henry Moyle, Brantford. Remarks on U. S. duty on wheat imported from Canada. Feb. 3, 1846.

460 C. T. E. Campbell to W. Badgley. Remarks concerning rumored plan of bridge across Lake Champlain. Apr. 3, I848.

A. Hamilton to the controller of customs, Quebec. The St. Lawrence to be thrown open to U. S. vessels. Aug. 23, I854.

Bury to the president of the Quebec board of trade. In reply to memorial for the appointment of a consul or commercial agent at Washington. June 9, r855.

460 F. Francis Retallach to the British consul at Boston. Comments on rumor that Massachusetts could obtain arms from Canada. Quebec, May 4, r86I.

460 G. Oct. 26 , I86I-Dec. $3 \mathrm{I}$, I862. In this volume about a dozen letters from the civil secretary to various persons deal with British subjects in the U. S. army, especially minors.

Apart from these, single communications relate to a violation of Canadian territory, and the arrival of 500 U. S. troops at Buffalo, for defense of the lake frontier.

460 I. Denis Godley to the British consul at Buffalo. Remarks on crimping for the U. S. service. Quebec, Aug. I5, r864.

Same to the attorney general. Instructions on reports of plots in Canada against U. S. cities on the Lakes. Quebec, Aug. 18, 1864.

Same to same. Instructions on U. S. recruiting agents in Canada. Quebec, Aug. 23, I864.

Same to same. Alleged organization and drilling in Prince Edward County of fugitives from the U. S. Quebec, Dec. 6, I864. 
Same to the British consul at New York. Further information desired on rumored plots for invading Canada. Quebec, May 27, 1865. (Confidential.)

Same to the president of the executive council. Relative to exportation of anthracite coal from Canada. Quebec, June I3, I865.

473. Brock to Liverpool. No. 6. State of feeling in various parts of the province. Numbers of militia and arms. York, May 25, I8I2.

478. Naitland to Bathurst. No. I I8. Various remarks on Barnhart's Island, the boundary, etc. York, Feb. 9, I824. (Enclosed is plan of the St. Lawrence at Barnhart's Island, showing the boundary line. This despatch is calendared in the Can. Arch. Rept., I898, in the $\mathrm{Q}$ series, but the map is missing there.)

495. Arthur to Glenelg. News of aid given to Papineau in the U. S., and negotiations between him and the British consul at New York. Toronto, Feb. 21, I839. (Private.)

496. Arthur to Normanby. Comments upon the press of the province and its attitude toward the U. S. Toronto, July 3, I839. (Private.)

516. Glenelg to Gosford. No. 220. Remarks on U. S. action in the Indian Stream settlement. June 9, I837.

Same to same. No. 228. Comments and instructions "relative to the outrage committed in October I 835 , within the Canadian Frontier by certain Citizens of New Hampshire", June 29, I837.

517. Glenelg to Gosford. No. 232. Relative to actions of certain citizens of New Hampshire in Oct., I835. May 3, I837.

519. [Glenelg to Durham.] No. 22. Requests certain information respecting the disputed territory east of the Connecticut River. Apr. 22, I838. (Abstract.)

523. Russell to Sydenham. No. 303. Sends despatch from the governor of Trinidad enclosing his correspondence with Dr. Rolph of Upper Canada, regarding the proposed emigration of colored persons from that province to Trinidad. Feb. 9, I84I. (Enclosures follow.)

524. This letter-book of $246 \mathrm{pp}$. contains despatches addressed to the governor general by various persons during the latter part of 1839 and the early months of i 840 . Those from Sir Richard Jackson, Nov. I9, I839-Mar. 22, I840, Lieut.-Gov. Harvey, Oct. 26, I839-Jan. 28, I840, and the British minister at Washington, Nov. 3, I839-Apr. 3, I840, are almost exclusively concerned with proceedings in the disputed territory and the Northeast Boundary question. A few from Lieut.Gov. Arthur, Oct. 24, I $39-$ Apr. I4, I 840 , relate to proceedings upon the frontier and the state of feeling. There are many important enclosures, usually consisting of diplomatic correspondence.

537. Sept. 9, I799-July 6, I808. ( I Io pp.) In this volume are despatches from the British minister at Washington to the lieutenant-governor of Upper Canada. There are nearly fifty letters, some of them with enclosures, and the contents are of great variety and interest.

Among the earlier despatches are comments upon what the minister calls a large class of persons who would be pleased to see " a democratick revolution in the King's American Dominions ". The presence of Jacobins in the U. S. is discussed and guesses made at the objects of the visit of Jerome Bonaparte. A detailed description of both him and his attendant is given. Only a few pages distant are various remarks upon the administration of Jefferson, its attitude respecting foreign relations, the Indians, the cession of Louisiana to the French 
and its purchase later by the U. S., adjustment of northern and western boundaries with Canada, projects in Vermont against the peace of British territory, etc.

A little later come disputes with the U. S. executive over commercial restrictions, such as the prohibition of Canadian traders on the Mississippi. Besides the above there are several topics of a less general nature including the case of Coulteulx, an alleged U. S. subject imprisoned at Niagara. There are also remarks interspersed in various despatches, upon passport rules, the fur-trade, Indians, and U. S. customs regulations.

538. Mar. 2, 1839-Feb. 26, I841. Despatches contained in this letter-book are from Lieut.-Gov. Arthur, of Upper Canada, to Henry S. Fox, British minister at Washington. There are somewhat less than Ioo pp.

Although sporadic border aggressions are discussed at length, yet the main feature of this book is the prominence given to feeling shown toward Canada by the U. S., especially by those states along the frontier. Ohio, Michigan, New York, Vermont, Maine-the attitude of each is treated with a fullness much greater than is displayed in the despatches of Lieut.-Gov. Head to the same official. In the latter part of the volume are several long communications upon the McLeod case and the danger of war with the U. S. which it occasioned.

539. Dundas to Dorchester. Remarks upon relations with the U. S. Suggestions. Whitehall, June 4, I794. (Secret. Enclosed is copy of Dorchester's speech to the Indians, at Quebec, Feb. IO, I794.)

Portland to same. Intelligence of the probable outcome and effect of negotiations upon certain points of the treaty. Whitehall, Aug. 6, 1794. (Private and secret.)

Same to Prescott. Remarks upon the capture of Ira Allen and the Olive Branch. Whitehall, Jan. 20, I797. (Secret despatch of Mar. 15 touches upon the same topic, and enclosures are upon rumors of French plots against Canada, and their emissaries in the U. S.)

Same to same. Rumors of French plots in the U. S. against the peace of Canada. Whitehall, June 7,1798 . (Most secret. One enclosure.)

Same to same. Sends documents. Whitehall, Dec. Io, I798. (Secret. Two enclosures relate to emissaries of Jacobinism, proceeding from Vermont to Upper Canada.)

\section{SERIES M: MISCELLANEOUS.}

The $\mathbf{M}$ series was begun about $\mathrm{I}_{85}$, under the late Dr. Brymner, and at present contains over Iooo volumes and portfolios. It may be kept open for some time as a convenient place for miscellaneous material which it would be difficult to amalgamate with any homogeneous series. The greater part of $\mathbf{M}$ can be classified under certain definite heads. First in both mass and importance come the various sub-series, such as Claus papers, Bagot papers, the America and West Indies series, Colonial Office transmissions, military despatches, War Office papers, boundary papers, state papers of the Maritime Provinces, records of the prévôté of Quebec, Canadian Post Office papers, etc. The Claus papers and Bagot papers are originals; the other English series were copied in London, and the French series in Quebec or Montreal.

Parish registers form an important portion of M. A few are originals, but the greater part were copied at various places ranging from Detroit to Gaspé. 
Certain volumes of the $\mathrm{C}$ series have been temporarily transferred to $\mathbf{M}$. They are in Lient.-Col. Cruikshank's Inventory of the $\mathbf{C}$ series, and will soon be replaced.

The remainder of $M$ is of a miscellaneous nature.

Beyond $731 \mathrm{~F}$ the series is in such a chaotic state at present that the portions having no relation whatever to United States history have been wholly ignored. A few of these are numbered, but as several are without any such distinguishing marks while many others have been placed among the reserved material $(q . \%)$ it was cleemed best to take no notice of such numbers as do exist, for this portion of the series is more liable to imminent change than any other.

1-67. These were all copied at Quebec and may be divided as follows:

1-8. "Actes de Foy et Hommage." Sept. 9, I667-Feb. 3, 1854.

9-12. "Cahiers d'Intendants. (Titres présentés par les vassaux.)"

13-33. "Ordonnances des Intendants." Sept.7, I705-Feb. 26, 1760. (Largely printed in the Edits ct Ordonnances.)

34-35. "Registres d'Intendants. (Concessions en fief et en roture.)"

36-46. "Aveus, Dénombrements et Déclarations." Feb. I5, I723-Dec. I2, I $78 \mathrm{x}$.

47-59. "Papiers Terriers Censives du Domaine du Roy." I723-1832.

60-67. "Insinuations du Conseil Souverain." (Conseil Supérieur from I708). Sept. IS, I663-Aug. 21, I758. (Largely printed in the Edits ct Ordonnances.)

68-93 B. Copies of various local registers. Nearly all of these were copied for the Archives between I8SO and I886.

68. Lands in Bonaventure (Quebec). Ninttes of locations, schedules of claims, etc. I789-1791, I832. (Some of the dates are subsequent to I832.)

69-71. "Registres de Port Royal." Baptisms, marriages, and burials. I702I728, I727-I74I, I74I-I755. (Originals in Halifax.)

72. "Divers Registres de 1'Acadie." I 768-1799. (No English names.)

73. "Registre de l'état civil de St. Joseph de Carleton" (Quebec). I759I 795 .

74. Registers of baptisms, marriages, and burials in Ste. Marie, I799-I88I ; Cocagne, I80I-I824; St. Antoine, I800-I824: St. Charles, I805-I825; and St. Louis, ISO5-1825. Material of the Maritime Provinces. (A brief search did not show any English names.)

75-77. "Registres du Fort Pontchartrain du Detroit." I703-1754, I755$1783,1783-1800$. (Originals among the records of the church of Ste. Anne, at Detroit.)

Vol. 75 also contains names of persons obtaining concessions from 1734 to 1750 between "Fort Pontchartrain and the Strait of the Lake Erie". The rest of the volumes are composed of the usual lists of baptisms, marriages, and burials.

78. "Registre, Pointe de Montreal, Detroit." Baptisms, marriages, and burials. July 16,$1 ; 61-$ Sept. $25,1767$.

79. "Registre des Baptêmes, Mariages et Sépultures de la paroisse de l'Assomption du Detroit, I78r-r799." (Copied from the original in the possession of D. Shea of New York.)

80. "Registre, Ste. Anne, Mackinac." Baptisms, marriages, and deaths. I695-I790.

81. "Registre de Poste Vincennes." Baptisms, marriages, and burials. I $749-1786$. 
82. This volume of $876 \mathrm{pp}$. contains copies of several registers of parishes and missions in Illinois. Baptisms, marriages, and burials do not always cover exactly the same period. The extreme dates are as follows :

Inmaculée Conception. I695-I790.

St. Joseph. I $76 \mathrm{I}-\mathrm{I} 790$.

Ste. Anne du Fort de Chartres. I72I-1765.

Notre Dame de l'Immaculée Conception aux Cascaskias. I74I-I799.

St. Philippe. I 76 I- 1765.

Poste des Arkansas. I744.

83. "Registre des Baptêmes, Mariages et Sépultures de l'Église paroissiale protestante de la ville des Trois-Rivières." I768-i 786.

84. "Registre des Notaires, Detroit." I737-I780. ( I092 pp. French.)

85. "Registre des Notaires, Detroit." I780-I784. (422 pp. French.)

86. Notarial register of William Monforton, at Detroit. I786-I792. (This is the original register, and comprises $540 \mathrm{pp}$. French.)

87. "Registre des Notaires, Detroit." I790-I796. (I33 pp. French.)

88. Notarial register, Detroit. I $766-$ I 780 . (352 pp. English.)

89. Notarial register, Detroit. I $780-1784$. (460 pp. English.)

90. "Index des Registres des Notaires de Detroit." I $737-1796$.

91. Cornwall register. Births, marriages, and deaths. I803-1846.

92. Cornwall register of marriages. I8O3-1845.

93. Cornwall register of burials. I813-1846.

93 A. Upper Canada marriage register, Eastern District. I83I-I865.

93 B. "Registre de l'État Civil de la paroisse de Saint Régis I764 à I82r."

94. "Journal ou Relation d'une Conspiration faite par les Sauvages contre les Anglais. Et du Siège du fort du Detroit mis par quatre Nations différentes le 7 Mai I $763 . "$ ( 132 pp.)

95. "Extraits des Registres du Conseil d'Etat du Roy [de France]. I7641767. (Rachat du papier monnai.)"

96. Protestant register, Montreal. I $766-1787$.

97. Journal of Rutherford on his captivity among the Indians in $I 76_{3}$, during the Pontiac War. (Biographical note at the end. $64 \mathrm{ff}$.)

98. "Journal de Laverendrye." I738-I739. With it are bound two letters of Bienville of Oct. 20, I7I3, and May 24, I749. The Journal has been printed with an English translation in the Report on Canadian Archives, 1889.

99. "Documents Historiques." Manuscripts purchased from Alfred Garneau in 1876 and 1877 . Those relating to American history are:

Examination of two prisoners (military) taken by the French at Crown Point. I758.

“Introduction à l'année I775."

"Journal tenu pendant le siège du fort St. Jean en I775."

"Mémoire de M. Amable Berthelot de Quebec sur la guerre de I775."

"Réflexions et notes sur le Canada." [Ca a. I760.]

Unsigned letter to Mgr. Briand respecting the American invasion. Oct. 28, I775. (French.)

Unsigned letter to Montgolfier on a victory gained at Pointe de la Chevelure. Sept., I776. (French.)

Unsigned letter to same on the situation at Verchères and several other places. Oct. 23, 1775. (French. Other unsigned letters to the same, of Oct. 2, I775, and Sept. I2, I777, give various details of the war, and are likewise written in French.) 
100. Quebec exports, I79I ; sketch of the Glengarry Highlanders by Bishop Macdonnell; and a "History of the County of Frontenac", by Miss M. Harman.

101. This volume is missing at present, but it contains nothing for $\mathrm{U}$. S. history.

102. Extracts from the communal archives of St. Malo relating to Jacques Cartier: and miscellaneous.

103. T. A. De Rottenburg to the quartermaster-general. Description of trip from Fredericton to Quebec. Quebec, July IO, I8I9.

Joseph Bonchette to the Earl of Dalhousie. Former's visit to the district of Gaspé. Quebec, Sept. 20, I822.

Report by Capt. DuVernet on progress of the Grenville Canal. Chambly, Nov., I822.

104-115. The contents of these twelve volumes, labelled "Indian Papers", were purchased in a loose form from descendants of the Claus family at Niagara, in 1883 . They are a combination of several units.

First are the papers of Col. Daniel Claus, deputy superintendent of Indian affairs under Sir William Johnson and Sir Guy Johnson. To these were added the papers of Col. William Claus, also deputy superintendent of Indian affairs at a later date. On the death of Col. Alexander McKee, deputy superintendent of Indian affairs, in I799 his papers were sent to Col. William Claus at Niagara, and incorporated with those of the latter.

There are also enough letters to Prideaux Selby, assistant secretary of Indian affairs, to warrant the theory that his papers at one time formed a separate unit. There is a certain amount of miscellaneous correspondence. Other units are taken up in the separate volumes. (Briefly indexed.)

104. I760-1777, with one exception. (246 pp.) In this volume the first document is dated I7I6, and has no connection with American history. The largest section is the correspondence of Sir William Jolnson and Daniel Claus. (Claus had been placed at Nontreal after its surrender to superintend Indian affairs in Canada.) Tohnson's letters were written from Albany, Castle Cumberland, and Fort Johnson. They deal almost exclusively with Indian administrative affairs and personal matters. They cover the period from Oct. Io, I 760 , to July I 3 , I 762 . (8o pp.)

Other letters to Claus are from Cramahé, Carleton, Guy Johnson, and John Johnson. Some of these are not concerned entirely with the Indians. E. g., a letter from Guy Johnson to [Daniel Claus], dated Staten Island, Aug. 9. I 776, gives an account of recent fighting about New York.

Many letters and some fragments are unaddressed or unsigned.

This volume also contains a copy (loose) of Sir William Johnson's will a document headed "Minutes of the Rebel Invasion of Canada", and another entitled "Answers to Doctor Robertson's Queries respecting the North American Indians". Besides these there are general orders, camp at Skeensborough, July IO, I777, and a list of officers killed and wounded of Fraser's advance corps at Hubbardton, July 7,1777 .

105. I778-I 780 . (276 pp.) The largest part of this volume is taken up with letters to Daniel Claus from various persons. Perhaps the most important are from Gov. Haldimand and his private secretaries; these 
often give orders or make comments upon various projects against the Americans.

Other correspondents are Joseph Brant, Mary Brant, John Johnson, Guy Johnson, Hamilton, Hay, John Blackburn, London, and various Indian agents. A letter from Taylor and Duffin to Claus, dated Niagara, Nov. 15, I 778 , gives an account of certain exploits of Brant.

Several important letters are from DePeyster to Alexander McKee. Besides Indian matters they throw light upon military projects of the time.

In addition to letters this volume contains a collection of anecdotes respecting Joseph Brant; a speech of Jackalopin, chief of the Fox Indians in Wisconsin, delivered at Quebec, June 6, I 779 ; several other Indian speeches written in the original tongue and not translated; and a conference with chiefs of the Five Nations held at Quebec on Aug. 20,1779 .

106. Feb. $1,178 \mathrm{I}-$ Dec. 17,1783 . (277 pp.) Perhaps a third of this number is taken up with letters to Daniel Claus from Haldimand and his private secretary, Capt. Mathews. There are also many drafts of letters to these from Claus. Other letters to him are from John Johnson, J. Blackburn, J. Macomb, J. Thompson, and Daniel Robertson.

Another important section of the volume is composed of letters from DePeyster, Detroit, to Alexander McKee. Communications addressed to the latter by William Caldwell, John Johnson, William Potts, and Ensign Fry are also present.

A few Indian speeches and replies thereto, most of which are in English, complete the volume. Stated briefly, its contents deal less with Indian administration and more with the war, especially in the West, than do those of the two numbers immediately preceding.

107. Jan. 8, 1784-Dec. 27 , I79I. (350 pp.) The contents of this volume are of a miscellaneous nature. In the first part the most important item in the correspondence is furnished by letters from Capt. Mathews to Daniel Claus and drafts in reply. Other correspondents of Claus are Lieut. Langan, Capt. Hill, John Johnson, and Richard Dobie, of which Langan's letters from Detroit are the most important.

There is a small amount of McKee correspondence, and a considerable quantity of Indian speeches, replies, etc., respecting western Indians, western posts, and the policy of both British and Americans toward them. Among these are an address of John Cleves Symmes to the Shawnees and their reply.

Several letters from Maj. Patrick Murray, Detroit, to various persons are important for the situation in that region. With these may be classed a communication to him from Arthur St. Clair, Marietta, Sept. 19, I790, conveying assurances of the peaceful intentions of the U.S. toward Great Britain and her colonies.

From this we pass to American papers captured by the Indians at St. Clair's defeat, and by them handed over to McKee. Nearly all of them are dated I79I, and the most important features are St. Clair's correspondence with Sec. Hamilton, Sec. Knox, and Gen. Butler. These are very valuable for the history of his expedition. A few are printed in Am. State Papers. Letters from him have the appearance of drafts, and probably all of them are of that character. Those written from Fort Washington during June-Aug., I79I, are very detailed. 
There are also many miscellaneous papers in this section. Among these are a copy of a contract for army supplies between Alexander Hamilton and Theodosius Fowler of New York, reports of several military boards, and the roll and muster of Capt. Jacob Tipton's company of infantry levied south of the Ohio, under the command of Maj. Rhea, July 25-Sept. 23, I 79 I.

108. Jan. 23, I79I-Aug. 3I, I793. (32I pp.) The first item of this book is the copy of a letter from Thomas A. Coffin to John Johnson on prevalent suspicions that the Indians were aided by the British during the campaign against St. Clair. This is immediately followed by a letter from Joseph Brant to Alexander McKee, with regard to a long communication from Gen. Knox inviting him (Brant) to a conference at the seat of government.

The largest part of the volume is filled with letters to McKee. By far the most important are from Lient.-Gov. Simcoe and from Brant. In the communications of the former can be traced his policy toward the western Indians and the various moves of the Americans with regard to them; while Brant's letters, though less numerous, yield valuable information upon his relations with both British and Americans, and his views concerning the attitude of the different Indian nations and their chiefs.

Other letters to McKee are from Joseph Chew (Montreal), and Thomas Duggan, Selby, Lamothe, Elliott, England, and Wilson-all from Detroit. Those of Chew are the most numerous; the others are of greater value to American history.

One of the most important features of this volume is the light it throws upon negotiations leading up to the intended council of the U. S. commissioners with the Indians at Lower Sandusky. In this line, besides the letters of Simcoe and Brant, there are numerous speeches between the Indians and Knox, Washington, and Simcoe; the latter's instructions to Mcliee and Butler as to the course they should pursue at the gathering; Simcoe's correspondence with the U. S. commissioners; and a letter from them to McKee. There is also a copy of the title of the Bay of Quinte grant to the Six Nations.

109. Sept. 8, I793-Dec. I4, I794. (324 pp.) As in the preceding volume, letters to Alexander McKee form the largest part of this book. Those from Simcoe and his secretaries are very important, as are also the few from Brant. Duggan, Caldwell, the Rev. Mr. Burke, England, and Schiefflin are other correspondents of McKee, whose letters-most of which were written from Detroit-furnish material for American history.

Besides these a series of communications from Thomas Smith at Swan Creek, as well as some from Welbank at the Glaize and one dated Cherokee Nation, Apr. 12, I794, are almost entirely concerned with the local situations.

There are several unsigned or fragmentary letters and some miscellaneous correspondence of minor value.

Besides letters the volume contains a schedule of papers received by the commissioners of the U. S. from Simcoe ; speeches of the latter and of Dorchester to the Indians; the diary of an officer in the Indian camp opposed to Wayne, June I4-July I, I794, information received from American prisoners and deserters, etc. 
The chief interest in this volume centres about negotiations with the Indians, their meetings and movements, and Wayne's expedition.

110. Jan. I I, I795-Dec. 3I, I796. (332 pp.) Letters to McKee in this volume cover rather more territory than formerly. Those from Simcoe and his secretaries are fewer; but communications from Duggan and Lamothe (both at Michilimackinac), Chew (Montreal), Capt. Stiele (Fort Miami), England (Detroit), Burke (Raisin River), Askin, John Johnson, and others continue to shed light upon Indian administration, political plans, movements and meetings of the tribes, trade, etc.

Many letters in this volume are from McKee and others to Prideaux Selby, assistant secretary of Indian affairs.

There is also a certain amount of miscellaneous correspondence under the names of Askin (Detroit), J. Williams (Sandusky), Coffin, etc., as well as a few unsigned documents and Indian speeches.

Stated briefly, this volume throws light upon political readjustment after I794, especially in the West, the courses of Indian administration and of trade.

111. Mar. 29, I797-Dec. 30, I803. (330 pp.) This volume is apparently composed of the papers of Prideaux Selby, Alexander McKee, and William Claus. The larger part of the letters are between these three, but other correspondents are John Johnson, John Chew, Thomas Duggan, George Ironside, M. Elliott, Peter Russell, and several others.

Besides administration and trade a considerable part of this volume is concerned with Indians, Spaniards, and Americans on the Mississippi, and news of any movements intended by either party. In this line are the instructions to Joseph Jackson, Jan. I5, I799, to proceed to the Mississippi and investigate any plots of French, Spanish, Americans, or English against British territory or against each other, and his report, dated May 5, I799.

112. Jan. IO, ISO4-Oct. 26 , I809. (289 pp.) The largest part of this volume is composed of the papers of William Claus and Prideaux Selby. There are also some letters to Sir John Johnson, superintendent of Indian affairs, from different persons, and communications from William Claus to Lieut.-Gov. Gore. These last are probably duplicate originals.

Most of this correspondence is upon administrative matters, but some of it shows the keen interest of the British in relations of the various tribes with the U. S., their meetings, and their intertribal relations.

Other documents are speeches delivered at a council at Fort George, Mar., I809; a fragment of William Claus's diary, May 7-Aug. Io, I 808 , and a requisition for an extra quantity of goods for I809 to supply His Majesty's Indian stores with presents for the Indians in Upper Canada in the event of a war with the U. S.

113. Apr. 16, I8Io-Dec. 26, I8I6. (235 pp.) Letters to William Claus form the greater part of this volume. The principal writers are Askin, J. Johnson, William Halton (London), and Coffin. There is also a good deal of miscellaneous correspondence, such as copies of letters of Prevost, Bathurst, Askin to Cameron and McDouall, etc.

Perhaps the most important document is an account by William Claus of operations of the Indian contingent with the British forces on the Niagara frontier. This covers I 7 pp., is composed of two letters, Oct. I3, I8I2, and Oct. 24, I8I4, and starts at Oct. I3, I8I2. 
Askin's letters from various western posts are valuable for Michigan. Those of John Johnson, Prevost, Bathurst, and Halton cover a wider range of politics, and some of them show the Indian question as a vexing problem in the treaty of peace.

Among miscellaneous documents is an account of a meeting of several Canadian and a few U. S. tribes at Niagara. Aug. 3I and Sept. I, 1815 .

114. Jan. 20, I8I7-Oct. II, I8I9. (275 pp.) At least half of this number is composed of minutes of councils with the Grand River Indians (Upper Canada) respecting land grants. These have only incidental references to U. S. history. The rest of the volume-a small amount of miscellaneous material excepted-is a continuation of the Claus papers. The Detroit Gazette for Feb. 19, 1819, is also present. A few letters from Askin and Sir John Johnson refer to American affairs, but in general this number contains much less material relating to the U. S. than the preceding volumes of Indian papers.

115. Jan. 24, I824-Sept. 6, 1826 . (315 pp.) Claus papers, minutes of Indian councils, and miscellaneous correspondence are combined in this number. Nearly everything has reference to Canadian Indians, and very little relates to American history.

116. This volume is largely composed of correspondence of Murray, I759I765: Carleton, I784-I700; and Hincks, I84I-I870. There are also many legal and commercial documents of a miscellaneous nature.

A few letters during Carleton's régime touch upon American affairs, and one letter of several Boston citizens to Sec. Marcy relates to expenses of the treaty of 1854 .

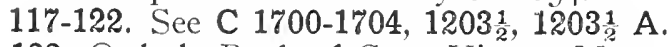

123. Orderly Book of Capt. Viger. Mar. 28-July 27, I8r3. Found among the archives of St. Mary's College, Montreal, and presented to the Dominion Archives in 1890.

Among miscellaneous papers in this volume are copies of documents respecting a plan for capturing Prince Villiam Henry during his stay at New York in 1782 , from the Atheneum, 1830.

Copies of Burgoyne's despatch to Germain, Oct. 20, 1777.

Minutes of councils of war, Oct. I2 and I3, I777.

Preliminary proposals, articles of capitulation, and report of killed, wounded, and prisoners of the British troops under Burgoyne to Oct. I 2, I 777 .

(Nearly all of these last are printed in the Statc of the Expedition.)

124. "List of Loyalists drawing Lands in St. John, N. B. I783-I784." ( 18 pp.)

In the same volume are several clippings of St. John newspapers, I883I89I, respecting the Loyalists.

125. See C $1203_{2}^{1}$ AA.

126. "Coquart's memorial on the state of the Posts within the King's Domain in New France." I750. Addressed to Bigot. (Original.)

127. Indian prayers. (In French and Indian.)

128. Documents copied in Rome. Almost entirely upon Canadian ecclesiastical matters. (In Italian, Latin, and French.)

129. "Correspondance du Marquis de Montcalm conservée par son arrière petit-fils Le Marquis Victor de Montcalm." Feb. 22, 1756-Mar. I9, I759. ( 156 pp.) Copies of letters from Montcalm to members of his family. They include the entire course of Montcalm's share in the 
Seven Years' War. Of especial interest to Americans are his accounts of the events at Lake St. Sacrement and at Carillon.

Other copies in this volume are letters from Bougainville to members of MLontcalm's family, July 25, I758-Dec. 3, I760: two accounts of the expedition against and capture of Fort William Henry; a narration of the victory at Carillon, July 8, $175^{8}$; and a list of French officers killed or wounded. (All of the documents are in French.)

130. "Lalemant-Récit véritable du martyre", etc.

131. "Navire Héros.-Remarques particulières des côtes et rivières du Canada."

132. "Memoirs of the Siege of Quebec and total Reduction of Canada in I759 and I 760 , by John Johnson Clerk and Quarter mas'r Sergeant to the 58th Reg't." (Probably a duplicate of the original. See Can. Arch. Rept., I888, p. viii.)

133. "Commerce de l'Amérique françoise. I77I. Extrait du dictionnaire de commerce."

134. "Mémoires de Nicolas-Gaspard Boisseau fils, notaire, né à l'Ile d'Orléans en I $655 . "$ Extends to I789. (Is not greatly concerned with political events, but interesting as coming from an observer of happenings at Quebec. $360 \mathrm{pp}$.

135. Journal of Capt. Enys-29th Regiment. I 787 . Description of Niagara Falls.

136. “Notes Prises à Terrebonne par F. H. Seguin." I83I-I833.

136 A. "Lieut. James Moody's Narrative." I783. (Printed in London by Richardson, 1783 , second edition. Copied.)

137-138. Papers relating to William Berczy's Markham settlement in Ontario. I79I-I83I.

139-146. See C 1705-1712.

147. May, I8I2-Jan., I816. This large volume contains letters from Andrew W. Cochran, assistant secretary to the governor general, to different members of his family. Written from Quebec and Montreal, they retail news of the war received at those places. The first communication gives a lively account of Boston society.

148. John Neilson Papers. 2 vols. I794-I845, I804-I843. Largely fiscal and constitutional. A brief examination failed to reveal anything relating to the U.S.

149-152 C. Correspondence and other papers of Capt. Andrew Bulger. For American history only those portions are important which cover the years I8I3-1816. During the greater part of this period Capt. Bulger commanded the British forces on the Upper Mississippi. The collection was obtained by the Archives about I888 from A. E. Bulger of Montreal.

149. Dec., I8Io-Mar., I8ı6. (6\%о pp.) Few of the documents are dated before I8I3.

For Americans the material in this volume is very important, giving as it does detailed information of Capt. Bulger's command at Fort McKay (Prairie du Chien) from the latter part of I8I4 until the restoration of the posts. There are numerous letters from Col. McDouall at Michilimackinac, which give detailed instructions and comments.

Material on the Indians-including the character and conduct of Robert Dickson, agent and superintendent of western Indians-is abundant. Not only is this true for the region in the vicinity of Prairie du Chien 
but for the western country, particularly that portion of it extending from Capt. Bulger's post to Michilimackinac. As examples may be cited the numerous minutes of Indian councils, as well as important documents on $\mathrm{U}$. S. charges that the tribes were incited against them by the British after news of the treaty of peace had arrived.

In addition to the above there are several miscellaneous documents on the war. Among these are Maj. Macdonnell's account of a successful expedition against the Americans at Ogdensburg, Feb. 23, I8I3, and Capt. Bulger's narration of the capture of the U. S. schooners Scorpion and Tigress.

There is also correspondence with U. S. officials, the promulgation of the treaty to the Indians and delivery of the posts.

Many of the documents in this volume are copies, and in numerous cases the originals are followed by copies. (Indexed.)

$152 \mathrm{~A}$. The only American items in this book are Capt. Bulger's own relation of his services in the War of 1812 , and various testimonials respecting the same.

152 C. A few documents of Capt. Bulger's régime at Fort McKay are in this number. They seem to be copies of some in M 149.

153. Reports and other documents on certain Canadian canals. I827-I843. No American material.

154. Elliott Letters. I835-1836. Minute of Council. Apr. 30, I836. Dr. Rolph Letters. I837-1854. No American items.

154 A. "Rolph's Letters, etc." I834- I885. Contains a few documents on the actions of Rolph, Mackenzie, etc., in the U.S.

154 B. "Rolph's Letters." Largely medical notes.

155. Correspondence of Miles Macdonell is the principal item in this miscellaneous volume. A few documents are of American interest, such as a roll of the first battalion of the Royal Regiment of New York; an undated, unsigned paper on Highland settlements in America; the capitulation of the U. S. force at Fort Michilimackinac, July I7, I8I2 ; and a few letters from John Macdonell upon the war, written about this time from Fort William.

156. "Quelques notes sur les événements politiques de I 837 en Canada."

157-167. Bagot Papers. These ten volumes comprise Sir Charles Bagot's official papers and many private letters during the periods when he was British minister at Washington, and governor general of Canada. Most of the Canadian despatches are the same as in G. The collection was obtained about I89 I from Captain Bagot, grandson of Sir Charles Bagot. It was also copied at the Archives, so that every volume, whether a letter-book or composed of original letters, has a copy beside it. (Indexed.)

15\%. This letter-book is divided into two parts. The first (I37 pp.) covers the period Mar. 2I, I8I6-Apr. I4, I8I9, and consists of letters from Charles Bagot as British minister at Washington to governors and lieutenant-governors in Br. N. America and the British West Indian possessions and to English naval commanders in those waters. Besides the usual intelligence of U. S. legislation upon all matters affecting British interests in N. America, and various complaints respecting arbitrary action by customs collectors, etc., of either nation, the chief topics in this part may be arranged in the following order:

Agreement with the U.S. respecting the naval forces to be kept on the Lakes. 
Fishery negotiations and regulations.

Surrender to the U. S. of islands in Passamaquoddy Bay.

The commercial convention with the U. S., signed at London, Oct. 20, I8I8. With this may be grouped despatches on commercial relations, and those dealing especially with the plaster of Paris trade.

American privateers sailing under S. American flags, and the change by Congress in the neutrality law.

Claims of British subjects to land in West Florida and Mississippi.

American prisoners yet held by Indians.

Hostile disposition of Canadian Indians against the U.S.

Claims of citizens of the U. S. to estates in Moose Island.

Desertion of British soldiers and their subsequent enlistment in the U. S. army.

Disposal of colored persons lately detained in the U. S., and a proposal with relation to a settlement in the Bahamas of free blacks from the U. S.

The second part consists of copies of letters from Bagot's correspondents either in answer to his despatches, or forwarding intelligence to which he replied in due course. There are $236 \mathrm{pp}$., and the extreme dates are Aug. I, I8I6, and Feb. Io, I8rg. The range of subjects is practically the same as in the first part.

158. Sept. 7, I838-Dec. 8, I842. (764 pp.) This volume contains origina! letters to Sir Charles Bagot from various persons. They are of a somewhat miscellaneous nature. For Americans the most important will be the private (and usually lengthy) communications from Lord Ashburton during the progress of the treaty of I842. They comment freely upon the various difficulties and the political situation, forming a valuable series.

Next in importance comes a parallel set of letters from the British consul at Boston. These also deal with the boundary question and U. S. politics at large. Special attention is paid to the northern situation, and at times diversions made in such directions as the MassachusettsRhode Island boundary dispute. A few enclosures are upon legislative actions in some of the northern states.

Besides the above a letter from the president of the Welland Canal Co. touches upon the diversion of western trade by the opening of the Erie Canal, and a lengthy communication from John Neilson at Philadelphia takes up the American political situation from several points of view.

159. Miscellaneous letters to Sir Charles Bagot. Jan. 4, I84I-Apr. 7, I 843. (57 pp.)

The first item in this volume of original letters is a note from Jacob Harvey, at New York, enclosing a printed address of the Home League to the people of the U. S., which pamphlet Harvey styles a high tariff manifesto. The address is signed by Joseph Blunt, C. C. Haven, John Travers, W. B. Kinney, and James Tallmadge.

Within a few pages are letters from T. A. Pulby, M. S. Bartlett, and Lord Seaton, which take up the situation in the U. S. with regard to Canada from different points of view. The first two speak of danger of invasion by Irish "Repealers" in the U. S., their fusion with Hunters' Lodges, etc. Lord Seaton's communication treats American politics in a broader way, noting the influence of Canadian troubles upon elections in the frontier states, the attitude of southern statesmen toward annexation, etc. 
These are the chief American items in this volume, but a few miscellaneous communications relate to the Northeast Boundary, frontier disturbances, a clause proposed by Webster on extradition arrangements, the release and escape of Hogan, and the cases of the Caledonia and the Crcolc. None of these are later than May, I842.

160. Letter-book of private letters from Sir Charles Bagot. Dec. 30, I84IJuly Io, I842. (337 pp.) Besides the initial letters in this volume, which give an account of Bagot's reception at New York, the only American items are about a half-dozen communications to Lord Ashburton, concerning treaty negotiations. In one of these Bagot gives his own views of the $U$. S. and its Constitution.

161. Continuation of no. 160 to Mar. 29, I843. (329 pp.) A few letters on the Ashburton treaty.

162-164. Letter-books of despatches from Sir Charles Bagot and Sir Richard Jackson to the Colonial Office. I84I-I843. (Already treated in G.)

165. Private despatches from Lord Stanley to Sir Charles Bagot. I84II843. No American items.

166. Applications and nominations for office. I842.

167. Letter-book of despatches from Sir Charles Bagot and Sir Richard Jackson to the Colonial Office. I84I-1842. (Already treated in G.)

168. "Through the Ranks for a commission fifty three years ago." I 88I. "Bush life, and Frontier Service." 1837. "A Reminiscence of the visit of the Prince of Wales to Canada in $1860 . "$

169. Copied extracts from several printed books of travels in Canada and the U.S.

170. "Observations on Clergy Reserves." I827.

171. Papers relating to the Sheubenacadie Canal (N. S.). 1826-I89o.

172. "Marriage Certificates." I848-1856.

173. "Immigration and Miscellaneous MSS." I792-1863.

174-176. See C $1203 \frac{1}{2}$ B-C $1203_{2}^{1}$ D.

17\%. In this small volume of documents relating to Prince Edward Island is the copy of a list of Loyalists who settled there in 1787 , and the number of acres granted to each.

178. "Remarques sur l'histoire du Canada," etc. Touches upon the American Revolution.

179. Memoir and other documents on New France. Memoir dated I7I8 and contains many observations upon Detroit. (5 I ff. French.)

180. In this miscellaneous volume is a letter from J. Brown to Commodore Sinclair, Fort Erie, Sept. 9, I8I4, on certain military projects.

181. Canadian Pacific Railroad explorations. I874-1876.

182. "Notes on the Population of the Dominion of Canada." I88I.

183. "Ottawa Fifty Years Ago." I 888.

184. "Montreal Shipping." I8I2-I824.

185. List of U. E. Loyalists in Upper Canada. Copied in 1875 from the original in the Crown Lands Department of Ontario. (78 pp.)

186. Documents relating to various exhibitions. I85I-I867.

187. "History of the County of Lanark."

188. Papers relating to Three Rivers, etc. 1827-1834.

189. "Précis des Actes de Foy et Hommage."

190. Hudson's Bay Co. Journals. I 754-1 755 , I $772-1773$.

191-192. Red River Journal. Nov. 16, 1769-Feb. I3, 1870. (I85 and 147 pp.) Some entries touch upon the actions of U. S. officials at Pembina, etc., and the possibility of annexation of the settlement to the U. S. (Copies.) 
193. Journal of Pierre Esprit Radisson. I682-I684. (Copied from the original in the Hudson's Bay House, London. Printed with English translation in the Can. Arch. Rept., I895. English translation also printed by the Prince Society in I885.)

194-195 I. See C $1203 \frac{1}{2}$ E-C $1203 \frac{1}{2}$ P.

196. Sable Island. I8or.

197. Report on Newfoundland. I827.

198. "Abrégé de l'histoire universelle."

199. Register of the Church of England at Quebec. I768- I786. $199 \mathrm{~A}$ extends this record to I80o.

200. "Registres"-Fort Frederic or Beauharnois, I 732-1760; Chateauguay, I75I-I762; Fort Duquesne, I753-I756; Fort St. John, I757-I760. (French. Copies.)

201. Papers of John McLeod, chief trader of the Hudson's Bay Co. I8I II837. Some of the letters to McLeod from I828 to I837, written at western posts, deal with the company's affairs on the Columbia River and the Pacific coast.

202. Callers at the office of the Canadian High Commissioner. London, I874-189I.

203-228. These volumes form a sub-series of correspondence between the British commander-in-chief in N. America and the Secretary of State for the Southern Department (American Department from I768) from I757 to I77I. They were copied from the former America and West Indies series at the Public Record Office, London. The originals are now nearly all classified there under $C . O .5$. They may be conveniently divided into three parts. The first is somewhat miscellaneous, and includes despatches from several officers. The second comprises Amherst's régime, which apart from its distinctive military characteristics is noticeable from a documentary point of view by its short despatches and numerous enclosures. With the entrance of Gage upon the scene communications become more numerous, with fewer accompanying documents, and the volumes have a sub-title of "Military Correspondence". It will be easily seen, even from the general summaries given below, that the series is an extremely valuable one for American history. It is supplied with numerous maps. These have been taken out, however, and are now in the map-room at the Archives. A slip giving the title and reference to present location is in the place of each map in the volumes. (Not indexed.)

203. "Secret and Miscellaneous Papers." May 7, 1756-Apr. 4, r76r. (I09 ff.) The first item in this volume is a letter from Fox to the Earl of Loudoun, with about twenty enclosures. These mainly concern intercepted letters from America to the Duke de Mirepoix on plans in the middle colonies to aid the French. The most important of these enclosures are between Fox. Halifax, Loudoun, Webb, and Hardy, governor of New York. This secret despatch and the documents with it cover $68 \mathrm{ff}$. See Annual Report of the American Historical Association for 1897 .

Besides the above there are miscellaneous papers, such as correspondence on colonial mails, Brig. Waldo's plan for taking Louisburg, scheme for a fund from duties, drawbacks, etc., in N. America to be applied to certain purposes beneficial to those colonies. memorandum relating to America, etc. (A. W. I. 8I, now C. O. 5: 52.)

204-1. Mar. I8, I755-Feb. 24, I756. (298 ff.) Despatches to the colonial secretary from Braddock and Shirley upon their expeditions and 
various matters connected with them. Among enclosures are Washington's account of Braddock's defeat, Shirley's correspondence with Tohnson and with some of the colonial governors, minutes of council of war, and letters of minor officers. (A. W. I. 82, pt. I, now in C. O. 5: 46.)

204-2. MIar. 8-Dec. 30, I756. (589 ff.) Communications to the colonial secretary from Shirley, Boscawen, Holburne, Pepperrell, and a few minor officers. The first despatch from Shirley deals with disputes in New York, New Jersey, Pennsylvania, and Maryland between recruiting officers and masters of indentured servants who had enlisted in the British service. The greater part of the material relates to details of military projects during this period, especially those connected with Oswego and Louisburg. Some of the enclosures date back to I754. Frontier defense and the attitude of colonial legislatures are treated at length. Letters of Shirley, Loudoun, William Johnson, various governors, and military officers at northern posts form the most important enclosures. (A. W. I. 82, pt. 2, now in C. O. $5: 46$.

205-1. Mar. 30-Oct. 3, I756. (273 ff.) Despatches to the colonial secretary from $\backslash$ Vebb, Abercrombie, and Loudoun. Those of the last named are the most numerous and important. Enclosures are abundant, and consist chiefly of instructions and colonial correspondence of Loudoun and Shirley, legislative resolutions, plans, miscellaneous letters of Johnson, etc. Material in this volume relates principally to Oswego, and the Crown Point expedition. The frontier, Indians, and aid given by the colonies are also topics of importance. (A. W. I. 83, pt. I, now in C. O. $5: 47$.

205-2. Oct., I 756 . (525 ff.) This volume contains Loudoun's despatches to Fox of Oct. 8, I I, and 12, 1756, and enclosures in that of Oct. 3 in the preceding volume. These last fill 489 folios and relate chiefly to the fall of Oswego and the general situation in the north from Albany to the frontier. Most of these are letters to and from Shirley, Loudoun, and various officers. Correspondence between these two is interesting. There are also miscellaneous papers, such as information gained from different quarters, a description of the condition of Fort IVilliam Henry, letters of Johnson on Indian matters, etc. (A. W. I. 83. pt. 2, now in C. O. $5: 47$.)

206. July I6, I755-Dec. I I, I757. ( I 44 ff.) "Sir Edward Hawke and Sir John Mordaunt's Expeditions against France." Instructions and correspondence, none of which relate-except indirectly-to America. (A. W. I. S4, now S. P. Dom. Naral 100.)

20\%-1. Nov. 22, I 756-May 3, I 757. (276 ff.) A continuation of Loudoun's despatches to the colonial secretary with the addition of a few from Gen. Hopson. As usual, Loudoun's communications have numerous enclosures. This material principally relates to stationing of troops for the winter, billeting. military information, the French attack upon Fort TVilliam Henry, the Indians, plans and mobilization in the spring, with numerous remarks upon the colonial attitude, aid given, etc. As examples may be cited Loudoun's comments upon the hindrances to enlistment in New Jersey, and the practice of "plugging" gold coins. (A. IV. I. 85 , pt. I, now in C.O. $5: 48$.)

207-2. May 30-Dec. 7, I757. (53I ff.) Despatches from Loudoun are continued in this rolume to Oct. I7, I757, and there are also several 
from Adm. Holburne. For Americans the main features of this material are the detailed accounts of the situation in the different colonies with respect to the war, intelligence received and reports of military movements. Among enclosures are several documents from New Orleans (including Kerlerec's propositions for a treaty between the French and the Cherokees), correspondence of Loudoun and the colonial governors, letters of Johnson, Webb, etc. One from the latter gives an account of the massacre at Fort William Henry. (A. W. I. 85, pt. 2 , now in $C . O .5: 48$.)

208. Feb. I4-May 3I, I758. (243 ff.) In this volume are two despatches from Loudoun to Pitt, the first of Feb. I4, I758, with numerous enclosures, and the second dated May $3 \mathrm{I}$ of the same year. This material takes up all of the recent military events in the American colonies, as well as actions of the assemblies, information received, etc. Nearly all enclosures in the first despatch are made up of Loudoun's correspondence with Governors Sharpe and Pownall, and Col. Stanwix. (A. W. I. 86 , now C. O. $5: 49$.)

209-1. Mar. I6-July I2, I758. (25I ff.) In this volume are despatches from Abercrombie to Pitt for the period embraced by the above dates. They show the preparations for the campaign of 1758 both by British officers and by the colonies themselves, and carry this campaign up to the defeat of Abercrombie near Ticonderoga.

There are returns of the British regular and provincial troops at Lake George on June 29, and of those killed and wounded near Ticonderoga, July 8. The distribution of British troops in N. America is also given. Besides these a despatch of May 24 is almost wholly upon Indian affairs, and has 25 enclosures, altogether forming about a third of the volume. (A. W. I. 87, pt. I, now in C. O. $5: 50$.)

209-2. May I, I758-Jan. 2I, 1759. (236 ff.) This volume contains despatches to Pitt from Abercrombie, Aug. 19-Dec. I7, I758, and Forbes, May I, I758-Jan. 21, I759. Those of the former have numerous enclosures. This material relates to Abercrombie's inaction during this period, the various skirmishes, the expeditions of Bradstreet and Forbes, and correspondence with Vaudreuil and Montcalm respecting the capitulation and treatment of prisoners at Fort William Henry. Among returns are those of the provincial forces which arrived at Albany, June 7-June 20, I758, and of Bradstreet's command. (A. W. I. 87 , pt. 2 , now in $C . O .5: 50$.)

210. Jan. 9-Dec. II, I759. (I53 ff.) Despatches to Pitt from Adm. Saunders, Gen. Wolfe, Brigs. Monckton and Murray, and Gov. Whitmore upon the expedition against Quebec. (A. W. I. 88, now C. O. $5: 51$.)

211-1. Dec. I8, I758-Mar. 29, I759. (275 ff.) In this number there begins a series of despatches from Amherst to the colonial secretary. Enclosures are very numerous, and consist mainly of Amherst's correspondence with the colonial governors. Taken as a whole the volume relates to detailed preparations for the campaign of I759, Amherst's pains to secure the co-operation of the colonies, the results of such a policy, skirmishes, scouts, and Indian matters. (A. W. I. 89, pt. I, now in $C . O .5: 54$.)

211-2. Mar. 29-Apr. I6, I759. (Ff. 276-549.) This volume is composed of Amherst's despatch of Apr. I6, I759, with 33 enclosures, and the remainder of the 75 enclosures in the despatch of Mar. 29. The material is of the same general character as in the preceding volume. (A. W. I. 89, pt. 2, now in C. O. $5: 54$. ) 
212. Amherst's despatch of June 9, I759, with its IO3 enclosures, fills the 282 ff. of this volume. These documents show the progress of the movements against Niagara and Ticonderoga and relations with the colonial legislatures and their governors. Amherst's correspondence with the latter and with his own officers forms the bulk of the enclosures. (A. W. I. 9o, now C. O. $5: 55$.)

213-1-2. July 27-Oct. 22, I759. (507 ff.) These two numbers contain three despatches from Amherst, dated July 27, Aug. 5, and Oct. 22, I759, which, with numerous accompanying documents, narrate at length the success of the expeditions against Niagara and Ticonderoga. Many of the 103 enclosures in the last despatch are in no. 213-2. Amherst's correspondence with his officers, governors, and lieutenant-governors, his journals, and documents on loans from New York and Pennsylvania are the chief features of the enclosures. (A. W. I. 9I, now C. O. 5:56.)

214-1. Oct. 22, 1759-Jan. 9, I760. (313 ff.) Two despatches of Amherst, dated Dec. 16, I759, and Jan. 9, I760, together with the 57 enclosures of the first and 42 of the second, fill this volume. These documents not only carry on the record of events from Oct. 22, I759, as regards the disposition of troops, minor military occurrences of the period, and intelligence received, but also continue the tangled course of the colonies themselves toward the war. Although most of this material is upon the situation at the north several letters are concerned with Cherokee outrages and measures taken in consequence of this outbreak. (A. W. I. 92, pt. 1 , now in C.O. $5: 57$.)

214-2. Feb. I7-Mar. 8, I760. (Ff. 314-649.) This volume contains two despatches from Amherst, dated Feb. I7 and Mar. 8, I760. The first has 3 I enclosures and the second 62 . The material is of the same general nature as that in the preceding volume. Military details are somewhat less prominent than the actions of colonial legislatures. The despatch of Feb. I 7 is placed after that of Mar. S. (A. W. I. 92, pt. 2, now in $C .0 .5: 5 \%$.)

215-1. Apr. 28-May 19, I760. (305 ff.) The contents of this number are Amherst's despatches of Apr. 28 ( 76 enclosures) and May i9, I760 (40 enclosures). For American history the chief features of this material are the actions of colonial legislatures and Indian affairs. (A. W. I. 93, pt. I, now in C. O. $5: 58$.)

215-2. June $2 \mathrm{I}-\mathrm{Sept} .8$, i 760 . (Ff. 306-603.) In this volume are three despatches from Amlherst, dated June $2 \mathrm{I}$ ( 74 enclosures), Aug. 26, and Sept. 8, and one from Lord Colville, of Sept. 12, I760. These documents bring the story of the land campainn of i 760 against Canada to the surrender of Montreal. (A. W. I. 93, pt. 2, now in C. O. 5: 58.)

216. Aug. 26-Nov. 7, г 760 (448 ff.) Amherst's despatches of Oct. 4, i8, and Nov. 7, with accompanying documents, and the enclosures to the despatch of Aug. 26 in the previous volume. American material is chiefly upon the capture of the western posts, colonial legislative action with regard to the war, disposition of troops, and a slight amount of military news from the southern colonies. (A. IV. I. 94, now $C . O .5: 59$.)

217. Dec. 8, r760-Apr. 6, г76r. (469 ff.) This volume contains Amherst's despatches of Dec. 8, I760, Jan. 7, I76I (60 enclosures), Jan. I8 ( I I enclosures), and Apr. 6 ( 48 enclosures). American material is chiefly upon the stationing and movements of troops, troubles with the Chero- 
kees in South Carolina, and the attitude of the colonial governors and assemblies toward Pitt's orders with regard to raising troops, etc. (A. W. I. 95, now C. O. $5: 60$.)

218-1. Feb. 27-Aug. I3, I76r. (404 ff.) Amherst's despatches of May 4, Feb. 27, May 15, and Aug. 13, all of 176 I. They are in the above order. The first has 70 enclosures, the second 27 , and the third I8. Levies raised by the colonies, continued troubles with the Cherokees, the building of forts, western posts, and trade, and the movements of troops are the principal American subjects. (A. W. I. 96, pt. r, now in C. O. $5: 61$.)

218-2. Aug. 13-Nov. 27, r76r. (Ff. 407-799.) In this volume are the 58 enclosures to Aniherst's despatch of Aug. 13, I76r, and his further communications to Pitt of Oct. 25 (2I enclosures), Oct. 2I (6 enclosures), and Nov. 27 (2I enclosures). American topics are the raising of colonial levies, Indian matters in various localities, and the movements of troops. (A. W. I. 96, pt. 2, now in C. O. $5: 61$.)

219-1. May I2-July 20, i 762 . (324 ff.) In this volume are Amherst's despatches of May I2 (4I enclosures), June $\mathrm{I}_{5}$ (24 enclosures), and July 20,1762 (24 enclosures). Actions taken in the various colonies for the levy of troops, Indian affairs, returns-some of them from the west - the movements of troops, and illicit trade with the French are the chief American topics. (A. W. I. 97, pt. I, now in C. O. $5: 62$.)

219-2. Aug. I5-Dec. I6, I762. (Ff. 325-652.) Amherst's despatches in this volume are five in number, and have a total of $7 \mathrm{I}$ enclosures. The chief American subjects are colonial quotas and enlistment, Indian matters, Acadians in Massachusetts, and Amherst's suggestions with regard to Crown Point, Niagara, and Detroit. (A. W. I. 97, pt. 2, now in C. O. $5: 62$.

220-1. Jan. 27-Aug. I3, 1763. (347 ff.) This volume contains Amherst's despatches with an average of twelve enclosures each. Of course the beginning of Pontiac's conspiracy is in the forefront, and accompanying documents include numerous letters and extracts from Gladwin, Bouquet, and minor officers, and Indian councils.

Besides material on the Indian outbreak there is a good deal of correspondence on Connecticut claims to lands on the Susquehanna, and on quotas raised by the different colonies. Amherst's suggestions to the government at home are important. An example is his opinion that many difficulties would be removed by placing Pennsylvania, Maryland, Connecticut, and Rhode Island on the same footing as the royal provinces.

Another item is a memorial of George Washington, Adam Stephen, and Andrew Lewis on behalf of themselves and fellow-officers and soldiers of Virginia in 1753 . This request for land was forwarded by the Lords of Trade. (A. W. I. 98, pt. I, now in $C . O .5: 63$.)

220-2. Sept. 3-Oct. 13,1763 . (Ff. 348-672.) This volume brings Amherst's command in America to a close. His despatches to Egremont are of Sept. 3, I7, and Oct. I3, I 763 . They continue the relation of Pontiac's conspiracy, and also give much information regarding Florida, Louisiana, and Indian trade with the south and west. Besides these there is a schedule of papers delivered to Gage, which occupies $29 \mathrm{ff}$.: also memoranda for the latter. (A. W. I. 98, pt. 2, now in C. O. $5: 63$.)

221. July 7 , I759-Oct. 22, I760. (264 ff.) In this volume, whose extreme dates are given above, are despatches to the Colonial Office from Stanwix (Pittsburgh), Lawrence (Halifax), Murray (Quebec), Colville 
(Quebec), Whitmore (Louisburg), and Atkin (Charleston, South (arolina). The greater part of this material relates to Canada and Louisburg. Communications from Stanwix, however, are important for Pittsburgh, while the long despatch from Edmund Atkin, Indian agent, with several enclosures, gives the result of his negotiations with Indians to the westward. (A. W. I. 99, now C. O. $5: 64$.)

222-1. Oct. 22, I 763 -Nov. 9, I 764 . (368 ff.) In this volume are despatches from Gage to Egremont and Halifax, and a few drafts from the latter in reply. Practically all of this material relates to American history, and is very important for the period covered. Indian affairs overshadow all other topics, and are treated in detail from Canada to Florida and the Gulf of Mexico. The progress of the Pontiac War, though given at length, is even less prominent than negotiations with and descriptions of southern Indians, and of the newly acquired regions inhabited by them.

On the side of civil government the record is almost as full. There are more or less detailed accounts of Florida, the Alabama region, Louisiana, and the Illinois country. Material is present upon the possession of Mobile, the Tombigbee, land matters in Florida, relations with the French, and steps to secure the Illinois country. Disputes with the colonies respecting supplies and levies are also prominent. Enclosures are not so numerous as in Amherst's despatches. (A. W. I. I2I, pt. I, now in $C . O .5: 83$.)

222-2. Dec. I3, I764-Nov. 9, I765. (Ff. 369-739.) In this volume are continued Gage's despatches, and drafts from Halifax and Conway in reply. In its importance for American history the material of this number in no way yields to the one preceding it. Chief among Indian affairs are the full accounts given in Gage's communications and their enclosures of Bouquet's expedition against the Shawnees and Delawares, the several Indian councils, the continued negotiations, the treaties, and the numerous outbreaks in this quarter. Akin to this is material respecting the Senecas, and events about Detroit, Michilimackinac, and other western posts.

Of a slightly different nature are documents upon the Illinois tribes, for here the chief interest lay in their attitude toward both French and English, with regard to the occupation of military posts by the latter.

With these items nay be placed attempts to gain the region by way of the Mississippi from below, Croghan's mission, and relations with the French. In West Florida the principal point of interest is furnished by disputes between civil and military officers. There is also material upon Mobile, Louisiana, and southern Indians.

Toward the end of the volume Gage's despatches are mainly devoted to the effects of the Stamp Act in the various colonies. While writing of resolves and riots his conclusion seemed to be that " it's to be feared in general that the Spirit of Democracy is strong amongst them ". (A. W. I. I2I, pt. 2 , now in C. O. $5: 83$.)

223. Dec. $20,1765-D e c .23, \mathrm{I} 766$. (454 ff.) In this volume is Gage's correspondence for the above period with civil and military authorities in England. Probably the subject of greatest prominence is the Illinois country. There is abundant material upon British occupation and the first stages of English rule in that region. Connected with this may be found descriptive matter, information on trade, both legal and illicit, as well as many comments upon the cession of Louisiana. 
Next in point of volume come documents upon disputes between civil and military authorities in West Florida, and further disturbances in America as a result of the Stamp and Mutiny acts. There are numerous enclosures upon both topics. Many of these are extracts from the New York Gazette.

Other subjects of importance are riots at Albany and in Dutchess county, and lands around Detroit. (A. W. I. I22, now C. O. $5: 84$.)

224. Dec. 23, I766-Dec. 19, I767. (365 ff.) This volume continues the correspondence of the preceding number. The largest part of the material relates to Indians and the fur-trade from Florida to Canada, but more particularly along the Mississippi. Much attention is paid to the practice of carrying furs down this river to New Orleans in order to obtain the higher prices there.

There is quite an amount of material upon relations of Indians with the frontier population, especially emigrants from Virginia. A copy of Capt. Harry Gordon's journal of his voyage down the Ohio and Mississippi to New Orleans and thence to Mobile and Pensacola is present. Florida matters occupy a good deal of space. Among these. may be mentioned disturbances of the Creek Indians.

Some of the documents deal with colonial boundary lines, especially those of Pennsylvania and Maryland. Relations with the Spaniards, information of their movements, and suggestions with regard to their acts and policy are scattered throughout the volume. Other topics of prominence are colonial resistance to quartering of troops, the northwest posts, and military administration. (A. W. I. I23, now C. O. $5: 85$.)

225. Jan. 23-Dec. 24, I768. (387 ff.) In this volume is correspondence of Gage, Shelburne, Hillsborough, and Barrington. Events at Boston form the most prominent subject, and fill about one-third of the book. With this exception the material is hard to classify, for it covers practically the whole field of British administration in America, and consists rather of a steady succession of documents upon many interests than of conspicuous masses centring about a few. The following list embraces the most prominent subjects.

Encroachments of the frontier population of Virginia, Pennsylvania, and Maryland upon Indian lands, troubles resulting therefrom, and negotiations with the tribes upon these matters.

Gage's recommendations on the expediency of retaining or abandoning military posts.

Suggestions and plans for the better ruling of the colonies-a large and important class.

Colonial boundaries and territorial claims.

Immigration into Pennsylvania, and the influence of discharged soldiers there.

Spaniards and French beyond the Mississippi, their influence respecting trade, etc.

Movements of troops.

Florida material. (A. W. I. I24, now C. O. $5: 86$.)

226. Jan. 5-Dec. 9, I769. (293 ff.) The correspondence of Gage and Hillsborough in this volume is largely grouped about three topics-Indians, the fur-trade, and colonial agitation. Documents relating to the treaty at Fort Stanwix and its results are numerous, and rumors of Indian war, and the disposition of the various tribes toward English, French, or Spaniards are carefully followed. 
With such items are mingled many observations upon colonial boundary disputes as affected by Sir William Johnson's treaty. Both Gage and Hillsborough discussed the Mississippi trade, which at this time was strongly in faro: of the French. Material is present upon attempts to induce the colonies to pay more attention to these matters and to appoint local superintendents upon Indian affairs.

Several despatches, besides taking up events in the Illinois country, discuss the question whether it would be profitable for the English to hold the region. Under this head are descriptions of the commerce of the Illinois country and settlements, and a list of Spanish and French posts and settlements on the Mississippi from the Missouri to New Orleans, with the numbers of troops and inhabitants in each.

Constitutional agitation in America is followed at length with several enclosures.

These letters also show the close watch kept upon Spaniards and French in America, and scattered information is given respecting the regions where they dwelt. The movements of British troops is a topic of some prominence, especially the withdrawals from West Florida and Nova Scotia. (A.W. I. I25, now C. O. $5: 87$.)

227. Dec. 4, I769-Nov. I2, I770. (423 ff.) Correspondence of Gage and Hillsborough is continued during the above period in this number, which is of the same general nature as the preceding volume. Constitutional agitation, non-importation agreements, tumults, and riots, especially at Boston, are taken up at length. There is also much material upon the Indians, western trade and navigation, the Illinois country, colonial boundaries and land claims, Louisiana and Florida. (A. W. I. I26, now C.O. $5: 88$.)

228. Dec. 5, I770-Dec. 4, I77I. (253 ff.) A large part of this portion of the correspondence of Gage and Hillsborough is devoted to the state of various fortifications, and their improvement. Those most prominent are Castle William at Boston, and Pensacola. Preparations for a rupture with Spain, which is responsible for most of this, also include plans for attacking Spanish possessions in America.

Information upon the Illinois region is continued and includes a description of posts and settlements on the Mississippi. Indian material abounds, and there are discussions concerning interior posts and western trade.

Agitation in the colonies is less prominent than in the two previous volumes, but there is some material upon the trial of Capt. Preston, a bill for a paper currency, refusals to provide for British troops, etc. Some of the despatches relate to Florida and Louisiana. (A. W. I. I27, now C. O. $5: 89$.)

229. Chancery Patents-Governors-I763-I867. These are governors' commissions, copied from the Patent Rolls. Instructions contained therein have been printed in Can. Arch. Rept., I904 and 1905. Boundaries are given in the commissions.

230-233. Instructions to Canadian governors, I763-1867. Copied from the Colonial Office, London. Printed in Can. Arch. Rept., I904 and I905.

234-268. Colonial Office Transmissions. These volumes contain official records which were transmitted to the Colonial Office by Canadian governors, etc., and which were recopied for the Canadian archives. Nos. 234-262 are filled with minutes of the executive councils of Upper and 
Lower Canada on state matters and crown lands. The dates are somewhat mixed, but the records cover most of the period I807-I84I.

The originals of these were obtained from the Privy Council office at Ottawa a few years ago, and are now at the Archives. Copies were also transmitted from time to time to the colonial secretary, and appear in the $Q$ series, where they are briefly calendared.

Vols. 263-268 are labelled Naval Officers' Returns. These are tabulated returns of ships at Quebec for the years I807-I8I3.

269-306. Board of Trade Papers-Minutes of Council. I764-I807. These volumes are copies of copies sent to London from Canada. As in the case of nos. 234-268 the originals are in the Archives. They are the early minutes of the legislative council of Quebec and the minutes of the executive council of Quebec (or Lower Canada) to I808. Copies were from time to time sent to the Colonial Office, and are briefly calendared in the $Q$ series.

307-323. This is a sub-series of military despatches to the British secretaries at war from officers in the English forces in N. America. They cover the period $175^{6-1785}$, and are concerned almost exclusively with military administration. Movements of troops, commissions, discipline, promotions, the medical service, numbers of the military establishment and their reduction or increase, general and local returns of troops and various supplies, and memorials of officers are the principal subjects, and may be called the constant factors. Among this administrative material are sometimes accounts of various engagements. The numerous returns are also valuable.

This material is an important complement to the America and West Indies series (M 203-228), and covers a wider period. The writers represented in each volume vary in number from two to about twentyfive. In the following summaries the general character of each number is indicated, as well as any special features which may be present. These volumes were copied from originals at the Public Record Office, in $W . O$. I, apparently 1-13. Not indexed.

307. June 25 , I758-June 23 , I763. (250 ff.) In this volume are communications from numerous officers of the British army in N. America and from certain governors with a military command. Abercrombie, Wolfe, Bradstreet, Bouquet, Amherst, and the governors Shirley and Ellis are some of the writers. Commissions, promotions, returns, the military chest, the records of various officers, memorials from them, and similar documents of an administrative nature fill most of the volume. Amid this there is some material of a narrative character, such as Webb's account of the capture of Fort William Henry and the massacre, documents on the quartering of troops, and the disputes between Georgia and South Carolina.

308. Jan. I3, I756-July 12, I758. (255 ff.) More than a third of this number is filled with Shirley's despatches and their enclosures, mainly upon his conduct and the Niagara expedition.

In the remainder of the volume are despatches of Loudoun and Abercrombie. Military administration is almost the sole topic. Returns are numerous. One paper in the earlier part of the volume is headed "Claim of the English and French to the possession of Fort Frontenac stated and examined".

309. June 25, I758-Dec. 9, I763. (37 I ff.) Despatches of Amherst, with enclosures of returns, courts-martial, articles of capitulation of Louis- 
burg, etc., and a few despatches from Gage. Military administration is the chief topic. Many returns are of American forces.

310. Jan. 20, I 764 -Apr. I, I 765 . (23I ff.) Despatches of Gage, often enclosing returns and private memorials. Military administration and discipline are the main features. American material principally in returns, estimates, and lists of works to be undertaken. $W .0 .1: 6$.

311. Apr. IO-Dec. 21, I765. (Ff. 232-45I.) In these despatches from Gage, besides the usual administrative material and returns, there are also accounts of, or comments upon, events in the southern provinces, Indian matters in the northwest, the Illinois country, and an attempt to reach it by an expedition from Mobile, quartering of troops, the Stamp and Mutiny acts and their effect at New York. W. O. I :6.

312. Jan. 8-Dec. 2 I, I 766. (294 ff.) In this volume of Gage's despatches apart from documents of military administration there is material upon West Florida, a little regarding events at Boston and New York, and a list of officers in the Indian superintendency under Sir William Johnson. $W$. O. I : 7 .

313. Jan. I5. I767-June I6, I769. (323 ff.) Gage's despatches in this number are devoted almost entirely to administration. There is a certain amount of material on disputes, etc., in West Florida, and a few sidelights upon excitement at Boston and New York, and upon the Illinois region. $W . O . \mathrm{I}: 8$.

314. Oct. 30, 1768-Sept. 2, 177r. (204 ff.) These despatches from Gage are practically all on the management and movement of troops, supplies, returns, and like subjects. $W$. O. I : 9 .

315. Oct. I, I77I-Dec. 25, I774. (Ff. 205-423.) This volume contains despatches of Gage for the above period, and some from Haldimand at New York. The first section is of the usual administrative nature, but the latter part is largely concerned with the growing excitement in New York and Massachusetts, and the destruction of the tea. W. O. г : 9 .

316. May 4, I773-Dec. I3, I775. (228 ff.) This volume contains despatches from numerous British officers in N. America. Memorials, complaints, and administrative matters compose the largest part of this material. Among returns is one of the killed and wounded at Breed's Hill, appended to Gage's account of the battle.

317. Feb. 20, I775-June 9, I 776. (Ff. 229-4Io.) Despatches from various officers in Br. N. America. There are several returns and invoices of supplies. Many of these communications give news of different military events, especially despatches from Carleton, which are important for the history of the invasion of Canada.

318. Aug. 20, I776-Apr. I 4, I 778. (249 ff.) A continuation of the previous volume and containing material of the same nature. The first part is mainly of Canadian letters.

319. Apr. I7, I778-Jan. 30, I782. (Ff. 250-467.) Despatches from numerous officers in Br. N. America, together with a small amount of Germain's correspondence. Besides the administrative matter, movements of troops and provisions, etc., there are many letters and enclosures upon the convention of Saratoga.

320. Aug. 9, I776-Oct. 31, 1780. (327 ff.) In this volume are despatches from Sir William Howe. Aug. 9, I776-Apr. 20, 1778, and from Sir Henry Clinton. June I 5, I $778-O c t .3$ I, I 780 . The documents are almost exclusively administrative in character. IT. O. I : 10. 
321. Jan. 28, I78I-Dec. 21, I782. (294 ff.) Despatches from Clinton and Carleton at New York. Those of the former are from Jan. 28, I78I, to May 4, I782, and those of the latter from June I4 to Dec. 21 , I782. There are also a few miscellaneous letters. Largely documents of military administration. There are some returns, and various lists, one being an exchange of Saratoga prisoners. $W . O$. I $: 12$.

322. Sept. I I, I782-Nov. 22, I783. (298 ff.) Despatches from Carleton at New York. Some of these documents relate to the history of certain regiments in N. America. There are several military and commissariat returns. One section of $37 \mathrm{ff}$. is headed "A short account of the King's American Dragoons, with authentic copies of all the Papers relative to the raising of that Regiment". $W . O$. I : 13 .

323. Jan. 4, I784-Nov. 9, I785. (264 ff.) Despatches of British officers in Canada. A few touch upon the western posts. W. O. r:3.

324-337. War Office papers, copied from bundles at the War Office, London. Some volumes are headed "Field Officers' Letters", the contents of which were written by officers at various posts to the adjutant-general at Quebec, or to his deputy. These are concerned almost wholly with local matters, usually of an administrative nature. Most of the remaining volumes are composed of military returns, of which those relating to the Loyalists are important for American history. A good share of this material may also be found in the Haldimand Papers, series B. (Not indexed.)

324. July 3, I778-Dec. 22, 1783. (257 ff.) Letters of officers of the 8th,

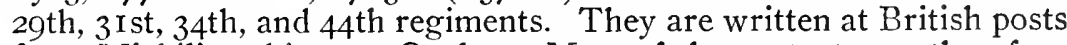
from Michilimackinac to Quebec. Most of the contents are therefore Canadian, with the exception of a certain amount relating to the western country and the frontier.

325. June $24,1777-N o v .18,1783$. (339 ff.) Letters of officers of the 53 rd and 84 th regiments. Some of these were stationed at Ticonderoga, Crown Point, Isle aux Noix, and a few frontier posts. With such exceptions, the documents are almost entirely on Canadian matters.

326. Dec. 3, 1777-Oct. 20, I783. (I66 ff.) The contents of this number relate almost wholly to Loyalists. There are letters from officers of Butler's Rangers and Jessup's Loyal Rangers. The more important and larger part of the volume, however, is composed of returns. These are numerous for the above commands and the several companies of which they were composed.

Besides such muster-rolls there are returns of the command of Maj. James Rogers, one of Royalists and their families at Quebec and Old Lorette, I 778, and the " present state of several detachments of Royalists who returned from Lieut.-Gen. Burgoyne's army to Canada after the convention".

327. June, I775-Aug. 29, I805. (Ff. I67-342.) A continuation of the preceding volume. Besides further letters and returns of Jessup's Loyal Rangers there are also monthly returns of Loyalists at St. Johns, Quebec, dates of their arrival from the colonies, and various remarks. These extend, with a few gaps, from Apr., I782, to May, I783. The remainder of the volume is composed of papers relating to the Royal Highland Emigrants, I775-1782, and recruiting in the Canadian Fencibles Corps, I802-1805.

328. June 19 , I776-Dec. 3 I, I 783 . (227 ff.) This volume begins with muster-rolls of companies of Sir John Johnson's Royal Regiment of New 
York for the periods June I9-Dec. 24, I776, and June 25-Dec. 24, I777. These are followed by letters of field-officers in the above regiment, written at various places in Canada, and ranging from Aug. I7, 1778 , to Dec. IS. I783. There are also a few papers on the reorganization of the second battalion, and the Loyalists who were thereby added to it.

Letters of officers in Rogers's Rangers cover the period June 29, I78IAug. 29, I 783 , and are followed by a list of officers of that body. The final item in the volume is a collection of documents relating to the Canadian barrack-master-general's department, I780-I 783 .

329. $1776-1783$. (228 ff.) About half of this volume is composed of papers of the military engineers' department in Canada, 1777-I 783 . There are numerous returns, the most important for American history being those of posts along the St. Lawrence and the Lakes, which were afterwards turned over to the U. S. These are headed "Garrison States and Returns from the Upper Posts".

Other lists containing American material are a schedule of general courtsmartial, courts of inquiry, letters, memorials, petitions and returns of British and provincial troops, I $776-1783$ inclusive ; a list of the officers of the Loyal Rangers and dates of their appointments; and the general and garrison staffs of the (British) northern army to 1783 . About Ioo ff. are filled with Canadian military hospital returns and letters, $1778-1783$.

330. $1776-1783$. ( $182 \mathrm{ff}$.) This volume is composed of papers of the quartermaster-general's department, I $778-178_{3}$, letters and returns of the ordnance department, I776-1783-both Canadian-and letters from Montreal officers, Mar. 29, 1779-Dec. 28, 1780.

331. Jan. 8, I78I-Nov. II, I783. (Ff. I83-405.) A continuation of fieldofficers' letters begun by those from Montreal in the preceding volume. The posts range from Detroit to Montreal.

332. May, I776-July 3 I, I783. (239 ff.) Letters of officers at Three Rivers, Carleton İsland, Cataraqui, Oswego, and Sorel. American material is chiefly upon rebel prisoners, detection of plots, scouting parties, and Loyalists. There are several returns.

333. Military and Provincial Memorials. I776-1783. Largely on personal matters, such as promotions, etc. Petitions from Royalists (Loyalists) fill ff. 74-142. These are dated 1777 and I 778 .

334. I775-I782. ( 2 I 2 ff.) Nearly all of the material in this volume is American in its bearing. In the first part are documents relating to the Indian Department, I775-I782. These include speeches delivered to the Six Nations, the Delawares, Wyandots, Shawnees, Ottawas ; observations by Paul Desruisseaux about forts Miami and Chartres, Vincennes, Belle Rivière, Kaskaskia, etc., in 1775 ; a return of parties of Indians sent from Detroit against the Americans after July 2, I777; and letters of various officers of the Indian Department, most of which are written from Canadian towns or posts.

Perhaps the most valuable portion of the volume is furnished by the numerous documents relating to Loyalists. These are largely returns of various corps or companies. Especially prominent are those of the Second Battalion of the King's Royal Regiment of New York. Most of them are dated 1777 and $I 778$, although there are a few of 1779 and 1783 . In some cases lists of women and children accompanying some of these corps are present, and also of Loyalists not connected 
with the army. One of these returns is of Loyalists from New York who have taken the oath of allegiance, dated Pt. Clair, Jan. 30, I777.

In general it may be said that this material throws light upon enlistment of Loyalists in New York about the time of Burgoyne's campaign; the relative proportions of English, Germans, and Dutch; reconstructions of such companies; and early Loyalist emigration from New York to Canada. Many of these Loyalist soldiers settled in the border counties of Quebec. Besides the above there are some miscellaneous letters, I778-I 783 . A few of these relate to affairs on the frontier.

335. Dec. 25, I 777-Jan. I, I782. (Ff. 214-328.) This volume is composed entirely of returns of Loyalist corps in Canada, and lists of Loyalists arriving from the colonies. Thus the material is similar in character to returns in the preceding volume. Only one document is previous to Oct., I779.

336. Jan. I, I782-Jan. $2 \mathrm{I}, \mathrm{I} 783$. (Ff. 329-439.) Returns of various troops in Canada. Most of these are of Germans, but there are a few of Loyalist corps. Name, country, age, and time of service are usually given.

337. Jan. I, I783-June I9, I785. Ff. 440-49I of this volume are filled with returns of Canadian troops. The dates run from Jan. I to Apr. 25, I783. Some are important for the Loyalists, such as those of Maj. Rogers's corps and of the Second Battalion of the King's Royal Regiment of New York. The rest of the volume (to f. 560 ) contains miscellaneous correspondence, principally relating to the western posts, Loyalists, and Indian matters. This covers the period June 24, I784June I9, I 785 .

338-369. ISI6-I850. A series of volumes relating wholly to the boundary between Br. N. America and the United States. They have been copied from originals in the Public Record Office, London, mostly from C. O. 6:1-14. "British North America-Boundary Line Papers" is the general title of the series. This material is of the greatest value for the Northeast Boundary question. Documents on the Northwest Bonndary are relatively few in number. It can be easily seen that the originals were badly arranged in several instances. Some of this material may also be found in $\mathrm{G}$ and $\mathrm{Q}$, and the Raymond Collection $(q . v$.$) contains$ originals or attested copies of portions of this sub-series. Vols. 356369 are briefly indexed.

338. Sept. 28, I8I6-Sept. 2, I8I7. ( I94 ff.) Letters from Thomas Barclay (British commissioner under the fourth and fifth articles of the treaty of Ghent) to Henry Goulburn (under-secretary for the colonies) for the period May 8-Sept. 2, I8I7. Also letters from Ward Chipman (British agent under the above articles of this treaty) to Bathurst and Goulburn, Sept. 28, I8I6-July 29, I8I7. Enclosures include claims of the two agents respecting the islands in question, and part of Chipman's argument in support of the British claim under the fourth article of the treaty. The volume also contains a map of the district and county of Gaspé. The above correspondence relates to both the fourth and fifth articles of the treaty.

339. Dec. 7, I8I6-June I2, I8I8. (Ff. I95-392.) Chipman's argument is concluded in this volume, and is followed by the decision of the commissioners under the fourth article of the treaty. The rest of the volume is upon the fifth article of the treaty, and comprises a continuation of Chipman's letters to June 12, r818, as well as two from Joseph Bouchette, surveyor, to Goulburn, dated Dec. 7 and I I, I8I6. 
Among enclosures may be mentioned "Observations upon the Points to be ascertained and determined by the commissioners under the $5^{\text {th }}$ Article of the Treaty of Ghent", and instructions to surveyor Bouchette. This volume also contains the following maps:

Map and chart of bays, harbors, post roads, and settlements in Machias, with the island of Grand Manan. (Compiled from actual survey by B. R. Tones.)

Moses Greenleaf's map of the district of Maine. I I $_{5}$.

Plan of the province of New Brunswick, with a part of Lower Canada, Nova Scotia, and the U. S. (Reduced from the original plan by George Sproule.)

Plan of the Indian territories between the 46 th and 53 rd degrees N. lat. and the goth and IoIst degrees W. long. from Greenwich. (By Bouchette.)

340. At the beginning of this number there are a few letters from Bouchette to Goulburn, June 7-Aug. 12, 18I7. These relate to both the fourth and fifth articles of the treaty of Ghent, and are accompanied by a few sketches and plans. Most of the volume, however, is filled with ten documents filed by the American agent in support of claims under the fourth article of the treaty. (Ff. 393-605.)

341-342. "Memorial of the Agent of His Britannic Majesty in Reply to the Memorial of the Agent of the United States in support of their claim to the Islands in the Bay of Passamaquoddy and Grand Manan in the Bay of Fundy." Sept. 26, I8I7. (Accompanied by three maps. $370 \mathrm{ff}$.

343. Sept. 20, ISI6-June I2, I8I8. (I I4 ff.) Correspondence of the British commissioners, agents, etc., under articles IV., V., VI., VII. of the treaty of Ghent, with the Foreign Office and with various other London offices.

344. I8I9-I82I. (I99 ff.) Material in this volume relates entirely to proceedings under the fifth article of the treaty of Ghent. Ward Chipman's letters to Henry Goulburn cover the period, June 21, I8I9Oct. 4, I82I. Among enclosures are his two memorials to the commissioners, dated 1820 and I82I, "concerning the Northwest Angle of Nova Scotia and the Northwesternmost head of Connecticut River", and his rejoinder to the reply of the U.S. agent to the claim and opening argument of the British agent. Besides two sketches there are three maps, as follows:

Map showing the country explored in I8I7-I820 inclusive by order of the commissioners.

John Mitchell's map of British and French dominions in N. America.

Tiarks's map of Connecticut River and its tributary waters near and to the northward of $45^{\circ} \mathrm{N}$. latitude.

345. I82I-I822. (Ff. 200-407.) Over a third of this volume is filled with the remaining enclosures in Chipman's letter to Goulburn of Oct. 4, I82I. There are also a few letters of Anthony Barclay and Thomas Barclay to various persons, I822, and Foreign Office material, including despatches from Stratford Canning at Washington, I822. Most of these documents are upon the fifth article of the treaty, but a few relate to the sixth. There is a copy of a map published by Arrowsmith in 1795 , with additions to ISO2.

346-347. These volumes contain twelve charts, many of them in several sheets, showing the surveys "carried on in Canada by the British and 
American Commissioners under the sixth and seventh articles of the Treaty of Ghent, shewing the progress of their proceedings from the commencement of their appointment to the close of last Season". They were transmitted to Henry Goulburn from the Foreign Office on Aug. 25, I821. Extracts of the despatches referring to these charts are also present.

348. Jan. I-Apr. I5, I828. ( 194 ff.) Communications from the British Foreign Office to the Colonial Office, sending copies of despatches and their enclosures from the British minister at Washington. These relate chiefly to the Northeast Boundary and disputes between Maine and New Brunswick. There is also a small amount of material upon the Oregon country, and the proposed territory of Huron [Wisconsin]. Newspaper articles, and public documents, both state and federal, figure among the enclosures.

349. Apr. 15-Apr. 29, 1828. (Ff. 195-401.) A continuation of the preceding volume. With the exception of two despatches from Vaughan this number consists of copies of the following:

A pamphlet of five letters on the Northeast Boundary, signed "Verax", published in St. John, N. B.

House Ex. Doc. No. 199, 20 Cong., I sess.

House Ex. Doc. No. 217 , 20 Cong., I sess.

350. The first part of this volume (ff. 402-573) is a continuation of nos. 348-

349. It relates to the Northeast Boundary and to the islands awarded to the U.S. by the commissioners under the fifth article of the treaty of Ghent. Among other documents are a request from Barbour (U.S. minister at London) for certain documents respecting the Northeast Boundary, and a copy of the convention between Great Britain and the U. S. relative to arbitration of disputed points under the fifth article of the treaty of Ghent.

The next section of this volume (ff. 575-620) comprises a letter from Nicholas Garry, of the Hudson's Bay Co., to R. W. Hay, of the Colonial Office, dated May 7,1828 . This communication with its cnclosures contains valuable material upon the Oregon country, its inhabitants, exploration, trade, etc. There are also a few remarks upon the American proposals to establish a territory west of Lake Superior.

In the remainder of the volume are two unimportant letters from Ward Chipman to R. W. Hay, one from D. Douglas to the same, with notes on British possessions on the northwest coast, and a copy of the convention of Aug. 6, 1827, between Great Britain and the U. S.

351. Sept. 29, I827-July I I, I829. About a third of this volume is filled with a printed copy of the first British statement according to the provisions of the convention signed Sept. 29, 1827, between Great Britain and the $\mathrm{U}$. S. More than IOO ff. of the remainder are composed of communications from the British Foreign Office to the Colonial Office, Jan. 2IJuly I I, I829. These transmit copies of despatches from the British minister at Washington with enclosures. The material relates to the Northeast Boundary, the Columbia River region, and the proposed territory of Huron. Documents on Indians and the U. S. fur-trade are included.

Besides the above a few letters from the Council Office and the Chancery, London, and from Ward Chipman relate to papers upon the Northeast Boundary, as do also some letters from Sir Howard Douglas to Sir George Murray, Jan. 5-June 4, I829. 
352. Dec. 3I, I829-Nov. 8, I830. In the first part of this volume are communications to Downing Street from WVilliam Black, N. B., June 23 and Nov. 8, I83o, Ward Chipman, Apr. I, I83o, and E. N. Kendall, June I4-Oct. I5, I830. All of these relate to the Northeast Boundary. Letters from Kendall contain many astronomical data.

After the above a few brief notes from the Foreign Office to the Colonial Office (without enclosures) cover the period Apr. 3-May 25, 1830, and also relate to the same topic.

The final item in the volume is a memoir of A. Stuart, dated Quebec, Dec. 3I, IS29, and entitled " Notes upon the Boundary Line which separates the British Provinces of Lower Canada and N. Brunswick from the United States of America". It comprises ff. 60-I62 and is accompanied by two maps.

353. Sept. 26, I829-Dec. 29, I83I. (3II ff.) In the first $64 \mathrm{ff}$. of this number are two despatches to Goderich by Lieut.-Gov. Campbell, dated May 26 and Oct. I9, I83 I. The second contains an official report of the trial of three persons concerned in an attempt to set up a government in the disputed territory.

Next come communications from the Foreign Office to the Colonial Office (ff. 65-278) covering the period Jan. 7-Dec. 29, I831. Among enclosures are despatches of Palmerston, Bagot (at the Hague), Vaughan, and Bankhead (Washington). This material relates to the award of the King of the Netherlands, protests, etc., resulting from it, and to subsequent troubles in the disputed territory.

The volume ends (ff. 280-3II) with Ward Chipman's report to Aberdeen upon the boundary question, dated Sept. 26, I829.

354. Printed award of the King of the Netherlands, and Lieut. E. N. Kendall's "Report on the Astronomical Observations made for the purpose of examining the Boundary Line between Great Britain and the United States ", with certain tables appended thereto. I 830 .

355. Lieut. Kendall's report is continued in this number, and is followed by other letters from him to the Colonial Office. These extend to Oct. 6, I83I, and have a few enclosures of astronomical data. There is also some miscellaneous correspondence upon expenses and supplies.

356. Jan. I2, I832-Jan. I, I834. Nearly all of this number (ff. I-2 I8) is filled with communications from the Foreign Office to the Colonial Office, Jan. I2, I832-Jan. I, I834. These transmit despatches of Palmerston, Bankhead, Vaughan, and correspondence of the last with the American Secretary of State. A slight amount of this bears upon the Oregon country, but nearly all relates to diplomatic proceedings of the two countries subsequent to the award by the King of the Netherlands, and to disputes in the territory in question. In addition to the above there are a few Treasury documents, and a despatch from Vaughan to Goderich, dated Feb. 2, I833.

35\%. Jan. 29, I834-Dec. IO, IS 35 . (332 ff.) A continuation of the preceding volume. The material relates to negotiations over the Northeast Boundary, and to complaints of alleged encroachments by Maine, Massachusetts, and New Hampshire. Enclosed are despatches of Taughan, Palmerston, and Bankhead; sub-enclosures consist chiefly of letters of governors of the states concerned, communications between Lieut.-Gov. Campbell and Vaughan, and the voluminous correspondence of the last named official with the U. S. Secretary of State. A map accompanies a report of an interview with the President in $\mathbf{I} 835$. 
358. Mar. 24, $1836-N o v, 29,1837$. In the first half of this number is a copy of House Ex. Doc. No. 3I, 25 Cong., I sess. In the second portion (ff. I05-2I4) is correspondence of the Foreign Office and the Colonial Office, Mar. 24, I836-Nov. 29, I837. The principal enclosures are despatches of Palmerston, drafts of his instructions to Fox, despatches of the latter and of Bankhead, with sub-enclosures of their correspondence with the U.S. Secretary of State. All of this material relates to continued negotiations regarding the Northeast Boundary, and to complaints of alleged encroachments and other illegal acts on the part of Maine and New Hampshire.

359. Feb. I I-Aug. 24, I837. (Ff. 2I5-420.) Nearly all of the volume is filled with communications from the Foreign Office to the Colonial Office, Feb. II-June 27, I837. Despatches from the minister at Washington are the chief enclosures. The Canada-New Hampshire boundary and disturbances in the Indian Stream territory are the chief subjects. Some of the material also relates to the Maine-New Brunswick line, including a letter from Capt. Yule to Glenelg, Aug. 24, I837, with a memorandum on the Northeast Boundary.

360. Apr. I9, 1838-Sept. I8, I839. (272 ff.) Letters from the Foreign Office to the Colonial Office. Some contain valuable remarks, and the majority have enclosures. A few documents relate to disputed territory east of Connecticut River, and one to the Oregon country. All the others are concerned with negotiations upon the Northeast Boundary, and proceedings in the disputed region, including the "Restook [Aroostook] war". Among enclosures are despatches of Fox (Washington) and his correspondence with Sec. Forsyth and Lieut.-Gov. Harvey, drafts of Palmerston's despatches, public documents of Maine, and communications from the British consul at Portland.

361. The first part of this volume (ff. 273-333) continues the Foreign Office transmissions of the previous number to Dec. 2, I839. Then come a few letters or memoranda upon the Northeast Boundary, by Sir W. Gordon, Sir Howard Douglas, and Garret Miller.

In the last and largest portion of the volume (ff. 379-54I) begins a series of unpublished "Correspondence Relative to The Boundary between The British Possessions in North America, and The United States". A note states that these papers were prepared for Parliament in I840, but eventually only about eight pages of extracts were presented.

The first item, which fills the rest of this volume, is a copy of a pamphlet compiled under the guidance of Chief Justice Chipman (N. B.), and sent to the Colonial Office by Lieut.-Gov. Harvey, Jan. 2, I839. It is entitled "Remarks upon the Disputed Points of Boundary under the Fifth Article of the Treaty of Ghent, principally compiled from the Statements laid by the Government of Great Britain before the King of the Netherlands as Arbiter".

362. The pamphlet begun in no. 361 is finished in this volume (ff. $542-626$ ). This is followed by further "Correspondence", comprising despatches between Lieut.-Gov. Harvey and Downing Street, Jan. I9Mar. 30, 1839 .

Among enclosures are Harvey's correspondence with the British minister at Washington and with the governor of Maine, public documents of New Brunswick and Maine, and letters between Gen. Scott and the lieutenant-governor of New Brunswick. This part occupies ff. 627754 . 
363. Mar., IS39-Mar. I I, I840. (Ff. 755-IO0I.) A continuation of the preceding volume. As in no. 362 , the documents relate to negotiations respecting the Northeast Boundary, and events in the disputed territory. Besides Harvey's correspondence with Downing Street and its enclosures, written by practically the same officials as in no. 362 , there are also despatches between other persons. The principal participants in these new combinations are the lieutenant-governors Harvey and Campbell (N. S.), Gov.-Gen. Thomson, Sir Richard Jackson, and Lord John Russell.

364. Feb. $7-D e c .24, I 8_{40}$. The largest part of this volume (ff. I-I42) is made up of communications from the Foreign Office to the Colonial Office, Feb. 7-Dec. 24, I840. Some of these letters have important expressions of policy. The principal enclosures are despatches from the British minister at Washington. This material relates both to the Northeast Boundary and to the Oregon question. A few letters from the Hudson's Bay Co., May I8-30, I830, relate to U. S. missionaries and settlers in the Oregon country (ff. I44-I 56).

The last item in the volume (ff. I57-I93) comprises some miscellaneous letters and other documents, dated I840, upon the Northeast Boundary. The principal ones have already been noted elsewhere.

365. Correspondence relating to the boundary between Br. N. America and the U. S. (Printed papers. Presented to Parliament, July, I840.)

366. Jan. I, IS40-Apr. 20, I846. ( 286 ff.) Letters from the Foreign Office to the Colonial Office. The chief enclosures comprise the correspondence of the British minister at Washington with Palmerston, the U. S. Secretary of State, and the Canadian governor general. Negotiations upon the Northeast Boundary occupy the foreground until I842. After that year communications chiefly relate to the "Disputed Territory Fund". There are a few references to Oregon. Ff. 224-286 are filled with a copy of part of House Ex. Doc. No. IIO, 29 Cong., I sess.

367. Mainly a continuation of M 366 to Nov. I9, I847. Foreign Office transmissions are chiefly upon the "Disputed Territory Fund". The last part of the volume is composed of English parliamentary papers of 1845 .

368. Foreign Office letters and transmissions to the Colonial Office, Feb. Io, I848-Oct. 22, I850. (I3I ff.) The principal enclosures are despatches from the British minister at Washington. This material relates to both the Oregon question and the Northeast Boundary. The volume also contains some miscellaneous correspondence, chiefly about maps, and the narrative and report of the commissioners employed to trace and mark the boundary between Br. N. America and the U. S. under the treaty of Washington. These have been printed.

369. Feb. 27-Oct. 23, I828. (343 ff.) Despatches on the Northeast Boundary question from Lieut.-Gov. Douglas (N. B.) to Downing Street. The principal enclosures are public documents of Maine, and Douglas's correspondence with the British minister at Washington. The former fill over half of the volume.

370-382. With one exception these volumes are copied from British Museum MSS. As all the American material has been listed in Andrews and Davenport's Guide to the Manuscript Materials for the History of the United States, to $I 78_{3}$, in the British Museum, etc. (Washington, I908), references have simply been made to this. 
370. "Papers relating to the Case of the Kennebeck River, Maine." I7521762. (Brit. Mus. Add. MSS. 15488. See Andrews and Davenport, Guide, p. 94.)

371. Stirling Peerage, Nova Scotia. (Brit. Mus. Add. MSS. 14034. See Andrews and Davenport, Guide, p. 9o.)

372. "Transactions Betweene England and France Relateing to Hudsons Bay. r687." (Printed in full in Can. Arch. Rept., I883, note C.)

373-374. "A General Description of the Province of Nova Scotia." By Col. Robert Morse, R. E., I784. (Printed in full in Can. Arch. Rept., I884, with the exception of the maps. See also Andrews and Davenport, Guide, p. 27.)

375. "Report on the State of the American Colonies." I72I-I762. (Brit. Mus. King's MSS. 205. See Andrews and Davenport, Guide, p. 26.)

376. "Boundaries of Massachusetts. I720-1754." (Brit. Mus. Add. MSS. 15486 and 1548\%. See Andrews and Davenport, Guide, pp. 92-93.)

377. Miscellaneous papers from the British Museum. I766-I780. (Copies of various papers in Brit. Mus. Add. MSS. 6865, 15491, 24322, and 24323. See Andrews and Davenport, Guide, pp. 76, 98, I II-II2.)

378. "Puisaye Papers. Lettres et Pièces Relatives à la Colonie Française Dans le Canada. I798-i8 1 2." (Brit. Mus. Add. MSS. 8075.)

379. "Captain Vancouver's Original Despatches. I79I-I793." (I7O ff.) The contents of this number are largely copied from vol. 686 of the America and West Indies series (now C. O. 5: 187). The material includes invoices of the stores of the Discovery and the Chatham; letters of Grenville to the Lords of the Admiralty, Feb. I I and 23, I79I, detailing the objects of Vancouver's expedition; the latter's despatches, Mar. 3, I79I-Jan. 7, I793, including his narrative, Aug. 28-Sept. 26, I792 ; and three maps.

380. "Exports and Imports of North America, I768-i769." (Brit. Mus. Add. MSS. 15485.)

381. "Lords of Trade Reports. I698-I7oo." (Brit. Mus. Lansdowne 849. See Andrews and Davenport, Guide, p. Io.)

382. "Papers relating to New Hampshire, Rhode Island, Pennsylvania, Maryland, New York, etc." (Brit. Mus. Add. MSS. 15489. See Andrews and Davenport, Guide, p. 95.)

383-385. "Dartmouth Papers." Copies of documents on Canadian history, from the papers of Lord Dartmouth.

383. I757-I772. Three letters, I757-I759, to which the name of Montcalm is appended, addressed to M. de Berryer and M. Molé, have comments upon the colonial situation.

384. I773-I792. Canadian material.

385. I773-1792. Some documents on the Quebec Act give information respecting boundaries, and show some of the reasons why the western country was included within the limits of Quebec.

385 A-385 B. These are also "Dartmouth Papers", but were copied from originals at the Public Record Office, London. The first volume has papers on Newfoundland, I759-I778, and the second relates to Labrador, $1772-1784$.

386-386 C. "Registres de la paroisse St. Charles des Mines, à la Grand-Prée, dans 1'Acadie, Province de Québec." Baptisms, I707-I748, marriages and burials, I709-I748. (Copies.)

38\%. Meteorological observations at Beauport (Quebec). I844-1859. 
388. "Quebec Grants and Warrants. I763-1768." (Copied from the Colonial Office.)

389-1-389-6. These six rolumes, with the single exception of the last, contain despatches from the British naval officer commanding on the American and West Indian station to the secretary of the Admiralty. No. 389-6 has those of Sir James Yeo to the secretary, and is labelled "Naval Correspondence". A good deal of this material is purely administrative, but accounts of practically every naval engagement are present, as well as information upon such topics as the capture of merchant shipping, blockades, the movements of ships, and diplomatic matters. (The series was copied from Admirals' Despatches in the Admiralty papers deposited at the Public Record Office, London, In-Letters, 502-509. Not indexed.)

389-1. Apr. 7-Oct. 5, i 8I 2. (206 ff.) Despatches of Vice-Adm. Sawyer, Apr. 7-Sept. 20, I812, and of Adm. Warren, Aug. 7-Oct. 5, I8I2. Largely on the movements of vessels, administration, and captures. There is a list of American privateers taken and destroyed by H. M. ships on the Halifax station, July I-Aug. 25, I8I 2.

389-2. Oct. 5-Dec. 28, I8I2. (Ff. 207-388.) Despatches of Warren and Sawyer. A few of these are from Bermuda. One document relates to licenses for vessels to trade between the U. S. and the West Indies, Portugal, and Spain. There is some diplomatic material, including two letters from Monroe to Warren, Oct. 27 and 28 , 1812 ; and a provisional agreement for the exchange of naval prisoners of war, concluded at Halifax, Nov. 28, I8I2. At f. 288 is a descriptive list of I 56 merchant vessels captured by the Americans since June I8, I8I2. This came "from a book kept by the Keeper of the Exchange Coffee House Books at Boston ", and was transmitted in a despatch of Nov. 5 .

389-3. Warren's despatches. Jan. 2-Dec. 2, I8I3. (283 ff.) In this volume is important information on the naval side of the war. Letters by Prevost and Yeo figure among the enclosures. Some of the principal doctments of special interest to Americans are the following:

Account of the fight of the Shannon and the Chesapeake, by the captain of the former, together with a list of his killed and wounded.

Lieut. McCrery's narration of the capture of the Boxcr by the Enterprise, and a list of the lilled and wounded.

Capt. Barclay's account of the battle on Lake Erie, Sept. IO, I8r3, and lists of killed and wounded on board the Detroit, Queen Charlotte, Lady Prevost, Hunter, and Chippawu.

Lists of ships captured by Warren's squadron, Sept. I6, I8I2-Feb. 26, I813, Apr. 20-Sept. 20, I8I3, and of ressels captured by H. M. S. Boxer.

Warren's proclamation directing an additional blockade comprehending the line of coast from New York to the Mississippi.

389-4. Jan. 6-June 25, I8I4. (I86 ff.) Despatches of Rear-Adm. Griffith, with a few from Adm. Warren. Not so important as 389-3, but containing some valuable material nevertheless. Besides papers on administration, notices of captures, etc., there are returns of the British naval forces on lakes Ontario and Champlain, and of British gunboats on these lakes and on the St. Lawrence above Montreal, both dated Jan. 26, I8I. ; a list of ships captured by Warren's squadron, Apr. I, I8I3-Jan. 3I, I8I4; Tice-Adm. Cochrane's order of blockade, Apr. 25,

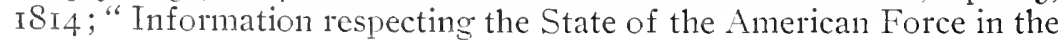


Ports of the United States"; and a return of the killed and wounded of the army in the action with the enemy at Oswego, May 6.

389-5. July 9, I8r4-June I6, I8I5. (294 ff.) Despatches of Rear-Adm. Griffith, and a few from Rear-Adm. Hotham. Among American material may be noted the following items:

Account of the capture of American islands in Passamaquoddy Bay, articles of surrender of Moose Island, etc.

Capt. Newton's report of the state of the inhabitants of Nantucket Island, Aug. 27, I8I4, and other documents upon this topic, including the declaration of a committee of the island.

Several letters respecting British naval operations in Maine.

Information of the "Public and Private Armed Vessels of the United States of America", enclosed in a despatch of Dec. 19, I8I4.

A letter of Monroe to Vice-Adm. Cochrane, Sept. 6, I8I4, protesting against the retaliatory order.

389-6. Mar. 6, I8I 3-Nov. 24, ISI5. (366 ff.) This volume is very important for naval operations on the lakes, containing as it does Sir James Yeo's despatches during this period. Besides dealing with administrative matters these despatches cover every engagement. Among enclosures are letters of Barclay, Prevost, and numerous minor officers. Returns are frequent, giving killed and wounded, and state and numbers of the U. S. and British naval forces on lakes Erie, Ontario, and Champlain. 390. Copy of Sir Charles Metcalfe's commission as governor of New Brunswick, etc.

391. Letters patent of the barony of Longueuil (Quebec), I700, etc.

392-1-392-3. These three volumes are composed of correspondence copied from the papers of Bougainville. They were received from M. de Kerallain, Quimper, France, in I898. Mention is made of them in the Can. Arch. Rept., 1898, p. vi. This material is important for the French side of the Seven Years' War in N. America, although nearly all the letters are written from Canada.

392-1. Mar. 29, I756-Sept. 3, I759. (333 ff.) A large part of this volume is filled with Bougainville's letters to his family. It also contains several of Montcalm, Pellegrin, Vaudreuil, Bigot, Cadet, De Blau, Thisbé de Belcour, and Malartic. This is the most valuable volume of the three for Americans. Besides sundry information regarding the military expeditions there are numerous mentions of the employment of Indians and of their raids.

392-2. Sept. 3, I759-May I3, I760. (320 ff.) Deals with Canadian campaigns. Principally composed of letters to Bougainville by Montcalm, Vaudreuil, Bigot, Lévis, Bourlamaque, Remigny, Bernetz, Montbeillard, De Blau, Townshend, Monckton, Repentigny, Bernier, La Rochebeaucour, and Cadet.

392-3. May I4-Aug. 30, I760. (34I ff.) Letters to Bougainville, then on the Lake Champlain frontier. Most of these are from Vaudreuil, but there are some from Bigot, Lévis, Bourlanaque, Roquemairie, Lusignan, Pouchot, Maron, etc. Frontier matters figure largely in this correspondence.

393. In this miscellaneous volume are the following American items:

Copy of Brig.-Gen. Smyth's proclamation at Buffalo, Nov. 17, I8 2.

Return of men, women, children, and servants in Capt. Robert Wilkin's company of Loyalists on board the ship Apollo. New York, June 8, 1783 . 
Typewritten copy of proceedings of the house of assembly of Vancouver Island. Aus. 2, I859-Mar. 5, 1860. (Has material on relations with the U.S. over the island of San Juan.)

Memoir of the Baldwin family. (Contains a few sidelights on the War of I8I2.)

Typewritten copy of proceedings of the house of assembly of Vancouver Island. Aug. I2, I856-Sept. 27, I858. (A few remarks upon commercial relations with the U. S.)

Sir William Johnson's treaty with the Hurons of Detroit. Niagara, July I8, г764. (Copy.)

A memorandum, Apr. 26, I900, from the Library of Congress, respecting the minutes of proceedings of the Loyalist Commissioners, which are in the Division of Manuscripts.

394-394 B. “Hudson's Bay State Papers.” I673-I759. (Copied from originals at the Public Record Office, London.)

394. Contains a few scattered remarks on New England traders. Covers the period I673-1 690 .

394 A. Ff. I27-I 34. Letter of E. Randolph to the Lords Commissioners of Trade and Plantations respecting his administration of the oath to certain officials in Maryland and Pennsylvania, the situation in the colonies, recent events, etc. New York. Apr. 26, i698.

Ff. I65-I67. Letter of same to same, "abt the Boundaries between the English and French Plantations". New York, May i6, I698.

394 B. Apparently no American material.

395-398. Nova Scotia state papers. These were copied from the Public Record Office and other depositories in London, arranged chronologically, and bound. Narginal notes indicate the location of the originals. These volumes may be divided as follows:

395-395-43. Correspondence. I603-175I. Calendared in Can. Arch. Rept., I894, app., pp. I-I80.

396-1-396-18. Ninutes of the executive council. I $720-1785$.

$397-1-397-29$. Journals of the house of assembly. $1758-1800$.

398-1-398-18. Journals of the legislative council. I758-I800.

Nos. 396-398 are not fully calendared in the Can. Arch. Rept., 1894. An examination of some of the volumes, however, revealed no American items, and a member of the Archives staff who is thoroughly conversant with these records stated that practically all material relating to the U. S. in these Nova Scotia papers is to be found in the Correspondence; nos. 395-395-43.

399. Census of Red River colony. I83I-I 846 .

400. Census of Manitoba. I870.

401. Indian Claims. I8I4-I826. Lists, letters, and affidavits. Largely relate to losses as a result of the War of I8I2. Besides the Moravian Indians, the Ottawas, Chippewas, Mohawks, Tuscaroras, Onondagas, Hurons, Senecas, and Cayugas are the tribes represented. This material has prefixed to it a typewritten "Brief History of the Indian Department [Canadian] from I 755 to date", compiled by the Department of Indian Affairs in I 897.

402. "Various." Contains the following American items:

"Copies of letters addressed to Sir Robert Peel, Lord Stanley, and Mr. Gladstone, in the summer of I840 and forwarded to them by $\mathrm{Mr}$. Gould of London." (Five letters by David Thompson on the survey of the boundary line under the sixth and seventh articles of the treaty of Ghent.) 
Letter of G. Simpson to Gov.-Gen. Metcalfe, with two enclosures, respecting the mission of Warre and Vavasour to the Columbia River, etc. Michipicoten, July 9, 1845. (Copies.)

Letter of W. Macaulay to Maj. Campbell, containing various remarks on the international boundary. Picton, Sept. Io, I847. (Copy.)

A Calm Address to our American Colonies. By John Wesley. 1775. (Manuscript copy of the pamphlet.)

403-403 M. New Brunswick state papers. No. 403 contained maps, which are now in the map room at the Archives. Vols. $403 \mathrm{~A}-403 \mathrm{M}$ are filled with official correspondence of the period 1784-1801. Like M 395-398 these papers were copied from the Public Record Office and other London depositories. They are calendared in an appendix of $62 \mathrm{pp}$. in the Can. Arch. Rept., I895.

404-409. Prince Edward Island state papers. Introductory remarks to Nova Scotia state papers will apply equally well to these. They may be divided as follows:

404-404 F, 405, 406-406 G. Correspondence. I763-I8oI.

407-1-407-9. Minutes of the executive council. I770-1798.

408-1-408-3. Journals of the legislative council. I773-180I.

409-1-409-8. Journals of the house of assembly. 1776-1801.

Correspondence calendared in an appendix of $83 \mathrm{pp}$. to the Can. Arch. Rept., I895.

410-1-410-6, 411-1-411-3, 421 $\frac{1}{2}-433$. Cape Breton state papers. Other volumes of the $\mathbf{M}$ series have been injected into the midst of this set, but it is given here as a whole. Copied in the same manner as the Nova Scotia state papers, etc. There are minutes of the executive council for $1785-$ 1798, and correspondence covering the period I784-1793. The last is calendared in the Can. Arch. Rept., 1895, app., pp. I-48.

412. Finlay Papers. I773-I793. Largely on postal matters. A few touch upon postal communications with the U.S.

413. Orders given by Wolfe. I759. (Copies.)

414. Memoirs of Roderic Mackenzie. 1784-1820. (Also contains stindry letters.)

415-416. See $C 1203_{2}^{1} Q$ and $C 1713$.

417. An account of the Northwest Co., remarks on the American Indians, etc. By Roderic Mackenzie.

418. Letter-book of Samuel Birnie. I785-I794. Letters to different persons on commercial matters written from various points in the U. S., Canada, and the West Indies.

419. Orderly book of the second battalion of the county of Effingham, I822I 829 , etc.

420. R. Mackenzie's note-book. I790-I810.

421. See C $1203 \frac{1}{2} \mathrm{~S}$.

434-473. A continuation of Nova Scotia correspondence in M 395-395-43. Calendared in the Can. Arch. Rept., I894. Covers the period 1752I769.

474-474 A. Copy of the register of Madawaska. Births, marriages, and deaths. I792-1850.

474 B-474 C. Copy of the church register of Ste. Anne de Fredericton. 1806-

475. Copy of the register of marriages in the parish of St. Gabriel de la Louisiane. I773-1859.

476-476 E. "Acadian Documents." I755-1769. Copied from Massachusetts archives. 
477. "Documents concernant la Famille Leborgne. I657 à I705."

478. Manuscript notes on various printed books of travel in America, etc.

479. Old list of Quebec maps.

481. "Copie des Registres de l'État Civil de différents endroits de l'Acadie et de la Gaspésie. I680 à I757."

482-525. A further continuation of Nova Scotia state papers from I770 to I803. Nos. 482-522 inclusive are calendared in the Can. Arch. Rept., I894. The following items relating to the U.S. are in the remaining folders :

524. Lieut.-Gov. Wentworth to Lord Hobart. No. Ioo. Remarks on commerce with the U. S. and smuggling, with a petition from Halifax merchants on the latter topic. Mar. 22, I802. General return of ships and vessels entering at Halifax. July I-Sept. 30 , I802.

525. General return of ships and vessels entering at Halifax. Oct. IDec. 3I, I 802 .

525 a. General return of ships and vessels entering at Halifax. Jan. IJune 30, I 803 .

526-545. A continuation of Cape Breton state papers. Correspondence covers the period I794-I8og. Nos. 526-536 inclusive are calendared in the Can. Arch. Rept., 1895, app., pp. 55-102. The remaining folders contain no American material beyond the general returns of ships entered and cleared at Sydney.

546. Commissions and instructions to lieutenant-governors of Cape Breton. I784-I8r6.

547. Papers relating to the union of Cape Breton with Nova Scotia. I8231838 .

54.8. "Mémoires Historiques sur la colonisation de l'Acadie par Charles d'Aulnay de Menou et son administration." (Copied from the Parkman collection in the archives of the Mass. Hist. Soc.)

549-563. A continuation of New Brunswich state papers. These folders cover the period I8OI-I826. In many cases correspondence of the lieutenant-governor, miscellaneous correspondence, and material relating to public offices are in the same folder. Therefore American items as listed below do not always appear in chronological order. Some of the folders have no pagination, while in others it begins anew for each section; so in only a few cases has the folio number been given.

549. George Leonard, superintendent of trade and fisheries, to Lord Hobart. Remarks on the fisheries and illicit trade with the U. S. St. John, Oct. Io, I8or.

Same to John Sullivan. Suggests expedients to prevent illicit trade between the U. S. and Br. N. America. St. John, Mar. 25, I802.

Same to same. Remarks on American fishermen, and the importation of plaster of Paris into the U. S. St. John, Nov. ro, ISo2. (Letter of Nov. 25 also on illicit trade and the exportation of certain articles to the U. S.)

550. Carleton to Hobart. No. 9. Remarks on the exportation of plaster of Paris and grindstones to certain parts of the U.S. Fredericton, Mar. 23, ISO3. (Two enclosures.)

Same to same. No. Io. Various remarks concerning the Loyalists. Fredericton, May 6, I 803 .

G. G. Ludlow to same. Sends petition of merchants and others of the province respecting the trade of the U. S. and the British West Indies. 
St. John, May i6, I804. (Enclosure follows. Letter on same subject from William Knox to Camden on June 9.)

George Leonard to John Sullivan. Steps taken to prevent illicit trade by Americans. St. John, Dec. I4, I8o3. (One enclosure. F. I43.)

Proclamation by Lieut.-Gov. Carleton, allowing conditional importation of certain articies from the U. S. for six months. Fredericton, June 28, ISO2. (F. 256.)

George Leonard to J. Chapman. Remarks on U. S. contraband trade. St. John, Nov. 30, I804. (Two enclosures.)

551. G. G. Ludlow to Windham. Sends joint legislative address on the claim of Massachusetts to certain islands in Passamaquoddy Bay. Fredericton, Mar. 5, I804. (Enclosure follows.)

George Leonard to Castlereagh. Sends pamphlet on trial of the American sloop Falmouth. Remarks. Feb. 4, I806. (Enclosure follows and relates largely to the right of the U. S. to islands in Passanaquoddy Bay.)

552. George Leonard to Castlereagh. Results of using armed vessels to prevent U. S. contraband trade. St. John, Sept. I2, I8o7. (One enclosure.)

Undated memorial of John Gray to the colonial secretary making certain statements about fixing of the Northeast Boundary in 1798 . (F. 488.)

Draft to Maj.-Gen. Hunter. Sends order in Council, etc., on trade of the U. S. with Nova Scotia and New Brunswick. Downing Street, Nov. 23, I808. (Enclosures missing.)

H. Richmond to George Harrison. Relative to U. S. encroachments. Custom House, Nov. I7, I808. (One enclosure.)

E. G. Lutwyche to Castlereagh. Sends memorial from the New Brunswick legislature. Kensington, Jan. I6, I8og. (Enclosure relates to trade of the U. S. with Br. N. America.)

553. Hunter to Liverpool. Relative to injury of the British colonial trade by that of the U.S. Fredericton, July 2, I8I I.

Same to - Sends clippings from Boston papers. St. John, Dec. 27, I8I r. (Enclosures relate to impressment, etc.)

Maj.-Gen. G. S. Smyth to Liverpool. Effect of the declaration of war upon New Brunswick. St. John, July 4, I8I2.

Draft to Maj.-Gen. Smyth. No. 5. Remarks on relations with the U. S. Downing Street, Sept. 30, I8I2. (No. 6, Oct. 2, is upon the same subject.)

Smyth to Liverpool. Privateers, and letters of marque against the U. S. Fredericton, July 28, I8r2. (Five enclosures.)

Same to same. Annoyance caused by small U. S. privateers. Has purchased a sloop for defense. St. John, Aug. I4, I8I2. (Draft of reply, no. 7 , dated Oct. 3 , follows.)

Same to Bathurst. Disposition of Americans on the borders. Indian neutrality. Fredericton, Aug. 3I, I8I2. (Two enclosures.)

Same to same. Local trade with the U. S. in plaster of Paris and flour. Fredericton, Oct. 31, I8I2. (One enclosure.)

Petition of David Owen to the Prince Regent in Council, respecting certain disputed islands in Passamaquoddy Bay, trade, etc. Campo Bello, June 4, I8I2. (Several enclosures.)

553 a. G. S. Smyth to Bathurst. Sends petition by owners of a privateer. Fredericton, Apr. I5, I8I3. (Enclosure relates to privateering and trade.) 
Thomas Salmarez to same. Admission of salted provisions from the U. S. for six months. Fredericton, Oct. 4, r8I3.

E. G. Lutwyche to same. Observations on the license trade with the Americans. Kensington, June I6, I8I3. (Followed by decision of the Lords of Trade upon the above letter, dated July I.)

554. Thomas Sammarez to Bathurst. Sends joint legislative address to the Prince Regent on the boundary between New Brunswick and the U. S. Fredericton, Mar. 22, I814. (Enclosure follows.)

E. G. Lutwyche to same. Observations upon the plaster of Paris trade, the disputed islands in Passamaquoddy Bay, the fisheries and the Northeast Boundary. Kensington, May I2, ISI4. (Another letter of June 6 relates to the importance of the islands in Passamaquoddy Bay, and the Northeast Boundary.)

554 a. G. S. Smyth to Bathurst. No. 6. Expenses of taking care of U. S. colored refugees. Fredericton, Apr. I7, I8I6. (Several enclosures, including a list of 38 I names.)

Rev. Roger Aitken to same. Remarlis at length relative to disputed islands in Passamaquoddy Bay. Moose Island, Jan. 2, 1816.

$\mathrm{D}$ [avid] Owen to $\mathrm{H}$ [enry] Goulburn. Sends two memorials on the exportation of gypsum. Campo Bello, May 4, i8r6. (Enclosures follow.)

Ward Chipman to Bathurst. St. John, Sept. 28, I8r6. (See M 338.)

Croker to Goulburn. Sends letter and enclosures from Owen on disputed islands in Passamaquoddy Lay. Admiralty Office, Sept. r, I8I 5. (Enclosures follow.)

Ward Chipman to Bathurst. Long communication (ff. I66-200) relative to the fourth article of the treaty of Ghent. St. John, Dec. I4, I8r5.

$\mathbf{5 5 4} \mathbf{b}$. H. W. Hailes to Bathurst. Sends two letters from the British consul at Baltimore on the trade in plaster of Paris with New Brunswick. Fredericton, June 23, I8I7. (Enclosures follow.)

Lieut.-Gen. Coffin to Thomas Bonnor. Remarks on the Northeast Boundary surveys, and the gypsum trade. Sept. 26, I8I7. (Extract.)

Same to Bathurst. Observations upon use of the fisheries by Americans, etc. Near Sherborne, Jan. I6, I8I7.

David Owen to Henry Goulburn. Gypsum trade with the U. S., and the Northeast Boundary. Campo Bello, Mar. 22 and Oct. 26, isi7.

Same to same. Relative to certain disputed islands in Passamaquoddy Bay. Campo Bello, Nov. 6, r8r8. (Several enclosures.)

555. G. S. Smyth to Bathurst. Relative to importation of corn, meal, and flour from the U.S. St. John, July 29, r820. (One enclosure.)

556. G. S. Snyth to Bathurst. No. I3. Sends petition of the chamber of commerce of St. John. St. John, Aug. 13, I82 I. (Enclosure touches upon illicit trade with the U.S.)

David Owen to Henry Goulburn. Plaster of Paris trade, etc. Campo Bello, Aug. I3, I82 I. (Several enclosures.)

55\%. Capt. Henry E. Napier to Rear-Adm. Fahie. Remarks on the nature, extent, and probable means of checking contraband trade with the U. S. H. M. S. Jaseur, May 25, 1822.

George Harrison to R. Wilmot. Sends report of customs commissioners relative to illicit trade by Maine citizens in Passamaquoddy Bay. Treasury Chambers, Mar. 18, I822. (Enclosure follows.)

558. Ward Chipman to Bathurst. Altered duties on U. S. vessels, etc. Fredericton, May I, I823. (One enclosure upon this subject, as is also a further letter of May I5.) 
559. Memoir of Sir Howard Douglas on the Northeast Boundary question. Feb. 27, I824. (Ff. 4I-75.)

Douglas to Huskisson. Discussion of importation of sugar and of general trade matters. London, Apr., I824.

560. John Porter to R. W. Horton. Relative to importation of U. S. flour. Office of Committee of Privy Council for Trade, Aug. 27, I824.

561. Douglas to Bathurst. Trade No. 7. Smuggling of tea from the U.S. Fredericton, Apr. I7, I825. (Two enclosures.)

Same to same. Miscellaneous no. II. Sends copy of a despatch of Addington with enclosures from the U. S. Secretary of State respecting alleged encroachments of British subjects upon Maine. Fredericton, Apr. 29, 1825. (Enclosures follow. No. 27, Sept. 2, with two enclosures, also deals with boundary matters.)

562. Douglas to Bathurst. No. 29. Maine encroachments upon New Brunswick. Fredericton, Nov. 8, I825. (Twelve enclosures.)

Same to same. No. 37. Return to the U. S. of certain land agents. Remarks. Fredericton, Dec. 29, I825. (Three enclosures.)

563. Joseph Planta to R. W. Horton. Sends despatch and enclosures from the British chargé d'affaires at Washington, on alleged depredations by inhabitants of New Brunswick upon U. S. territory. Foreign Office, May 24, 1825. (Enclosures follow. Letter of July 27 relates to the same matter.)

Same to same. Present state of the question respecting the fifth article of the treaty of Ghent. Requests Lord Bathurst's opinion. Foreign Office, Dec. 7, I825. (Reply follows.)

563 a. Douglas to Bathurst. No. 7 . Sends joint legislative address on late actions of Maine and Massachusetts, and report of their land agents. Fredericton, Mar. I0, I826. (Enclosure follows.)

Long memorandum on the cession of Barnhart's Island to the U. S. (Undated, but placed after Douglas's despatch of Sept. 27, I826.)

Douglas to Bathurst. No. 28. Operations of U. S. land agents in the disputed territory. Fredericton, Nov. I0, I826. (One enclosure)

563 b. Henry Bliss (agent for New Brunswick) to R. W. Horton. Sends copy of joint legislative memorial regarding the boundary. Remarks, Apr. 19, I826. (Memorial listed elsewhere.)

Joseph Planta to R. W. Horton. Sends despatch and enclosures from the British minister at Washington relative to land agents of Maine and Massachusetts, in the Madawaska settlement. Foreign Office, Jan. 26, 1826. (Enclosure follows. Another communication of Mar. I I, with a despatch and enclosures of diplomatic correspondence from the minister at Washington, is upon the same topic.)

Howard de Walden to R. W. Hay. Sends despatch from the British consul general at Washington relative to the admission of $U$. S. vessels to New Brunswick ports. Foreign Office, Mar. 28, 1826. (Enclosure follows.)

[Lord] Clanricarde to R. W. Horton. Sends despatch and enclosures from the minister at Washington relative to the conveyance of lands and the sale of timber in the disputed territory. Foreign Office, Aug. 26, I826. (Enclosure follows.)

563 C. "P. E. I. Wm. Townsend Case. 1789-9r."

564-575 F. A continuation of Prince Edward Island state papers for the period I802-1818. A few scattered petitions and memorials from various officials and others detail their records as Loyalists. During 
the War of ISI2 there is a certain amount of material respecting defense. A despatch of ${ }^{8}{ }_{13} 3$ stated that the island had " no American trade, cruisers or prize judicature".

In $575 \mathrm{~A}$ a despatch from Lieut.-Gov. Smith to Bathurst, June I, I8I4, gives the former's observations upon the boundary between Canada and the U. S., and the fishing of Americans in the Gulf of St. Lawrence and on the coast of Nova Scotia.

576-577 k. A further continuation of Nova Scotia state papers, covering the period ISO4-I8II. These documents contain much information upon the triangular trade of Nova Scotia, the U. S., and the West Indies. The commercial and political results of the U. S. embargo form another important topic. The reports of the secret agent John Howe (printed in Am. Hist. Rev., XVII. 70-I02, 332-354) are somewhat similar to the John Henry letters of the same period.

576. Jan. I-Nov. I6, I804. Among despatches from Lieut.-Gov. Wentworth to the colonial secretary for this period, six deal more or less with American affairs. Trade of Nova Scotia with the U. S. and with the West Indies, the effects of existing commercial regulations, ill-treatment of an American merchant vessel by a Nova Scotia privateer, and rumors of French plots in the U.S. are the chief subjects. The folder also contains descriptive lists of vessels entering and clearing at Halifax, Jan. I-Mar. 3I, I804.

577. Scrope Bernard (provincial agent) to Camden. Sends petition from the merchants, etc., of Halifax. London, May i6, i804. (Enclosure relates to trade with the West Indies and competition with the $\mathrm{U}$. S. Letter from R. J. Uniacke to Bernard of Oct. I3 relates to the same topic.)

George Leonard, superintendent of trade and fisheries, to Edward Cooke. The report of the former with enclosures giving information about U. S. trade and fishermen. St. John. Nov. 30, ISO4.

List of ships entering and clearing at Halifax, Apr. I-June 30, I804.

577 a. Wentworth to Camden. No. I36. Remarks on U. S. trade and British seamen in $\mathrm{U}$. S. ships. Halifax, Mar. 22, I805.

Same to Castlereagh. No. I 46 . Observations respecting emigration to the U. S. Halifax, Feb. 3 , I8o6.

Same to Windham. No. I 50. Sends return of fish and fish-oil exported from the districts of Halifax and Shelburne to the West Indies and the U. S. in I805. Halifax, Apr. I7, I806. (Enclosure follows.)

Same to same. No. 153. Relative to U. S. fishermen. Halifax, June I6, I806.

5777 b. Petition of a committee of merchants and others concerned in the West India trade respecting emigration to the U. S., trade of the latter, etc. Dec. 2I, I805. (In proceedings of the assembly.)

Richard John Uniacke, speaker of the assembly of Nova Scotia, to - Long letter (ff. 549-589) chiefly upon commercial matters, including $U$. S. trade and fishermen, French agents in the U. S., etc. London, Feb. I8, I8o6.

577 c. Nentworth to Windham. No. I66. Interest in trade with the U. S. Smuggling. Halifax, Apr. 4, I807.

577 d. Nentworth to Castlereagh. No. I7I. Sends newspaper extracts respecting the Lcopard-Chesapeake affair and its effects in the U. S. Remarks. Halifax, July I4, I807. (Enclosures are from various papers in the U. S. and in Nova Scotia.) 
Same to same. No. 175. Sends letter from the British minister at Philadelphia on prospects of war with the U. S., etc. Halifax, Sept. I9, 1807. (Enclosure follows.)

Same to same. No. 178. Secret observations on the reported situation in the U. S., rumors of military preparations, etc. Halifax, Nova Scotia, Nov. 14, I807.

W. W. Pole to Edward Cooke. Sends communication from Vice-Adm. Berkeley " respecting an illicit trade carried on between the United States and His Majesty's subjects in the Bay of Fundy, and to the right of occupying Moose Island". Admiralty Office, Sept. 9, I807. (Enclosure follows.)

577 e. Extract from the Columbian Centinel, Boston, Dec. 26, 1807, on the embargo. (Enclosure in Lieut.-Gov. Wentworth's despatch to Castlereagh of Jan. 3, 1808.)

Maj.-Gen. Hunter to Edward Cooke. Sends papers, with remarks. Halifax, Mar. 27, r8o8. (Enclosures are extracts from the Baltimore North American of Feb. 26 and the National Intelligencer of the same date, respecting the political situation in the U.S.)

Wentworth to Castlereagh. No. 185. Observations upon the U. S. embargo and its effects in various ways. Halifax, Mar. 28, I808.

Maj.-Gen. Hunter to E. Cooke. Sends pamphlet. Halifax, Apr. 4, r8o8. (Enclosed is a manuscript copy of the second edition of Timothy Pickering's Letter to Gov. Sullivan upon the war.)

Lieut. William Girod to Lieut.-Gov. Wentworth. Report of his journey through the seaboard states as far as Philadelphia, recounting what military preparations had been made, and the apparent sentiments of the people. Halifax, May 28, r808. (Printed in Am. Hist. Rev., XVII. 74-76.)

Draft to Lieut.-Gen. Prevost. Private and secret instructions regarding relations with the U. S. Downing Street, Feb. I3, I808.

Prevost to Cooke. Has sent an agent to Boston, Norfolk, Washington, and New York to obtain information. Encloses copy of his instruc. tions. Remarks. Halifax, Apr.27, 1808. (Private. Enclosure follows.)

Prevost to Castlereagh. No. 2. Arrival of U. S. military forces at Moose Island, and their seizure of flour. Steps taken with regard to this. Relative to admission of certain U. S. produce. Halifax, May 28, I808. (Seven enclostures. Draft of reply follows.)

577 f. Prevost to Cooke. Sends papers. Halifax, May 28, I8o8. (Enclosed are a report of the special agent, John Howe, dated Boston, May 5, documents showing the state of affairs at Moose Island, and newspaper extracts relating to the embargo and the feeling in New England.)

Same to Castlereagh. No. 6. Arrival of Aaron Burr from New York under the name of Edwards, and his communication of "several projects relating to the Floridas, and other settlements appertaining to Spain". Steps taken by Prevost and Vice-Adm. Warren in the matter. Halifax, June I7, I808. (Private.)

Same to Cooke. Burr will go to England, and has been given introductions to Castlereagh and Cooke. His projects are fit only for the consideration of government, "as they aim at objects of magnitude involving many political circumstances". Halifax, June I8, 1808. (Enclosed are two further reports from John Howe, the special agent, at New York, upon the political and economic situation, and two newspaper clippings containing letters of Senator J. Q. Adams.) 
Same to Castlereagh. No. 8. Observations upon the situation at Moose Island, British seamen in the U. S., the continued effect of the embargo upon the Americans. Halifax, June 19, I808. (Four enclosures, one of them being a report from John Howe.)

Same to Cooke. Sends papers. Remarlis on the embargo, etc. Halifax, July 30, ISo8. (Enclosed are account of capture and detention of boats of the British Michilimackinac Co. by an American force, a report from John Howe at Philadelphia, and a clipping from the New York Gasctte, July Io, I So8, respecting Burr's movements.)

Same to Castlereagin. No. Io. The situation in Passamaquoddy Bay, the embargo and American politics. Halifax, Aug. I, ISo8. (Four enclosures. Followed by draft of reply.)

Same to same. No. I3. Relative to disputed islands in Passamaquoddy Bay. Halifax, Aug. 24, I8o8. (Two enclosures.)

Same to Cooke. Sends report from John Howe, and some Bostonian pamphlets. Halifax, Aug. 25, ISo8. (Private. Enclosures follow.)

Same to Castlereagh. No. I5. Sends copy of letter from bimself and Vice-Adm. Warren to the British minister at Washington, relative to the disputed islands in Passamaquoddy Bay. Halifax, Sept. 6, I8o8. (Enclosure follows.)

Same to same. No. I7. Sends extract of a letter from New York relative to commercial matters. Halifax, Sept. 22, ISoS. (Enclosure follows.)

Prevost to Cooke. Sends Howe's last report. Halifax, Sept. 23, I8o8. (Enclosure follows.)

577 g. Prevost to Castlereagh. No. 2r. Sends a remonstrance respecting the conduct of the U. S. frigate Chesapcake. Halifax, Oct. 27, I808. (Enclosure follows.)

Same to [Cooke?]. News from the U. S. Halifax, Oct. 27, I808. (Private. Several newspaper clippings enclosed.)

Same to Castlereagh. No. 24. Sends returns showing the beneficial results to Nova Scotia of the U. S. embargo. Halifax, Nov. 4, I808. (Enclosures follow.)

Same to same. No. 25. Sends letters. Halifax, Nov. 24, i8o8. (One letter to Sir James Craig gives the steps taken to obtain information from the U. S.)

Same to Cooke. Has persuaded Howe to return to the U. S. Other steps to obtain information. Sends copies of Howe's instructions and his first letter. Halifax, Nov. 30, i808. (Private. Enclosures follow.)

[Castlereagh] to the Lords of the Admiralty. Has instructed Lieut.Gen. Prevost to find out the prevailing sentiments in the northeastern states, etc. Downing Street, Feb. I3, ISo8. (Secret.)

577 h. Alexander Croke (president of the council) to Castlereagh. No. 2. Sends papers. Halifax, Jan. 7, I809. (Enclosed are a report from Howe and four lespatches from the British minister at Washington upon the political situation and military matters in the U.S.)

Prevost to same. No. 36. Relative to regulations for trade with the U.S. Halifax, May 5, I809. (Three proclamations enclosed.)

Same to Cooke. Sends papers. Halifax, May I9, I8og. (Enclosures are Howe's final report on his second mission, under 36 heads, $45 \mathrm{ff}$., printed in Am. Hist. Rev., XVII. 344-354, and Dearborn's printed report on port and harbor fortifications.) 
Same to Castlereagh. No. 43. Sends merchants' petitions. Halifax, July 22, I 809. (Petitions followed by list of duties on foreign fish imported into the U. S. in foreign vessels.)

$577 \mathrm{k}$. Prevost to Liverpool. No. 26. Account of the incident of the President and the Litile Belt. Halifax, May 29, I8I I.

Same to Adam Gordon. Sends pamphlet. Halifax, July 30, I8ri. (Enclosure is Robert Smith's Address to the People of the United States.)

578. Notes on Nova Scotia Archives. By Dr. James Hannay. See post, p. I93. 579. Loyalist claims. Halifax, I785. Copied from Audit Office papers at the Public Record Office, London.

580. Notes on Prince Edward Island Archives. By Dr. James Hannay.

581-586. "Nova Scotia Instructions." I I $08-1840$. Various instructions to governors of Nova Scotia, and to the governors general, for this province. Practically all the special trade instructions are of interest to Americans. (Copied at the Public Record Office, London.)

581. To Gov. Vetch respecting an expedition against Canada, and the steps he should take to obtain troops from New York, Rhode Island, Pennsylvania, Connecticut, and "New England”. Feb. 28, I708.

To Gov. Nicholson respecting the Port Royal expedition. Mar. I8, I709I 7 ro.

Additional instructions to the same. Apr. I5, I7Io.

To the same respecting acts of trade and navigation. Date in entrybook margin is A.pr. I, I I I3.

To Lieut.-Gov. Dunbar (New Hampshire) respecting the boundaries of Virginia and Carolina, Maryland and Pennsylvania, etc. Entry-book date, Apr. 22, I73I.

Additional instructions to Gov. Richard Philipps mentioning Irish families in Maine desirous of emigrating to Nova Scotia. Entry-book date, Mar. 25, I73o. The same thing is mentioned in additional instructions to Dunbar of the same date.

583. Trade instructions for the governor of New Hampshire. Mar. I6, I763. (Copied from Board of Trade papers, New Hampshire.)

584. Additional instructions to Gov. Parr respecting the Loyalists. June Io, I783. (Further instructions on the same subject, Aug. 7.)

Trade instructions for Gov. Parr. I784.

Lord Dorchester's trade instructions for Nova Scotia. Aug. 23, I786.

585. Sir James Craig's trade instructions for Nova Scotia. Aug., I807. Sir George Prevost's trade instructions for Nova Scotia. Oct. 22, I8II.

Sir John Sherbrooke's trade instructions for Nova Scotia. Apr. I2, I816.

586. Dalhousie's trade instructions for Nova Scotia. Apr. 27, 1820.

587-588. Commissions of Nova Scotia governors. I7 IO-1840. (Copied principally from Patent Rolls and Board of Trade papers at the Public Record Office, London. Boundaries are not given in the earlier commissions. No. $\mathbf{5 8 7}$ also contains Gov. Cornwallis's trade instructions, Apr. 29, 1749.)

589-591. Instructions to governors of New Brunswick. I784-I839. (Copied at the Public Record Office, London.)

589. Instructions to Gov. Thomas Carleton relating partly to the Loyalists. July I8, I784. Also trade instructions to the same.

Dorchester's trade instructions. Aug. 23, 1786.

590. Trade instructions for New Brunswick of the governors general Craig, Prevost, Sherbrooke, Richmond, and Dalhousie. 
592. Commissions to governors of New Brunswick. I784-I839.

(Copied at the Public Record Office, London. Boundaries given.)

593. Instructions to and commissions of governors of Prince Edward Island. гт69-1839. (Copies.)

594-604. Logs of the British fleet. I756, I758-i760. Masters' and captains' logs, Canadian material. (Partly printed, with a long introduction, in Col. Nood's Logs of the Conquest of Canada.)

605. Copy of M 132.

606. Journal of the siege of Quebec, I775-I776, with preface and notes by IV. T. P. Shortt. Printed in I824. (Typewritten copy.)

606 A. Amended copy of no. 606.

$60 \%$. Officers of the British regiments present at the siege of Quebec, I759.

$607 \mathrm{~A}$. Copies of muster-rolls of the $28 \mathrm{th}, 35 \mathrm{th}, 43 \mathrm{rd}, 47 \mathrm{th}, 48 \mathrm{th}$, and 58 th regiments. 1760 .

608. I. State of Canadian militia who served during the siege of Quebec, I $775-1776$.

2. Letters relating to the services of Capt. (afterwards Rear-Adm. Sir Charles) Douglas in Canada, i776. (Typewritten copies.)

3. Another copy of no. 606.

609-633 A. Various records of the "Prévôté" of Quebec. I666-I757. (Copies.)

634-638. "Registre des Audiances. Chambre des Milices. District de Montréal." Oct. 28, I860-Aug. I6, I764. (Copies.)

639. "Appels des Jugements de la Chambre des Milices. District de Montréal." г $760-1764$. (Copy.)

640. "Conseil Militaire de Québec. Ordonnances, Règlements, Sentences et Arrèts." Nov. 4, i760-June I3, I761.

641-642. Logs of the British fleet at the siege of Louisburg, I745. In no. 641 are those of H. M. S. Lark, Superb, Sunderland, Canterbury, and Launceston. In no. 642 are logs of the Princess Mary, Eltham, Chester. Hector, Vigilant, and Mermaid. (Copied from Admiralty papers at the Public Record Office, London.)

643. La Salle's journal. I684-I685. Journal of the Rev. Stephen Williams at Louisburg. I745-I749. (Copied from the Parkman collection of the Mass. Hist. Soc., and bound in one volume.)

$643 \mathrm{~A}$. Copy of Williams's journal from the above.

644. Mar. 4, I839-Jan. I6, I840. (230 pp. and an index of 3 I pp.) Letterbook of Lieut.-Gov. Harvey, New Brunswick. Letters to Maj.-Gen. Scott, U. S. A., Col. Goldie (I Ith reg't), Lieut.-Col. Maxwell (36th reg't), the warden of the disputed territory, and numerous other persons. About a third of the volume relates to military matters with regard to the disputed territory and action from Maine, cutting of timber in the Madawaska settlement, and the fisheries of New Brunswick and Nova Scotia. (Copy.)

645. May I, I84I-Jan. 5, I843. (6I I pp. and an index of $\mathrm{I} 22$ pp.) Letterbook of the lieutenant-governor of New Brunswick and of his private secretary. These letters are to various persons, and the subjects are local in character. About twenty scattered communications deal with the "Disputed Territory Fund ", various actions taken by Maine, cutting of timber in the Madawaska settlement, rafting of logs down the St. John by Americans, British immigrants in the U. S., and the Northeast Boundary. (Copy.) 
646. May I8, I84I-Apr. 4 , I848. (468 pp. and a partial index of 32 pp.) Letter-book of the lieutenant-governor of New Brunswick and of his private secretary. About a dozen letters relate to the disputed territory, the treaty, etc. Few American items after I843. (Copy.)

647. A continuation of the preceding number to Sept. I6, I854. About a dozen scattered despatches to the British minister at Washington, and a letter to J. R. Cuningham, Mar. 23, I843, comprise the American items. These chiefly relate to the tariff and commercial matters. (409 pp., no index.)

648-649. Notes on New Brunswick archives. By Dr. James Hannay. (In one folder.)

649 B. Ancient epitaphs from cemeteries of York County (N. B.).

650. July, I765-Mar. 6, I775. (Ca. $700 \mathrm{ff}$.) The contents of this volume were copied in 1907 from original papers in the possession of the Dartmouth family. The documents relate wholly to American affairs. The volume is unpaged. About half consists of correspondence of Gage with the secretaries of state for the colonies, which may also be found in part of the $A . W$. I. series, now C. O. (M 222-2-228, q.v.). Apart from this there are (I) letters to Dartmouth or to Hillsborough from Dennys de Berdt, William Johnson, Rochford, Gov. Chester (West Florida), and Maj.-Gen. P. Lyman; (2) letters to Gage from Hillsborough, Dartmouth, and Pownall ; and (3) miscellaneous correspondence and other papers.

Material in the first two classes is concerned with commercial relations with England, effects of the Navigation and Stamp acts, internal trade in America, proposed settlements at the Natchez and at the White Cliffs (near Pointe Coupée), emigration from the colonies to various parts of the interior, the Indians, plans regarding the Illinois country, and the Ohio grant (Vandalia). A letter from Rochford to Dartmouth, Sept. 7, I773, relates to the last subject, and has among enclosures a memorial of Thomas Walpole and his associates, giving the boundaries of the tract applied for, and a report of the attorney general and the solicitor general upon this memorial.

Among miscellaneous material are letters of Capt. Blane, Bouquet, Lavanchy, Fetherstonhaugh, Edward Abbott's account of Detroit, cabinet memoranda, and a few unsigned documents. A letter of Baynton, Wharton, and Morgan to George Whitefield, with two enclosures, relates to Indians, trade, and religion. Philadelphia, Oct. 29, I765.

651. Brown papers. Copied from Brit. Mus. Add. MSS. 19071. (See Andrews and Davenport, Guide, pp. IO3-IO4, and the Can. Arch. Rept., I88I, pp. 33-35.)

652. Simcoe correspondence relating to the government of Upper Canada. I79I.

Etat de la milice de Québec. I775.

Admirals' despatches. I759-I 760 .

653. Pichon papers. I753-I762. Copied from the Bibliothèque de Vire (Calvados), France. No American items.

654. Names of persons naturalized. I740-176r. Copied from "Board of Trade, Plantations General", vols. 59 and 6o, now C.O. 324: 55 and 56. Lists for Jamaica, Virginia, South Carolina, Maryland, Pennsylvania, New York, and Massachusetts. The Pennsylvania list fills over three-fourths of the 283 folios. 
655. Commissions and instructions to various Canadian officials, land grants, etc. The only American item is a copy of minutes of a council at New York, Mar. 22, I766, relative to appeals. (Enclosed are copies of a representation to His Majesty from the Lords of Trade and Plantations, Sept. 24, I765, and a report of the attorney general and the solicitor general, Nov. 2, I765, on the case of Thomas Forsey and Waddet Cunnyngham.)

656. Diary of a journey from Portsmouth to Canada. I8I4.

657-659. See C 1714, 1716, and $1203 \frac{1}{2} \mathrm{~N}$.

660. Register of St. Andrew's church, Quebec. I770-1829. (Copy.)

660 A. Minute-book of the Rideau Methodist church. I8I9-1874. (Original.)

$660 \mathrm{~B}$. Methodist meetings (Rideau circuit), I823-1856. Registry of baptisms, I825-I843. (Original.)

661. See C 1717.

662. Typewritten copy of a letter from W. Macaulay to Maj. Campbell respecting Carleton Island. Picton, Sept. IO, I847.

663. Canadian constitutional documents. I759-1784. (Copies. Printed in Doughty and Shortt, Constitutional Documents.)

664. Catalogue of the Parkman collection. (Copy.)

665-678-15. Typewritten copies of documents in various series at the General Post Office, London, which relate to the Canadian post office. After the first few numbers this material becomes much more routine in character. There are numerous references to Canadian or British mails passing through various points in the U. S., but such items rarely yield any information as to the postal relations of either Canada or England with that country. Lists of letters and their dates accompany each number.

665. I769-I8I5. The first document in this volume is a "copy of the real contract between the province of Canada and the United States" on postal affairs, dated Philadelphia, Mar. I7, I792. A few pages beyond are five letters of J. Haversham [Habersham] (Postmaster-General of the U. S.), George Heriot (deputy postmaster-general of $\mathrm{Br}$. N. America), and Francis Freeling (secretary at the General Post Office, London), with respect to a renewal of the agreement of I792.

The volume also contains the commissions of Benjamin Franklin and John Foxcroft as deputy postmasters-general over the greater part of $\mathrm{N}$. America, a memorandum on suggested improvements in the management of the post-office in N. America, the letter dismissing Franklin, and others written to Foxcroft and to Hugh Finlay, Franklin's successor, immediately after that occurrence.

Somewhat out of the usual order of this material is a long letter from John Howe (postmaster at Halifax, then special agent in the U. S.) to Freeling, describing the situation at IVashington. Dec. 9, I808.

666. I800-I83I. This volume has about a dozen letters bearing on postal relations with the U.S. Most of these are to Freeling. Conveyance of mails between New York and various Canadian points, commissions of postmasters in the U. S., rumored trouble on the northeast frontier, and the payment of postage at New York are the chief topics. There is also a copy of evidence (which has been printed) before a legislative committee relative to the post-office.

James Irvine to Gov. Prevost. Remarks on certain mail routes between Canada and the U.S. Quebec, Feb. I7, ISI2. 
D. Sutherland, deputy postmaster general, to Freeling. Relative to a mail route between St. Andrews (N. B.) and Robinstown (U. S.). Quebec, July 3I, I8I7. (Two documents follow on postal relations with the U. S., one dated Oct. 9, I8I7.)

Heriot's account for a trip to Washington to make postal arrangements after the war. Aug., i8 6 .

Goulburn to Freeling. Sends papers on improving the postal communication between Great Britain and Canada (by way of the U. S.). Downing Street, June I7, I820. (Four enclosures.)

668. Communication from "Truth" to the York Patriot, giving data on U.S. postage rates, etc. Dec. 29, 1832 .

T. A. Stayner, deputy postmaster general, to Freeling. Transmission of newspapers and pamphlets from the U.S. to New Brunswick and Nova Scotia. London, Nov. 15, 1833. (Two enclosures. Letter from John Howe of May I5, I834, on the same topic follows.)

670. T. A. Stayner to Lieut.-Col. Maberly. Proposed improved communication between Canada and the U. S. Quebec, Sept. 24, I837.

Article in the New York Commercial Advertiser on the outbreak of the Canadian rebellion. Dec. 7, [1837].

671. T. A. Stayner to the Postmaster General. Remarks respecting the Caroline affair. Quebec, Jan. 8, I838. (Enclosed is copy of Gov. Marcy's message to the New York legislature.)

James Stephen to Lieut.-Col. Maberly. Sends memorandum from the British consul at New York on the conveyance of letters and despatches to Quebec and Montreal. Downing Street, May 25, I838. (Several sub-enclosures on mails from England to Canada via New York.)

John Howe to Thomas Lawrence. Relative to interchange of letters with the U. S. Halifax, July I8, I838.

T. A. Stayner to Lieut.-Col. Maberly. Raid near Prescott by band from the U. S. Remarks. Quebec, Nov. I9, I838. (Several enclosures upon the rebellion.)

672. Extract from draft of conditions for the conveyance of mails between Great Britain and N. America, etc. [1839.]

676. T. A. Stayner to Lieut.-Col. Maberly. Charges upon U. S. newspapers in Canada. Quebec, Aug. 24, 1842.

677. G. Clerk to the Postmaster General. Proposed official interchange of letters with the U.S. Treasury Chambers, Jan. I8, I842. (One of a small package of letters and returns relative to postal relations with the U. S., some of them dating back to 1838 .)

678. Thirty-five sheets comprising letters on transmission of correspondence between the U. S. and Canada, and the proposed convention. I838I842.

678-14. T. A. Stayner to Lieut.-Col. Maberly. Relative to premium on remittances to Washington for U. S. postage collected in Canada. Montreal, Oct. 26, I844. (Several enclosures.)

679. Bedard papers. 1804-1829. Nothing relating to the U. S.

680. Viger papers. I82I-I 834 . Nothing relating to the U.S.

681. Townshend papers. I 759-I799. Nothing relating to the U. S. (Copies.)

682. "Généalogie des Familles de la Côte de Beaupré, par l'abbé Chs. Beaumont."

683. Memorandum on Canadian responsible government.

684. Papineau-Neilson papers, etc. I819-I832. Nothing relating to the U. S. 
685. Catalogue of the Gagnon collection.

686. Baldwin papers. I 36 -I852. Typewritten copies of letters addressed to Robert Baldwin. Originals at the Toronto Public Library. Nothing relating to the $U$. S.

68\%. Reports on parish archives of Quebec.

687 A. Journals of James Thomson: May I3-Sept. I3, I759; June I8-Sept. 9, I776; Oct. I4, I779-Jan. 22, I780; June 29, I787-Aug. 5, I788. All at Quebec. (Copied from the archives of the Literary and Historical Society of Quebec; see p. 222.)

688-689. Report on the Baby collection of manuscripts.

690. Vermont papers. (Copied from the Public Record Office, London.) List as follows:

Minutes of Council, Vermont. Feb. I2, I $7 S_{1}$.

Articles of union agreed upon between the legislative committee of Vermont and the committee of the convention of the New Hampshire Grants. Feb., 1;8I.

Extract of a letter from Gen. Haldimand to Sir Henry Clinton respecting Vermont, etc. Feb. 28, I78I.

Letter of Ethan Allen to Pres. Samuel Huntington, on various matters affecting Vermont. Bennington, Mar. 9, I7Sr.

Same to same sending two acts of the V'ermont legislature. Sunderland, Mar. Io, I78I.

"Notes respecting that part of the country called Vermont." Apr. 28, I7SI.

"Intelligence by MIr. Micah Townsend." Apr. Io, I 7 I.

691. Copies of certain documents in the archives of the General Hospital at Quebec. I645-I797. Nothing relating to the U. S.

692-698 A. "Extraits des Archives de l'Hôtel-Dieu de Québec." I636-I824. Nothing relating to the U.S. (Copies.)

698 B. Notes on the archives of the General Hospital, Montreal.

699-706 C. "État Civil, Paroisse N[otre] D[ame] de Montréal." I68oI720. (Copy of the registers.)

706 D. Diary of Capt. Johnson of Pefferlaw, Ontario. Sept. I, I84I-June 22, I846. Nothing relating to the U.S. (Copy.)

707. See C $1203 \frac{1}{2}$.

708. See C 1718.

709-709 B. Laidlaw's reports on Ontario archives.

710. "Hudson's Bay Memorial Book." I680-I 7 I9. Nothing relating to the U. S. (Copy.)

711-717-6. Ninute-books of the Hudson's Bay Co. i67I-I7o7. (Copied from the originals at the office of the company in Lime Street, London.)

718. Petitions to the king by the Hudson's Bay Co. I687-I778. Nothing relating to the $U$.S. (Copied from the originals in London.)

719-720. Correspondence of James Anderson (Hudson's Bay Co.). I850I 5 8. Nothing upon the U. S. (Copy.)

720 A. George MIurdoch's diary at Calgary. I883-I886. (Copy.)

r21 A. Ninutes of the council of Assiniboia. Nay 4, I832-NIar. 5, I86I. (Copy.)

721 B. "Register A", etc. Copies of various records relating to the Canadian northwest.

722. Copies of Manitoba records of various dates.

722 a. "The Councell Book of York Fort." I72I. (Copy.) 
722 B. Anthony Beal's journal of transactions at Albany Fort. I705-I706. (Copy.)

722 c. S. Taylor's diary at Red River. I849-I857, I859-1866. (Copy.)

722 d. R. Campbell's journal. I8o8-185I. (Copy.)

723. Miscellaneous documents. Includes a "Projet d'un Gouvernement pour les Illinois". n. d., n. sig.

723 A-723 D. James Anderson papers. I849-1863. Material relating to the Hudson's Bay Co. (Copies.)

724-727. Cadillac papers. I669-1745. (Copies. Printed in translation in vols. XXXIII. and XXXIV. of the Michigan Pioneer and Historical Collections.)

728. "Registres de la paroisse de Notre Dame de la Conception des Cascaskias." Baptisms, I695-I735, marriages, I724-I 729, deaths, I $721-\mathrm{I} 834$. (Copy.)

729. Copies of certain French manuscripts in the possession of the Louisiana Historical Society. 1679-I769. Contains several well-known grants, edicts, and arrêts respecting Louisiana, such as Crozat's charter, Sept. 24, I7 I2, the edict regarding negro slaves in Louisiana, Mar., I724, warrant authorizing the establishment of the Jesuits in Louisiana, Aug. I7, I726, etc.

730. Dr. Hannay's report on the archives of British Columbia and Saskatchewan.

730 A. Journal of Alexander Hunter Murray. I848. Exploration in the Yukon country, Alaska. (Copy. Printed as Publications of the Canadian Archives, no. 4, I9Io.)

731. Yukon Territory. Information gathered for the Year Book, 1904.

731 A. Copies of thirteen journals of John Work. I823-1835. (Originals in Victoria, B. C.) Titles as follows :

Trading expedition under Chief Factor Ogden from Columbia to Fort George. I823.

Journal of a voyage from Fort George to the northward to discover the entrance to Fraser River. I824.

Trading expedition made by the Interior Brigade from Fort Vancouver under the command of McLeod. I825.

Trading expedition from Colville under the command of Connelly. I826.

Trading expedition from Fort Colville to Okanagan. I828.

Journey from Colville to Fort Vancouver. I830.

Hunting and trading expedition down Snake River and some of its tributaries to Utah and return to $\mathrm{Nez}$ Percés. I83I.

Trading expedition to the southward. Encounters with Blackfeet and Flathead Indians. I83I.

Hunting expedition to the Bonaventure valley by way of Ogden's River. I 832 .

Hunting expedition down Snake River. I833.

Trading and trapping expedition to the southward from Fort Vancouver. 1834 .

Expedition of a steamer from Fort Vancouver for the Northwest coast, under command of Capt. McNeil. I834.

Description of work of completing Fort Simpson. British and American trade with Indians.

Voyage to Fort Vancouver with annual return of furs. I835.

$731 \mathrm{~B}$. Copies of various western journals. Among them are the following: 
F. Ermatinger's journal of an expedition under Alexander McLeod (Fort Vancouver) to avenge the death of Alexander McKenzie. I828. Diary of John Dease, Fort Colville to Fort Vancouver. 1829.

Journal of William Fraser Tolmie of a voyage from Cape Disappointment to Fort Vancouver and thence overland to Nisqually. 1830.

Journal of William Fraser Tolmie, descriptive of time spent at Forts Nesqually, McLoughlin, and Vancouver. 1833 .

Sir James Douglas's journal of a journey from Fort Vancouver to Okanagan. 1835 .

Journal of John Tod. (Description of the building of Fort Kamloops, and capture of the Indian murderer of Black.) I84I.

$731 \mathrm{C}$. Copies of Hudson's Bay Co. papers. Include a journal of John Stuart at the Rocky Mountains, I805, a few letters of Simon Fraser to James Macdougall, I806-I807, and various letters of Dugald McTavish, J. W. Pelly, W. F. Tolmie, John Work, Archibald Macdonald, R. Finlayson, and a few others, I828-I857. The greater part of this correspondence relates to personal matters and the affairs of the Hudson's Bay Co., but there is some information about the Oregon country. Some of the letters are to persons at Nesqually.

731 D. 'The copies of Hludson's Bay Co. papers in this folder contain much information concerning the affairs of this company and of the Puget Sound Agricultural Co. in Oregon and Washington, the relations of these territories with their Canadian neighbors, and the Indian troubles of 1855 -1856. There are numerous letters to William F. Tolmie, factor of the Hudson's Bay Co. at Nesqually, during the period I84II857. The greater part of these are from Gov. James Douglas, and Peter Skene Ogden.

The folder also contains a long account of the Indian war of $1855^{-18} 86$ in Washington and Oregon, by Col. Granville Haller; a prospectus of the Puget Sound Agricultural Co. and several accounts; A. C. Anderson's relation of the origin of this company: a letter of W. F. Tolmie to Gov. McMullen, Jan. I2, I858, respecting Loschi, a Nesqually chief ; and a journal of the house of assembly of Vancouver Island, Aug. I2, $1856-$ Sept. $2 \%$, I 858.

$731 \mathrm{E}$. June 26, 186I-August 26, 1864. Copy of the journals of the house of assembly of Vancouver Island.

731 F. Jan. 2I, I864-May I, I868. Copy of journals of the legislative council of British Columbia.

Aug. I2, I856-July 6, 1859. Copy of papers of the house of assembly of Vancouver Island.

One portfolio of correspondence of James Douglas, journals of explorations, etc. I839-I864. Contains a few items on U. S. trade, economic matters, Indian raids, and the boundary question. (Copied from originals at Vancouver.)

Notes on the means of speedily and economically determining the boundaries of Br. N. America. By Sir J. Edward Alexander. Kingston, Feb. 21, 1842. (Accompanied by three maps. 8 pp.)

In a small portfolio ff. I I9- 169 have miscellaneous documents on the disputed territory, 1818-1828, the Madawaska and Aroostook riots of I827I 828, and the trial of John Baker, I828.

Report of C. M. Burton on the "Archives of the West". ( $150 \mathrm{ff}$.) Comprises in its scope the Burton collection at Detroit; manuscripts on Canadian history in the possession of the Chicago Historical Society; 
and the Kaskaskia, Cahokia, and Fort de Chartres papers at the University of Illinois.

Journal of the campaign in Canada under Sir Guy Carleton in 1776 , and of Burgoyne's expedition from Canada in I777. ( I 6 ff.) (Copied from the original in possession of the United States Military Academy at West Point.)

Jan. 4, I866-June I7, I867. (90 pp.) "Correspondence relating to the Fenian Raid on New Brunswick, the Fisheries, etc., between Vice Admiral Hope, Sir Hastings Doyle, Sundry Naval Officers, and the Lieutenant Governor of New Brunswick."

Three portfolios of copies of land grants in Upper Canada under Lieut.Govs. Simcoe and Hunter, arranged alphabetically according to districts. Nothing shows whether the grantees were Loyalists. Another portfolio has some U. E. Loyalist grants, Upper Canada, I8201835. (All of these were copied from the originals in the Department of Crown Lands, Ontario.)

In a small portfolio of miscellaneous documents received from the Department of Militia and Defense is a part of the Boston Gazette and Country Journal for Feb. 25, I77I.

A small portfolio has a manuscript marked "Index to New Brunswick Land Grants from I784". (64 pp.) Arranged alphabetically. (Copy.)

Registers nos. I and 2 of lots drawn by Loyalists on the rivers St. John, Kennebaccasis, etc. I786-I 787 . (Pp. 45-100 and I-44. Either no. I was paged in continuation of no. 2 , or these pages have been abstracted.)

Letter-book of the surveyor general of New Brunswick, together with sundry instructions, warrants, etc. June $16,1785-J u l y ~ I 8, ~ I 789 . ~(328$ $\mathrm{pp}$. Copied from the original in the possession of the provincial government at Fredericton.)

A portfolio entitled "New Brunswick Boundaries" contains copies of despatches of the lieutenant-governors, Campbell and Harvey, Sir R. D. Jackson, miscellaneous correspondence and other documents relating to the Northeast Boundary question. I839-1840.

A smaller folder has about a dozen letters of David Thompson to the governor general on surveys of the international boundary, etc.; and two letters of the British consul at Portland, Feb. I7, I84I, and the warden of the disputed territory, Jan. 30, I84I, on the actions of Maine with regard to the Northeast Boundary question, etc. These letters apparently belonged to series $\mathbf{S}$ at one time.

Another thin portfolio has an unsigned and undated manuscript enclosed in a wrapper labelled "Boundary Question between Maine and New Brunswick. I 787-1840"; and also a few drafts to the warden of the disputed territory, written in I840, apparently by the governor general.

"Miscellaneous Papers re New Brunswick." I834-1842. Portfolio of original papers, some of them being despatches from Lord Aberdeen to Lieut.-Gov. Campbell. A few deal with the boundary question. (Presented to the Archives in I 909 by Professor Ganong.)

One large portfolio entitled "New Brunswick Boundaries" has copies of letters from Maj.-Gen. Sir Archibald Campbell to the military secretary at Halifax, and other correspondence extending from Sept. I3, I83I, to Sept. 20, 1840, with numerous enclosures; also copies of several letters from Lieut.-Gov. Colebrooke to Lord Sydenham in I84I.

These documents are largely concerned with the disputed territory and the boundary question. Letters from the warden of the region in dispute 
are numerous and important. These documents were also presented to the Archives by Professor Ganong.

Warrants of survey, New Brunswick. May 22, I786-Sept. 20, I788. (Copy in medium portfolio.)

Letters of John Richardson. I789-I799. Many were written from various places in the U.S. The volume relates chiefly to matters of trade, and only occasionally comments upon political events. (Copied from the originals in the possession of H. R. Howland, Buffalo, New York.)

Manuscript volume of the "Golden North". Principally on Alaska. By Malcolm MacLeod, Ottawa.

"Joln Polley's Journal, which was kept in the year I775, wherein is contained an account of the battles and skirmishes which happened near Boston between the American and Regular Troops, when we were engaged in the civil war." (97 pp.) Copy of the original in the possession of the Chicago Historical Society. In the same portfolio are a few typewritten letters on the services of Capt. Douglas in Canada, one of which describes the relief of Quebec in 1776 .

Extracts from certain registers at Mobile. I704-I764. Thin portfolio.

Five portfolios and about 20 volumes contain copies of records on American Loyalist claims, from Audit Office papers at the Public Record Office, London. Two portfolios are filled with memorials and evidence of Loyalists from Connecticut; a third has the decisions upon these; a fourth contains reports of commissioners John Wilmot, Robert Kingston, and John Marsh; while the fifth is a minute-book of Loyalist claims heard at Halifax and other places in Canada, $1785-1788$.

One typewritten volume is composed of a list of American Loyalists, and the other is an index to claimants found in bundles of original memorials, certificates, etc.

King papers. Two bulky portfolios contain records of the Rev. William King in the anti-slavery cause. According to these records King at one time lived in Louisiana where he married a planter's daughter. In I 848 he liberated a few slaves that had come into his possession and brought them to Canada, where they formed the nucleus of an association established for fugitive slaves in Canada. This was incorporated as the Elgin Association in 1850 , and purchased land in western Ontario.

One portfolio is filled with Canadian, British, and U. S. newspapers containing items on slavery and King's activities; its fellow has manuscript records on the Buxton negro settlement, and the Elgin Association.

\section{SERIES Q: TRANSCRIPTS FROM LONDON.}

The $Q$ series is composed of copies of Canadian state papers in the Public Record Office (Colonial Series), London. It covers the period from I76I to the end of IS 40 for Lower Canada, and to Mar., I84I, for Upper Canada. Correspondence of the governors, lieutenant-governors, and administrators with the colonial department forms the core of the series. Enclosures in the despatches from Canada are often numerous and lengthy, and besides these there are many communications from minor officials and private persons. Large spaces are filled with what are virtually sub-series, such as Minutes of the Legislative Council of Quebec, I79r, Court of Common Pleas, Quebec, r 787 , Jesuits' Estates, etc. In the later volumes correspondence of other departments of the government-Admiralty, Foreign Office, etc.-upon Canadian affairs becomes an important factor in the series. 
From the standpoint of United States history this is one of the most important collections at the Archives. Its value as a primary source, however, is greatly lessened by the fact that the originals of a large portion of these documents are now to be found in other series in the manuscript room.

From the ample records of that part of the Revolutionary period which ended at Saratoga we pass to those respecting plans for invading Canada after 1777. Then come the tangled diplomacy, the divergent interests from the Canadian frontier to New Orleans and from the western prairies to the Atlantic, the ever present friction between British and Americans, and the voluminous records of Dorchester's secret service-all in the years between the adoption of the Constitution of the United States and the ratifying of Jay's treaty. From the delivery of the western posts it is but a step to the John Henry letters, here given in full. From this point United States material is abundant until the treaty of Ghent. The period I8I2-I8I5 occupies about twenty-five volumes. After this there is no large mass of items relating to the United States until 1838, where we meet with both the Northeast Boundary question and the international relations growing out of the Canadian rebellion and attempts made then and subsequently to invade British territory from various points on the frontier. Both topics are treated in great detail, especially the latter, enclosures in despatches being numerous and bulky.

For our purposes the $\mathbf{Q}$ series may be conveniently divided into three parts.

I. The calendared portion.

2. The uncalendared section.

3. Volumes composed solely of despatches.

I. The entire collection consists of 869 volumes, of which about 670 have been calendared in the Canadian Archives Reports for I890-1902 inclusive (with the exceptions of those for 1894 and I895). This brings Lower Canada to the middle of 1838 and Upper Canada to the close of 1836 . This part, as in the cases of other collections at the Archives of which calendars have been printed, has here been treated in a separate report, which follows.

2. As it now stands $Q$ extends to the year I84I for Lower Canada, and to March, I84I, for Upper Canada, leaving sixty-three uncalendared volumes of the former and eighty-nine of the latter. These have been treated in this book on the same general plan and scale as the $\mathrm{G}$ series.

3. The latest part of $Q$ to be copied was a separate series of despatches from the colonial secretaries to the Canadian governors, lieutenant-governors, and administrators, I768-1840. These were taken from a series of entry books at the Public Record Office, in the class designated as C. O. 43. They have been bound in fifty volumes of a different color (dark red), and are labelled "A", "B", or "C ", as the case may demand. Only those despatches have been listed from them which are to be found neither in series G nor in the calendar of $Q$.

Before $18 \mathrm{I} 6$ the $Q$ series is not indexed, but from that date onward, starting at Q 136 for Lower Canada and Q 320 for Upper Canada, each number contains an index giving the purport of every despatch, etc. Where a number is divided into two or more parts the index is placed at the end of the final volume. This does not apply to the recent volumes of despatches; these are not indexed, but the chronological arrangement makes it an easy matter to locate any given despatch.

The calendar of the $Q$ series is the work of the late Dr. Brymner, the first archivist of Canada, and has been printed in the Canadian Archives Reports for 1890-1902 inclusive (with the exceptions of those for 1894 and 1895). To note deficiencies in the calendaring of United States material in such a 
mass from beginning to end would be a long task and would occupy an unnecessary amount of space. The main purpose will be served by an examination of a particular period, with the addition of a few examples from other dates. With this object the years I786-I790 have been selected. In the first place material on United States history in the $Q$ series for this period is voluminous, important, and, generally speaking, less known to historians than that upon the Revolution, the War of 1812 , or even the episode of the John Henry letters. Both its volume and its importance are largely due to Lord Dorchester. Under him the Canadian secret service became an expert, efficient body, although somewhat irregular, and special agents supplemented the work of spies of a lower class. Besides such reports Dorchester had the further advantage of many private correspondents in the United States, most of whom naturally were strong Loyalists. Many prominent men in Republican ranks also trusted him as a British officer of ability and honor, with pure motives and an established reputation for fair dealing. Under these circumstances he was able to furnish to the ministry in London detailed information on events in the United States. Although such documents are for the most part strongly partizan-they could hardly be otherwise-yet on the whole the news they conveyed was much more accurate than that obtained by Dorchester's successors.

Secondly, United States material for this period is treated with less attention in the calendar than at any other point in the series. As was noticed with respect to the Bouquet and Haldimand collections, certain subjects are given more space than others. Without quarrelling with this method it will be sufficient to note that in some portions of $Q$ there is also a certain lack of uniformity. The events of $1775-1783$ and $18_{12-I} S_{5}$ are such important sections of Canadian history that documents relating to those years are usually calendared about twice as well as those upon the constitutional struggles, economic readjustment, or trade and diplomatic relations of the young republic during the period selected for special examination.

In addition to Dr. Brymner's numerous dicta in the Canadian Archizes Reports there are several selections of documents printed in extenso. In the Report for I8go "Note C" contains material on the northwest fur-trade. I785, while the correspondence in "Note D" (pp. 97-I75) gives much information on relations with the United States, I787-I791. French republican machinations in the United States against Canada, I793-I8oI, form the principal subject of "Note D" in the Report for I801, and "Note B" in the Report for 1896 is devoted to foreshadowings of the War of 1812 , containing among other items the John Henry letters.

Q 11. Enclosures in Canadian despatches sent during the Revolution are often dismissed with a mere heading, and the contents are not given. Carleton's communication to Dartmouth of June 7 , I775, may be taken as an example. Among other enclosures is a letter from Benedict Arnold, dated at Crown Point, May 24, I775, to Thomas Walker at Montreal. In it the former states-doubtless for the good of the cause-that he has at Ticonderoga about a thousand men and expects to be joined in a few days by two thousand more; others are making new carriages for the guns; tools and artificers are expected at any moment, etc. In the calendar this is merely given as "Benedict Arnold to Walker, dated Crown Point, 24th May".

A similar case is furnished by Carleton's despatch no. I6 to Dartmouth, dated Oct. 25, I775. A letter from Montgomery on the treatment of prisoners is enclosed. The stibject of the enclosure is not given in the calendar, therefore besides this fault of omission Carleton's comments upon the letter 
as calendared in his despatch lack a proper connection with the rest of the document.

Q 27, pt. I. Dorchester to Sydney. No. 7. Dec. II, i786. In the account of Clark's movements about Vincennes the despatch states that the Frencl: in the district joined him with between three and four hundred men. The calendar omits this.

The omission of certain items necessary for the proper understanding of a document is a frequently recurring fault. It is illustrated very well in Dorchester's secret despatch to Sydney, no. Io, of Jan. I6, I787. To quote in part from the calendar: "The military preparations in the United States and the formation of magazines as far as to Saratoga are said to be for the purpose of reducing the Indians. .... The weakness of these (upper) posts; the want of subordination among the Indians unfits them for great enterprises". The manuscript for these portions reads as follows: "The military preparations in the United States with the measures taken to form Magazines along the frontier of Virginia and as far as to Saratoga, their leading men say, are intended to reduce the Indians. . . . . The weak situation of these Posts, more particularly, Fort Ontario, near Oswego, seems to invite an insult ; the strongest of them depends on the Savages for protection, and these having neither national bands nor subordination of any sort, can not have that firmness necessary for great confidence."

The calendar also overlooks Dorchester's remarks that the surrender of the forts would draw many reproaches (from the Indians) upon the British, and "open a door for much smuggling".

Q 36-1. Dorchester to Sydney. No. 66. June 9, I788. A portion of this despatch will show the occasional obscurity of the calendar. A part of the print reads, "The Six nations declare that the lease to the Americans was signed without authority, that the Governor of New York has declared it illegal, forbidding any of the subjects of New York from taking possession of the lands. So far as regards the King's interests the effect will be the same, whether it is in the hands of the New York Government or of individuals". The text for the latter part of this is, "a message and proclamation from the Governor of New York has been brought to them [the Six Nations], declaring the lease to be illegal, and forbidding the subjects of the State of New York taking possession of any part of their lands in consequence thereof, inviting the six nations at the same time to a particular meeting with delegates from that State. Of this the object probably will be a similar arrangement respecting their lands, on the part of the New York Government, in the event of which taking place, the consequence, in regard to the King's interests, will be the same".

Q 41-1. Dorchester to Sydney. No. I07. Apr. I I, I789. After noting the disposition of Kentucky to join Spain the calendar omits any reference to the following: "Their appreliension that Congress will consent to give up the navigation of the Mississippi for twenty-five years is one of the reasons which induces them to listen to the overtures of Spain. . . . . A committee of private correspondence has been appointed by them to influence all the inhabitants west of the mountains in the same measures."

Q 42. In a secret despatch from Dorchester to Sydney, dated June 7, I789, the former speaks of overtures made to him by certain persons in the United States for aid in keeping the western country out of the clutches of France. The calendar notes their propositions, but disregards this sentence: "They required no more, and doubted not, but they would be able to take New Orleans and deliver it over to Great Britain, desiring only freedom and pro- 
tection of their trade down the Mississippi." Likewise the summary of Grenville's despatch to Dorchester, no. 2, dated Oct. 20, I789, which relates to the proposed act of I79I, fails to include anything corresponding to the following passage: "There will however be a considerable difficulty in the mode of describing the Boundary between the District of Upper Canada and the Territories of the United States. As the adhering to the Line mentioned in the Treaty with America would exclude the Posts which are still in His Majesty's Possession, and which the infraction of the Treaty on the part of America has induced His Majesty to retain, while on the other hand the including them by express words within the Limits to be established for the Province by an Act of the British Parliament would probably excite a considerable degree of resentment among the Inhabitants of the United States, and might perhaps provole them to measures detrimental to Our Commercial Interests. Possibly the best solution of this difficulty might be to describe the Upper District by some general words such as "All the Territories etc., etc., etc., possessed by and subject to His Majesty, and being to the West or South West of the Boundary Line of Lower Canada, except such as are included within the present Boundaries of the Government of New Brunswick " .

Q 44-1. Washington to Governor Morris, Oct. I3, I789. This of course should be Gouverneur Morris.

In Grenville's secret despatch to Dorchester, no. 24, May 6, I 790, on the relations of the United States, England, and Spain in America the calendar disregards that portion reading "and the Fur trade from the North West Coast of America may uecome a valuable accessory and assistant to the China trade in which the Americans have already embarked extensively ".

Dorchester to Grenville. No. 27. May 27, I790. The calendar mentions two companies of artillery to oppose the western Indians. The manuscript shows that these were the southern Indians.

One of the most important features of $Q$ for the period 1786-I794 is furnished by communications to Dorchester from his agents or private correspondents in the United States. Many examples of faults in the calendaring of these could be given, but perhaps it will be sufficient to bring forward two of them.

Q 43-2. Dorchester to Grenville. No. 9. Oct. 25, I789. The summary of the conversation with "No. 4 " omits the following: "Commissioners are gone to negotiate a treaty with the Creek Indians, who are said to have fifteen thousand men, and are supported by Mr. Gillivray 「McGillivray〕, who sets the power of the states at defiance; this man it is thought is supported by Lord Dummore, or at least from his government ".

Q 49. Dorchester to Grenville. No. 73. Nov. Io, I790. The purport of the first enclosure in this despatch is given by the calendar in these words: “Report respecting St. Clair's movements and the policy towards the Western territories, towards Spain, etc. Offer of a Dutch financier to open a loan for funding the public debt. Character of Walker, aide-de-camp to Washington during the war". The lengthy manuscript represented by these few lines may be quoted as evidence of a degree of compression not infrequent throughout this portion of the calendar. It reads as follows:

"General St. Clair has returned to his government, after a very short stay, and if rumour may be credited considerable exertions are making for the Indian War. Mr. St. Clair early in life was an officer in the King's Service, and afterwards a Major General in the late American Army, he is not a man of much capacity, either in military or civil matters, but he is considered to be an officer of firmness, experience and fair private character. Brigadier 
Harmar, the second in command, has been usually at Fort Pitt, although not deficient in understanding, he is said to be frequently intoxicated; Majors Wyllis and Doughty are officers of merit, the latter particularly, who is commandant of the Artillery, is a man of talents and capacity, these men are all in the Continental or regular forces, but many officers are settled in different parts of the western territory, who have activity, knowledge, and inclination to head bodies of hardy militia with resolution and ability.

"Clothing and necessaries for the regular Troops were lately sent from hence to Philadelphia, by water on their way to Fort Pitt. If any particular cordiality has existed between Governor St. Clair and the Spaniards, I am convinced it must have been without authority from this Government; a smuggling trade has been carried on for some time past between the western settlers and the Intendant at New Orleans in the Article of Tobacco, in which many individuals are concerned; this traffic is prejudicial to the Spanish Revenue, as a high price is paid for the Tobacco brought down the Mississippi, on the presumption that they are the produce of Louisiana, and they are shipped to old Spain on account of the Crown, but this as well as every other indulgence shewn at present by the Spaniards to the Exports of the Western Settlers is perfectly inadequate to the condition of that rising country, ready at this moment to open the Mississippi by arms; and I am not without an idea, that this would actually have taken place in a few months, notwithstanding any endeavours of the general government to prevent it, if Spain had been involved in a war, and provided the Indian Expeditions now in agitation shall prove successful.

"The inhabitants of the western country wish New Orleans to be in our possession, as the best nineans for getting a good price for their productions.

"The Atlantic people in general wish the navigation to remain closed, from their dread of a rivalship, especially in the West India market.

"The Executive Government are anxious to possess it themselves, in order to connect and consolidate both sides of the Allegany Mountains, knowing that although the western exports must issue from the Mississippi, their imports will to a certainty be conveyed through the Atlantic States. Tha free navigation of this river, whether to have been secured by the possession of New Orleans, or by the erection of a post in a preferable situation, was I am convinced the boon of all others the most likely to have induced the States to have taken an active part against Spain; they do not wish for a West India Island at this time, sensible that they have no marine to protect it; these remarks apply to the Executive government.

"I have not been able to learn that any treaty or conference has been held on the Wabash river, or that any Spanish Agent has been there.

"I am confirmed in my ideas respecting the seafaring people in New England, in case a rupture with Spain had actually taken place. I do not think either the General Government, or the State Governments would have repressed the privateering spirit of that hardy enterprizing people, who have suffered more by the Act of Independence than any part of this Country, from the decay of their ship building, and the effect which the dismemberment of the Empire has produced on their oil and fish in foreign markets.

"As soon as the Presidents speech to the Legislature at the opening of the late sessions reached Holland, and which amongst a variety of other objects recommended the taking measures for funding the public debts, the house of Van Stapphurst wrote to the Secretary of the Treasury, offering to open a loan to the extent of three millions of dollars for the use of the States, which they would guarantee; they demanded an interest of five per cent for the 
subscribers, with an additional per centage for their own risk and trouble. It has been asserted here, that Colonel Humphries is gone to Europe to negotiate this business; it is on the other hand supposed, that his objects are in England.

"Colonel Walker who was an Aid de Camp to General Washington during the war, has lately sailed from hence to London, this gentleman is the naval officer at this port. With plain unaffected manners, he is a man of sense and discernment, and superior to $2 \mathrm{I}$ in many respects. Mr. Walker is by birth an Englishman, although he has been many years here, and his father, who is a brewer near Knight's bridge has pressed him greatly for some years to pay him a visit, to which he has at last consented; whether Mr. Walker has anything in charge of a public nature I do not know, but he has always been on the best terms with the President."

The calendar gives no indication that a large part of the documents are duplicates or copies. "Confidential" is often omitted, and even the numbers of despatches are in many cases not given. Enclosures are sometimes calendared immediately after the covering document, but usually are arranged chronologically. One despatch of Dorchester has fifty-three, which are scattered about in several pages of print. Another from Hunter to Portland (Q 286-2), Oct. I I, I 799, has seven enclosures, all calendared under August 22. In this case, however, and indeed in many others (but not all), in order to correct this error the date of each document is placed in the calendar at the end of the item, and a parenthetical note signifies to what despatch the entire seven belong.

These remarks on the calendaring of the $Q$ series are not made in a censorious spirit, or with a view to expressing harsh criticism of Dr. Brymner's work. On the contrary, cordial admiration for the pioneer labor performed by him must be felt by the student who traverses carefully the path which he blazed through this great mass of documents. But the investigator who seeks materials for American history in Canadian archives is entitled to have laid before him at some length, a selection of evidence as to the accuracy, and especially as to the adequacy, with which his material is represented in these calendars.

\section{LOWER CANADA.}

242 , pt. I. This volume of $287 \mathrm{pp}$. is the first of four which contain miscellaneous correspondence during 1837 . At page 38 begins an inflammatory address, entitled "Meeting in behalf of Canada!" which was placarded in New York, Dec. 27, I837. There is also an address to the people of the U. S., adopted at a meeting at Sherbrooke, Lower Canada, Dec. I3, I837. (Settlers in this part of the province were mainly of U. S. origin.)

The second part of the volume contains correspondence of James Buchanan, British consul at New York. A few of the earlier documents deal with the financial crisis, commerce, and navigation. Others in the latter half of Dec. give information on events at the frontier, and meetings of sympathizers in the U. S.

242, pt. 2. Communications from Buchanan to Downing Street are continued in the first It pages of this volume. These include several short extracts from U. S. newspapers upon Canadian affairs. One item is upon the burning of the Wisconsin legislative building.

Besides the above an extract of a letter from an agent of the Bank of England, dated Philadelphia, Dec. I5, I837, comments upon various 
political interests in the U. S., and a five-page letter from James Ellice to Sir George Grey, Nov. 9, I837, deals with American and Russian policy on the northwest coast.

243, pt. I. Gosford to Glenelg. Remarks upon martial law, sentiment and policy in the U. S. toward Canada, etc. Quebec, Jan. 5, I838. (Confidential.)

Same to same. Sends documents on the Caroline affair. Comments. Quebec, Jan. 8, I838. (Five short enclosures from Buffalo papers, etc.)

243, pt. 2. Gosford to Glenelg. Exaggeration of feeling in the U. S., unreliability of newspapers, etc. Quebec, Feb. 16, I838. (Private.)

Same to same. His reception in the U. S., and the attitude shown towards Canada. Washington, Mar. 22, I838. (Private.)

244, pt. I. Jan. 24-Apr. 2, I838. (274 pp.) This volume contains despatches from Sir John Colborne to the Colonial Office with numerous enclosures. The principal subjects are Canadian rebels and U. S. sympathizers at Navy, Bois Blanc, and Pointe Pelee islands, and upon the Vermont frontier; the attitude of the generals Scott and Wool ; martial law, and the punishment of prisoners. More than half of the volume is occupied with these subjects.

245, pt. I. Colborne to Lieut.-Gen. Somerset. Information as to hostile intentions of part of the Americans in border states. Quebec, Oct. 20, I838. (Private and confidential.)

Same to same. Sends Maj. Young's report of attack and defeat near Prescott of invaders from the U. S. Remarks. Montreal, Nov. I7, I838. (Enclosure follows.)

245, pt. 2. Colborne to Glenelg. Remarks upon rumors of preparations for invading Canada. Montreal, Nov. 30, 1838 . (Confidential.)

246, pt. I. Durham to Glenelg. No. 4. Sends report on proposed distribution of troops in Upper and Lower Canada. Quebec, June 3, I838. (Enclosure touches upon rumors of plans for invasion from the U. S.)

Same to same. No. II. Sends two despatches (with enclosures) from Lieut.-Gov. Harvey, regarding the Northeast Boundary question, and his reply. Comments. Quebec, June I6, I838. (Enclosures follow.)

Same to same. No. I6. Return of Col. Grey from Washington with despatch from Fox. Sends copy of this and of Col. Grey's report. Remarks upon intentions of U. S. government. Quebec, June 23, I838. (Enclosures present, some of them printed.)

246, pt. 2. Arthur to Durham. No. 4. Remarks on bands of marauders upon the frontiers. Toronto, June 22, I 838 .

Durham to Glenelg. No. 25. Various remarks concerning the Welland Canal. Encloses U. S. paper dealing with the canal, navigation, and trade. Niagara, July I6, I838. (Enclosure follows.)

248, pt. I. Durham to Glenelg. Intelligence from Fox, alarming state of the frontier, and condition of the province. Quebec, Oct. 20, I838. (Confidential.)

248, pt. 2. Durham to Glenelg. No. Io8. Sends report from Maj. Head on disputed territory east of the Connecticut River. Need of settling boundary disputes with the U.S. Quebec, Oct. 30, I838. (Enclosure follows.)

249, pt. 2. John Barrow to Sir George Grey. Sends report of Lieut. Harper on the state of affairs in Canada. Admiralty, Apr: I9, I838. (Enclosure relates to proceedings of invaders near Kingston.) 
Fitzroy Somerset to same. Sends confidential despatch from Sir John Colborne. Horse Guards, Ang. I I, I838. (Enclosure, dated June 23, with 9 sub-enclosures, relates to state of feeling on the U. S. frontier and in Upper Canada, frontier outrages, efforts of U. S. officers, etc.) 249, pt. 3. June 5-Nov. 5, I838. In this volume are despatches from Sir John Colborne to Lord Fitzroy Somerset. Nearly all of these have numerous enclosures of letters from sundry military and civil officers to Sir John Colborne, and of correspondence between the latter and Sir George Arthur. About two-thirds of the volume is filled with this material, which relates to such topics as organizations of Canadian rebels and their sympathizers in the U. S., border affrays, rumors of plans for invasion, and the scope of U. S. frontier hostility.

250. Feb. 5-Dec. 4, I838. ( 345 ff.) This volume is largely filled with despatches from Henry S. Fox, British minister at Washington, to Lord Palmerston. They are usually very detailed. In them the state of feeling toward Canadian affairs manifested both on the border from Vermont to Michigan, and in the U. S. generally is followed closely from week to week. The attitude of the U. S. executive can be traced in Fox's reports and the numerous enclosures of correspondence with Secretary of State Forsyth. Also important enclosures are from officials on the border and British consuls at New York, Paltimore, and Norfolk. Other topics more or less prominent are the passage of the neutrality bill through Congress, intrigues of Canadian insurgents at New York, Fox's report upon the U.S. navy, supply of arms to the rebels, and the missions of Vail and Grey.

There are also several consular despatches, likewise transmitted to the Colonial Department from the Foreign Office. Nearly all of these relate to Canadian disturbances. In brief, one may say the entire volume is connected with U. S. history.

251. This volume (255 ff.) is entirely filled with documents relating to the Caroline affair. Besides detailed descriptions of the affair there are opinions of law-cfficers upon its legality, correspondence between Fox and the U. S. government, protest of the latter, etc.

252, pt. I. Fox Maule to J. Stephen. C. IV. Howard, agent for Georgia, to be allowed to inspect and make extracts from documents in the "State Paper Office" relating to Georgia from i 735 to i 775 . Whitehall. Nov. 3. 1838 .

R. B. Dean to A. Y. Spearman. Export of arms. Sends account of guns exported from Liverpool to the U. S. during parts of $1837-1838$. Customs, Jan. Io, 1838 . (Confidential. Enclosure follows.)

254 , pt. I. In the first part of this miscellaneous volume are three letters on a peculiar kind of American rifle used by Canadian insurgents, on Mackenzie in New York, and naval force and trade of the Lakes. Nearly one-half of the volume, however (ff. I68-286), is filled with consular despatches from James Buchanan at New York, with their enclosures. These cover the period Jan. 2-Sept. 24, I 838 . Apart from news of events on the frontier they contain interesting accounts of meetings held, principally in New York, on behalf of the Canadian insurgents.

254, pt. 2. Buchanan's despatches continue in this volume to the end of ${ }_{1} 88$, and occupy nearly all of it. The character of the material is the same. Among enclosures are many copied clippings from U. S. and Canadian newspapers, showing among other things the tone of the press in various parts of the U. S. toward Canadian affairs. 
254, pt. 3. James Davies to Glenelg. Sends papers. North and South American Coffee House, Feb. 2, I838. (Enclosures extend from f. 7II to f. 780 , and relate to the attitude of the U. S. government toward the Canadian troubles and frontier raids. They comprise copies of letters between Forsyth and Poinsett and various officers, messages, and proclamations of the President, and debates in Congress. Most of these may be found in "U. S. Pub. Docs." and in reports of the debates.)

Same to same. Sends further news. North and South American Coffee House, Feb. 25 and Mar. I8, I838. (Enclosures cover 14 ff., and relate to frontier action in Ohio and Michigan.)

255, pt. I. John Fraser to Glenelg. Observations upon the Northeast Boundary. Sherbrooke, Feb. I9, I838.

255, pt. 2. Thomas Moore to James Stephen. Sends message of the President to Congress of Dec. 3. New York, Dec. 5, 1838. (Enclosure follows.)

Prospectus of a History of the Indian Tribes of North America, by Thomas M'Kenney and James Hall.

Charles West to [Grey]. Sends extracts from U. S. papers, showing the sympathy with the Canadian rebels felt in the U.S. and its motives. London, Jan. 5, I838. (Several enclosures.)

Same to same. Americans joining the rebels. Remarks upon the weakness of the U. S. executive. Jan. 27, 1838. (Enclosed are copies of numerous extracts from U. S. newspapers.)

Same to same. Sends documents. Enclosures are largely extracts from U.S. and Canadian newspapers with information of movements along the border, address from societies and meetings in Canada to the citizens of the U. S., etc.

256 , pts. 2 and 3 . These two volumes continue the communications from Charles West to Sir George Grey, together with the numerous enclosures. These relate to the details of frontier attacks, state of feeling displayed, actions and letters of U.S. officers, debates in Congress, the neutrality bill, and the Northeast and Northwest boundaries. The greater part were taken from newspapers. West's letters extend to June II, I838. At least half of these two volumes relates to the U.S.

257. Colborne to Glenelg. No. 5. Rumors of projected raids from Vermont, and steps taken to prevent them. Montreal, Jan. 15, I839. (Correspondence with the governor of Vermont is enclosed.)

Same to same. No. 28. Sends his correspondence with the governor of Vermont regarding another frontier outrage. Remarks. Montreal, Feb. 19, 1839. (Enclosure present.)

Same to same. Sends his correspondence with Lieut.-Gov. Harvey on the conduct of the Maine legislature in authorizing the entrance of an armed force into the disputed territory. Montreal, Feb. 27, I839. (Confidential. Enclosure follows.)

258. Colborne to Glenelg. No. 37. Relative to arrest of the Russian consul at Boston, together with his wife, on a charge of treasonable practices. Montreal, Mar. 13, 1839. (Two enclosures.)

Same to same. Remarks upon the disputed territory and danger of frontier raids. Montreal, Mar. I8, I839. (Confidential.)

Same to same. No. 50. Withdrawal of Maine militia from the Aristook, etc. Montreal, Apr. 2, I839.

259, pt. 2. Colborne to Normanby. No. 74. Observations on the Northeast Boundary question. Montreal, May 17, I839. (Map enclosed.) 
Same to same. No. 8I. Remarks on seizure and release of the U. S. vessel G.S. Wecks. Montreal, June 5, I839. (Followed by nine documents relating to this event, some of them of a later date than the despatch.)

Same to same. No. 86. Rumors of continued plots in the U. S. against Canada, the encouragement given to them, etc. Montreal, June 8, I839. (Seven enclosures, including correspondence between Sir John Colborne and the governor of Vermont.)

Same to same. Frontier plots. Imprisonment of Mackenzie at Rochester. Emigration of habitants to the U. S. Montreal, July 2, I839. (Confidential. One enclosure.)

Same to same. Incursion at Barnston. Montreal, July 28, I839. (Confidential. Two enclosures.)

260, pt. I. Colborne to Normanby. No. II3. Emigration of habitants to the U. S. in search of work. Montreal, Sept. I6, I839. (One enclosure.)

260, pt. 2. Colborne to Normanby. No. II7. Sends correspondence with Lieut.-Gov. Arthur relative to proceedings on the frontier. Montreal, Sept. 27, I839. (Enclosure follows.)

261. Thomson to Russell. No. 6. Relative to the disputed territory. Montreal, Nov. I I, I839. (Six documents on this subject follow.)

262. Thomson to Russell. No. 25. Sends correspondence with Lieut.-Gov. Harvey on the military occupation of the disputed territory. Toronto, Dec. 3I, I839. (Enclosure extends from f. I 72 to f. 246 , and includes several sub-enclosures.)

Jackson to same. No. 3. Sends copy of his letter to the governor general respecting the disputed territory; also extract of report on same, and a sketch. Montreal, Dec. 2, I839. (Enclosures follow.)

Same to same. No. 4. Occupation of the disputed territory, and probable result of differences with Maine. Montreal, Dec. 8, I839.

Same to same. No. 8. Reports reoccupation of military posts near the disputed territory, between Fredericton and Quebec. Montreal, Dec. 27. I839. (Four enclosures.)

264. C. Wood to Sir George Grey. Sends copy of letter from Capt. Sandom to Vice-Adm. Paget. Admiralty, Jan. I4, I839. (Enclosure relates to attack upon the frontier near Sandwich.)

Draft to C. Wood. Relative to depredations from the U. S. border. [Downing Street], Aug. 7, I839. (Five enclosures.)

J. Dodson and I. Campbell to Lord John Russell. Report upon questions connected with convention with the U. S. for the mutual surrender of fugitive criminals. Doctor's Commons, Dec. I2, I839. (Draft of convention follows.)

265 , pts. I and 2. Communications from the Foreign Office to the Colonial Office fill pt. I and the first $38 \mathrm{ff}$. of pt. 2. Most of these simply transmit copies of despatches from the consul at New York and the minister at Washington. Letters from the Foreign Office extend from Jan. 29 to Nov. I3, I839; few of the enclosures are before June, I838.

Over half of this material is of interest to the student of U. S. history. There are long documents on apprehensions of a war between Great Britain and the U. S., information on border raids, plots in the U. S. against Canada, the energy of General Scott, and the growth of a better feeling along the border toward Canada. The negotiations of Buchanan with Papineau are given in full, and some of the letters treat of the Northeast Boundary, negotiations with the U.S. on extra- 
dition matters, steps taken by Bancroft to obtain the privilege of examining and copying certain historical documents, and detailed advice from Henry S. Fox on the treatment of Americans taken in raids upon Upper Canada.

267. Thomas Moore to James Stephen. Sends the President's message to Congress, Dec. 2, I839. New York, Dec. 26, I839. (Enclosure follows.)

270, pt. I. Thomson to Russell. Observations upon rumors of intended attacks upon the frontier. Sends despatch from Lieut. Jones, who has been sent on a tour in the U. S., to ascertain the state of feeling, etc. Toronto, Jan. I3, I840. (Confidential. Enclosure follows.)

Same to same. Sends another letter from Lieut. Jones and comments upon it. Toronto, Jan. I7, i840. (Confidential. Duplicate. Enclosure follows.)

270, pt. 2. Thomson to Russell. No. 35. Course adopted with regard to the disputed territory. Toronto, Jan. 22, I840. (Enclosed are several letters of Thomson, Sir John Harvey, Sir Richard Jackson, and G. W. Featherstonhaugh upon the subject.)

Same to same. No. 40. Sends report of Derbyshire on the present state of affairs in Maine and sentiment there respecting the boundary question. Toronto, Feb. IO, I840. (Enclosure follows.)

Same to same. No. 45. Sends copy of his despatch to Lieut.-Gov. Harvey regarding the disputed territory. Toronto, Feb. I2, I84O. (Enclosure follows.)

270, pt. 3. Thomson to Russell. No. 53. Sends addresses to the queen from the assembly. Toronto, Feb. I5, I840. (Some of the enclosures relate to commercial intercourse with the U.S. With them are copies of a few despatches from the governor general to Lord John Russell later in 1840 and in $184 \mathrm{I}$ upon these subjects.)

271, pt. 2. Thomson to Russell. Observations at length regarding the disputed territory. Montreal, Mar. 25, I840. (Confidential. Several enclosures.)

Same to same. Sends memorandum by Sir Richard Jackson on the state of Montreal and its immediate frontier. Montreal, Mar. 26, I840. (Confidential. Enclosure also deals with the American forces and frontier forts.)

272, pt. I. Thomson to Russell. No. 98. Observations upon the tea-trade and smuggling from the U. S. Montreal, May I, I84O. (One enclosure, followed by a draft of later date.)

Same to same. Remarks on local corn bill, etc. Montreal, May 27, I840. (Confidential.)

272, pt. 2. Observations respecting arrangement with regard to the disputed territory. Montreal, June 27, I840. (Confidential. Four enclosures.)

273, pt. 2. Thomson to Russell. No. I55. Comments upon attempt of Maine authorities to take a census of the Madawaska settlement. Drummondville, Aug. 24, I840. (Enclosed is correspondence with Lieut.-Gov. Harvey and a despatch to Henry S. Fox.)

Same to same. No. I57. Relative to the disputed territory. Drummondville, Aug. 28, I840.

Same to same. No. I70. Relative to duty on wheat exported from Upper Canada to the U. S., etc. Montreal, Oct. 3, I840.

273, pt. 3. Sydenham to Russell. No. I76. Remarks on numbers of Canadian and American vessels on the Lakes. Montreal, Oct. 9, I840. 
274, pt. I. Sydenham to Russell. No. 196. Sends three despatches and their enclosures from Lieut.-Gov. Harvey, and his reply. Comments regarding the disputed territory. Montreal, Nov. 23, I840. (Enclosures follow.)

Same to same. No. 209. Sends further report from Sir R. D. Jackson on the defense of Canada. Montreal, Dec. 24, I840. (Enclosure also touches upon the U.S. frontier forts, etc.)

274, pt. 2. Sydenham to Russell. Sends further correspondence between Lieut.-Gov. Harvey and himself respecting the disputed territory. Comments. Montreal, Dec. 28, 1840. (Confidential. Several subenclosures also present.)

Jackson to same. No. 8. Sends extract from legislative message of Gov. Fairfield of Maine on alleged occupation of part of the disputed territory by British troops, and remarks upon it. Montreal, Jan. I6, 1840. (Enclosure follows.)

Same to same. Opinion, from a military point of view, of question of occupying certain posts on the St. John River. Montreal, Apr. 4, I840. (Private. Sketch enclosed.)

275 , pt. I. Jan 30-Apr. 27 , I840. In this volume are communications from the Foreign Office to the Colonial Office. The subject of most importance is the proposed arrangement between Great Britain and the U. S. for the mutual surrender of criminals and deserters. A draft of a proposed convention is present. Other papers-including Palmerston's opinion upon the matter-deal with demands of the U. S. for the surrender of negro slaves who had escaped to Canada. A few documents are ujon the case of a British deserter who had enlisted in the U. S. navy.

277, pt. I. Henry Bliss (agent for New Brunswick) to Lord John Russell. Sends petition. Remarks. King's Bench Walk, Temple, June 25, I 840. (Enclosure is from the chamber of commerce of St. John, and relates to contraband trade in wines between New Brunswick and the U.S.)

\section{UPPER CANADA.}

398, pt. I. Head to Glenelg. No. I I2. Case of Jesse Happy, a fugitive slave demanded by the governor of Kentucky on a charge of horse stealing. Toronto, Oct. 8, I837. (Several documents on this case follow.)

398, pt. 2. Head to Glenelg. No. I32. Attack of Canadian insurgents upon Toronto. Escape of Mackenzie to the U. S. Toronto, Dec. I9, I837. (Enclosures fill the few remaining pages of this volume and nearly half of pt. 3. Many of them relate to the reception of Mackenzie in the U. S., the feeling displayed there, Mackenzie's first actions, and movements looking to an invasion of Canada.)

398, pt. 3. Head to Glenelg. No. I33. Sends documents on the rebellion and the possession of Navy Island by the Americans. Toronto, Dec. 28, I837: (Several enclosures, most of which are printed in the English parliamentary papers.)

400 , pt. I. J. D. Hume to James Stephen. Remarks upon address of the Upper Canada assembly regarding foreign trade and smuggling along the U. S. frontier. Whitehall, May 2, I\$37.

401, pt. 2. Archibald McLean to Lord Glenelg. Is proceeding to Washington to remonstrate against actions of Americans on behalf of the rebels Feeling on the frontier, etc. New York, Dec. 30, I837. 
402, pt. I. Head to [Glenelg]. Remarks on danger from the side of the U. S. Has written to the minister at Washington and to the governor of New York. n. d. [Jan., I838.] (Private and confidential.)

Same to same. No. 3. Sends copy of despatch and enclosures to the minister at Washington on the destruction of the Caroline, as well as a private letter showing the feeling in New York. Toronto, Jan. Io, 1838. (Enclosures largely printed in English parliamentary papers.)

Same to same. No. 4. Sends memorandum regarding a proposed attack upon Navy Island. Toronto, Jan. Io, 1838. (Enclosure follows.).

Same to same. Fears that the Americans may overwhelm the province. Toronto, Jan. IO, I838. (Private and confidential.)

Same to same. Expulsion of "pirates" from Navy Island and Bois Blanc Island, and capture of a schooner off Malden. Niagara, Jan. I6, I838.

402, pt. 2. Head to Glenelg. Rumors that attempts will be made to murder the former if he passes through the U. S., etc. Feb. 9, I838. (Private. Private despatch of Feb. I I also mentions this.)

403, pt. I. Head to Glenelg. No. 23. Sends copy of his despatch to the minister at Washington. Comments. Toronto, Mar. 6, I838. (Enclosure relates chiefly to invasions. With it is extract from the New York Gazette on the treatment of Lady Head in the U. S.)

Same to same. No. 26. Sends council minute and report on the case of Jesse Happy, a fugitive slave. Toronto, Mar. 8, 1838. (Enclosures follow.)

Same to same. No. 33. Sends account of skirmish with Americans at Pointe Pelee Island. Toronto, Mar. I4, I838. (Two enclosures.)

Same to same. No. 38 . His attitude toward the U. S. Toronto, Mar. 17, 1838. (Two enclosures.)

403, pt. 2. Head to Glenelg. Sends memorandum on Stevenson's representation to Lord Paimerston respecting the Caroline affair. Grosvenor Square, June 26, 1838. (Enclosure follows. With it are numerous other documents on the whole subject of U. S. raids, etc., totalling about $80 \mathrm{ff}$.)

404, pt. I. Arthur to Glenelg. Cordial reception of the former at New York, reported attitude of the U. S. government, etc. New York, Mar. 9, I838. (Private.)

Same to same. No. 7. Trial of Sutherland, an instigator of one of the frontier raids. Toronto, Apr. 23, I838. (Enclosures fill over twothirds of this volume and are continued in about $25 \mathrm{ff}$. of pt. 2. Some of the evidence throws light upon the U. S. raids.)

404, pt. 2. Arthur to Glenelg. No. 8. Various remarks upon attitude of the U. S. government, lawless characters on the frontier, etc. Toronto, Apr. 24, 1838 .

Same to same. No. 9. Remarks on case and trial of Edward Alexander Theller, a state prisoner. Toronto, Apr. 25, I838. (Eight enclosures, some of which relate to occurrences on the U. S. side of the border.)

Same to same. No. II. Conduct of U. S. authorities and excitement in frontier towns of the U. S. Sends correspondence with Henry S. Fox on Aaron Vail's mission to Canada. Toronto, May I, I838. (Enclosure present.)

Same to same. No. I2. Does not think reduction of the militia force should be carried too far at present. Reasons. Toronto, May 2, I838. (Three enclosures.) 
Same to same. No. I3. Remarks upon his instructions to preserve a friendly attitude toward the U. S. Toronto, May 4,1838 .

Same to same. No. I4. Legal difficulties of proceeding against U. S. citizens taken in raids upon Canada. Asks for instructions. Toronto, May 5, I838. (Duplicate. One enclosure.)

Same to same. N'o. I7. Sends correspondence with Henry S. Fox regarding Francis Dawson, a British subject arrested in the $\mathrm{U}$. S. on a charge of being concerned in the destruction of the Caroline. Toronto, May I I, I838. (Enclosure present.)

405. Arthur to Glenelg. No. 22. Treats in detail the subject of punishment of prisoners, its effect in the U. S., border restlessness, etc. Toronto, May 30, I838. (Numerous enclosures on trials of American and Canadian prisoners give lists with comments, evidence, legal opinions, addresses, etc. This despatch and its enclosures fill the entire volume of $354 \mathrm{ff}$.)

406, pts. I and 2. In these two volumes (598 ff.) are Lieut.-Gov. Arthur's despatches to Lord Glenelg, with their numerous enclosures, during June and July, I838. At least two-thirds of this material bears upon relations with the U.S. Frontier attacks are the most important items, and there are many enclosures upon them. One despatch relates to Mackenzie's paper in New York and measures to suppress its circulation in Canada. Over half of pt. I is taken up with extracts from this paper.

Other subjects of prominence are the Sir Robert Peel, the Caroline, treatment of prisoners, Aaron Vail's mission, and the general questions of state of feeling in both countries and the attitude of their respective governments.

407, pt. I. Arthur to Glenelg. Sends report of Sullivan on the state of the province. Toronto, Aug. IO, I838. (Private. Enclosure takes up relations with the U.S., their trade, politics, etc., and is equal to nearly a volume, forming about a fourth of pt. I and one-half of pt. 2.)

407, pt. 2. Arthur to Glenelg. No. 58. Conments and explanations regarding provincial act to protect its inhabitants against lawless aggressions from subjects of foreign countries at peace with Her Majesty. Toronto, Aug. I I, I 838 . (Three enclosures.)

408 , pt. I. Arthur to Glenelg. No. 62. Sends two memorials from British subjects respecting their treatment in the U. S. on account of charges of being concerned in the destruction of the Caroline. Toronto, Sept. I8, ı838. (Enclosures follow.)

Same to same. No. 67. Relative to the destruction of the Sir Robert Peel. Toronto, Sept. 27, I838. (Several enclosures, the greater part being depositions.)

Same to same. Rumors of renewed projects of invasion along the frontier. Toronto, Sept. 29, I838. (Private. Separate despatch of Oct. I 2 touches upon this subject.)

409 , pt. I. Arthur to Glenelg. Believes that the whole frontier is overrun with "patriots", and that the U. S. government cannot or will not put them down. Toronto, Oct. 22, I838. (Private. No. 75, of the same date, with seven enclosures and numerous sub-enclosures, deals at length with these reports.)

Same to same. No. 78 . State of the province, preparations in the U. S. for invasion, and his opinion of the attitude of the U. S. authorities. Toronto, Oct. 30, I838. (Several enclosures.) 
Same to same. Plans of conspirators in the U. S., defense of the province, and possibilities of contests on the Lakes. Toronto, Oct. 3I, I838. (Confidential. Three enclosures.)

Same to same. No. 83. Relative to the size of armed vessels on the Lakes. Toronto, Oct. 30, 1838.

409, pt. 2. Arthur to Glenelg. No. 88. Sends letters from Henry S. Fox, communication from the latter to the U.S. government, and reports, etc., on the state of the U. S. frontier. Remarks. Toronto, Nov. I4, I838. (Enclosures follow.)

Same to same. No. 89. Invasion near Prescott by a force from New York. Comments. Toronto, Nov. I5, I838. (Two enclosures. Nos. 92,93 , and 94 are concerned with this raid and the attitude of the U. S. authorities. They contain numerous enclosures filling at least half of the volume.)

410, pt. I. Arthur to Glenelg. No. 99. Sends copy of a despatch to the minister at Washington, respecting an error in the President's proclamation of Nov. 2I. Toronto, Dec. 4, I838. (Enclosure follows.)

Same to same. No. I05. Account of and comments upon a frontier raid near Windsor. Toronto, Dec. I3, 1838. (Numerous enclosures.)

Same to same. No. Io6. Relative to sentence passed upon certain persons captured in the Prescott raid. Toronto, Dec. 13, 1838. (Eight enclosures.)

Same to same. Sends report of Col. Prince respecting the summary execution of certain persons captured in the recent invasion. Remarks. Toronto, Dec. 13, I838. (Confidential. Two enclosures.)

Same to same. Sends various depositions, etc., on the destruction of the Caroline, and remarks at length upon them. Toronto, Dec. $17,{ }_{1} 838$. (Confidential. Enclosures follow, and continue in pt. 2.)

410, pt. 2. Arthur to Glenelg. No. I I I. Prevalence of U. S. schoolmasters, who instruct their pupils in republican doctrines, etc. Toronto, Dec. I8, I838.

411, pt. I. John Barrow to Sir George Grey. Sends letter from Andrew Drew reporting the destruction of the Caroline. Admiralty, Feb. 27, I838. (Enclosure follows.)

W. Fox Strangways to the under-secretary of state, Colonial Department. Instructions on the questions of fugitive slaves in Canada and demands on various pretexts that they be given up. Foreign Office, Feb. 28, 1838 .

Law-officers to Lord Glenelg. Their opinion regarding the court-martial in the case of T. J. Sutherland, an American prisoner in Canada. Doctor's Commons, May 28, 1838 . (Immediate. Other communications of May 28, 31, June 7, 26, Aug. 2I, and Sept. I deal with questions of Americans captured in hostilities against Canada.)

412 , pt. I. Archibald McLean to Lord Glenelg. Comments on acts of the U. S. government with regard to invasions of Canada. New York, Jan. 8 , I 838 .

413, pt. I. Jan. I-Feb. 5, I839. The thirteen despatches in this volume are from Lieut.-Gov. Arthur to Lord Gleneig. Seven of them deal with prisoners captured in frontier attacks, and proceedings of the "patriots" and their sympathizers on the border. The numerous enclosures also relate to these attacks and to relations with the U.S. The enclosures in no. I 2 fill nearly half of pt. 2. 
413, pt. 2. Arthur to Glenelg. No. I3. Destruction of property of British subjects by U. S. invaders. Toronto, Feb. 5, 1839. (Five enclosures.)

Same to same. No. 32. Case of Howland Hastings, a British subject arrested in Detroit. Toronto, Feb. I, I839. (Eighteen enclosures.)

413, pt. 3. Arthur to Glenelg. No. 33. Comments at length upon enclosed despatch from the minister at Washington upon the relations of Canada and the U. S., and the disposal of American prisoners. Toronto, Feb. 19, r839. (Three enclosures.)

Same to same. No. 34. Believes Canada should not be dependent upon the U. S. for part of her military equipment. Toronto, Feb. 20, I839. (One enclosure.)

Same to same. No. 36. Sends copy of his despatch to the governor general on a British armed force on the frontier waters, and the pursuit of rebels beyond the boundary line. Toronto, Feb. 21, 1839. (Enclosure follows.)

Same to same. No. 42. Sends his speech on the opening of legislature. Toronto, Feb. 27, I839. (Enclosure takes up frontier attacks and general relations with the $U$. S.)

Same to same. No. 44. Relative to the conduct of Col. Prince toward prisoners taken in the Windsor raid. Toronto, Feb. 27, I839.

414, pt. I. Arthur to Glenelg. No. 47. Sends letter from Gov. Mason on the satisfactory termination of the case of Howland Hastings. Toronto, Mar. 2, I839. (Enclosure follows.)

Same to same. No. 49. Sends council minutes on disposal of certain Windsor and Prescott prisoners. Toronto, Mar. 5, r839. (Enclosures follow.)

Same to same. No. 55. No fresh movement on the frontier of Upper Canada has resulted from recent events in the disputed territory. Toronto, Mar. 7,1839 .

Same to same. No. 56. Quantity of cattle exported to the U. S. Comments. Toronto. Mar. I I, I839. (Six enclosures.)

414, pt. 2. Arthur to Glenelg. No. 66. Further remarks on the summary execution of four prisoners at IVindsor. Toronto, Mar. 30, r839. (Six enclosures. Confidential despatch of this date is upon the same topic.)

Same to same. No. 68. Tranquil state of the province and "general expectation and desire for war" on the U. S. frontier. Toronto, Mar. 30, 1839 .

415, pt. I. Arthur to Glenelg. No. 74. Transportation of prisoners, and relations with the U. S. Toronto, Apr. 2, 1839. (Confidential. Enclosed is despatch to Henry S. Fox.)

Same to same. No. 74. Relative to case of W. P. Smith, formerly assistant state geologist of Michigan, who claimed to have lost that position as a result of his actions to frustrate plots against Canada. Toronto, Apr. 2, I839.

Same to Normanby. No. 8o. Discharge of certain American prisoners. Toronto, Apr. Io, r839.

Same to same. Sends long report of a dinner given to Col. Prince. Comments. Toronto, Apr. rr, r839. (Private and confidential. Enclosure follows.)

415, pt. 2. Arthur to Normanby. No. 87. Proceedings of the provincial legislature since the beginning of the session. Toronto, Apr. I2, I839. (Duplicate. Touches upon raids, relations with the U. S., and expor- 
tation thither of cattle from Upper Canada. Among the enclosures are correspondence of Lieut.-Gov. Arthur and Henry S. Fox, and of the latter with the U. S. government.)

Same to same. No. 9o. Relative to release of twenty-two U. S. brigands. Toronto, Apr. I7, 1839. (Duplicate. One enclosure.)

Same to same. No. 94. Firing on the U. S. steamer United States at Prescott. Toronto, Apr. 24, 1839 . (Duplicate. Three enclosures.) 416, pt. I. Arthur to Normanby. No. 99. Outrages on the U. S. schooner Stephen Girard and the British steamboat Traveller. Toronto, May 7,1839 . (Nine enclosures.)

Same to same. No. Ioo. Reports further release of American prisoners. Toronto, May 7, I839. (Two enclosures.)

Same to same. Further proceedings on the execution of prisoners at Windsor. Toronto, May 8, 1839. (Confidential. Three enclosures.)

Same to same. No. IO2. Sends various documents. Toronto, May II, 1839. (Some of the enclosures relate to frontier raids, and relations with the U.S.)

Same to same. No. 105. Rumors of plans for invasion. Toronto, May I3, I839. (Two enclosures.)

416, pt. 2. Arthur to Normanby. No. I 13. Liberation of American prisoners and attack on the Stephen Girard. Toronto, May 18, I839. (Two enclosures.)

Same to same. Number of prisoners shot at Windsor. Toronto, May 18, I839. (Private. Duplicate.)

Same to same. No. II5. Discharge of Howland Hastings. Toronto, May I8, I839. (Duplicate.)

Same to same. No. 123. Sends memorial to the queen from colored subjects in Upper Canada. Toronto, May 23, 1839. (Enclosure asks for protection from claims of former owners.)

417 , pt. I. Arthur to Normanby. No. 126. Comments upon Griffin's mission to Albany on extradition matters. Toronto, June 6, i839. (Two enclosures.)

Same to same. No. 127. Sends documents regarding the firing on the steamboat United States. Toronto, June 7, 1839. (Five enclosures.)

Same to same. No. 132. Seizure and release of the U. S. schooner G.S. Weeks at Brockville. Remarks. Toronto, June 8, I839. (Nine enclosures.)

417, pt. 2. Arthur to Normanby. No. 147. Sends documents on the seizure and release of the G.S. Weeks. Toronto, June 29, 1839. (Three enclosures.)

418, pt. I. Arthur to Normanby. No. I49. Disaffection in the Newcastle and Midland districts, which were largely settled by persons from the U. S., the imprisonment of Mackenzie by U.S. authorities, etc. Toronto, July I, I839. (Several enclosures.)

Same to same. State of public feeling, dread of outbreaks on July 4, etc. Toronto, July 2, 1839 . (Confidential.)

Same to same. No. 163. Further remarks on the state of the province and of the frontier. Toronto, July 27,1839 . (Two enclosures.)

Same to same. No. 165. Extradition matter. Toronto, July 27, I839. (Two enclosures.)

418, pt. 2. Arthur to Normanby. No. I70. Violation of U. S. territory in capturing the pirate Kelly, and negotiations with U. S. authorities respecting the same. Toronto, July 27,1839 . (Nine enclosures.) 
419, pt. I. Arthur to Normanby. No. I76. Account of various frontier disturbances. Toronto, Aug. 21, 1839. (Several enclosures. No. I79, with three enclosures, is a continuation of no. 176. )

Same to same. No. I84. Extent of smuggling along the frontier. Recommends a reduction of the duty on tea imported from the U. S. Toronto, Sept. Io, I839.

Same to same. No. I9I. Frontier disturbances, rumors of plots and Russian agencies in the U. S. Toronto, Sept. I7, I839.

419 , pt. 2. Arthur to Normanby. No. I98. Comments on question of a convention with the U.S. for the mutual surrender of criminals. Toronto, Sept. $27,1839$.

Same to same. In continuation of despatch no. I9I. Toronto, Sept. 27, I839. (Confidential. Several enclosures, including correspondence with Henry S. Fox, and a report from a private agent at New York.)

420 , pt. I. Arthur to Normanby. No. 200. Sends memorandum on persons captured in attempts to invade the province. Toronto, Oct. I4, I 839 . (Enclosure follows.)

Same to same. Long account of "patriot" proceedings on the American frontier. Toronto, Oct. I5, I839. (Confidential. Seven enclosures.)

Same to same. Relative to Gen. Scott's alleged connection with the "patriots", and the nature of the employment of the Caroline. Toronto, Oct. 22, I839. (Confidential. Two enclosures.)

420 , pt. 2. Arthur to Russell. No. 217. Increase in U. S. military force on the frontier, etc. Toronto, Nov. I 5, I839. (Enclosed is correspondence of Lieut.-Gov. Arthur and Gen. Scott.)

Same to same. Relative to U. S. works of frontier defense. Toronto, Nov. I6, I839. (Confidential. Two enclosures.)

421. Arthur to Normanby. No. 146. Reports further proceedings in the case of Col. Prince and his summary execution of prisoners taken in a raid at Windsor. Toronto, June 29, I839. (Despatch and enclosures fill the entire volume of $352 \mathrm{ff}$.)

422. In this volume are I $34 \mathrm{ff}$. of correspondence between the Foreign Office and the Colonial Department. This covers I839 and includes diplomatic correspondence with the U.S. government. The chief subjects are claims for the destruction of the Sir Robert Peel, border outrages, the case of Howland Hastings, the schooner G. S. Weeks, imprisonment of Mackenzie and others in the U. S., need for extradition arrangements, and the firing upon a U. S. steamer at Prescott.

424, pt. 3. Samuel C. Johnston to Lord John Russell. Alleges ill treatment at the hands of U. S. authorities. New York, Aug., I839. (Accompanied by memorial and other enclosures.)

425, pt. 2. Chief Justice Robinson to Lord John Russell. Observations regarding proposed extradition arrangements with the $\mathrm{U} . \mathrm{S}$. Wandsworth, Nov. 29, I839.

Thomas Rolph to same. Remarks on petition of colored persons in Upper Canada respecting demands by U. S. authorities for their surrender. Cavendish Square [London], Sept. 24, I839. (Further letters on this topic on Nov. 3 and Dec. Io.)

426, pt. I. Arthur to Russell. No. 2. Sends acts of the last session and report of the attorney general upon each. Toronto, Mar. 2, I840. (A few touch upon trade relations with the U. S.) 
426, pt. 2. Arthur to Russell. No. 20. Sentiment in the province respecting diplomatic negotiations at Washington. Report from Buffalo shows that no hostile preparations are apparent. Toronto, Apr. I I, I840.

Same to same. No. 24. Attempt to destroy Brock's monument. Believes it the work of persons from the U. S. Toronto, Apr. 24, I840. (Several enclosures.)

Same to same. No. 3o. Relative to issuing presents to visiting Indians. Toronto, May 4, i840. (Several enclosures.)

427, pt. I. Arthur to Russell. No. 43. Attempt to burn a British vessel at Oswego, etc. Toronto, June 27, 1840.

427, pt. 2. Arthur to Russell. No. 6I. Firing of colored soldiers at Fort Erie upon U. S. steamboats. Toronto, Aug. I4, I840.

428. Arthur to Russell. No. 72. Immigration of Indians from the U. S. Details. Prevention by U. S. authorities of bands of 800 from coming, etc. Toronto, Oct. 6, I840. (Several enclosures.)

Same to same. No. 84. Remarks on the arrest of Alexander McLeod. Toronto, Dec. 2, I 840 .

429, pt. I. John Barrow to James Stephen. Decision of the U. S. government to build two steam-vessels for service on Lake Ontario. Admiralty, Jan. I7, I840.

J. Backhouse to same. Sends legal report on refusal of the U. S. to surrender an alleged criminal. Foreign Office, Jan. 8, i840. (Enclosure follows.)

Same to same. Sends copy of note to the U. S. minister on the case of the steamer United States. Foreign Office, Jan. I6, I840. (Enclosure follows.)

Same to same. Relative to firing on a U. S. steamer. Foreign Office, Jan. 29, I840. (One enclosure.)

430 , pt. 2. John Irving to James Stephen. Relative to emigration of free blacks from Canada to Trinidad. Understands there are I5,000 of them. Richmond Terrace, July $2 \mathrm{I}, \mathrm{I} 840$.

430, pt. 3. Thomas Rolph to Lord John Russell. Various remarks on colored population of Upper Canada, and demands of U. S. authorities for the surrender of former slaves. Woodford, Essex, Jan. 19, 1840. (Another letter on the same topic, Mar. I2.)

431, pts. I and 2. These volumes contain despatches from Lieut.-Gov. Arthur to Lord John Russell during the first quarter of $\mathrm{I} 84 \mathrm{I}$, and contain 527 $\mathrm{ff}$. At least two-thirds of this material relates to the case of Alexander McLeod. It comprises the correspondence of the lieutenant-governor with the British minister at Washington, and of the latter with the U. S. government, voluminous evidence, steps taken on behalf of McLeod, local feeling, and detailed accounts of proceedings in the case.

Besides the above, one despatch deals with immigration, and the numbers of those who went to the U.S.

$431 \mathrm{~A}$, pts. I, 2, and 3. John Macauley to Lieut.-Gov. Arthur. Detailed and lengthy report on the trade of Canada. Toronto, Mar. 2, I84I. (Takes up each article by itself, such as the tea-trade, corn-trade, etc. A good share of the report deals with commercial relations with the U. S. It covers $56 \mathrm{ff}$. and the enclosures fill the remainder of the three volumes which total $533 \mathrm{ff}$.) 


\section{RED VOLUMES OF DESPATCHES.}

26 A. Sydney to the governor of Quebec. Relative to preventing the importation of certain articles from the U. S. Whitehall, May 30,1785 .

125 A. Jan. I2-Dec. 27, I8I3. In this volume are eighteen despatches upon various topics connected with the War of 1812 , which are neither in $G$ nor in the calendared portion of $Q$. Of these fifteen are from Bathurst to Lieut.-Gen. Prevost, and three from the former to Col. Beckwith.

136 A. Jan. 20, I8I4-Sept. 30, 18I6. There are twenty-two despatches in this volume, which touch upon American matters, and which are neither in $\mathbf{G}$ nor in $\mathrm{Q}$. All are from the colonial secretary to governors general Prevost and Sherbrooke. By far the largest part relate to military affairs, both upon land and on the Lakes, but a few deal with Indian emigration from the U. S., claims of Americans for property at Moose Island and the passage of British subjects from the Maritime Provinces to the U. S.

151 A. Bathurst to Richmond. No. i8. Various remarks upon the Indian nations in the vicinity of Drummond's Island. Downing Street, Feb. 28, I8I9.

155 A. Bathurst to Dalhousie. Intercourse between Indians in the U. S. and British authorities in Canada. Downing Street, Aug. 15, I820.

Same to same. Certain documents claimed by New York. Remarks. Downing Street, Aug. 29, I821. (Repeated Oct. 30.)

242 C. Glenelg to Colborne. Rumored shipment of arms through the U. S. to Lower Canada. Downing Street, Dec. 9, 1837. (Confidential.)

256 A. Glenelg to Colborne. Rumor that Papineau has gone to the U. S. to obtain a particular kind of rifle. Downing Street, Jan. 20, I838. (Confidential.)

Same to same. Opinion of law-officers of the crown is that the destruction of the Caroline was justified by the circumstances of the case. Downing Street, Feb. 22, 1838. (Private and confidential.)

Same to Durham. No. 22. Asks for report on several points respecting the present state of the disputed territory to the east of Connecticut River. Downing Street, Apr. 22, I838.

Same to same. Sends memorandum from the Foreign Office of instances in which the U. S. government has pursued enemies or alleged criminals on neutral territory. Downing Street, May 9, I838. (Confidential. Enclosure missing.)

319 A. Bathurst to Drummond. Sends warrant authorizing the restoration of all territory, places, and possessions taken from the U. S. during the war. Downing Street, Apr. 5, I8I5. (Enclosure missing.)

Goulburn to J. Buchanan. Instructions regarding the encouragement of immigrants at New York to proceed to Canada, etc. Downing Street, July 7, i8r7.

337 A. Bathurst to Maitland. Remarks upon certain proceedings of Methodists aiming at the substitution of U. S. missionaries in Upper Canada in the place of those from Great Britain. Downing Street, July 24, I 821 .

Same to same. Complaint of a seizure of tobacco on Carleton Island by a British customs officer. Downing Street, Jan. I2, I822.

372 A. Huskisson to Maitland. No. I9. Relative to communication from the U. S. government on the need of a lighthouse on Long Point, Lake Erie. Downing Street, Mar. 26, I828. 


\section{SERIES S: SECRETARY OF STATE'S PAPERS.}

As a result of an order in Council of November, I903, various records prior to 1867 were removed from the Department of the Secretary of State to the Archives in I906. They are officially reported as 5756 volumes of registers and correspondence. The bulk of the collection, however, consists of loose papers, which have been arranged in portfolios according to various methods.

Correspondence of the provincial secretaries in Canada forms the bulk of the series. ${ }^{1}$ Other local correspondence is present for various reasons, either because it concerned local affairs, or because it came under one of the numerous activities of the department at one time.

Viewed as a unit the $\mathrm{S}$ series is concerned with local matters of the provinces now known as Quebec and Ontario. Local government, justice, customs, lands, appointments, etc., are only a few of the many topics for which valuable material exists in these files. Looked at from another aspect $\mathbf{S}$ presents matters that are only of provincial import in much greater detail than do $\mathbf{G}$ and $\mathbf{Q}$.

Documents relating to United States history in this series are comparatively few ; in fact during several periods they are entirely missing. This is noticeable for the years I840-1867, when administrative functions became more sharply defined, and as a result the correspondence on certain topics must be sought elsewhere.

It will be convenient to divide this mass in the following manner:

I. Registers and letter-books (out-letters).

2. Files for $1840-1867$ (in-letters).

3. Miscellaneous volumes and loose papers.

4. Records for Upper Canada, I792-I840, and for Lower Canada, I76I1840 .

5. Papers relating to Indian affairs.

I. For Upper Canarla there are registers and indexes of letters received, I82I-I867; letter-books of the provincial secretary, I840-I867; and 1etterbooks of the chief secretary and of the provincial secretary after the Union, I822-I842. Lower Canada is represented by registers and indexes of letters, petitions, etc., received, I786-I867, and by provincial letter-books for I828$1867 .^{2}$ As guides to the present location of documents the registers are of use only for the years I84I-I867. There are about I 50 registers and nearly the same number of letter-books. An examination of several of the latter revealed nothing which related to the United States beyond an occasional extradition case.

2. Correspondence received for the years I84I-I867 is arranged numerically under each year. Canada East and Canada West are separate series. These papers amount to about 2000 portfolios. The registers show no material for the American scholar beyond such minor and routine items as extra-

\footnotetext{
${ }^{1}$ Before the union of the two Canadas each province had its provincial secretary. The civil secretary to the governor general, sometimes known as the chief secretary, was an important official in the direction of local administration. After I84I local government underwent much change, and a secretary for the united province succeeded to many of the former duties of the civil secretary and the secretaries of Upper Canada and Lower Canada. In addition to this central official there continued secretaries for both Canada East (L. C.) and Canada West (U. C.) who were known as provincial secretaries but whose functions became much curtailed.

${ }^{3}$ There are a few exceptions to this general statement, but none of the special or odd volumes contain anything for United States history.
} 
dition cases, etc. Many of the papers docketed in the registers are missing from the files.

3. Official lists, minute-books, indexes, journals, volumes on public accounts, etc., form a miscellaneous section of about 550 volumes. A few books relate to applications for land by Loyalists, but they seem to be only duplicates or rearrangements of material in the $\mathrm{E}$ series. Apart from such, this material is strictly Canadian.

With these may be grouped three portfolios of loose papers. One is labelled "Political Situation in the Prov. of Quebec, I800-I8I2". It consists largely of correspondence of Jolin Richardson with H. W. Ryland, I800-18I3. Most of these letters deal with Jacobinism in Canada and the U. S., I800-I804. There are several reports of secret agents, and two letters of Richardson, written at Albany, Jan. 3I and Mar. 25, I8OI, on the political situation in the U. S. A few papers at the end deal with the beginnings of the War of ISI2. Another portfolio entitled "Fenian Raid" has two telegrams of Apr., I86I, on a threatened invasion of southern Illinois and a possibility of obtaining arms from Canada, and a letter and petition respecting the Fenian invasion of Canada in I870.

"L. C. Boundaries, I $763-1803$ " forms the title of a third portfolio. This contains among other items correspondence, orders in Council and miscellaneous documents on the evacuation of the western posts, the boundaries between Quebec on one side and New York, I768-1772, New Hampshire, I793, and Vermont, I792, on the other, the surveying of the branches of the Connecticut River, 1792, and papers of Joseph Bouchette, 1824 , on the differences of the commissioners under article $\mathrm{V}$. of the treaty of Ghent.

4. Under the present arrangement registers for the period before I84I are valueless as guides to the location of documents in the files. Most of these loose papers are grouped as "Sundries" for each province, but there have been special arrangements of certain parts, and some have also been grouped by subject. It will not be necessary to take up numerous divisions such as public accounts, justice, marriage bonds, school returns, etc., but only those parts that have any bearing upon United States history.

\section{Upper Canada.}

A few papers of an early date have been arranged under various classifications and placed in small, white-backed portfolios. Two of these are upon United Empire Loyalists. They relate largely to names to be inserted in or taken from the official list of Loyalists, and cover the period I798-I8I I.

Early land papers in this division contain some correspondence and petitions respecting lands for Loyalists.

The first portfolio of Indian papers, I794-I 806 , has a communication from Col. Claus to Pres. A. Grant, with five enclosures on hostile intentions of sundry Indian tribes toward the U.S. The second folder, I807-I808, contains several letters of Sir James Craig, Lieut.-Gov. Gore, Col. William Claus, Sir John Johnson, and correspondence of Lieut. Grant of the British army with Gov. Hull. These letters relate to Indians and the United States, the probable attitude of the former in case of war, etc.

\section{Sundries-Upper Canada.}

These are arranged chronologically in portfolios. An examination of them from the earliest date to the end of the War of I8I2, and from I 837 onward revealed a few items relating to the United States, which are given below. 
Agreement between Dearborn and Prevost for exchange of prisoners. Nov. I2, I8I2. (Copy.)

M. Elliott to William Claus. Arrival of deputation from Shawnees, Kickapoos, Winnebagoes, etc., from the Wabash, council held and its purport. Amherstburg, Feb. 3, I8I3.

General orders respecting head-money to be paid to Indians for the capture of Americans. Kingston, July 26, I813.

Gordon Drummond to Sir George Murray. Importation of provisions from the U. S. should be allowed for a time. Quebec, Apr. 29, I8I 5.

Evidence taken at the Jan. term of the Niagara general sessions, 1838 , in the case of the people of New York state $v$. Angus McLeod and eleven others for the murder of William Durfee and others at the burning of the Caroline. (Copy. 74 pp.)

Andrew Drew to Sir John Barrow. Account of the destruction of the Caroline. Chippewa, Jan. I, 1838 .

H. S. Fox to [Sir F. B. Head]. Relative to the destruction of the Caroline. Washington, Feb. I7, 1838. (Copy. Private and confidential. Followed by other despatches of Feb. 7 and I7, with enclosures of Fox's correspondence with Forsyth and Palmerston.)

During the period of the rebellion in Upper Canada there are also a few scattered letters on wild rumors of invasion, reported conditions along the frontier, etc. They are of little historical value, and have not been listed.

A separate division of "Rebellion Papers" for Upper Canada covers the period I837-I 840 . Ten portfolios are chiefly concerned with the legal aspects of the rebellion and its results. A small quantity of correspondence relates to raids at Prescott, the Short Hills, Philipsburg (L. C.), and the movements of the schooner Anne. Among the voluminous papers on trials for treason are some letters and petitions from citizens of the United States. One portfolio, consisting of duplicate despatches, is concerned with the McLeod case and the affair of the Caroline.

Four portfolios are filled with fragmentary records of Upper Canada imports and customs, I $820-1835$.

\section{Sundries-Lower Canada.}

Sundries for Lower Canada were examined for the same periods as those for Upper Canada. About one-third of the portfolio for Jan.-Feb., I809, is composed of correspondence of John Henry with $\mathrm{H}$. W. Ryland (the governor's secretary). The letters from Henry covering the time of his mission to Boston in 1809 are important, and very few are printed in the Report on Canadian Archives, I896. There is also a draft of his instructions. The remaining items relating to United States history in these folders are given below.

John Richardson to H. W. Ryland. Prospects of war with the U. S., and the acts of a secret agent. Montreal, Aug. 17, 1807 .

Memorial to Craig by certain Montreal merchants relating to alleged seizure of goods of the Michilimackinac Co. on Lake Ontario by U.S. authorities. Montreal, Oct. 20, 1808 . (Accompanied by correspondence, etc.)

[H. W. Ryland] to [John] Henry. The governor desires Henry to undertake a secret and confidential mission to Boston. Quebec, Jan. 26, I809. (Draft. Most secret and confidential.) 
William Lindsay to H. W. Ryland. Statements of imports from and exports to the U.S. through St. Johns. St. Johns, Jan. I3 and 17 , I8Io.

Report of the attorney general to the governor respecting a temporary act regulating trade with the $U$. S. Quebec, Feb. 7, r8Io.

J. Mondelet to Lewis Foy. Feeling in the U. S. over the reported intention of the new British chargé d'affaires to visit Canada before proceeding to his post at Washington. Montreal, Sept. I3, I8Io.

J. P. Morier (British chargé d'affaires) to Sir James Craig. Is satisfied that "this Government have determined upon the entire occupation of both the Floridas". Washington, Jan. 24, I8I I. (Copy.)

Brock to Prevost. Remarks on Indian attack upon the U. S. frontier. York, Dec. 3, I8I I.

A. J. Foster to Prevost. Alleged counterfeiting of U. S. money in Canada. Washington, Feb. 20, I8I2. (Two enclosures.)

Same to same. Remarks on the disclosure of John Henry's secret mission to the U. S. in I8o8. Washington, Mar. Io, I8I2.

Same to same. The situation in the U. S. Washington, June 2, I8I2. (Followed by letters of June 9 , July 18 , and 20 respecting the war.)

Same to same. Sends copies of his correspondence with Monroe on alleged British instigation of Indian attacks upon the U. S. New York, July I0, I8I2. (Two enclosures.)

Anthony St. John Baker (British chargé d'affaires) to same. Professed inclination of the U.S. government toward a termination of hostilities, etc. Washington, Aug. ro, r812. (Secret and confidential.)

J. Ogden to John Taylor. Details of the battle of Queenston Heights. Montreal, Oct. 22, I8I2.

General order on excliange of prisoners. Quebec, Feb. 8, I8I3. (A few accompanying papers relate to the same topic.)

"Rebellion Papers" for Lower Canada are in twenty-eight portfolios, the first of which contains a considerable quantity of miscellaneous documents on acts of the rebels and of their sympathizers in the United States.

Nearly 300 portfolios contain land papers relating to Lower Canada. These are mainly arranged by townships, and extend from the beginning of British rule to 184 I. A little Loyalist material may be found among these.

Ordinances of Quebec, I764-I79I, fill twenty portfolios, while the proclamations for I $785-1839$ are contained in forty-four.

5. The most important portion of the $\mathbf{S}$ series for United States history is that devoted to Indian affairs. Fifty-six portfolios are allotted to Lower Canada, and extend from I76I to I88I, while Upper Canada has forty-six, covering the period $1787-1866$. In reality this distinction is somewhat artificial, nor are the documents always assorted correctly. They are classified as a subdivision of the "Sundries", but both their origin and their character plead for their recognition as a separate unit. The explanation as to why such papers occur in the $S$ series at all is that Indian affairs were for the period I867-1873 under the control of the Department of the Secretary of State.

1761-1774. A large portfolio containing very important material for this period. It is fullest for the time of Pontiac's conspiracy, upon which 
there are minutes of councils held with the Indians, correspondence between Amherst and Johnson, etc.

A copy of a despatch from the Lords of Trade to John Stuart (superintendent of Indian affairs for the southern district), July Io, I 764 , is accompanied by a plan for the future management of Indian affairs. Another plan bears the date 1768 .

Miscellaneous correspondence, proclamations, minutes of Indian councils, and journals of McKee, I773-1774, complete the folder. Very few documents relate solely to Quebec.

1775-1787. About a third of this portfolio relates to the U.S. Affairs in the west, particularly Michilimackinac, Indian trade, the treaty at Fort Stanwix, Oct. 22, 1784, and councils form the chief topics.

One paper gives the numbers of Indians at Detroit and places depending thereon in 1782 .

1788-1791. At least one-third of this portfolio deals with councils held with the Indians at the Great Miamis and Buffalo Creek, the treaty at Fort Harmar, Indian affairs at Michilimackinac, and Indian trade.

1788-1791. Folder of papers in the case of Dease and Ainse. They relate principally to Michilimackinac, but some are of value for trade and the western Indians generally.

1792-1800. This portfolio contains a good deal of material upon the treaty of Greenville, Indian affairs at Michilimackinac, and a purchase of Indian lands by New York. Letters of McKee, Dorchester, Knox, Pickering, and Brant are prominent features.

1797. A few letters in this folder relate to Brant's conduct and speeches at Philadelphia. The most important is from Robert Liston to Lieut.Gen. Prescott, Philadelphia, Apr. 8, I797.

1798-1810. T. McKee to Capt. Claus. Relative to complaint of the U. S. government that the former's father had advised the Shawnees to get a modification of the treaty of Greenville. Amherstburg, Aug. I9, I 799 .

1787-1800. At least half of this portfolio relates to the U. S., most of the material covering the years I793-I795 inclusive. For the council held at the foot of the Miami Rapids in 1793 there are speeches of the general council to the U. S. commissioners, July 27 and Aug. I3, the reply of the latter, Aug. I6, Brant's journal of proceedings, May I7-June 9, correspondence, etc. Material on later councils and treaties is present, though less abundantly.

Letters of Matthew Elliott, Chapin, Timothy Pickering, Brant, Simcoe, Dorchester, Prideaux Selby, and reports of Indian affairs in various quarters are other features of note.

1792-1807. In this portfolio are a few minor items relating to western posts, and a reply of the Six Nations to a speech of Gen. Knox, delivered at the council held at Buffalo Creek in I794.

1800-1813. A few miscellaneous papers throw light upon the conduct of the western Indians during the earlier part of the War of I8I2.

1814. John Askin to William Claus. News of Prairie du Chien and the westward country in general. Michilimackinac, Feb. 4, I8I4.

Same to Sir John Johnson. Various items respecting that region. Michilimackinac, June I, I8I4.

R. Dickson to Sir John Johnson. Movements of the Sacs, Lieut.-Col. McDouall's speech, etc. Michilimackinac, June I8, I8r4. 
Same to same. McKay's expedition for the Mississippi, intelligence received from Indians, etc. Michilimackinac, July 12, I8I4.

Large portfolio containing Loyalist lists for various parts of Upper Canada. Some relate to the general list; a considerable number are for the Home and Midland districts. This belongs to no series at present, but the material apparently comes from series S. Most of the dates are before 1790 .

\section{MisCELLANEOUS COLLECTIONS.}

\section{SERIES FI.}

In November, I907, the Department of Finance sent to the Archives about twenty-seven volumes, etc., of records which deal principally with the financial side of land matters, the Welland Canal and other matters relating to navigation. There is no material for United States history.

\section{SERIES MD.}

In the manuscript room are about 240 volumes and 262 portfolios received from the Department of Militia and Defense. Nearly all of these have arrived since Igo8. All of these documents are concerned with militia matters, and the dates range from I8I 2 to 1867 .

In addition there are over 2000 portfolios upstairs, most of which are relatively modern. With the exception of a few items regarding the Canadian militia during the Fenian raids these documents contain nothing for United States history. Many of the volumes are registers of files in the office of the deputy assistant adjutant-general, and these records previous to July, I882, were destroyed by order of General Herbert.

\section{RESERVED PAPERS.}

Apart from the collections in the manuscript room at the Archives there is a considerable quantity of documents which may be said to form a reserved class. They are not available for ordinary historical investigations, and certain portions, for obvious reasons, are practically confined to use in diplomatic negotiations. Through the kindness of the archivist an examination of these records was permitted. The notes given below are of course limited, but it is hoped they are full enough to afford a good general idea as to the contents of this class of documents.

It will be convenient to divide this material into four parts:

I. Indian records, the greater portion of which relate to the régimes of the commissioners at Albany and of Sir William Johnson.

2. Shelburne papers. The originals of these manuscripts form part of the Lansdowne collection in England, and nearly all of them are calendared in pp. 21 5-26o passim of an appendix to the fifth report of the British Historical Manuscripts Commission.

3. Documents copied in France. These are confined to the years I7791783 inclusive, and relate chiefly to treaty negotiations centring at Paris during this period. They are of great value for relations of the United States and France and for everything connected with the peace of I783. Correspondence of Vergennes with the French diplomatic representative in the United States, letters of Franklin to various persons, treaty drafts, etc., are some of the chief items. These papers were copied from two series among 
the records of the Ministère des Affaires Etrangères at Paris, viz., "Angleterre, Correspondance Politique", vols. 537-541 inclusive, and "Fonds EtatsUnis, Correspondance Politique", vols. 7, 8, 19-25 inclusive, and 27. A full treatment of this material will be found in W. G. Leland's forthcoming Guide to the Materials for United States History in the Archives of Paris. Vols. 7 and 8 are calendared in Can. Arch. Rept., I912, pp. I78-195.

4. Miscellaneots. With the exception of three portfolios of confidential despatches and the Grey and Elgin documents, which are originals, all material in this division has been copied from originals in England, of which nearly all are at the Public Record Office. At the time when examined, several portfolios bore numbers in the $\mathbf{M}$ series, but as they related to the fisheries they were kept apart from the remainder of the series. They are now no longer in that series.

\section{Indian Affairs.}

Records of Indian affairs form one of the most important portions of the reserved material. They are all originals, and consist of the following:

Two large folio volumes of minutes of the "Commissioners of the Indian affairs" at Albany. Jan., I723-July, 1748.

Five large folio volumes of "Indian records", or minutes of Indian affairs under Sir William Johnson, beginning with a copy of his commission from Braddock in May, I755, and ending with the treaty of Fort Stanwix, Nov. 5, I768. One volume, for the period Apr., I759-Jan., $176 \mathrm{I}$, is missing.

One volume of minutes of Indian affairs. July I7, I779-Apr. 23, I780. Rough minutes of the council with "Pondiac", beginning July 22, I 766. Minutes of Indian affairs under Guy Johnson. Oct. I, I $774-$ Mar. 25, I775. One folio volume of minutes of councils held at Detroit with various Indian tribes. Apr. 26, 178I-Oct. 22, I783.

All of these records before I774 were taken to Canada by the Johnson family at the time of the Revolution, and for many years were in the office of the secretary of Indian affairs at Montreal. Their importance can hardly be overestimated. Records of councils held with the Indians, intelligence conveyed by the latter, and correspondence are some of the chief features of these volumes. Minutes of Indian affairs during the Revolution are also of great value for that period.

\section{Shelburne Papers.}

M 480. Letters of G. Croghan, P. Lyman, Maj.-Gen. Gage, Sir William Johnson, and miscellaneous documents relating principally to the Illinois country and Indian affairs. I767.

M 781. Correspondence and miscellaneous documents, chiefly on Newfoundland and Labrador fisheries. I782-I794.

M $781 \mathrm{~A}$. Unsigned and undated hints on the government of the colonies; reasons for establishing a British colony at the Illinois; observations relating to the boundaries of Carolina; thoughts on Indian affairs; two letters from S. Wharton relating to the Indian boundaries; B. Frobisher's observations on the Indian trade, Dec., I766; Shelburne's observations on a plan for Indian administration, etc. I $763-1767$.

A large bundle, containing letters of Oswald, Shelburne, Franklin, Vergennes, Grenville, Fox, Fitzherbert, treaty drafts, memoranda, etc. The chief features are the correspondence of Oswald, Strachey, and Fitzherbert with the British Foreign Office. This material covers a large part of $I 782$ and extends to Feb. 9, 1783 . It is very full respecting 
negotiations at Paris during this period. The originals are in Foreign Otfice, Miscellaneous, vol. 563, and Foreign Office, France, vol. 2 , at the British Public Record Office, and in vol. 71 of the Shelburne MSS.

Portfolio containing letters of Franklin, Vergennes, Thomas Walpole, and others respecting the war, peace negotiations, etc. I780-1783.

Portfolio containing correspondence of Shelburne with Fitzherbert, Jan. 5-Mar. 8, 1783, Vergennes, Sept. 6, 1782-Jan. 24, 1783, Rayneval, Sept. Io, 1782-Mar. 20, 1783 , drafts of preliminaries, and a copy of the provisional treaty, Nov. 30,1782 .

Portfolio of letters of Oswald, Franklin, and others, copies of proceedings of Congress, and numerous memoranda of Shelburne. Relates to treaty negotiations, the peace, trade, and the British colonial theory. Most of the dates are in 1783 .

Portfolio of correspondence and miscellaneous documents relating chiefly to Pennsylvania, Indian land claims, and the western country. I7551769. (A note states that these papers were copied for Professor Alvord.)

\section{Miscellaneous.}

M 764-767 inclusive, 771 A, 772, 778, $778 \mathrm{~A}$ and 792 consist of correspondence-chiefly of governors and other officials with Downing Streetrelating to the Labrador boundary, Newfoundland, the Magdalen Islands, and the fisheries. They extend from I 763 to 1844 .

M 778 B. Correspondence of Newfoundland officials with the Board of Trade. 17 I $2-17$ I 5 .

M 778 C. Minutes of the Board of Trade for the same period, containing some correspondence.

M 778 D. Correspondence copied largely from Colonial Correspondence, Nerefoundland, at the Public Record Office. I84I-I850. (These three numbers are largely concerned with the fisheries.)

M $778 \mathrm{H}$. Letters of Oswald and Grenville to Fox and Shelburne, and of Grantham to Fitzherbert, and a draft of Grenville's instructions, Apr. 30, r782. Grenville's letters recount conversations with Franklin and Vergennes. This portfolio covers the period July 3I-Dec. 26 , I 782 . (Copied from vol. 2 of the series Foreign Office, France, at the Public Record Office.)

M 771. Newfoundland correspondence, largely on the fisheries and smuggling. $\mathrm{r}_{7} 8_{5-1} 8_{3} \mathrm{I}$.

M 773. Correspondence relating to the fisheries. I837-I838.

M 768. Correspondence on Newfoundland and Labrador fisheries, and United States fishermen. I773-I8I8. (Copied chiefly from Colonial Correspondence, Nezifoundland.)

Portfolio containing correspondence on the fisheries. I8I5-I820. (Copied from Colonial Correspondence, Nowa Scotia and Cape Breton, C. O. $217: 56-62,94-98$.

Five portfolios of correspondence and miscellaneous documents, copied from the series Foreign Office, America at the Public Record Office, relate to fisheries, trade, capture and detention of vessels, the convention of $\mathrm{r} 8 \mathrm{I} 8$, etc. I79r-I84I.

M 652-653. Oswald Correspondence.

"Part I. Instructions to the Earl of Carlisle and others, Commissioners appointed for quieting disorders in certain British North American Provinces." r 778 . 
"Part II. Extracts from the Foreign Office Correspondence relating to the cession in 1783 to the United States of America of that portion of the former Province of Quebec south of the Great Lakes." (Two small numbers.)

Five volumes of private letters from Lord Elgin (governor general of Br. N. America) to Lord Grey. I847-I852. They contain a good deal respecting reciprocity, the economic situation in Canada and the U.S., and annexation sentiment in the former. Reciprocal immigration and emigration, fugitive slaves, and Elgin's journey to Boston, etc., are other topics of interest to Americans. The letters also show what close attention was paid to Congressional happenings and the general political situation in the U. S. Clippings from New York papers frequently occur among the enclosures. A calendar of the first two of these volumes is printed in the Archives Report for Igro, pp. 74-84.

Two volumes of private letters from Lord Grey to Lord Elgin furnish replies to the foregoing item. They cover the period I846-Feb. 20, 1852 .

A long statement of Lord Grey on recent British colonial policy and detailed comments of Lord Elgin upon it are each bound as a small volume. Reciprccity is one of the subjects of discussion.

These Grey-Elgin documents have been under special reservation. A collection based on them, entitled Correspondence between Lord Elgin and Lord Grey on the Affairs of Canada, edited by Dr. Arthur G. Doughty, Dominion Archivist, and Professor Adam Shortt, has just been published (London and New York, I9I3).

Two portfolios of confidential despatches from the Secretary of State to the governor general, I 845 -I 866 , and one portfolio of drafts of confidential despatches from Sir Edmund Head, Lord Monck, and Sir John Michel to the colonial secretary in reply, covering the period $185^{6-}$ I866.

Reciprocity, Confederate agents in Canada, the St. Albans raid, rumors of intended invasions of Canada during the Civil War, naval armaments on the Lakes, Fenian raids, the Alabama, and the Shenandoah form the chief U. S. items.

\section{ASKIN PAPERS.}

The Askin collection was purchased from Alexander Henry Askin of Walkerville, Ontario, and was received at the Archives in 1907. These papers of the Askin family ${ }^{1}$ fill thirty-four portfolios, and the dates range from 1774 to I86I.

Correspondence in this collection comprises twenty-three portfolios, of which the first two contain the letters of John Askin, sr., I786-18I8. These are arranged alphabetically by names of the writers. Letters of various members of the Askin family to each other, and communications received from friends and traders, form the bulk of the correspondence. Since the Askins were concerned in trade, Indian affairs, civil administration, and military operations in the West, these various activities are reflected in the documents penned by them or their correspondents. A large part of these papers

\footnotetext{
${ }^{1}$ The Askin family was originally Scottish and was called Erskine. This name was changed to Askin when they fled to Ireland for safety and settled in the vicinity of Strabane. A second emigration brought some to America. Here John Askin, sr.. became a western trader, with headquarters at Detroit. The final settlement was at Strabane near Sandwich, Ontario, named thus in memory of the earlier Irish home.
} 
are of no value except for biography, for they deal only with personal matters. Many also which relate to western trade are concerned with routine matters, such as the collection of debts, freight of goods, etc. By a study of these in the mass, lowever, much may be learned regarding methods, prices, and many other details of operations whose Canadian range was from Montreal to Detroit and Michilimackinac. Some of this correspondence is with Vigo and others at Vincennes, and shows the ramifications of trade as far as the Illinois country.

Material on western Indians is much less than one would expect. Practically all the records of John Askin's part in Indian administration are segregated in other series in the manuscript room.

Some members of the family were interested in western lands, both in Michigan and in Upper Canada. The correspondence shows to what extent they speculated in Michigan lands, and their difficulties with land laws and land officials.

Two portfolios contain papers relating to military affairs, I787-I838. The first is chiefly concerned with Detroit and Essex militia up to I8og. In the second is some important material on the War of 1812 . Fragments of a diary of Charles Askin afford valuable information. One portion for July 24-Sept. I5, I8I2, relates to military operations on the Detroit River centring about the surrender of Detroit, and another part for May 25-July II, I8I3, deals with actions along the Niagara frontier, including the battle of Beaver Dams. Among miscellaneous correspondence are accounts of the battle of Queenston Heights, the fall of Chicago, a report at second hand of Winchester's defeat at the Raisin, the attempt against Fort Wayne, etc.

For later years parts of a diary of Charles Askin for Dec. 23-Dec. 26, I 837 , and Feb. I8-June 4, I 838 , relate to military operations on the Detroit River frontier.

One portfolio of diaries, I774-I850, five of accounts, receipts, and other routine financial papers, and three of miscellaneous documents, of which a few relate to Detroit chimneys, I79r, complete this collection.

\section{BAGOT PAPERS.}

These are copies of a portion of the papers of Sir Charles Bagot, British minister to the United States, I8I5-I820, and governor general of Canada, I84I-I843. The originals are at Levens Hall. Lists are given in Archives Report for I9I0, pp. $28-50$. Originals of part of the same collection are in series M. The portfolios are unpaged, but average about 200 folios. Each bears on the back an indication of the volumes in England from which its contents was copied.

Portfolio I. (vols. I.-III.) covers the period July, I8I6-I8I9. The greater part of the contents of the original letter-books was not copied as the despatches are among papers of the British Foreign Office. What remains relates chiefly to negotiations upon the fisheries, British consuls, the attitude to be taken by both nations toward various political movements in South America, alleged acts of piracy, personal matters, etc. The despatches are from Bagot to the British Secretary for Foreign Affairs and to the undersecretary.

The second portfolio (vol. IV.) is divided into two parts. The first contains notes from Bagot to the Secretary of State of the United States from Mar. I9, I8I6, to Apr. 6, I8I9. The subjects under discussion are the conduct of the commander of the U. S. sloop Peacock, the release of colored 
persons captured during the late war, several seizures, and various matters respecting trade relations, negotiations upon fishery questions, the hostile attitude of certain Indian tribes toward the United States, naval armaments on the Lakes, alleged enlistment of British deserters in the United States army, sale of lands in the Mississippi territory that were granted by the British government in West Florida and guaranteed under the treaty of $I_{783}$, American privateers, and the delivery of islands in Passamaquoddy Bay to the United States.

Part II. of this portfolio extends from Mar. I9 to Dec. 30, I8I6, and consists of replies to part of the above. Enclosures are missing in part I., but are usually present in part II. Vol. V. continues these notes from the United States Secretary of State to Bagot to the end of I8I8.

Vol. VI. is nearly a copy of $\mathbf{M} \mathbf{1 5 7}$. Some secret correspondence is omitted in the latter, however, the most important subject being the fortifications erected by the United States on Lake Champlain, which ultimately proved to be in British territory.

Vol. VII. has letters from Bagot to British consuls, members of commercial firms, and private individuals, Apr. 27, 1816, to Apr. I8, ı818. Consular affairs, such as alleged enlistments of British deserters in the U. S. army, seizures of goods, complaints of individuals on a variety of topics, trade regulations, etc., are the main constituents. At the end are a few letters of Thomas Barclay to Bagot, regarding islands in Passamaquoddy Bay, and United States fortifications on Canadian soil.

One small unnumbered portfolio has some correspondence of the British Foreign Office with Bagot for I8I7-I818 on certain questions and negotiations arising out of the treaty of Ghent. Another letter of Thomas Barclay deals with United States fortifications on Lake Champlain. There is also a list of Bagot papers which are to be found among the Foreign Office papers at the Public Record Office in London, which relate to the treaty of Ghent. According to a note originals of all the papers in the above portfolio are in the Public Record Office.

Seven portfolios contain correspondence of Sir Charles Bagot for I820I824, during the period when he was British ambassador at St. Petersiurg.

\section{DURHAM PAPERS.}

These are portions of the papers of the Earl of Durham which relate to his administration in Canada, 1838 . They have been received since 1904 , and are arranged in twenty-one portfolios, each of which contains one or more "Parts". A calendar, in French and English, forms the first portfolio.

Nearly all of the items bearing on United States history in this collection may also be found in the $\mathrm{Q}$ series $(q . v$.). As the latter is composed solely of copies, while the Durham papers are largely originals, for certain documents it would be preferable to consult the latter.

In part VII. ("International"), May I0, I837-Aug. I4, I838, are several despatches from the British minister at Washington to Palmerston on the Northeast Boundary, Canadian rebels in the United States and the part taken by United States citizens on their behalf. Alleged outrages by United States fishermen, and the naval forces on the Lakes are minor topics in this section.

Part VIII. ("Treasons and Conspiracies"), covering the period May 29Oct. 24, 1838, contains some miscellaneous documents on rumors of plots in the United States against Canada, while part XII., which contains " Military Correspondence", has a few papers on the same subject. 
Part XIII. relates to "Boundary Troubles" within the dates Mar.-Oct., 1838. The chief item is furnished by letters from Lieut.-Gov. Harvey of New Brunswick to Durham. These are duplicated largely if not wholly in series $\mathrm{G}$ and $\mathrm{Q}$.

\section{RAYMIOND COLLECTION.}

These originals and certified copies of documents relating to the Northeast Boundary were recently obtained from Archdeacon Raymond of Halifax. In point of dates and subject matter most of them rightly should precede those volumes on the international boundary which are in series $\mathbf{M}$. The first octavo portfolio contains the following originals:

Field book of the survey of the river Chibnitkook or Cheputnaticook by John Harris, July 5-Sept. 30, I797.

Journal of the survey of the river Magaguadavic, Sept. I4, I796-Sept. 20, I797. (Copy by John Peters, jr.)

Field book of the survey of the Nagaguadavic by D. Campbell and John Peters, jr., May 29-Aug. 24, I797.

A second octavo folder or portfolio has the note-books listed below. They are copies, and average about Ioo pp. each.

One book of eight letters of Ward Chipman (British agent) to the provincial agent in London, Lieut.-Gov. Carleton, Sir John Wentworth, and the provincial secretary, and one letter from the provincial agent in reply. This correspondence relates to the St. Croix boundary, and extends from Aug. I2, I796, to Aug. 6, I799.

Two books of correspondence of Ward Chipman (British agent) with Joseph Bouchette (British surveyor), John Johnson (U. S. surveyor), Capt. Cairnes, Colin Campbell, etc., on a survey of the western boundary of New Brunswick in ISI7. The dates extend from the latter part of I8I6 to I828, but there is little of historical value after I8I8. Enclosures are sometimes important, such as a report of John Johnson on the joint survey.

One book containing notes by W. O. R[aymond], lists of papers, and correspondence on the boundary case at the Hague, I828-I83I. The letters are chiefly between IVard Chipman, the British under-secretary for foreign affairs, and Dr. Tiarks.

One small portfolio of original papers, consisting of memorials, statements, and miscellaneous correspondence relating to the Northeast Boundary. I7 83 - I 827 .

Nearly all of the remaining papers of this collection are official records of the commissions under the treaties of I794 and I8I4. Those coming under the fifth article of Jay's treaty are as follows:

\section{Jay's Treaty, Art. v.}

Journal of the proceedings of the commissioners appointed pursuant to article five of the treaty of amity, commerce, and navigation between $\mathrm{His}$ Britannic Majesty and the U. S. of America. Aug. 3o, I796-Oct. 25, I798. (I 47 pp.)

The claim of the U. S. to the Magaguadavic as the St. Croix boundary, stated by their agent James Sullivan. I797. (About 200 pp.)

Rejoinder of James Sullivan to the reply of the British agent. (Filed with the secretary of the board of commissioners on June I4, I798. $553 \mathrm{pp}$.)

"Appendix to Sup. Argument." Volume of documents, evidently an appendix to an argument of the U. S. agent under the treaty of 1794 . (268 pp.) 


\section{Treaty of Ghent, Art. IV.}

Journal of the proceedings of the commissioners under the fourth article of the treaty of Ghent. Sept. 23, I8I6-Nov. 24, I817. (Copy of the original journal, attested by A. Barclay. 73 pp.)

Certified copies of certain Nova Scotia land grants, licenses, etc. I765-I784. (Copied in 1816.32 pp.)

Memorial of the agent of the U. S. in support of their claim to the islands in the Bay of Passamaquoddy and to Grand Menan in the Bay of Fundy. (Copy attested June 17, I817. 459 pp.)

Appendix to the memorial of the agent of the U.S. (Certified copy of the original filed June 4 , I8I 7.98 pp.)

Memorials of the British agent on the islands in Passamaquoddy Bay and the island of Grand Menan. Sept. 24, 1816, and June II, I8I7. (I 35 pp.)

Appendix to memorial of the British agent in reply to that of the agent of the U. S. regarding islands in Passamaquoddy Bay and that of Grand Menan. (Filed Sept. 29, I817. Attested copy. I4 pp.)

Memorial of the British agent in reply to that of the U. S. agent respecting the fourth article of the treaty of Ghent. Sept. 26, 1817. (260 pp.)

Reply to the first memorial of the British agent, by James Austin, U. S. agent under the fourth article of the treaty of Ghent. (Filed Oct. I, I8I7. Attested copy. I86 pp.)

\section{Treaty of Ghent, Art. V.}

Journal of the commissioners under the fifth article of the treaty of Ghent. Aug. I-I4, I82I. (48 pp.)

Memorials of the British agent under the fifth article of the treaty of Ghent. I 820 and I82I. (Pp. 31 and 26.)

The claim of the U. S. under the fifth article of the treaty of Ghent. (I I pp.)

The reply of the British agent to the claim of the U. S. under the fifth article of the treaty of Ghent. Aug. 2I, I82I. (426 pp.)

Observations of the British agent upon the answer of the agent of the $U$. $\mathrm{S}$. to the claim and opening argument on the British side. Sept. 25, I 82 I. (37 pp.)

Report of the British commissioner under the fifth article of the treaty of Ghent. (324 pp.)

Duplicate report of the U. S. commissioner under the fifth article of the treaty of Ghent. (68 pp. Three copies.)

In addition to the above, two portfolios contain the printed records of the convention of Sept. 29, 1827, for referring to arbitration the disputed points under the fifth article of the treaty of Ghent. These parliamentary papers are entitled Correspondence relating to the North American Boundary, $1838-1840$.

\section{SELKIRK PAPERS.}

This collection, of which so far seventy-nine portfolios have been copied, centres about the settlement at the forks of the Red River and the Assiniboine. The dates run from 1803 to 1870 . The collection contains nothing for United States history. A calendar is being compiled. The papers are copied from the originals in the possession of Captain Hope at St. Mary's Isle, Kirkcudbright, Scotland. 


\section{DEPARTMENT OF THE SECRETARY OF STATE.}

By virtue of the order in Council of November, I903, a large portion of the records of historic importance possessed by this department were transferred to the Dominion Archives, where they form series S. But among material prior to I 867 not removed, is a series of registers of proclamations covering the period Oct. 7, 1763-July I, I867. These are copied by hand into large folio volumes. Those at the Archives are original copies. Among other topics are found fishery questions, aliens, the announcement of treaties, proclamations warning certain persons to leave the country, etc. It would be well for investigators of diplomatic and trade relations to consult the index to these proclamations for material which may possibly not be found at the Archives.

There is also a series of twenty-six indexes-one for each letter-to Upper Canada land grants, I790-I825. The patents themselves are presumably in the possession of the Department of Crown Lands, of Ontario. 


\section{DEPARTMENT OF INDIAN AFFAIRS.}

The commissioners appointed to investigate the state of the public records visited this Department in 1897 , and recommended that certain documents be removed to a central archives building. This was effected by the order in Council of November, IgO3. These old records were not numerous, and have been briefly described among the reserved documents at the Dominion Archives. There are many files of historic value, however, which were not transferred. Only a relatively small portion of these relate to United States history. All inquiries should be addressed to the deputy superintendent-general of Indian affairs, Ottawa.

In one corner of a room largely devoted to records of the department are a number of large portfolios, or, more properly, large pasteboard cartons, which are filled with loose papers. These were examined to the close of the War of I8I2. The first, marked "I $765-1793$ ", contains the following material relating to the United States :

1765-1793. Minutes of Indian affairs. Mar. I-July 28, I765. There is also a considerable quantity of minutes of various dates, a few as early as 1753 and 1756 . Those for $1770-1772$ are the fullest. These minutes are similar to those in the volumes at the Archives, and evidently are unbound fragments.

Instructions to Albert Vanslyke going to the Six Nations. Fort Johnson, Mar. 23, 1756.

Extract from the proceedings with the New England Indians on their way to Oneida, where the Six Nations had provided an asylum for them. Guy Park, Mar. 25-Apr. 8, I775.

Copy of Haldimand's grant to the Six Nations. Oct. 25, I 784.

Speech delivered at the court house at Wackitumekie by Piteasewa, a speaker of the Shawnees, to American messengers. Nov. 8, 1785.

Letter from John Johnson to Alexander McKee, on the western Indians, etc. Black Rock, Sept. 2, I787.

Transactions of the council at Muskingum between Gov. St. Clair and the Indians. Dec. I3, I788-Jan. 9, I789. (Two copies.)

Speeches of Cornplanter (Seneca), the President of the U. S., etc. June, I79I. The speech of Cornplanter is long, and is addressed to "Fathers of the Quaker State".

Copy of a speech of the Shawnees, Delawares, Ottawas, Chippewas, and other western tribes to Capt. Mathew Elliott. Miami River, May i6, I792.

Proceedings of a general council held at the Glaize with severa! Indian tribes. Sept. 30-Oct. 9, I 792.

Letter from G. Welbank to Alexander McKee, dated Creek Nation, Jan. I6, I793, dealing with the situation at the south with regard to Indians, especially Cherokees, Spain, trade matters, the treaty obtained by Gov. Blount in July, I79I, the Cumberland and Holston settlements, etc. Another letter from Welbank, Old Town, Creek Nation, Feb. 6, I793, deals with southern Indians, and Indian speeches delivered at Coweta in Apr. and May of I793 are also present. 
Letter of G. Lamothe, on the situation in his part of the country. Mackinac, June 12, 1793 .

Address to McKee by six Quakers at Detroit. June I9, 1793.

Several letters to McKee from England (Detroit), Chew (Montreal), Coffin, Duggan, and others are similar in character to those among the Claus papers in series $\mathbf{M}$ at the Archives. They contain important material on the situation in the west in 1793 .

[1792-1796.] The next carton has no label, but the dates extend from 1792 to 1796 . The items for U.S. history are as follows :

Proceedings at a council between the Shawnees and Delawares and Capt. Brant, at the Rapids, Oct. 28, I792.

Speech of the U. S. commissioners to the confederate Indians, at the foot of the Rapids. Aug. I4, I793.

Reply of the U.S. commissioners to the speech of Capt. Brant on behalf of the western Indians. Niagara, July 9, I793.

Copy of speech of Wayne to the sachems and war chiefs at Sandusky. Jan. 1, I 794 .

Copy of the treaty of Greenville.

Proceedings at a council held at Buffalo Creek. June-July, I794.

Copy of Wayne's speech to the Indians northwest of the Ohio. Aug. I3, 1794 .

Copy of the treaty between the U. S. and the Six Nations, concluded at Konondaigua (Canandaigua), Nov. I I, I794.

Continuation of letters to McKee from Chew, Duggan, Elliott (Detroit), England (Detroit), Lamothe (Mackinac), Maj. IVilliam Campbell and Capt. Steele (Fort Miami), Capt. Thomas Smith, and George Ironside (Swan Creek). There are also a few letters of John McDonald, written from the Cherokee country, which deal with events in that region.

In brief, this carton continues the correspondence addressed to McKee, together with minutes of Indian councils, and miscellaneous papers. It is important for affairs in the West during Wayne's campaign.

[1796-1799.] The following carton also has no label. It covers the period I796-I799. Letters from James Green to Joseph Chew furnish the chief item. There is very little on the U. S. Among miscellaneous papers is a translation of a speech delivered at Tuckalatchee, May 27, I 798 .

[1805-1806.] Until I 805 there is a gap, another carton covering the years I $805-1806$. It has nothing respecting the U. S. beyond a few speeches to and from the Sacs, Foxes, Potawatomies, etc.

[1806-1810.] The carton for 1806-r8 io has a speech of the Cherokees on the attitude of the Indians toward the U. S., delivered at Highwassee, Mar. 26, I8o9. There are also a few letters written at St. Joseph on western Indians, but nothing of importance.

[1811-1814.] The carton for ISI I-ISI4 has these items relating to the U. S.: Speech of Sir George Prevost to the deputation of chiefs and warriors of the western tribes. Quebec, Mar. 17, I8I4.

Despatch from Bathurst to Prevost sending the treaty of peace and recommending a policy to be observed by the Indians toward the U. S. Downing Street, Dec. 27, I8I4.

Proceedings at an Indian council held, by Lieut.-Col. Joseph Wilson. U.S. A., with a number of Ottawas, at Fort Miami, May 2 I, I8I2. 
This carton has in addition some minutes of councils and speeches, but the correspondence is usually of little value for affairs in the U.S.

\section{Records which at the time of inspection were in room 95.}

In a letter-book relating to the Six Nations are the following copies:

Treaty between Sir William Johnson and the Senecas. Johnson Hall, Apr. 3, I764. (P. 78.)

Peace made by Col. John Bradstreet with the Indians of Scioto. L'Anse aux Feuilles, Aug. I2, I764. (P. 82.)

Joseph Brant's will. (F'P. I 5 I-I 55.)

Haldimand's deed of land to those of the Six Nations who migrated to Canada. Oct. 25,1784 .

An unlabelled carton of miscellaneous documents contains these items among many others:

Extract of instructions for Alexander McKee. Mar. 27, 1787.

Despatch from Bathurst to Sherbrooke on the issue of presents to Indians residing in the U. S. Downing Street, July 13, I8I6.

Copy of part of a plan for the regulation of Indian affairs, drawn up by the Lords of Trade. Whitehall, July Io, I764.

Schedule of propositions of the Indians and answers from the government at Albany. Sept. 20, I677-Dec., I706. (I27 pp. Gives name of tribe, subject of the proposition, and references to the first volume of Indian records. At the beginning it is merely a brief index to this missing volume, but during the latter part it is considerably fuller, giving the purport of the speeches, etc.)

In the same carton are typewritten copies of several documents pinned together, as follows:

I. "Remarks on the management of Indians in North America delivered in to Mr. Knox at the Secretary of State's Office, Whitehall, end of February 1777 and received the 22nd Nov., 1782." '(No signature.)

2. Copy of the king's commission to Sir John Johnson. Mar. I4, I782.

3. Letter from Haldinand to Sir John Johnson, with instructions as to his duties as superintendent general of Indian affairs. Quebec, Feb. 6, I783. (Followed by Johnson's instructions of the same date.)

In another unlabelled carton, whose contents relate chiefly to organization, are these items:

Copy of a letter from John Norton to Goulburn, desiring a land grant in Upper Canada for certain tribes then in the U. S. London, Dec. I, I8I5.

Despatch (separate) of Bathurst to Prevost on Indians and the treaty of peace. War Department, Dec. 27, I8I4.

Private letter from Joseph Chew to Alexander McKee, respecting Brant, treating with the U. S. commissioners in 1793 , and the Indian boundary. Montreal, Oct. I7, I794.

Confidential letter of J. G. Simcoe to

Creek. Navy Hall, May 3, 1796.

In an unlabelled portfolio is a copy of the land cession by the Six Nations at Fort Stanwix, Nov. 5, 1769 [1768]. The remainder of the portfolio consists of copies of documents and notes of the official in charge, and is of no value. 


\section{LIBRARY OF PARLIAMENT.}

The Library of Parliament contains a small collection of transcripts from French archives and of original manuscripts. A detailed list of the transcripts and full account of the original manuscripts are printed in the Catalogue of the Library of Parliament (Toronto, I858), pp. I448-1655.

Faribault Transcripts. First series, I6I4-1727, I I vols.; second series, I654I729, I2 vols.

These transcripts were made in Paris by Faribault in $185 \mathrm{I}-\mathrm{I} 85_{2}$, and are for the most part taken from the Archives des Colonies, series $\mathrm{C}^{11}$ (Correspondance Générale, Canada). A few are from the Archives du Ministère de la Guerre, the Archives Nationales, and the departmental archives of Seine-et-Oise. The principal present value of the collection is due to the fact that volume I. of the first series contains a few transcripts (pages $2 \mathrm{II}, 233-237,25 \mathrm{I}-263,273,292-322,330-349,378-$ $4 \mathrm{I} 5,42 \mathrm{I}$ ) from the d'Argenson papers which were destroyed in the burning of the Bibliothèque du Louvre at Paris in I87I. Both series have been copied in their entirety for the Dominion Archives, which also possess fresh transcripts of most of the documents; a copy of first series, volumes I.-V., IX.-XI., and second series, volumes II., V.-XII., is among the Parkman papers, Massachusetts Historical Society, in five volumes labelled "Correspondance Officielle". The transcripts in the first series appear to have been collated or verified by Margry. For a complete list of the documents in the two series see Catalogue of the Library of Parliament, pp. I 500-I6I I.

Franquet, Voyages et Mémoires sur le Canada, I75I-I753, 2 vols.

These are evidently copies of the two volumes entitled "Voyage du $\mathrm{S}^{\mathrm{r}}$ Franquet" in the Archives du Ministère de la Guerre.

Miscellaneous, I 504-1763, I vol.

Canadian chronology, capture of Fort Necessity, battle of Fort Duquesne, assassination of la Salle, etc. Said to have been copied from various sources by Morin.

Miscellaneous, I758-i 760 , I vol.

Copies in English of documents relating to the fall of Canada. List in Catalogue, p. I644.

Chisholme Papers, I752-I793, I vol.

Papers collected by David Chisholme for the purpose of writing a history of Lower Canada. List in Catalogue, pp. 1645-1647.

Letters, I792-I793, I vol.

Describing a tour through Upper and Lower Canada.

Pownall Papers, I672-1725 (ca.), 7 vols.

Papers of John Pownall, secretary of the Board of Trade. They deal mainly with matters relating to the American colonies which came Maps. before the Board of Trade. Complete list in Catalogue, pp. I648-1655.

A collection of 97 maps copied in Paris by P. L. Morin in I852-1853. The copies are not considered very reliable. Complete list in Catalogue, pp. I6I4-I62I.

A collection of maps copied in Paris and Rome by Martin, in 1859 .

Map of Province of Quebec and parts of Maine, New Hampshire, Massachusetts, and New York, I79I. 


\section{ARCHIVES OF THE PROVINCES.}

\section{NOVA SCOTIA.}

The province of Nova Scotia has been fortunate in the zeal of its historical workers, and can lay claim to the longest continuous archival organization in Canada. In 1857 the house of assembly passed a resolution providing for the collection of historical records illustrative of the history of the province, and Thomas B. Akins was appointed commissioner to carry it into effect. His activity and fitness for the work are well shown in the amount of records which he gathered for the province, and also in the valuable mass of books, pamphlets, manuscripts, and newspapers known as the Akins collection, now the property of the Nova Scotia Historical Society.

In accordance with the recommendations of the commissioner copying was begun at the State Paper Office, London. Local records were brought to light, valuable material was rescued from destruction, and transcripts were obtained at various times from Ottawa, Boston, the Public Record Office, and the Royal Institution. In 1877 these records had reached 360 volumes. Since that time the amount has increased steadily, and at present there are about 700 vols., and several boxes of loose papers, maps, etc.

This collection is known as the Public Records of the Province of Nova Scotia, the term archives not being employed officially. It is located in a fireproof vault in the modern Nova Scotia Technical College at Halifax.

These records contain important material on the Seven Years' War, the American Revolution, the War of I8I2, the fisheries question, reciprocity, and the commerce of the trade route between Nova Scotia, the United States, and the West Indies. Many volumes, however, have been copied from originals at London, Boston, and elsewhere, and several are letter-books.

The entire collection is under the charge of Harry Piers, Esq., deputy keeper of public records, and all inquiries should be addressed to him at the Provincial Museum, Technical College, Halifax.

The contents of the archives of the province in 1877 were set forth in a pamphlet of 35 pages, bearing the fully descriptive title, Cataloguc or List of Manuscript Documents, arranged, bound and catalogued under the Direction of the Commissioner of Public Records, together with a List of Books of Entry, consisting of Minutes of His Majesty's Council, Letters, Registers of Crown Grants of Land, Commissions, Orders of Government, etc., etc. from the year I7IO to [the] year I867, preserved in the Government Offices at Halifax, Nova Scotia; also, a List of the Boxes which contain Papers assorted in Bundles, with Memorandum of Contents of each Box (Halifax, 1877). Its contents at a more recent date are fully catalogued by Dr. James Hannay in M 578 (see p. I45, above).

1. Transcripts of documents at the Public Record Office respecting Acadia, 1624-I668; extracts from Sainsbury's catalogue of American documents at the same depository; and copies of portions of the Egerton and Lansdowne collections at the British Museum, I630-1699. Several documents relate to American history, but nearly all are extracts. (Calendar in volume.)

2. Transcripts of documents in French archives respecting Acadia, 16321699. A few relate to war with the English, trade, and the southern boundary of Acadia. (Calendar in volume.) 
3. Continuation of the preceding volume to 1749. Among other material it contains a memoir of Capt. John Alden, Boston, Apr. 9, I7oo, to the Earl of Bellomont, on the boundary of Nova Scotia ; correspondence of Gov. Dudley at Boston and M. de Subercase, I708, on the siege of Port Royal and other matters ; and several documents relating to Capt. Churclis expedition, Rouville's raid, and similar incidents of border warfare.

4. Supplementary volume of French transcripts. Contains the capitulation of Port Royal, Aug. I6, I654, and documents pertaining thereto. Copies of documents from the Seminary at Quebec, I7OI-I 784 , seem to contain nothing on the U.S. (No index.)

5. Transcripts from the State Paper Office, London, of letters from the governors of Annapolis Royal to the secretaries of state and Board of Trade, I7IO-I7I4. Many relate to the abortive expedition of Gen. Hill and Adm. Sir Hovenden Walker against Quebec in I7I I. Vetch's journal of this expedition is present, and also his instructions of 1708 with regard to the expedition against Canada. Some letters of Gov. Vetch were written at Boston. (Calendar in volume.)

6. This volume centres about the years I709-I7I4, and among other items contains copies of Gen. Nicholson's commission for commanding the forces against Port Royal, Mar. I8, I709/10, his instructions of the same date, additional instructions of Apr. I5, I 7 Io, and his journal of the expedition, containing correspondence.

7. Correspondence, largely of the governors of Nova Scotia with the Secretary of State and Board of Trade, I7I2-I725. One letter of Cols. Nicholson and Vetch, dated Boston, Sept. I6, I7 Io, stated they were then embarking for the expedition against Port Royal. This volume was copied at the Public Record Office. (Briefly calendared.)

$7 \frac{1}{2}$. Transcripts of documents at the Public Record Office relating chiefly to affairs at Annapolis Royal during I IO-I I I4. Two memorials to Queen Anne from the governor, council, and assembly at Boston, Aug. 22 and Nov. II, I 710 , and one from the agent of Massachusetts Bay, Jan. 3. I 7 IO, relate to the expedition against Port Royal, the fisheries, etc. (Briefly calendared.)

8. Transcripts from Sloane MSS. 3607 at the British Museum which relate largely to conditions at Annapolis Royal under Col. Vetch, I7 II-I7I3.

9. Transcripts from the Brown collection at the British Museum on Nova Scotia affairs, I7 13 -I 753 .

12. Transcripts from papers of the Massachusetts government at the Public Record Office. These documents relate chiefly to Indians and land matters in New England and Nova Scotia, 1725-I744. Letters of Shirley are a prominent feature of the later years. (Briefly calendared.)

13. A continuation of the foregoing number for the period $1745-1748$. Largely composed of letters from Gov. Shirley to the Duke of Newcastle. Others from Gov. Wentworth relate to New Hampshire, Nova Scotia, etc. (Briefly calendared.)

$13 \frac{1}{2}$. Continues the preceding item to $I 749$, and is mainly composed of the correspondence of Shirley with Newcastle. (Briefly calendared.)

18. Transcripts from the State Paper Office, London, of despatches from governors of Nova Scotia to the Lords of Trade. I7 I5-1749. A letter of Gov. Philipps, Nov. 26, 1730, states that the people of Boston are 
said to discourage immigration to Nova Scotia. A few other items pertain to immigration from New England, trade, and fisheries. (Calendared in vol. 38 .)

19. Copies of despatches from the governors of Louisburg to the Secretary of State, June, I745-July, I749. The first third of the volume is largely composed of letters from Warren and Pepperrell on the reduction of Louisburg, which relate partly to the New England troops and their own attempts to obtain governorships. (Calendared in vol. 38.)

21. Commission and letter-book kept at Annapolis Royal, June, I742-Nov., I749. One letter of Mascarene to the Lords of Trade, Sept. 20, I744, announces reinforcements of troops from New England.

29-33. These volumes contain original despatches to the governors of Nova Scotia from the Lords of Trade, I749-I 799 . After 1768 they are few, their place being largely taken by despatches from the Secretary of State, whose communications begin about I754. Minutes of the Board of Trade often appear as enclosures.

During the years 1756-I 763 this material shows little for American history, relating as it does mainly to military preparations in Nova Scotia. From 1765 to 1783 there are occasional references to events at the southward, and during $1776-1783$ a few instructions are upon refugees in Nova Scotia. The last volume, 1784-r799, however, has much material on the settlement of Loyalists, commercial relations with the U. S., the fisheries, and boundary questions. Loyalists form the outstanding topic.

A calendar of these five volumes will be found in no. 34. Copies of despatches from the Lords of Trade are calendared in an appendix to the Arch. Rept., I894.

35-48. These volumes are composed of despatches of the governors of Nova Scotia to the Lords of Trade and Secretary of State, I749-I 794. They are either transcripts or letter-books. No. 38 contains a calendar of these papers. There is important material for U. S. history in these volumes; copies from originals at London, however, have been calendared in an appendix to the Can. Arch. Rept., I894.

49-54. Letter-books of Sir John Wentworth, I783-I807. Some of this correspondence was penned before he became governor of Nova Scotia, and pertains to his duties as surveyor general of His Majesty's woods and forests. Though the largest part of these letters relates to Nova Scotia a few personal ones to friends in New Hampshire have a certain value for that state. (Not indexed.)

55. This is the first of three letter-books of Sir John Wentworth as governor of New Hampshire. It covers the period June 16, i $767-$ Oct. 28 , I770, and contains $374 \mathrm{pp}$. Letters to officials at London, interprovincial correspondence, and private missives are all valuable for the course of events in New Hampshire at this time and for colonial history in general. A long letter to Dr. Anthony Belhan, Aug. 9, I768, may be especially noted as dwelling at length upon New Hampshire politics and the attitude of the people. There is some material on the genesis of Dartmouth College. (No index.)

56. Feb., I772-Oct., I774. ( 85 pp.) Of the same general character as $\mathbf{5 5}$, but of less value. (No index.)

57. Nov., I $774-$ May, I 778 . ( I 72 pp.) Important for the Revolution and its preliminaries. From Sept., I775, to Apr., I778, the letters were 
written at Boston, and after that period at Halifax, New York, Flatbush, Newport, and London. (No index.)

58-59. Letter-books of despatches from the lieutenant-governor of Nova Scotia to the Secretary of State, I808-I8I3. All pertinent material has been noted in connection with copies of the originals which form part of series $\mathbf{M}$ at the Dominion Archives, Ottawa.

60-69. Volumes containing original despatches of the Secretary of State to the lieutenant-governor of Nova Scotia from I800 to I833. (Vol. 70 contains a brief calendar of these despatches.)

60. Camden to Wentworth. Importation of U. S. goods into the West Indies. Downing Street, Oct. 4, I804.

61. Sir Stephen Cottrell to Edward Cooke. Conditional importation of provisions from the U. S. July 30,1808 .

Castlereagh to Prevost. U.S. measures, the embargo, etc. Sept. 8, 1808.

Fawkener to Cooke. Remarks on trade between New Brunswick and Nova Scotia and the U. S. Oct. 22, I808. (Preceded by an order in Council of Oct. 26 on this subject.)

Regulations on U. S. ships sailing to and from Holland. St. James, May 3I, I8og.

Cottrell to Cooke. Manner of regulating the trade of New Brunswick and Nova Scotia with the U. S. June I6, I809.

62. Liverpool to Prevost. Injury to trade of England with Br. N. America by the introduction of East Indian and other goods through the U. S. Apr. 6, i8i i. (Five enclosures.)

Order in Council permitting commercial intercourse of Nova Scotia with the U. S. Oct. I, I8II. (Another of Apr. 8, I8I2, relates to New Brunswick. Other items on trade relations follow. Two despatches of I8I4 touch upon the occupation of part of the district of Maine.)

63. This volume for the years I8I5-I820 has a few items on trade, fisheries, and plans for settling colored refugees in Trinidad.

64. Bathurst to Kempt. U. S. encroachments in New Brunswick. Jan. I3, I822. (One enclosure.)

Order in Council imposing duties on U. S. goods in certain cases. July 2 I, 1823 .

65. R. W. Horton to Kempt. Relative to removal of negroes from Halifax to Trinidad. Apr. 30, I825. (Three enclosures.)

Same to same. Relative to closing ports of Newfoundland and the West Indies against U. S. shipping. Aug. I I, I826. (Two enclosures.)

67. Backhouse to Hay. Removal of trade restrictions by the U. S. Nov. 5, I830. (Four enclosures, followed by several other documents on the same topic.)

68. Goderich to Maitland. Commerce between the U. S., the West Indies, and Br. N. America. Feb. 9, I83I. (Two enclosures, besides other letters on this subject.)

72-91. A continuation of 60-69 for the period IS34-I852. (Nearly every volume contains a brief calendar.)

77. Glenelg to Campbell. No. 200. Remarks at length upon U. S. refugees from the late war, in Nova Scotia. Jan. 8, 1839.

80. Russell to Falkland. No. 45. Complaint of the U. S. minister at London against actions of Nova Scotian authorities against U. S. fishermen. Apr. 9, I84 I. (Two enclosures.)

81. Stanley to Falkland. No. 86. Alleged encroachments by Americans on fisheries of Br. N. America. Nov. 28, I842. (Two enclosures.) 
82. Stanley to Falkland. No. 132. Desires report on seizure of the U. S. fishing schooner Washington. Aug. 3I, I843. (Four enclosures. No. 176 in 83 relates to the same topic.)

83. Stanley to Falkland. No. IgI. Seizure of the U. S. fishing vessel Argus. Oct. 26, 1844. (Three enclosures.)

84. Stanley to Falkland. No. 213. Concession of right of Americans to fish in the Bay of Fundy. Mar. 30, 1845. (Five enclosures.)

Same to same. No. 225. Instructions as to relaxation of the rule excluding U. S. fishing vessels from bays in Br. N. America. May I9, I845. (Three enclosures. No. I47, Sept. I7, also relates to this topic.)

88. Grey to Harvey. No. I67. Postal arrangements between the U. S. and Br. N. America. May Io, 1849. (Six enclosures. No. I7I, May I2, relates to the same topic.)

Same to same. No. I83. Trade of Nova Scotia with the U. S. July I9, I849. (One enclosure.)

91. Pakington to Le Marchant. No. Io. Instructions given for protection of fisheries in $\mathrm{Br} . \mathrm{N}$. America. Aug. 19, I852. (One enclosure.)

96-110. A continuation of original despatches from the Secretary of State to the lieutenant-governor of Nova Scotia for I852-1867. These despatches were sent to Ottawa after the Confederation, and were not returned until I879. It is understood that all private and confidential despatches were taken out and sent to England. (Each volume has a table of contents.)

96. Pakington to Le Marchant. No. 22. Sends report of law-officers on the fishery convention of 1818 . Oct. I9, I818. (Three enclosures. No. 30 , Dec. 7 , relates also to the fisheries.)

98. Clarendon to Le Marchant. No. 7. Instructions and comments on the reciprocity treaty. Aug. I8, 1854 . Nos. II, 20, 22, 23, and 25 of the same year also relate to the treaty.)

99. Grey to Le Marchant. No. 31. Relative to reciprocity. Jan. 6, I855. (Six enclosures. No. 5, Feb. 24, is a formal despatch on this subject.)

Same to same. No. 3. Instructions on the regulation of trade with the U.S. Mar. 9, 1855. (Two enclosures.)

Russell to same. No. I I. Recruiting in the U. S. for the Foreign Legion must be given up, etc. June 22, 1855 . (Nos. 16 and 17 relate to the same question.)

Molesworth to same. No. 4. Sends extract of letter from the British consul at Norfolk, Va., on trade between Virginia and Br. N. America. Aug. 3, I855. (Enclosure follows.)

Same to same. No. 2I. Regulations binding upon U. S. fishermen in Br. N. America. Oct. I9, I855. (Four enclosures.)

100. Labouchere to Le Marchant. No. 55. Remarks at length upon the reciprocity treaty. July $\mathrm{I} 5,1856$.

109. Cardwell to MacDonnell. No. 6. Complaint of alleged organization at Halifax for predatory attacks upon U. S. commerce. Feb. 4, I865. (One enclosure.)

111-128. Letter-books of despatches from the lieutenant-governor of Nova Scotia to the Secretary of State during the period 1808-I867. (Only about half of these volumes contain a table of contents.)

112. Dalhousie to Bathurst. No. I9. Refugee negroes. Halifax, May I6, I817. (No. 27, Aug. I4, relates to the same topic.)

113. Kempt to George Harrison. Departure of certain negro refugees for Trinidad. Jan. 20, I822. (Letter of Apr. 17, 1821, on same topic.) 
115. Campbell to Glenelg. No. 92. Condition of refugee negroes. Aug. 25, 1837 .

118. Falkland to Stanley. No. 27I. Seizure of the U. S. fishing vessel Washington, and rights of Americans in the Bay of Fundy. Sept. 17, I844. (One enclosure.)

Same to same. No. 331. Objections to relaxation of the fishery treaty of ISI8. July 2 , I 845 .

121. Harvey to Grey. No. I26. Relative to postage on letters between the U. S. and Br. N. America. July 24, I 849 .

Same to Elgin. Interest of Nova Scotia in negotiations with the U. S. regarding commercial relations. Strong feeling in favor of "a reciprocal interchange of staple productions". Dec. I3, I849. (Confidential. Letters of Feb. 20, Mar. 9. July 5, I85o, to Elgin relate to the same topic as does one of Jan. 29, I85I, to Sir Henry Bulwer.)

123. Le Marchant to Pakington. No. 7. Arrival of Commodore Perry, U. S. N., with the Mississippi, to warn U. S. fishermen against trespassing within the three-mile limit and to protect them until the settlement of points then in dispute. Aug. 19, 1852 .

Same to same. No. 29. His views at length upon reciprocity negotiations. Nov. 22, 1852. (Several other despatches in the same volume relate to reciprocity, some of them addressed to Elgin and to Crampton.)

Same to Herbert. No. 19. Joseph Howe's mission to enlist men in the U. S. for the Foreign Legion. Mar. I, 1855. (Confidential. One enclosure. Other despatches on this subject are in the same volume.)

135. Nov. 7, 1753-Oct. 5, I756. (57 pp.) Letters from Gov. Lawrence of Nova Scotia to the governors of other colonies and the French governor of Cape Breton. Some of these letters are to the governors Shirley, DeLancey, Morris, and Hardy. They are chiefly concerned with military matters, such as disposition of forces, fortifications, military supplies, etc. (No index.)

137. Letter-book of Gov. Parr and Sec. Bulkeley, I784-I79I. One order to a collector of customs prohibits the importation of lumber from the U. S. A few other items, of no great importance, are on commerce and the Loyalists. (No index.)

140. Letter-book of the provincial secretary for the years I808-I8I4. A circular of Oct. 3. I808, to senior justices relates to immigration from the U. S. (No index.)

141. Letter-book of the provincial secretary, covering the period I8I4-I8I8. A letter of Oct. 3. I8I4, deals with the condition of negro refugees and the need of relief. (No index.)

178. July 4 , I778-Nov. I5, I 780 . List of vessels, with names of their masters and crews, arriving at Halifax. Vessels coming from or sailing for the U.S. are not numerous. (No index.)

186-203. Minutes of the Council of Nova Scotia. I749-I87o. Nearly every volume is indexed. Nos. 189 and 190 cover the period of the Revolution and of the Loyalist inmigration. These volumes are in the vault in the office of the provincial secretary, but 209-214 are transcripts of them to I809 and are accessible. Of these 210-213 were examined. They cover the period I753-I 798 . There is practically nothing for the Seven Years' War, a few items on the Revolution, largely respecting disturbances in Cumberland County, and an occasional reference to the Loyalists. 
215-218. Journals of the Council as a legislative body. I758-I783. (Not indexed. No. 218 has a few items on the Revolution and the Loyalists.)

219-249. I748-184I. This is a set of volumes of miscellaneous documents relating to Nova Scotia. Some are originals while others are copies; they are often mingled in such a way that it is impossible to draw general distinctions. (These volumes are briefly calendared in nos. 250 and 251.)

219. May I9, I749-I763. (I I8 documents.) In the first part of this volume are several letters from Shirley to Sir Thomas Robinson and Gov. Lawrence, together with a few replies, respecting the French in Nova Scotia, troops raised in New England for the expedition against this region, the campaign of 1755 , etc.

Next in order are some letters of Lieut.-Gov. Phips, Gov. DeLancey, and miscellaneous papers relating to Braddock's defeat, including a list of officers present, and another of the killed and wounded.

From I 759 onward a large part of the volume is composed of Amherst's letters to Lawrence; there are also a few to the latter from Gov. Pownall.

In general this number may be said to relate chiefly to the French war. The main topics for Americans are New England troops in Nova Scotia and their operations there; Braddock's defeat; the deportation of the Acadians, and their situation in the American colonies; the siege and capture of Quebec; the demolition of Louisburg; various information on different events of the war.

No. I I6 in this volume is an undated paper entitled "Remarks on some parts of Nova Scotia and New England respecting Navigation, etc."

220. Dec. 6, I752-Sept. I8, i784. (67 documents.) Drafts of despatches from Gov. Lawrence to the Lords of Trade, the Secretary of State, Gov. Shirley, Col. Monckton, etc. Copies of nearly all of the despatches are calendared in the Can. Arch. Rept., I894. The deportation of the Acadians, and New England troops in Nova Scotia are important subjects.

221. Apr. 26, I75 I-Nov. 25, I79I. (I72 documents.) Largely drafts of despatches from the governor to the Secretary of State. The principal topics relating to the U.S. are the damage caused by American privateering during the Revolution, and the Loyalist immigration to Nova Scotia. (Copies of the despatches are calendared in the Can. Arch. Rept. for I894.)

222. May 28, I753-Sept. 20, I78I. (96 documents.) Miscellaneous documents, only a few of which refer to events of the Revolution.

223. Feb., I783-Nov., I787. (I73 documents.) Several numbers are accounts for boards, shingles, etc., furnished to Loyalists.

225. June, I807-Oct., I8I I. (II7 documents.) Several letters from Adm. Sir J. B. Warren to Prevost relate to the embargo, events in the U. S. and the West Indies, and a communication from D. M. Erskine to Canning, dated Jan. I, I809, is upon the state of affairs in the U. S. with reference to the expected outbreak of hostilities. There is also some miscellaneous correspondence on trade relations with the U.S.

226. Dec., I8I2-Dec., I8I4. (I50 documents.) A few papers show the effect of the war upon Nova Scotia's maritime trade.

227. Jan., I8I4-Oct., I8I6. (I37 documents.) A few of the early numbers refer to commercial relations. 
228. Jan., I8I7-Jan., I820. (I50 documents.) No. I8 is a copy of the decision and award of commissioners Barclay and Holmes, Nov. 4, I8I7, on the international boundary in Passamaquoddy Bay. A few letters relate to fisheries and minor trade matters.

229. Jan., I $820-F e b .$, I 82 I. (I 55 documents.) A few papers relate to the Americans and the fisheries.

230. Jan., I $82 \mathrm{I}-\mathrm{July}, \mathrm{I} 822$. (202 documents.) A small number of papers refer to the fisheries, and about half a dozen from Ward Chipman to various persons relate to the Northeast Boundary and islands in Passamaquoddy Bay.

248. I69I-I839. (312 documents.) A supplementary volume. There are a few Loyalist petitions.

252-277. A set of volumes containing miscellaneous documents of Nova Scotia for the period I835-1866. Each volume has a brief calendar of its contents. These papers were selected and arranged in 1875 .

258. John F. Crampton to Elgin. Reciprocity negotiations. Washington, July 2, I849. (Copy. Two enclosures of diplomatic correspondence.)

Provincial secretary of New Brunswick to the provincial secretary of Nova Scotia. Relative to united action for reciprocity with the U. S. Fredericton, July 31, I849. (One enclosure.)

Minutes of a conference at Halifax on free trade. Sept. 4, I849. (Delegates present from Canada, New Brunswick, and Prince Edward Island.)

259. W. Young to Sir Henry Bulwer. Reciprocity. Washington, June I7, I850. (Reply follows.)

W. Young's report on his mission to Washington regarding reciprocity. Halifax, July 3,1850 .

Harvey to Sir Henry Bulwer. Views of the government as to reciprocity. July 25, 1850 . (Copy. One enclosure.)

260. E. Cunard to Att. Gen. Uniacke. Reciprocal trade regulations. Boston, Jan. I $4,185 \mathrm{I}$.

262. Council minute on reciprocity. Halifax, Nov. 19, 1852 . (Followed by several documents regarding the fisheries.)

272. M. Muir (of the U.S. post-office department) to the postmaster general at Halifax. Relative to postage on mail carried by land between Nova Scotia and the U. S. Washington, Dec. IO, I852. (Copy.)

284. Transcripts from the Brown collection at the British Museum. (See Andrews and Davenport's Guide, p. IO3.)

285. Contains, among other items, a list of "Rebel Prisoners" on board the snow Lord Stanley at the time of the Revolution.

286-298. A set of volumes containing selections from the files of the legislative council of Nova Scotia during the years I760-I84I. In addition to the items given below these legislative records contain the usual references to trade and fisheries from time to time. (These volumes are briefly calendared in numbers 299 and 300 .)

286. I760-I 790. This volume has very little material upon the Revolution and the Loyalists. A message from Gov. Belcher to the assembly, May 3, 1762 , relates to the boundary between Nova Scotia and Massachusetts.

290. I823-1829. Contains a copy of an undated report of the attorney general of New Brunswick to Sir Howard Douglas, on the case of Baker et al., charged with misdemeanors in the Madawaska settlement. 
295. Lieut.-Gov. Harvey to Lieut.-Gov. Campbell. Relative to invasion of the province. Fredericton, Mar. 9, I839. (Enclosed are copies of legislative resolutions.)

301-314. A set of volumes composed of original papers selected from the files of the assembly of Nova Scotia from I 758 to I84I. In addition to the items given below there are numerous petitions, messages, etc., on the usual topics-trade, fisheries, and the conduct of U. S. fishermen.

Papers of the assembly later than I84I are in the custody of the clerk of the assembly.

303. The lieutenant-governor to Lord Hobart. Remarks on trade of the British West Indies and the U. S. Feb. 25, I804. (Copy. Petition of Halifax merchants to the assembly, of Nov. 28, 1805 , also relates to this subject.)

305. Message of the lieutenant-governor to the assembly respecting people of color from the U. S. Feb. 23, I8I5. (Several other documents on colored refugees are in this volume, whose dates cover the years I8I4I8I8.)

306. I819-1822. This volume has a few papers on the fishery convention of Oct. 20, $18 \mathrm{I} 8$.

315-317. I784-1820. Volumes of original despatches from the Secretary of State to the governor of Cape Breton. (Each number has a brief calendar.)

315. I784-1797. A few despatches relate to trade with the U. S., while some are concerned with the Loyalists.

317. Jan., I809-Aug., I820. A few items on the commercial effect of the War of I8I2, such as regulations bearing on captured U. S. ships, etc., are found in this volume.

318-323. Original minutes of the council of Cape Breton, I785-1820. Nos. 318 and 319 have a few references to Loyalists and other immigrants from the U. S.

333. Printed acts of the imperial Parliament, and other printed documents from England, including orders in Council, etc., I785-1816; also proclamations in Cape Breton, I788-1820. Many acts and some proclamations relate to trade with the U.S.

342. I749-1778. Papers connected with crown prosecution for treason, sedition, etc. A few are concerned with charges of disloyalty during the American Revolution.

345. Printed copies of imperial acts relating to the colonies from 1748 to 1822 . (Not complete.)

346. Royal and gubernatorial proclamations issued in Nova Scotia during the period I $748-1807$.

348-351. Volumes of royal instructions to governors of Nova Scotia, 1729I846. These instructions, some of which are originals, are valuable for matters of trade. Both general and trade instructions are usually given.

No. 348 has the instructions given to the Earl of Orkney as governor of Virginia, Mar. 22, I $727 / 8$, and also those to Lord Cathcart, commanding the expedition to the West Indies, Dec. 26, I739. A copy of the instructions for Gov. William Tryon of New York, Apr. 3, I775, is in 349 .

354-356. Imperial orders in Council relating to Nova Scotia, 1752-1852. A few in the first two volumes are concerned with commercial relations and the Loyalists. 
357. Col. John Winslow's journal during the siege of Fort Beauséjour in I755, copied from the original at Boston. (Printed in vol. IV. of the Transactions of the Nova Scotia Historical Society.)

358. A continuation of the preceding journal during the removal of the Acadians. (Printed in vol. III. of the Transactions of the Nova Scotia Historical Society.)

359. Papers relating to the settlement of the old townships of Nova Scotia after the removal of the Acadians. Among the earlier documents are some lists of subscribers in Massachusetts Bay for these lands; at the close of the volume are several Loyalist lists, particularly of those from South Carolina and Westchester.

363. Principally copies from the Brown collection at the British Museum, respecting the removal of the Acadians.

364. Copies of Massachusetts records at the State House, Boston, regarding the invasion of Nova Scotia by Americans during the Revolution, and unrest in Cumberland County and among the settlements on the St. John.

365. Military correspondence, copied from the British Museum, Public Record Office, Dominion Archives, etc. These papers extend from I745 to $18 \mathrm{I} 8$, and thus cover the colonial wars, the Revolution, and the War of $18 \mathrm{I} 2$.

366-367 $\frac{1}{2}$. Selected papers bearing on the history of Nova Scotia, copied from the Haldimand Papers at the British Museum. They have important material on the Loyalist immigration.

368-369. The papers in these volumes cover the period $1776-1784$, and were copied from the Dorchester Papers at the Royal Institution, London. No. 368 has letters from Germain, Clinton, and Massey to Sir William Howe, letters to Clinton from officers in Nova Scotia, and miscellaneous corresponderice. This volume relates chiefly to the Revolution, but has a few Loyalist lists at the close.

No. 369 is concerned with the Loyalist immigration, and has important correspondence between North and Carleton, communications to the latter from various persons, especially Gov. Parr, numerous memorials, and several lists of Loyalists.

These two volumes of course include New Brunswick and Prince Edward Island. There are a few documents on disbanded soldiers and negroes who emigrated with the Loyalists.

375. Abstracts of sales of property made by order of the court of vice-admiralty at Halifax. I812-1816.

376. Copies of muster-rolls of Loyalists in various parts of the Maritime Provinces in 1784 .

378. Catalogue (prepared in I88I) of causes in the court of vice-admiralty at Halifax, with list of other papers of the court, etc.

385-387. These volumes are largely composed of correspondence of the Britisl minister at Washington with the lieutenant-governor of Nova Scotia. No. 385 has fifty-eight papers, which range from I798 to I830. The chief topics are the condition of the U. S. with regard to politics and military preparations during ISO8-ISIo, the fisheries, and commerce.

No. 386 has thirty-five documents dealing with reciprocity and the fisheries, which cover the period I $844-1854$. 
Vol. 387 is also concerned with the fisheries and reciprocity, and has in addition a few items on the Civil War. There are thirty-eight despatches, within the years $1852-1864$.

Nos. 386 and $\mathbf{3 8 7}$ have brief catalogues of contents, but there is nothing of such a character for 385 .

388-391. Interprovincial correspondence. These volumes extend from I833 to 1858 , and have a few items on trade, fisheries, and reciprocity. (Each number has a brief catalogue of its contents.)

394-395. Jan. I, I783-Oct., I788. Letter-books containing instructions from the surveyor general of Nova Scotia to the deputy surveyors. The first volume relates chiefly to surveys for Loyalists, and has no index.

404-405. Quit-rent accounts for I $783-1785$.

409. Papers connected with settlements on the river St. John from 1764 , including the Loyalists in this region. The volume extends to I8I5, but there is little after 1783 . (Not indexed.)

419-423. Papers relating to refugee negroes in Nova Scotia. Most of these immigrants came from the U.S. Vol. 419 covers the period I790I834.

The early documents pertain to plans for removing to Sierra Leone negroes who wished to go from Nova Scotia and New Brunswick. Papers on the maroon negroes from Jamaica, I8oo, are numerous.

The last of the volume is mainly concerned with those who came to Nova Scotia during the War of 1812 . There is but little previous to 1815 .

No. 420 has correspondence, lists, and expenses regarding negroes in Nova Scotia during 1813-1816. Most of these had escaped to British ships during the war.

No. 421 follows the fortunes of these U. S. refugees to Feb., I8I8, and gives much information on their condition, settlements, and progress.

No. 422 has a few papers of 1815 and 1816 , but the majority extend from 1818 to 1839 .

A brief calendar of $419-422$ inclusive is in vol. 470 .

No. 423 consists of copies from certain volumes of the Dorchester Papers entitled "Books of Negroes". These relate to negroes who left New York and the vicinity in 1783 for Nova Scotia. (The volume has a brief calendar.)

443. Census returns, which have among other items lists of ratepayers of the several townships from I 770 to I 794 .

In Box no. 12 are: records of proceedings of the court of vice-admiralty in Nova Scotia for the years $1749^{-1} 759,1761-1764,1769-1811$, May 3 , I8I3-Dec. 7, I8I3 (9 vols., for the most part indexed); register of letters of agency, court of vice-admiralty: $1776-1781$ (marked Liber 2), I78I-I798 (marked Liber 3), Jan. 20, I8I3-Aug. 30, I82 I (indexed); and fees of the vice-admiralty court of Nova Scotia ( I vol.).

The volumes of proceedings of the vice-admiralty court for I8I 2 and years after 1813 are supposed to be in the basement of the county court house at Halifax, together with a large mass of admiralty court papers subsequent to that time. The proceedings of the court for the period of the Revolution ( $1776-1783$ ) and for the period of the War of I8I2 have been printed in abstract by the Essex Institute in Historical Collections, vols. XLV., XLVI., and XLVII., passim, and also separately, under the title American Vessels captured by the British during the Revolution and War of 1812 . 


\section{NEW BRUNSWICK.}

There are no provincial archives in New Brunswick, and public records are scattered through the various executive offices at Fredericton. Many valuable portions passed long ago into private hands, while others have suffered destruction by fire and water. The various archives of the province are fully catalogued by Dr. James Hannay in M 648-649 (see p. I47, above).

For students of United States history there is little indeed. A vault attached to the office of the provincial secretary furnishes some Loyalist data in the shape of council journals and registers of land grants. The journals are of proceedings of the council with regard to allotments of crown lands, and begin Dec. 22, I784. One abstract register of land grants in New Brunswick includes the years I785-1817. At the outset it has many names of Loyalists. Place, name, number of lot, and date are given. A register of lots in Parrtown (later St. John) fills twenty-two folio pages, and has numbers, dimensions, and the proprietors' names. A note states that the general grant was dated Aug. I4, I784, and a separate grant to Thomas Leonard and ninety others Aug. 9 of the same year.

A cupboard in the office of the clerk of the executive council contains, among other relicta, registers of lots drawn by Loyalists on the St. John, Kennebecasis, etc.; two letter-books of the surveyor general, which begin with the separation of the province from Nova Scotia and end in Sept., I788; and a long original letter from Ward Chipman to Lieut.-Gov. Carleton, dated St. John, Aug. I2, I796, and dealing with the Northeast Boundary. 


\section{QUEBEC: CIVIL ARCHIVES. ${ }^{1}$}

The public records of the Province of Quebec consist of those of the French and the English régimes. The records of the French régime are those which in accordance with article 45 of the articles of capitulation of Montreal. September 8, 1760, were retained in Canada; they consist principally of the records of the council, those of the royal and seigniorial courts, the records relating to land tenure, and the notarial records. Thus they are the necessary complement of the archives of the Ministry of the Colonies, in Paris. They relate not merely to the present province of Quebec but to all of French Canada, including many places now within the territory of the United States. The greater part of these French archives is in the city of Quebec, but important groups are also to be found at Montreal and Three Rivers.

The records of the English régime are more completely provincial in character, those records that deal with external affairs having passed to the Federal government as inheritor to the successive governments of the old provinces of Quebec (to I79I) and Lower Canada (I79I-I840), and of the government of united Canada that sat in Quebec (1840-1855).

There are two principal depots of public records in the city of Quebec that contain material of interest for the history of the United States-the Provincial Archives, attached to the office of the Provincial Secretary, located in the Parliament Building, under the immediate charge of M. Eudore Evanturel, and the Judicial Archives, attached to the office of the Attorney General, located in the Court House under the direction of M. Philéas Gagnon. ${ }^{2}$ Both depots contain archives of the two régimes.

Of great aid in the use of these archives is the report of the committee appointed in 1787 to examine the public records. The proceedings and report of the committee, including lists of the volumes and documents examined, are printed in full in Can. Arch. Report, 1904. ${ }^{3}$ Useful lists are also to be found in the first, second, third, sixth, seventh, and eighteenth reports of the Secretary and Register of the Province of Quebec. A detailed historical account of the French archives of Canada, by J. Edmond Roy, is printed in the Transactions of the Royal Society of Canada, third series, volume IV. (I9ro). Numerous documents from these archives have been printed in various collections, the most important of which are as follows:

Jugements et Délibérations du Conseil Souverain de la Nouvelle France, I663-I7I6, 6 vols. (Quebec, I885-1891). This is a publication in extenso of the Registres des Jugements et Délibérations to 1716.

Edits, Ordonnances Royaux, Déclarations et Arrêts du Conseil d'Etat du Roi concernant le Canada, 3 vols. (Quebec, $1854-1856$ ). This is the second edition ; the first edition, in two volumes, containing a smaller number of documents, was published in I803-1806. The documents in these volumes are taken mainly from the Ordonnances des Intendants and the Insinuations.

${ }^{3}$ This account has been prepared by Mr. Waldo G. Leland, of the Carnegie Institution of Washington, after personal researches at Quebec.

${ }^{2}$ Grateful acknowledgment is made to Messrs. Evanturel and Gagnon for facilities accorded and valuable aid rendered in the preparation of this report.

${ }^{3}$ See p. I, note 3 , supra. 
Picces et Documents relatifs à la Tenure Seigneuriale, 2 vols. (Quebec, I852-I854). An English edition was published at the same time bearing the title Titles and Documents relating to the Seigniorial Tenure. The second volume contains 376 documents, nearly all of which are titles to lands, taken from the Registres d'Intendance. A few documents are from the Cahiers d'Intendance.

Cadastres abrégés des Seigneuries, 6 vols. (Quebec, 1863). Two volumes relate to the district of Quebec, three to that of Montreal, one to Three Rivers, and one to the crown lands. These are topographical and descriptive records compiled from the Aveux et Dénombrements.

\section{PROVINCIAL ARCHIVES.}

As noted above, the Provincial Archives are located in the Parliament Building and are attached to the office of the Provincial Secretary, to whom application should be made by those wishing to consult them. Excellent accommodations are provided for students. The hours are from 9 to I2, and from I to 4 ; on Saturdays, 9 to I.

\section{Administrative Records.}

Jugements et Délibérations du Conseil Souverain. I663-I760, 7 I volumes.

These are the records of the sittings of the Conseil Souverain, or Conseil Supérieur as it was entitled from I703. The series is made up of various groups, as follows:

(1) Registres, Sept. 18, 1663-Apr. 28, 1760, 56 vols. The first volume is bound with the first volume of the Insinuations, and the second volume is made up of two small volumes which supplement volume I. The binder's titles of these volumes vary considerably, a cause of some confusion.

(2) Plumitifs, Jan. I I, I677-Dec. 22, I68 I ; Apr. Io, I690-Dec. 20, I702; Dec. I, I705-Aug. 9, I706. 8 volumes. The Plumitifs are the volumes of rough minutes, and consequently contain the same material as the Registres. It should be noted that ten of the latter, Aug. I6, I 706-May I4. I7I7, and July I, I726-Jan. I3, I727, are erroneously labelled "Plumitif".

(3) Registres Criminels, June I8, I678-Oct. 7, I720; June I6, I730-Dec. 29, I759. 4 volumes.

(4) Certificates of papers filed by parties to cases before the Council, July I7, I733-May 25, I759. 3 volumes. Labelled erroneously "Regtre Criminel. vol. 8"; "vol. 25 ", and "vol. $36 "$ ":

A list of the above volumes is printed in Can. Arch. Rept., I904, pp. IOO-IO5. The contents of the Registres to 1716 have been printed in Jugements . . . . du Conscil Souvcrain de la Nowvelle France, noted above. A list of the contents of the Registres from I 716 to 1738 is printed in the sixth and seventh reports of the Provincial Secretary (I892, I893). As evidenced by the printed volumes and lists these records of the Council do not contain much material of value relating to the United States. Such as there is consists mostly of orders to register various edicts, decrees, orders, etc., and the documents thus ordered to be registered are found in extenso in the Insinuations (see below). For this reason the notes on the series of Insinuations serve to indicate the character of such material bearing on the history of the United States, as may be found in the Registres. 
Registres des Insinuations du Conseil Supérieur, 1663-1758. Io volumes.

These volumes are lettered A to $K$. The first volume is bound with the first volume of the Registres des Jugements. A modern copy of the original Registres des Insinuations is filed with them, and several manuscript tables or indexes are available. Many of the documents in this series have been printed in Edits et Ordonnances. The Insinuations are the official registrations by the Council of royal or other decrees, edicts, orders, etc. The series is therefore the natural complement of the Registres des Jugements. The following list includes the more important documents that bear upon the history of the United States.

1663, Nov. I9. Commission de Lieutenant Général de 1'Amérique Meridionalle et Septentrionalle pour M. Prouville de Tracy. Vol. A. fol. I3.

I664, May. Etablissement de la Compagnie des Indes Occidentales. Followed by various documents relating to the company. A. I4.*

I665, July I5. Requête du Sr. Le Barroys contenant 3i articles ou demandes avec les réponses concernant les droits de la Compagnie. Relates in part to fur-trade. A. 22.

I666, Apr. 8. Arrêt du Conseil d'État touchant les droits de la Compagnie des Indes. Followed by Mandement du Roi sur l'arrêt ci-dessus. A. $25 *$

I675, Dec. Lettres de rémission pour les nommés Medard Chouart Groseiliers et Pierre Esprit Radisson. B. 8.

1676, Apr. I5. Ordonnance du Roi défend d'aller à la traite des pelleteries dans les habitations des sauvages. A. 63 . $^{*}$

1676, Apr. I5. Articles présentés au Roi, par Nicolas Oudiette, fermier du droit appelé le quart des castors et dixième des originaux, sortant du pays de Canada, et traite de Tadoussac. A. 63.*

I684, Apr. Édit du Roi pour la punition des Français qui se retirent à Manatte, Orange, et autres lieux apartenant aux Anglais et Hollandais. B. 24 .

I686, Nov. I6. Traité de neutralité conclu à Londres entre les rois de France et d'Angleterre touchant les limites des pays des deux rois en Amérique. B. $57 . *$

I689, June 25. Déclaration de guerre contre les Anglais et Eccossais. B. 84.

I69o, July I4. Arrêt du Conseil d'Etat du Roi et lettres de confirmations des concessions faites à divers particuliers y dénommés. Includes Sr. de St. Castin, and de la Forest and Tonty for fort of St. Louis at the Illinois. Followed by Lettres patentes de Sa Majesté qui confirment l'arrêt ci-dessus et les concessions de terres y mentionnées. B. 99.*

I704, May 6. Déclaration du Roi portant défense d'aller en traite dans la profondeur des terres, avec terme de deux ans à ceux qui y sont pour revenir en cette colonie ou celle de Mississipi. B. I43.

I709, July 6. Edit du Roi portant défenses de faire le commerce et le transport du castor chez les étrangers au préjudice de la Compagnie. C. 40.*

I7I2, Sept. I4. Edit du Roi portant l'établissement de la Louisiane par le Sieur Crozat. C. 9o.*

I7I3, June. Lettres de naturalité à plusieurs particuliers. Including Daniel Fish, Simon Lucas, Thomas Dean [?], and Catherine Parsons, of New England. D. 9 .

* Documents marked with an asterisk, on this and the following pages, have been printed in Edits et Ordonnances, vol. I. 
I7I4, Mar. I9. Ordonnance du Roi qui accorde une amnistie entière aux habitans de la Nouvelle France qui ont été sans congé parmi les nations sauvages, et ce sous certaines conditions. D. 8.*

I7 I5, May 6. Déclaration du Roi qui rectifie son ordonnance du 6 Juillet 1709 au sujet de la fraude des castors en Canada. Relates especially to trade with English colonies. D. I2.*

izi6, Mar. Lettres patentes en forme d'édit, portant amnistie pour les coureurs de bois, et qui établit de nouvelles peines, et la forme de procéder contre ceux qui n'en profiteront point. D. 27.*

I7I6, Apr. Letters patent cancelling all the grants made by the Sr. de la Mothe Cadillac at the straits of Lake Erie. D. 36 .

I7I7, Aug. Lettres patentes pour l'établissement d'une Compagnie de Commerce sous le nom de "Compagnie d'Occident". Accorded exclusive right of trade with Louisiana for 25 years, and of beaver trade in Canada through I 742. Followed by Arrêt du conseil d'état qui unit et incorpore le pays des sauvages Illinois au gouvernement de la Louisiane, Sept. 27, I7I7; and Mandement du Roi sur les lettres patentes et l'arrêt ci-dessus, June 19, I718. E. 7.*

I7 I8, July I I. Arrêt du Conseil d'f́tat du Roi portant réglement pour la recette des castors. E. 33.*

I719, June 4. Arrêt du Conseil d'État du Roi au sujet des fraudes du castor. E. 4I.*

I720, June 2. Arrêt du Conseil d'État du Roi concernant les marchandises étrangères. E. $47 . *$

I720, July 23. Réglement concernant le commerce étranger aux colonies. Followed by Mandement du Roi sur l'arrêt ci-dessus. E. 56.*

I722, Jan. 27. Brevet de naturalité pour Marie Wilis [sic], anglaise, femme de Pierre Derisy, marchand à Québec. The document states that Marie Wilis was a native of the town of "Destreual" in New England, was captured at the age of eight by the Abenakis, and was brought up in Quebec by the Wilis family, related to her by marriage. F. I.

I722, Jan. 28. Arrêt du Conseil d'État du Roi qui ordonne l'exécution de celui du 30 Mai I 72 I portant établissement du privilège exclusif de la vente du castor en faveur de la Compagnie des Indes. Followed by Mandement du Roi sur l'arrêt ci-dessus. E. I 30**

1722, May I5. Arrêt du Conseil d'État du Roi qui ordonne que les marchandises de fabrique étrangère qui seront saisies au Canada, seront remises à l'agent de la Compagnie des Indes. E. I $32 . *$

I724, May 22. Déclaration du Roi au sujet des voyages qui se font de Canada à la Nouvelle Angleterre. F. 26.*

I726, May I4. Ordre du Roi au sujet des marchandises de fabrique étrangère. F. IO3.*

I727, Oct. Lettres patentes du Roi en forme d'édit, concernant le commerce étranger aux isles et colonies de l'Amérique. F. I Io.*

I735, Feb. 22. Ratification de plusieurs concessions en roture au Detroit. (Chauvin, Philis, Pierre Esteve, Binault, Louis Campaux, Marsac des Rochers, Jean Chapoton, Pierre Meloche, Jean Gilbert, Jacques Campaux père, Moran, la Butte, La Deroute, St. Aubin père, Pierre St. Aubin fils, François Lauzon. G. 55.

I735, Feb. 8. Brevet de ratification de concession en faveur du Sr. de St. Vincent fils, d'un terrain en seigneurie .... dans le lac Champlain. G. 59 . 
I735, Feb. 8. Brevet de ratification d'une concession accordée à Pierre de Pecaudy, Sr. de Contrecoeur, fils ainé, enseigne dans les troupes, d'un terrain en seigneurie sur le bord du lac Champlain. G. 68.

I735, Feb. 8. Same for Hugues Jacques Péan, Sr. de Livaudière, major de Québec, d'un terrain en seigneurie . . . . le long de la rivière Chambly [Richelieu] et lac Champlain. G. 69.

I735, Feb. 8. Same for Charles René Le Gardeur, Sr. de Beauvais, fils, d'un terrain en seigneurie sur le bord du lac Champlain. G. 70 .

I735, Feb. 8. Same for François Antoine de Pecaudy, Sr. de Contrecoeur, capitaine, . . . . d'une isle en seigneurie dans le lac Champlain . . . . appellée la Grande Isle. G. 76.

1735, Feb. 8. Same for Sr. Migeon de la Gauchetière, capitaine d'infanterie, d'un terrain en seigneurie sur le lac Champlain. G. 78 .

1737, Apr. 16. Ratification de plusieurs concessions en roture au Detroit (grantees and dates of concessions as follows: Charles Bonhomme, Sept. I, I736; Jacques Cardinal père, Sept. 2 ; Jacques Cardinal fils, Sept. 3 ; Philippe Daniau, Sept. 4 ; Joseph Dutremble, Sept. 5 ; François Gilbert, dit Sanspeur, Sept. 6 ; Claude Campot, Sept. 7 ; Pierre Cosme, Sept. 8; Pierre L'aurent, Sept. 9; Gaetan, dit La déroute, Sept. Io; Jacques Séguin, dit La déroute, Sept. I I ; Gabriel Casse, dit St. Aubin, Sept. I2 ; Jacques Casse, dit St. Aubin, Sept. I3 ; Etienne Safare, Sept. I4; Hebert, Sept. I5 ; Jean Bte. Malles fils, Sept. I6. H. 42.

I737, Apr.30. Brevet de ratification d'une concession à Pierre Raimbault, d'un terrain dans le lac Champlain. H. 48.

I737, Apr. Déclaration du Roi portant amnistie pour les coureurs de bois. H. $20 .{ }^{*}$

I740, Apr. I3. Brevet de naturalité pour Marie Scamon. Captured by the Abenakis about $\mathbf{1} 724$. Hi. 54 .

1740, Apr. I3. Brevet de naturalité pour Marie Anne Jordan. Captured by the Abenakis about $17 \mathrm{I} 6$. H. 54 .

I742, Feb. I4 . Ordonnance au sujet des faux-sauniers destinés pour Canada qui trouvent les moyens de s'en retourner en France, soit par les colonies anglaises ou par les vaisseaux marchands. H. 83.*

I743, Apr. 20. Brevet de ratification de concession dans le lac Champlain. For Hocquart, intendant. I. 7.

I743, July 17. Déclaration du Roi concernant les concessions dans les colonies. I. 23.

I743, Nov. 25. Déclaration du Roi concernant les ordres religieux. I. I6.*

I744, Mar. I. Arrêt du Conseil d'Êtat du Roi portant réglement sur le commerce des colonies françaises de l'Amérique. I. 36.*

I745, Apr. I. Additional grant of land to Hocquart on Lake Champlain. I. 34 .

I749, Apr. 3o. Brevet de naturalité pour Gilles Stroud. A native of London expelled from the Carolinas, who came to Canada in I738. I. 69.

I745, July 23. Arrêt du Conseil d'État du Roi portant que les nègres qui se sauvent des colonies des ennemis aux colonies françaises, appartiennent à Sa Majesté. I. 50 .*

I749, Apr. 30. Brevet de ratification, etc., of lands on the river Missisquoi and Lake Champlain, for Nicolas René le Vasseur. I. 74.

I753, June $\mathbf{I}$. Brevet de ratification, etc., of lands on the river Chambly [Richelieu] and Lake Champlain for Sr. Bedout. K. I. 
I753, June I. Brevet de ratification, etc., of lands on Lake Champlain for Sr. de Beaujeu. K. 6.

I755, Jan. I. Provisions de Gouverneur et Lieutenant-général en Canada, la Louisiane, Isle Royale, Isle Saint-Jean et autres isles, terres et pays de l'Amérique Septentrionale pour Monsieur de Vaudreuil de Cavagnal. K. $8{ }^{1}$

Arrêts du Conseil d'État du Roi, March 26, I736-June I, I738, I vol.

The original title of this volume, as given on the inside, is " Registre Pour Les arrêts du Roy, du conseil Supérieur, ordonnances et Congés". The contents consist mostly of congés (permits to engage in the Indian trade), apparently copied from a register among the records of the prévôte of Montreal. The congés are given at Quebec by Beauharnois and Hocquart in the years 1736 and 1737 , and are registered at Montreal. Each congé indicates the name of the person to whom it is issued, the destination and object of the trip, the number of canoes and men making up the expedition, the various supplies to be taken, the names of the crews, and the date of issue at Quebec and of registration at Montreal. The following congés were noted: Antoine Picard, to go to Detroit; de la Corne, to Detroit ; François Auger, to the Ottawas; d'Auteuil, to the Miamis; Guillory to join de la Ronde, going to the post of Chagouamigon; Desriviers, to go to the Illinois ; Leveillé, to go to the Sioux; La Marque, with ten canoes, to go to the Mer de l'Ouest; St. Ange to "la pointe Chaquamigon"; Chartier, to the Baye des Puantes; the brothers Bizaillon, passport to go to Philadelphia to look after their affairs; Gatineau and Hamelin to go to the river St. Joseph; various traders for Michilimackinac, etc. etc.

Registres des Édits, Arrêts, Déclarations et Provisions de Sa Majesté.

This series is in six volumes, lettered " A ", " B ", "C", "D ", "E", "F". The fifth volume is entitled "Tolume détaché des édits, déclarations et arrêts concernant le commerce étranger et le privilège exclusif de la Compagnie des Indes pour la vente des castors", I664-I727. The sixth volume is entitled "Volume détaché des édits, arrêts, et déclaration du Roy qui ont raport au gouvernement de Montréal ", I644-I727. The documents in all these volumes appear to have been taken from the volumes of Insinuations, or to have been copied from the originals.

Matières de Police et de Voirie, I683-1756, I vol.

A volume of miscellaneous papers, originals and authenticated copies, e.g., Etat et tarif des droits que le Roi ... a ordonné être levés en Canada . . . à l'entrée et à la sortie sur toutes les marchandises, Feb. 25, I748.

Matières de Police, I695-I755, I vol.

Similar to above. Among contents was noted the examination ( I696) of Anne Edmond who, disguised as a man, stated that she came from Boston where she had been a prisoner for four years and declared that the English were coming to attack Quebec with I0,000 men. There is also, July 22, I734, a "Mémoire pour M. de Boisclerc dans le voyage qu'il doit faire jusqu'au portage des Chats pour y faire la découverte d'une mine de plomb qui s'y trouve".

${ }^{1}$ Printed in Édits et Ordonnances, vol. III. 
Ordonnances des Intendants, I705-1760, 44 volumes.

This is one of the most valuable series of documents in the Provincial Archives. It contains the orders, whether general or special in character and application, issued by the intendant, and throws much light on the details of administration and government. A list of the volumes is included in the report of I787, reprinted in Can. Arch. Rept., 1904, pp. 89-92, and a considerable number of the orders have been printed in full in Édits et Ordonnances, including however only a very few of the numerous orders that bear upon the history of the United States. A copy of the series is to be found in the Dominion Archives at Ottawa, M 13-33, p. I04, above, and the following list is in part compiled from the Ottawa copy by Mr. David W. Parker, as at the time of preparing this account of the Quebec archives more than half the volumes of this series were in the bindery and hence inaccessible. For a valuable essay on the functions of the intendant see W. B. Munro, "The Office of Intendant in New France ", American Historical Review, XII. I5-38.

The following list includes practically all the orders bearing upon the history of the United States. The date of any order enables it to be readily found in the original series at Quebec or in the transcript at Ottawa.

I705, Sept. 26. Permission aux Srs. de Lotbinière et du Plessis de faire mettre des affiches pour affermer le fort de Frontenac.

I705, Oct. 9. Permission au bar d'une requête présentée par le Sr. Welch, marchand de la Nouvelle Angleterre, pour débarquer et vendre en ce pays des marchandises étrangères jusques à la concurrence de 3000 livres.

I705, Oct. I8. Ordonnance au bar d'un procès-verbal portant confiscation au profit du Roi des castors trouvés dans les barriques du Sr. Welch, Anglais.

I706, Jan. 23. Commission au Sr. de la Gorgendière pour exploiter le fort de Frontenac.

I706, Jan. 23. Jugement concernant la dame La Forest et la Compagnie. I706, Aug. 4. Ordonnance pour la reception des Castors.

I706, Aug. I4. Ordonnance contre la dame La Forest et le Sr. d'Auteuil.

I706, Oct. I2. Ordonnance pour la dame La Forest contre le Sr. Boudort.

I707, Mar. 19. Ordonnance pour le prix du castor à Montréal.

I707, June I2. Ordonnance qui défend la traite de l'eau-de-vie au Détroit.

I707, June I4. Ordonnance concernant le moulin de la seigneurie des Mille Isles.

I708, July 6. Ordonnance rendue au sujet des castors.

I709, Apr. I3. Ordonnance rendue au sujet des nègres et des sauvages nommés Panis. Printed in Édits et Ordonnances, II. 27 I.

I7 I I, May 29. Ordonnance pour des défenses faites à l'égard des prisonniers anglais qui sont dans cette ville [Quebec].

I7II, July 22. Ordonnance concernant un accord fait double entre les Srs. de La Forest et de la Mothe [respecting the command of Fort Ponchartrain].

I7 I 5, Oct. 20. Commission de subdélégué au Sr. Raimbault à Montréal concernant les fraudes tant sur les castors que sur les marchandises anglaises.

I7I6, Apr. 2. Ordonnance qui fait défense à toutes personnes d'aller à la Nouvelle Angleterre.

I716, Apr. Io. Ordonnance qui défend à tous ceux qui monteront dans les pays d'en haut de traiter avec les français qui y sont. 
I718, July 8. Ordonnance portant commission au Sr. Raimbault de subdélégué pour faire extraordinairement le procès aux accusés pour avoir été à la Nouvelle Angleterre.

I720, July 6. Ordonnance entre François Pelletier habitant du Détroit et Julien Trottier Desrivières [respecting beaver skins].

I 720 , Oct. I6. Ordonnance portant confiscation de marchandises étrangères saisies au fort de Chambly au profit de la Compagnie.

I721, Feb. I2. Ordonnance portant que visite sera faite pour les marchandises étrangères dans les maisons des habitants de Montréal.

I72I, Mar. I4. Ordonnance portant défense à toutes personnes d'aller traiter dans le lac Ontario et lac Erie et aux environs.

I72I, May 26. Ordonnance portant défense à toutes personnes de vendre ny traiter en l'eau-de-vie ou autres boissons enivrantes aux sauvages.

I722, Jan. 13. Commission de subdélégué au Sr. Lotbinière à Montréal pour recevoir les affirmations des procès-verbaux de saisie des castors en fraude.

I722, Sept. 4. Ordonnance qui enjoint au Sr. de Tonty de remettre au Sr. Mallet ou autre porteur du pouvoir du Sr. Sabrevois les effets appartenant au Sr. de la Mothe.

I722, Sept. 5. Ordonnance portant confiscation des castors saisis au fort de Chambly.

I723, Mar. I4. Ordonnance qui défend à toutes personnes de vendre de l'eaude-vie aux sauvages.

I723, Aug. I6. Ordonnance portant confiscation de marchandises étrangères saisies à Chambly.

I724, Mar. I4. Ordonnance entre le Sr. Jacques Baudry et le Sr. de Tonty, commandant au Détroit.

I724, May i6. Commission de subdélégué à l'aumonier du fort du Détroit pour les confiscations.

I724, Aug. I4. Ordonnance entre le Sr. Grandmesnil et le Sr. de Tonty.

1724, Aug. I4. Ordonnance entre le Sr. de Tonty et le Sr. de Berré.

I724, Aug. I6. Ordonnance entre la dame veuve de La Forest et le Sr. de Tonty.

I724, Oct. 6. Ordonnance entre le Sr. de Grandmesnil et le Sr. de Buisson commandant du Détroit.

I724, Oct. 7. Ordonnance portant confiscation des pelleteries saisies sur le chemin de la Chine.

I725, July 2. Ordonnance qui confisque plusieurs marchandises de fabrique étrangère introduite en ce pays par des sauvages, au profit de la Compagnie des Indes.

I725, July 27. Ordonnance qui confisque de marchandises de nature étrangère introduite en ce pays par le nommé Groüard.

I726, Apr. 25. Ordonnance qui fait défense à toutes personnes de faire directement ny indirectement aucume traite au fort de Niagara.

I726, Sept. 14. Ordonnance concernant les traites qui se font en fraude dans l'étendue des postes des lacs Ontario et Erie appartenants au Roi.

I728, Mar. 5. Ordonnance concernant les effets saisis sur le nommé Desjardins habitant du Détroit en passant à Niagara le 29 Septembre, I727.

I728, July I4. Le Sr. Le Gardeur contre Robert Germain au sujet d'une concession dans la seigneurie de Portneuf que ce dernier a abandonnée pour voyager à la Louisiane. 
I729, Sept. 21. Ordonnance au sujet de la vente des pelleteries des forts Frontenac et Niagara.

I729, Oct. 25. Commission au Sr. Raimbault père, pour empêcher le commerce étranger.

I730, May 23. Ordonnance obtenue par le Sr. Grandmesnil comme fondé de procuration de M. la Mothe Cadillac au sujet de ses biens au Détroit.

I730, July II. Ordonnance qui défend aux marchands de recevoir aucunes couvertes en gage des sauvages sur les plaintes des directeurs et agents des compagnies.

I732, June 29. Ordonnance qui condamne le nommé Vincent Lenoir en l'amende de 500 livres pour avoir été en la Nouvelle Angleterre sans permission.

I733, Jan. 4. Ordonnance concernant la Compagnie des Indes, castor sec et gras.

I734, May 22. Commission de notaire pour le Sr. Navarre au Détroit.

I734, June 7. Ordonnance qui ordonne au Sr. Desjardins, voyageur au Détroit, de retenir une somme de 27 livres, ${ }_{5} 5$ sols, sur les gages du nommé Grogué, son engagé, débiteur de la dame veuve Portneuf.

I734, July 22. Commission de notaire pour le Sr. Leonard Biller au fort des Caskaskias, province de la Louisiane.

I735, Aug. 23. [Ordonnance de] police pour les négociants du Détroit et de Michilimakinac.

I735, Sept. I3. Ordonnance au sujet de la Compagnie des Indes, qui fait défense de passer en France et autres lieux des chapeaux de castor.

I736, Mar. 27. Ordonnance qui renvoie le Sr. de la Corne à se pourvoir pardevant le Sr. Navarre au Détroit à l'occasion de plusieurs dettes qu'il a au dit lieu.

I736, Aug. 16. Commission de receveur du domaine du Roi pour le Sr. Navarre au lieu du Détroit.

1736, Aug. 16. Memoire pour servir d'instructions au Sr. Navarre.

I738, Mar. I8. Memoire donné au Sr. de la Ronde, commandant à Chagouamigon, pour la découverte des mines de cuivre au lac Supérieur.'

I738, Apr. 25. Ordonnance portant réglement en cinq articles en addition aux réglements déjà faits en faveur de la Compagnie des Indes. Regulation of fur trade and prohibition of trade with New England.

I738, June 16. Entre Pierre Meloche habitant du Détroit, et le nommé Jacques Campeau aussi habitant au dit lieu.

I739, June 18. Ordonnance qui autorise M. Navarre, notaire au Détroit, à faire l'inventaire de la succession du nommé Jacques Roussel fils, décédé au Détroit.

I739, June 30. Ordonnance qui commet M. Navarre, notaire au Détroit, pour connaitre de l'affaire d'entre Jean Bte. Forestier et autres et la veuve de Pierre Estève.

I74I, June 6. Ordonnance au sujet des marchandises étrangères dans les pays d'en haut.

1743, June 9. Commission de subdélégué de Monsieur l'Intendant au Détroit du lac Erie pour le sieur Navarre, notaire au dit lieu.

I743, Oct. 3 . Ordre à David Corbin, maitre charpentier, pour l'exploitation des bois de construction dans le lac Champlain pour le service du Roi.

'Printed in Édits et Ord., II. 373.

Ibid., 374. 
I744, Aug. I I. Ordre au Sr. Levasseur d'aller dans le lac Champlain pour y faire couper le bois nécessaire pour la construction des vaisseaux du Roi.

I744, Aug. II. Mémoire servant d'instructions au Sr. Levasseur, chef de construction à Québec, dans le voyage qu'il va faire au lac Champlain.

I744, Sept. 24. Ordre et instructions à Joseph Corbin pour exploiter des bois dans le lac Champlain.

I745, Jan. 9. Ordre au Sr. Levasseur pour se rendre au lac Champlain et autres lieux pour l'exploitation des bois.

I745. Jan. 9. Mémoire d'instructions pour le dit Sr. Levasseur.

I746, Feb. 7. Ordre au Sr. Levasseur, maitre constructeur, de se rendre dans le lac Champlain à l'occasion des bois de construction pour les vaisseaux du Roi.

I749, Jan. 25. Mémoire d'instructions pour le Sr. Levasseur constructeur des vaisseaux du Roi dans le voyage qu'il va faire au lac Champlain.

I749, Apr. I. Commission de subdélégué au Détroit pour le sieur Navarre.

1749, Apr. I. Commission de garde-magazin au Détroit pour le sieur Navarre.

I749, July 2. Mémoire d'instructions pour le Sr. Levasseur, constructeur des vaisseaux du Roi, dans le voyage qu'il va faire au lac Champlain.

I750, Jan. 2. Ordonnance qui régle les avantages dont jouiront les habitants qui iront s'établir au Détroit.

I750, Jan. 20. Mémoire d'instructions pour le Sr. Levasseur, chef des constructions des vaisseaux du Roi, dans le voyage qu'il va faire au lac Champlain.

I750, Oct. 9. Ordre à Joseph Corbin pour monter dans le lac Champlain.

I75I, Jan. I4. Instructions pour le Sr. Levasseur, chef des constructions des vaisseaux du Roi, dans le voyage qu'il va faire au lac Champlain.

I752, May 4. Commission à M. Landrière pour faire les fonctions de commissaire au Détroit.

I752, May 4. Commission de subdélégué de M. l'Intendant au Détroit pour Monsieur Landrière.

I752, May 4. Mémoire d'instruction pour le-dit Sr. Landrière.

I754, Apr. 6. Commission de notaire à Michilimakinac pour le Sr. Cardin.

I754, May 23. Commission de subdélégué au Détroit pour le Sr. Navarre.

I758, June I2. Commission de notaire au Détroit pour Campeau.

I759, Feb. I7. Commission de subdélégué au Détroit pour le Sr. Navarre.

\section{LAND RECORDS.}

The records of land grants are in various series as follows:

Registres d'Intendance, October I7, I672-October I 5, I759, 2 vols.

These contain the concessions and ratifications of the intendants. A copy of them is in the Dominion Archives at Ottawa.

Cahiers d'Intendance, 4 vols.

These contain the registrations of the titles of concessions, ratifications and other acts, under the ordinances of Michel Bégon, intendant, of December 24, I722, May 24, I 724, and January I4, I725. They include the actes de foi et hommage from 1674 to 1723 . A copy of them is in the Dominion Archives at Ottawa, M 9-12; see p. IO4, above. 
Aveux et Dénombrements, I723-I746.

These volumes have been bound in such a confusing manner that it is thought best to give a complete list (by binder's titles) of the originals and copies.

(I) Papier Terrier. I5 Fév. 1723 au I Juin, I732. C. 2. Aveux et Dénombrements, vol. I.

(2) Papier Terrier. I Juin I732 au I Sept. C. 2. Aveux et Dénombrements, vol. 2.

(3) C. I. Supplément. Papier Terrier. 9 Janv. I743 au I4 [26] Fév. [I746].

These three are authenticated originals, and constitute the complete series.

(4) Dom. Française. Avetıx et Dénombrements. Copies, I. Copy of ( I).

(5) Same, 2. Copy of (2).

(6) C. II. Supplément. Papier Terrier. Incomplete copy of (3).

(7) Dom. Française. Aveux et Dénombrements. Copies, 4. Copy of first part of (4).

(8) Same, 5. Copy of remainder of (4).

(9) Same, 3. Authenticated copies of part of (3).

There are also two volumes of aveux et dénombrements of the English régime, but none of the seigniories mentioned therein are within the present bounds of the United States. It may be further noted that there are other volumes, labelled "Papier Terrier", "Cahiers des Emplacements", and "Déclarations des Censitaires", which relate only to the city of Quebec.

A list of these volumes will be found in Can. Arch. Rept., I904, pp. 88, 96. Copies are in the Dominion Archives at Ottawa, M 36 et seq. The avent et dénombrement, which had to be deposited by the seignior upon receiving his grant and at intervals thereafter, consisted of a description of the grant showing its location, boundaries, terms of tenure, acreage, jurisdiction, tenants, etc. See Munro, Seigniorial Régime, p. 57.

Actes de foi et hommage, I667-1854.

The volumes in the archives at the time of this examination were four in number, labelled I723-1754, I78I-I8IO, I8IO-I835, I835-I854. A copy in the Dominion Archives in Ottawa is in eight volumes, M 1-8, covering the dates September 9, I667-February 19, I674 and January 30, I723-February 3, I854, while a note in the Ottawa transcripts of the "Cahiers d'Intendance" states that these latter contain the "Actes de Foi et Hommage" of I674-I723. An abstract of the "Actes de Foi et Hommage" for I723-I78I is printed in Can. Arch. Rept., I884, pp. I-30, and for I668-1674 and I78I-I854, ibid., I885. pp. $3 \mathrm{I}-77$. These actes de foi et hommage were the declarations of fealty and homage due from the seignior to the representative of the sovereign. See Munro, op. cit., p. 56.

The value of the various land records for the present purpose lies in such part of them as relate to lands within or adjacent to the present boundaries of the United States. Along the Maine boundary, at Detroit, in the Illinois country, and especially around Lake Champlain, were numerous grants, many of them seigniorial. Of considerable aid in locating them is a manuscript volume in the Provincial Archives entitled "Table Générale des titres de concessions, ratifications, etc.", which is made up from the Registres des 
Jugements du Conscil, the Insinuations, the Registres d'Intendance, and the Cahicrs d'Intendance. Over 350 titles have been published in the volume of Titles and Documents relating to the Seigniorial Tenure noted above. The Report of the Secretary and Registrar of the Province of Quebec, I892, contains, pp. I20-I66, a "Chronological list or index of grants in fief and royal ratifications of grants in fief made in New France to .... I 600 ". The following list includes most of the grants lying within or nearly adjacent to the present territory of the United States.

I686, Oct. I. Rev. Father Dablon and Jesuits, on the river St. Joseph.

I69, July I6. Jean Meusnier, inhabitant of Acadia, whose place had been phundered by the English; land on the river MIaricadouy, five leagues below Pasmaquoddy.

I69I, Aug. 4. Mathieu de Goutin, at Mouscoudabouet in Acadia.

I695, June 20. Pierre Thibaudeau, land on the river Konaskagouche between Mount Desert and Majais [Machias?].

I695, July 8. Michel Chartier, land on the river Descoudet, in Acadia.

I697, Apr. I2. Sr. Hautteville, fief of Villeclaire on coast of Acadia between Pentagouet and the river St. John.

I697, Apr. I2. Sr. Le Gardeur, grant, to bear name of Tilly, on the coast of Acadia, from the river Quiquischeoubeugouet to the river Memehic.

I697, Apr. 23. Charles Genaples, Sr. de Vilrenard, land on each side of the river St. John.

I733, Apr. Io. Sr. Péan, land on the river Chambly [Richelieu] and Lake Champlain, with Isle Lamotte.

I733, Apr. I I. Migeon Delagauchetière, on Lake Champlain.

I733, Apr. I2. Sr. de St. Vincent, on Lake Champlain.

I734, June I6. Chauvin, inhabitant of Fort Ponchartrain at Detroit, grant under title of cens et rentes, of land on the straits of Lake Erie.

I734, July I. Sr. de Contrecoeur, Grand Island in Lake Champlain.

1734, July 6. René Boucher, Sr. de la Périère, land on Lake Champlain at mouth of river Ouynouski [Winooski].

I734, July 7. Pierre Claude Pecaudy de Contrecoeur (eldest son), land on Lake Champlain, at mouth of Rivière aux Loutres [Otter Creek].

I734, July 20. Philippe René Legardeur, Sr. de Beauvais fils, land on Lake Champlain.

I736, Sept. I. Charles Bonhomme, alias Beaupré, land at Detroit.

I736, Oct. 6. Pierre Raimbault, land on Lake Champlain including Lamoille River.

I736, Oct. 8. Michel Daigneux, Sr. Douville, land on the east shore of Lake Champlain.

I737, Apr. I6. Various concessions en roture at Detroit; see above, under Insinuations, p. 209.

1737, June I3. Louis Joseph Rocher, land on Lake Champlain including the river Boquet.

I74I, May I. François Mocquier, land south of Fort St. Frederic [Crown Point].

I743, June IS. Jean Chapotier, land on straits of Lake Erie.

I744, Jan. I 5. Guillaume Estèbe, land on Lake Champlain, formerly granted to Migeon Delagauchetière.

I744, Mar. I 5. Hertel Beaubassin, land south of Fort St. Frederic [Crown Point].

I747, May I. Robert Navarre, land on the straits of Lake Erie. 
I748, Sept. 23. Nicolas René Levasseur, land on Lake Champlain along the river Missiquoi. (The greater part of this was in the present state of Vermont. Later it was called St. Armand.)

I749, Nov. I. Sr. Daine, Grande Isle in Lake Champlain.

I750, Apr. I. Pierre Réaume, land on the shore of the Detroit River.

I750, Oct. Io. Sr. de Bonne and Chev. de Repentigny, the Sault Ste. Marie.

I75I, Apr. I. Chev. de Longueuil, land on the Detroit River.

I752, June I2. Sr. Douville Dequindre, grant of Isle aux Cochons in Lake Erie above the fort of Detroit.

I752, Sept. 29. Jacques Pierre, Sr. de Muy, land on Lake Champlain extending to the northeast from Otter Creek.

I752, Nov. I. Sr. Bedou, land on Lake Champlain including Isle Lamotte and Chazy River.

I753, May I6. Sr. Dequindre, land on the Detroit River.

I755, July 20. Louis Liennard de Beaujeu, Sr. de Villeneuve, land on Lake Champlain including the river St. Anara.

\section{Court Records. \\ Quebec.}

The records of the Prévôté de Québec, in about I20 volumes, I666-I759, are preserved in the Provincial Archives. They consist mainly of the minutes of the court sessions (registres) but there are various short or broken series labelled "Criminel ", "Déclarations", "Licitations", "Amirauté", etc., and there are two series of miscellaneous papers labelled "Matières Civiles", in two volumes, I682-1730, I738-1746, and "Procédures Judiciaires": "Matières Criminelles", in six volumes, 1665-1696, I70I-1759. These last two series were transferred to the archives by the Quebec Literary and Historical Society in I888. The registers were taken from the Judicial Archives in I888, where it would appear that they more properly belong. The insinuations however were retained in the Judicial Archives, q. $v$. Earlier lists of the records of the prévôté will be found in Can. Arch. Rept., I904, pp. I08-109, and in the Report of the Secretary and Registrar of the Province of Quebec for 1904, pp. 8-II. The material in these records relating to the United States is exceedingly scattered and relates either to incidents in the careers of individuals, or to such matters as the Indian trade in particular cases.

Three Rivers.

The registers of the Prévôté of Three Rivers, I 655 -I 757 , and a few volumes of miscellaneous documents, are in the Provincial Archives. They were brought to Quebec about I 822 .

\section{Montreal.}

The records of the Prévôté of Montreal were transferred to Quebec in I889 (see list in Report of Secretary of the Province of Quebec, I888-1889, pp. I3I ff.) but have recently been returned to Montreal. The records of the militia court, I760-1764, have however been retained in Quebec, and the following volumes are in the Provincial Archives:

Chambre des Milices de Montréal, I760-1764. 5 vols.

These contain the record of cases tried before the militia captains who sat as a court, the decisions of Thomas Gage and Ralph Burton in appealed cases, etc. In a volume bearing the date $1760-1764$ is found material bearing on 
prices and trade, as for example, "Relevé des marchandises dont le Sr. Pierre Réaume [of Detroit] est comptable à la société ... suivant le tableau arrèté le 22 mars I760", which contains a long list of prices of general merchandise, furs, tobacco, etc.

Gouvernement de Montréal. Divers Documents, I760-1763. I vol.

Registre des Sentences, I,64. I rol.

\section{Transcripts.}

There is a large collection of transcripts of documents from archives in London, Paris, Boston, and Ottawa. They consist in part of copies of docnments now printed in Documents relating to the Colonial History of the State of New York, and in Manuscrits ... relatifs à l'Histoire de la Nouvelle France (Quebec, I883-I 885.4 vols.). There are also copies of the Faribauit transcripts in the Library of Parliament at Ottawa (q. $v$. p. I92), of the copies of Franquet's two volumes in the same depository, and of certain of the Simcoe papers in the Dominion Archives. Although these transcripts contain more material relating to the history of the United States than any other groups of documents in the Provincial Archives, so much of it has been printed or is more accessible in the form either of better copies or of originals (Ottawa and Boston) that it is not necessary to give any detailed account of it here.

\section{Maps and Plans.}

The Provincial Archives contain copies of numerous maps and plans. The dates, authors, and locations of the originals are in most cases not indicated. The copies are tracings, colored and mounted, and seem to be carefully made. They were prepared by L. P. Tallerand in I 889.

Plan des forts faits par le régiment Carignan Salières sur la rivière de Richelieu dite autrement des Iroquois en la Nouvelle France. Includes Lake St. Pierre, Lake Ontario, Lake Champlain, Fort Orange, Fort Ste. Thérèse, Fort St. Louis, and Fort de Richelieu.

Plan et élévation du Fort St. Jean Richelieu et du Fort Richelieu Sorel.

Le siège de l'Isle aux Noix en r760. Includes island and surroundings, with Chambly [Richelieu] River and upper part of Lake Champlain.

Plan du Fort Vaudreuil situé sur la montagne de Carillon en Canada composé de quatres bastions en bois pièces sur pièces.

Plan of Fort Carillon and its surroundings.

Plan des attaques du Fort George appellé par les Anglais William-henri, par Mr. le Marquis de Montcalm, général des troupes de S. M. en Canada.

Fort Lidius.

Carte de l'entrée de la rivière Choueguen ou des Onantagué [Onondaga] scituée au sud du lac Frontenac. Includes plans of forts St. Frederic, Quaris, de Cannatchocary, and Hunter.

Plan de la rivière et des forts de Chouagen. No. 3. Includes old Fort Oswego and Fort Ontario.

Plan des attaques des Forts Chouagen. Includes Forts George, Chouagen [Oswego], and Ontario.

Plan of forts Présentation, Frontenac or Cataracoui, Lawrence, and Pointe au Baril.

Plan du Terrain de la Pointe à la Chevelure où est marqué le fort de pieux construit en I73I.

Plan des denx Forts des Natchez, assiégés au mois de février I730 par les français Tchactas, Tonicas, Colapissas, et Oumas. 


\section{RECORDS SINCE I 788 .}

The office of the Provincial Secretary is the principal office of record of the province. Here are recorded or registered the grants of lands, the commissions of officials, the charters of incorporated companies, proclamations, election returns, etc. The first report of the secretary and register, I 888 , contains a list of these record volumes. As this material is not however of interest to the history of the United States, it is not necessary to give it more than passing notice.

\section{JUDICIAL ARCHIVES.}

The Judicial Archives are in the custody of the Attorney General, from whom permission to use them should be obtained. They are located on the upper floor of the Court House or Palais de Justice, and are under the immediate charge of M. Philéas Gagnon. They are admirably arranged and cared for and excellent indexes have been prepared for most of the series. The principal groups of archives are the notarial papers ( $1635^{-}$), the papers relating to the appointment of guardians, family councils, etc. (I639-

), the minutes (procès-verbaux) of the superintendents of roads (grands-voyers) ( $1660-$ ), the registers of baptisms, marriages, and burials of parishes in the district of Quebec, from I68I, the registers of insinuations of the French prévoté of Quebec, $1667-1759$, the records of the various courts-military, common pleas, king's bench, appeals, circuit, admiralty, bankruptcy, etc.-under the English régime, and finally a great mass of miscellaneous judicial papers. A brief examination was made, chiefly through the indexes, of certain of these groups, and the following notes serve to indicate, by illustrative examples, the sort of material relating to the United States that may be found among these archives.

\section{Notarial Records.}

These records consist of the papers which accumulated in the offices (ćtudes) of the various notaries, and which were required by law to be carefully preserved. In general they consist of documents relating to property and personal and business relations, such as concessions, sales, deeds, receipts, agreements, leases, marriage contracts, wills, etc. The earliest papers date from about 1636 . They are arranged by notaries or rather by études and for each étude is an inventory of the papers pertaining to it. For an historical account of the notarial institution see J. E. Roy, Histoire du Notariat au Canada (Lévis, I899-I902, 4 vols.). This contains lists of the notaries and detailed accounts of some of the notarial archives. Lists of the études whose records were deposited in Quebec are printed in Can. Arch. Rept., I904, pp. I 7 I -176 .

According to Roy ( $o p$. cit., p. I I 5) the files of the notary Louis Chambalon, I692-I 7 I6, contain all the agreements that were passed between the directors of the Compagnie de la Colonie and la Mothe de Cadillac respecting the trade at Fort Ponchartrain (Detroit), while those of François Genaple de Bellefonds, I682-I709, contain an engagement of Tonty, I684, and the marriage contract, June 2I, I687, between la Mothe de Cadillac and Marie Thérèse Guyon.

The English notary, John Jones, had dealings with many English and Americans, and among his files, ISOI-ISIr, are to be found according to the manuscript inventory such papers as the following: 
1802, Oct. 13. Deposit of a deed of sale from John Jacob Astor of New York to George Astor of London.

I805, Nov. 2. Acquittance and release from Thomas Thomas to the Northwest Company.

I806, July 5. Transfer and conveyance from George Pyke, Esq., acting for Asa Porter, Esq., in the United States of America.

I8ro, Aug. 20. Note from Roswell Snith to Levi Bigelow of Derby, Vt., for $£ 62.10$ in currency of Lower Canada.

\section{Registres des Insinuations de la Prévôté.}

These registers extend from March I, I667 to April I5, I759, but are missing for the periods January. 10, I669-March 9, I671, February 5, I700April I2, I703, and March, I7I5-December, I7I7. They contain the official registration (insinuation) of commissions from the king or company to the various judicial officers, of marriage contracts, wills, deeds, etc., of edicts and arrêts of the king and of the council, and of ordinances and regulations of the prévôté. An index to proper names has been prepared, and one finds the names of such men as Pierre Lemoyne d'Iberville, and de la Salle. The other records of the prévôté-the court minutes-have been transferred to the Provincial Archives, thus destroying the unity of this important fonds d'archives.

\section{Miscellaneous Judicial Papers.}

This is a group of several thousand documents which appear to be made up of the dossiers of cases before the courts of Quebec, Montreal, and Three Rivers, or before the council sitting as a court of appeal. An elaborate inventory of this collection is in the form of a manuscript volume entitled "Pièces d'Écriture de toutes sortes". The following extracts from this inventory illustrate the value of this collection for the history of the United States.

I69I. Procédures relatives à la prise d'une caïche sur les Anglais par le sieur Simon Denis de Bonaventure par le travers du Cap Breton. Among the signatures are those of Thomas Archeve [Ashley] Cooper of New England, Rolland Preish of Boston, Eliah Broder living in New England, etc. (Liasse 5. No. 217.)

I696. Procès de Joseph Mareau et Louis Durand contre le sieur Delamothe Cadillac. (Liasse 6. No. 266.)

I696. Procédures relatives à la prise de navires sur les Anglais, vers le Cap de Sable, par le brigantin Frontenac sous le commandement du sieur Jean Outlas [John Outlaw]. Les noms des deux navires Anglais sont Sloop Brothers Adrenturers commandé par Joseph Turner, ayant avec lui un homme du nom de Hugh Puhnan [Putnam ?], tous deux de Massachusetts Bay. L'autre navire portait le nom de Brigantin Adventure et était commandé par James Philbricke .... du New Hampshire. (Liasse 6. No. 260.)

I704. Requête de Marie Magdeleine femme de Philippe Letourneau absent de cette ville pour le Mississipi, pour être autorisée à la poursuite des droits de son mari. (Liasse 62. No. 3406.)

I7I3. Papiers concernant la prise de deux sloops sur les ennemis de l'état par le charroy Le Trompeur armé en course et commandé par Jacques Morin dit Bonsecour. Signatures of James Campbell, Joseph Dudley, etc. (Liasse Io. No. 482.) 
I724. Pierre Trottier Desauniers contre Charles Renaud Dubuisson et Paul Trottier Desruisseaux associés pour le commerce du poste des Miamis et Ouyatanous. (Liasse I6. No. 688.)

1725. Jacques Charbonnier contre Charles Lemoine, baron de Longueuil, faisant au nom et comme procureur de son frère residant à la Louisiane. (Liasse I7. No. 715.)

1725, Feb. 6. Fort de Chartres (Illinois). Vente par Augustin Simon Lapointe à François Mercier. (Liasse 57. No. 2359.)

I727, June 20. Grand campement de la Pointe Pelée. Acte d'accord entre Messieurs Dubuisson capitaine commandant aux Miamis, et le nommé Paul Desruisseaux son associé. Acte qui parait dressé par Alphonse de Tonty ..... commandant au Fort Ponchartrain. (Liasse 57. No. 2369.)

I729, Jan. I 5. Lettre de Fleuriau procureur général du Roy à la Nouvelle Orleans .... Respecting Rottot killed by the Fox Indians, and Perrault supposed to have gone to New Orleans as procureur du Roi. (Liasse 65. No. 4217.)

I73I. Louis Gatineau contre Augustin Lesieur comme procureur de Joseph Lesieur son frère, décédé au Mississipy. (Liasse 23. No. 871.)

I753. Donation entre vifs de Jean Baptiste Coutourier, voyageur, à ce moment en la ville de Cascaskias, aux Illinois, à son frère Joseph Coutourier. (Liasse 67. No. 4260.)

I754, July I4. Fort du Détroit. Procuration de Joseph Coutourier à Louis Gouin. (Liasse 58. No. 2500.)

I77I, July 29. Montreal. Ignace Pillet to secretary of province asking for permit for Detroit with 2 canoes in the name of Gabriel Huneau. (Liasse 67. No. 4278.)

I792, Feb. 3. Court of St. James. Decision of privy council in case of Thomas Franklin of Philadelphia vs. Robert Wilcocks of Quebec. (Liasse 67. No. 4294.)

\section{IndiAn AcCounts.}

Two volumes used as exhibits in the case of J. Monk, Esq., AttorneyGeneral ws. Taylor and Forsyth. One of these volumes, labelled "Indian Department, May I, I779, No. 2 ", contains the accounts of the Crown with Thomas Robinson for "Sundries furnished the Indian Department, May I, I779-August 22, I779", for " sundries given to royalists and prisoners ", May 8, I779-September 3, I779, and for "Colonel John Butler's expences in the Indian Country", and the accounts of Colonel Guy Johnson on account of the expedition under Sir John Johnson, September 20-December 20, I780. The other volume is labelled "Colonel Johnson's account and Extracts therefrom by his order charged to his Public Account", I780-I78I.

\section{LITERARY AND HISTORICAL SOCIETY.}

The Literary and Historical Society of Quebec, the oldest learned society of Canada, was founded in 1824 and incorporated in I83I. Its principal activity is the maintenance of a library for the use of its members. Its publications, under varying titles-Transactions, Historical Documents, etc.-extend from 1829 (see list in Griffin, Bibliography of American Historical Societies, I905, pp. 976-983). The society has a small collection of manuscripts-originals and copies-which are kept in a large sheet-iron chest in 
the basement. Nost of the more important of the manuscripts have been published. At one time the society possessed a considerable number of original documents emanating from the archives of the French régime, but these have now been transferred to the office of the Provincial Secretary. The society has rooms on the second floor of the Morrin College building, Ste. Anne and Stanislaus streets, where its library is open from 9 a. m. to $6: 30$ p. m., with the exception of about two hours at noon.

Découvertes du Cap ${ }^{\text {ne }}$ Cook et de la Pérouse.

A MIS. in modern binding with illustrations clipped from some printed work. There are chapters on "Habitants de Nootka", "Habitants des Iles Sandwich", "Habitants de la Baye des Manilles", etc.

Correspondence of Perrault, sr. I755-I772.

Letters to a Quebec merchant from La Rochelle, Montauban, Bordeaux, Montreal, Paris, London, etc., relating to business affairs, news from the Ohio (May 3, I755), Louisiana, etc.

Journals of James Thomson. I759-1788.

Four small volumes and four large volumes. From iz79 to i 787 Thomson was overseer of works on the fortifications of Quebec and the journal for that period relates almost entirely to details of construction.

Sieges of Quebec. 1759, 1775-1776.

A volume of copies. Most of these documents have been printed by the society. The following however have not been published:

"Le Témoin oculaire de la Guerre des Bastonnais en Canada, dans les années 1775 et $1776 \%$, by Simon Sanguinet.

"Journal tenu pendant le siège du Fort St. Jean en I775, par feu Mr. Foucher, ancien notaire de Montréal".

Military Government, Canada, etc. I760-1;64.

Contains "Lettres et placards affichés dans le Gouvernement des Trois Rivières", I760-I764, copied by Ed. Glackemeyer from originals in his possession, and presented to the society in 1872 .

Histoire de l'Eglise Paroissiale de Québec.

This volume contains, among other things, two letters addressed to Perrault, sr., merchant of Quebec, by his London correspondent, Antoine Vialars, relating to trade, prices of skins, etc., with references to New York, the Mississippi, etc., December 27, 1762, December Io, 1763 , and minutes of courts-martial at Fort Chambly, August 17, I8r2.

Némoire sur le Canada, i 763.

A document in 27 pages entitled "Mémoire sur la partie occidentale du Canada depuis Michilimakinac jusqu'au fleuve du Mississippi tant par la Baie des Puants, Rivière des Renards et Ouisconsin, que par Chicagou et rivière des Illinois .... En un mot tout ce qui peut contribuer à une connaissance générale et exacte de ces différentes contrées . . . Le tout puisé dans les notes qu'en ont données ceux qui après avoir couru ces différents païs ont été reconnus pour les plus intélligens. . . . ."

Warrants, Lands, etc. I764-I 775 .

Order-book of Murray, Carleton, and Cramahé, containing orders and march routes, e.g. (p. I64), July I, I 767 , company of Royal Artillery, Capt. George Grove, ordered to province of New York. 
Col. Henry Caldwell's Letter and Inventory of Losses, etc. I775-1776.

A letter, attributed to Col. Caldwell, giving an account of the invasion of Canada in $1775-1776$, printed by the society in Historical Documents, second series, and an inventory of the damage to property due to the invasion.

Minutes of the Society Instituted at Quebec for the Encouragement of Agriculture, I789-April I3, I792.

Contains a number of letters addressed to Hugh Finlay, secretary of the society.

Memoirs, Letters, etc.

A volume of miscellaneous documents containing, among other things, a letter from S. Sewall to Judge Chipman, November 8, 1813, respecting the operations of Wilkinson and the intense loyalty of the people.

The Book of Arrivals for 1833 .

This is a list of the vessels arriving in Quebec, giving such data as date, class, name of master, where from, length of passage, name of consignee, cargo, tonnage, number of passengers, etc. A few vessels from Boston, New York, and Charleston are noted. 


\section{QUEBEC: ARCHIVES OF THE ARCHBISHOPRIC.}

The search for materials for United States history in the archives of the archbishopric from I $844 .^{2}$ The jurisdiction of the bishop originally, besides Reverend Professor Frederick J. Zwierlein, Ph. D., professor of ecclesiastical history in St. Bernard's Seminary at Rochester, New York. The following account of these archives has been prepared from his notes, with some additions from notes taken by Professor Clarence W. Alvord of the University of Illinois.

The position of the Bishop of Quebec was in the period before the American War for Independence and for some time after that event one of such impcrtance in respect to civil affairs that in the case of that city it is proper, to a degree not paralleled in the case of the other capitals of Canada, to include in such a book as the present a survey of the ecclesiastical as well as of the civil provincial archives. Of ecclesiastical archives there are at Quebec two great collections: the archives of the archbishopric, preserved in the palace of the archbishop, and those of the seminary, preserved at Laval University. The latter are not simply the records of the seminary itself. The bishops of Quebec, deprived of a residence of their own from the conquest in I759 until I847, dwelt at the seminary with their secretaries. The archiepiscopal archives had likewise been deposited there, and when they were transferred to the new palace, many of them, through want either of classification or of accommodation, were left behind and have remained there. ${ }^{1}$ Of these archives at the seminary a classification was begun some years ago by the Abbé Amédée Gosselin, now rector of Laval University but at that time archivist. Some four or five thousand of their documents were catalogued by him; but the task was of necessity interrupted by his promotion to his present position, and until it can be completed the documents, which in any case are in a large degree not of a public nature, are not open to examination by historical scholars. Professor Zwierlein's report is therefore, so far as ecclesiastical archives at Quebec are concerned, confined to the archives of the archbishopric.

The bishopric of Quebec dates from 1674 (in a sense from 1658), the archbishopric from $I S 44 .^{2}$ The jurisdiction of the bishop originally, besides comprising Newfoundland and all the area of the present Dominion of Canada, extended as far south as New Orleans, embracing thus the whole of the Mississippi valley and the far West. The Spanish occupation of Louisiana and the appointment of Peñalver y Cardenas as Bishop of New Orleans in I793 withdrew a part of this area from the jurisdiction of Quebec, and the appointment of Dr. Carroll as Bishop of Baltimore in I79o operated still further to withdraw from its sway most of those parts of the diocese which were within the boundaries of the United States. But in the period before

\footnotetext{
${ }^{1}$ See an article on "The Archives of the Archbishopric of Quebec" in the Records of the American Catholic Historical Society of Philadelphia, XVIII. 8-II, by the Abbé Lionel St. G. Lindsay, the archivist.

${ }^{2}$ The Bishop of Quebec was given the title of archbishop in 1819 , but did not assume it. The bishopric was not erected into a metropolitan see until I $8+4$, after which date the title of archbishop was formally assumed.
} 
these dates, and to some extent in the subsequent period, the correspondence of the bishop with missionary and other priests in the present area of the republic was extensive and interesting. The bishops and subsequently the archbishops were also, as a matter of course, constant correspondents of the prelates of the United States.

The archives of the archbishopric include: ${ }^{1}$

I. The Registers of the Archbishopric, begun on the arrival of Monseigneur de Laval in 1659 , and continued without interruption to the present day. They comprise seventy-three large folios of about $600 \mathrm{pp}$. each.

II. Ancient deeds and documents, the oldest of which bear respectively the dates of 532 , I 287 , I449, and 1575 . These four deeds relate to the abbeys of Maubec and Lestree, which were given by the King of France to the bishopric of Quebec to create a revenue for its support.

III. Papal bulls nominating the bishops of Quebec and others, beginning by those appointing Monseigneur de Laval bishop of Petraea ( 1658 ).

IV. Correspondence with Rome, the dioceses of Canada and of the United States, with the religious orders and communities, the parishes and missions of the diocese of Quebec.

V. Correspondence with the vicars-general of Montreal, Three Rivers, and Upper Canada, before the erection of any diocese outside of Quebec.

VI. Correspondence with the missionaries dispersed throughout the vast territory formerly depending on the diocese of Quebec, from the Gulf of St. Lawrence to the mouth of the Mississippi.

VII. Manuscripts in several Indian tongues: Micmac, Abenaki, Algonquin, Montagnais, etc., written by the following missionaries: the Abbés Maillard, Manach, Bellanger, and the Jesuits Bigot (Vincent), de Crespieul, Vaultier, Laure, Silvy, Coquart, Maurice, Aubéry.

VIII. Baptismal, marriage, and death registers kept by the earliest missionaries of New France.

The mandements, pastoral letters, and circulars of the bishops have been comprehensively printed in Mandements, Lettres Pastorales, et Circulaires des Evếques de Québec, edited by Mgrs. H. Têtu and C. O. Gagnon, in six volumes (Quebec, I887-1890).

The materials in the archiepiscopal archives may be conveniently classed under two general heads: (I) letters sent, $i$. e., those sent by the bishop or archbishop; and (2) letters received. For the former a manuscript index in two volumes by Rev. B. Ph. Garneau proved very useful. He made use of the capital letters A, B, C, etc., to indicate the "Registres des Insinuations" (i. e., of documents), the numbers $\mathrm{I}, 2,3$, etc., to designate the "Registres des Lettres", and the sign * after a number to signify a different pagination at the end of the volume. In the "Registres des Insinuations" the leaves are numbered, in the "Registres des Lettres" the pages. This repertory covers all the original documents of this kind except some letters on loose sheets collected together in a number of portfolio volumes. No such index exists for the letters received by the bishops and archbishops of Quebec, but fortunately these letters have been gathered together in portfolio volumes bearing as titles the names of the missions, dioceses, or persons from which they emanated.

There are also six volumes of transcripts of episcopal letters and documents, of which the originals are to be found elsewhere. Some of these originals are in the archives of the Quebec Seminary.

\footnotetext{
${ }^{1}$ From Mgr. H. Têtu, Histoire du Palais Episcopal de Québec (Quebec, 1896), p. 296, as translated by Abbé Lindsay, loc. cit.
} 
The following list of letters and documents having a bearing on the history of the United States begins with the section called "Letters Sent"; in the case of numbered volumes the period in the midst of each reference marks the distinction between volume and page. In the section devoted to "Letters Received ", the arrangement follows that of the volumes themselves, being by subjects instead of in chronological order.

In concluding his report, Professor Zwierlein says: "The work of research in the archiepiscopal archives was made possible and greatly facilitated by the generosity of the ecclesiastical authorities in Quebec. Special thanks are due to His Grace the Most Reverend Archbishop Bégin, who not only permitted this investigation, but also kindly encouraged the progress of the work. I am deeply indebted to M. l'Abbé Lionel St. George Lindsay for the many kindnesses shown to me in the course of the work, without which it could not have been accomplished. Finally I wish to express my appreciation of the kind reception at the Quebec Grand Séminaire, and to testify my gratitude especially towards the rector, M. 1'Abbé Anédée Gosselin."

\section{LETTERS SENT.}

\section{DIOCÈSE. ${ }^{3}$}

No date. To the people. To dispose them to defend themselves properly against the English. A. 487 .

I744, Aug. 29. Charge to the clergy to give thanks upon the occasion of the king's victories. C. I83 v.

I745, June 20. Charge to the clergy to offer public prayers at the approach of war. C. Igo r.

I745, June 20. Letter of the king requesting the singing of a Te Deum. C. $195 \mathrm{r}$.

I746, May I4. Charge to the clergy to give thanks upon the occasion of the king's victories. C. I93 r.

I746, July I7. Charge to the clergy to sing the Te Deum requested by the king. C. $195 \mathrm{v}$.

I749, Feb. I. Letter of the king requesting a Te Deum. C. I99 r.

I776, May i2. Charge to the clergy upon the occasion of the defeat of the Americans. C. $299 \mathrm{v}$.

I776, Dec. 29. Charge to the clergy upon the evacuation of Quebec by the Americans. C. $302 \mathrm{r}$.

I797, Mar. 4. To the curés. Circular letter urging them to build a church at Albany. D. 78 r.

I807, Sept. I7. To the curés. Circular letters upon the preparation of the people to defend the country. G. I I $\mathrm{r}$.

I807, Sept. I7. Charge to the clergy upon the preparation of the people to defend the country. G. I 7 r.

I8Io, Mar. 2I. To the curés. Circular letter urging them to preach loyalty. G. I $89 \mathrm{v}$.

ISIo, Mar.2I. To the archpriests. Id. G. I99 v.

I8I I, Jan. 6. Sending of letters to the Bishop of Boston to act as vicar-general. 7.240 .

ISI I, Jan. 28. To Abbé Louis Raby. Faculties in the diocese of Boston. $7.25 \mathrm{I}$.

\footnotetext{
${ }^{1}$ This section comprises mandements, ordinances, and other acts of jurisdiction relating to the diocese of Quebec, while documents relating to the $s e c$ and the chapter, their erection and endowment, are grouped in the next section, entitled Éc'ché.
} 
1812, Apr. 9. Charges to the clergy to offer public prayers upon the occasion of war. H. IO v.

1812, Oct. 6. To the curés. Circular letter thanking them for their aid in raising the army. H. 3 I r.

1812, Oct. 29. Charges to the clergy to offer public prayers upon the occasion of war. H. $35 \mathrm{r}$.

I8I3, Apr. 22. Id. H. 43 v.

I8I3, July 8. Id. H. 50 r.

I8I3, Oct. 8. To the clergy. Circular letter informing them that the king is pleased with their conduct during the war. H. $62 \mathrm{r}$.

I8I3, Nov. II. Charge to the clergy to offer public prayers upon the occasion of war. H. $64 \mathrm{v}$.

18I4, Mar. 31. Id. H. 7I v.

I8I 5 , Mar. Io. $I d$. upon the restoration of peace in the country. $\mathrm{H} 95 \mathrm{r}$.

1817, Nov. I7. To Abbé Louis Marcoux. Passamaquoddy. 9.269.

I8I9, Mar. 3I. To Abbé A. T. Lagarde. Jurisdiction for the diocese of Boston. 9.52I.

1824, July 31. To Rev. Gabriel Richard, vicar-general, Cincinnati. Letters giving faculties. I. $90 \mathrm{v}$.

I846, Sept. 28. To the clergy. Circular from the Bishop of Oregon City asking aid. N. I $82 \mathrm{v}$.

1846, Oct. 5. To the clergy. Circular from the Bishop of Walla-Walla asking aid. N. $183 \mathrm{r}$.

1850, Aug. I6. To Abbé A. Lebel, curé of Ste. Claire. He shall have his exeat for the diocese of Chicago. 23.355.

1850, Oct. I4. Id. O. I26 v.

I85I, Aug. 20. To Abbé Z. Lévêque, Paspébiac. Letters testimonial and exeat for the diocese of Boston. O. I $50 \mathrm{r}$.

ÊVÊCHÉ.

I8I I, Feb. II. To Bishop J. O. Plessis. Faculties as vicar-general for the diocese of Boston. G. $216 \mathrm{v}$.

I8I I, May I4. To Bishop Plessis. Id. for the diocese of New York. H. 3 r. I816, June 6. To Bishop Plessis. Id. H. I30 v.

1820, Aug. 26. To Archbishop Plessis. Faculties for Louisiana. H. 266 v. I821, Oct. 9. To Archbishop Plessis. Id. for the diocese of Philadelphia. H. $303 \mathrm{r}$.

1833, Mar. 25. To Archbishop Joseph Signay. Letters as vicar-general for Boston. L. $76 \mathrm{v}$.

I833, Mar. 27. To Archbishop Signay. Id. for Philadelphia. L. $77 \mathrm{r}$. I833, Apr. II. To Archbishop Signay. Id. for St. Louis. I. 78 v.

\section{Gouvernements.}

1824, Aug. 6. To Col. Darling, secretary. The Iroquois of St. Régis wish to emigrate to the U.S. I2.29.

\section{Séminaire.}

I698, Apr. 30. Permission to go and evangelize the tribes of the Mississippi (Tamarois). A. 718 .

1717. Exclusive permission to go to the Tamarois. C. I13 $\mathrm{r}$. 


\section{URSulines (Québec).}

I822, May I8. To Sister St. Henri, superior. Sister St. Etienne may be allowed to go to Louisiana. I0.407.

I822, June I. Letters of obedience for New Orleans to three nuns. H. $318 \mathrm{r}$. I822, Oct. 3. To Thomas Maguire, curé of St. Michel. Commission and faculties to accompany nuns to New York. I. 8.

1823. May r7. To Sister St. Henri, superior. Must comply with the letter of Mr. Collman [Kohlmann ?]. II.I97.

I824, Mar. 17. To Sister St. George. Letter of obedience for Boston. I. 7 I r.

I830, Feb. 22. To Sister St. George. Id. K. I26 v.

I833, Mar. 5. To Sister St. George. Id. L. 7 I r.

I835, Jan. 27. Letters of obedience for three nuns of Boston granted by Bishop Fenwick. L. I 50 r.

1835, Apr. 28. Id. for four nuns. L. 163.

I836, May 9. To Sister St. George. Letters of obedience for New Orleans. M. I3 v.

I839, June 4. To Sister Mary John. Letters of obedience for Quebec granted by the Bishop of Boston. M. I33 r.

I839, June I3. To Sister St. Gabriel, superior. Arrangements for receiving Sister Mary John. I 8.566.

1840, Apr. I4. To Sister Mary Joseph. Letters of obedience for Quebec granted by the Bishop of Boston. M. I $58 \mathrm{r}$.

I840, Apr. I4. To Sister Mary Ursula. Id. M. I 58 r.

I849, Sept. I8. To Sister Ste. Françoise. Letters of obedience for Texas. O. $49 \mathrm{r}$.

I849, Sept. I8. To Sister St. Thomas. Id. O. $49 \mathrm{r}$.

\section{JÉSUITES.}

r69o, Dec. r 5. Mission for the countries of the Outaouais, Illinois, Miamis, and others and faculties of a vicar-general to the superior. A. 503 .

\section{Roure.}

I820, Sept. 6. To Cardinal Fontana, prefect of the Propaganda. Report upon the dioceses of the U. S. I0.94.

(Printed in Journal d'un Voyage en Europe par Mgr. Joseph Octave Plessis, Evêque de Québec, I8I9-I8zo, Quebec, I903, pp. 430-432.)

I844, Mar. 24. To Cardinal Franzoni, prefect of the Propaganda. Request for faculties for the vicar-apostolic of Oregon; mitigation of the law concerning Lent. 20.6 3 .

\section{France.}

I792. Nov. To M. Hody, sup. S. M. Et. Affairs of the diocese of Baltimore. 2.8.

\section{Iles Britanniques.}

I8Io, Nov. 5. To the Archbishop of Dublin. Affairs of the suffragans of Baltimore. 7.213.

I81 5, Dec. I3. To the Archbishop of Dublin. Affairs of the Bishop of New York, etc. 8.4I6. 
I821, Apr. 30. To the Bishop of Halia, London, [i. e., Rev. William Poynter, vicar-apostolic of the London district]. State of ecclesiastical affairs in the U. S. and Canada. I0.206.

I822, Mar. 23. To the Bishop of Halia, London. Nomination of bishops in the U.S. Io. 384 .

I822, June Io. To the Bishop of Halia, London. State of the Church in the U. S. 10.417 .

I838, June 7. To Abbé Delaporte, London. Objects to be sent to Father Blanchet, missionary. 18.324 .

\section{Ursulines (Trois Rivières).}

I 822, Sept. 30. Letters of obedience for a nun, for Louisiana. I. 7 v.

1829, Aug. I4. To Abbé J. Holmes, professor in the Seminary of Quebec. Permission to bring to Three Rivers Visitandines from Georgetown. K. $99 \mathrm{r}$.

I835, July 29. To Sister Ste. Marie, superior. The bishop hopes to send her two Ursulines coming from Boston. I7.30.

I840, Mar. 3. To Thomas Cook, vicar-general. Concerning Sister Mary Joseph of Boston. I9.I25.

I840, Mar. 26. To Thomas Cook, vicar-general. Id. I9.I46.

I840, Apr. 2. To Sister Ste. Marie, superior. Id. I9.I52.

I840, Apr. 29. To Sister Ste. Marie, superior. Admit provisionally Sister Mary Ursula of Boston. I9.203.

\section{Diocèse de Montréal.}

I837, Mar. 6. To Mgr. Lartigue, bishop of Montreal. Father F. N. Blanchet designated for the Columbia River region. I8.42.

I838, Mar. 22. To Father F. N. Blanchet, curé of Soulanges. Requested to go as missionary to the Rocky Mountains. I8.252.

1838, Mar. 21. To Mgr. Lartigue, bishop of Montreal. The bishop [of Quebec] will make a substitution for Father Blanchet, desired for the Columbia River region. I8.252.

I838, Mar. 29. To Mgr. Lartigue, bishop of Montreal. Mission of the Columbia River region; passage in the boats of the Hudson's Bay Company. I8.259.

1838, Mar. 30. To Mgr. Lartigue, bishop of Montreal. The Hudson's Bay Company will take two missionaries to Cowlitz; Father A. Théberge will replace Father Blanchet. I8.26I.

1838, Mar. 30. To Father F. N. Blanchet. Has he decided to go to the Columbia River region? I8.262.

1838, Mar. 31. To Father F. N. Blanchet. Congratulates him on having accepted the mission to the Columbia River region; information for this object. I8.264.

I838, Apr. 2. To J. Keith, esq., Lachine. The bishop thanks the company [Hudson's Bay] for having been willing to take two missionaries to the Columbia River region. I8.267.

I838, Apr. Io. To Father F. N. Blanchet. They are preparing a box of goods for him; he will be well received by the commandant of Vancouver. I8.273.

1838, Apr. 20. To George Simpson, esq., Montreal. Thanks him for his kindness; MM. Blanchet and Mayrand will follow his instructions. I8.28g. 
I838, Apr. 27. To J. Keith, esq., Lachine. Asks favors for the two missionaries of Vancouver. I8.29I.

I838, Apr. 27. To Father F. N. Blanchet, Montreal. He is to go by way of the Red River; information concerning his journey. I 8.292.

I 838 , June 29. To Father Magloire Blanchet, curé of Soulanges. Method of sending things to his brother in the Columbia River region. I8.316.

I840, Jan. 7. To George Simpson, superintendent of the Hudson's Bay Company. Will the company admit French priests to the Columbia River region? I9.SI.

I840, Apr. 3. To Mgr. Ign. Bourget, bishop of Telmessus [coadjutor to the bishop of Montreal]. Mission to the Columbia River region. I9.153.

I843. June I2. To Father Chazelle, S. J. To take pains to send an American priest to the Columbia River region. 20.384 .

1852, Mar. 29. To Mgr. Ign. Bourget, bishop of Montreal. The state of Oregon. 24.4IO.

1853, May 17. To Mgr. Ign. Bourget, bishop of Montreal. Business of the Bishop of Nesqually at Rome. 25.17 I.

\section{Montréal: Notre Danie.}

I8I I, Oct. 3. To Abbé J. H. A. Roux, vicar-general. Faculties for the diocese of New York. 7.315.

I8I I, Dec. 2. To Abbé J. H. A. Roux, vicar-general. Jurisdiction for the inhabitants of the dioceses of New York and Boston. 7.350.

I8I3, Nov. I I. To Abbé J. H. A. Roux. Prayers and charge to the clergy against the invasion of the Yankees. 8.I 33 .

I820, June. To Abbé J. H. A. Roux. Bishop Cheverus authorized to make ordinations. I0.87.

I822, Sept. 7. To Abbé Janvier. Concerning the departure of the Ursulines for Louisiana. I0.455.

\section{District de Montréal.}

I821, Nov. 26. To Mgr. Lartigue, bishop of Telmessus. Not to employ M. Brouillet, but rather Father Malou of New York. IO.3I8.

1822, Sept. 28. To Mgr. Lartigue, bishop of Telmessus. Departure of the Ursulines for Louisiana. II.I I.

I822, Sept. 30. To Mgr. Lartigue, bishop of Telmessus. Id. II.I3.

I824, Sept. 8. To Mgr. Lartigue, bishop of Telmessus. The Indians of St. Régis allowed to emigrate. I 2.66.

1827, Aug. I. To Mgr. Lartigue, bishop of Telmessus. Honors to be rendered the Bishop of New York. I3.205.

\section{Etats Unis.}

I788, Oct. 6; I79I, Jan. 27, Dec. 5; I792, May IS, June 24; I793, July I 5 ; I796, Jan. I4, Nov. 26; I798, Oct. Io; I800, Nov. 18; 1804, Apr. 26; I806, Feb. 20, Mlay i9. Nov. 20; i8o7, June I5; ISoS, Oct. 24; I8Io, Nov: 5. To Mgr. John Carroll, prefect apostolic and later bishop of Baltinore. I.3, D. $9^{*}$ r, 1.273, I.323, I.327, 2.68, 2.253, 2.319, 4.5; $4.7 \mathrm{I} ; 4.155 ; 5.74,4.2 \mathrm{I} 7,5.2 \mathrm{I} 6 ; 4.242 ; 6.272 ; 7.2 \mathrm{I} 2$.

(These letters are printed in English translation in the Records of the American Catholic Historical Society of Philadelphia, XVIII. I56-160, i62, 166-167, I69I70, 172-173, 178-184, 187, 286-287, 288-289, 294-295; and the first in Illinois Historical Collections, V. $586-590$.) 
I796, Oct. I I. To Abbé Levadou, vicar-general at Detroit. Requested to serve the parish of the Assumption till it has a curé. 2.300.

(Printed in English translation in the Records of the Am. Cath. Hist. Soc. of Phila., XVIII. 178.)

1803, Dec. 3I. To Father Fitzsimmons, New York. Offering him the cure of St. Raphaël de Glengarry. 4.I49.

I804, Apr. 24. To Father Fitzsimmons, Lancaster. Requesting him to come to St. Raphaël de Glengarry as soon as possible. 4.I 53 .

I806, Sept. I5. To the Rev. Joseph Signay, missionary, Chazy River. Letters conveying faculties. G. $88 \mathrm{r}$.

I807, Mar. I, 9, May I8, Nov. I6; i8 I r, Jan. 6. To Father Joseph Signay, Chazy River. $5.248,5.254,6.37,6.158,7.240$.

(These letters are printed in English translation of the Records of the Am. Cath. Hist. Soc., XVIII. 283-286, 287-288, 295.)

I810, June 7. To Father N. Zocchi, Fancytown, Frederick County, Maryland. 7.I7I.

(Printed in English translation in the Records of the Am. Cath. Hist. Soc., XVIII. 289-29I.)

I8I I, Jan. 5. To J. Cheverus, bishop of Boston. Letters to him as vicargeneral for the diocese of Quebec. G. 2 I3 r.

I8I I, Jan. 6. To J. Cheverus, bishop of Boston. Congratulations and expressions of sympathy. Faculties as vicar-general for Quebec. 7.240.

I8I I, Feb. Io. To B. J. Flaget, bishop of Bardstown. Id. G. 2I 5 r.

I8I I, Mar. I8. To Father A. Kohlmann, administrator, New York. Id. G. $216 \mathrm{v}$.

I8I I, Mar. 28. To Father A. Kohlmann, administrator, New York. Faculties as vicar-general sent and requested. $7.28 \mathrm{I}$.

I8I I, May 29; I8I6, Feb. 21; i8I9, Mar. 26, 27, Apr. 6. To B. J. Flaget, bishop of Bardstown. $7.303,8.463,9.513,9.515$, 10.4.

(Letters of these dates are printed in English translation in the Records of the Am. Cath. Hist. Soc., XVIII. I5-17, 22-23, 37-40.)

I8II, Sept. To Father John Grassi, Georgetown, D. C. Invitation to come and work in Nova Scotia. 7.3II.

I8I I, Dec. I9. To Father A. Kohlmann, administrator, New York. Can Mgr. subdelegate the faculties which he has received from him (Kohlmann)? 7.354 .

I8I2, Jan. I I. To the Bishop of Boston. Id. 7.360.

I8ı2, Feb. I. To the Rev. Joseph Signay, Chazy River. Faculties for the dioceses of Boston and New York. 7.375.

I812, Feb. 3. To MM. Berthelot and Signay. Faculties for the diocese of Boston. H. 900.

I812, Apr. I6. To Father Grassi, S. J., Georgetown. 7.397.

(Printed in English translation in the Records of the Am. Cath. Hist. Soc., XVIII. 435.)

I815, Sept. 25. To the Bishop of Boston. Dr. Matignon; M. Brosius will be employed in the district of Montreal. 8.360 .

I816, Feb. 20. To Mgr. J. Connolly, bishop of New York. Letters to him as vicar-general. H. I I4.

I8ı6, Feb.2I. To Mgr. J. Connolly, bishop of New York. Exchange of faculties; Is Abbé McQuade regular? 8.464.

I8I6, Feb. 21. To J. Tessier, superior of the seminary at Baltimore. Letter to the Bishop of Bardstown; to urge M. [Chisholm] to come into Upper Canada. 8.465. 
I8ı6, Aug. 25. To the Bishop of New York. Abbé McQuade; writings relative to the diocese of Quebec. 8.535.

ISI6, Oct. I7. To the Bishop of Boston. Administrative affairs; various matters; mission of Madawaska. 9.17.

ISI9, Jan. 2. To Father Malou, S. J., New York. Mgr. will not interfere in the government of the diocese of New York. 9.469.

I821, Feb. 7, Apr. I3; 1823, Nov. 18, Dec. 16. To the Archbishop of Baltimore (Maréchal). IO.153, Io.198, 1 I.368, I I.382.

(These letters are printed in English translation in the Records of the Am. Cath. Hist. Soc., XVIII. 439-442, 452-454.)

IS2 I, Mar. I3. To Abbé W. Taylor, New York. Will have no employment until relieved from censures; details upon Rome. IO.I74.

I82 I, Oct. 27. To Henry Conwell, bishop of Philadelphia. Letters to him as vicar-general. H. $302 \mathrm{v}$.

I822, Jan. 7. To Father Malou, S. J., New York. Conditions upon which he will be admitted into the diocese of Quebec. Io.343.

I822, Jan. 7. To John Power, New York. Requested to obtain the exeat of Father Malou. Io.344.

IS22, Apr. I3. To the Bishop of New Orleans. Three Ursulines will go to Louisiana; faculties as vicar-general for Mgr. Provencher. I0.402.

IS22, Oct. 6. To Edward Fenwick, bishop of Cincinnati. Faculties which he has given are not extensive enough. I I.I9.

I822, Oct. 7. To Edward Fenwick, bishop of Cincinnati. Letters to him as vicar-general. I. $9 \mathrm{v}$.

I823, Feb. 4. To the Bishop of New York. A Sister of Charity wishes to join the Ursulines of Quebec. II.I I4.

IS23, June 7. To Mgr. Cheverus, bishop of Boston. Requested to give letters of excorporation to Abbé John Holmes. I I.22 I.

I823, Aug. I 5. To Father John Dubois, Emmitsburg. Has paid fifty gourdes to M. Hayes. I I.250.

I823, Aug. I5. To Mgr. Conwell, bishop of Philadelphia. A gift of fifty dollars for his establishment. I I.25I.

IS23, Dec. 5. To Mgr. Conwell, bishop of Philadelphia. Falsely accused; Abbé A. Inglesi ; contributions for his cathedral. I I.379.

I824, July 3I. To Father Gabriel Richard, vicar-general, Cincinnati. Letters granting faculties for Quebec. I. $90 \mathrm{v}$.

IS25, May 30. To Abbé P. Byrne, Boston. Faculties for the province of New Brunswick. I2.277.

I825, Nov. I5. To Mgr. B. Fenwick, bishop of Boston. Letters to him as vicar-general. I. I $36 \mathrm{v}$.

I825, Dec. 24. To Mgr. H. Conwell, bishop of Philadelphia. Id. K. I I v.

I825, Dec. 24. To Mgi. B. Fenwick, bishop of Boston. Id. K. I I v.

IS25, Dec. 24. To Mgr. J. Rosati, bishop of St. Louis. Id. K. I I v.

I825, Dec. 25. To Mgr. B. Flaget, bishop of Bardstown. Id. K. I I v.

IS25, Dec. 25. To Mgr. E. Fenwick, bishop of Cincinnati. Id. K. I I v.

I826, Jan. Io. To J. Power, administrator, New York. Id. K. I4 r.

I826, Feb. 7. To Mgr. B. Fenwick, bishop of Boston. Has not the right of reclaiming J. Holmes. $\mathrm{I} 2.436$.

I826, Apr. 2 I. To Sister St. George, Ursulines, Boston. Can not have pecuniary aid at this time. I2.489.

I827, Jan. 5. To Mgr. J. Dubois, bishop of New York. Faculties; Abbés Shanley and Campion. I3.94. 
1827, Jan. 6. To Mgr. J. Dubois, bishop of New York. Letters to him as vicar-general. K. $36 \mathrm{v}$.

1827, Feb. 22. To Mgr. J. Dubois, bishop of New York. Sending of faculties; his visit is expected. I3.I33.

I828, June 9. To Mgr. Rosati, bishop of New Orleans. Sending of and request for faculties. 13.407 .

I828, June 9. To Mgr. Flaget, bishop of Bardstown. Id. I3.4IO.

I828, June 9. To Mgr. Flaget, bishop of Bardstown. Letters to him as vicar-general. K. 67 v.

I828, June 9. To Mgr. Rosati, bishop of St. Louis. Id. K. 67 v.

I828, Aug. 20. To Mgr. B. Fenwick, bishop of Boston. Mgr. can not procure priests. I 3.434 .

I829, Nov. 25. To Mgr. Rosati, administrator, New Orleans. Letters to him as vicar-general. $\mathrm{K}$ II7 $\mathrm{r}$.

I830, Feb. 22. To Sister St. George, Ursulines, Boston. Letters of obedience for four more years. K. $126 \mathrm{v}$.

I83o, Feb. 22. To Mgr. B. Fenwick, bishop of Boston. Id. I4.I82.

I83 I, June 20. To Mgr. Rosati, bishop of St. Louis. The diocese can not contribute to the construction of his seminary. I4.406.

I83 I, Oct. 8. To Mgr. Conwell, bishop of Philadelphia. Letters testimonial respecting $M$. Madden. 14.482 .

I833, Mar. 6. To Mgr. B. Fenwick, bishop of Boston. Letters to him as vicar-general. L. 7 I r.

1833, Mar. 6. To Mgr. Dubois, bishop of New York. Id. L. 7 I r.

1833, Mar. 6. To Mgr. P. Kenrick, bishop of Philadelphia. Id. L. 7 I r.

I833, Mar. 6. To Mgr. Flaget, bishop of Bardstown. Id. L. 7 r r.

I833, Mar. 6. To Mgr. Rosati, bishop of St. Louis. Id. L. 7 I r.

I833, Mar. 6. To Mgr. A. de Neckere, bishop of New Orleans. Id. L. 7I r. I833, Mar. II. To Mgr. B. Fenwick, bishop of Boston. Sending of letters to him as vicar-general and letters testimonial. I 5.3 I I.

I835, Feb. 25. To Mgr. B. Fenwick, bishop of Boston. His nuns of Mt. Benedict will be received among the Ursulines. I6.477.

I835, Mar. 28. To Sister St. George, Ursulines, Boston. Mgr. revokes her letters of obedience. I6.497.

I835, Mar. 28. To Mgr. B. Fenwick, bishop of Boston. Mgr. revokes letters of obedience; will endeavor to send two sisters to the Ursulines of Three Rivers. I6.497.

I835, July 29. To Mgr. B. Fenwick, bishop of Boston. His Ursulines have arrived; he ought to have sent two to Three Rivers. I7.28.

1837, Dec. 30. To Mgr. B. Fenwick, bishop of Boston. Letters of recommendation in favor of Charles Lévêque. I8.198.

I839, Mar. 27. To Mgr. John England, bishop of Charleston. Two Ursulines of Quebec will go to the aid of those of Charleston. I8.50I.

I839, June 14. To Mgr. B. Fenwick, bishop of Boston. Reception of Sister Mary John into the Ursulines; revalidation of the marriage of Antoine Bédard; sending of an extract from the ritual of Quebec. r8.50r.

1839, Sept. 2. To Mgr. B. Fenwick, bishop of Boston. The Penobscot Indians desire to keep their uses and customs. I8.592.

I840, Apr. 5. To Mgr. B. Fenwick, bishop of Boston. Sister Mary Joseph will be admitted into the Ursulines of Three Rivers. I9.I59.

I840, Apr. 25. To Mgr. B. Fenwick, bishop of Boston. His Ursulines will not be received cither at Quebec or at Three Rivers. I9.I97. 
I840, May I2. To Mgr. J. Hughes, administrator, New York. Letters to him as vicar-general of the diocese of Quebec. M. I 55 r.

I840, May I5. To Mgr. B. Fenwick, bishop of Boston. Concerning the admission of his Ursulines. I9.220.

I840, May I5. To Mgr. J. Hughes, administrator, New York. Sending of letters to him as vicar-general. I9.222.

I840, Nov. I I. To Mgr. Forbin-Janson, at Detroit. Pleased at the remembrance of him by Mgr. I9.328.

I840, Nov. 20. To Mgr. Rosati, bishop of St. Louis. Asks him to interest himself in the missions of the Columbia River region; requests information. I9.333.

I841, Jan. 27. To Mgr. Mathias Loras, bishop of Dubuque. Letters to him as vicar-general of the diocese of Quebec. M. I84 v.

I84I, Jan. 27. To Mgr. Mathias Loras, bishop of Dubuque. Sending of letters to him as vicar-general : respecting the route from Quebec to the Red River by way of Dubuque. I9.385.

I84I, Apr. 3o. To Mgr. Forbin-Janson, New York. Thanks and invitations; contributions for the Columbia River region. 19.480.

184I, May 22. To Mgr. Forbin-Janson, New York. The ecclesiastical retreat will take place Sept. 8 ; invited to give other retreats. I9.497.

I84 I, July 23. To Mgr. Forbin-Janson, New York. Concerning the retreat which he is to give at La Beauce. I9.5 I5.

I84I, Aug. 3I. To Mgr. B. Fenwick, bishop of Boston. Recommendations in favor of MM. Langlois and Bolduc upon their departure for the Columbia River region. I9.536.

I84 I, Nov. 24. To Mgr. Forbin-Janson, New York. Establishment of the Brothers at Quebec; various matters. I9.597.

1842, Nov. I5. To Mgr. B. Fenwick, bishop of Boston. Faculties renewed; journeys of MM. Langlois and Bolduc to the Columbia River region. 20.186.

I842, Dec. 2. To Mgr. R. Kenrick, bishop coadjutor of St. Louis. Letters to him as vicar-general of the diocese of Quebec. N. 29 r.

I842, Dec. 2. To Mgr. Rosati, bishop of St. Louis. Letters of extraordinary faculties. N. $38 \mathrm{r}$.

I842, Dec. 2. To Mgr. Rosati, bishop of St. Louis. Exchange of faculties; boundaries between his diocese and that of the Columbia River. 20.206.

I842, Dec. 2. To Mgr. Kenrick, bishop coadjutor of St. Louis. Sending of letters to him as vicar-general. 20.208.

I842, Dec. 3I. To Mgr. Rosati, bishop of St. Louis. Concerning the erection of the Columbia River region into a diocese. $20.23 \mathrm{I}$.

I843. Mar. I4. To Mgr. Kenrick, bishop coadjutor of St. Louis. Boundaries of, and the selection of a bishop for, the diocese of the Columbia River region. 20.296.

I843, June I2. To Mgr. Kenrick, bishop coadjutor of St. Louis. Proposed changes in the plan of the Council of Baltimore concerning the diocese of the Columbia River region. 20.368.

I844, Jan. 23. To the Archbishop of Baltimore. Could Sisters of Charity found an establishment at Quebec? 20.563.

I844, Feb. 29. To Mgr. Kenrick, bishop of St. Louis. M. Blanchet appointed bishop of Oregon; details requested from Father De Smet, S. J. 20.598.

I844, Mar. 2. To the Bishop of Tincennes. Will M. Ducoudray obtain his exeat? 20.610. 
I844, Aug. I3. To Abbé Deluol, superior of the seminary at Baltimore. Can he receive two clergymen from Quebec who wish to learn English? 21.66.

I846, Aug. 24. To Mgr. J. B. Fitzpatrick, bishop of Boston. Letters to him as vicar-general of Quebec. N. I75 v.

I847, Feb. 5. To Mgr. S. Eccleston, archbishop of Baltimore. Information requested concerning the Odd Fellows. 21.579.

I847, June 20. To Mgr. Fitzpatrick, bishop of Boston. Boundaries between his diocese and those of Quebec and New Brunswick. 22.23.

I847, July I2. To Abbé Courjault, Bourbonnais. Sending of objects for his chapel. 22.33 .

I847, Aug. 9. To Mgr. A. Blanc, bishop of New Orleans. Letters to him as vicar-general of Quebec. N. 2 I8 v.

I847, Nov. 29. To Mgr. Henni, bishop of Milwaukee. Abbé Mayrand is authorized to go into his diocese. 22.164.

I848, May 6. To the Com. Départ. Sauvage. Sending of Indian books. 22.319.

I849, Feb. I4. To Father J. Larkin, S. J., New York. Bulls appointing him bishop of Toronto have arrived. 22.5 I2.

I849, Mar. IO. To Father J. Larkin, S. J., New York. Concerning his appointment to the bishopric of Toronto. 22.520.

I849, Oct. 4. To Father J. Larkin, S. J., New York. Urged to accept. 23.54.

I850, Feb. I I. To Mgr. Audin [Odin], bishop of Galveston. Concerning the Ursulines. 23.I72.

I850, Mar. I3. To Father Boulanger, S. J., New York. To urge Father Larkin to accept the bishopric of Toronto. 23.209.

I850, Mar. 27. To the Bishop of Chicago. Mgr. will give up to him Abbé Lebel. 23.229.

I850, May I5. To Mgr. Fitzpatrick, bishop of Boston. Missions to the frontiers. 23.296.

I850, June 4. To Abbé L. Provencher, curé of Tring. Faculties for the frontier missions. 23.318 .

I850, Oct. IO. To the Bishop of New Orleans. Letters to him as vicar-general of Quebec. O. I27 r.

I850, Oct. Io. To the Bishop of New York. Id. O. I27 r.

I850, Oct. Io. To the Bishop of Boston. Id. O. I27 r.

1850, Oct. Io. To the Bishop of Albany. Id. O. $127 \mathrm{r}$.

I850, Oct. Io. To the Bishop of Buffalo. Id. O. I27 r.

1850, Oct. Io. To the Bishop of St. Louis. Id. O. I27 r.

I850, Oct. Io. To the Bishop of Dubuque. Id. O. I27 r.

I850, Oct. Io. To the Bishop of Chicago. Id. O. I27 r.

I850, Oct. Io. To the Bishop of Detroit. Id. O. I27 r.

I850, Oct. Io. To the Bishop of Cincinnati. Id. O. I27 r.

I850, Oct. Io. To the Bishop of Milwaukee. Id. O. I27 r.

I850, Oct. Io. To the Bishop of Cleveland. Id. O. I27 r.

1850, Nov. I3. Abbé Sheridan. Mgr. has no jurisdiction over him. 23.489. I85o, Dec. 6. To Mgr. Audin [Odin], bishop of Galveston. Apprehensions of Mgr. concerning the Ursulines. 23.542.

I852, Sept. 8. To Dr. E. B. O'Callaghan, New York. Thanks for the gift of a book to the archbishop. 24.574.

I852, Dec. 29. To M. O'Dwyer, Illinois. Mgr. will not interfere between him and the Bishop of Toronto. 25.17. 
1853, Aug. 30. To L. O'Donnel, Lawrence. Mgr. can not furnish him with priests. 25.230 .

I853, Nov. 9. To A. Courcy, New York. Felicitations upon his writing against the history of Abbé Brasseur de Bourbourg. 25.289.

I853, Nov. 25. To A. Courcy, New York. The history of Abbé Brasseur de Bourbourg ; reproaches against the Seminary of Quebec; pamphlet of Abbé Ferland; his connection with Canada. 25.306.

I853, Dec. Io. To A. Courcy, New York. Thanks for his article on Canada. 25.3 I9.

1853, Dec. I6. To A. Courcy, New York. Pamphlet of Abbé Ferland; his article in L'Univers. $25 \cdot 327$.

\section{Mississippi.}

I698, July I4. Confirmation by Bishop St. Vallier of the permission given to the Seminary of Quebec to have exclusively the mission to the Tamarois. C. I I I v.

I7 I7, Oct. 6. Id. C. I I3 r.

I7I7, Oct. 6. To Abbé D. M. Varlet. Letters to him as vicar-general for the Mississippi region. C. II $2 \mathrm{v}$.

I72 I, July I9. Charge to the clergy upon the occasion of disorders committed upon the Mississippi. C. I I8 r.

I734, May 6. To P. de la Rue [Abbé de 1'Isle-Dieu]. Letters to him as vicargeneral for the Mississippi. B. 3 IO v.

I740, Aug. 3I. To Abbé P. de la Rue. Id. B. 326 r.

I74I, May I7. To Abbé J. B. Mercier. Id. for the Tamarois. B. 349 r.

I754, Apr. I6. To Abbé Nicholas Laurent. Extraordinary faculties for the Tamarois. C. $2 \mathrm{I} 8 \mathrm{v}$.

I757, Apr. 29. To Abbé Charles Beaudoin, S. J. Id. for Louisiana. C. $224 \mathrm{r}$. I767, Apr. 28. To Abbé P. Meurin. Letters to him as vicar-general for Illinois. C. $235 \mathrm{r}$.

I768, May 3. To Abbé P. Gibault. Id. C. 249 v.

\section{DÉtroit.}

\section{A. L'ASSOIIPTION (OR SANDWICH).}

I720, June 8. To the inhabitants. Episcopal charge requiring them to live better. C. IIg r.

I789, Nov. 2. To the inhabitants. Pastoral letter requiring them to be faithful to His Britannic Majesty. D. I84 v.

I 789, Nov. 2. To the Fiurons. Id. D. I $86 \mathrm{r}$.

I789, Nov. 2. To Abbé F. X. Dufaux, missionary. Accused of inciting a revolt against the king. I.87.

I790, May 20. To P. Murray, major of the 6oth Regiment. Thanks for the valuable information given concerning the missions. I.I32.

I790, May 20. To D. Powell, judge of the district of Hesse. Mgr. is happy to learn of the good conduct of M. Dufaux. I.I33.

I79I, Jan. I9. To Abbé F. X. Dufaux, missionary. Invited to remain at his mission. I.I95.

I796, Oct. I I. To Abbé J. B. Levadoux, vicar-general, curé of Ste. Anne. Charged with the parish till the arrival of a curé. 2.300 .

I8I7, Apr. 30. To Abbé J. B. Marchand, curé. Cordial relations with his vicar (J. Crevier) ; the Hurons living in American territory. 9.I53.

I8I9, Apr. 6. To Abbé J. Crevier, vicar. Asked to accompany the Bishop of Bardstown. I0.4. 
B. STE. ANNE.

1789, Nov. 2. To the Abbé P. Fréchette, missionary. Accused of inciting a revolt against the king. I.88.

I79I, Jan. I9. To Abbé P. Fréchette, missionary. Invited to remain at his mission. I.I32.

I792, Aug. I r. To Abbé P. Fréchette, missionary. Matters relating to pews and the accounts of the fabric. I.33I.

I793, June 22. To Abbé P. Fréchette, missionary. Concerning Sieurs J. Piu, Rancourt, La Cuillerier. 2.58.

1794, Sept. I5. To Abbé P. Fréchette. Concerning the episcopal charge of Oct. 28. 2.150.

I795, Dec. 22. To Abbé P. Fréchette. To enter into arrangements with Mr. Burke, vicar-general. 2.246.

I796, Oct. I I. To Abbé J. B. Levadoux, vicar-general and curé. Requested to serve the parish of the Assumption till the arrival of a curé. 2.300 .

Red River.

I8r8, Apr. I3. To Abbé J. Crevier, vicar. Requested to accompany M. Tabeau to Fort William, Michilimackinac. 9.352.

I8r9, Mar. 20. To Lady Selkirk. Boundaries between Canada and the U. S. 9.5 II.

1824, Aug. 2r. To the Bishop of Juliopolis (Bishop Provencher, of St. Boniface). Extent of his faculties; Mgr. Dubourg. I2.4I.

\section{Halifax.}

I802, Sept. io. To Fatlier Edmund Burke, vicar-general and curé. A new college; Father Z.occhi has gone to the U. S. 4. Io6.

r8ro, Feb. I8. To Father E. Burke, vicar-general and curé. Details upon certain political and religious affairs in Europe and in America. 7.I II. I8ri, Sept. 3. To Father E. Burke. To labor to secure the services of Father Grassi. 7.309.

I812, Jan. 26. To Father E. Burke. To arrange with the local government for the admission of American Jesuits. 7.37 I.

New Brunswick.

1798, May 30. To Abbé François Ciquard, missionary. Exeat for the diocese of Baltimore. 3.3r.

\section{MADAWASKa.}

I835, Aug. 31. To Rev. F. X. Mercier, missionary. Difficulties with the U.S. 17.66.

I850, Jan. 21. To Rev. L. A. Proulx, curé of Rivière du Loup. Madawaska does not belong to the diocese of Quebec. 23.I56.

1850, Mar. 26. To Rev. A. Langevin, missionary. Faculties for the benefit of Canadians in his jurisdiction. 23.223.

\section{Boucherville.}

I8r3, Oct. 23. To Abbé P. Conefroy, vicar-general and curé. To suspend prayers against the invasion of the Yankees. 8.r33. 


\section{Chambly.}

I8I9, Oct. 21. To Abbé P. M. Mignault. The mission to the south of Lake Champlain is dependent upon the Bishop of Boston. Io.43.

Paspébiac.

I85 I, Aug. I. To Rev. Z. Lérêque, missionary. He is authorized to leave the diocese and accept employment in that of Boston. 24.165.

St. George.

I842, July. To Rev. Mö̈se Fortier, curé. Faculties for the diocese of Boston. 20.95 .

\section{St. Luc (Cotenu des Hêtres).}

ISI2, Feb. I. To Abbé Charles Berthelot, curé. Faculties for the dioceses of Boston and New York. $7 \cdot 375$.

ST. RÉGis.

I807, Dec. 24. To Abbé J. B. Roupe. Extent of his faculties; to pledge the Indians to loyalty. 6.I72.

I8Io, Nov. 8. To Abbé J. B. Roupe. Jurisdiction in the U. S.; deserters. 7.220 .

I812, Feb. I. To Abbé J. B. Roupe. Faculties for the diocese of New York. 7.374 .

I8I2, Dec. I5. To Abbé J. H. Roux, vicar-general of Montreal. The Indians must be kept neutral. 8.5 .

I8I4, Sept. I8. To Abbé Joseph Marcoux, missionary. Validity of marriages celebrated before magistrates in the diocese of New York. 8.240.

I8ı6, Aug. I. To Abbé Joseph Marcoux, missionary. Faculties for the diocese of New York. 8.266.

I8I9, Feb. 2. To Abbé Joseph Marcoux, missionary. Requested to refute the accusation of disloyalty made against him. 9.489 .

\section{Ste. Marie (de Monnoir or Ramsay).}

I806, Sept. I5. To Abbé J. Signay, curé. Letters of faculties for the Chazy River (diocese of Baltimore). G. 88 r.

I807, Mar. I. To Abbé J. Signay, curé. Concerning the mission of Chazy River. 5.248.

I807, Mar. 9. To Abbé J. Signay, curé. Concerning a site for the chapel of Chazy River. 5.254.

I807, May I8. To Abbé J. Signay, curé. Concerning the mission of Chazy River. 6.37.

I807, Nov. I6. To Abbé J. Signay, curé. Same subject; boundaries of his parish. 6.I 58.

I8og, Mar. 6. 'To Abbé J. Signay, curé. Regulations for the marriages of members of the diocese of Baltimore. 6.34I.

I8I I, Jan. 6. To Abbé J. Signay, curé. His faculties for Chazy cease till further orders. 7.240 .

I8r2, Feb. I. To Abbé J. Signay, curé. Faculties for the dioceses of Boston and New York. 7.375.

I81 2, Feb. 3. To Abbé J. Signay, curé. Id. H. 9 v. 
Colombie (States of Oregon and Washington).

1838, Mar. 31. To Rev. F. N. Blanchet, curé of Soulanges. Nominated as missionary. I8.264.

I838, Mar. 31. To Rev. J. A. Mayrand. Id. I8.264.

I838, Apr. I6. To Rev. J. A. Mayrand. Letters to him as vicar-general. M. $94 \mathrm{v}$.

I838, Apr. I6. To the faithful. Pastoral letter on sending them missionaries. M. $96 \mathrm{r}$.

I838, Apr. I7. To the missionaries. Instructions for their cures. M. $96 \mathrm{v}$.

I838, Apr. I9. To Rev. F. N. Blanchet, missionary. Sending of his letters as vicar-general; concerning his instructions and faculties; to go by way of Red River. I8.279.

I838, Oct. 22. To Rev. F. N. Blanchet, vicar-general. Sending of faculties; two lost lists; M. Delaporte will forward effects to him. I8.393.

I839, Apr. I 5. To Rev. F. N. Blanchet, vicar-general. Duplicate of faculties ; various reports concerning politics, colonization, etc. I8.5 I9.

I840, Apr. I3. To Rev. F. N. Blanchet, vicar-general. Memoir upon the designs of the Hudson's Bay Company, upon the obstacles to and celebration of marriages, upon the union of the two Canadas; many miscellaneous matters. I9.173.

I84I, Apr. I4. To Mgr. Provencher, bishop of St. Boniface. Memoir upon the means of aiding the missions for the Columbia River region. I 9.447 .

I84 I, Apr. I7. To Rev. F. N. Blanchet, vicar-general. Memoir upon the means of aiding the missions for the Columbia River region ; information received; various matters. I9.457.

I841, Apr. I7. To Dr. [John] McLoughlin, Vancouver. To plead the cause of the missionaries with the Hudson's Bay Company. 19.464.

I84I, Aug. 30. To Rev. Ant. Langlois. Nominated as missionary. I9.532.

I84I, Aug. 30. To Rev. J. B. Z. Bolduc. Id. I9.532.

I84I, Aug. 30. To Rev. A. Langlois. Letters testimonial. M. 205 v.

I84I, Aug. 30. To Rev. J. B. Z. Bolduc. Id. M. 205 v.

I84I, Aug. 30. To Rev. F. N. Blanchet, vicar-general. New missionaries; conversion of Dr. McLoughlin; temporal affairs and various matters. I9.333.

I84I, Aug. 3I. To Dr. McLoughlin, Vancouver. Congratulations upon his conversion. I9.535.

I842, Apr. 9. To Rev. F. N. Blanchet, vicar-general. Numerous administrative details and various matters. 20.47 .

I842, June 7. To Rev. F. N. Blanchet, vicar-general. Renewed faculties. 20.84 .

I842, Nov. I4. To Rev. F. N. Blanchet, vicar-general. Difficulties of finding missionaries and nuns; many miscellaneous matters. 20.179.

I843, Apr. I9. To Rev. F. N. Blanchet, vicar-general. Memoir upon the erection of his diocese; his faculties; his consecration; pecuniary aid; difficulties of finding missionaries ; many miscellaneous matters. 20.232.

I843, Apr. 22. To Rev. M. Demers, missionary. Requested to take notice of the letter above; encouragement. 20.340.

I843, July I I. To Rev. F. N. Blanchet, vicar-general. Differences of Mgr. with the bishops of the U. S. relative to the erection of his diocese. 20.391 .

I843, Dec. I. Bulls erecting the Columbia River region into a vicariate apostolic. N. 89 r. 
I843, Dec. I. To Rev. F. N. Blanchet, vicar-general. Bulls nominating him bishop of Philadelphia. N. $90 \mathrm{v}$.

I843, Dec. I. To Rev. F. N. Blanchet, vicar-general. Bulls nominating him vicar apostolic. N. $90 \mathrm{r}$.

I844, Apr. I2. To Rev. F. N. Blanchet. His bulls as vicar apostolic and his consecration; journey of Mgr. Provencher to Europe; aid of the Society of the Propaganda; various matters. 20.625.

I844, July ro. To Rev. F. N. Blanchet. His title is changed [to bishop of Drasa $i . p$.$] ; encouragement; reprehensible conduct of M. Langlois.$ $2 \mathrm{I} .55$.

1844, Sept. 22. To Rev. F. N. Blanchet. Urged to accept the bishopric; various ecclesiastical matters. 2 I.84.

I845, Apr. I 5. To Rev. F. N. Blanchet. Id.; details of the allocutions of the Propaganda. 21.210.

I845, Aug. 2. To Mgr. F. N. Blanchet. Letters to him as vicar-general of Quebec. N. I4I v.

I846, Dec. I I. To Mgr. F. N. Blanchet. Ordination of young Rousseau. $2 \mathrm{I} .543$.

I847, Mar.2. To Rev. F. N. Blanchet. Letters to him as vicar-general of Quebec. N. $201 \mathrm{r}$.

I848, Sept. I4. To Mgr. M. Demers, bishop of Vancouver. Id. O. 6.

I849, Apr. I8. To Bishop F. N. Blanchet, Oregon City. Allocution of the Propaganda; congratulations upon his church. 22.548.

I850, Apr. 17. To Bishop F. N. Blanchet, Oregon City. News from Canada. I852, May I. To Rev. J. Bayard. Permission to become attached to the diocese of Nesqually. 23.263 .

\section{Hudson's Bay Company.}

I838, Mar. 26. To J. Keith, secretary, Lachine. Thanks for the passage of two missionaries to the Columbia River region. 20.106.

I842, Sept. 29. To Sir George Simpson, London. Id. 20. I I3.

r843, Mar. Io. To J. Keith, secretary, Lachine. Passage for the Columbia River region in boats of the company. 20.297.

\section{LETTERS RECEIVED.}

Etats Unis: Detroit. I767-I 797.

Letters of Father Simple Bocquet, Recollet Missionary.

r767, Apr. 27. To Bishop Briand. Authority of commandant regarding matrimony; religious liberty. p. 3 .

1767, June 30. To Bishop Briand. Division of Detroit parish; marriage case; war in Illinois and Ohio; liquor traffic. p. 5.

1767, Oct. 5. To Bishop Briand. Condition of Catholicism; Indian troubles; liquor traffic ; Iroquois cession of land to M. Jeanson [?]. p. 8.

I767,Oct. 2 I. To Bishop Briand. Marriage matters; good morals of women; Potier's parish. p. Io.

No date. To Bishop Briand. Ruin of trade by liquor traffic; condition of religion. P. II.

I768, May I2. To Bishop Briand. Episcopal jurisdiction in Upper Louisiana; authority of commandant regarding marriage. p. I4. 
1769, May I2. To Bishop Briand. Good relations with English commandant; Indian wars; Father Meurin; Catholics of Post Vincennes petition for a priest. p. I6.

I770, May I4. To Bishop Briand. Condition of two parishes; prudence of new commandant; Spanish rebels in Louisiana. p. I8.

I770, Oct. 2. To Bishop Briand. State of Catholicism in Detroit; increased population; prerogatives of judge in the church. P. 2 I.

I770, Sept. I. To Bishop Briand. Forty Hours; marriage cases. p. 23.

I77 I, July I8. To Bishop Briand. Marriage cases; disposition of Michilimackinac church goods; English attitude toward the Catholic religion; fears of future in case of his departure. p. 24.

I773, May I. To Bishop Briand. Marriage matters; Indians ruined by liquor traffic; recall on account of illness desired; Sieur Dejean, judge. p. 26.

I773, Aug. I6. To Bishop Briand. Troubles with churchwardens. p. 29.

\section{Letters of Bishop Briand.}

I77I, Apr. I7. To Father Simple Bocquet. Marriage cases. p. 23.

I774, May 4. To Father Simple Bocquet. Prerogatives of a judge in the church; condition of Catholics. p. $3 \mathrm{I}$.

1775, Aug. I0. To Father Simple Bocquet. Father Gibault in Quebec; marriage case ; reconciliation of excommunicated persons. p. 32 .

\section{Letters of Father Dufaux.}

I787, Aug. 24. To Bishop Hubert. State of parish (Sandwich); Payet in Michilimackinac; Gibault's reputation. p. 47.

I787, Sept. I3. To Bishop Hubert. Presence of M. Payet; Michilimackinac. P. 52.

I788, Jan. 28. To Bishop Hubert. Need of a mission at River Raisin. p. 57. I790, Jan. 28. To Bishop Hubert. Charge of disloyalty repelled. p. 69.

I790, Oct. 26. To Bishop Hubert. Troubles between Indians and Americans. p. 8I.

I79r, Feb. I. To Bishop Hubert. Troubles between Americans and Miamis. p. 85.

I794, Nov. 7. To Bishop Hubert. Mission at River Raisin; M. Ledru at Michilimackinac and Detroit. p. I02.

I796, July 6. To Bishop Hubert. Departure of M. Fréchette regretted; ministry in vacant parish only allowed in articulo mortis; no missionary in American territory. p. I24.

I796, Sept. 2. To Bishop Hubert. American occupation; character of M. Levadoux, vicar-general of Baltimore; differences in discipline; good relations with all. p. I26.

\section{Letters of Father Fréchette.}

I788, Apr. 24. To Bishop Hubert. Moral, religious, and temporal state of the parish. p. 61 .

I790, Jan. To Bishop Hubert. Innocent of plots against the government. p. 67.

I790, Aug. 24. To Bishop Hubert. Free of charge of disloyalty; desire of recall. p. 78. 
I793, May 20. To Bishop Hubert. Rumors of war between "Bostonnais" and Indians; marriage matters. p. 96.

I795, Oct. 23. To Bishop Hubert. Complaints against Mr. Burke, vicargeneral. p. I IO.

\section{Letters of Father Payet.}

I 7 3, Jan. 8. To Bishop Briand. Condition of his parish. p. 39 .

I783, July I3. To Bishop Briand. Improvement of his parish; Michilimackinac. p. 40.

I786, Feb. 20. To Bishop Hubert. Progress of his parish; sickness, especially among the English; trouble with the Indians. p. 45.

\section{Miscellaneous.}

I767, Jan. 5. To Geo. Turnbull, captain 2d battalion, 6oth Regiment, commandant. Permit to cousins german to marry. p. 3 .

I768, Sept. 6. Father Potier to Bishop Briand. State of his parish; faculties. p. I5.

I770, June 22. P. Dejeans to Bishop Briand. Prerogatives of judges in the church, with reply (interlinear). p. I9.

I78I, Nov. I6. Account rendered by M. Montforton of the use of the funds accruing from the estate of the late Father Potier. p. 34.

I785, Oct. I2. Wm. Ancrum, major commanding at Detroit, etc. Passport to Niagara for M. Hubert, vicar-general, and three servants. p. 42.

I789, Dec. 26. W. Dummer Powell, judge in the district of Hesse. Excellent testimony in favor of Father Dufaux's loyalty. p. 65.

I790, Jan. 30. P. Murray, major of the 6oth Regiment, commanding at Detroit, to Bishop Hubert. Loyalty of Detroit missionaries; calumny due to disreputable Indians. p. 7 I.

I790, May 3. Hurons request missionary, and testify loyalty to the Catholic religion and the English king. p. 72.

I790, May 20. Bishop Hubert to Powell. His satisfaction at the good report. p. 65 .

I790, May 20. Bishop Hubert to Major Murray. All suspicions dissipated. p. $7 \mathrm{I}$.

No date. Prayer for the lieutenant-governor. p. 83 .

I796, Sept. I3. Abbé Levadoux, vicar-general, to Bishop Hubert. Death of Father Dufaux; ministry during vacancy in virtue of faculties received. p. 128 .

\section{États Unis: Missions des Illinois.}

\section{Letters of Bishop Briand.}

I767, Aug. 7. To Father Meurin. Encouragement; letter sent to Kaskaskias, etc., to make the people better disposed; more clergy to be sent; marriage matters. p. 6.

No date. [ I768 ?] To Father Meurin. Solicitude for distant flocks ; faculties for vicar-general for Illinois and New Orleans if Spanish government permits; Capuchins and Ursulines in New Orleans. p. 8.

I768, Oct. I3. To Father Gibault. Extract from deliberations of the Seminary at Quebec, asking the bishop to authorize use of sum held in reserve for Louisiana missions, in payment for sums expended by the Seminary for said missions, in particular for Gibault's education. p. I I. 
I769. Post Vincennes. Gibault's visit; religious work of the habitants. p. I4. I769, Apr. 26. To Father Meurin. Capuchins and Quebec jurisdiction in New Orleans; Ursulines; advice on restriction of church property; relations with Protestants; liquor traffic. p. I5.

I769, Apr. 26. To Father Gibault. Good work at Michilimackinac except marriage between Frenchmen and Indians; his family; advice. p. I7. I769, Aug. I3. To Father Gibault. His family; conduct toward Father Meurin ; his ministry; mission to the Tamarois. p. 19.

(Partially printed in the Records of the Am. Cath. Hist. Soc., XX. 413.)

I770, Mar. 22. To Father Meurin. Tithes; mixed marriages; Gibault. p. 20.

I770, Mar. 22. To Father Gibault. His ministry to extend to Post Vincennes; order of work ; revenue; permit to serve two parishes if necessary; conduct toward Meurin. p. $2 \mathrm{I}$.

I770, Aug. I6. To Father Gibault. No other priest to be sent before I774. p. 23.

I770, Aug. I9. To Father Gibault. Jubilee celebration. p. 24.

I77I, Apr. I I. To Father Meurin. Extent of jurisdiction ; marriages between whites and Indians; Jesuit property. p. 26.

I77I, Apr. 24. To Father Meurin. Liquor traffic; restoration of church property. p. 26.

I77I, Apr. 24. To Father Gibault. Precedence ; faculties in Louisiana ; marriage of slaves. Lettres de Mgr. Briand, IV. 2 I3 2

I775, Aug. Io. To Father Gibault. Marriage cases; discipline, etc. p. 32.

1777, Apr. 27. To Father Meurin. His authority as vicar-general; jurisdiction in Louisiana ; dearth of priests ; praise for Jesuits; marriage cases ; rebellion in English colonies. p. 42.

1777, Aug. 26. To Father Gibault. Moral cases; charges against him. p. 43.

Letters of Father Gibault.

1768, July 28 ; 1769, Feb. I5, June I 5 ; I770, June I5, I 770 without further date; I783, Apr. I ; I788, May 22. To Bishop Briand. pp. Io, I3, I8, $22,23,48,68$.

(Printed in English translation in the Records of the Am. Cath. Hist. Soc., XX. 406-418, 425, 429-430; the last two also, in French, in the American Historical Reviere, XIV. 55I, 556-557, and in Illinois Historical Collections, V. 520-521, 583-586.)

I772, June 20 ; I775, Oct. 9, Dec. 4. To Bishop Briand. pp. 28, 38, 40.

(Partially printed in English translation in the Records of the Am. Cath. Hist. Soc., XX. 420-424.)

I777. To Bishop Briand. Marriage and restitution cases. p. 43.

I786, June 6. To Bishop Mariaucheau. p. 53 .

(Printed in the American Historical Review, XIV. 552-556, and in French and English in the Illinois Historical Collections, V. 534-547.)

\section{Letters of Father Meurin.}

I767, Mar. 23; I768, June Ix. To Bishop Briand. pp. 4, 9.

(Printed in English translation in the Records of the Am. Cath. Hist. Soc., XII. 4.)

I767, May 9. To Bishop Briand. Work for four priests in Illinois. p. 5 . I769, June I4; i 770 , June I I. To Bishop Briand. pp. I6, 26.

(Partially printed in Records, XX. $4 \mathrm{TO}-41 \mathrm{Ir}, 4^{\mathrm{I} 8-420}$.) 
I775, Mar. 29. Dissolution of the Jesuit order; Gibault, missionary tour to Michilimackinac; poverty. p. 30. (Partially printed ibid., p. 42r.)

I776, May 23. To Bishop Briand. Jurisdiction contested in Spanish territory; charges against Gibault; Ursulines at New Orleans; " Bostonnais" at Detroit; seminary property free. p. 42.

\section{Miscellaneous.}

I743, Aug. 16. Father Dujaunay, S. J., to Father St. Pé. Marriage case. p. 2.

I767, Apr. 6. Phillibert, sexton, to Bishop Briand. Spiritual destitution since the withdrawal of the priests. p. 3 .

I 767 , Aug. 7. Father Menrin to Bishop Briand. Long letter on the state of the mission; its parishes; need of priests ; uncertainty as to source of jurisdiction, etc. p. 6.

I767. Condition of Illinois missions (data from Meurin letter, Mar. 23, r 767$)$. p. 7 .

I768, Oct. I3. Extract of a register in which are written the results of the most important deliberations which took place in the assemblies of the superiors and other officers of the Seminary of Quebec. p. II.

(Partially printed in English translation in the Records of the Am. Cath. Hist. Soc., XX. 408.)

I768. Instructive memoir of the lands belonging to the mission of the Holy Family of the Cahokias. p. I2.

I769, Apr. 22. Ste. Marie, commandant, and others to Bishop Briand. Petition for a priest for Post Vincennes; spiritual destitution. (Summary of reply on same sheet.) p. I4.

I778, Aug. 7. Laffont to Col. George Rogers Clark. Affidavit: Gibault innocent of any political schemes. p. 45 .

(Printed in the American Historical Review, XIV. 550-55I, in Ill. Hist. Coll.,

V. 50-5I, and in the Records of the Am. Cath. Hiist. Soc., XX. 429 .)

I786. Request of travellers from Michilimackinac. p. 49.

(Printed in Bulletin des Recherches Historiques, X. 66-68.)

1786, Feb. r8. De St. Pierre to Father Payet. Documents bearing on church property of mission Ste. Famille requested; conditions in Illinois; jubilee. p. 51. (In Latin.)

(Printed in the Illinois Historical Collections, V., pp. 532-534.)

1786. Copy of the procuration of the superiors of the Seminary of Quebec to Father Gibault and the inhabitants of Cahokia, filed by a notary public of Cahokia, Nov. 6, I786. p. 55.

I786. Action of the inhabitants regarding seminary property. p. 58.

I786, Nov. 7. Claims of A. Dubuque to seminary property contested. p. 59.

I 787, Apr. 22. Letters of the inhabitants of Cahokia to M. de la Valinière of Kaskaskia in defense of their pastor St. Pierre. p. 62.

(Printed in the Ill. Hist. Coll., V. 554-557.)

1787, May 26. De la Valinière to Bishop Hubert. Desires to return to Quebec; conduct of St. Pierre and Gibault. p. 64.

(Printed ibid., pp. 558-560.)

I787, June 6. Extract of a letter of the inhabitants and churchwardens of the fabric and mission of the Holy Family of Cahokia in Illinois to the superiors of the Seminary of Quebec. p. 65 .

(Printed ibid., pp. 560-567.) 
I787, Aug. I4. Father Payet to Bishop Hubert. Conditions at Michilimackinac; doings of de la Valinière; colleagues at Detroit. p. 67. (Printed in Bulletin des Recherches Historiques, X. 73.)

I790, Mar. 29. To Le Dru. Apology for his conduct at St. Mary's Bay sent to Illinois by Mgr. Carroll; pastor in St. Louis. p. $7 \mathrm{I}$.

I792, May 7. Gravé to Bishop Hubert. Bishop Carroll sends information of Gibault's usurpation of seminary property at Cahokia. p. 73 .

I802, Oct. 27. Titles to church property in Illinois; seminary and Jesuit property; American Congress. (Incomplete.) p. 74.

I8ı3, Dec. I2. To D. Olivier. Pastoral letter of Bishop Flaget to the people of Vincennes and Illinois; confirmation. p. 76 .

I834, Jan. 8. State of Illinois, St. Clair County. Deed of a lot and house from A. W. Snyder and wife Adelaide to Rt. Rev. Joseph Rosati. p. 78.

I838, Nov. 20. Bishop Bruté, of Vincennes, to Archbishop Signay. Catholic beginnings in his diocese; map of missions sketched. p. 80 .

I840, June 25. A. Snyder to Rev. P. J. Verhaegen. Title of a lot sold to Bishop Rosati. p. 82.

I847, June I9. Father Courjault to Bishop Turgeon, coadjutor. Poverty of his church; Quebec immigrants; help requested. p. 84.

I847, Aug. 30. Father Courjault to Bishop Turgeon. Ecclesiastical furniture received; Canadian immigration. p. 86.

I853, Jan. 8. Father Edw. Daems to Archbishop Turgeon. Collection in Quebec requested to finish the church of a Canadian congregation. p. 88.

1872, Feb. 22. Rev. C. P. Maes to Archbishop Taschereau. Condition of French Canadians in the Detroit region. p. I47.

Etats Unis: Diocèses de Baltimore, Bardstown, New Orleans. BALTIMORE.

Letters of Bishop (and Archbishop) Carroll.

I788, May 5 ; I792, Jan. 20, May 4 ; I793, May I2 ; I794, Jan. I 5 ; I796, Mar. 2, May 2 ; I806, July 28 ; I810, Oct. I5; I8II, Mar. I2 ; I8I4, Mar. 2 ; 18I 5, July 9. To Bishops Hubert, Denaut, and Plessis. pp. I, 2, 3, 5, 7 , I2, I3, I5, I 8, 2I, 23, 24.

(Printed in the Records of the Am. Cath. Hist. Soc., XVIII. I55-156, I60-165, I67-169, 171-172, 174-175, 177-178, 184-187, 291-293, 299-300, 302-305; and the first three in Ill. H Hist. Coll., V. 581-582, 593-596, 599-60I.)

1795, Apr. 24. To Bishop Hubert. Provision for a religious of the order of St. Francis de Sales in Ursuline convent of Quebec. p. Io.

I806, July 28. To Bishop Plessis. Formula of faculties. (In print and in manuscript.) p. 16.

\section{Letters of Archbishop Maréchal.}

1819, Nov. 17. To Bishop Panet. Troubles in New York. p. 27.

I820, Oct. 3. To Archbishop Plessis. Action of the Propaganda anent Rev. Browne and trustee agitation. p. 28.

I821, Jan. 6. To Archbishop Plessis. Nomination of bishops in the U. S. p. 29.

(Printed in Mgr. Têtu's Journal d'un Voyage en Europe par Mgr. Plessis, I903, pp. 433-434.) 
I82 I, Apr. 28, June 25, Oct. 9: I822. Nov. 22: i823. Jan. 8; i824, May i6; I825, Apr. 23. To Archbishop Plessis. pp. 30, 3I, 32, 34, 35, 4I, 44. (Printed in the Records of the Am. Cath. Hist. Soc., XVIII. 442-449, 45I-452, $455-456,459$.

I823, Mar. I I i824, Nov. 6, Dec. I8. To Archbishop Plessis. pp. 37, 42, 40. (Partially printed ibid., 449-450, 456-459.)

I823, Jan. I8. To Archbishop Plessis. Mixed marriages; his suit against the Jesuits and history of the question. p. $3^{6}$.

1823, May 22. To Archbishop Plessis. Recommendation of Sister Cecilia. p. 39 .

\section{Miscellaneous.}

I793, Nov. I8. Mr. Delavau to Bishop Hubert. Offers his services. p. 6. (Printed in the Records of the Am. Cath. Hist. Soc., XVIII. I70-I7I.)

I794, May I. Nagot, superior of the seminary at Baltimore, to Bishop Hubert. Passports for MM. Chicoineau and Ciquard; consolation in American work. p. 8.

(Printed ibid., pp. I75-177.)

r795, Apr. 24. Sister Félicité to Bishop Hubert. No sisterhoods in the U. S. ; request for admission to the Ursulines. p. II.

I808. Cardinal Antonelli to Bishop Plessis. Division of the diocese of Baltimore. p. I7.

(Printed ibid., pp. 296-298.)

I8Io, Dec. 8. J. Tessier, superior of the seminary at Baltimore, to Bishop Plessis. Vezina freed from censure; employment in Kentucky. p. I9.

I8Io. Testimonials for Vezina. p. 20. (Printed ibid., pp. 293-294.)

I8I I, June 5. Father Grassi, S. J., to Bishop Plessis. Reasons of refusal to send Jesuits to Halifax. p. 22.

(Printed ibid., pp. 301-302.)

I8I6, Mar. 20. J. Tessier to Bishop Plessis. Episcopal succession in Philadelphia and Baltimore. p. 26.

(Printed ibid., pp. 437-438.)

I82 I, Nov. 23. T. Tessier to Archbishop Plessis. Correspondence transmitted; troubles in Philadelphia and New York. p. 33. (Printed ibid., pp. 446-447.)

I823, May io. John Hickey to Archbishop Plessis. Recommendation of Sister Cecilia to the Ursulines. p. 38 .

I83I, Aug. 26. S. Deluol, superior of the seminary, to Archbishop Panet. Testimonial for M. Aniot at Baltimore seminary. p. 45.

I844, Mar. 9. Archbishop Eccleston to Archbishop Signay. No Sisters of Charity can be sent for a year or two to Quebec. p. 46.

I845, July 27. S. R. Deluol, superior of the seminary, to C. Cazeau. Testimonials for Dupuis and Trahan; recall ; accounts. p. 48 .

1845, Aug. 2. Deluol to Mgr. Turgeon, coadjutor to the archbishop. Testimonial for Trahan. p. 49.

I846, July I. S. R. Deluol, superior of the seminary, to Archbishop Signay. 'lestimonial for M. Dupuis. p. 47.

I848, Feb. I. W. Undill [?] to Mgr. Turgeon, coadjutor to the archbishop of Quebec. All books in Indian languages made in Canada requested. p. 50 . 
I856, June 3. Father Ruland, Redemptorist, to Bishop Baillargeon. Request for Redemptorist fathers refused till later. P. 5I.

1856, Aug. 20. Father Ruland, Redemptorist, to Bishop Baillargeon. In two years Redemptorists can come to Quebec; St. Patrick's Church offered them. p. 52.

I857, June 4. Father Ruland to Bishop Baillargeon. Visit to Quebec for arrangements. p. 53 .

I857, Jan. I7. Father Ruland to Bishop Baillargeon. Nature of Redemptorist congregation; missions. p. 54.

BARDSTOWN.

\section{Letters of Bishop Flaget.}

I8I I, Mar. 6, 3I ; I8I2, Jan. I5, 23; I8I5, Nov. II ; I8I6, June I8, Sept. I9; I8I8, Jan. 22, July 21, Oct. I3; I8I9, Feb. 21, Mar. 16; I820, Nov. 3 ; I833, May 30. To Bishop (Archbishop) Plessis. pp. 8I-86, 88-95.

(Printed in the Records of the Am. Cath. Hist. Soc., XVIII. 13-15, 17-24, 27-36, 4I-43.)

Miscellaneous.

I816, July i8. Father Gabriel Richard to Bishop Plessis. Sale of cemetery land at Detroit opposed by Northeast Shore people. p. 87 .

(Printed ibid., pp. 25-26.)

1833, May 29. Mgr. David, bishop coadjutor, to Archbishop Panet. Faculties. p. 96 .

NEW ORLEANS $=$ ST. LOUIS.

\section{Letters of Bishop Dubourg.}

I8I8, Mar. I3; I820, Aug. 26; I821, Feb. 25, July I7; I822, Feb. 4, Mar. I9, May 3o, July 29, Dec. 20. To Archbishop Plessis. pp. IoO, Ior, IO2-IO6, IO9-IIO, I2I.

(Printed in the Records of the Am. Cath. Hist. Soc., XIX. 185-204, 207-209.)

1820, Aug. 26. To Archbishop Plessis. p. IO2.

Letters of Mgr. Janvier.

1822, Apr. 20, Oct. 2. To Archbishop Plessis. pp. I08, I 18.

(Printed in the Records of the Am. Cath. Hist. Soc., XIX. 200-201, 207.)

1822, Sept. 3. To Archbishop Plessis. Ursulines for New Orleans; means of travel. p. II2.

I822, Sept. I6. To Archbishop Plessis. His departure for New York; Ursulines to follow. p. II 5 .

I822, Sept. 2I. To Archbishop Plessis. Vessel sailing from New York to New Orleans. p. I 6 .

\section{Miscellaneous.}

1822, Sept. II. L. Willcocks to Mgr. Janvier. Ships and price of passage from New York to New Orleans. p. I 3 .

(Printed in the Records of the Am. Cath. Hist. Soc., XIX. 204-205.)

I822, Sept. I2. T. Maguire to Archbishop Plessis. Journey of Ursulines from Quebec; stay in New York; accommodations on voyage to New Orleans. p. II 4 .

(Printed ibid., pp. 205-206.) 
1823, Mar. 6. Sister St. Joseph Laclotte, superior, to Archbishop Plessis. Ursuline convent in New Orleans. p. I I 5.

(Printed ibid., pp. 209-210.)

I823, Apr. 3. Sisters Hélène, etc., to Archbishop Plessis. Reception at New Orleans; translation of convent. p. i 16 .

(Printed ibid., pp. 210-21 I.)

I839, Sept. I3. J. Baudoinen to Archbishop Signay. Yellow fever; Canadians in New Orleans. p. I33.

I843, Mar. 4. Bishop Blanc to Archbishop Signay. Information anent Tapin and Bedard; poverty of immigrants; troubles with church wardens at cathedral. p. I37.

1847, Sept. 24. Bishop Blanc to Archbishop Signay. Formula of faculties. p. 138 .

I847, Sept. 25. Bishop Blanc to Archbishop Signay. Faculties exchanged; division of the diocese; scourge of yellow fever. p. I26.

(Printed ibid., pp. 211-213.)

ST. LOUIS.

1829, Nor. 25. Bishop Rosati to Archbishop Panet. Faculties for St. Louis and New Orleans. p. I25.

(Printed in the Records of the Am. Cath. Hist. Soc., XIX. 305-308.)

I83 I, May 8. Father J. M. Odin to Archbishop Panet. Collection in Canada for his church requested. p. I28.

(Printed ibid., pp. 308-309.)

I83 I, May 9. Bishop Rosati to Archbishop Panet. Canadian help for building of cathedral. p. I29.

(Printed ibid., pp. 309-310.)

1833. Apr. II. Bishop Rosati to Archbishop Signay. Faculties and decennium. p. I 30 .

I833, Apr. I I. Bishop Rosati to Archbishop Signay. Exchange of faculties; news about various persons; researches on Illinois country in Quebec archives requested. P. I 3 I.

(Printed ibid., pp. 3I2-3I3.)

I840, Dec. 31. Father Verhaegen, S. J., to Archbishop Signay. Flathead mission ; journey to Columbia region via St. Louis. p. I34. (Printed ibid., pp. 317-318.)

I843, Jan. 5. Bishop P. R. Kenrick to Archbishop Signay. Faculties, especially for Quebec priests in Oregon. p. I35.

États Unis: Diocèses de Boston et de Philadelphie. BOSTON.

\section{Letters of Bishop Cheverus.}

I8Io, June 26. To Bishop Plessis. Information regarding Dr. Concanen and Mgr. Flaget's efforts in France to obtain clergy; Ursulines for New Orleans; M. Matignon on Maine mission. p. I5.

I8I I, Jan. 20. To Bishop Plessis. Exchange of faculties; M. Romagné at Passamaquoddy mission; limits of dioceses. p. I7.

I8I I, Feb. I2. To Bishop Plessis. Faculties; formula. pp. I8, I9. I8I2, Jan. 23. To Bishop Plessis. Id. p. 20.

I8I2, Apr. 4. To Bishop Plessis. Offer of hospitality in Boston. p. 2 I. 
1815, May 22. To Bishop Plessis. Dedication of New York cathedral; information regarding Bishop J. Connolly. p. 22.

I8I5, June I9. To Bisliop Plessis. Boston clergy; confirmation at Pleasant Point, Passamaquoddy. p. 23.

I 8 I 5, Oct. 30. To Bishop Plessis. Brosius going to Quebec; Boston families ; etc. p. 25 .

(Partially printed in Mgr. Têtu's "Visites Pastorales par Mgr. Plessis", in La Semaine Religieuse, vol. XVII., no. 5, pp. 74-75.)

I8I6, Mar. 28. To Bishop Plessis. School-teacher not to be found; faculties ; death of metropolitan; character of the Bishop of New York; etc. p. 26.

(Partially printed ibid., pp. 75-76.)

I8I7, Apr. 2. To Bishop Plessis. Jurisdiction of the vicar apostolic of Newfoundland; episcopate of Baltimore; journey to Maryland; etc. p. 28. (Partially printed ibid., pp. 76-77.)

I8I7, Aug. 8. To Bishop Plessis. Matignon in Canada; Passamaquoddy mission; bulls for the Bishop of Philadelphia and Archbishop Maréchal; etc. p. 30 .

(Partially printed ibid., p. 78.)

I8 18 , Aug. 26. To Bishop Plessis. Approaching death of Matignon; Passamaquoddy mission; etc. p. 33 .

(Partially printed ibid., pp. 78-79.)

I8I8, Sept. To Bishop Plessis. Death of Matignon ; Ursulines. p. 34.

(Printed ibid., pp. 79-80.)

I8I8, Dec. To Bishop Plessis. His clergy ; poverty. p. 35 .

I8r9, Feb. I8. To Archbishop Plessis. McQuade's troubles ; criminals converted; loss of Matignon. p. 36.

I8I9, May I7. To Archbishop Plessis. Conditions in New York; building in Boston; Maine mission. p. 37.

I82 I, Jan. 2. To Archbishop Plessis. Canadian Catholic life; new American bishops; conditions in New York; Ursuline school in Boston. p. 38.

(Partially printed in Mgr. Têtu's "Visites Pastorales par Mgr. Plessis", in La Semaine Religieuse, vol. XVII., no. 5, p. 8o.)

I82 I, Sept. 6. To Archbishop Plessis. Journey to Canada; information about M. Larissy, M. Taylor, Bishop England, Archbishop Maréchal; conditions in Philadelphia and New York; exchange of faculties. p. 48. (Partially printed ibid.)

I82 I, Oct. I7. To Archbishop Plessis. Journey to Canada; business affairs ; Archbishop Maréchal leaves for Rome. p. $4 \mathrm{I}$.

1822, Mar. 8. To Archbishop Plessis. Journey to Canada; conditions in New York and Philadelphia; Bishop England's paper; Ursuline convent; Taylor's character. p. 42.

1822, Sept. 19. To Archbishop Plessis. Canadian Catholicity. p. 43. (Partially printed ibid., no. 6, pp. 86-87.)

1823, Mar. 19. To Archbishop Plessis. Bishop England's paper; church at Claremont; trusteeism in Philadelphia; temporalities of the Archbishop of Baltimore and the Jesuits. p. 44.

1823, June 19. To Archbishop Plessis. Ordination of Abbé Holmes; nomination to Montauban; few clergy in Boston. p. 45. 
Letters of Bishop Benedict Fenwick.

I825, Dec. I2. To Archbishop Plessis. Exchange of faculties; Holmes desired to take the place of Taylor. p. 56 .

I826, Jan. To Archbishop Panet. Death of Archbishop Plessis; Holmes desired; Boston clergy. p. 57.

I826, Apr. Io. To Archbishop Panet. Faculties. p. 60.

1826, Apr. 12. To Archbishop Panet. Holmes; desolation of the Boston church. p. 6I.

I828, July 29. To Archbishop Panet. Holmes to remain in Quebec diocese in exchange for Father McMahon; destitution of the Boston diocese. p. 62.

1830, Feb. 8. To Archbishop Panet. Ursuline convent at Charlestown. p. 63. I833, Feb. 20. To Archbishop Panet. Id. p. 65.

1834, Aug. 27. To Archbishop Signay. Burning of Ursuline convent by mob. p. 66.

1834, Nov. I8. To Archbishop Signay. Ursulines; trial of Charlestown rioters. p. 67.

I835, Jan. 27. To Bishop Turgeon. Temporary convent of Ursulines in Roxbury; Boston Ursulines in Quebec. p. 69.

1835, Jan. 28. To Archbishop Signay. Faculties; future of Ursulines in Boston diocese. p. 68.

1835, Mar. I9. To Archbishop Signay. Indemnity refused Ursulines by legislature; removal to Quebec. p. 70.

1835, May 3. To Archbishop Signay. Departure delayed by trial. p. 72.

1835, May 23. To Archbishop Signay. Departure of Boston Ursulines for Quebec; under jurisdiction of the bishop there. p. 73 .

I835, July 27. To Archbishop Signay. Boston Ursulines in Quebec. p. 74. I835, Oct. 25. To Archbishop Signay. Apology for sending all Ursulines to Quebec; conferring of pallium on the Archbishop of Baltimore. p. 75. I836, Feb. I8. To Archbishop Signay. Faculties; Ursuline trouble; Maria Monk calumnies. p. 76 .

I838, Mar. 9. To Archbishop Signay. Canadian rebellion; Ursulines. p. 77. 1838, Sept. 2. To Archbishop Signay. Return of Boston Ursulines. p. 78.

1839, June 4. To Archbishop Signay. Request for admission of Boston Ursuline in Quebec convent. p. 80.

1839, Mar. 20. To Archbishop Signay. Marriage case; Ursuline community in Boston. p. 8I.

1839, July 3. To Archbishop Signay. Ursulines; marriage case; ritual adopted by U. S. bishops. p. 82.

I840, Apr.21. To Archbishop Signay. Marriage case; Ursulines. p. 85. 1840, May 3. To Archbishop Signay. Ursuline affairs. p. 86.

I84I, Apr. 24. To Mgr. Turgeon. Information on cost and frequency of passages from Boston to Columbia via Sandwich Islands. p. 87.

I843, Dec. I. To Archbishop Signay. Title deeds of Ursuline property; dissolution of convent. p. 88.

\section{Letters of Bishop Fitzpatrick.}

I846, Oct. 5. To Archbishop Signay. Exchange of faculties. p. 89. Formula of faculties. (In Latin.) p. 90.

1847, June 9. To Mgr. Turgeon. Visitation in Maine; limits of diocese. p. 9 I. No date. To Mgr. Turgeon. Maine mission; Mr. Brownson. p. 93.

I85o. To Mgr. Turgeon. Catholicism in Maine and New Hampshire. p. 94. 
I853, July 26. To Archbishop Turgeon. Letters testimonial for M. Lévêque. p. 95 .

1853, Oct. I7. To Archbishop Turgeon. Dimissorial letters. p. 96.

\section{Letters of Father Matignon.}

1799, Jan. 3I. To Mgr. Plessis. Clergy; France losing influence in the U. S. p. II.

I80o, Mar. II. To Mgr. Plessis. Canadian help for Albany church; aid requested for Boston church. p. I3.

I8Io, Dec. 27. To Bishop Plessis. New dioceses erected in the U. S.; faculties. p. 16.

I816, Apr. 27. To Bishop Plessis. No teacher for Quebec found; Bishop Cheverus in Rhode Island and Maine. p. 27.

I8I 7, July 3. To Bishop Plessis. Ursulines; Bishop Dubourg expected from Europe with clerical help; Bishop Cheverus received by President Monroe. p. 29.

(Printed in Mgr. Têtu's "Visites Pastorales par Mgr. Plessis", La Semaine Religieuse, vol. XVII., no. 5, p. 77.)

I8I7, Aug. 3I. To Bishop Plessis. Books for Quebec; Bishop Cheverus in Maine. p. 32.

\section{Letters of Father de la Poterie.}

1788, Oct. 6. To Bishop Hubert. Lacking consolation of faith in Boston, requests adoption in Quebec. p. I.

I789, May I6. To Bishop Hubert. Holy oils, etc., requested. p. 2.

I789, Jan. 29. To the public. Indebtedness of the Catholic church in Boston; subscription; his school. (Printed.) p. 4.

I789, Mar. I. To Bishop Hubert. Financial straits; help requested. p. 5.

I789. To the public. Religious ministration to sick and dying; apology against calumnies ; credentials ; inscription on his portrait. (Printed.) p. 6.

I789, Feb. 22. Pastoral letter; the Order of the Publick Offices and of the Divine Service during the Fortnight of Easter in the Catholic Church of the Holy Cross at Boston; an Abridged Formula of the Priest's Discourse made every Sunday in the Church of the Holy Cross at Boston. p. 7.

\section{Letters of Father Taylor, Administrator.}

I824, Mar. I. To Archbishop Plessis. Bishop Cheverus in France; Father Taylor administrator; Ursulines in Boston. p. 39.

I824, May i7. To Archbishop Plessis. Ursuline convent; Bishop Cheverus in France. p. 46.

I824, June 9. To Archbishop Plessis. Ursuline convent; coadjutor to New York; Bishop Cheverus proposes Taylor as successor in Boston. p. 47.

I824, June I9. To Archbishop Plessis. Bishop Cheverus to remain in France ; Ursulines. p. 48.

I824, Nov. I9. To Archbishop Plessis. Need of priests in Boston; Abbé Holmes; Dominicans at Rome opposed to Taylor. p. $5 \mathrm{I}$.

I825, Apr. I5. To Archbishop Plessis. His powers as administrator sede vacante; Ursulines; gratitude. p. 52.

I825, Sept. 28. To Archbishop Plessis. Fenwick, bishop of Boston; Taylor to return to France; Ursulines. p. 55 . 


\section{Letters of the Ursulines.}

I826, Mar. 22. Sister St. George to Archbishop Panet. Condition of the Ursulines in Boston; help needed. p. 59 .

1830, Mar. I3. Ursulines (Boston) to Archbishop Panet. Thanks for permitting the reverend superior to remain. p. 64 .

I835, Mar. 21. Sister St. George to Archbishop Signay. Good of religion requires Ursulines to remain in New England. p. 7 I.

\section{Miscellaneous.}

I790, Ja1n. 2. L. de Rousselet to Bishop Hubert. Information requested regarding de la Poterie. p. 8.

I8I5, Aug. II. M. Painchaud to Bishop Plessis. News about the Quebec clergy ; routes back to Canada. p. 24.

1825, May i7. P. Byrne to Archbishop Plessis. Passamaquoddy Indian mission; request for faculties. p. 53 .

PHILADELPHIA.

\section{Letters of Bishop Conwell.}

I82 I, Oct. 25. To Archbishop Plessis. Collection and Ursulines requested; trustee question. p. I 30 .

I82 I, Oct. 29. To Archbishop Plessis. Faculties. p. I32.

1822, Jan. 6. To Archbishop Plessis. Decision of the Supreme Court in trustee suit; Ursulines in Philadelphia. p. I33.

I822, July 4. To Archbishop Plessis. Trustee riots; his absence from Philadelphia. p. I34.

I823, July 25. To Archbishop Plessis. Collection in Canada for Philadelphia; trustee tenets : clerical community. p. I 38 .

I823, Sept. I3. To Archbishop Plessis. His presence in Montreal; trustee situation in Philadelphia. p. I39.

I824, July II. To Archbishop Plessis. Lawyer Randell; Hogan back in Philadelphia. p. I4I.

I824, July 27. To Archbishop Plessis. Mr. Egan sent to collect for the college, burned down at Emmitsburg; trustee situation in Philadelphia. p. I42.

\section{Miscellaneous.}

I773, Apr. 22. Father Ferdinand Farmer to R. P. Well. State of the Catholic religion in the English colonies. (In Latin.) p. I24.

I833, Mar. 27. Mgr. F. P. Kenrick, bishop coadjutor, to Archbishop Signay. Faculties. p. I44.

I842. Bishop F. P. Kenrick to Archbishop Signay. Faculties. p. I45.

I843, Nay 29. Bishop F. P. Kenrick to Archbishop Signay. Vicariate in Oregon; list of candidates. p. I48.

I864, Oct. 28. Bishop Wood to Archbishop Turgeon. Invitation to dedication of cathedral. p. I 49 .

États Unis: Diocèse de New York.

\section{Letters of Bishop Connolly.}

I8I6, June 7. To Bishop Plessis. Exchange of faculties; dearth of priests in New York, especially at Albany. p. 5.

I8I6, June 6. To Bishop Plessis. Manuscript formula of faculties. p. 6. 
I8I6, Oct. 25. To Bishop Plessis. Brochure, Ordres du Gouvernement d'Angleterre à ses Ministres en Canada, Malthe, etc., à l'Égard des Eccl. Catholiques à ces Endroits, sent to Quebec. p. 7.

I82 1, Feb. I7. To Archbishop Plessis. P. Malou's refusal to leave New York; robbery in the cathedral. p. 27.

\section{Letters of M. DeCourcy.}

I853, Apr. 8. To Archbishop Turgeon. His articles in Le Courrier des États Unis and in the Paris Univers against Abbé Brasseur de Bourbourg's History of Canada. p. 56.

I853, Nov. I 5. To M. J. Viger. Mgr. Bedini; intrigues of Brasseur for the creation of an ecclesiastical province in California with himself as archbishop ; Brasseur's History of Canada discredited. p. 62.

I853, Nov. I6. To Archbishop Turgeon. Brasseur's intrigues in Rome and France; Bedini edified in Canada; Ferland's refutation of Brasseur's History of Canada. p. 63 .

1853, Dec. 3. To Archbishop Turgeon. Suggestions for a new edition of Ferland's brochure against Brasseur's History. p. 64.

I854, Feb. 2. To Archbishop Turgeon. Plots against Mgr. Bedini. p. 65.

I854, Feb. 3. To Archbishop Turgeon. Secret departure of Bedini counselled by mayor and police; Canadian address to Mgr. Bedini suggested. p. 66.

I854, Feb. I9. To Archbishop Turgeon. Canadian address; refutation of calumnies needed; his article on agitation against Bedini enclosed. p. 67 .

1854, Feb. 27. To Archbishop Turgeon. Transmission and publication of Canadian address. p. 68.

I854, Mar. I5. To Archbishop Turgeon. Bedini's arrival at Liverpool; Canadian address; Bishop Goesbriand; Brasseur's work translated. p. 69.

I854, July 22. To Archbishop Turgeon. Madonnas of Rimini presented by Bedini; peculiar attitude of American bishops on Bedini's departure; Canadian address. p. 72.

1854, Oct. 2. To Archbishop Turgeon. Canadian address to Mgr. Bedini. p. 74 .

I854, Oct. 23. To Archbishop Turgeon. Mgr. Bedini. p. 75 .

I856, Apr. I I. To Archbishop Turgeon. His Sketch of the History of the Church in the United States. p. 78 .

\section{Letters of Bishop Dubois.}

I824, June Io. To Archbishop Plessis. Fire in his college; collection in Canada desired. p. $4 \mathrm{I}$.

I827, Jan. 2I. To Archbishop Panet. Exchange of faculties; visitation of his diocese before going to Europe. p. 43.

I827, Feb. 9. To Archbishop Panet. Faculties; visitation of his diocese; New York clergy. p. 44.

I827, Feb. 9. To Archbishop Panet. Manuscript formula of faculties. p. 45. I828, June 27. To Archbishop Panet. Id. p. 46.

\section{Letters of Ffrench.}

I819, Mar. I. To Archbishop Plessis. His good work for religion in New England; his sacrifices in becoming a Catholic; calumnies of enemies. p. 20. 
I822, Jan. I8. To Archbishop Plessis. Defense of his work in New York against calumnies of enemies; requests permission to return to St. John, New Brunswick. p. 35 .

\section{Letters of Father Kohlmann.}

ISI I, May I. To Bishop Plessis. Exchange of faculties ; ministry on Canadian frontier; state of the faith in New York. p. I.

I8I I, May I4. To Bishop Plessis. Manuscript formula of faculties. p. 2. I8I2, Jan. 8. To Bishop Plessis. Faculties delegated. p. 3 .

\section{Letters of Father Malou.}

I8ı8, Dec. 9. To Bishop Plessis. Clerical factions; Ffrench's intrigues; Carbery plots. pp. I6-I7.

I8I9, Jan. I5. To Bishop Plessis. Weakness of Bishop Connolly under domination of bad Irish faction. p. I8.

I8I8, Feb. 23. To Bishop Plessis. Ffrench denounced in trustee meeting; the bishop's refusal to intervene. p. I9.

I8I9, May 2i. To Archbishop Plessis. Bishop Connolly's refusal to accept evidence against Ffrench, and his unfairness to Malou. p. 22.

I8I9, June 23. To Archbishop Plessis. Ffrench protected by the bishop and Irish faction and made president of the Orphan's Aid Society; Carbery's schismatic church in Norfolk; libel suit of Ffrench against Willcocks; memoirs sent to Rome; intrigues against Malou. p. 23.

I819, Nov. I5. To Archbishop Plessis. Evidence against Ffrench; fear of schism in New York; New York clergy; memoir sent to Archbishop Plessis. p. 25.

I822, Jan. 20. To Archbishop Plessis. Refusal to leave New York for Canada. p. 36 .

\section{Letters of Father Power.}

I821, Jan. 3. To Archbishop Plessis. Recommendation of young Irish clergyman. p. 25.

I82 I, Mar. 23. To Archbishop Plessis. Acceptance of Irish clergyman; his character; departure for Montreal. p. 30.

I82 I, Nov. 6. To Archbishop Plessis. Father Malou deprived of faculties, etc.; trustee situation in Philadelphia. p. 34.

I826, Apr. I3. To Archbishop Panet. Exchange of faculties. p. 42.

\section{Letters of Father Taylor.}

I82I, Feb. 8. To Archbishop Plessis. His difficulties in New York; false conceptions in Rome anent French bishops and the state of religion in the U. S. ; offers services. p. 26.

I821, Mar. 27. To Archbishop Plessis. Reasons of his departure from New York; asylum in Boston; intervention of Rome. p. 28.

\section{Letters of Lewis Willcocks.}

Series of business letters of little historical importance.

I8I9, Mar. 3. To Archbishop Plessis. Ffrench's libel suit ; charges against Ffrench; testimony of Mgr. Plessis desired. p. 2 I. 
I821, Mar. I9. To Archbishop Plessis. Taylor not allowed to exercise any clerical function in New York; all action postponed in Rome; degraded state of the faith in America. p. 29.

1824, June 2. To Archbishop Plessis. Kohlmann left for Rome; Mrs. Mattingly miraculously cured; attitude of the Archbishop of Baltimore. p. 40.

\section{Miscellaneous.}

I8I7, Feb. 3. Rev. B. Fenwick to Bishop Plessis. Controversial works sent to Quebec; The Trial, together with Dr. Gallagher's answer to Wharton formerly a Catholic priest but now an Episcopalian minister. p. 8. I84I, May 8. Mgr. Hughes, bishop coadjutor, to Archbishop Signay. Faculties. (In Latin.) p. 5 I.

I845, July. M. A. Lafont to Archbishop Signay. Sixty-five dollars sent for the relief of sufferers from fire. P. $5^{2}$.

1852, Sept. 6. T. Romeyn Beck, New York State Library, to M. Cazeau. Donation of catechism and hymns in Chippewa; mass, psalms, and catechism for Montagnais Indians; catechism of Abnakis and Principes de la Langue des Sawvages (1839). p. 53 .

I852, Nov. 20. Copy (Italian and French) of Cardinal Asquini's letter of commendation to M. Brasseur de Bourbourg anent the History of Canada; copy (Latin and French) of commendatory letter of Pius IX. to the same. p. 59 .

1853, May 12. Abbé Brasseur to Archbishop Turgeon. An apology for his History against criticisms. p. 60.

I859, Jan. 20. Father I. T. Hecker to Bishop Baillargeon, coadjutor. MIission at St. Patrick's (Quebec). p. 79.

États Unis: Diocèses de Cincinnati, Cleveland, Portland, Marquette, San Francisco, Galveston, Trappe de Kentucky et Illinois.

\section{CINCINNATI.}

\section{Letters of Bishop Edward Fenwick.}

I822, Apr. 3. To Archbishop Plessis. Exchange of faculties (Michigan and Northwest territory). p. I ; formula (in Latin). p. 2.

1826, Apr. 3. To Archbishop Panet. Faculties. p. 4.

\section{Letters of Archbishop Purcell.}

I855, Mar. I2. To Archbishop Turgeon. Value of Noiseux's History. p. 9. I855, Mar. 31. To Bishop Baillargeon. Refutation of Shea's criticism requested. p. I2.

\section{SAN FRANCISCO.}

\section{Letters of Archbishop Alemany.}

1854, July I 5. To Archbishop Turgeon. Father Kerrigan requested; death of M. Olivier Lacroix; dearth of priests. p. 22.

I854, Aug. I4. To Archbishop Turgeon. Estate of M. Lacroix. p. 24. I856, July 20. To Archbishop Turgeon. Id. p. 25.

I860, Oct. 28. To Bishop Baillargeon. Siclness of Father A. Langlois, O. P. p. 26. 


\section{Miscellaneous}

I855, Oct. 6. E. Lacroix to M. Cazeau. Estate of M. Olivier Lacroix. p. 23. I860, Nov. 8. Brother F. Sadoc Vilarrasa, O. P., to Bishop Baillargeon. Sickness of Father A. Langlois; poverty of Californian Dominicans. p. 27.

I864, Mar. I I. Brother V. Vinyes, O. P., to Bishop Baillargeon. Poverty of Dominicans and immigrants (French especially); support of Father Langlois when ill. p. 28.

\section{CLEVELAND.}

\section{Letters of Bishop Rappe.}

I853, Oct. 24. To Archbishop Turgeon. His reception at Quebec; orphans of Cleveland; consecration of Bishop Goesbriand. p. 30 .

I854, Nov. 28. To Archbishop Turgeon. Hard times; cholera. p. 3 I.

\section{CHARLESTON.}

\section{Letters of Bishop England.}

I823, Jan. 2I. To Archbishop Plessis. The Miscellany; difficulties of sending it to Canada. p. 35.

I824, Mar.2I. To Archbishop Plessis. State of religion in the diocese; his work; future hopeful ; present poverty; Miscellany. Distribution and correspondence. p. 35 .

I839, Mar. 9. To Archbishop Signay. Catholic education in Charleston; Ursuline convent. p. 36.

\section{PORTLAND.}

\section{Letters of Bishop Bacon.}

I 866, July 6. To Bishop Baillargeon. Portland catastrophe; collection in Canada requested. p. 44.

I871, Sept. I6. To Archbishop Taschereau. Canadian priests asked for two French parishes in Madawaska. p. 45.

I87 I, Sept. 20. To MI. Cazeau. Thanks for priests sent. p. 46.

$$
\text { MARQUETTE. }
$$

I865, June 22. Mgr. Fox to Bishop Baillargeon. Ursuline convent; sisters requested from Quebec. p. 5 o.

I 865, June 22. Sister Ste. M. de la Visitation to Bishop Baillargeon. Obedience requested. p. $5 \mathrm{I}$.

I865. July I 4. Sister St. André to M. Cazeau. Sister Ste. M. de la Visitation may remain or return; no other sister can be spared. p. 52 .

\section{GALVESTON.}

\section{Letters of Bishop Odin.}

I849, Sept. I2. To Archbishop Turgeon. Ursulines and Oblates for his diocese; dearth of priests in Rio Grande region. p. 6r.

I849, Oct.6. To Archbishop Turgeon. Instructions for voyage of two Ursulines from Quebec. p. 62. 
I850, Jan. 8. To Archbishop Turgeon. Good work of two Ursulines in Galveston convent; Oblates in Rio Grande region. p. 63.

I855, Dec. I7. Sister St. Thomas to Archbishop Turgeon. Provincial council at New Orleans; state of religion in Texas. p. 65.

\section{TRAPPE DE KENTUCKY ET ILLINOIS.}

\section{Letters of Father Urbain.}

I806, July 24. To Bishop Plessis. Nature of Trappist order; money and members received for his monastery. p. Ioo.

I806, Mar. 27. To Bishop Plessis. New location of monastery in Kentucky; price of land; invitation to found monastery in Canada declined. p. 107.

No date. To Bishop Plessis. Trappists may go to Canada later; payment of lands purchased; fervor of M. Langlois; hardships in founding a monastery in poverty. p. Io8.

I807, Mar. 27. To Bishop Plessis. Ticket of association (Trappist prayers). p. 108.

I808, Feb. 3. To Bishop Plessis. God's providence in his finances; vows taken in new monastery. p. I Io.

I808, Oct. I8. To Bishop Plessis. His sickness; a monastery near St. Louis and Post Vincennes planned for Indian mission centre. p. II 2.

I8o9, Feb. 4. To Bishop Plessis. Fire in monastery; boat building for removal. p. IIg.

I809, July i7. To Bishop Plessis. Removal of Trappists to Louisiana ; Florissant near St. Louis. p. I I4.

I8og, Sept. 4. To Bishop Plessis. Trappist history in Europe and America. (Largely autobiographical.) p. I I5-I.

I809, Jan. 26. To Bishop Plessis. Autobiography since expulsion from France. p. I I8.

I809, Dec. I4. To Bishop Plessis. Kentucky monastery destroyed by fite; removal of Trappists to Louisiana near St. Louis and Illinois near Cahokia ; petition to Congress for land grant. p. I2I.

18ro, May i. To Bishop Plessis. Apology for his journey to Congress; conditions of land grant; reputation of Gibault; new dioceses in the U. S. ; Trappists minister to destitute parishes ; dearth of priests ; conditions at New Orleans. p. I22.

I8Io, Nov. r8. To Bishop Plessis. Second petition to Congress; internal affairs of monastery; desolate state of religion in Louisiana and Illinois. p. I23.

I8ro, May I5. To Bishop Plessis. Dearth of priests; Trappist ministry; new candidates; death of Father M. Bernard (Langlois). p. I24.

I8I I. To Bishop Plessis. Death of Trappists; Congress on petition for land; dearth of priests; Bishop Flaget; poverty of crops. p. I25.

I8I I, Nov. 9. To Bishop Plessis. Deaths and sickness; danger of famine; new members; Trappist women; parish priest for Cahokia. p. I26.

I8I2, Feb. I8. To Bishop Plessis. Conversions; ministry; earthquake; removal to Canada improbable; death rate prevented famine. p. I27.

1812, Mar. I4. To Bishop Plessis. Trappist women at Baltimore; parish priest M. Lavine in charge of Cahokia and St. Louis; Trappists in charge of other parishes; earthquakes. p. I28. 


\section{Letters of Father Langlois.}

I806, July 30. To Bishop Plessis. State of faith in Baltimore; beauty of country; Trappist community; departure for Kentucky. p. Io2.

I806, June I2. Will of Louis Antoine Langlois, priest. p. Io3.

I807, Jan. I2. To Bishop Plessis. Journey from Baltimore to Kentucky; new dioceses; Trappist community and life ; poverty; temporary residence. p. ro6.

I808, Feb. Ir. To Bishop Plessis. Profession; nomination as subprior of temporary monastery near Bardstown; candidates. p. Iog.

I808, Sept. I8. To Bishop Plessis. Illinois establishment; Trappist community divided between two houses; watch-repairing and converts. p. I I I.

I808, Oct. 23. To Bishop Plessis. Trappist community; mixed marriages; Dominican estabiishment. p. I I 3 .

I8o9, Feb. 4. To Bishop Plessis. Trappist community; candidates needed; removal to Illinois. p. I I9.

Lettres de Mgr. F. N. Blanchet, Missionnaire À la Colombie. i837-i859. r838, June 27. To Mgr. Év. de Sidyme, [Mgr. Turgeon, coadjutor to the archbishop of Quebec]. Information from Dr. McLoughlin anent religious conditions at Wallamet. p. 5 .

I839, Jan. 27. To Father Modeste Demers. Favorable condition for Catholic mission. p. 7 .

I839, Jan. I8. To Father Demers. Services at Wallamet; visit of ministers ; temperance. p. 8.

1839, Apr.7. To Father Demers. Ministers at Nesqually; missions desired by savages; ministry at Cowlitz. p. 9.

1839, Jan. 7. To Father Demers. Wallamet mission; measures to promote religion and morals. p. Io.

I839, Apr. I I. To Father Demers. Preparation for mission at Nesqually. p. II.

I839, Mar. 25. To Father Demers. Religious ceremonies and instruction of Indians. p. I2.

No date. To Father Demers. Marriage; Mr. Douglas; ministers at Wallamet. p. I3.

r839, Apr. 20. To Father Demers. Attitude and customs (nudity and polygamy) of Indians; Protestant and Catholic missions at Nesqually. p. I4.

I839, May 22. To Father Demers. Mission at Nesqually ; Protestant calumnies (Maria Monk). p. I5.

No date. To Father Demers. Religious ceremonies; temporalities of mission; Indians arrive at Cowlitz. p. I6.

I839. June 7. To Father Demers. Trouble between Indians and whites; Americans; progress of religion; calumnies cease. p. I7.

I839, June Io. To Father Demers. Iroquois calumnies. p. I8.

I839, June 22. To Father Demers. Marriage question. p. I9.

I839, June 29. To Father Demers. Power of Catholic preaching; day's work; marriage question. p. 20.

I839, Aug. 27. To Father Demers. Mission of Cowlitz; bad influence of Canadians on converted Indians; Americans. p. 2 I.

I839, Dec. Io. To Father Demers. Building at St. Paul du Wallamette. p. 23. 
I840, Jan. I3. To Father Demers. Protestant and Catholic relations in St. Paul du Wallamette; mission property; American encroachments northward. p. 26.

I840, Mar. 2. To Father Demers. Effectiveness of the Historical Ladder; Protestant and Catholic relations; price of live stock. p. 27.

I84I, Oct. I5. To Mgr. Provencher. Missionary journey with results; Indian hostility and American immigration. p. 28.

I84I, Nov. 27. To Archbishop Signay. Statistics of Columbia River missions; American immigration. p. 29.

I842, June 24. To Archbishop Signay. Plans adopted for mission work with Father De Smet. p. 3r.

1842, Oct. 28. To Archbishop Signay. Catholic missions among whites and Indians; Methodist missions. pp. 33-34.

1842, Mar. I2. To Sir George Simpson. Petition for passage of mission people. (Copy.) p. 36 .

I842, Mar. I2. To Sir George Simpson. Id. (Copy.) p. 39.

I84I, Nov. 15. To Sir George Simpson. Defense of effectiveness of Catholic Columbia missions. (Copy.) p. 4r.

1843, Mar. 27. To Archbishop Signay. State of missions. p. 46.

I843, Mar. 2I. To Mgr. Turgeon, coadjutor to the archbishop. Hostility among Indians; distribution of missionaries; temporal affairs of mission. pp. 48-49.

I843, Apr. I I. To Mgr. Turgeon. School and church building; difficulties with Rev. Langlois ; Dr. White's intrigues for American troops. p. 50. 1843, Mar. 28. To Mgr. Turgeon. Differences with Rev. Langlois. p. 5I. I843, Nov. 6. To Mgr. Turgeon. Arrival of American immigration and Jesuits; temporary abandonment of Indian missions; Catholic and Protestant schools; temporal affairs. p. 52.

I844, Mar. 24. To Archbishop Signay. His episcopate; American immigration; condition of missionary work ; financial statement. pp. 53-54.

r844, July 5. To Father M. A. Blanchet. Father De Smet's reinforcements; no further help from the company; progress of work; Methodist mission abandoned. p. 55 .

I844, Apr.6. To Mgr. Turgeon. Activity of American colonists; support of religion; Catholic Ladder. p. 56.

1845. Notice on arrival of Father De Smet with priests and Sisters of Notre Dame and account of voyage to Canada via Cape Horn.

(The notes written upon this leaf were handed over by Mgr. Blanchet, when in Canada to receive his episcopal consecration, to the editor of reports upon missions.)

I845, July 25. Faculties of vicar-general for Oregon given to Archbishop Signay. p. 62 .

I845, Nov. 29. To Mgr. Turgeon. His finances and the Propagation of the Faith ; lithographing of his Ladder; its value. p. 63.

1845, Mar. I8. To Mgr. Turgeon. Erection of an ecclesiastical province in Oregon. p. 64.

1846, Mar. 27. To Mgr. Turgeon. Erection of an ecclesiastical province in Oregon; Cross of St. Gregory for Dr. McLoughlin; brief on rights and jurisdiction of bishop in regard to regulars. p. 65 .

1846, June I3. To Mgr. Turgeon. Oregon province established; plea before the Society of the Propaganda at Lyons; volunteers for Oregon missions. p. 66. 
I 846, Aug. 30. To Mg1. Turgeon. Oregon province; indebtedness; helpers. p. 67.

I 847 , Jan. 28. To Mgr. Turgeon. Financial and spiritual resources of his diocese. p. 68.

I 848, Sept. Central Council of Lyons. Report of what had taken place in Oregon up to his return from Europe; detailed description of Oregon Catholicism. p. 69.

I849, Apr. 9. To Mgr. Turgeon. Bad conditions in Oregon; abandoned by Canadians and Americans for mines. p. 70.

1855, May I3. To Archbishop Turgeon. Bad reports of Oregon country refuted ; financial embarrassment. p. 7I.

I853, Aug. 1. Rev. LeClair to Archbishop Blanchet. Request to leave for Canada. p. 74 .

I853, Aug. 20. To Rev. LeClair. Bad reports of Oregon; exhortation to stay in Walla Walla. p. 73 .

Missions de la Colombie: Lettres des Evêoues Blanchet et Demers. VOL. I. $1835^{-1} 840$.

Letters of F. N. Blanchet.

1836, Nov. I9. To Bishop Provencher. His call to Columbia mission; information requested. p. 4.

1837, Oct. 3. To Archbishop Signay. Readiness to go to Columbia mission; plans of journey. p. 18 .

1838, Mar. 25. To Arclibishop Signay. Perseverance in obeying call to mission. p. 22.

1838, Apr. 6. To Archbishop Signay. Request for instructions. p. 26.

1838, Apr. 25. To Archbishop Signay. Plan of journey to Columbia River. p. 29.

1838, Apr. 30. To Archbishop Signay. Passage in light canoe; supplies for mission; his disposition of mind. p. $3 \mathrm{I}$.

1838, May i. To Archbishop Signay. Departure of laden canoes; faculties. p. 33 .

1838, May 6. To Archlishop Signay. Departure; generosity of the Propaganda (Quebec) to Coltumbia mission; Wallamet population. p. 35 .

I838, May i6. To Archbishop Signay. Journey; supplies for Columbia mission requested by Hudson's Bay Company's boat leaving England in September. p. 39 .

I838, June 22. To Archbishop Signay. The voyage to Red River; appointment of M. Demers to Columbia mission ; itinerary thither ; "Subscription of the Honble Hudson Bay Co. Servants for the benefit of the Catholic Mission in the Willamette, 2 Feby. I838". p. 4 I.

I838, June 28. M. Cazeau. The voyage; list of supplies wanted via England. p. 45 .

I838, July 24. To Archbishop Signay. The voyage; religious conditions in Columbia ; kindness of officials; mission supplies. p. 47.

I838, Oct. Io. To Archbishop Signay. The voyage ; further itinerary ; register of mission work. pp. $56,5^{8}$.

1839, Mar. I. To Archbishop Signay. Condition and needs of Columbia mission. p. 70 .

I839, Mar. I3. To Archbishop Signay. Denominational differences; immorality; American question. p. 76 . 
1840, Mar. 21. To Archbishop Signay. Note drawn on the bishop in favor of J. McLoughlin for supplies of mission. p. 80.

1839, Aug. 24. To Mgr. Turgeon, coadjutor to the archbishop. Columbia missions; marriage question; obstacles to conversion of Indians; American immigration. p. I I I.

I839, Oct. 5. To Mgr. Turgeon. Indians inclined to Catholicism; Wallamet mission ; Catholicism in the Sandwich Islands ; Colville mission. p. I I3.

I840, May I9. To Mgr. Turgeon. Spiritual and temporal affairs of missions; Protestant counterfeit of the Historical Ladder and other intrigues; Sandwich Islands. pp. I 53, I 55.

I840, Nov. 9. To Archbishop Signay. Methodist troubles at Wallamet; refusal of passage to mission people by the Hudson's Bay Company; Jesuit missions; etc. p. I6r.

I842, June 20. To Bishop Rosati. State of religion in Columbia mission; Jesuit increase desirable ; advantage of erecting Columbia into a diocese. p. 165 .

\section{Letters of M. A. Blanchet.}

I838, May 3. To Archbishop Signay. Misfortune in his brother's departure. p. 37 .

I838, June I4. To Archbishop Signay. His brother's voyage and zeal ; sending mission supplies via England. p. $4 \mathrm{I}$.

I838, Sept. Io. To M. Cazeau. Mission supplies to Columbia via England. p. 52 .

I838, Sept. 24. To M. Cazeau. Id. p. 54.

1839, Apr. 21. To M. Cazeau. Purchase of supplies in England for Columbia mission. p. 90.

\section{Letters of M. Demers.}

1837, Mar. 9. To Archbishop Signay. His desire to evangelize Indians realized by call to Red River. p. Io.

I838, July 25. To M. Cazeau. Appointment to Columbia mission under Blanchet; ministry at posts en route. p. 49.

I839, Jan. I7. To Father F. N. Blanchet. Immorality at Fort Vancouver; Indians at Cowlitz; mission work. p. 65.

I839, Jan. 23. To Father F. N. Blanchet. Woman question; ministry among the Indians. p. 68.

1839, Mar. I8. To Father F. N. Blanchet. Religious observances. p. 78.

I839, Mar. 25. To Father F. N. Blanchet. Id. ; Indians. p. 82.

I839, Mar. 3o. To Father F. N. Blanchet. Id.; marriage question; Sandwich Islands news; etc. p. 84 .

I839, Apr. 3. To Father F. N. Blanchet. Sandwich Islands ; sickness ; chief of Walla Walla and ministers. p. 86.

I839, Apr. 4. To Father F. N. Blanchet. Methodist minister to build at Nesqually. p. 88.

1839, Apr. 22. To Father F. N. Blanchet. His reception by Indians at Nesqually; obstacles to conversions. p. 92.

I839, May i6. To Father F. N. Blanchet. Mission supplies arrive; Indians at Cowlitz troublesome ; concubinage ; catechism for women. p. 94.

1839, May 20. To Father F. N. Blanchet. Children entrusted to ministers; marriage permits. p. 96. 
I839, May 22. To Father F. N. Blanchet. Sickness; trouble at Cowlitz; Maria Monk calumny. p. 98.

I839, May 24. To Father F. N. Blanchet. Sickness; Maria Monk and Dr. White. p. Ioo.

I839, June 5. To Father F. N. Blanchet. Sickness; chapel without windows. p. IO2.

I839, June 22. To Father F. N. Blanchet. Hudson's Bay Company's instructions on marriage permits. p. 104.

I839, June 26. To Father F. N. Blanchet. Protestant and Catholic rivalry; Indians pleased to see him; Ogden. p. Iо6.

I839, July 3. To Father F. N. Blanchet. Kindness of officials; marriage question; Protestant ministers; Indians love the "Black Robes". p. 108.

I839, July 31. To Father F. N. Blanchet. Obstacles to Indian conversions.

I839, Nov. 4. To Father F. N. Blanchet. Building operations; knowledge of new tribes; study of Indian languages; the Ladder. p. I I7.

I840, Feb. 26. To Father F. N. Blanchet. Dr. McLoughlin building chapel ; Mr. Lee's wailings; Cowlitz; Ladder. p. I3I.

I840, Mar. I. To Father F. N. Blanchet. Protestant intrigues; Indians pleased with the Ladder; Dr. McLoughlin, etc., at mass. p. I33.

No date. To Father F. N. Blanchet. Bad report of Kalapaya Indians; women at hospital. p. I35.

I840, Mar. 8. To Father F. N. Blanchet. Mission property; Indians at mission; false prophets; Dr. McLoughlin. p. I37.

I840, Mar. 24. To the bishop's secretary, Quebec. Protestant and Catholic methods of evangelization compared; reason of Indian inconstancy. p. I59.

\section{Letters from the Hudson's Bay Company.}

I838, Feb. I7. G. Sinıpson to the Archbishop of Quebec. Passage for two Columbia missionaries to be established at Cowlitz. p. 20.

1838, Mar. 28. J. Keith to the Archbishop of Quebec. Further instructions for the two Columbia missionaries. p. 24.

I838, Apr. 30. J. Keith to the Archbishop of Quebec. Father F. N. Blanchet permitted passage in light canoe; Hudson's Bay Company officials all notified. p. 28.

I839, Jan. 7. William Smith to M. Cazeau. Supplies for Columbia mission shipped in Hudson's Bay Company's boats; only one boat a year. p. 63.

1839, Apr. I5. W. Kitson to Father F. N. Blanchet. American ministers preach to Indians in his house. p. I9.

\section{Letters from Bishop Provencher.}

1835, June 9. To Archbishop Signay. Petition from Columbia River district for establishment of mission there. p. 2.

1836, Jan. 19. To Archbishop Signay. Projected Columbia mission. p. 3.

1837, Jan. 22. To Archbishop Signay. The missionaries Blanchet and Demers. p. 6.

1837, Apr. 15. To Archbishop Signay. Passage of missionaries to Columbia. P. I2.

I837, Oct. I3. To Archbishop Signay. Cowlitz chosen in preference to Wallamet as site of mission because of the U. S. boundary claims. p. I6. 


\section{Miscellaneous.}

1838-1843. List of the ornaments and other effects imported by the missionaries of the Columbia mission and sent to the same mission. p. I2I.

I838-1843. List of the papers given to Mgr. Blanchet, vicar-general and missionary of Cowlitz River, etc. p. I23.

1839, Feb. 25. Robert A. Walsh to Father F. N. Blanchet. Persecution of Catholics in Sandwich Islands by Calvinists. (Copy.) p. I I9.

1839, Aug. Case proposed to be resolved in favor of Columbia mission. p. I27; solutions of the case proposed by the missionaries of the Columbia mission. p. I29.

1839. Nov. IO. Robert A. Walsh to Father F. N. Blanchet. Triumph of the Catholic Church over enemies (Maria Monk). (Copy.) p. II9.

I840. Questions sent to Mgr. Blanchet, vicar-general. p. I25.

There is also a series of letters from different parish priests in answer to enquiries sent them by M. Cazeau, secretary of the archbishop, on request of F. N. Blanchet, about the state (married or single) of a number of Canadian habitants and Indians living in Columbia.

Missions de la Colombie: Letres des Évêques Blanchet et Demers. VOL. II. I $84 \mathrm{I}-1855$.

Letters of Bishop F. N. Blanchet.

I842, Mar. I2. To Bishop Turgeon. Support of mission; notice of California; Russian establishment at the north. (Last two separate papers enclosed in a letter.) p. 9.

184I, Mar. 17. To Archbishop Signay. Note for mission supplies. p. Io.

184I, Mar. I8. To Mgr. Turgeon. Growth of Catholicism; decrease of Methodist influence. p. I2.

I84I, Mar. 2I. To Archbishop Signay. Note for mission supplies. p. I4: I842, Mar. 30. To Mgr. Turgeon. Catholic Ladder; explanation of it; catechism for its use. (Last two enclosed in a letter.) p. 20.

I842, Mar. 3I. To M. Cazeau. Errors in mission reports corrected. p. 40. 1842, Nov. 3. To M. Cazeau. Distribution of missionaries; the Ladder. p. 50.

I843, Mar. Io. To M. Cazeau. Dr. White and American cause; mission register; temporal affairs of mission; school at Wallamet; indults. p. 58.

1843, Mar. 28. To. M. Cazeau. Register of baptisms at Cowlitz; Presbyterian success among Nez Percés. p. 64.

1843, Nov. 28. To Mgr. Turgeon. Decline of Methodist mission; new forces for Cathclic mission; the summer's work; American immigration; his episcopacy. p. 78.

I844, Aug. 6. To M. Cazeau. Catholic Ladder; Methodist mission; register of Vancouver baptisms; his episcopacy; temporal affairs of mission; sickness among the children. p. 92.

1848, Mar. 3. To Mgr. Turgeon. Voyage to Columbia ; lack of priests; war between Indians and Americans; calumnies. p. I66.

I852, Jan. 5. To Archbishop Turgeon. Religious tepidity; liquor question. p. 183 .

18 


\section{Letters of Bishop M. A. Blanchet.}

1846, Nov. Io. To Mgr. Turgeon. His brother's passage from France to Oregon; difficulties in obtaining priests. p. I37.

1846, Nov. 22. To Mgr. Turgeon. Difficulties in getting priests, etc. p. I39. 1847, Jan. 3. To Mgr. Turgeon. Collection in Quebec for Walla Walla; priest problem; itinerary. p. I45.

I847, Feb. 3. To Mgr. Turgeon. No priests. p. I49.

I847, Feb. I 5. To Mgr. Turgeon. A priest for Oregon. p. I5I.

I847, Feb 8. To Mgr. Turgeon. Faculties of vicar-general for Walla Walla. p. I53.

I847, Feb. 24. To Mgr. Turgeon. Oblates, etc., for Walla Walla. p. I55.

I847, Mar. I3. To Mgr. Turgeon. Exchange of faculties; departure. p. I57. I847, Mar. I3. To Mgr. Turgeon. Faculties; Oblates. p. I 59.

I847, Oct. I4. To Mgr. Turgeon. Indian mission; Dr. Whitman's intrigues against Catholics; clergy. p. I63.

I848, May I5. To Mgr. Turgeon. Relation of the journey of the Bishop of Walla Walla in Oregon. pp. I69-I70.

I848. To Mgr. Turgeon. Journey to Oregon; missions, Catholic and Protestant; Dr. Whitman and Indians. p. I78.

1852, Apr. 12. To Archibishop Turgeon. His travels: Mexico, the U. S., Canada; Baltimore council. p. I84.

I852, Apr. 27. To Archbishop Turgeon. Candidate for Oregon mission. p. 185 .

I852, Apr. 29. To Archbishop Turgeon. Translation from Walla Walla to Nesqually; funds. p. I86.

I853, Sept. 24. To Archbishop Turgeon. Difficulties with Oblates of Oregon at Baltimore Council. p. I9I.

\section{Letters of M. Bolduc.}

I842, Jan. 27. To Mgr. Turgeon. Journal of his journey. p. 30 .

I844, Mar. I9. To M. Cazeau. Oregon episcopate; Langlois carping ; printing outfit; dictionary of the Chinook jargon. p. 91.

\section{Letters of Bishop Demers.}

I842, Mar. I8. To Archbishop Signay. Missionary journey to the north; priests needed. p. 34 .

I842, Mar. 3I. To M. Blanchet. Religious ceremonies; conversions through the Ladder; Methodist mission. p. $3^{6}$.

I84 I, Mar. 27. To M. Cazeau. Obstacles to missions; Indian tongues; conversion of Kitson. p. 38 .

1843, Oct. 4. To M. Cazeau. Langlois carping; Indian missions. p. 73. I843, Nov. I9. To M. Cazeau. Conduct of Langlois. p. 77.

I844, Feb. 7. To Archbishop Signay. N. Caledonia mission; Father De Smet in search of help; qualities of missionary. p. 79.

I844, Mar. 5. To M. Cazeau. Hardships of mission tour; dissatisfaction with mission employees. p. 94.

I844, Mar. 8. To M. Cazeau. Oregon City growing; Waller and Dr. McLoughlin; American immigration; Indian hostility. p. 96.

I844, Nov. ro. To M. Cazeau. Blanchet's episcopate; increase of priests and nuns; Protestant missions decline; American immigration. p. Ioo. 
1845, Feb. 21. To M. Cazeau. Church property; dispositions of the Hudson's Bay Company immigration; local government. p. IIo.

1845, Mar. Io. To M. Cazeau. American immigration; confessional struggle feared. p. I I2.

1845, June 19. To M. Cazeau. Catholic progress; fanaticism of Protestant ministers. p. II4.

I845, Oct. Io. To M. Cazeau. Oregon conditions; progress of the faith; Protestant Christianity. p. I 8 .

I845, Nov. I4. To M. Cazeau. Langlois imprudent; Oregon question. p. I20. I845, Dec. 20. To M. Cazeau. Liquor question; Oregon situation. p. I22. I846, Mar. 5. To M. Cazeau. Jesuits in Oregon; liquor question; Methodist mission disbanded ; freemasonry; Dr. McLoughlin. p. I28.

I846, Mar. 30. To M. Cazeau. English intrigues; nationalism of Americans. p. I34.

I847, Sept. 22. To M. Cazeau. His episcopate; the clergy; fallen Protestant missions. p. I6r.

I848, June 24. To M. Blanchet. Disposition towards Catholic religion. p. I73.

1848, Sept. 19. Faculties of vicar-general to Quebec. (In Latin.) p. I74.

I848, Nov. 21. To Mgr. Turgeon. Collection in Canada for his diocese. p. 176 .

I849, Oct. 30. To Mgr. Turgeon. Financial condition of Oregon province. p. I8I.

I85I, May I4. To Archbishop Turgeon. Religious help for diocese. p. I82. 1852, Oct. 26. To Archbishop Turgeon. Distribution of mission funds; lack of religious help ; position of his diocese regarding Canadian or American jurisdiction. p. 187.

\section{Letters of the Hudson's Bay Company.}

I840, Feb. I7. G. Simpson to the Archbishop of Quebec. Refusal of passage to new missionaries. p. 2.

1840, Dec. 20. G. Simpson to the Archbishop of Quebec. Id.; Hudson's Bay Company's attitude toward missions. p. 3 .

I84I, Apr. I 5. G. Simpson to the Archbishop of Quebec. Visit to trading posts; impartiality of report. p. I8.

1842, Aug. II. James Keith to Archbishop Signay. Passage for new missionaries. p. 46.

1843, Nov. 17. James Keith to Archbishop Signay. Id. p. 60.

1843, Mar. 2o. J. McLoughlin to Archbishop Signay. The Catholic mission work; American future of the country. p. 62.

\section{Letters of Father Langlois.}

1840, Oct. 18. To Mgr. Turgeon. Journey to Columbia via Cape Horn ; spiritual and temporal state of the mission. p. 4.

I84I, Sept. I2. To M. Cazeau. Travel experiences. p. 24.

I84I, Sept. 7. To M. Cazeau. Sailings for Valparaiso at New York and Boston. p. 26.

I842, Mar. 2. To Mgr. Turgeon. Voyage from Chili to Columbia via the Sandwich Islands; religion in both places. p. 32 .

I842, May II. To M. Cazeau. Routes to Columbia; Pacific missions. p. 42. 1842, Oct. 16. To M. Cazeau. The country; Indians ; Protestant missions; American domination; missionary methods. p. 48. 
I843, Mar. 3. To M. Cazeau. Temporal affairs of the mission; influence of whites on the Indians; distribution of missionaries. p. ${ }^{6}$.

I843. July I2. To M. Cazeau. Mission at Cascades; mission results ; Jesuits ; Protestant college. p. 69.

I843, Oct. 28. To M. Cazeau. Sterility of Indian missions; Wallamet school; Jesuits. p. 70.

I844, Feb. 7. To Mgr. Turgeon. Obstacles to mission work ; temporal affairs of the mission; school. p. 80.

I844, Feb. I I. To M. Cazeau. Indian mission; Catholic school; local government and Americans; carping. p. 8I.

Plan of the Catholic school at Wallamet; discipline of pupils. p. 85 .

Observation to the professors of the Catholic school at Wallamet; furnishings which each pupil must bring for three months. p. 87 .

I844, Feb. 29. To M. Cazeau. Temporal affairs of Oregon mission. p. 89.

I844, June 23. To M. Cazeau. School; Jesuits; distribution of missionaries; temporal affairs of mission. p. 98 .

I845, Feb. I7. To M. Cazeau. Indian missions; Catholic school. (Plan of a school at Cowlitz is enclosed.) p. Io6.

I845, Feb. 21. To Archbishop Signay. Voyage to Columbia; mission work. p. 126.

I845, Mar. 7. To Archbishop Signay. Desire to return to Canada; state of religion, etc., in California; Cowlitz. p. I 30.

1847, Mar. 9. To Archbishop Signay. Trade competition; work of religious ; political situation; Dr. McLoughlin. p. I32.

\section{Miscellaneous Letters and Documents.}

I839, June 2. P. C. Pambrun to Father F. Blanchet. Brigade in need of spiritual ministration; Cowlitz establishment. p. 5.

I84I, Aug. I7. Father De Smet, S. J., to Father F. Blanchet. Route to Oregon; Flathead interpreter. p. 22.

1843, Feb. 7. Bishop P. R. Kenrick to Archbishop Signay. Episcopate for Oregon. p. 52.

1843. C. Cardinal Acton to Archbishop Signay. Id. p. 7I.

I843, Nov. 26. Decennial and quinquennial faculties given Mgr. F. N. Blanchet. (In Latin.) p. IO2.

I844, Catholic clergy of the apostolic vicariate of Oregon Territory in I844. p. 124 .

I848, Feb. 27. Sophie Pellèque and her companions, pupils of the Sisters of Notre Dame, to Archbishop Signay. Gratitude for missionaries sent to give the light of religion. P. I64.

No date. Appeal to all charitable souls in favor of poor missions, by an old missionary of the Rocky Mountains. p. 193 .

\section{Letters of Father Montgolfier, Vicar-General of the District of Montreal.}

1775, Sept. 25. To Bishop Briand. Siege of Fort St. Jean. p. 38.

x775, Oct. 9. To Bishop Briand. Id. p. 39.

I775, Oct. 23. To Bishop Briand. The American war. p. 4I.

1775, Oct. 26. To Bishop Briand. Surrender of Fort Chambly ; siege of Fort

St. Jean; rebel army increasing. p. 42. 
1775, Oct. 27. To Bishop Briand. Government in power; rebellion checked; advance against "Bostonnais". p. 43.

I775, Oct. 3 o. To Bishop Briand. "Bostonnais" invasion; disposition of the Canadians; Indians of St. Régis. p. 44.

1775, Nov. 6. Surrender of Fort St. Jean ; Canadian prisoners; Montreal citizens asked by Carleton to wait only forty-eight hours for succor. p. 46.

I776, June I7. To Bishop Briand. Evacuation of the town by the Americans; rebel Canadians. p. 50.

I776, June 20. Copy of compliments to Gen. Carleton by M. Montgolfier, vicar-general and superior of the seminary, upon his return from his expedition against the Americans. p. $5 \mathrm{I}$.

I776, Aug. I2. To Bishop Briand. Canadian loyalty; construction of a fleet on Lake Champlain ; Indians offer to England their services in the war but are refused. p. 54 .

1776, Oct. 21. To Bishop Briand. Naval engagement; Cumberland Bay. p. 55 .

I777, Feb. Io. To Bishop Briand. Desolate condition of American rebels; Albany to be the theatre of war. p. 59 .

I777, Apr. 21. To Bishop Briand. Rumors anent the American war; Hessians surprised; Americans defeated at Elizabethtown; Washington captured; etc. p. 60.

1777, Apr. 25. To Bishop Briand. Return of rebels feared; danger of the Detroit region; preparations at Montreal ; rumor that Gibault has been hanged for treason. p. 61 .

I777, June I2. To Bishop Briand. Advance of Burgoyne; St. Leger; Catholic chaplains. p. 62.

I777, July IO. To Bishop Briand. Uncertainty of rumors anent war; Burgoyne's proclamation; threat of cruelty of the Indians in case of resistance. p. 64 .

1777, July 31. To Bishop Briand. Advance of Burgoyne and St. Leger. p. 63 .

1777, Aug. Io. Joannes MacKenna (chaplain) to Bishop Briand. Capture of Fort Stanwix. (In Latin.) p. 66.

I777, Aug. 24. To Bishop Briand. Defeat of Burgoyne at Saratoga. p. 67.

I777, Sept. I I. To Bishop Briand. Burgoyne and St. Leger; dissolution of armies. p. 68.

1777, Sept. I6. To Bishop Briand. St. Leger's army returns in a miserable state; fears for Burgoyne. p. 69.

1777, Sept. 29. To Bishop Briand. Rebel manoeuvres against Burgoyne.

I777, Nov. 2. To Bishop Briand. Engagement between Burgoyne and rebels. p. 7I.

Angleterre. Vol. II. I8I4-I828.

Letters of William Poynter, Vicar-Apostolic of the London District.

I820, Dec. 5. To Archbishop Plessis. Intrigues against the exercise of episcopal authority; Archbishop Maréchal and the Propaganda; Plessis's letter to the Propaganda. p. 77.

I82I, Jan. 3. To Archbishop Plessis. Intrigues at Rome against the Archbishop of Baltimore. p. 82. 
1821, Feb. 27. To Archbishop Plessis. Gradwell to be the agent at Rome for Archbishops Plessis and Maréchal. p. 84.

I821, July 2. To Archbishop Plessis. Nomination of bishops in the U. S.; disorders caused by the Irish; Archbishop Maréchal; Philadelphia pamphlets. p. 88.

I821, Aug. 31. To Archbishop Plessis. Philadelphia affairs at Rome; the Propaganda has its eyes open to the Irish intrigues and supports Maréchal. p. 9 I.

1822, Feb. 6. To Archbishop Plessis. Reception of Archbishop Maréchal in Rome; Cardinal Fontana ready to repair evils in the U. S. churches; Irish faction in Rome nearly broken down. p. 95.

I822, June 4. To Archbishop Plessis. The Archbishop of Baltimore and the Jesuits in Rome ; active opposition of the latter ; episcopal nominations ; Bishop Kelly of Norfolk [Richmond] transferred to Waterford, Ireland. p. Ioo.

Indults, Pouvoirs, Privilèges accordés aux Évêoues de Québec, Lettres de Grands Vicaires.

I835, June 26. Benedictus [Fenwick], ep. Boston. To Mgr. Turgeon. Faculties. p. 9.

I84I, May 8. Joannes Hughes, ep. Basileopol., coadj. Neo-Ebor. et Administr. To Mgr. Turgeon. Id. p. $2 \mathbf{I}$.

I845, July 25. Francis. Norbert. Blanchet, ep. Drasensis, V. A. Oregon. To Mgr. Turgeon. Id. p. 3 I.

I847, Feb. 8. Aug. Maglorius Blanchet, ep. Walle-Wallensis. To Mgr. Turgeon. Id. p. 34 .

I850, Oct. 8. Joannes Rernardus [Fitzpatrick], ep. Boston. To Archbishop Turgeon. Id. p. $4 \mathrm{I}$.

I850, Nov. 2. J. B. [Purcell], ep. elect. of Cincinnati. To Archbishop Turgeon. Id. p. 43 .

I850, Nov.8. Matthias [Loras], ep. Dubuque. To Archbishop Turgeon. Id. p. 44 .

1850, Nov. I6. Ant. [Blanc], archêv. élu, N. Orléans. To Archbishop Turgeon. Id. p. 49 .

I85I, Jan. 25. Petrus Ricardus Kenrick, archbishop, St. Louis. To Archbishop Turgeon. Id. p. 52 .

LetTREs d'IRLANDE.

I820, Oct. 21. J. T. Troy, archbishop of Dublin, to Archbishop Plessis. Two new sees in the U.S.: Richmond in Virginia and the Carolinas including the Georgias; appointments. p. 22.

Correspondance de Rome Manuscrite, i703-1825.

I756, Dec. 23. Benedict XIV. to Abbé de l'Isle-Dieu, vicar-general of Quebec, in Paris. Dispensation permitting the Bishop of Quebec to make Jestit superior at New Orleans his vicar-general there. (Copy in French.)

I77I, Sept. 7. Cardinal Castelli, prefect of the Propaganda, to Bishop Briand. Bishop of Quebec asked to confirm in Maryland, Pennsylvania, Virginia, etc.

1787, Jan. I3. French translation of Propaganda letter. Illinois and Tamarois in English territory and therefore in Quebec jurisdiction. 
I788, Mar. I. Cardinal Antonelli, prefect of the Propaganda, to M. De Villars, Dir. M. E. Paris. Illinois and Tamarois passed to the U. S. and to Carroll's jurisdiction. (French translation.)

I79r, Jan. 29. Cardinal Antonelli to Bishop Hubert. Jurisdiction of the Bishop of Baltimore extends not only to states themselves, but also to territories in the U. S. (Latin duplicate.)

1792, Nov. 28. Cardinal Antonelli to Bishop Hubert. The bishops of Quebec and Baltimore should settle limits of respective dioceses.

182I [?], Nov. I7. F. Cardinal Fontana, prefect of the Propaganda, to Archbishop Plessis. Archbishop Maréchal in virtue of his primacy has not the right of electing bishops to vacant sees; English rules regarding regulars (Benedict XIV.) can not be extended to America.

1823, Mar. 22. Cardinal Consalvi, prefect of the Propaganda, to Archbishop Plessis. Trustee troubles in Philadelphia; aid asked to build a new Philadelphia cathedral without trustees.

Lettres de Mgr. de Laval, Mgr. de St. Vallier, Mgr. de Mornay, Mgr. Dosquet, Mgr. de Pontbriand, Mgr. Briand.

I698, May I. Bishop St. Vallier. Seminary empowered to send missionaries to the Mississippi valley. p. I I.

No date. Bishop Pontbriand to the Minister M. Rouille. Picquet's mission to the Présentation; a pension for him. (Copy.) p. 66.

\section{Letters of Bishop Briand.}

I763, June 4. Episcopal charge of M. Briand, vicar-general, sede vacante, to the priests and faithful of the district of Quebec. Peace; surrender of Quebec to the English.

I767, Aug. 7. Pastoral letter to the inhabitants of Kaskaskia. Mission of the Illinois. p. 122.

I768, Feb. 28. M. Marchant, curé, vicar-general, Boucherville. Illinois mission; M. Gibault to be sent. p. 128 .

1768, Sept. 3. Father Simple, Recollet, Detroit. Marriage case ; admonition to live in peace with English comniandant; delegation of faculties to Father Potier. p. I32.

1775, May 22. Episcopal charge upon the invasion of the Anglo-Americans. P. I7I.

I775, June 4. Id. (Copy.) p. 173.

I775. Draft of a circular letter upon the occasion of the occupation of the posts by the Anglo-Americans. p. 175 .

I775 [?]. Pastoral letter of the Bishop of Quebec to the inhabitants of the diocese. Concerning the American war. p. I76.

No date. Pastoral letters to the inhabitants of Detroit to exhort them to show zeal in securing ornaments for the cathedral, to pay faithfully their tithes, etc. p. I/7.

Lettres de Mgr. Desglis, Mgr. Hubert, Mgr. Bailly, Mgr. Denaut. I784, Sept. 26. Hubert, vicar-general, to Bishop. [Mariaucheau] d'Esglis. Parsonage built ; much moral evil ; desecration of Sunday. p. 4.

I787, Oct. I 5. Bishop Briand to M. de Villars, vicar-general. Cession of the Illinois country to the Americans; apparently spiritual provision by the apostolic prefect of England. p. 28. 
1796, Nov. 19. Mgr. Denaut, bishop coadjutor, to Bishop Hubert. Information regarding Mr. Thayer, convert. p. I45.

I796, Dec. I. Mgr. Denaut to Bishop Hubert. Good character of Mr. Thayer; church at Albany; retreat. p. I47.

I797, Jan. I2. Mgr. Denaut to M. Plessis. Thayer's stay in Montreal. p. I48.

Letrtres de Mgr. Panet.

I821, Nov. 5. To Archbishop Plessis. EIo for the Philadelphia church. p. I 44.

I821, Nov. 29. To Archbishop Plessis. Id. p. I46.

TRANSCRIPT LETTERS.

I. Mgr. de Laval. i659-I707.

I684, June 4. To the king. War declared by the Iroquois; appeal for aid. pp. $259-260$.

(Copied from the original preserved in the Seminary of Quebec.)

I687, May 30. Reasons for not permitting the Huguenots to establish themselves in Canada. pp. 359-362.

(Copied from a copy.)

I690, Nov. 20. To M. de Denonville. Siege of Quebec by the English. pp. 4I7-424.

(Copied from the original preserved in the Seminary of Quebec.)

I699. To M. Tremblay. Mission among the Tamarois; it does not encroach upon the rights of the Jesuit fathers. pp. 47I-48I.

(Copied from a copy made from the original one preserved in the Seminary of Quebec but which has disappeared.)

II. Mgrs. DE St. Vallier, etc. i68I-I764.

No date. Liquor traffic with the Indians. Does cheap liquor influence the Indians to join the English?

I722, July 20. Mission of the Mississippi. pp. 32I-322. 


\section{MONTREAL. ${ }^{1}$}

No general examination has been made of such archives as are preserved in Montreal, with the exception of those in the office of the Archives of the District of Montreal which is a branch or department of the Prothonotary's Office in the Court House. Here are principally the records of the old seigniorial jurisdictions (the only group of records that has been classified and indexed), which have value for local history only, the records of the court of royal jurisdiction, under the French régime (Prévôté de Montréal), and notarial records. The records of the Prévôté de Montréal are for the most part unarranged except for being in two main series "Documents Divers", and "Registres d'Audience". In I888 these two series, with some other records, were removed from Montreal to Quebec where they were placed in the office of the Provincial Archivist (see Report of the Secretary of the Province of Quebec, I888-I889, pp. I29-I35, and id., I904, pp. II-I4, where they are listed). Recently they have been returned to Montreal, and, as stated above, are now in the Court House, where they may be examined upon application to the archivist.

\section{Documents Divers (1653-1769, 79 volumes).}

In general each volume of this series is devoted to a single year. Vol. 78 covers the years I658-I723, and vol. 79 those of I759-I769. The series consists of miscellaneous papers, for the most part petitions, relating to cases before the prévôté. The material bearing upon the history of the territory now included within the United States is very fragmentary and scattered. A better estimate of its extent and value will be possible when the index, about to be prepared, has been completed. A fair specimen of it, however, is to be found in the volume for the year 1755 , in the form of a few letters from the French commander at Fort Duquesne, and his superior officer at La Belle Rivière, addressed to the governor at Montreal and relating to the trial of French deserters who had attempted to join the English.

Registres d'Audience (I68I-I760, 28 volumes).

These are minutes or records of the sessions of the court of royal jurisdiction, and they relate almost exclusively to local matters. Volume nine, which clearly seems to be out of place in this series, is entitled "Enregistrement des Congés, Ordonnances et Arrêts, Juridiction de Montréal, I72 II726." The congés, or permissions to engage in the fur-trade, number twelve or fifteen for each of the years I72I-I726. The majority are for the Great Lakes, the Mississippi, and to the southward, as for example to the Miami country. In each congé is indicated the number of canoes and their crews, e. g., "le 29me avril I722, Jacques Hubert La Croix, Enregistrement et Permission pour 3 Canots pour le Detroit ". Few of the congés exceed a page in length, except in cases where a complete inventory of the merchandise to be carried is entered. So far as could be ascertained by a hasty survey, material of this sort is confined to the volume just described.

${ }^{1}$ This account of the archives in the Court House at Montreal is based upon information kindly furnished by Professor C. E. Fryer of McGill University.

${ }^{2}$ See under Quebec, p. 210, for other congés. 


\section{Notarial Records}

The notarial records, for which an index has been prepared, are arranged primarily by names of notaries, and secondarily by years. Among the records after 1760 , are to be found various documents relating to the fur-trade, especially the papers known as engagements. These are printed forms on which the names of the voyageur and of the trading companies are filled in, together with a description of the routes to be followed. Some of the notaries kept the engagements separate from the rest of the files, especially Louis Chaboillez, among whose papers are 18 volumes entitled "Ls. ChaboillezEngagements faites pour le pays d'enhaut", I788-I8I3, and Gray, among whose papers is a volume entitled "Engagements de Gray, I809-I8I2". In the files of Lukin fils are the engagements made by Gabriel Franchère, the Montreal agent of the American Fur Company, who secured the Canadian z'oyageurs for Astoria and the Oregon country. 


\section{ONTARIO.}

The Ontario Archives are a comparatively recent creation, the first report being that for I903. Their scope is limited to material relating to the history of the province.

In spite of this the records have a wider interest than might be supposed. In many cases official series are of a mixed character and cover a wide field; miscellaneous items have been thrown into certain collections ; while personal papers often reveal much diversity of interest.

Records of the various departments of the government form the basis of the Archives. To these have been added some local records, various material given by private individuals, newspapers, maps, plans, pamphlets, etc.

Manuscript matter for United States history may be summarized under the following heads :

(a) Records of grants of land and other aid given to Loyalists, I783-1798.

(b) A considerable quantity of narratives, diaries, etc., on the War of I8I2, collected among descendants of those who took part in the war. These are upon the campaigns in Upper Canada and along its border, and include the original papers of the capitulation of Detroit.

(c) David Thompson papers. This collection amounts to about fifty volumes, of which probably one-half deal with the delimitation of the international boundary under articles VI. and VII. of the treaty of Ghent. These include journals, field notes, and triangulation. A few of the remaining volumes relate to Thompson's explorations along the Columbia River, the Upper Mississippi, and the Upper Missouri.

(d) Miscellaneous papers on the Mackenzie rebellion of 1837 , and the Fenian raid of $\mathbf{1} 866$.

In the second report of the Archives (for 1904) were printed the records of the commissioners appointed to investigate Loyalist claims. These were taken from copies at Toronto. The originals are at the Library of Congress at Washington, D. C.

The Archives are kept in a vault in the Parliament buildings, Toronto. All inquiries should be addressed to the provincial archivist, Mr. Alexander Fraser.

Reports on certain Ontario archives, by Mr. Walter Laidlaw, are in the Dominion Archives, in M709 and M709B. 


\section{THE TORONTO PUBLIC LIBRARY.}

In addition to its valuable Canadiana in the shape of books, pamphlets, newspapers, maps, pictures, and plans the Toronto Public Library has become the depository of about 250 bound volumes of manuscript. These relate chiefly to Ontario history. A few have no number; the remainder are arranged in series "A " and series " B". In the list given below are included those which have any bearing upon United States history.

All inquiries should be addressed to the chief librarian, Dr. George $H$. Locke.

A 1. Jan., I757-Oct., I759. (348 pp.) Manuscript history of the "American War", by a Scotch officer. The title states that the writer was an eyewitness of the events described, but apparently this applies only to certain parts of the narrative. There are lists of the distribution of troops destined for the invasion of Canada, also for the expeditions against Louisburg, and the Ohio forts, a return of killed and wounded at the siege of Louisburg, the strength of the army on July 30,1758 , after the surrender of Louisburg, military supplies captured at that place, killed and wounded at Ticonderoga, etc.

A 16. Gabriel Franchère's "Journal d'un voyage sur la côté du nord ouest de l'Amerique septentrionale pendant les années I8II-I8I4". (27I pp.) This was printed in French in 1820 , and in an English translation in I854. The original manuscript differs considerably in parts from the printed versions, which are usually somewhat fuller.

A 24. Copy of a diary of Maj. R. Mathews, Feb. 6-June I8, I787. Touches upon Indians, Americans, and British in the northwest, and Loyalist immigrants.

A 93-A 98. Mrs. Powell's letters to various persons. A 93, I803-I8I6, and A 98, I833-1838, contain a few references to passing events of the War of ISI2 and to the rebellion in Upper Canada but are of little importance.

B 18. America. Interference with Neutrals. I806-r8o7. A bulky volume, containing about 400 documents. These vary in date from 1802 to I8I I, and range in extent from Spain to Prince Edward Island. Most of them deal witl $\mathrm{N}$. America, however, and are confined to the years I806-I807. The greater part of the letters are addressed to Vice-Adm. Sir George Berkeley, and relate to the right of search. The bulk of this correspondence is from British consuls at Philadelphia and Norfolk, and the British minister at Washington. Among miscellaneous papers may be mentioned an undated plan of military operations in the event of war with the U.S.

B 38. Miscellaneous papers of John McGill. I78I-I794. A few refer to western affairs and to the Queen's Rangers.

B 56-B 69. The S. P. Jarvis collection. These volumes relate principally to Indian affairs in Upper Canada. The first, which runs from 1788 to I837, has a few speeches of western Indians, etc. 
B 70-B 94. The Dummer Powell collection. Papers of Judge Powell, an early settler in the district of Hesse in western Ontario.

B 77. Quebec papers. Enquiry Boards at Sorel, etc. 1787. Has some information respecting Loyalists at Sorel, their trials and grievances.

B 81. Letters to Lord Dorchester. I789-I79I. Drafts to Lord Dorchester and to his secretary, Henry Motz. A few were written at Detroit, and touch upon occurrences in that region, but they are not important.

B 84. A small volume on Indian affairs, containing among other items a copy of a general report of the Lords of Trade on Indian affairs, of Mar. 7, I768, with several documents appended, including a plan for the future management of Indian affairs, drawn up by the board in I764.

Manuscript journal of Capt. Peter Russell of the 64th Regiment, Dec. 25, I779-May 2, I780. Capt. Russell sailed from New York with Clinton's force, and his journal is chiefly concerned with military operations in the south, particularly at Charlestown.

(Printed in American Historical Revieze, IV. 479-50I.)

Manuscript journal by Capt. Charles Prentice, of a trip through Massachusetts, Vermont, New York, and Upper Canada, Sept. I5-Oct. 29, I807.

Letters and accounts of the Northwest Co. I763-1787. The letters are copies of originals in the possession of Herman Edgar of $3 \mathrm{I}$ Nassau Street, New York. They are largely addressed to William Edgar, and were written by Alexander Henry, Simon McTavish, and others, principally from Michigan, Niagara, and Montreal. The main topics are the affairs of the Northwest Co., personal matters, the Quebec Act, Indians, etc. 


\section{MANITOBA.}

The territory now forming the provinces of Manitoba, Saskatchewan, and Alberta, with the area lying to the north of these provinces, was taken over by the Dominion of Canada in 1870 from the Imperial Government, the country having, prior to that date, been governed by the Hudson's Bay Company. The province of Manitoba was established in the southeastern part of the territory referred to upon its acquisition, but it is only of recent years that the government of the rest of the country has been out of the hands of the Dominion authorities except for some purely local purposes. The archives of the province form a section in the Provincial Library at Winnipeg. This section of the Library is as yet in its infancy. The Provincial Librarian, Mr. J. P. Robertson, reports that so far as he has yet gone with it, it contains nothing of importance to the history of the United States, unless perhaps in connection with the proposed invasion of Manitoba from Minnesota by a band of Fenians in 1870 , at the time of the Riel Rebellion. 


\section{ALBERTA.}

For information respecting the province of Alberta at Edmonton, we are indebted to Miss Katherine Hughes of that city, who formerly had charge of them. Alberta, created an autonomous province in 1905, appointed an archivist in the latter part of 1908 . The active duties of this office were temporarily suspended in I9IO, as the work was hampered by inadequate office-space in the temporary administration building, and by the lack of a definite appropriation for research work. Upon the occupation of the permanent Administration Building this branch will shortly be reorganized and placed upon a more adequate footing.

The work already done mainly covers territory in central and northern Alberta and consists of copies of entries in Hudson's Bay Company journals for various years from I82 I, and histories of individual settlements and persons.

Records pertaining to the various departments of the Northwest Territory, of which Alberta was once a part, were retained by Saskatchewan at the old capital, Regina, when the division took place in 1905. Later records of Albertan administration are as yet preserved in the various departments in which they originate. Civic and municipal records of Alberta are preserved in the offices of the various cities, towns, and municipalities. 


\section{SASKATCHEWAN.}

Mr. John A. Reid, Deputy Provincial Treasurer at Regina, who is familiar with the records of the province, expresses the opinion that there are no documents available in them that can be of interest to the student of United States history. He writes, "The local documents dealing with the area that in 1905 was formed into the provinces of Alberta and Saskatchewan are all here, each within the department of the public service of this province corresponding to the sinilar department under the Government of the Northwest Territories. The Territorial documents can have no connection whatever with the history of the United States, as all matters which would affect that subject in any form or shape will have been dealt with at Ottawa. . . . This will apply to the periods both before and since the establishment of the provinces". He instances journals of exploration, which might be found in the possession of the Geological Survey at Ottawa or of the Department of the Interior, while records illustrating the migrations of citizens of the United States into Canada would naturally form part of the records of the Immigration Branch of the Department of the Interior.

In the Dominion Archives, in M 730 (see p. I5I, above) is a brief report on the archives of Saskatchewan, by Dr. James Hannay. 


\section{BRITISH COLUMBIA.}

\section{ARCHIVES DEPARTMENT.}

The Archives Department, under the direction of Mr. E. O. S. Scholefield, Provincial Archivist, is of recent creation, and the material in its custody is not as yet (1913) accessible for purposes of investigation. It has therefore been necessary to compile the present statement from such information as could be got from a manuscript report on file in the Dominion Archives at Ottawa, M 730 (see P. I5I, above), and from the Report of the Provincial Archivist, 1910, printed in the Sessional Papers of that year. Hence it is impossible to indicate with any degree of certainty, or to describe, those portions of the material that may bear upon the history of the United States. It should be remembered that the history of the territory now within the province of British Columbia is to an unusual degree connected with the history of the territory included within Washington, Oregon, and Alaska. Indeed, the various parts of the Northwest coast may be said to have had a common history until 1846 .

The early trade on the coast, carried on largely by Boston vessels, the Nootka Sound controversy of I789-I790, in which the United States was indirectly concerned and which established the "open-door" policy for the Northwest coast, the founding of Astoria by John Jacob Astor and its occupation by the Canadian Northwest Company after I8I3, the joint occupation of the territory between $42^{\circ}$ and $54^{\circ} 4 \mathrm{O}^{\prime}$ by Americans and English from I8I8 to 1846 , the domination of the Hudson's Bay Company with posts in the present state of Washington (Vancouver, Nesqually, Okanagan, Colville, etc.), its headquarters being at Vancouver until I847-I849, the settlement of the boundary at $49^{\circ}$ in 1846 , the gold rush of 1858 , the dispute over the San Juan water boundary, terminated in 1872 , the settlement of the Alaskan boundary, the controversies over the Bering Sea fisheries, the immigration of Americans into British Columbia, the problem of Chinese exclusion-these are all matters, the history of which, as it relates to the United States, is illustrated by the material in the Archives Department.

The archives, properly speaking, in the custody of the Provincial Archivist, extend from 1849 to about I892. They fall into three groups: the records of the colony of Vancouver Island, I 849-1866; the records of the colony of British Columbia, I858-187I ; and the records of the province, from $187 \mathrm{I}$. In each of these groups the most important material appears to have come from the governor's office. The colony of Vancouver Island was created in 1849 and remained a separate colony until 1866 , when it was united with the crown colony of British Columbia, created in 1858 . The united colonies joined the Dominion of Canada as the Province of British Columbia in I87I. The ordinances of Vancouver Island from I863 to I866 are in print, as are the proclamations and ordinances of British Columbia from I858 to I87I. The Revised Statutes of British Columbia, I871, contain such laws as were continued in force by the legislature of the new province, and the appendix to that volume recites certain colonial laws repealed at the time of confederation. The Journals and Sessional Papers of British Columbia have been printed since 1872. In the Sessional Papers are materials relating to the Bering Sea fisheries ( 1892 , I897), the report of the commissioners of British Columbia at the 
Chicago exposition ( 1894 ), and documents relating to the Alaskan boundary ( I902, 1903).

The historical manuscripts, a good collection of which appears to be well begun, consist largely of transcripts from the Bancroft Library, now at Berkeley, California, and the British Public Record Office, but include a number of valuable original documents. Much of this material has already been exploited by H. H. Bancroft, particularly in his volumes on The Northwest Coast, on British Columbia, on Washington, Idaho, and Montana, and on Oregon.

A complete annotated catalogue of the documents in the Provincial Archives will be issued as soon as the Department moves into its new quarters, now being built, and the material will then be available to the student.

A. ARCHIVES.

Colony of Vancouver Island, 1849-1866.

Governor.

Despatches to the Secretary of State for the Colonies. I849-I864. 5 vols.

Despatches from the Secretary of State for the Colonies. 1852-1857, I862-I866. 7 vols.

Miscellaneous, Letter-books. I850-1866. 7 vols.

Miscellaneous, General letter-books. I864-1866. 2 vols.

Private official letter-book. I859-I864. I vol.

Letters to Hudson's Bay Company. I850-I855. I vol.

Correspondence with naval officers (Gov. Douglas). I vol.

Proclamations. I853-1858. I vol.

Messages, replies to addresses. 1856-1863.

Legislative Council.

Minutes. I85I-I86I (contain references to San Juan Island, Indian wars in Washington, etc.), I864-1866. 3 vols.

Journals. I863-1866. I vol.

House of Assembly.

Minutes. I856-I858, I860-I866. 3 vols.

Journals. I861-1863. I vol. Copy in Dominion Archives, M 731 E (see p. I52).

Bills, amendments, etc. I86I-I865. I vol.

Committee on Supply, Minutes. I860-I866. I vol.

Select Committees, Reports. I858-I865. I vol.

Acts, proclamations, etc. I860-I863. I vol.

Messages, returns to addresses, etc. I856-1860, I864-1866. 2 vols.

Correspondence. 1856-1864. 2 vols.

Treasurer.

Letter-book. I859-I864. I vol.

Lighthouse Board.

Correspondence. I863-I869. I vol.

Colony of British Columbia, 1858-1871,

(including Vancouver Island after I866).

Governor.

Proclamations and ordinances. I858-I864. I vol.

Circular despatches from Downing Street. I852-1868. 3 vols.

Despatches from the Secretary of State for the Colonies. I866-I87I. 5 vols.

Despatches from the Secretary of State, Ottawa. I870-187I. I vol. 
Legislative Council.

Minutes. I859-187 I. I vol.

Journals. I864-I87I. 2 vols. See M 731 F, on p. I 52.

Messages from governor. I864-I871. 2 vols.

Secretary.

Letters. I860-1872. 2 vols.

Collector of Customs.

Letters. I859-I870. I vol.

Naval Officers.

Letters. I859-I87I. I vol.

Lands and Works.

Cash-books, correspondence, indexes, etc. I858-I873. 9 vols.

Departmental letters.

Governor. I859-1870. I vol.

Secretary. I86I-I872. 2 vols.

Miscellaneous. I858-1873. Io vols.

Indexes, etc.

\section{Province of British Columbia, 1871-.}

Lieutenant-governor.

Despatches to the Secretary of State, Ottawa. I87I-I874. 4 vols.

Despatches from the Secretary of State, Ottawa. I871-I892. I8 vols. Executive Council.

Memoranda of proceedings. Nov., I87 I-Apr., I872.

Minutes relating to trouble on Skeena River. I888.

Miscellaneous letters. I874-I894. 7 vols.

Miscellaneous letters, Local. I87I-I88I. 2 vols.

Miscellaneous letters, Foreign. I87I-I881. 2 vols.

\section{B. HISTORICAL MANUSCRIPTS.}

Journal of the Hope, Capt. Joseph Ingraham, Boston to the Northwest coast of America. I790-I792. (Transcript. Original is in the Library of Congress, Division of Manuscripts.)

Nootka Sound Controversy.

Transcripts (many from the British Public Record Office). I790-I793. Correspondence of Don Juan de la Bodega y Quadra, Robert Gray, Joseph Ingraham, Lieutenant John Meares, Capt. George Vancouver, Don Juan de Viana, Robert Duffin, Evan Nepean, Grenville, etc., petitions, memoranda of information respecting American vessels. Cf. W. R. Manning, in Amer. Hist. Assoc., Report, 1904, and Bancroft, Works, XXII.

Journal of John Stuart. Dec. 20, I805-Feb. 28, I806. (Copy.) Cf. Bancroft, Works, XXII. $90 \mathrm{ff}$.

Papers of Simon Fraser.

Journals, Apr. I2-July I8, I806 (original manuscript), May 30-June Io, I808; letters from the Rocky Mountains, Aug. I, I806-F eb. I0, I807 (copied from the Academy of Pacific Coast History); three letters to James McDougal, I806-I807 ; letter to John Stuart, Feb. I, I807 (original manuscript). See Bancroft, $W$ orks, XXIII. 93 ff., where much of the substance of the journals is given; $c f$. also L. R. Masson, Les Bourgeois de la Compagnie du Nord-Ouest, $\mathrm{I}^{\mathrm{re}}$ série (Quebec, I889), where is printed Fraser's Journal of a Voyage from the Rocky Mountains to the Pacific Coast. 
Journals and Correspondence of John McLeod, sr. I8I2-I844.

Transcript of originals in Dominion Archives (Series M, 201); see above, p. II 5 .

Journal kept by Dixey Wildes on board the Paragon, Jan., I8I9-May I, I820. McNeil's voyages.

Journal of a voyage from Oahu toward Nantucket in the Golden Farmer, I827-I828; Journal of a voyage from Bahia to the coast of Africa on board the ship Burton of Boston, I828-1830.) Originals, presented by Mrs. H. J. Baker.) Capt. W. H. McNeil, of Boston, was in the Northwest coast trade. Later he was in the service of the Hudson's Bay Co. See Bancroft, Works, XXIII. 520.

Letters to Edward Ermatinger from Archibald McDonald and John Work. I828-I 856.

Hudson's Bay Company.

Account of sales of goods shipped on the Llama at San Francisco, I834; "Skin Book" of the steamer Beaver and the brig Llama, I836-1839; letter-book of IV. H. McNeil, Nesqually, Sitka, and Stikeen, I84II845; letter-book of W. H. McNeil, Fort Simpson, I85I-I855; letterbook of H. Moffat, Fort Rupert, Fort Simpson, and Kamloops, I857I867. (Originals, presented by Mrs. H. J. Baker.)

Papers of James Douglas.

Diary of a Journey to Norway House, I835; journal, Apr. 22, I840Jan. 23, I84I ; establishment of servants, Columbia District, Oct., I839; continuation of a voyage to Sitka, I84I-I843; letters, July I3, I840-Mar. I6, I867. (Originals.)

Journal of Thompson's River Post, Aug. 3, I84I-Dec. I4, I843, kept by John Tod. (Original.)

Reports upon Oregon Territory and Northwest America, made by George Simpson to Sir John Pelly, governor of the Hudson's Bay Company. Nov. 25, I84I, Mar. IO, I8 42 .

Cowelitz, memorandum book, I84I-I843, and log-book, I843-I 844 .

(Originals.) The Cowlitz was one of the Hudson's Bay Company's vessels, and during the period I84I-I844 was frequently on the California coast, in the Columbia River, and at Sitka.

Puget Sound Agricultural Company.

Transcripts of papers relating to the affairs of the company: prospectus; list of shareholders; memorandum relating to the Cowlitz Farm, by by A. C. Anderson ( 1841,3 pages); judgment of Supreme Court of Washington Territory in the case of Puget Sound Agric. Co. vs. Pierce County (Jan. I7, I862) ; papers relating to Nesqually and Cowlitz claims; account of Frank Clarke with the company (1865) ; origin of the Puget Sound Agric. Co., by A. C. Anderson (1865) ; agreement between the company and the U.S. (June 20, 1867). See the published evidence, arguments, memorials, documents, etc., presented to the British and American joint commission for the settlement of the claims of Hudson's Bay and Puget Sound Agricultural Companies, printed in I4 parts (Montreal, parts 2-7, I4, I868; Washington, parts I, 8-I3, I 865-I868).

Papers and letters relating to the Oregon territory and boundary. I842-I845. (Transcripts from the P. R. O.)

Papers relating to the expedition of Lieutenants Henry I. Warre and M. Vavasour to the Oregon Territory, I844-I846. (Transcripts from the P. R. O. Warre and Vavasour were sent out as confidential commis- 
sioners to report upon the Oregon Territory, and possibly also to investigate the conduct of John McLoughlin as manager of the Hudson's Bay Co. and the Puget Sound Agric. Co.)

Correspondence of William Fraser Tolmie with John McLoughlin, James Douglas, Peter Skene Ogden and others. I844-I864. (Transcripts.)

Establishment of Fort Yukon.

Letter of 84 pages from Alexander H. Murray of the Hudson's Bay Company to Murdo McPherson at Fort Simpson; contains account of his journey from Peel's River to the Yukon, June II-25, I847, record of temperatures at Fort Yukon, July, 1847-May, I848, and pen and ink sketches of Fort McPherson, Fort Yukon (with plan), Indians, etc. Printed as no. 4 of the Publications of the Canadian Archives.

Blanshard Despatches.

Despatches from Richard Blanshard, governor of the colony of Vancouver Island, to the Secretary of State for the Colonies, Dec. 26, I849-Aug. 30, I85I, and despatches to Blanshard from the Secretary of State, I849-I850. (Transcripts.) Cf. H. H. Bancroft, Works, XXXII., ch. Xvi.

Indian war of $1855^{-1856}$ in Washington and Oregon, by Col. Granville O. Haller, U. S. A. (Transcript.) Cf. H. H. Bancroft, Works, XXXI., ch. IV.

Diary of Augustus Pemberton. Jan. 15, 1856-Aug. 3, I858. (Copy.)

Reminiscences of Boundary Survey by Robert Semple. I858-1862.

Vancouver Island Exploring Expedition.

Record of exploration of Vancouver Island by expedition under Robert Brown. June 7-20, I864.

History of Northwest Coast, by Alexander C. Anderson.

Transcript of Manuscript in Academy of Pacific Coast History, I32 pp. This source was much used by H. H. Bancroft.

Pioneer reminiscences of Robert Holloway, Charles Holtz, John McIvor, A. IV. Rogers, and James Yates.

\section{OTHER DEPOSITORIES.}

OFFICE OF REGISTRAR OF DEEDS, VICTORIA.

Registry books. 24 volumes.

These contain the registrations of deeds granted by the Hudson's Bay Company as well as those since relinquishment of the company's rights to Vancouver Island. One would undoubtedly find many deeds recorded by American citizens emigrating to Vancouver Island.

CATHEDRAL OF THE CHURCH OF ENGLAND, VICTORIA.

Marriage records. Feb. 28, 1837 -

Burial records. Mar. I3, $1837-$.

Baptism records. Oct. 25, I836-

From I 836 to 1849 the headquarters of the Hudson's Bay Company were at Fort Vancouver, Washington, and these records were kept there.

CLOVERDALE FARM, VICTORIA.

In possession of John Tolmie: Diary of Dr. W. F. Tolmie, 1883-1886, kept at Nesqually House, Fort McLoughlin, and Fort Vancouver. 


\section{NEWFOUNDLAND.}

The records of this colony are open for inspection up to 1802 ; at the discretion of the government a further examination up to 1830 may be granted. There is no archival organization or central repository of documents; each department is responsible for its own records. The time limit virtually restricts search to the records at the Ministry of Justice and the Colonial Offices. The departments which hold considerable archival collections, with some indication of the character of such collections, are as follows:

The Prime Minister's Department (Court House Building). This department has in charge the Legislative Council Records. In the Colonial Building Library are the printed Joumals of the House of Assembly since I833, those of the Legislative Council since 1848 , and John Cartwright's manuscript account of the Beothics.

The Post Office Department (General Post Office Building). The department was informally constituted in $\mathrm{I} \mathrm{O} 5 \mathrm{~S}$ and formally constituted by the British govermment in 1840 . Most of its records save those referring to the period about 1840 have been destroyed by fire.

The Department of Justice (Departmental Building). The department was reconstructed from the attorney general's department in I895. It has in charge the routine records of its work.

The Supreme Court (Court House Building). The judicial records, under the care of the registrar of the Supreme Court, commence on September 23, I79I, immediately after the passing of the Judicature Act. As, however, all matters of historical interest came under review by the governor and are noticed in the letter-books described below, these records have, for this report, been examined for judicial purposes only. The early records of the surrogate court at Placentia, etc., were in existence some years ago but have now been almost entirely destroyed.

The Finance and Customs Department (Customs Building). This department was reconstituted in 1898 from the receiver general's department. Its only records are those pertaining to the work of the department since I 892 .

The Department of Agriculture and Mines (Museum Building). This department also was reconstructed in I 898 from the surveyor general's department. The records are those since the fire of 1892 . In the geological survey branch are Jukes's report of a geological survey of about I 840 and Carmack's itinerary across the island.

The Marine and Fisheries Department (Customs Building). This department has its records since the fire of I892.

The Public Works Department (Departmental Building). This has routine records only.

Govermment House. The gubernatorial records begin in 1854 . Records earlier than this were all taken to England. land.

${ }^{1}$ This account has been prepared by G. F. R. Prowse, Esq., of St. John's, Newfound- 


\section{THE COLONIAL SECRETARY'S DEPARTMENT.}

\section{(Court House Building.)}

The historical records, under the care of the Colonial Secretary, to whom application should be made for information, are stored in the fire-proof vault of the department.

The collection of original letters received commences in 1825 . What became of letters received prior to this date is unknown. They may have been burnt in one of the frequent fires prior to $\mathrm{I} 825$ or have been taken to England each fall by the governor. Pickmore, commanded to remain for the winter of I8I7, died here; the first real resident governor was Hamilton, I8I8. The present Government House was built in Cochrane's governorship and the first session of the house of assembly opened in 1833 .

All information about the colony's history possessed by the government up to ${ }^{8} 825$ is contained in a series of letter-books, extending in an unbroken line from I743 to the present time. For the period under review, I743 to I830, these books not only contain all the admiral-governor's correspondence, but all his administrative acts, commissions, licenses, reports on judicial, military, naval, and civil acts ; the financial records; and, prior to the formation of the Supreme Court, all court records. The entries show no signs of carelessness or haste. They have never been calendared but as they have been repeatedly and carefully examined by historians, politicians, and diplomatists in connection with French and American fishing rights in this colony, all documents vital to the relations of the United States with this country will be found printed in one or other of the following: histories from Reeves forward (see bibliography in Prowse's History of Newfoundland, I895) ; Report of the Halifax Fisheries Commission, I877; Hague Arbitration, I9I I British, American, and French official publications relating to Newfoundland fisheries; and the Journals of the house of assembly.

The records referring to the Seven Years' War are unfortunately now missing. Up to the opening of the Revolutionary War and in fact during the whole period under consideration, the illicit passenger traffic to the United States caused the governors continual worry. The Labrador and Magdalen fisheries were also much under discussion. At the outbreak of the Revolutionary War and also the War of I8I2, American privateers caused considerable anxiety and damage, generally after the convoy had left for Europe or early in the spring before it returned. But gradually conditions changed, trade was prosperous, and before these wars were over, the colony had assumed comparatively normal conditions; in fact the tables were turned and the colony was being enriched by many prizes. Active recruiting was carried on during the earlier war for the British army in America. Between 1783 and 1812 , the colony was largely dependent on the United States for cereals and meats, and, after the closing of the Baltic, for tar and turpentine. Prior to the conclusion of hostilities in I8I4 Newfoundlanders took active steps to have Americans excluded in the future from fishing privileges in Newfoundland and Labrador. From I8I 4 forward there are many important despatches on this subject.

1. 79. Lease from William Downing of North Carolina to J. Masters and M. Ballard of London of all his estate, houses, etc., in St. John's, for I6 years. Nov. 5 , I743.

3I3-320. Letter and order in Council simplifying correspondence between plantations, etc., and English government. St. James, Mar. I I, I $75^{2}$. 
345. Petition of Robert Bully of Philadelphia claiming land in St. John's under bill of sale dated Apr. 20, I723. Aug. 29, I752.

2. Missing.

3. IOO. Proclamation by Gov. Graves requiring all masters of New England ships to "enter into obligations not to carry away any of the handicraft men, seamen or fishermen ". H. M. S. Antelope, St. John's, Sept. Iо, I7бI.

I5I. Proclamation. Same as no. Ioo. Oct. 30, I762.

223. Lord Egremont to Palliser, relating to illicit trade with the U. S. July 9, 1763 .

225. Copy of council meeting held at St. James concerning "a clandestine trade being carried on in America ". Oct. 5, 1763.

25I. Palliser's "order for vessels trading to America not to carry passengers and to sail by the 5 th of Nov." I 764 .

276. Palliser's order to Richard Edgecombe, naval officer of Great and Little Placentia, " to be very exact in examining the clearances certificates and cockets of all New England vessels . . . upon no account to grant such certificates without being fully satisfied that the quantity of goods, especially foreign goods, have been landed". Nov. I, i 764 . 278. Order not to carry any "men passengers" to America. Nov. I, I 764 .

28I. Regulations for "the Fishery on the coast of Labradore, Anticosti, Madelaines, and Whale Fishery". Apr. 8, I765.

290. Palliser to Bernard, Boston, respecting illicit trade "from your province with St. Pierre". July I5, I765.

Same, at Great St. Lawrence, to M. Gill, judge of vice-admiralty court, sending three New England schooners seized at St. Pierre to St. John's. July 8, i 765 .

(See Prowse, History of Nezufoundland, I895, p. 324.)

292-293. Various letters on the same subject.

30I. Palliser to the governor of Canada, forbidding Canadians to fish or trade in Labrador. Aug. 28,1765 .

310. Decree upon Thomas Stout of the Good Intent for carrying passengers to New England the preceding fall.

(See Prowse, p. 323.)

340. Fine on Good Intent compromised, the Good Intent carrying 60 passengers to Ireland free. Sept. 30,1765 .

4. 2I. Order for American vessels to leave before Oct. 3I, otherwise sails and rudders to be taken away and lodged in the fort. Sept. $20,1766$.

29. Palliser's order concerning the whale fishery on the coast of Labrador. Copy sent to Gov. Bernard, Boston. Aug. I, 1766.

48. Palliser's order against the firing of the woods of Labrador by vessels from the plantations. July 23,1767 .

52. Memorial from the merchant adventurers in Labrador against lawlessness of plantation crews. n. d.

(See Gosling, Labrador, I910, p. I87.)

66. Palliser's answer to merchants and adventurers in Labrador. Aug. I0, 1767 .

(See Gosling, p. I89.)

I43. Byron's order for American ships to leave every year by Nov. I. July 7, i 769 . 
I68. Bond of $£$ I0o from Peter Curry of Philadelphia to carry passengers. July 28,1769 .

I82. Byron's instructions for Fort York, Labrador. Sept. I, I769. (See Gosling, p. rir.)

224. Bond from Isaac Phillips of Boston for $£$ Iooo indemnifying James Hay and others respecting the Betsy, laden with rum, which, without proper certificate, was confiscated but later released. 1770 .

287. Byron's order forbidding New Englanders, etc., to establish at Magdalen Islands without his permission. Aug. 12, I77 I.

3 reverse. ${ }^{1}$ Palliser's order respecting plantation captains who refuse to show their papers. Aug. 9, I766.

I I rev. Palliser to Bernard, respecting whale fishery, etc. Aug., I 766. (See Prowse, p. 327.)

5orev. Major Gorham. lieutenant-governor of Placentia, to Byron, asking leave to go to headquarters (New York) on business. Leave granted. Oct. I0, 1770.

5. 5. Byron's order forbidding New Englanders to settle or destroy seacows on Magdalen Islands without his license. Aug. 29, I77I.

I I-I7. Indenture between W. Sheppard, Boston, attorney for E. Breed of Charlestown, T. Jenner, l. Miller, James Russell, administrator of estate, C. Chamber, and D. Russel on one part, and W. Corkeran of Boston, transferring land, etc., in St. John's. Oct. I5. 1764.

57. Shuldham's order for Americans to leave before Nov. I. June 24, 1772.

65. Id. permitting British subjects " to take Salmon stations from inhabitants of Newfoundland or other his Dominions in America ". [June] 24,1772 .

70-72, 75. Id. enforcing customs act and navigation act. June 24, I772.

I 6 . Shuldham's instructions for York Harbor; crimes committed by irregular crews from the colonies. Aug. 3, I772. (See Gosling, p. 206.)

I55. Shuldham's order respecting sea-cow fishing at the Magdalens. Apr. 3, I773.

I3rev. Shuldham's letter requiring shipping returns, etc., to be forwarded promptly to His Majesty's Commissioners at Boston. June 25, I772.

6. I9. Duff's order respecting enticing men to America. July I2, 1775 . Various other usual orders issued.

124. Royal Highland Emigrants ordered to replace detachment of 65 th required by Gen. Howe at Halifax. May 27, 1776 .

25 rev. Fortification of St. John's pushed forward. 1775 .

26rev. Gen. Gage wanting carpenters and seamen at Quebec. Sept. II, 1775 .

29rev. Duff's letters to justices. "The present Exigencies on the Continent" make it necessary for Gage at Boston and Carleton at Quebec to send Capt. Campbell, R. H. E., with a party to recruit. This not to interfere with fishermen's engagements. Sept. 26, I775.

(See Palliser's act forbidding impressment of fishermen.)

3orev. Duff to Gage, withdrawing garrison from Fort York, Labrador. for winter; commiserates his Excellency on situation he is involved in by the unhappy rebellion but hopes for a speedy restoration. Sept. I 5 , I 775 .

${ }^{1}$ Many of the earlier volumes are used from both ends with similar pagination. 
$35 \mathrm{rev}$. Same to Capt. Campbell. As Vice-Adm. Graves, at Boston, needs men badly for his ships he [Duff] must revoke the order to enlist for the Royal Highland Emigrants. Oct. 2, 1775.

$36 \mathrm{rev}$. Same to Capt. Pratt. Similar letter revoking order to enlist for the Royal Fencible Americans. Oct. 2, I775.

4 Irev. Stand of arms granted to Capt. Campbell, R. H. E., who was to go to Quebec with recruits, he "being apprehensive of molestation in going up the river St. Lawrence by the rebels which at this time infest the country in that quarter". Oct. IO. I775.

$46 \mathrm{rev}$. Lieut. Crause, 65 th, allowed to join his regiment in Boston. Oct. I 5,1775 .

5orev. Capt. Barrett being apprehensive of attack "very early in the spring", Duff thinks affairs in America are not "so very alarming as to justify me in putting the government to any extraordinary charges .... whilst we have so numerous a Fleet in those seas". Oct. 20, 1775 .

73 rev. Gen. Howe, Halifax, to Montagu, drafting men of the 65 th into corps to serve in North America, and sending officers to England; replacing company of $65^{\text {th }}$ at St. John's by company of R. H. Emigrants. Mar. I9, I776.

74 rev. Montagu to Howe, acknowledging instructions: no orders to victual women and children belonging to 65 th or artillery. May 27 , 1776 .

75 rev. Same to J. Jackson, Trepassey. Lieut. Murry of Nova Scotia Volunteers enlists three of his servants, who are to be returned. May $27,1776$.

7 Srev. Same to Howe. Neglect of victualling garrison by Nova Scotia contractors. May 29, 1776 .

94rev. Baron de Casperance, St. Pierre, to Montagu, assuring him a friendly relation and mutual good will to ships. Mаa 26, I776.

9Srev. Montagu to de Casperance. When he left England there "appeared to be a good understanding ". July 6, 1776.

I Iorev. Montagu's order to fire on any vessel not showing her colors " at a time that H. M. is at War with his rebellious subjects". Aug. 23, 1776.

I 5 rev. Montagu to merchants at Trinity. In answer to request for man-of-war to protect them from American privateers during winter, he is leaving two sloops and four armed vessels at St. John's and Placentia; they must defend themselves; impossible to comply with requests made for different settlements. Sept. 23, г776.

I I6rev. Same to merchants of Ferryland. They say they "are exposed to every American armed vessel which may be sent on the coast and likely to be more so in November and December as they can come and go out of these places when they please and not the least obstruction can be made against them "; they must defend themselves. Sept. 23. I 776 .

I 20 rev. Same to J. Coghlan, respecting report that "four sail of armed schooners" were cruizing in the Straits of Belle Isle : two men-of-war are there. Sept. 28,1776 .

I2rrev. Montagu's permission to Capt. Cunningham. Nova Scotia Volunteers to recruit. Sept. 29, г776.

I 24 rev. MIontagu's order for all ships to rendezvous at St. John's on Oct. 20. Oct. 5, 1776. 
I27rev. Montagu, in answer to petition saying that merchants will not be ready for Oct. 20, agrees to leave one man-of-war till Nov. 25. Oct. 7, I776.

Montagul's permission to Lieut. Bliss, R. H. E.,, to enlist at Bay Bulls, etc., till Mar. 31, 1777. Oct. 7, 1776.

7. 7. W. Baker, lieutenant of artillery, Placentia, to Montagu, reporting loss of Fox; " two American privateers are come to burn and destroy and to destress the fishery". June I5, I777.

9. Archibald Stuart, lieutenant in 62nd Reg., Placentia, to Montagu, reporting loss of convoy and mutiny of IOO "Germans" who declared they would surrender if attacked. I 777.

37. Montagu to justices. Sir G. Collier, Halifax, reports recapture of Fox and capture of Hancock. I777.

81. J. Coghlan, Fogo, to Montagu. "There will be four vessels sail from hence to England with passengers about middle of Oct. . . . should they unluckily fall into the hands of American pirates it will be of ill consequence as it is feared too many of them may be deluded to enter with the former which circumstance though contrary to what has been practised heretofore in this country seems to encourage that of an Impress; as a merchant (it is speaking against myself) still I think this trade never can be upon a firm Basis until we have totally suppressed the present Rebellion." Sept. 25, I777.

85. Montagu to J. Coghlan. "I think it is more probable that upon the arrival of the four ships here when they are informed of the almost impossibility of their escaping the Press when they arrive upon the coast of Ireland many may be induced to enter voluntarily into the king's service for the sake of the Bounty." Oct. 4, 1777.

Lieut.-Col. Gorham, Fort Cumberland, to Montagu. "Acting under Sir W. Howe's instructions to complete regiment [R. F. A.] am sending parties to recruit in Newfoundland." Sept. I I, I777.

86. Eyre Massey to same, reporting arrival of rebel prisoners by sloop Martin. Sept. I5, I777.

87. Montagu's permission to Lieut. Constant Connor of Royal Fencible Americans to recruit up to March $3 \mathrm{I}, \mathrm{I} 778$.

92. Montagu to merchants at Bay Bulls, etc. "As I have received information from different harbours to the Southward that small American privateers from six to ten guns have threatened to destroy them and have already burnt several boats you are to have guns to protect yourselves", batteries not to exceed six guns. July 27, I 778 .

96-98. Petition from Renews to Montagu. Brig of twelve guns has destroyed eight large shallops; sedition among inhabitants. July 29, 1778 .

99. C. Garland, justice, Harbor Grace, calls meeting to organize defense against small privateers for winter. Aug. I, I778.

IOO. Montagu to Lieut.-Col. Hay, sending recruits of 4 th and 54 th regiments with the remainder of the Royal Highland Emigrants to Halifax in Resolution. Aug. 4, 1778 .

II8. Merchants of St. Marys to Montagu. Privateer robbed and sank boats off Cape Pine. "We hope there will be no fear of any of the Rebell Privateers visiting us but [they are] more like pirates than any thing else." Aug. 21, I778.

I2O. Merchants of St. John's petition for convoy for Sept. 25 to sell their fish before war breaks out with France and Spain. Aug. 28. 1778. 
I2I. Montagu to merchants of St. John's. Can not comply, squadron small, "great depredations the American privateers are daily committing on the different parts of the Island". Aug. 30, I 778 .

I25. Same to Lieut.-Col. Hay. Secret instructions to prepare Ioo men to board his squadron to go on an expedition. Sept. 5, I778.

132. Address of Fogo merchants to Montagu. Being now under arms, they thank him for speedy steps taken to stop late depredations of American privateers in Labrador. Aug. 31, I778.

139. Merchants of Trepassey ask for convoy to St. John's, as two privateers have been seen between Cape Pine and Cape Ballard, one brig about ten guns, and the "other small schooner which took a brig off Cape Pine on Sunday last". Oct. 8, I778.

I40. J. Coghlan to Montagu. "You will be advised of the precipitate departure of Grimes and his motley crew." Fogo, Sept. Io, I778. (See Gosling, p. 333.)

I53. Active steps taken by Chief Engineer Pringle to fortify all likely places; report. Oct. 20, I 778 .

I57. Montagu to Carter. Opposition to battery at Ferryland alleged to be due to the fact that the principal person opposing is American born; he will endeavor with Lord George Germain to remove all such families. Oct. $2 \mathrm{I}, \mathrm{I} 778$.

I72. Edwards to Curtain, respecting form of condemning Wild Cat, privateer, prize to H. M. S. Surprize. July 24, I779.

I75. Work resumed at new Fort Townsend.

I76. T. Pasley, H. M. S. Sybil, to Edwards. On passage out he retook the brig Townside, a privateer; difficulty about prize in vice-admiralty court. July 3I, I779.

I8o. W. Saunders, Placentia, to Edwards. "A fast sailing brig and sloop have been continually cruizing at the mouth of our bay that a vessel cannot pass.... vessels taken with bread and flour which have greatly distressed this part of the island." July 2I, I779.

I99. Edwards to D. Coke. Sorry to hear of privateers being to northward, as the only two small vessels of squadron are to the west. Sept. 25, I779.

7rev. Montagu to commander of Fort William. Number of privateers off coast ; must send Romney to sea, so force must be taken off works at Fort Townsend and South Side Fort manned. June I I, I777.

8. Iog. Corps of New foundland Volunteers formed. Oct. 28, I779.

I2I-I25. Instructions, should St. John's be attacked during governor's absence for winter. Nov. 3, I779.

Irev. Petition from Fogo merchants to Edwards. Distress at Fogo owing to war; vessels caught were those with provisions or salt. Sept. I6, 1779 .

20rev. Edwards to Lord G. Germain. "I believe most of the out harbours to the eastward of Placentia will be able to defend themselves against any attack that can be made by the Paltry Privateers who used to annoy and distress them very much." I779.

$35 \mathrm{rev}$. Edwards in London to commanding officer, St. John's. Has reason to believe armament at Brest, consisting of considerable land and sea force, may have destruction of Newfoundland fishery and taking island as object. Apr. 3, I78o. 
43rev. Edwards, "Portland at sea", to Gov. Hughes, Halifax. "I am sorry the [account] I received after I left Newfoundland last year of the irregular proceedings of the recruiting parties obliges me to say I cannot countenance so many of them in future." June I2, I780.

5orev. Edwards to Sir W. Hughes. Maidstone sprung her mast "and as there is a number of privateers of force upon this coast (not withstanding we have already taken five)" wishes Hughes to furnish her with a mast. I780.

9. I9r. W. Cockran's affidavit about death of William Cockrane of Watertown in Boston on way from Jamaica to Newfoundland. Apr. 2I. I780.

2I 5-220. Edwards' regulations for defense during absence for winter. Oct. 22, I 780 .

292. Proclamation respecting escape of nine American prisoners from Proteus, prison ship, who are concealed in woods with arms. Oct. 4, I78I.

3orev. Edwards to Sir R. Hughes. As above.

$36 \mathrm{rev}$. Edwards orders 300 men to be raised. Oct. 8, r780.

39rev. Edwards to Gen. Haldimand. "One of the ships of my squadron having taken the Mercury Packet on 3 rd inst with Mr. Laurence late president of the American Congress and a great number of papers of consequence .... among which there being one of the highest importance to the governor of Newfoundland, Nova Scotia and Canada, I herewith enclose you a copy. I have directed a Corps to be raised immediately for defence of Newfoundland . . . . and trust you will not permit any more [recruiting] parties coming to this place." Sept. I7, I780.

4I rev. Same to Lieut.-Col. R. Pringle. "From the papers which were taken on the Mercury Packet $I$ have great reason to suppose that the enemys of our country look on this island with a jealous eye. Its situation for our cruizers, their success the last two summers in taking so many American privateers and above all the immense trade and security to the Gulf of St. Laurence and Quebec have given them the utmost uneasiness and I am of opinion that if they can possibly get together unmolested a sufficient force they may visit you in the spring." Oct. 22, I780.

48rev. Same to Lieut. Hawkins, 84th Regt., Placentia. Acknowledges receipt of "list of American prisoners taken on Fortune Bay and now in your custody". They are to be delivered to ship of his squadron to come to him. Sept. 2, I78I.

52rev. Same to Lieut. Grant, 42 nd Regt. Men of 42 nd to go to New York to be incorporated with other companies of the Ist battalion; officers to go to England. Sept. 4, I78I.

72-73̧rev. Pinney, Frampton, and others to Campbell. Sloop, American privateer, mounting six carriage guns besides swivels, etc., and twentyfour men, about burden of twenty-five tons, plundered boat near Cape English. Narrators manned sloop with 22 men and 6 carriage guns in pursuit and on I6th " she struck to us and is now here [St. Mary's] held at yr Excly command. She is Hazard, Hugh Elmes commander, belonging to Salem. We have sent prisoners in 3 boats. We have now enclosed the Hazard's commands [?] likewise Capt. Elmes's orders from Congress and remark that John Dant (not a native of 
America) the pilot served out of Trepassey many years. Capt. Elmes informs us he [Dant] was the occasion of his cruizing here and he informs us a great number of privateers are now on this coast." St. Marys, Sept. I8, I 782 .

83 rev. Volunteers disbanded and troops from New York replace them. Sept., I783.

10. 56. Petition of merchants of St. John's to Campbell, against U. S. vessels being allowed to trade there. Aug. 12, 1784.

57. Campbell to officers of customs. Must admit British ships importing American produce in spite of fact that Newfoundland is not mentioned in H. M.'s order in Council relative to trade with America. Sept. Io, 1784 .

11. Missing.

12. I35. Courts of Judicature formed. (I791.)

335. Mowatt to Wallace, respecting four American vessels with cargoes of provisions for France captured. Sept. 3, I795.

337. Ainsley Curtain, Quebec, to Wallace. "I have heard people of Liverpool and other places in Nova Scotia import flour, etc., from U. S. under governor's proclamation for their own use and never land it but export it to Newfoundland." Aug. I2, I795.

13. I84. J. Waldron, Harbor Briton, to J. P. Rance. "For more than ten years the Whale Fishery has been carried on in Hermitage Bay by vessels belonging to the $U$. S. Their men are now become familiar with our men and they make a practise for these several years past of taking British subjects as passengers out of this country. In these vessels I have no doubt deserters from the army and Navy find means to escape..... In the Spring of the year a very considerable Herring fishery is carried on in this district much to the injury of the Cod Fishery, most of these herrings are carried to Halifax and the States in deck'd schooners which carry a great number of men away." Sept. I, I797.

14. I28-I5I. A. Crofton to Waldegrave. Lengthy report on Labrador, Magdalens, Harbor Briton, herring fishery, etc. Jan. Io, I798.

(See Gosling, p. 335.)

I66. Copy of act regulating trade between colonies and the U. S., and license to import bread, flour, and live stock. Feb. I9, I798.

I69. Form of license.

280. Waldegrave to Portland, referring to Capt. Crofton's report upon Magdalens. Sept. 28, I798.

I. Coffin, Lisbon, to Waldegrave, claiming islands and appointing agents. July I I, I 798 .

28I. Extract from Capt. Coffin's letter. Lisbon, July i I, i 798. (See Gosling, p. 338.)

361. Memorial for register from P. Ryan who had purchased American schooner, prize to H. M. Sloop Shark, taken in illicit trade on western coast of this island, and her being warranted with a British register. Oct. 9, I798.

Routh to Waldegrave. Unlawful for either governor or collector of customs to sign such a register. Oct. IO, I798.

39I. Waldegrave to Capt. Warren, respecting prize money on American schooner Deborah (seized for trading evidently). Oct. I5, I798. 
15. I47. J. Le Breton to R. Routh. Continued emigration from west coast to Halifax and America. Dec. I 3, I 798.

182. Petition of Capt. Warren to IValdegrave, respecting Deborah, captured at St. George. n. d.

209. Portland to same. Encloses letter to King, American minister, explaining clearly American rights in Magdalen Islands. Apr. I7, I799.

2 Io. Same to King. "Care that no interruption is given to the liberty granted to American fishermen." Oct. I8, I799.

309. Waldegrave to J. Broom, magistrate of Burin. Emigration to Vermont from Burin and Placentia evidently due to lack of provisions. Oct. 22, I799.

313. Same to Portland, respecting Broom's letter; can offer no remedy. Oct. 22, I799.

326. Ogden, C. J., to Waldegrave, respecting petition of certain persons to Col. Carleton to be allowed to emigrate; explains only governor can give license to go to America. I 799 .

386. Swedish ship Nordiska Vänskapen, from New York to Nantes, seized by Pluto. I 780 .

43I. Pole's license to Charles Somers, Bridget Lyons, and four children, to proceed to Boston. Sept. 29, I780.

433-434. Rev. G. Clinch's Indian vocabulary.

16. 84. Under-Sec. King to Pole. Owing to difficulty of getting British ships, flour for garrison allowed to come in American bottoms. White hall, Nov. 22, I80I.

85. Recitation of act for regulating trade, etc. I80 I.

89. Form of license. ISor.

17. 73. Tremlett, C. J., to Gambier. The price of fish last year in the U. S. was I3s. $6 d$. per quintal. Newfoundland price since Oct., I $3 s$. to $22 s$. $6 d$. for merchantable and I Is. to I4s. for Madeira; evident American merchants can undersell Newfoundlanders. Jan. I, I803.

I4I. Discharge of two American subjects from H. M. ships with permission to go to U. S. Sept. Io, I803.

I48. Gambier to H. M. minister to U. S. Order strictly forbidding impressing of American seamen (copy enclosed). Sept. I2, I803.

238. Same to Lord Hobart, asking permission to extend annual licenses to import provisions to May or June of following year, as Nova Scotia ships which are not subject to such restrictions smuggle in American provisions to the detriment of the revenue. Dec. I3, I803.

18. II2. Gower to Earl Camden. "Newfoundlanders in Newfoundland Regiment exposed to the temptation of emigrating to the United States, where [there is] an increasing fishery already so extensive as to have risen to alarming competition with that of Newfoundland." Nov. 19, I804.

125. Camden to Gower. " Although allowing enlistment in Nova Scotian and other regiments facilitates fishermen emigrating to United States yet demand for men in the army is so urgent, assistance must be given to recruiting in general in Newfoundland." Nov. 30, I804.

132-I46. Gower to Camden. Lengthy letter advocating extension of articles licensed to come from U. S., to include tar, turpentine, molas. ses, etc. Dec. $2 \mathrm{I}, \mathrm{I} 804$.

I83. Camden to Gower. Above application refused. Mar. 8, I805. 
244-248. Gower to Camden. As fish will probably have to go to Portugal in neutral bottoms and Americans will carry their fish without such additional charge he suggests that fish should be exported to the U. S. in exchange for salted beef and pork. Strict enforcement of 28 Geo. III. c. 6, whereby American fish is excluded from the islands, has already improved market for Newfoundland fish in West Indies and produced increased imports of molasses, thus obviating his suggestions of Dec. 24 [21 ?]. July I8, I805.

297. J. M. Northay to Gower. Complaints about Americans in Labrador; faults on both sides. Sept. 8, I805.

336. Proclamation against illicit trade from U. S. to south coast; one hundred pounds reward to informer. Oct. 4, I805.

347-353. Merchants of St. John's to Gower, respecting West India trade. Sept. 24, I805.

(See Gosling, p. 340.)

393. Gower to Castlereagh, inclosing merchants' letter asking for complete embargo on U. S. salted fish in British West Indies now that principal European markets are closed. Nov. 28, I805.

4I5. Same to Windham, pressing West India proposal, suggesting bounty of one shilling per quintal; also asking for license to import salted beef and pork from U. S. Feb. 13, 1806.

19. 3. Windham to Gower. One shilling bounty to be in force from June I, I806, to June I, ISo7 ; also countervailing duty on all fish imported from U. S. of one shilling from June I, I807. Apr. 2, r 806 .

89. Castlereagh to same. Newfoundland appears to be growing more dependent on Vermont than on the mother-country. May I6, I8o7.

94. Eyre Coote to same. Letter and copy of act granting bounties in Jamaica. Dec. 2, I8o6.

I I9. Privy Council grants licenses to import pitch, tar, and turpentine from the U. S. June I I, ISo7.

I40. Society of merchants to Holloway, objecting to same licenses to Nova Scotians to trade from U. S., which diverts trade from merchants. Oct. I6, I8o7.

I97rev. Holloway to Castlereagh. Americans accused of smuggling in Labrador and bartering provisions for fish not caught or cured by Americans; suggests annexing Labrador to Newfoundland. Sept. 9, I 807 .

I99rev. Holloway to Cotterell. Americans in Labrador. Sept. 9, I807.

2 Iorev. Macbean to Williams. Permission to land green fish from American schooner Malinda, seized for breach of navigation laws in Labrador. Sept. 27, 1807 .

247 rev. Holloway to Castlereagh. Opposed to importation of tobacco, salted meat, and molasses, as recommended by Gower; nine-tenths of molasses comes from French West Indies. Nov. 25, I807.

20. 7I. Same to Cotterell. U. S. embargo on provisions will cause high prices; bread last year was $24 s$. per cwt., now is $38 s$. and planters have not yet laid in winter stock. Sept. 29, I808.

(See Gosling, p. 341.)

89. Holloway grants licenses to import from U. S. Oct. 25, I808.

205. Holloway to Castlereagh. Understands U. S. passed another nonintercourse bill which will greatly affect Newfoundland; few American ships on north shore or Labrador, due probably to present state of Europe. Sept. I6, I809. 
7rev. Castlereagh to Holloway, enclosing warrant to import bread, etc., from the U. S. under order in Council, Feb. 24, I808. Mar. 4, I808. 5I, 53rev. Merchants of Newfoundland to Lords of Council, asking for bounty and countervailing duty against the U.S. June 7, I808. (See Gosling, p. 34I.)

82rev. Merchants to Holloway. Ships, waiting in the U. S. for removal of embargo, ask for extension of time; appears little probability of embargo being taken off before meeting of Congress in ensuing month. Oct. I4, I808.

21. Nothing relating to the U.S.

22. 25I. Resolution passed at meeting of merchants and householders on the American declaration of war, forming a committee of defense. July 8 , I8I2.

255. G. R. Robinson's application for letter of marque for cutters Fly and Hero. July 20 , I8I2.

257. Application in no. 255 refused; English government, by suspension of orders in Council, hopes to conciliate the U. S. July 2I, I8I2.

258-262. Duckworth to Committee of Defense. Advice. July 22, I8I2. 263. Committee of Defense, further resolutions.

268. Duckworth to Bathurst, suggesting regiment be formed. July 23, I8I2.

277. Society of merchants to Duckworth, asking permission to import provisions from Azores or Western Islands. July 29, I8I2.

280. Duckworth to society of merchants, promising that permission will be granted. July 30 , I8I 2 .

287-289. Account of arms sent to out harbors southward of St. John's; the same northward.

Also, much correspondence respecting organization of volunteers, night watches, manning batteries, convoys.

The Newfoundland Gazette, started about I806, contains orders, etc. 374. Certificate by Duckworth that "brig Dolphin, Capt. P. Cabot, was captured by American ship of war Hornet and recaptured by H. M. Sloop Hazard". She was bound from Jersey, Channel Island. Aug. I7, I8I2.

379. Society of merchants to Duckworth, asking protection for trade to Quebec and to the French shore fishery. Aug. I9, I8I2.

(See Gosling, p. 344.)

38I. Duckworth to society. Although enemies' cruisers are so numerous along headlands he is sorry he can not provide ship ; Electra, Adonis, and Comet are on the French shore. Aug. 20, I812.

430. Pass to Mrs. Maria Page of American ship Arab, captured by H. M. S. Jason, to go to U. S. Aug. 29, I8I2.

437. Pass for eighteen prisoners of war to go to U. S. in unarmed schooner Haiac. Aug. 29, I8I2.

438. Pass to four French passengers and one Swiss, on American ship Castor from Plymouth, sent to Newfoundland by Antelope. Aug. 29, I812.

23. 5. Bathurst to Duckworth. Vessels not to be armed without a license. June 25, I8I2.

6. Same to same. Warrant to grant license to import provisions from U. S. July 5 , I8I2. 
16. Naval officer at Burin to same. Application for licenses to arm ships for Spurrier and Co. of Poole, who have sent out guns and ammunition. Aug. 25, I812.

20-24. Licenses to Mars, Capt. James Allen; Princess Royal, Capt. John Norta; Emulation, Capt. T. Roe; Freedom, Capt. John Broom, jr.; Apollo, Capt. Charles Walker; Marianne, Capt. J. Hardy, all of Poole and owned by Spurrier and Co. Sept. 2, I8I2.

269. Duckworth to judge of the vice-admiralty court. Letter of marque to Crawford and Co. for Tagus against French government. Oct. 22, I8I2.

24. 96. Chetwynd to Duckworth. Wishes to know his opinion on petition from inhabitants of Newfoundland to import American flour in British ships from Lisbon. Dec. 23, I8I2.

97. Duckworth to Chetwynd. "It will be indispensibly necessary that some extraordinary means should be adopted for the subsistence of the inhabitants" while war with U. S. lasts. Dec. 25, I8i2.

211. Keats to Prevost. Congratulations on success in Canada; asks that provisions be allowed to come to Newfoundland if their conditions admit. May 20, I8r 3 .

222. Coote, chief magistrate, St. John's, to Capt. Cumby. Will assist to capture deserters but "can by no means sanction landing of parties for impressment as it would inevitably lead to dangerous consequences". Apr. I4, I8I3.

225. Bathurst to Duckworth. Order of July 3I, I8I2, for detention of Americans (inserted here). Aug. I, I8I2.

228. Circular respecting dollars found on American ships. Sept. I2, I 8 I2.

243. American commissioners' office, Martin Lane, about American property, several circulars, etc. Nov. I3, I8I2.

290-293. Society of merchants to Keats. Detailed account of quantities and prices of provisions; starvation last winter avoided by seasonable supply of bread and flour from Canada and by drawing on military stores. June 23, I8I3.

294. Keats to Bathurst. Seed potatoes used for food; governors of Canada and Nova Scotia not expected to depart from their system. June 23, I8I3.

315-320. Report of sea defenses of out-ports.

325. Account of warrants for letters of marque granted by Keats: Acdus, Vulture, and James. July-Aug., I8I 3.

327. Account of arming licenses granted by Keats (I 2 ships). July 8 to Oct. 30, I8I3.

339. Society of merchants to Keats. Full report on prices of provisions; one American vessel detained with I60o barrels will suffice, together with unusual import of potatoes and biscuit from Halifax, shared out in small quantities to most distressed. July I6, I8I3.

34 I. Keats to Bathurst, respecting provisions. July 20 , 1813 .

350 et seq. Same to Lieut.-Gen. Moore, commanding officer. To deliver remainder of American dollars to captain of man-of-war (the rest had been circulated locally) to be taken to England. July 29, I8I3.

Considerable correspondence about embargo on provisions to Canada, Nova Scotia, and New Brunswick, Keats says " to secure a circuitous supply for New foundland ". 
369. Maj.-Gen. Moore to Keats. Finds it hard to get money for the chest from England so wishes to keep dollars. Aug. 4, I8I3.

389-394. Keats to Bathurst. About passengers in American ships, great expense ; enclosure respecting ships W.P. Johnson, Eliza, Castor, and Arab; 84 persons cost $£_{403}$ I $5 s$. $5 d$. for rations and passage money; itemized account. July 30 , 1813 .

402-404. Same to master of ship Hawke. "Flag of truce" from passengers of American cartel ship Jenny, D. Myers, which put into St. John's in distress (with smallpox on board) from Dartmouth to Rhode Island, with I50 American subjects; prisoners of war to proceed in chartered ship Hazeke. Sept. I6, I8I3.

406. Pratique to Jenny. Sept. 23, I813.

25. 45. Petition of John Ryan (a Loyalist from Newport who followed the British army to New Brunswick, was king's printer to Gov. Carleton in New Brunswick in I799, in I8o6 started Gazette in Newfoundland) against competition. Oct. 26, I8I 3 .

50. Keats to Ford of Bonavista. Is informed by merchants "that provisions of all kinds are in great abundance at St. John's".

76. Saumarez to Keats. "I have been induced to facilitate and encourage the importation of all sorts of provisions .... from the U. S. . . . I I have, with advice of H. M. Council . . . . granted permission to admit for six months, salted provisions from the U.S." Frederickton, Sept. 24, I813.

I09-I I6. Memorial from merchants for exclusion of foreigners in fishery. Nov. 8, 1813.

(See Gosling, pp. 345-349.)

I69-I7I. Keats to Bathurst. On petition of nos. I09-1 I6. Dec. I8, I8I3. 23o. Hunter and Co. to Keats, requesting permission to export 600 barrels of flour to Quebec, as the " market is now so glutted". (Refused.) June IO, I8I4.

24I. Petition for merchants to export provisions which are deteriorating; plenty of time to secure fresh supply for winter. [June I8, I8I4.] 263. Arming licenses granted in 1814 (2 ships).

287-294. Keats to Bathurst, respecting American fisheries. July 27, I8I4.

(See Gosling, p. 35r.)

343. Same to Duff, Lisbon. Hopes he will not give any more passes to Americans, as "strangers especially Americans should not be permitted to visit Newfoundland". Sept. I5, I8I4.

26. 2I7 Same to Bathurst, respecting seizure of vessels for importing American produce from Gibraltar; considered in Newfoundland court contrary to law. June I, I8I5.

229-233. Bathurst to Keats. Nos. 20 and 2I about American fisheries. June 17,1815 .

(See Gosling, p. 356.)

235. Warrant authorizing importation of bread, etc., from U. S. Apr. I8, 1815 .

245-248. Instructions to captains, respecting American fishing. July 24, I8I 5 .

274. Keats's notice that passes can not be granted to British subjects to proceed to British colonies in America or to the U. S. Aug. 3, I8I5. 
27. I40. Bathurst to Pickmore. Notwithstanding former order he must now furnish any information required by Bagot relative to admission of American citizens to a participation in fisheries. May 31, I8I6.

452. Pickmore to Baker, Washington. Mentions act referring to U. S., and asks for information about U.S. regulations as to exportation and importation of goods. Oct. I, I8I7.

476. Langdon, St. Lawrence, to Butler. Two American vessels carrying on whale fishery in Hermitage Bay with great success. June 23, I8I7.

28. II. Bagot to Pickmore. American government has declined propositions which he was authorized to make. Take such measures in regard to American vessels fishing within British limits as Your Excellency may deem most proper under your former instructions. Jan. I0, I8I7.

237. Pickmore to Bathurst. American vessels, encouraged by temporary permission of May I2, have appeared in some numbers in Labrador. As indulgence expires with the season, he will act under instructions of June I7, I8I5, next season; cargo of provisions from U. S. Dec. 22,1817 .

26r. Merchants of Boston to Pickmore, regarding fire and famine in St. John's; brig Messenger, Capt. Peterson, takes provisions as per list. Boston, Dec. 27, I817.

(See Prowse, p. 407.)

264. Pickmore to Boston merchants, thanking them. Jan. 20, I8I8.

343. Bathurst to Pickmore. Permission under "present circumstances" to import from U. S. without clearance from St. John's or license from the governor. Feb. 6, I8I8.

345. Adam and Ross to Privy Council, asking permission to import provisions from U. S. to Newfoundland in Apollo, clearing from the West Indies and not from British European possessions. Jan. 6, 18I8.

346. Bathurst to Pickmore. Warrant for importation of provisions and live stock. I8I8.

350 . A. St. J. Baker to same. Information regarding U. S. tariff and the Navigation Act. Washington, Mar. I6, I8I8.

377. P. Hine to Bowker. Permission for sloop Alert, lately arrived with present of supplies from New York, to carry passengers back. May I2, 1818 .

422. List of licenses granted to import provisions from U. S. in I8I8 (8 ships).

483. Bagot to governor, enclosing copy of act of Apr. 18, concerning navigation. Apr. $2 \mathrm{I}, \mathrm{I} 8 \mathrm{1} 8$.

488. Bowker to Bagot, enclosing copy of letter from Admiralty regarding capture and detention of Princess Elizabeth by two armed vessels under Spanish colors on her way from Rio Janeiro to England (no copy of the letter). June I7, I8I8.

5I5-526. Dalhousie to Bowker, enclosing copy of address from legislature of Nova Scotia and petition of Halifax merchants regarding encroachments made by U. S. fishing vessels upon this coast and Labrador. June 30, I8I8.

(See Gosling, p. 36r.)

526. Bowker to Dalhousie, sending Drake to guard the coast. July 7 , 1818 . 
29. 48. British Treasury to Goulburn. Commissariat officers must negotiate the bills at highest possible rate and not at 5 s. for each dollar as hitherto has been the practice. Apr. 28, I8I8.

97. Capt. Rowley to Hamilton, reporting detention of two U. S. vessels fishing on New foundland coast. Aug. 27, 1818.

IOI. Hamilton to Bagot. Acting under instructions, reports detention of two U. S. vessels; understanding H. M. government desires amicable relations, has released them under agreement to proceed from "Bays Harbors and Creeks" of Newfoundland; encloses extract of letter from Goulburn to Pickmore as to allowing U. S. fishermen a privilege which they had not enjoyed even under the treaty of 1783 . Aug. 28, I818.

102. Extract from Goulburn's letter.

I03. Endorsement on license of schooner guns.

I04. Hamilton to Bathurst, reporting above matters. Aug 28, I8I8.

II3-II9. Midshipman Waller to Rowley, describing the recapture of U. S. sloop Hannah by her crew. Aug. 23, I8I8.

Hamilton to Bagot, reporting above. Sept. 7 , i818.

I20. Same to Bathurst, on same subject. Sept. 7, 1818.

I22-125. C. Waller's deposition. Sept. 7, I818.

Midshipman W. Cowling's deposition.

128. Hamilton to Bagot, with above. Sept. IO, I8I8.

139. List of U. S. vessels boarded and warned from "settled bays and creeks" on coast of Labrador ( 6 vessels); Shiffner reports about 400 U. S. vessels on the Labrador coast, season I818.

250. Several letters on value of silver, regarding order to take silver at $5 s .6 d$. per ounce.

260. Hamilton to Bathurst, reporting proceedings of U. S. fishermen in Newfoundland and Labrador. Nov. 21, I8I8.

274. Memorial of P. Le Messurier to be allowed to employ Marshall Crosbie, an experienced whaler, an American, in the whale fishery. (Refused.) Dec. 5, I8I8.

276. Bagot to Hamilton, acknowledging receipt of information about seizure. Oct. I7, I818.

289. Bathurst to same, approving of release of two U. S. vessels. Oct. I5, I8I8.

30. I05. Bagot to same, enclosing copy of convention ratified to-day. Jan. 30, I8I9.

I43. Bathurst to same, with instructions regarding convention. Apr. 8, I8I9.

I69. Hamilton to Capt. Gordon, to visit Labrador and report regarding U. S. fishermen. June II, I8Ig.

I75. Similar order to Capt. Rowley. June I9, I819.

I83. Dollars to be taken into military chest at $4 s$. 8d. Apr. 22, I8I9.

210. Order to Capt. Glascock to patrol south coast and keep on good terms with U. S. officers on same service. July 22, I819.

227-232. Bathurst to Hamilton. Important despatch regarding U. S. fishing rights. June 2I, I8I9.

Order in Council regarding act to enable H. M. to make regulations with respect to taking and curing fish in Newfoundland, Labrador, etc. June I9, I819. 
236. Hamilton's proclamation regarding the same. Aug. 3, I8I9.

245. Hamilton's further proclamation. Aug. 5, I8I9.

263. Hamilton's instructions to captains regarding U. S. fishing rights. Aug. I3, I8I9.

31. 62. Same to Bathurst. U. S. fishery carried on with spirit; no one fishing on treaty shore; two ships violating treaty, having anchored and fished in a settled harbor of Trinity Bay. Nov. 19, I819.

(See Gosling, p. 37r.)

97-98. Regarding petition from P. Beard, Dartmouth, to Chetwynd asking protection against encroachments of U. S. fishermen in Sandwich Bay, Labrador. Nov. 27, I819.

Bathurst to Hamilton. Can Beard be secured by "specific grant"? Dec. 4, 1819 .

99-I04. P. Beard's petition.

179. Hamilton to Robinson. Instructions about regulation of Labrador fishery. June I 5 , I 820 .

182. Regulations for salmon and herring fisheries in Sandwich Bay. June I 5,1820 .

187. Memorial of merchants of St. John's in Labrador to Hamilton. June 16,1820 .

(See Gosling, p. 37I.)

194. Antrobus to Hamilton. Notice of navigation act of May 15, 1820. May I9, I820.

2I2. Hamilton to Capt. Vernon. To "cruize diligently" between Ramea Islands and Cape Ray to ascertain nature and extent of U.S. fishing and illicit trade. July 5 , I 820 .

216. Same at Cape Charles Harbor, Labrador. July 27, 1820.

264. Same to Bathurst. P. Beard and Co. now in possession.

317. Complaint of Samuel Gordon against John Conel of Boston. Sept. I5, I820.

(See Gosling, p. 37r.)

370. Petition of St. John's merchants to king. Surrogate decided dispute about salmon fishery " without trial or any enquiry".

498. Hamilton to Capt. Nicholas, Labrador surrogate, regarding Gordon's claims ; representation made from H. M. minister at Washington on subject. July I6, I82I.

32. 55. Same to Capt. Murray. Instructions to proceed to Labrador. Aug. I5, I 821 .

IIg. Pinson to Hamilton, regarding U. S. fishermen throwing gurry. Sept. I3, I82 I.

(See Gosling, p. 37r.)

I57. Hamilton to Canning. Piracy of Newfoundland ship Maria. Sept. I9, I82I.

(See Gosling, p. 37r.)

283. Same to Bathurst. American fishery "but to a moderate extent this year". Dec. 4, I82I.

4IO. Petition of St. John's merchants to Hamilton. "From this blow [French rights, etc.] we were just beginning to recover when the Treaty with America concluded the 2oth Oct. I8I8 prostrated all our hopes and rendered the return of our former prosperity for ever impossible." May 6, I827.

(See Gosling, p. 372.) 
33. 28I. Archbald to Hamilton, regarding seizure of his vessel. Aug. II, I823.

343. Hamilton to Harrison, regarding Polly.

37I. Same to same, regarding U. S. schooner Polly, condemned for smuggling; suggests granting British register to seized vessels, otherwise they hardly sell for enough to pay fines. Oct. I I, I823.

456. Same to Bathurst, acknowledging receipt of order in Council, July 2I, I823, imposing certain duties on U. S. vessels and cargoes. Nov. I, I823.

34. I7. Same to same. Notice of U. S. fishery. Nov. 28, I823.

(See Gosling, p. 372.)

62-90. "Papers relating to a question [between] France and the U. S. as to fishery rights. Transmitted in a note from Mr. Stratford Canning of 3I March 1824."

(See Gosling, p. 373.)

35. 424. Cochrane to Chief Justice and judges, requesting further opinion as to rights of French and American subjects fishing on the coast. Aug. I6, I826.

36. 4. Tucker, C. J., to Cochrane. Under sect. 2, 59 Geo. III., c. 38, U. S. vessels found fishing within three marine miles of Newfoundland without the limits prescribed by convention of $\mathrm{I} 8 \mathrm{I} 8$ are liable to seizure and confiscation, and that U. S. citizens as well as French may be proceeded against by indictment in Supreme Court under 5 Geo. IV., c. 5 I, sect. 2, for taking bait or using any sort of fishing whatever in Newfoundland or Labrador or islands unless they are specially authorized by treaties; punishment upon conviction by jury can not exceed moderate fine or short imprisonment. Aug. I8, I826.

\section{Nothing.}

The original records from 1825 to 1830 consist of five bound copies of letters received and an account book. The letters appear to relate almost entirely to judicial matters. 



\section{INDEX.}

Abbott, Edward, I47

Abercrombie, Maj-Gen. James, correspondence, I23; defeat of, II7; despatches, II6, II 7

Aberdeen, Earl of (George Hamilton Gordon), correspondence, 47,52 ; despatches, 153

Abnakis, catechism of, 255

Academy of Pacific Coast History, 28I, 283

Acadia, boundary, I93; colonization of, I38; documents relating to, 33, I37, I93; registers of, $\mathrm{IO}_{4}$

Acadians, deportation of, 199, 202; in Massachusetts, I I9

Acadie, 34

Act of Independence, I59

Act of Union (1840-1867), 2

Acton, Cardinal (C.), letter of, 266

Acts of trade and navigation, I45

Adam and Ross, letter of, 298

Adams, C. F., despatch from, 66 ; memorandum on fishery question, 68 ; papers of, 67

Adams, Pres. John Quincy, proclamation on trade, 98

Adams, Senator John Quincy, letters of, I43

Addington, Henry U., despatch of, I4I

Addison, T. F., letter of, 30

Additional Manuscripts, British Museum, Io

Admirals' despatches, I34, I47

Admiralty, correspondence, I7, 52 ; fishery protection by, 69 ; instructions to, $57,5^{8}$

Adonis, ship, 295

Adventure, brig, 220

Aedus, ship, 296

Africa, 282

Agreement of $1817,42,43,53,66,75$

Agricultural products, duties on, 93 ; free trade in, 56

Agriculture, Dept. of, Archives Branch assigned to, 3 ; archives separated from, 7 ; concentration of documents in, 6; establishment of, $3 \mathrm{n}$.; transferred to State Dept., 7 Agriculture, Society for Encouragement of, 223 Ainse, case of, 179

Airey, Colonel, letters of, 22

Aitken, Rev. Roger, letter of, 140

Akins, Thomas B., collection by, 193

Alabama, account of, I20

Alabama, vessel, I 83

Alaska, 154; boundary, 279; exploration in, I5I ; purchase, 90 ; trade of, 90

Albany, Bishop of, letter to, 235 ; church at, 226, 25I, 270; priests in, 252; riots at, I2I; theatre of war, 267

Albany, Fort, I5I

Alberta, 276

Alden, Capt. John, memoir of, I94

Alemany, Joseph, Archbishop of San Francisco, letters of, 255

Alert, sloop, 298
Alexander, Sir J. Edward, notes on boundary, 152

Alien Bill, remarks on, 46

Aliens, I5, 46, I88; naturalization, 47

Aligash River, 5I, 78

Alleghany Mountains, I 59

Allen, David, pardon of, 53

Allen, Ethan, correspondence, I50; negotiations with, I4

Allen, Ira, I4; capture of, I03

Allen, Capt. James, 296

Alvord, Prof. Clarence W., 224

America, colonies, I92; despatches on affairs in, I 42 ; foreign commerce of, 208; history, documents on, 12, 67, 98 ; Northwest, report on, 282; political and religious affairs, I44, 237, 255; property, returns of, 39; rebels, 267 ; subjects, discharge and cases of, 76, 293; traders, 64; see also United States

America and West Indies series, I03, II5, I23, I33

American bar, admission of members, 9I

American Catholic Historical Society of Philadelphia, Records, 224 n., 230, 23I, 232, 243 , $244,246,247$

American Colonics, $A$ Calm Addrcss to our, by John Wesley, I37; Report on the State of, I33

American Fur Company, 272

American Historical Association, Report, 28r

American Historical Review, I42, I43, I44, 21 I, 244,275

American Historical Societies, Bibliography, Griffin, 22I

American imports, duties on, 47

American prisoners, see Prisoners of war.

American Revolution, 82, I03, I I4, I43, I56, I78, 193, 195, 199, 200, 201, 202, 266, 267, $269,274,296$

American rifle, kind of, $\mathrm{I} 62$

American State Papers, 107

American Vessels captured by the British, etc., 203

Americans, 200, 258; arrival from Europe, 85; at Navy Island, 42, 47; capture of, 48, 66, I77; charges relating to treaty of Ghent, 20 ; defeat of, 226 ; disposition of, I39; encroachment of, 20,259 ; invasion of Canada, 47,48 , ro5; nationalism of, 265 ; ordered to leave Newfoundland, 287 ; remarks on, I9; settlement in Upper Canada, 46

Amherst, Lord (Jeffrey Amherst), correspondence, IO, II, I4, II5, I I7, I23, I79, I99; despatches, II8; II9; instructions to Monckton, I3; suggestions relating to Crown Point, Niagara, and Detroit, I I9

Amherstburg, Upper Canada, officers at, 27, 30 
Amiot, Monsicur, testimonial for, 246

Ancrum, Maj. William, 242

Anderson, a fugitive slave, case of, 62

Anderson, Alexander C., I52, 282, 283

Anderson, James, correspondence, I50 ; papers, I 5 I

Anderson, Capt. Thomas G., Canadian officer, letter of, 3 I

Andrews, Israel D., 56, 59

Andrews and Davenport, Guide to the Manuscript Materials for the History of the United States, etc., I32, I33, I47, 200

Angleterre, Correspondance Politique, I8I; Ordres du Gouvernement d', 253

Annapolis Royal, affairs at, I94; commission and letter-book at, I95; governors, letters of, I94; see also Port Royal

Annc, schooner, 47, 48, 49, I77

Antclope, ship, 286, 295

Anthracite coal, see under Trade

Anticosti, fisheries, 286

Anti-slavery, 154

Antonelli, Cardinal (Giacomo), letters of, 246, 269

Antrobus, letter of, 300

Apollo, ship, I35, 296, 298

Arab, ship, 295, 297

Arbitration, 40, I29, I87

Arclibald, letter of, 301

Archibald, appointment of, 72

Archives, see names of countries and places

Archives Act, Public, Jan. I9I2, 7

Archivist, see Dominion Archivist

Argus, ship, I97

Arkansas, I05

Armistice, between Sheaffe and Van Rensselaer, 25 ; proposed, 26, 31

Armitage, Archdeacon, ix

Arms, application for, 94; importation into Canada, 4I; sale of, 69; supply to U. S. soldiers, 84

Army, British, I26

Arnold, Benedict, grant to, 45 ; letter of, I 56

Arnprior, Ont., Confederate organization at, 77

Aroostook war, I3I, I52

Arrivals, book of, 223

Arrowsmith, Aaron, map by, I28

Arthur, Sir George, correspondence, 22, 69, 70, 79, I02, I6I, I62, I64, I67-I73; despatches, 35, 50, 69, 8I, 98, 103, I68, I69, I73; report on Welland Canal, 43, 49; speech of, i70

Ashburton, Baron (Alexander Baring), I I4; correspondence, 52,75, I I 3

Ashburton treaty, letters on, I I4; ratified, 52 ; see also Washington, Treaty of (1842)

Ashes, see under Trade

Ashmun, George, mission of, 75 ; visit at Quebec, 63

Askin, Charles, diary of, 184

Askin, John, sr., correspondence, Io9, II0, I79. I $83-184$

Askin family, origin of, $183 \mathrm{n}$.

Asquini, Cardinal, letter of, 255

Assiniboia, council, minutes of, 150

Assiniboine River, settlement at, I87

Astor, George, deed of sale to, 220
Astor, John Jacob, 279; deed of sale from, 220 Astoria, founding of, 279 ; see also Fort George Astronomical data, I30

Atheneum, The, I Io

Atkin, Edmund, despatches, I20

Attwater, Reuben, 27

Aubéry, 225

Audin (Odin), Bishop J. M., correspondence, $235,248,256$

Auger, François, journey of, 2 Io

Augustine, Fla., 9th Regt. at, I3

Aulnay, Charles d', memoirs concerning, I3 8

Austin, James, reply of, 187

Auteuil, Sicur d', journey of, 210; ordinance against, 2 I I

Aylmer Barow (Mathew Aylmer), correspondence, 96

Azores, permission to import provisions from, 295

Baby, F., letters of, 22

Baby collection of manuscripts, I 50

Backhouse, J., letters of, I73, I96

Bacon, Bishop (David WV.), letters of, 256

Bagot, Sir Charles, correspondence, 20, 70, 7I, 92-93, I I2-I I4, I84, 298, 299; despatches, I 4 , I 30 ; reception at New York, I I 4

Bahama Islands, negroes in, 43, I I 3

Bahia, Brazil, $28_{2}$

Baillargeon, Bishop (Charles F.), letters to, 255,256

Bailly, Monseigneur, letters of, 269

Baker, Anthony St. John, British chargé d'affaires at Washington, letters of, 27, 28, I78, 298

Baker, Mrs. H. J., 282

Baker, John, trial of, I 52, 200

Baker, W., letter of, 289

Baldwin family, I36, I50

Ballard, M., 285

Baltimore, Archbishop of, 268 ; attitude of, 255 ; intrigues against, 267 ; letters to, 232, 234 ; pallium conferred on, 250 ; temporalities of, 249

Baltimore, Md., consul at, correspondence of, I40, I62; council, 264; diocese of, 228, 237, 246 ; Episcopal church, 246, 249; state of faith in, 258; Trappist women at, 257

Baltimore seminary, 246

Bancroft, H. H., copying of historical documents, I65; Works, $280,28 \mathrm{I}, 282$

Bancroft Library, 2\&o

Bankhead, Charles, despatches, I30, I3 I

Bank of England, letter from agent, I60

Barbour, James, request from, I29

Barclay, Anthony, letters of, I28

Barclay, Capt. Robert H., account of battle on Lake Erie, I34; correspondence, I35

Barclay, Thomas, decision and award of, 200; letters of. 127, 128

Bardstown, Bishop of, 236 ; letter to, 23 I

Bardstown, Ky., 258

Barker, Oliver, memorial of, I6

Barnhart's Island, boundary, 46, I02; regaining of, 71 
Barnston, Que., raid at, 69, I64

Barrett, Captain, 288

Barrington, Lord (William Wildman Barrington), letters of, 28 , I2I

Barrow, John, letters of, I6 , I69, I73

Bartlett, M. S., letters of, I I3

Bathurst, Henry, third earl, correspondence, 25, $39-40,45-46,82-83$, I09, I10, I96, 295, 296 , 297, 298, 299, 300; despatches, 23, 24, 25, I74, I90, I9I; opinion of, I4I

Batdoinen, J., letter of, 248

Baudry, Jacques, 2 I2

Bayard, Rev. J., letter to, 240

Baynes, Col. Edward, letters of, 26, 27 ; mission to Albany, 24

Baynton and Co., letter of, I47

Bay of Fundy, trade in the, 143

Beal, Anthony, journal, I5I

Beard, P., petition from, 300

Beaubassin, Hertel, land grant of, 2 I6

Beaudoin, Abbé Charles, letter to, 236

Beauharnois, see Fort Frederick

Beaujeu, Sr. Louis Liennard de, land grant, 2IO, 217

Beaumont, Abbé Charles, Généalogie des Familles de la Côte de Beaupré, I49

Beauport, Que., meteorological observations, I33; officers on parole at, 3 I

Beaver, steamer, 282

Beaver Dam, affair at, 25 ; battle of, 184

Beck, T. Romeyn, 255

Beckwith, Sir Thomas Sidney, despatches, I74; letter of, 25

Bédard, Pierre Stanislas, judge of Three Rivers, 248 ; papers, 149

Bedini, Monseigneur (Cajetano), address to, 253 ; plots against, 253

Bedou, Sieur, land grant of, 217

Bedout, Sieur, lands for, 209

Bégin, Archbishop (Louis N.), 226

Bégon, Michel, ordinances of, $2 \mathrm{I} 4$

Behring Sea fisheries, 6, 279

Belcher, Gov. Jonathan, N. Scotia, message from, 200

Belhan, Dr. Anthony, I95

Bellanger, $A b b e ́, 225$

Bellefonds, François Genaple de, 2 I9

Belle Isle, Straits of, 288

Bellèque, Sophie, letter of, 266

Belvidera, ship, 28

Benedict XIV., letter of, 268

Beothics, account of, 284

Berczy, William, i I I

Berdt, Dennys de, correspondence. I 47

Berkeley, Vice-Adm. George Cranfield, I43

Bermuda, 9th Regt. at, I3

Bernard (Langlois), Father M., death of, 257

Bernard, Scrope, letter of, 142

Bernetz, correspondence, 135

Bernier, correspondence, I35

Berré, Sieur de, 2 I2

Berthelot, $M$. Amable, memoir on the war of I775, I05

Berthelot, $A b b e ́$ Charles, letters to, 23I, 238

Betsy, vessel, 287
Bidwell, Barnabas, case of, 46

Bienville, J. B. le Moyne, letters of, $1_{5}$

Biggar, Henry P., European agent, 8, 33

Bigot, François, I35

Bigot, Vincent, 225

Biller, Sr. Leonard, commission of, $2 \mathrm{I} 3$

Binault, 208

Birch, letters of, 9 I

Birnie, Samuel, letter-book of, I37

Bishops, French, 254; nomination of, 245, 268

Bisshopp, Maj. Cecil, letters of, 24, 25

Bisson, François, treatment of, 99

Bizaillon, journey of, 2 Io

Black, $\longrightarrow$, murder of, I52 $^{2}$

Black, William, communications from, ז30

Blackburn, Dr., case of, 68, 73

Blackburn, John, correspondence of, Io7

Blackfeet Indians, encounter with, I5I

Black Rock, attack and capture of, 25, 26, 27

Blanc, Bishop Antoine, New Orleans, correspondence, 235, 248, 268

Blanchet, Father Aug. Maglorius, correspondence, 230, 259, 26r, 268

Blanchet, Bishop Francis Norbert, appointment of, 229, 234, 240; correspondence, 229, 230 $239,258,260,261,262,263,264,265,268$; faculties, 239,266 ; papers given to, 263

Blane, Capt. A rchibald, correspondence, I47

Blanshard, Richard, despatches, 283

Bliss, Lieut. Samuel, 289

Bliss, Henry, letters of, I4r, I66

Blockades, I34

Block-houses, 45, 79

Blount, Gov. William, treaty obtained by, I89

Blue Book, 7I, 72, 91, 94

Blunt, Joseph, II 3

Board of Trade, minutes of the, I95; papers, I23; Plantations General, I47

Bocquet, Father Simple, correspondence, 240$24 \mathrm{I}$

Bodega y Quadra, Juan de la, letters of, 28r

Boerstler, Lieut.-Col. Charles G., letters of, 25

Boilven, N., 25

Bois Blanc Island, claims of United States to, I6, 21 ; expulsion of pirates from, I67; interference with Americans on, 30; possession of, I9, 30; sympathizers at, I6I

Boisclerc, Monsieur de, discovery of lead mine, 210

Boisseau, Nicolas-Gaspard, fils, memoirs of, II I

Bolduc, Rev. J. B. Z., correspondence, 239, 264; departure for Columbia River, 234

Bonaventure, Simon Denis de, 220

Bonaventure, Que., lands in, I04

Bonaventure valley, expedition to, I5I

Bonhomme, Charles, land grant of, 209, 216

Bonne, Sieur de, land grant of, 217

Books of Negroes, 203

Boquet River, 216

Bordeaux, letters from, 222

Border outrages, see Raids

Boscawen, Adm. Edward, correspondence, II6

Boston, Bishop of, 226, 238; correspondence, $228,231,232,235$ 
Boston, Mass., I24, 249; archives, 218; arrest of Russian consul, I63; asylum in, 254; battles near, I54; British consul, letters of, I I3; churches in, 250, 25I ; clergy, 249, 250; clippings from papers. I39; diocese of, $226,227,238,248$; events at, I2I ; fever at, 22; merchants' letters, 298; riots in, I22; society in, III; transcripts from, I93; Ursuline school, 249; vessels, 279

Bostonnais, advance against, 267; at Detroit, 244 ; war of the, 222,242

Boucher, Réné, land grant of, 216

Bouchette, Joseph, instructions to, I28; letters of, I06, I27, I28; papers of, 176

Boudort, 2II

Bougainville, Louis Antoine de, correspondence, III, I35; papers of, I35

Boulanger, Father. S. J., letter to, 235

Boulduc, Rev. J. B. Z., see Bolduc

Boundaries, award of King of Netherlands, 4I; between English and French plantations, I36; colonial, I2I, I22; documents relating to, 85,96 , I03, I 4 I, I 52 ; disputes, 43 , 78,80, I30, I3I, 165, I86, I95; Indian, I37, I53, I 86 , I9I, 200; lack of accurate definition, 60 ; lines, 99, I30; settlement of, I6I; suggestions from Thomas Morgan, 45; surveys, $46,52,136,283$

Boundary, Northeast, correspondence, ix, 44, 74, 75, 98, I02, II4, I3I, I 32, I 39 , I 4 I, I 46, I 53 , I64, 204; decision of King of Netherlands, 4I ; despatches, 44, 5I, 8I, 99, I6I, I85; dispute on, 23 ; documents on, ix, I27, I55, I63, I 86,200 ; exploration of, 82 ; infractions of agreement, 44; instructions, 44; Maine aggressions, 4I, 44; negotiations for settlement, 80, I3I, I32; Preble's protest, 4I; remarks on the, $4 \mathrm{I}, 43,44,49,92,97, \mathrm{I} 63$; road from the St. Lawrence, 40 ; surveys; 43, I 40; Thompson's course regarding, 44; treaty on, 75

Boundary, Northwest, adjustment of, I03; documents relating to, 60,72 , 9I, 92, I27, $163,187,279$; survey of, 60,90

Boundary post, 55

Bouquet, Col. Henry, biography of, Io; collection presented to British Museum, Io; correspondence and papers, 3, IO-II, II9, I23, I 47 ; expedition of, $I 20$; force for the possession of the Ohio, II; Indians, dealings with the. II ; will of, Io

Bourget, Bishop Ign., letter to, 230

Bourlamaque $M$. de, correspondence, I35

Bowker, letters of, 298

Boxer, ship, I34

Braddock, Maj,-Gen. Edward, defeat of, I I6, I99; expedition of, II5

Bradstreet, Col. John, correspondence, I23; expedition of, II7; peace with Indians, IgI

Brant, Capt. Joseph, anecdotes respecting, Io7; conduct of, I79; correspondence, I8, I9, I07, I08, I79; exploits, I07; journal of, I79; speeches of, I79, I90; will of, I9I

Brant, Mary, correspondence of, Io7
Brasseur de Bourbourg, Abbé Charles, History of Canada, 236, 253, 255; correspondence, 255

Bread, importation of, 82, 292, 295, 297; price of, 294

Breadstuffs, duties on, 69,86

Breed, E., 287

Breed's Hill, battle of, 124

Brenton, E. B., letter of, $3 \mathrm{I}$

Brest, armament at, 290

Briand, Bishop Jean Olivier, correspondence, $240-24 \mathrm{I}, 242-243,244,266-267$; episcopal charge of, 269

Brigands, release of, I7 I

Briscoe, Capt. Vincent, report of, 2I

British army, United States men in, 59

British-built ships, United States registration of, 56

British claims, 23

British colonies, 84,98 , I8I

British colored soldiers, 79, 8I

British Columbia, archives, I5I, 279-283; commissioners, report of, 279; history, 279; immigration, 279; Legislative Journals and Sessional Papers, 279; miners in, 89; see also Columbia River Region

British Columbia (colony), 279; collector of customs, correspondence of, 28I ; departmental letters, 28I; executive council, minutes, 280 ; governor of, despatches, ordinances, and proclamations, $28,36,280$; lands and works, correspondence, 28I; legislative council, journals of, 152,280 ; naval officers, correspondence of, $28 \mathrm{I}$; records of, 279; secretary, correspondence of, $28 \mathrm{I}$

British Columbia (province), correspondence, $28 \mathrm{I}$; executive council, proceedings of, 281 ; lieutenant-governor, despatches of, 28I ; minutes, 28I

British Columbia, by H. H. Bancroft, 280

British Columbia, Consolidated Statutes of, 279

British commander-in-chief, correspondence of, II 5

British commissioners, correspondence, I28

British consuls, at Boston, II3; at Buffalo, 6I, 64; at Chicago, 6I, 7I, 94; at Detroit, 64; at New Orleans, 63; at New York, 17; at Norfolk, 58, 59

British courts of inquiry, proceedings of, 20

British fleet, logs of, I 46

British forces, estimates of, 28, 3I, 74

British Foreign Office, see Foreign Office

British Guiana, governor, despatch from, 62; negroes in, 62

British Historical Manuscripts Commission, I80

British manufactures, duties on, 62

British Michilimackinac Co., capture of boats of the, I44

British Minister, at Washington, D. C., correspondence, $28,42,51,53,6 \mathrm{I}, 62,70,80,82$, $85,87,102,132$, I $41,173,202,274$; despatches, $23,24,35,36,37,56,59,60,64,65$, 
66, 73, 74, 98, I3I, I32, I4I, I44, I64, I70, I85; reciprocity conference, 84 ; report on trade with Nova Scotia, 58; see also the names of ministers

British minors, in the United States army and navy, 76,77

British Museum, papers, I33

British Navy, instructions for officers of, 68

British North America, boundary, I27, I3I, I32, I 52 ; fisheries, 69; trade, 59, I39, I96, I97

British officers, correspondence, 23, 30, 125; despatches, I23, I24, I25; instructions, 30 ; present at siege of Quebec, I46

British ports, prizes carried into, 63

British possessions, notes on, I29; trade of, 52 British posts, state of, in western country, 2I

British prisoners, held as hostages, I5

British Public Record Office, I82, 28I

British seamen, 6I, I42

British ships, attack upon, 75 ; circular to captains of, 2I; duties on, 78; importing American produce, 292 ; sold to Confederacy, 75

British stores, passage through United States, 76

British subjects, cases of, 76 ; discharge from United States army, 76, 87; for foreign service, 63; in the United States army, 67, 75 , 9.4; kidnapping of, 54, 93; murder of, 61 ; outrage upon, 97; passports for, 64; recruiting of, 77 ; settlement in Canada, 45 , 52

British territory, invasion of, 155 ; peace of, I03; settlers in, 98

British Treasury, letter of, 299

British troops, distribution, II7; for provinces, 64 ; passage through the United States, 76

British vice-consulate at Oswego, 76

British War Office, see War Office

British West Indies, trade, I38, 20I

Brock, Maj.-Gen. Isaac, letters of, I6, 24, I02, I78; monument of, 173

Brockville, Ont., 22, 43, 49, 50; see also Elizabethtown

Broder, Eliah, 220

Broom, Capt. John, jr., 296; letter of, 293

Brosius, 249

Brother Adventurers, sloop, 220

Brouillet, $M ., 230$

Brown, of Cleveland, O., correspondence of, 52

Brown, Captain, party with flag of truce, 25

Brown, J., letter of, I I 4

Brown, Robert, 283

Brown collection, I47, I94, 200, 202

Browne, Rev., 245

Brownson, Orestes A., 250

Bruce, Sir Frederick Wm. A., despatch from, 68

Bruté, Bishop (Simon), of Vincennes, letters of, 245

Brymner, Dr. Douglas, appointment as Dominion Archivist, 3; collections made by, 3-4; copies of Haldimand collection, I2; exploitation of archives in England and
France, 3; military papers classified, I5, I5 n.; work of, 3, I03, I55, I56, I60

Buchanan, James, British consul at New York, despatches from, I62; letters of, 50, I60; negotiations with Papineau, 74, 99, I64

Buckingham, Richard Plantagenet-Grenville, third Duke of, correspondence, 69, 84, 90

Buell, Maj. John, general order of, I8

Buffalo, Bishop of, letter to, 235

Buffalo, N. Y., British consul at, 64,65 ; British plans for attack on, 26 ; capture of, 26 ; recruits, 60 ; report from, I73; troops at, IoI ; vessels built at, $64,66,76$

Buffalo Creek, councils at, I8, I9, I79, I90

Bulger, A. E., collection from, I I I

Bulger, Capt. Andrew, command at Fort McKay, I I I, I I 2 ; correspondence, I I I

Bulkeley, secretary of Nova Scotia, letters of, I 98

Bulletin des Recherches Historiques, 244, 245

Bullock, Captain, letters of, 26

Bully, Robert, petition, 286

Bulwer, Sir Henry, instructions to, 56; negotiations with the United States, 83

Burgoyne, Gen. John, campaign of, I27; despatch from, IIo; engagement with rebels, 267 ; expedition from Canada, I53; proclamation of, 267 ; troops under, i Io

Burin, naval officer at, letter of, 296

Burke, Father Edmund, correspondence, 18, I08, 109, 237, 242

Burlington, Vt., military preparations at, 99; United States post at, 2 I

Burnley, enclosure from, 73

Burr, Aaron, arrival of, 143; movements of, I44

Burton, C. M., report on archives, ${ }_{52}$

Burton, Ralph, decision of, 2 I7

Burton, ship, 282

Bury, letter of, IOI

Bush Life and Frontier Service, II 4

Butler, Col. John, expenses of, $22 \mathrm{I}$; letters of, I6, I8, 27, IO7

Butler's Rangers, letters of, 125

Buxton negro settlement, I54

Byrne, $A b b e ́$ P., letters, 232, 252

Byron, Capt. John, orders and instructions, 286,287

Cabinet memoranda, I47

Cadet, correspondence, I 35

Cadillac, see La Mothe-Cadillac

Cahokia, Ill., 257; letters of inhabitants of, 244 ; papers, I53; seminary property, 245

Cahokias, Holy Family of, mission, 244

Caldwell, Col. Henry, letter of, 223

Caldwell, William, correspondence of, I07, I08

Caledonia, ship, I I4

California, mining laws, 89; religion in, 266; trade, 88

Camden, Earl, letters of, I96, 293

Cameron, Simon, letter of, 63

Campaign of 1758 , I I7

Campaux, Louis, 208

Campbell, Captain, 287, 288 
Campbell, Maj-Gen. Sir Archibald, despatches, g\$, 130

Campbell, Sir Colin, correspondence, 83, I32, I53, I98; despatches, I53

Campbell, D., survey by, I86

Campbell, Sir Donald, correspondence, 83, 86

Campbell, I., letter of, I64

Campbell, James, 220

Campbell, Adm. John, letter of, 292

Campbell, R., journal, I5I

Campbell, T. E., letter of, IOI

Campbell, Maj. William, letter of, Igo

Campeau, Jacques, commission to, 2I4; letter from, 2 I3

Campion, $A b b e ́, 232$

Campot, Claude, grant to, 209

Canada, I60; annexation of, 56, 93, II 3,183 ; archives, I-9, I5, I10, I22, I23, I88, I89, 192, 193-204, 21 I, 218, 278, 28I ; Archives Branch established, 3 ; scc also names of places; barrack-master-general's department, I26; board of trade, letter of, 61 ; boundary, 16 , I3I, I42, 237; canals, 65; capital, location of, $2-3$; consular appointments, 64 ; correspondence, I7, 23, 42, 124, I75, 225; defense of, $43,63,64,72$, I66; despatches, 37-38; disturbances in, 56 ; documents on, I33, I48; ecclesiastical matters, IIO; English parliamentary papers, 35 ; entry of suspected persons into, I5; expeditions against, I45, I94; express agents, 55; fall of, I92; Fencible Corps, recruiting in, I25; fisheries, $23,73,78,92$; forces, returns of, I5; French plots against, 103; frontier, 30, 74 , I55; fugitive slaves, 49, I54; government, I49, 205; governors, I7, I22, I32, 296 ; history, 3, 33, II4, I33, I52; hostility toward, 55, I03, I64: immigration and emigration, $44,45,96,245$; importation of arms into, 4I; Indian administration in, 19; insurgents, aid to, 42 ; invasion of, I2, $21,22,44,47-50,62,68-70$, I02, I24, I 55, I6I, 169, I83, 223, 274; journeys to New England from, 208; land, 72, I I8; loyalty, 267; mails, 55; marauding expedition. 77; memoir on, 222 ; military engineer's department, I26; military equipment, I70; military government, 222 ; militia, 32 ; notes on. I05; Northwest, records on, I50; peace of, I03; political events of 1837 , I I2; population, II4; post office papers, I03; posts, state of, 2I; prisoners, see Prisoners of war; punishment of invading foreigners, 79; quartermaster-general's department, papers of, I26; railway connecting with New England, 57; rebellion, I55, 250; see also Rebellion of $1837-1838$; rebels, 32,163 , I85, 267: refugees, activity of, 92 ; relations with the United States, 20; routes to, 252 ; secret agents sent to, 63,156 ; secretaries, I75 n.: state papers, I54; subjects. 63. 267; tariff, 54, 55; total reduction of, III : trade, 39, 55, 62, 7 I, 78, 94, 103, I73, 208; troops, I6, 30, I27; union, 239; vessels, 53 ; West, correspondence, etc., I75; west- ern frontier of, 24; Wilkinson's proclamation to, 26

Canada, Edits, Ordonnances Royaux, etc., conccrnant le, 205, 207

Canada, Histoire du Notariat au, by J. E. Roy, 219

Canada, History of, by Abbé Brasseur, 253

Canada, Rapport sur lcs Archives de France relatives à l'Histoire $d u$, by J. E. Roy, 33

Canada, Lower, attorney-general, letters of, 37 ; boundaries, 176; documents on, 160-166, I77-179, 205; executive council, minutes of, I22, I23; frontier raids in, 87 ; governors, letters of, 36 ; history of, I92; land, $\mathrm{I} 78$; lieutenant-governors of, correspondence, 36 ; plan of, 128 ; records for, 175 ; secretaries, I75 n.; tour through, I92; trade, 74 ; troops in, 161

Canada, Upper, I78; act relating to assembly members, 46 ; act to protect province against aggressions, 48; administrators of, despatches from, 36 ; assembly of, proceedings, I66, I70; of the, I66; attacks against western frontier of, 98 ; Barnabas Bidwell elected to assembly of, 46 ; boundaries, 158 ; campaigns in, 273 ; correspondence, 36,37 , 45,225 ; documents on, 31 , 35, I 55, I66-174, 176-177; enmity of Ohio and Michigan, 49; executive council, minutes of, I22 ; finances of, 43 ; foreign interest in, 46 ; government, I47; grant of acres to Benedict Arnold, 45; Indian Department of, letters, 36 ; Indians in, 45 ; invasion of, 43 ; land grants, 32 , Canada, steamer, seizure of, 56

32 n., I53, I88; marriage register, 105; naturalization of aliens in, 47 ; negroes in, 50, I7 I, I72, I73; newspapers published in United States, 48 ; papers on, 154 ; preparations against, 22 ; raids upon, 165 ; rebellion in, 98,274 ; records for, 175 ; relations with Michigan, 20 ; secretaries, I75 n.; tour through, I92; trade, 46; troops in, I6I; United States citizens, attitude toward, 28; United States deserters in, 19; United States settlers in, 46,47

Canada Co., correspondence of, 52

Canada Trade Act, petition on, 70

Canadian Archives, I n., 3, 4 n., I0, I2, I3, I5 n., 33 , 105, III, I15, 122, 133, I35, 136, I37, I38, I $47,151,155,177,184,195,199,205$, $206,211,215,217,219$

Canadian High Commissioner, I 5

Canadian Northwest Company, 279

Canadian Pacific Railroad, explorations, II4

Canal de Arro, see Haro, Canal de

Canals, between the Aligash and Penobscot, 5I, 9I, IOI; Canadian, II2; from Albany to Lake Ontario, I6; protection of, 63; see also Erie Canal; New York and Erie Canal; Oswego Canal; Welland Canal Canandaigua, treaty at, 18 , 190

Canning, Stratford, 301 ; despatches from, I28 Canso, N. S.. fisheries, etc., 97

Canterbury, H. M. S., I 46 
Cape Breton, 220; council of, $20 \mathrm{I}$; lieutenantgovernors of, 138; proclamations, 20I ; state papers, I37, I38; union with Nova Scotia, I38; scc also Ile Royale

Cape Charles Harbor, 300

Cape Disappointment, I52

Cape Horn, 259

Cape Pine, 289

Cape Ray, 300

Cape Sable, 220

Capuchins, 242, 243

Carbery, plots, 254; schismatic church, 254

Cardin, Sieur, commission to, 214

Cardinal, Jacques, fils, grant to, 209

Cardinal, Jacques, père, grant to, 209

Cardwell, Viscount (Edward Cardwell), correspondence, 66-69, 84, 89, 90, I97

Cargoes, duties on, 83 ; manifests of, 84 ; owned by British subjects, 63

Carillon, Que., victory at, I I I

Carleton, Gov. Sir Guy, see Dorchester, Lord

Carleton, Lieut.-Gov. Thomas, I45; letter of, I38; proclamation of, I39

Carleton Island, 97, I48, I74; claim of the United States, 40; officers at, I26; seizure at, 96

Carmack, itinerary, 284

Carnarvon, Earl of (Henry Howard Molyneux Herbert), despatch from, 68; letters of, 62, $69,89-90$

Carolina, boundary, I45, I8I ; Creek outrages in, 13

Caroline, steamer, destruction of, $47,48,50,92$, 98 , I67, I68, I69, I74, I77; documents relating to, 2I, 47, 49, 5I, 70, 74, 75, I49, I62; employment of, I72

Carroll, Bishop John, 224; letters of, 245; see also Baltimore, Archbishop of

Cartier, Jacques, archives relating to, 106

Cartwright, John, 284

Cascades, missions at, 266

Cascaskias, Caskaskias, see Kaskaskia

Casperance, Baron de, letter of, 288

Casse, Gabriel, grant to, 209

Casse, Jacques, grant to, 209

Castle William, Boston, I22

Castlereagh, Viscount (Robert Stewart), introduction of Burr to, I 43 ; letters of, 38 , I44, I96, 294, 295

Castor, ship, 295, 297

Cataraqui, Ont., officers at, 126

Catechism, in Chippewa, 255

Cathcart, Earl (Charles Murray), correspondence, $7 \mathrm{I}, 93$

Catholic Historical Ladder, 259, 261, 262, 263, 264

Catholics, 24I, 249, 253, 259; condition of, 240; dioceses in the United States, 251 ; English attitude toward, 24I ; growth of, 263; in Detroit, 24I ; in Maine and New Hampshire, 250; in Oregon, 260; in St. Paul du Wallamette, 259; in the English colonies, 252 ; missions, $259,260,263$

Cattle, see Live stock
Cayugas, 136

Cazeau, M., 255, 260; enquiries of, 263 ; letters to, $256,261,263,264,265,266$

Cecilia, Sister, recommendation of, 246

Cereals, sec under Trade

Certificates to vessels, 62

Chaboillez, Louis, 27 I

Chambalon, Louis, 219

Chamber, C., 287

Chambers, Maj. P. L., communications from, 25

Chambly [Richelieu] River, 216, 218

Champlain, Lake, 214, 218; affairs on, 26 ; bridges, 55, 57, I07; British vessels on, 78; construction of fleet on, 267 ; fisheries, 78 ; flotillas, 3I ; fortifications on, 185 ; frontier, 39 ; land on, $216,2 \mathrm{I} 7$; losses at, I6; mission south of, 238; naval forces on, I34, I35; operations on, 25 ; ratification of grants on, 209 ; rise in, 96 ; statement of United States army at, 31 ; timber on, 2I3, 2 I4

Chancery, I22, I29

Cliapin, General, letters of, I8, 179

Chapotier, Jean, land grant of, 216

Chapoton, Jean, 208

Charbonnier, Jacques, 22 I

Chargé d'affaires at Washington, despatch from, 55

Charlestown, Mass., $25^{\circ}$

Chartier, Michel, journey of, 2Io; land grant to, 216

Charts, military, 70

Chateauguay, battle of, 25 ; register, II 5

Chatham, ship, 133

Chauvin, 208; land grant of, 216

Chazelle, Father, S. J., letter to, 230

Chazy River, 2I7; faculties and mission, 238

Cherokee Indians, I89; in South Carolina, I I9; speech of, I90; treaty with the French, I 7 ; troubles with the, II8-II9

Chesapeake, U. S. frigate, I34, I44

Chester, Gov. Peter, correspondence, I47

Chester, H. M. S., I46

Chetwynd, letter of, 296

Cheverus, Bishop (Jean Louis), 230, 25I ; letters of, $248,25 \mathrm{I}$

Chew, John, correspondence of, I08, 109

Chew, Joseph, letters of, I8, r9, I05, I90, I9r

Chew, William Johnson, letter of, is

Chibnitkook River, survey of, I 86

Chicago, Bishop of, letters to, 235

Chicago, Ill., British consul at, 6I, 71, 94; exposition, 279; fall of, I84; Indian outrages. 20 ; trade, 6I ; vice-consul at, 78

Chicago Historical Society, I52, I54

Chichester, Colonel, letters of, 22

Chicoineau, passport for, 246

Chili, religion in, 265

China, trade, 158

Chinese, exclusion, 279

Chinook jargon, dictionary of the, 264

Chipman, Ward, letters of, I27, I28, I29, I30, I40, I86, 200, 204; remarks on boundary, I3I

Chippaw'a, vessel, I3.4 
Chippewa, Ont., battle of, 26; British colored Coffin, Lieut.-Gent. John, letter of, I.40 soldiers at, $8 \mathrm{I}$; outrage upon United States citizens at, 45

Chippewa Indians, I36; language of the, I89, 255

Chisholm, M., 23I

Chisholme, David, papers collected by, 192

Chittenden, Gov. Thomas, negotiations with, I4

Choctaws, 218

Cholera, 256

Choueguen River, 2I8

Chrysler's farm, engagement at, 26

Church, Capt. Benjamin, expedition of, 194

Churches, Protestant Episcopal, closer union between, 53

Church in the United States, Sketch of the History of, by Archbishop Turgeon, 253

Church of England, Quebec, register of, I I5

Churchwardens, 24I, 248

Cincinnati, Bishop of, 235

Cincinnati, O., diocese, 255

Ciquard, $A b b e ́$ François, letter to, 237; passport for, 246

Civil War, I5, 28, I54, 202

Clanricarde, Lord, letter of, I4I

Clara F. Friend, schooner, 85,87

Claremont, church at, 249

Clarendon, Earl of (George W. F. Villiers), correspondence, I 97

Clark, Lieutenant-Colonel, letters of, 25

Clark, George Rogers, movements of, 157

Clarke, Frank, 282

Clarke, J. W., letters of, I6, 22

Claus, Col. Daniel, correspondence, I06, I07; papers, 106, 190

Claus, Col. William, diary of, Iog; letters of 20, 24, 109, I76; papers, 106, I09, I 10

Clearance certificates, 286

Clergy reserves, observations on, II4

Clerk, G., letter of, I49

Clerk. John Johnson, siege of Quebec, III

Cleveland, Bishop of, letter to, 235

Cleveland, O., board of trade memorial, 72; communications from, 22; diocese, 255; intriguers against Canada in, 52 ; orphans of, 256 ; situation at, 32

Clinch, Rev. G., Indian vocabulary of, 293

Clinton, Sir Henry, I24; despatches, I25; letter of, 202

Cloverdale Farm, Victoria, B. C., 283

Coal, exportation of, 68,94 ; for war vessels, 65,67

Cocagne, registers of baptisms, marriages, and burials in. 104

Cochran, Andrew W., letters of, Ioo, Ior, III

Cochrane, Vice-Adm. Sir Alexander F. I., instructions, 27; letters of, 26; order of blockade, I34

Cochrane, Sir Thomas J., governor of Newfoundland, 285,30 I

Cockets, 286

Cockran, W., see Corkeran

Cockrane. William, death of, 29I

Cod. see Fisheries

Coffin, Capt. Sir Isaac, letter of, 292

Coffin, Thomas A., letters of, 99, 108, 109, 190

Coghlan, J., 288; letters of, 289,290

Coins, plugging of, I 6

Colapissas, 218

Colborne, Sir John (Lord Seaton), conduct toward refugees, 42 ; correspondence, 30 , $69,97,98$, I6 I, I62, I63, I64; despatches, I6 I

Colebrooke, Sir IVilliam, despatches, 80, 82; letters of, 8I, I53

Collier, Sir G., letter of, 289

Colonial Correspondence, Newfoundland, I82

Colonial Correspondence, Nova Scotia and Cape Breton, 182

Colonial Department, correspondence, I72 ; despatches to, $I 62$

Colonial governors, correspondence, II6, II7

Colonial laws relative to fishing, 65

Colonial legislatures, actions of, i I 8

Colonial Office, correspondence, 3, I7, 2I, I3I, I64; despatches, 21,84 ; transmissions, I03, 122

Colonial Secretary, despatches from, 24, 35, 36, 37, I74

Colonial shipping, United States registry of, 64

Colonial wars, 202

Colonies, acts relating to, 20I; comments on, I33; Company of the, 219; emigration from, I47; English, rebellion in, 243; grants in the, 209; southern, military news from, i I 8

Colonists, American, 259

Columbia, see Columbia River Region

Columbian Centinel, extract from, I43

Columbia River, 80, I29, I5I; explorations along, 273; fortifying the mouth of, 90 ; journey to, 260; mission of Warre and Vavasour to, I37; settlements on, 40, 100

Columbia River Region, bulls concerning, 239; missions in, 229, 234, 239, 240, 259-266; routes to, 265 ; voyage to, 248,266 ; see also British Columbia, Oregon, and Washington Territory

Colville, Lord, despatches, II8, II9

Colville, Wash., 279 ; missions, 261 ; trading expeditions from, I5I

Comeau, report of, 52

Comet, ship, 295

Commerce, see Trade

Commercial Advertiser, New York, I49

Committee of Council for Trade and Plantations, see Trade and Plantations

Conefroy, Abbé P., letter to, 237

Conel, John, complaint against, 300

Confederate agents, I83

Confederate refugees, $65,76,94$

Confederates in Canada, 67,73

Confederate vessels, $65,66,67,76,89$

Congress, United States, debates in, I63; petitions to, 257

Connecticut, Amherst's suggestions, II9; claims, II9; troops from, I45

Connecticut River, I6I ; disputed territory east of, 102 ; map of, I28; survey of, 176 
Connelly, William, trading expedition under, Craig, Sir James H., governor-general of CanI5I I Bishop J., 249, 254; letter of, 252; letter to, 23I

Consalvi, Cardinal, letter of, 269

Consular appointments, $64,68,72$

Consul general, United States, arrest of, 95

Contrecoeur, Pierre Claude Pecaudy de, land grant of, 216

Conventions, of $1818,57,58$; of Sept. 29 , 1827, I87; postal, 69; with the United States, 85, Ij2; see also Treaties

Convents, 256, 257

Conway, Lieut. Gen. H. S., correspondence, I 20

Conwell, Bishop Henry, correspondence, 232, 233,252

Cook, Capt. James, discoveries of, 222

Cook, Thomas, letters to, 229

Cooke, E., introduction of Burr to, I43

Cook's Mills, skirmish at, 27

Cooper, Thomas Archeve [Ashley], 220

Coote, Eyre, letters of, 294, 296

Coquart, 225 ; memorial, i Io

Corbin, David, order to, $2 \mathrm{I} 3$

Corbin, Joseph, instructions to, 214

Corkeran, W., 287; affidavit of, $29 \mathrm{I}$

Corn, duty on, 52, 86 ; effects of laws, 93 ; importation of, 82, I40; trade, I73

Corn bill, IOI, I65

Cornplanter, speech of, I89

Cornwallis, Gov. Charles, trade instructions, I 45

Cornwall register, I05

Correspondance Officielle, 192

Correspondence, intercepted, 77

Cosme, Pierre, grant to, 209

Costelli, Cardinal, letter of, 268

Côteau du Lac, barges through lock at, I6; duties on United States vessels at, 97

Cotton, see under Trade

Cottrell, Sir Stephen, letter of, 196

Coulteulx, Louis C., I5, IO3

Council Office, London, letters from, I29

Council, Privy, see Privy Council of Canada and Privy Council of Great Britain, and Trade and Plantations

Councils of war, minutes of, I IO

Counterfeiting, 86, 97, 178

Courcy, A., letters to, 236

Courjault, Abbé, correspondence, 235, 245

Courrier des Etats-Unis, 253

Courts, vice-admiralty, jurisdiction, 58

Courts-martial, schedule, 126

Cousins, marriage of, 242

Coutourier, Jean Baptiste, 22I

Coutourier, Joseph, 22I

Coweta, Indian speeches at, I 89

Cowling, Midshipman W., deposition of, 299

Cowlitz, 258, 262; establishment of, 266 ; missionaries at, 262; plan of school at, 266 ; register of baptisms at, 263

Cozerlitz, vessel, 282

Cowlitz Farm, 282

Cowlitz River, 263 ada, correspondence of, $35,95,96,176$; trade instructions, 145

Cramahé, Hector Theophilus, letter of, I06; order-book, 222

Crampton, John F., correspondence, $80,83,84$. 200

Crause, Lieut. Charles, 288

Crawford and Co., letter of marque to, 296

Creek Indians, disturbances, I2I; outrages in Carolina and Virginia, I3; treaty, ${ }_{15}^{8}$

Creole, ship, II 4

Crespieul, Abbé de, 225

Crevier, Abbé J., letters to, 236, 237

Criminals, abduction of, 78 ; surrender of, $5 \mathrm{I}$ $52,91,164,166,172$

Crofton, Capt. A., report of, 292

Croghan, G., letters of, I8I ; mission of, I20

Croke, Alexander, letter of, I44

Croker, J. W., letter of, I 40

Crooks, James, claim against United States, 44

Crops, 257

Crosbie, Marshall, 299

Cross of St. Gregory, 259

Crown Lands Department, Ontario, II4, I53, 188

Crown Point, 2I6; Amherst's suggestions regarding, II9; expedition, II6; prisoners at. I05

Crozat, Sieur, 207 ; charter, I5I

Cruikshank, Lieut.-Col. Ernest A., I5; Inventory of, IO4

Cruisers, belligerent, 66

Cumberland Bay, 267

Cumberland County, N. S., disturbances in, I98, 202; settlement, IS9

Cunard, E., letter of, 200

Cunningham, Capt. Daniel, 288

Cunningham, J. R., I47

Cunnyngham, Waddet, case of, 148

Currency, bill for paper, I22

Curry, Peter, 287

Curtain, Ainsley, letter of, 292

Cushman, U. S. commissioner, succeeded by Wiggin, $6 \mathrm{I}$

Customs, act, 52,287 ; officers, 77 ; regulations, I03; see also Tariff

Cuvillier, Capt. Augustin, letters of, 25

Dablon, Rev. Father Claude, land grants of, 216

Daems, Father Edw., letter of, 245

Daigneux, Michel, land grant of, 216

Daine, Sieur, land grant of, 2I7

Dalhousie, Earl of (George Ramsay), correspondence, 96, 97, 197, 298; trade instructions, I 45

Daly, correspondence of, 86

Daniau, Philippe, grant to, 209

Dant, John, 29I-292

D'Argenson papers, 192

Darling, Col., letter to, 227

Dartmouth, Earl of (George Legge), letters of, 28, I47; papers, I33

Dartmouth College, genesis of, 195 
Dartmouth family, papers, I47

Davenport, Guide, see Andrews

David, Bishop (Jean B.), letter of, 247

Davies, James, letter of, I63

Dawson, Francis, 48, I68

Dean, R. B., letter of, I62

Dean [?], Thomas, letter of, 207

Dearborn, H., agreement relating to prisoners, I77; army of, 29; letters of, 15, 24; report of, I4t

Dease, John, case of, I79; diary of, 152

De Blaı, correspondence, I35

Deborah, schooner, 292, 293

Decennium, 248

De Courcy, letters of, 253

Defense, Committee of, 295

Defense, estimates for, 94

Dejean, Sicur, 24I

Dejeans, P., letter of, 242

Delagauchetière, Migeon, land grant of, 2 I6

DeLancey, Governor James, I98; correspondence, 199

Delaporte, $A b b \dot{\varepsilon}$, letter to, 229

Delaporte, M., 239

Delavau, $M r$., letter of, 246

Delaware Indians, details relative to, I I ; expedition against, I20; speeches to, I26, I89

Deluol, $A b b e ́$ S. R., correspondence, 235, 246

Demers, Bishop Modeste, correspondence, 239, $240,258-259,260,26 \mathrm{I}, 262,263,264,265$

Denaut, Bishop Pierre, letter to, 245 ; letters of, 269, 270

Denonville, Monseigneur de, letter to, 270

De Peyster, Col. Arent S., letters of, I4, I07

Dequindre, $S r$. Douville, land grant of, 2 I 7

Derby, Earl of (Edward George Geoffrey Smith Stanley), correspondence, 4I, 46, 5I, $52,53,61,83$, I36, I96-I97; despatches, 51, II 4

Derbyshire, report of, I65

De Rottenburg, T. A., letters of, I06, $2+4$

De St. Pierre, letter of, 244

Desauniers, Pierre Trottier, 22I

Descoudet River, land on the, 2 I 6

Deserters, 238, 292, 296; arrest of, 57,77 ; news gained from, I8; surrender of, 5I, 9I, I66

Deserters, British, 96, I I6; enlistment of, 23, 30 , II3; in the United States, 23,74 ; order relating to, ig

Deserters, Canadian, arrest of, 95

Deserters, French, 27 I

Deserters, United States, arrest of, 88, 9I, 94, 95 ; discharge of, 63 ; in Canada, I9; order relating to, I9; pursuit of, 75,79

Desglis, Monseigneur, letters of, 269

Desjardins, goods seized by, 212

Desjardins, Sieur, order concerning, 213

De Smet, Father Peter John, 234, 269; letter of, 266; mission work, 259

Desriviers, Julian Trottier, journey of, 210; order regarding beavers, 2 I 2

Desruisseaux, Paul Trottier, 22I ; observations, I 26

Detroit, Bishop of, 235
Detroit, Mich., account of, I47; address by Quakers at, I9o; Amherst's suggestions regarding, II9; British consul at, 64 ; capture of, 29, 105, I84, 273; Catholicism in, 24I; cemetery, 247 ; chimneys, 184 ; citizens' protest against orders to leave, 25 ; communications from, 22; councils with Indian tribes, I8I ; events about, I20; information from Indians, I5; lands around, I2I ; letters to inhabitants, 236, 269; militia, IS4; observations upon, II4; order concerning merchants of, 2I3; ordnance issued at, 2I ; ratification of grants to, 208 ; registers of baptisms, etc., I04; treaties at, I9; whisky trade in, 2 II

Detroit, vessel, I34

Detroit, Convention of, I865, ix

Detroit River, 2I7; military operations on, I $S_{4}$ Derastation, H. M. S., 83

De Watteville, Maj.-Gen. Abraham Louis Chas., letters of, 27

Dickson, Gen. Robert, commander of Indian Liberating Army, 47 ; conduct of, II I ; instructions of, 20 ; letters of, I9, 20, 179, I80; services among western Indians, I9

Diemar, Baron de, notes of, 24

Diplomatic affairs, 134

Diplomatic correspondence, 54,85

Discovery, ship, I33

Disputed territory, $80,8 \mathrm{I}_{1} 82,98,99, \mathrm{I} 46, \mathrm{I} 47$, I52, I53, I64, I65, I66, I70; attempt to set up government in, I30; British troops on, I66; correspondence, $5 \mathrm{I}$; east of Connecticut River, I3I, I74; fund, 8I, I32, I46; lands and timber in, I4I ; military arrangements in, 98 ; occupation of, 51 ; remarks on, 163 ; report on, $16 \mathrm{I}$

Distilleries, information on, 82

Dobie, Richard, correspondence of, 107

Doctor Robertson's Queries, Answers to, 106

Documents, episcopal, 225

Dodson, J., letter of, 164

Dolphin, brig, 295

Dominicans, 25I, 256, 258

Dominion archives, see Canada

Dominion Archivist, appointment of, 3; duties of, 7 ; regulations relative to control of documents, 7-8; title of Keeper of the Records, 6; see also Brymner, Douglas; Doughty, Dr. Arthur G.

Dorchester, Lord (Gov. Sir Guy Carleton), I 53, I 56, 287; appointment of committee to investigate Quebec archives, I; compliments to, 267; correspondence, 36, 97, 106, I Iо, I 56, I 57, I 58, I79, 202, 275 ; despatches, I24. I25, I56, I57, I60; instructions, 95; order-book, 222 , order of, 95 ; papers, 202 , 203 ; petition to, 293 ; secret service of, I 55 ; speeches of. I03, I08; trade instructions, I 45

Dosquet, Monscigneur, letters of, 269

Doughty, Maj. John, I 59

Doughty, Dr. Arthur G., I83; appointment as Dominion Archivist, 7 ; work of, 8 
Douglas, Capt. Charles (aft. Sir Charles, aft. rear-adm.), services of, I46, 154

Douglas, D., letter from, I29

Douglas, Sir Howard, correspondence, I29, I3I, I32, I4I ; despatches, I32; memoir, I4I

Douglas, Sir James, 258 ; journal of, 152 ; letters of, 90-9I, I52; loan made by, 89; papers of, 282

Douglas, Senator Stephen Arnold, bill to establish reciprocity with Canada, 56

Dover, N. H., American raid at, 26

Downing, William, 285

Downing Street, 23, 35, 280

Doyle, Sir Charles Hastings, correspondence, 87. I53; telegram from, I7

Doyle, Capt. William, letter of, 18

Drake, sent to guard coast, 298

Draper, William Henry, instructions from, 72

Drawbacks, 93, II5

Drew, Capt. Andrew, conduct of, 47 ; letters of, I69, 177

Drummond, Sir Gordon, despatches, 30 ; letters of, $16,26,27,28,29,30$, 177; memorials to, I6; plan to remove Indians, 20

Drummond's Island, I74; evacuation of, 23; Indian speeches at, 20 ; letters written from, 20

Dublin, Archbishop of, letters to, 228

Dubois, Bishop John, correspondence, 232, 233, 253

Dubois, Abbé Nazaire, papers of, ix

Dubourg, Bishop (Louis), 237, 25I ; letters of, 247

Dubuisson, Charles Renaud, 22I

Dubuque, Bishop of, see Loras, Mathias

Dubuque, A., claims, 244

Duckworth, Sir John Thomas, certificate of, 295; letters of, 295, 296

Ducoudray, M., 234

Dudley, Gov. Joseph, 220; correspondence, 194

Dudley Island, to be given to the United States, 30

Dufaux, Abbé F. X., correspondence, 236, 24I, 242 ; death of, 242

Duff, Vice-Adm. Robert, orders, 287, 288

Duffin, Robert, correspondence, I07, $28 \mathrm{I}$

Duggan, Thomas, diary of, I8; letters of, I8, 108, 109, 190

Dujaunay, Father, S. J., letter of, 244

Dunbar, Lieut.-Gov., New Hampshire, I45

Dundas, George, letters of, 86

Dundas, Henry, first Lord Melville, letters of, IO3

Dundas, Col. Henry (aft. third Lord Melville), letters of, 22

Dunn, Thomas, correspondence, 95

Dupuis, 246

Durand, Louis, 220

Durfee, William, murder of, 177

Durham, Earl of (John George Lambton), letters of, I6I ; papers, 185

Dutchess County, N. Y., riots in, I21

Duties, commercial, 98 ; fund from, II5; on American vessels, 40 ; on British manufactures, 62 ; on United States goods, I96; pro- tective, 41 ; refund of, $52,85,86$; see also names of commodities; Customs; Ships; Tariffs

Dutremble, Joseph, grant to, 209

Du Vernet, Captain, report of, 106

Eagle, vessel, 25

Earthquakes, 257

Eastern Townships, material relative to, 22

East India trade, 39

Eastport, Me., sale of arms at, 69

Eccleston, Archbishop Samuel, letter of, 246; letter to, 235

Edgar, Herman, 275

Edits et Ordonnances, I04, $2 \mathrm{II}$

Edmond, Anne, examination of, 210

Education, Catholic, 256

Edwards, Gov. Richard, letters of, 290, 291

Effingham County, orderly book, I37

Egan, 252

Egerton collection, 193

Egremont, Lord, letter of, 286

Electra, ship, 295

Electric cable, completion of, 89

Elgin, Lord, correspondence, 7 I, 93, 94, 183; despatches, 94 ; documents, $18 \mathrm{I}$; trip to Boston, 94

Elgin Association, 154

Eliza, ship, 297

Elizabethtown (Brockville), American raid upon, 25,267

Ellice, James, letter of, I6I

Elliott, Matthew, letters of, 24, I08, I09, II2, I77, 179,190

Ellis, Gov. Henry, correspondence, 123

Elmes, Capt. Hugh, 29I, 292

Eltham, H. M. S., I46

Embargoes, 196, I99; on provisions, 294, 296: removal of, 295 ; views on, 95

Emigrant Office, letters from, 35

Emigration, see Immigration and emigration

Emmitsburg, college, 252, 253

Emulation, ship, 296

England, Lieut.-Col. Sir Richard, letters of, I8, I9, I08, 109, I90

England, Bishop John, correspondence, 233, 249,256

England, 267; archives of, 8; commercial relations, 82; despatches, 37 n.; government of, orders, 253; purchase of supplies in, 26I ; trade, I 47, 196; see also Great Britain English, Cape, 29I

English, protection against the, 226; war against the, 207

English colonies, trade with, 208

English despatches, 32

English intrigues, 265

English ports, opening to vessels, $4 \mathrm{I}$

English works, reprints of, $4 \mathrm{I}$

Enlistment, colonial, I19; laws relating to, 63

Enquiry Boards, 275

Enterprise, ship, I34

Enys, Capt. John, journal of, I I I

Epitaphs, York County, N. B., I47 
Erie, Lake, attack by patriots, 7o; battle on, Federals, aided by Canada, 72 I3+; commissariat matters along frontier, I6; islands in, 4I; lowering of, 40; manceuvres on, 25; naval forces on, 26, 135 ; order forbidding trade on, 212 ; Perry's victory, 26; straits of, $104,208,216$; trade on, 212 ; vessels on, $15,26,66,79,96$

Erie Canal, 40 ; enlargement of, 76 ; opening of, II 3

Ermatinger, Edward, letters to, $2 \mathrm{~S}_{2}$

Ermatinger, F., journal, I 52

Erskine, D. M., letter of, I99

Erskine, see also Askin

Essex, U. S. frigate, 28

Essex County, Upper Canada, records of militia at, 3 I, IS4

Essex Institute, Historical Collections, 203

Estcourt, Lieut.-Col. James B. B., boundary survey by, 52 ; letters of, 22

Estèbe, Guillaume, land grant of, 2 I6

Fsteve, Pierre, 208

Etats Unis, arclive section, I8I

États Unis, Correspondance Politique, I8I

Europe, Journal d'un Voyage en, by Bishop Plessis, 228

Europe, political and religious affairs, 237

Eustis, Sec. William, letter of, 24

Evans, Capt. Samuel, U. S. N., instructions to, 23

Evans, Lieut.-Col. Sir George De Lacy, letters of, 25 ; orders for, 30

Evanturel, Eudore, 205, $205 \mathrm{n}$.

Exchange Coffee House Books, Boston, Mass. I34

Excommunicated persons, 24I

Executive Council committee, report of, 87

Exhibitions, documents relating to, II 4

Exports, see Imports and exports

Extradition, arrangements, 49, 97, I72; cases, $50,53,61,62,82,92,93,96,97,99$; correspondence on, 59,60 ; documents relating to matters of, $55,56,68,70,7 \mathrm{I}, 73,74,75$, $76,77,78,79,82,97,98,99$, I 14, I64, I65, $\mathrm{I} / \mathrm{I}$; instructions on, $52,8_{3}$; of criminals, 75 ; of James Gallagher, 52

Eyre, Maj.-Gen. Sir William, despatches of, 94

Faculties, 237, 242, 245, 247, 248, 249, 250, 25I, $252,253,254,255,259,260$; see also names of persons and places

Fairfield, Gov. John, agreement with Lieut.Gov. Harvey, 44; message of, I66

Falkland, Viscount, Jetter of, 198

Fallen Timbers, battle of, 18

Falmouth, sloop, I39

Famine, 257

Faribault collection, 34, I92, 2 I8

Farmer, Father Ferdinand, letter of, 252

Fauquier, Gov. Francis, part taken by, Io; requested to meet Amherst at Philadelphia, Io

Fawkener, letter of, 196

Fealty and homage, acts of, II4, 2I4, 2 I5

Featherstonhaugh, G. W., letter of, 165

Federal cruisers, prizes captured by, 66

Félicité, Sister, letter of, 246

Fenian raids, $6,15,30,77,183,273$; at Fort Erie, 68 ; attack upon Canada, 78 ; compensation for, 69 ; correspondence relating to, I7; despatches on, 95; measures against, 17,68 , 60, 79; on New Brunswick, I53; papers relating to, 176 , I80; rumors of, 87

Fenians, 276; despatch on, 93; Ogdensburg as a centre for, I5; President's proclamation on organization of, 73

Fenwick, Bishop Benedict, 25I; correspondence, 228, 232, 234, 250, 255, 268

Fenwick, Bishop Edward, correspondence, 232, 255

Ferland, Abbé, 236

Ferries, 92 ; rights to be settled by treaty, 5I

Ferryland, Newfoundland, 288; battery at, 290

Fetherstonhaugh, correspondence, I47

Feudalism, 2I5

Ffrench, charges against, 254; correspondence, 253-254

Field officers, letters of, I25, 126

Finance, Dept. of, concentration of documents recommended, 6

Financial crisis, $8 \mathrm{I}, \mathrm{I} 60$

Finlay, Hugh, 223; papers, I37

Finlayson, R., correspondence, ${ }_{52}$

Fish, Daniel, letter of, 207

Fish, Hamilton, signs protocol on Treaty of Washington, 85

Fisli, see under Trade

Fisheries, 88, I40, I53, I85, I88, I93, I94, I95, 196, 200, 201, 202, 203, 286, 294; American, $297,298,300$; cod, 202; commissioners, award of, 63 ; conventions, $57,58,82,197$, 20I; correspondence, 68, 69; despatches relating to, 86; encroachments, 74, I96; exclusion of foreigners, 297 ; French shore, 295; herring, 292, 300 ; injurious mode of deep-sea fishing, 73; inshore, admission of Americans to, 87 ; instructions regarding, 68 ; laws and regulations, $58,65,83,85$; licenses, $68,69,84,86$; memorandum by $\mathrm{C}$. F. Adams on. 68 ; negotiations respecting, 30 , II 3 ; protection of, $57,69,78,80,83,85$, 86 , I97; reduction of duties, 78 ; remarks o11, 86 ; report regarding, 68 ; rights, 58,59 , $60,84,85,94,197,108,285,301$; salmon, 300 ; treaty, 86, I98; use of set lines, 69; whale, 286, 287, 292, 298, 299; see also names of places, rivers, and lakes

Fisheries Commission, ix

Fishermen, I38, I96, 293, 299; act relating to, 86; complaints against, 97 ; emigration of, 293; impressment of, 287 ; in Newfoundland and Labrador, 299 ; in P. E. I. waters, 85 ; licenses, $68,69,84,86,87$; outrages by, I85; privileges to, 86 , IOI; regulations binding upon, I97; warnings to, I98

Fishery boundary commissioners, see Fisheries Fish-oil, see under Trade

Fish River, American armed force at, so

Fitzgibbon, Lieutenant, letters of, 25

Fitzherbert, Alleyne (Lord St. Helen's), letters of, ISI 
Fitzpatrick, Bishop J. B., correspondence, 235, Fort Frederic, I15, 210, 216; plan of, 218 250,268

Fitzsimmons, Father, letter to, 23I

Five Nations, conference with chiefs of the, I07; sce also Iroquois and Six Nations

Flaget, Bishop B. J., correspondence, 233, 245, 247,257

Flags of truce, 26

Flathead Indians, encounter with, $15 \mathrm{I}$; interpreter, 266 ; mission, 248

Fleuriau, 221

Florida, documents relating to, I2, I2I, I22; information regarding, I19, I20; projects relating to, 143

Florida, East, cession to Spain of, 82 ; occupation of, 178

Florida, West, I20, I21, I24; claims, II 3 ; land grants. I85; land in, II3; occupation of, I78: withdrawal of troops from, I22

Flour, duty on, 52, 54, 93; for garrisons, 293; importation of, $40,46,82$, I 40, I 4 I, 292, 296 ; seizure of, I43; trade in, 139

Fly, cutter, 295

Fogo, distress at, 290; merchants, 290

Fontana, Cardinal ( $\dot{\mathrm{F}}$ ) , 268; letter of, 269; report to, 228

Forbes, Brig.-Gen. John, despatches and expedition, II7

Forbin-Janson, Monseigneur, letters to, 234

Foreigners, mode of dealing with, in late insurrection, 48

Foreign Legion, ix ; recruits for, 59, 72, 94, 197, I98

Foreign Office, correspondence of, 52, 60, 6I, $62,68,69,75,84,85$, I 29, I 3 I, I 32, I64, I66, I72, I8I, I85; despatches, I62; instructions on fishery question, 68 ; memorandum from, $\mathrm{I} 74$; on repeal of navigation laws, 60

Foreign Office, America, I82

Foreign Office, France, 182

Forcign Office, Miscellancous, ix, 182

Foreign shipping, exclusion of, 62

Forsey, Thomas, case of, I 48

Forsyth, John, correspondence, I62, I63

Forsyth, Richardson, and Co., memorial of, $2 \mathrm{I}$

Fort Beauséjour, siege of, 202

Fort Belle Rivière, I26

Fort Carillon, plan of, 218

Fort Chambly, confiscation of merchandise at, 2I2; courts-martial at, 222; seizure of beavers at, 212; surrender of, 266

Fort Chartres, I3, 105, 126, 153, 221

Fort Chouagen (Oswego), 218

Fort Colville, see Colville, Wash.

Fort Dearborn, prisoners taken by Indians at, 25

Fort de Cannatchocary, plan of, 218

Fort de Chouagen, plan of, 218

Fort Duquesne, battle of, 192; French commander at, $27 \mathrm{I}$; register, II 5

Fort Erie, Fenian raids at, 68 ; firing upon, 95 , I73; letters from officers at, $3 \mathrm{I}$; siege of, 27

Fortescue, Chichester (aft. Lord Carlingford), letters of, 88,89

Fort Frontenac (Kingston), claims to, 123; improvement of, 2II; permission to rent, 2 II ; plan of, 218

Fort Garry, troops for, 54

Fort George, 15; attack on, 25, 218; British prisoners taken at, 28; capture of, 25; council at, I09; trading expedition, $15 \mathrm{I}$

Fort Harmar, treaty at, I79

Fort Hunter, plan of, $2 \mathbf{I} 8$

Fortier, Rev. Moïse, letter to, 238

Fortifications, I22

Fort Kamloops, I52

Fort Kaskaskia, I3, I26

Fort Lawrence, plan of, 218

Fort Lidius, 218

Fort McKay, capture of, 27, 3I

Fort McLoughlin, I 52, 283

Fort McPherson, 283

Fort Miami, I26; Indian council at, 190; ordnance, etc., 21

Fort Michilimackinac, capitulation of, II2

Fort Necessity, capture of, I92

Fort Nesqually, I52

Fort Niagara, British preparations for attack on, 25 ; forbidding trade with, 212; orders and proceedings at, 28 ; supplies for, 16

Fort Ontario, 2IS; weak situation of, I57

Fort Orange, 218

Fort Oswego, 218

Fort Pitt, 159

Fort Pointe at Baril, plan of, 218

Fort Ponchartrain, command of, 2 II ; register of. IO4; trade at, 219

Fort Présentation, plan of, 218

Fort Quaris, plan of, 218

Forts, building of, I I9; of Natchez, plan of, 218

Fort Ste. Thérèse, 218

Fort St. Jean Richelieu, 218; siege of, 105, 222, 266, 267

Fort St. John, register, II 5

Fort St. Louis, 218

Fort Schlosser, British raid upon, 25; provisions for, 14

Fort Simpson, 15 I

Fort Stanwix, capture of, 267 ; Indian cession at, 20 ; treaty at, I2 I, I79, I8I

Fort Stephenson, Procter's attempt against, 25

Fort Townsend, new, work resumed at, 290

Fortune Bay, prisoners taken on, 29I

Fort Vancouver, I 52, 283; immorality at, 261

Fort Vaudreuil, plan of, 2I8

Fort Vincennes, I26

Fort Wayne, British expedition against, 25,184

Fort William, Michilimackinac, 237

Fort William Henry, attack upon, II6; capture of, III, I23; condition of, II6; Loyalists victualled at, 16 ; massacre at, II7 ; prisoners, at, II 7

Forty Hours, 24I

Fort York, Labrador, 287

Fort Yukon, 283

Foster, Colonel, letters of, 50

Foster, A. J., letters of, 178

Foucher, Mrr., 222 
Fowler, Theodopus, contract for army supplies, 108

Fox, Monseigneur, letter of, 256

Fox, Henry S., advice from, I65; correspondence, 75, 82, 92, II5, I68, I69, I7I, I72, I77, I8I; despatches, 8I, I3I, I6I, I62; relations to McLeod case, 92 ; report on navy, etc., I62

Fox, ship, 289

Foxcroft, John, commission of, 148

Fox Indians, 22I

Foy, L., II4; acts of, IO4; letters of, I00

Frampton, letter of, 29I

France, aid to keep western country from, I57; archives, 8, 33, I92, I93, 205: expeditions against, I 16 ; influence in the United States, 25 I ; king of, 225

France, New, documents on, IIO, II4; land grants in, 216 ; ordinance for the inhabitants of, 208; register, 225

France, Nouvelle, Jugcments et Délibérations du Conscil Souverain de la, 205, 206

Franchère, Gabriel, engagements made by, 272 ; Journal d'un Voyage sur la Côté du Nord Ouest de l'Amerique Septentrionale pendant les Annćes I81I-1814, 274

Franklin, Benjamin, commission of, I48; dismissal of, I48; letters of, I8I

Franklin, Thomas, 22I

Franquet, 218; voyages and memoirs on Canada, 192

Franzoni, Cardinal, letter to, 228

Fraser, Alexander, 273 ; letter of, I4

Fraser, John, letter of, I63

Fraser, Simon, Journal of a Voyage from the Rocky Mountains to the Pacific Coast, 28I; letters of, I52, 28I ; papers, 28I

Fraser River, I5I ; navigation of, 88,90

Fréchette, Father P., correspondence, 237, 24I$2+2$; departure of, $24 \mathrm{I}$

Frederick Island, to be given to the United States, 30

Fredericton, N. B., I64; public records at, 204

Frecdom, ship, 296

Freeling, Francis, letter of, 148

Freemasonry, 265

Freer, Capt. Noah, military secretary at Quebec, 20 ; papers of, $3 \mathrm{I}$

French, colonies, commerce of, 209; illicit trade with, I19; in America, I22; in Canada, I33; in Nova Scotia, I99: influence on trade. I2I; plots in the United States of, I7, 23, I42; punishment of, 207; relations with, I20; republican machinations, 156 ; treaty with the Cherokees, II7

French and Indian War, correspondence relating to, I99; see also Seven Years' War

French Archives, Ancient, etc., I n.

French Canadians, 245

French Mills, Wilkinson's army at, 31

Frobisher, B., observations on Indian trade, I8I

Frontenac, brig, 220

Frontenac, County of, History of the, by M. Harman, I06
Frontenac. Lake, 218

Frontier, attacks on, 47, 51, 70, 93, 97, 99, I0I, 102, 163, I68; Canadian ministry on, 254; Comeau's report on the, 52 ; conditions on, I6I ; conduct of United States authorities, 76 ; defense of, $42,50,8$ I, I I 6 , I72 ; documents on, 74, I16, 125, I35; hostilities on the, $51,82,97$, I I4, I6I, I62, I63, I64, I72; instructions regarding, 40; northeast, I48; Patriot organizations on the, 75,79 ; proceedings on the, I64; townships on, 40 ; United States military force on, I72; violations of territory, 76 ; see also Boundaries Fry, Ensign Philip, communications from, I07 Fryer, Prof. C. E., 27 I n.

Fugitives from justice, 22, 7I ; surrender of, $62,8 \mathrm{I}$

Fundy, Bay of, I28; fishery rights in, I97, I98 Fur companies, papers of, 2

Fur-trade, I03, I2I, I29, I5I, I58, 207, 213, 218, 272 ; confiscation of furs, 212 ; duties, 2I; exports, 99; northwest, 156 ; outrages on traders, 96; permission to engage in, $27 \mathrm{I}$

G. S. Weeks, schooner, 43, 74, I64, I71, I72

Gaetan, grant to, 209

Gage, Maj.-Gen. Thomas, 287; correspondence, I I, I3, I4, I9, II5, I2I, I22, I24, I47, I8I ; decisions of, 217; despatches, I20; memoranda for, II9; order-book, 28 ; recommendations for military posts, I2I

Gagnon, Mgr. C. O., Mandements, Lettres Pastorales, etc., edited by, 225

Gagnon, Philéas, 205, 205 n., 219

Gagnon collection, I50

Gale, Samuel, letter of, 99

Gallagher, James, extradition of, 52

Galveston, Tex., blockade of, 76,87 ; diocese, 255

Gambier, Lord, letter of, 293

Ganong, Prof. W. F., I53; documents presented by, $15+$

Garland, C., 289

Garneau, Alfred, manuscripts purchased from, 105

Garneau, Rev. B. Ph., index by, 225

Garrison States, I26

Garry, Nicholas, letter from, I29

Gaspé, Que., consular agents for, 64; map of, I 27

Gatineau, Louis, 22I ; journey of, 210

Gazette, 63

Gazette, Detroit, I Io

Gazette, London, 82

Gazette, New York, 121, 144, I67

Gazette and Country Journal, Boston, I 53

Genaples, $S r$. Charles, land grant of, 216

Genaples de Bellefonds, François, 2I9

Genesee, N. Y., 53

George III., 294

George, Lake, returns of troops at, i 77

George Town, township of, 95

Georgia, dispute with South Carolina, I23; documents relating to, 162

Georgia, Gulf of, boundary, 60 
Georgiana, steamer, 68, 73

Germain, Lord George, see Sackville, Viscount Germain, Robert, suit with Sr. Le Gardeur, 212 Germans, arrest of, 60 ; recruitment of, 59

Ghent, treaty of, 20, I27, I28, I29, I 40 , I4I, I55, I85; articles of, $20,23, \mathrm{I} 76, \mathrm{I} 87,273$; authorizes boundary survey, 46 ; boundary line, I36; disputed points, 4I, I3I ; islands awarded by, $4 \mathrm{I}$; ratification of, 27

Gibault, Father P., 24I, 245, 269; charges against, 244; correspondence, 236, 242, 243 ; education, 242; hanged for treason, 267 ; reputation of, 257 ; visit to Vincennes, 243

Giddings, Joshua R., appointment of, 63,65

Gilbert, François, land grant to, 209

Gilbert, Jean, 208

Girod, Lieut. William, letter of, I43

Givins, L., letter of, 20

Glackemeyer, Edward, 222

Gladstone, William E., correspondence, 53, 54, I 36

Gladwin, Maj. Henry, letters of, II9

Glaize, council at, I89

Glascock, Captain, order to, 299

Glegg, Capt. John B., letter of, i9

Glenelg, Baron (Charles Grant), correspondence, 4I, 42, 47, 48,49, 83, I02, I96; despatches, 49,174

Glengarry Highlanders, sketch of, I06

Goderich, Viscount (Frederick J. Robinson, aft. Ear1 of Ripon), letters of, 41,46 , 196

Godley, Denis, letters of, IOI, IO2

Goesbriand, Bishop (Louis de), 253, 256

Gold, coinage, 89 ; hunters from the United States, 64; rush of 1858,279

Golden Farmer, ship, 282

Golden North, manuscript volume of the, 154

Good Intent, vessel, 286

Gordon, Sir Arthur Hamilton, letter of, 87

Gordon, Capt. Harry, journal, I2I

Gordon, Samuel, complaint of, 300

Gordon, Sir W., correspondence, $\mathrm{I}_{3} \mathbf{I}$

Gore, Lieut.-Gov. Sir Francis, letters of, I9, I76

Gorham, Lieutenant-Governor, letters of, 287 , 289

Gosford, Earl of (Archibald Acheson), letters of, 97,161 ; reception in the United States, I6I

Gosling, W. G., 286, 287

Gospel in New England, Corporation for Propagating, 20

Gosselin, Abbé Amédée, 224, 226

Gouin, Louis, 22I

Goulburn, Henry, despatches, I74; letters of, 45, $82,149,299$

Goutin, Mathieu de, land grant of, 216

Government House records, concentration of, 8

Governor-general, civil secretary, letters of, 35,37 ; despatches, $35,36,37,79$; letters of, 35 ; military secretary, letters of, 37 ; private secretary, letters of, 37

Governors, commissions of, I22; instructions to, 35

Gower, Sir Erasmus, letters of, 293-294

Gradwell, agent at Rome, 268
Grain, duties on, 54; importation of, 40; trade, letters on, 91 ; see also Corn; Wheat

Grand Glaize, Indians at, Wayne's speech to, 18

Grand Island, 2 I 6

Grand Menan Island, I87; map of, I28

Grandmesnil, Sieur de, 212 ; ordinance obtained by, 213

Grand-Pré, register of baptisms, etc., I33

Grand River Indians, minutes of councils with, IIO

Grant, Alexander, letter of, $9 \mathrm{I}$

Grant, Lieut.-Col. Lewis, letter of, I6

Grant, Lewis E., proposal to raise men for British army, 59

Grant, Pres. U. S., Canadian correspondence, 36

Grantham, Baron (Thomas Robinson), letters of, 182

Granville, Earl, letters of, 84, 85, 90

Grassi, Father John, 237; letter to, 23I ; letter of, 246

Grattan, Edmund, correspondence, 83

Gravé, letter of, 245

Graves, Vice-Adm. Samuel, 286, 288

Gray, notary, engagements of, 272

Gray, John, memorial of, I39

Gray, Robert, correspondence, 28I

Great Britain, boundary, 130 ; cessation of hostilities, 73 ; convention with the United States, I29; jurisdiction upon Great Lakes, 69; relations with the United States, 95; statement relative to Ghent treaty, 4I; treaty with, 65

Great Lakes, ascendancy on the, 45; attack upon British vessels, 75 ; command of flotilla on, 48; defense of the, 64 ; documents relative to, $79,27 \mathrm{I}$; fisheries on, 92 ; interference with vessels on, 45 ; invasion by Canada, 66; jurisdiction of, 69; naval depots on the, 67,76 ; naval forces on the, 22 , $29,42,5 \mathrm{I}, 52,53,55,56,6 \mathrm{I}, 64,66,67,69,7 \mathrm{I}$, $73,74,77,82,93,94,95$, IOI, I 12, т35, I65, I69; negotiations respecting naval armaments on, 23 ; surveys, $2 \mathrm{I}, 76$; United States observing force on the, 76

Great Miamis, Indian councils at, I79

Greek fire, manufacture of, $67,73,77$

Green, Capt. James, I8; correspondence of, I9, 190

Greenleaf, Moses, map of Maine, 128

Greenville, Indians at, I8; treaty of, 179,190

Grenville, Baron (William Wyndham Grenville), despatch, 158 ; letters of, $38,133,181$, I82, $28 \mathrm{I}$

Grenville Canal, progress of, I06

Grey, Earl (Charles), correspondence, 54-59, $83,84,88,183,197$; mission of, 162,183 , I97; report of, I6I ; return from Washington, 161

Grey documents, I8I

Griffin, A. P. C., Bibliography of American Historical Societies, 22I

Griffin, mission to Albany, I7I

Griffith, Rear-Admiral, despatches, I34, I35

Grimes, departure of, 290

Grindstones, see Trade 
Groghan, James, arrest of, 51, 75, 99; case of, Hampton, Lord (John Somerset Pakington), 78,82

Groseliers, Medard Chouart, letter for, 207

Groilard, introduction of foreign merchandise by, $2 \mathrm{I} 2$

Grove, Capt. George, 222

Groavler, U. S. vessel, capture of, 25

Gubbins, Lieutenant-Colonel, communications from, 25

Guide to the Manuscript Materials for the History of the United States, to 1783 , in the British Museum, etc., IO

Guide to the Materials for Amcrican History in the Archizes of Paris, 33

Guillory, journey of, 2 Io

Gunboats, proposals for, 5 I

Guns, exported from Liverpool, 162 ; license of schooner, 299

Guyon, Marie Thérèse, 219

Gypsum, exportation of, I40

Habersham, J., letter of, I 48

Habitants, emigration of, I64

Hackett, Nelson, 92

Hague, The, boundary case at, I 86

Hague Arbitration, 285

Haiac, schooner, 295

Hailes, H. W., letter of, Ito

Haldimand, Gen. Sir Frederick, biography, 12; correspondence, 13. I4, I06, 107, 150, I9I; despatches, I24; diary, I2; executor of H. Bouquet's will, Io; land grant to Six Nations, I89, I9I; papers of, I2, I25, 156, 202

Haldimand, William, presents papers to British Museum, I2

Halia, Bishop of (Rev. Wm. Poynter), letters to, 229

Halifax, N. S., agreement at, I34; attacks from, S4: biscuit from. 296; concentration of military records, 8 , I4; conference at, 200; correspondence, 24,30 , II5, I20; merchants of, I38, I42, 201 ; organization for seizing United States ships, 77: potatoes from, 296; sales of property, 202; vessels arriving at, I $38,142,198$

Halifax Fisheries Commission, Report of the, 285

Halkett, F., letter of, I6

Hall, James, History of the Indian Tribes of North America, 163

Haller, Col. Granville O., 152, 283

Halloway, Robert. 283

Halton. William, letters of, Io9, i io

Hamelin, journey of, 210

Hamilton, A., letter of, IOI

Hamilton, Sec. Alexander, contract for army supplies, 108: correspondence, I07

Hamilton, Gor. Sir Charles, correspondence 299, 300, 301 ; proclamations, 300

Hamilton, Lieut.-Gov. Henry, correspondence, IO7

Hamilton, Ont., board of trade, 7I ; consul at, 78: recruits for the United States army, 63

Hamlin, United States commissioner, 63

letters of, $57,83,87$, I97

Hampton, Maj.Gen. Wade, movements of United States forces under, 26

Hancock, ship, 289

Hanks, Lieut. Porter, return of garrison under, 24

Hannah, sloop, 299

Hannay, Dr. James, 145, 147, 193, 204, 278; report of, I5I

Happy, Jesse, case of, I66, I67

Harbor Briton, report on, 292

Hardy, Gov. Sir Charles, Ig\&; correspondence, I I5

Hardy, Capt. J., 296

Harman, M., History of the County of Frontenac, 106

Harmar, Brig.-Gen. Josiah, I 59

Haro, Canal de, islands in, 88

Harper, Lieutenant, report on Canadian affairs, 161

Harris, John, survey by, I86

Harrison, George, letter of, 140

Harrison, Brig.-Gin. William Henry, agreement for exchange of prisoners, 25 ; instructions of, 25 ; position at Miamis, 28

Harvey, Jacob, note from, II 3

Harvey, Sir John, I31; agreement with Gov. Fairfield, 44; correspondence, 25, 26, 27, 102, I32, I46, I63, I64, I65, I86, 198, 200, 201 ; despatches, 80, 8I, 98, I3I, I53, I6I, I66; order for advance against enemy, I7; recall of, 45,88

Harvey, Iice-Adm. Sir T., letter of, 82

Hastings, Howland, case of, 49, 74, I70, I7 I, I72

Hautteville, Sieur, land grant of, 2 I6

Haven, C. C., II 3

Hawke, Sir Edward, expedition against France, II 6

Haw'ke, ship, 297

Hay, Lieutenant-Colonel, I07; instructions to, 290

Hay, James, 287

Hay, see under Trade

Hayes, $M ., 232$

Hazard, ship, 291, 295

Head, Lady, treatment of, I67

Head, Major, report from, I6I

Head, Sir Edmund, despatches from, I83; correspondence, I6, 7I, 72, 87, 94

Head, Sir Francis Bond, attitude toward the United States, I67; correspondence, 47, 9I, 166, 167; despatches, I03

Heald, Capt. Nathan, letters of, 27

Heathcote, Major, letters of, 24

Hebert, grant to, 209

Hecker, Father I. T., letter of, 255

Hector, H. M. S., I 6

Hélène, Sister, letter of, 248

Henni, Bishop (John Martin), letter to, 235

Henry, Alexander, letters of, 275

Henry, John, letters of, I42, I55, I56, I 77 ; mission to the United States, I 77, I 78

Herbert, General, destroys papers, I80

Herbert, Lord (Sidney Herbert), letters of, 58 
Heriot, George, letters of, 26, 148

Hermitage Bay, 292; whale fishery in, 298

Hero, cutter, 295

Herring, see Fisheries

Hessians, surprise of, 267

Hickey, John, letter of, 246

Higginson, J. W., letters of, ror

Highland settlements, in America, II2

Highwassee, speech delivered at, I9o

Hill, Captain, correspondence of, 107

Hill, Brig.-Gen. John, expedition of, 194

Hillsborough, Earl of, correspondence, 121, 122, I47 ; instructions relating to settlement on the Ohio, I7

Hincks, Sir Francis, correspondence, IIo

Hine, P., letter of, 298

Histoire du Palais Episcopal de Québec, by $M g r$. H. Têtu, $225 \mathrm{n}$.

Historical Documents, 223

Historical Manuscripts Commission, creation of, 8 ; members, 9

Hobart, Baron, letters of, I6, 45

Hocquart, 2ro; grant of land to, 209; letter of, I

Hodgson, Licut.-Gov. Sir Robert, correspondence of, 86

Hody, Monsieur, letter to, 228

Hoffman, Peter, information respecting, 96

Hogan, 92, II4, 252

Holburne, Adm. Francis, correspondence, II6; despatches. II7

Holcroft, Maj. W., letters of, 25

Holloway, Adm. John, letters of, 294; licenses granted by, 294

Holmes, John, commissioner, decision and award of, 200

Holmes, Abbé John, 232, 249, 250, 251; letter to, 229

Holston settlement, 189

Holtz, Charles, 283

Holy oils, 25I

Home, Lient. Thomas, I3

Home District, petition from, 52

Home League, address of, II3

Hoinmage, I04, II 4

Hongkong, China, steam communication with San Francisco, 90

Hope, Captain, papers of, I87

Hope, Vice-Adm. Sir James, correspondence, โ53

Hope, vessel, 28I

Hops, see under Trade

Hopson, Maj-Gen. Peregrine Thomas, I I6

H'ornet, ship, 295

Horse Guards, communications from, 23

Horse Shoe Reef, appropriation for, 56 ; cession of, 57 ; lighthouse on, 56

Horton, R. W., letters of, 46 , 196

Hospital, military, returns, 126

Hostilities, negotiations for a cessation of, 73

Hotham, Rear-Adm. Sir Henry, despatches, 135

House of Representatives, proceedings in, 64

Howard, C. W., to make extracts from documents on Georgia, 162
Howard de Walden, Lord (Charles Augustus Ellis), letter of, I4I

Howe, John, correspondence, I44, I48, I49 ; reports of, I42, I43, I44; return to the United States, I44

Howe, Joseph, letter of, 80; mission to the United States, 59 ; papers of, ix ; recruiting, I 98

Howe, Sir William, 287, 288, 289; despatches, 124

Howick, Lord, letters of, 4I

Howlan, E. W., reciprocity conference, 84

Hubbardton, Fraser's advance corps at, 106

Hubert, Bishop, correspondence, 24I-242, 245, 25I, 269; passport for, 242

Hudson's Bay Company, 229, 230, 260, 276, 279, 282; affairs of, 152 ; aid against Indian War, 88; claims, 282; correspondence, 21 , 60,64 , I I5, I $32,240,262,265,280$; deeds granted by, 283; designs, 239; encroachments on Alaska, 9o; immigration, 265; instructions on marriage permits, 262 ; journals, II, 277 ; memorial book, I 50; minutebooks, I5O; papers, I5I, I52; petitions, I50; relations with missionaries, 239,261 ; state papers, 136 ; transactions, 133

Hudson's Bay House, London, I 5

Hudson's Bay territory, 72; migration of Mormons to, 60 ; pursuit of Sioux refugees, 76 Hughes, Captain, report of, $3 \mathrm{I}$

Hughes, Bishop John, 255; correspondence, 234,268

Hughes, Katherine, 277

Huguenots, forbidden in Canada, 270

Hugunin, John C., letters of, 50

Hull, Gov. William, letters of, 24; remarks of, I9

Hume, J. D., letter of, i66

Humphreys, Col. David, journey to Europe, 160

Huneau, Gabriel, 221

Hunter, Lieut.-Gov. Peter, 153; despatch of, 160 ; letters of, I39, I43

Hunter, vessel, 134

Hunter and Co., letter of, 297

Hunters' lodges, 5I, II3

Huntley, letter of, 86

Huron, Lake, canal connecting Ottawa River, 65; fisheries, $60,70,72,92,94$; islands in, $4 \mathrm{I}$; mercantile vessels on, I5; report relative to British superiority on, 26; water connection with Montreal, 65 .

Huron, territory of, 129

Huron Indians, 136, 242 ; in American territory, 236 ; letter to, 236 ; treaty with, 136

Huskisson, William, despatches from, 174; letters of, $4 \mathrm{I}, 46$

Hymns, in Chippewa, 255

Iberville, Pierre Lemoyne d', 220

Idaho, 280

Ile Royale, 34

Illinois, I3, I24, 245, 255; account of, I20; application for arms, 75 ; British occupation of, 120 ; cession of, 269 ; commerce and settlements, I22; establishment, 258; events 
in, I22; faculties for vicar-general, 242; government for, I5I; missions, I05, 242, 244,269 ; monasteries, 257 ; plans regarding, I47; religion in, 257 ; researches in, 248

Illinois, University of, I53, 224

Illinois Historical Collections, 230, 243, 244

Illinois Indians, I 20

Immigration and emigration, II4, I73, 248; American, 72, 198, 259, 261, 263, 264, 265, 274, 279; British, 146; contracts with emigrants, 67 ; French, 256 ; grants of land, 44 ; immigrants encouraged to settle in Canada, I74; regulations, 67 ; remarks on, 39 ; reports, 7I ; returns from agent, 70 ; statistics, $8 \mathrm{I}$; see also names of countries and places

Imports and exports, 77, I00, I39, 298

Impressment, 296

Indentured servants, I 6

Indian affairs, I5, I I9, I22, I24, I26, I5I, I78, I79, I9I ; administration of, I9, IO9; claims, I36; commissioners of, I8I ; correspondence on, IO, I2; documents relating to, 127 , I75, I8I ; management of, I79; minutes of, I89; news of, 23 ; see also Indian Department

Indian books, 235, 246

Indian boundaries, 181

Indian cession, copy of, at Fort Stanwix, 20

Indian Department, Canadian administration of, 19; archives, 2; correspondence, I7, I26; documents relating to, 6,126 , I89-I9I ; history, I36; requisitions for, I9

Indian Liberating Army, 47.

Indians, accounts of, $22 \mathrm{I}$; aided by the British, I08; at Cowlitz, 258; at Detroit, I5, I79; attacks upon United States citizens, 88, I78; attitude and customs, 258; Canadian, documents on, IIO; capture of prisoners at Fort Dearborn, 25; charges relative to aggressions by, 30 ; comments on, 45 ; conduct of the United States toward, 20, 40; conpiracy against the English, I05; conspiracy of Pontiac, II9; councils, I8, I08, I IO, I I2, I79, I90; disposition toward colonists, I2I ; disputes among, 93; documents relating to, I3, 20, 3I, 39, IO3, I I I, II6, II7, II 8 , I19, I 20, I21, I 29 , I47, I 57 , I94, 225, 24I, 242, 262, 265, 274, 283; enticed to Canada, 44, 50; expeditions, I 59; headmoney, I77; hostile, pursuit of, 65 ; hostility to the United States, II3, I76, I 85 , 259,264 ; immigration of, I9, 79, 8I, 98 , IOI, I73, I74; influence on, 258,266 ; in North America, I9I ; in Oregon, 88; in Scioto, I99; instructions, 29, 258; intelligence received from, I80; in vicinity of Drummond's Island, I74; journey to Washington, I9; lands, IIO, I2I, I79; language, 262, 264 ; letters relating to, 20, 30 ; liquor traffic, $78,212,241,270$; loyalty of, 238 ; meeting within the United States lines, Ioo; ministry among, 227, 257, 259, 26I, 262; negotiations with, I09, I20; neutrality, I39, 238 ; New Brunswick, attachment of, I9; New
England, proceedings with, I 89 ; operations with the British, I09, 267; outrages near Chicago, 20; outrages on fur-traders, 96 ; papers, I06, I76; policy towards, 20; prayers, IIO; presents for, $20,45,109,173$, I9I; prisoners held by, II3; see also Prisoners of war; pursuit into Canada, 76 ; raids, I35, I52; records of, I80; relations with Canada, I8; relations with United States, I8; remarks on, I37; resident in British territory, 45 ; report on, 68 ; southern, I58, I89; speeches, I8, 20, 103, 107, I09, I89, I90; stores for, I09; threats of cruelty, 267 ; trade with, 74,88 , 95, 96, I5I, I79, I8I, 210, 2I7; treaties, I8, 20 , I1 2 ; troubles, 258 ; wars with, 88 , I52, I 58, 241, 263, 283; western, 19, 20, 27, 108, 158. I79, I89. I90; see also names of tribes Indian Stream settlement, 74, IO2 ; authority of New Hampshire in, 4I, 96; disturbances, I3 I

Indian territories, plan of, I28

Indian Tribes of North America, History of the, by Thomas M'Kenney and James Hall, 163

Infected clothing, 68

Inglesi, Abbé A., 232

Inglis, $R t$. Rev. Charles, papers of, ix

Ingraham, Capt. Joseph, correspondence, 28I Insinuations, 206, 207, 210, 216, 220, 225

Insurgents, defeat of, 47 ; documents relating to, 9I; on Navy Island, 47

Intendance, ordinances of, 2I I r registers of, 206, 2 I 4, 216

Intercolonial Railway, purchase of land for, 6I

Interior Brigade, trading expedition, I5 I

Interior Department, concentration of documents recommended, 6

Interprovincial correspondence, 203

Invoices, from vessels, 59

Ireland, letters from, 268

Irish, designs of, 62 ; disorders caused by, 268 ; sympathizers with the United States, 55

Ironside, George, correspondence, I09, I90

Iroquois Indians, calumnies, 258; emigration of, 227: war declared by, 270; see also Five Nations and Six Nations

Irvine, James, letter of, 148

Irving, John, letter of, 173

Isle aux Cochons, 217

Isle aux Noix, account of situation at, 25 ; siege of, 2 IS

Isle Lamotte, 216,217

Jackalopin, speech of, IO7

Jackson, Pres. Andrew, interview with, I30

Jackson, Joseph, instructions to, Iog

Jackson, Sir Richard D., correspondence, 8I, 82,92 , I02, I 32, I64, I65, I66; despatches, 8 I, 98, II4, I53; memorandum of, I65; report from, I66

Jacobins, 102, 103

Jamaica, act granting bounties in, 294; despatch from governor, 58; list of persons naturalized, I.7 ; negroes, 58, 62, 94, 203 
James, ship, 296

Janvier, $A b b e ́$, correspondence, 230, 247

Jarvis, S. P., collection of, 274

Jaseur, H. M. S., I40

Jason, H. M. S., 295

Jay, John, treaty of, I55, I86

Jeanson [?], land to, 240

Jefferson, Thomas, administration of, 102

Jefferson Davis, vessel, I6, 72

Jenner, T., 287

Jenny, American cartel ship, 297

Jessup's Loyal Rangers, I25

Jesuits, 225, 237, 243, 244, 246, 249, 259, 266 , 268 ; in Louisiana, 151 ; in Oregon, 265; land grant of, 216 ; missions, 228 ; property of, $154,243,245$

Jesuits, History of, by Father Jogues, $\mathrm{x}$

Jogues, Father Isaac, $\mathrm{x}$

Johnson, Captain, diary, I50

Johnson, George, papers of, ix

Johnson, Col. Guy, accounts of, 22I ; correspondence, 106, 107; Indian affairs under I8I

Johnson, Sir John, correspondence, I9, I06, I07, I09, II0, I76, I79, I89; expedition under, $22 \mathrm{I}$; king's commission to, I9I ; report of, I86; Royal Regiment of New York, I25

Johnson, Sir William, I24; correspondence, I8, I06, I I6, II7, I24, I47, I8I ; régime of, I 80 , I8I ; treaties, I22, I36, I9I ; will of, 106

Johnson family, 2

Johnston, Lewis, letter of, 20

Johnston, Samuel C., letter of, I72

Johnstone, George, letter of, I9

Jones, murder of, 72

Jones, Lieutenant, despatch from, I65; letter of, I65; statement on political conditions, 50

Jones, B. R., survey by, 128

Jones, John, English notary, 219

Jordan, Marie Anne, naturalization for, 209

Judges, prerogatives in the church, 24I, 242

Judicature, Act, 284 ; courts of, 292

Judicial Archives, 217, 219

Jukes, report, 284

Julia Smith, vessel, 60, 94

Juliopolis, Bishop of, letter to, 237; see also Provencher, Bishop

Justice Department, concentration of documents recommended, 6

Kalapaya Indians, 262

Kaskaskia, I5I, I 53, 213, 242, 269

Kate Carleton, vessel, 67

Kearney, Lieut.-Col. James, U. S. A., survey by, 53

Keats, Gov. Richard G., letters of, 296, 297 ; licenses granted by, 296

Keeper of the Records, title added to Dominion Archivist, 6

Keith, J., letters to, 229, 230, 240, 262, 265

Kelly, Bishop (Patrick), transferred to Ireland, 268

Kelly (pirate), capture of, 5I, I7I
Kempt, Sir James, despatches from, 37; letters of, 97,197

Kendall, E. N., report of, 130

Kennebaccasis River, land grants on, 153

Kennebec River, case of, I33

Kenrick, Bishop (Peter R.), correspondence, $233,234,248,252,266,268$

Kentucky, 255, 258; disposition to join Spain, I57; fugitive slave demanded by, 47 ; monasteries of, 257

Kerallain, $M$. de, I 35

Kerby, Col. James, letter of, 2I

Kerlerec, Gov. Louis, propositions for treaty, II7

Kerrigan, Father, 255

Kickapoo Indians, deputation from, I77

Kidnapping cases, 79, 96, 100

Kimberley, Earl of, correspondence, 85

King, Rev. William, activities of, I 54

King's American Dragoons, account of, I25

King's Royal Regiment of New York, 29, I26, I27

Kingston, Robert, report of, 154

Kingston, Ont., batteries, I7 ; port regulations, 75,79 ; reports from agent at, 81

Kinnaird, Rev. T. M., case of, 67

Kinney, W. B., II 3

Kirkman, letter of, I3

Kitson, W., conversion of, 264 ; letter of, 262

Knox, Gen. Henry, correspondence, 107, 108, 179; speech of, I79

Knox, William, letter of, I39

Kohlmann, Father A., 255; correspondence, 23I, 254

Konondauqua, see Canandaigua

Kouaskagouche River, land on the, 216

La Bodega y Quadra, see Bodega y Quadra

Labouchere, Henry, letters of, 59, 60, 88, 197

Labrador, Americans in, 294; annexation to Newfoundland, 294; boundary, I82; depredations in, 290; fisheries, 9I, I8I, 286, 299, 300; merchants in, 286, 300 ; papers on, I33; report on, 292 ; smuggling, 294

Labrador, Gosling, 286

La Butte, 208

Laclotte, Sister St. Joseph, letter of, 248

Lacolle, battle of, 26,29

La Corne, Sieur de, journey of, 210; return to Detroit, 213

Lacroix, E., letter of, 256

La Croix, Jacques Hubert, $27 \mathrm{I}$

Lacroix, Olivier, 255 ; estate of, 256

La Cuillerier, Sieur, 237

La Deroute, 208

Lady Prevost, vessel, I34

Lafont, M. A., letters of, 244,255

La Forest, Sieur de, 207, 2 I I

Lagarde, $A b b e ́$ A. T., charge to, 227

La Gauchetière, Migeon de, grant to, 209

La Gorgendière, commission to, 2 II

Laidlaw, Walter, reports on Ontario archives, I50, 273

Lakes, see Great Lakes

La Marque, journey of, 2 ro 
Lamoille River, 216

Lamothe, G., letters of, I8, I08, I09, 190, 212

La Mothe-Cadillac, Antoine de, 219, 220 ; grants made by, 208; papers of, I5I

Lanark County, Ont., history of, II4

Land, claims, I22; crown, I23; grants, 19, 39, $44,148,257$; records, 215

Land boards, appointments to, 95

Land Books, 32

Landrière, Monsieur, commission to, 214

Langan, Lieutenant, correspondence of, 107

Langdon, letter of, 298

Langevin, $R e i$. A., letter to, 237

Langlois, Father Louis Antoine, 255, 256, 257, 259 ; conduct of, 264 ; correspondence, 239 , 258,265 ; departure to the Columbia River, 234; will of, 258 ; see also Bernard, Father

Lansdowne collection, I80, 193

Lapointe, Augustin Simon, 22I

La Poterie, Father de, 252; letters of, 25I

La Prairie, port of entry at, 100

Larissy, 249

Lark, H. M. S., I46

Larkin, Father J., letter to, 235

La Rochebeaucour, correspondence, I35

La Rochelle, letters of, 222

La Ronde, Sieur de, memoir given to, 213

Lartigue, Bishop Jacques, letters to, 229, 230

La Rue, $A b b \dot{c}$ P. de, letters to, 236

La Salle. Robert Cavelier, Sr. de, 220 ; assassination of, I92; journal, I46

La Semaine Religiense, 249, $25 \mathrm{I}$

Launceston, H. M. S., I46

Laure, Abbé, 225

Laurent, Abbé Nicholas, letter to, 236

L'Aurent, Pierre, grant to, 209

Lauzon, François, 208

Laval, Bishop (François X.) de, appointment of, 225 ; letters of, 269,270

La Valinière, Father Pierre H. de, 245 ; letter of, 244

Laval University, archives in, 224

Lavanchy, correspondence, I47

La Verendrye, Pierre Gauthier, Sr. de, journal of, 105

Lavine, 257

Law-officers, letters of, I69

Lawrence, of Boston, correspondence of, 59

Lawrence, Abbott, protocol signed by, 57

Lawrence, Gov. Charles, correspondence, Igs; despatches, II9, I99

Lawrence, Capt. Charles, instructions to, 23

Lawrence Collection, ix

Leather, sce under Trade

Le Barroys, Sieur, requests of, 207

Lebel, $A b b e ́$ A., charge to, 227

Leborgne family, documents concerning, I3 8

Le Breton, J., letter of, 293

Le Clair, Reverend, letters of, 260

Le Dru, 24I ; letter to, 245

Lee, Rcv. Jason, 262

Leeds, memorial from, 65

Lees, John, letters of, I8, I9

Le Gardeur. Charles René, grant to, 209; suit against Robert Germain, 212
Le Gardeur, Philippe René, land grant of, 216

Leland, Waldo G., 205 n. : Guide to the Materials for American History in the Archives of Paris, $18 \mathrm{I}$

Le Marchant, Sir Gaspard, correspondence, 59, 198

Le Messurier, P., memorial of, 299

Lemoine, Charles, 22I

Lenoir, Vincent, $2 \mathrm{I} 3$

Lent, law concerning, 228

Leonard, George, letters of, I38, I39, I42

Leonard, Thomas, grant to, 204

Leopard-Chesapeake affair, $\mathrm{I}_{42}$

Lesieur, Augustin, 22I

Lesieur, Joseph, 22I

Lestrée, $A b b \dot{e}, 225$

Letourneau, Philippe, 220

Le Trompeur, 220

Letters, episcopal, 225; of marque, 64, 139

Levadoux, Abbé J. B., character of, $24 \mathrm{I}$; correspondence, 23I, 236, 237, 242

Le Vasseur, Sr. Nicholas René, lands for, 209, $2 \mathrm{I} 7$; order to, $2 \mathrm{I} 4$

Leveillé, journey of, 210

Lévêque, $A b b e ́$ Z., $25 \mathrm{I}$; charge to, 227 ; letter to, 238

Levies, I I9, I20

Lévis, Duc de, correspondence, I35

Lewis. Andrew, memorial, ing

Library of Congress, $28 \mathrm{I}$

Licenses, arming, 297; fishing, 86; form of, 292, 293

Lighthouses, remarks on, 97

Lincoln, Abraham, assassination of, $67,77,86$

Lindsay, Abbé Lionel St. G., 22.4 n., 225 n., 226

Lindsay, William, letter of, I 78

Liquor traffic, see Trade, spirits

Liston, Robert, letters of, I9, I79

Litchfield, H. C., letter of, 82

Literary and Historical Society of Quebec, documents of, $221-223$

Little Belt, vessel, 145

Littlehales, Major, letter of, I8

Livaudière, Sicur de, grant to, 209

Liverpool, letters of, 39 , I 96

Live stock, 259; buying of, 16; duties on, 93; exports and imports, $16,28,49,76,94,97$, $98,170,171,292,298$; horned, 78

Llama, ressel, 282

Logs of British fleet, 146

London, archives in, 2I8; letters from, 222; State Paper Office, I93, I94; transcripts from, I54-I74

Long Point, Lake Erie, I74

Long Sault Islands, navigation, 40; regaining of, $7 \mathrm{I}$

Longueuil, Baron de (Charles Le Moyne), 221 ; land grant, 217

Longueuil, Que., patent of barony, I35

Loras, Bishop Mathias, correspondence, 234, 235,268

Lord Stanley, vessel, 200

Lorimier, Charles de, interpreter, i8

Loring, Robert, letters of, Ioo

Loschi, chief, I52 
Lotbinière, de, 2 I I, 2 I 2

Loudoun, Earl of, correspondence, I I5, II6, I 7 ; despatches, I 6 , I I7, I23

Louisburg, N. S., capitulation, 123, 195, 199; despatches relating to, I20, I95; expedition against, II 5, I I6, I46, 274

Louisiana, 207; account of, I20; cession of, I2O; documents on, 34, II9, I20, I22, I5I ; faculties for, 227, 236, 243; missions, 242; religion in, 257; Spanish occupation of, 224; Spanish rebels in, 24I; trade, 208; united with Illinois, 208; Upper, episcopal jurisdiction in, 240

Louisiana Historical Society, French manuscripts of, I 5 I

Louvre, Bibliothèque $\mathrm{du}, \mathrm{I} 92$

Loyalists, 32, I I4, I 25, I26, I 38 , I4 I, I 53 , I 54, I 56 , I78, I98, I99, 200, 20I, 274; accommodation of, 95 ; at St. Johns, Que., I25; at William Henry (Sorel), 2o; boards furnished to, I99; claims, I45, I 54, 273; commissioners, I36; correspondence, I2; data, 204 ; immigration of, I98, I99, 202; in Capt. Robert Wilkins's company, I35; in New York, I 27 ; in Prince Edward Island, 87 ; instructions respecting, I45; land for, IIo, 176 , 273 ; lists, 33, I80, 202 ; memorials of, 21 ; muster-rolls, 202 ; petitions, 22, 200 ; return to Canada, I27 ; settlement of, I95; surveys for, 203; United Empire, papers on, 176

Loyal Rangers, officers, I26

Lucas, Simon, letter of, 207

Ludlow, G. G., letters of, I38, I39

Lumber, importation of, Igs

Lundy's Lane, battle of, 26 ; see also Niagara

Lusignan, correspondence, I35

Lutwyche, E. G., letters of, I39, I.to

Lyman, Maj.-Gen. P., correspondence, I47, I8I Lyons, Bridget, license to, 293

Lyons, Lord (Richard Lyons), despatch from, 89

Lyons, Central Council of, 260

Lytton, Baron (Edward George Earle Lytton Bulwer), correspondence of, $61,62,88,89$

MacArthur, Brig.-Gen. Duncan, raid from Detroit, 27

Macaulay, John, letters of, 32, 173

Macaulay, W., letters of, I37, I48

Macbean, letter of, 294

McClure, Lieutenant, arrest of Kelly, 5I

McCrery, Lieutenant, account of capture of the Boxer, I34

McDonald, Archibald, 282 ; letters of, ${ }^{2} 2$

McDonald, John, letters of, Igo

McDonald, M. de Léry, 28

Macdonell, John, case of, 46

McDonell, Lieut.-Col. John, letter of, I5

Macdonell, John, of Ft. William, letters of, II2

Macdonel1, Maj. Miles, correspondence of, II2; expedition against the Americans, II

Macdonnell, Bishop Alexander, sketch of the Glengary Highlanders, 106

MacDonnell, Sir Richard G., letter of, 87
McDouall, Lieut.-Col. Robert, letters of, 20, 26,27 , I09, III ; speech of, I79

McDougal, James, letters to, $28 \mathrm{I}$

McGill, James, letter of, I6, 20

McGill, John, papers of, 274

McGillivray, W., I58; letter of, 20; statement of, 89

Machias, Me., map of, I28

McIvor, John, 283

McKay, Lieut.-Col. William, expedition to the Mississippi, 20, I80

McKee, Col. Alexander, instructions for, I9I ; letters of, I8, I9, I07; papers, I06, I09

McKee, T., journals of, I79; letters of, I9, I79 MacKenna, Rev. John, letter of, 267

M'Kenney, Thomas, History of the Indian Tribes of North America, I63

Mackenzie, Alexander, at Navy Island, 42; death of, I52; escape of, I66; imprisonment, I64, I7I, I72; newspapers published by, 48 , I 68

Mackenzie, Roderic, letters, etc., of, I37

Mackenzie rebellion, 273

Mackinac, local disputes at, 20 ; register of Ste. Anne, I04; stores captured at, 24 ; see also Michilimackinac

McLean, Archibald, letters of, I66, I69

McLean, Capt. Hector, letter of, 19, 28

McLeod, Alexander, arrest of, I73; case of, 50, 51, 70, 75, 78, 79, 81, 82, 97, 99, 103, 173; expedition under, $I_{5} \mathrm{I}, \mathrm{I}_{52}$

McLeod, Angus, I77

McLeod, John, sr., journal and correspondence, 28 I ; papers, I I 5

MacLeod, Malcolm, I 54

McLoughlin, Dr. John, 259, 262, 282 ; conversion, 239; correspondence, 239, 26I, 265 ; information from, 258

McMahon, Father, 250

McNab, Sir Allan, conduct of, 47; letters of, 22

McNeil, Capt. W. H., 282 ; expedition under, I5I; letter-books, 282 ; voyages, 282

Macomb, Brig.-Gen. J., letters of, 26, I07

McQuade, $A b \dot{b} e^{2}, 232,249$

McTavish, Dugald, correspondence, I52

McTavish, McGillivray and Co., memorial of $2 \mathrm{I}$

McTavish, Simon, letters of, 275

Madawaska, 237 ; priests for, 256 ; register, I37; riots, I52; settlements, $43,44,80,8 \mathrm{I}$, I4I, I46, I65

Madden, Monsieur, 233

Madelaines, fisheries, 286

Maes, Rev. C. P., letter of, 245

Magaguadavic River, claim to, I86; survey of, I86

Magdalen Islands, I82, 287; American rights in, 293; report on, 292

Maguire, T., letter of, 247

Maidstone, ship, 291

Mail, see Postal matters

Maillard, Abbé, 225

Maine, IO3; actions of, I4I, I46; affairs in, I65; border outrages, 43 ; boundary, 4I, 44, I53, 
2I5; see also Boundary, Northeast; British operations in, 27, I35; Catholicism in, 250; differences with, I64; disputes with New Brunswick, I29; emigrants from, I45; encroachments by, 4I, 44, 80, I30, I3I, I4I ; land agents of, I4I ; legislature, 9I, I63; map of, I28, I92; military works in, 42 ; mission, 249, 250; naval operations in, I35; occupations of, 196 ; proceedings relating to disputed territory, 43 ; public documents, I3I, I32; survey of rivers in, 6I; trade, 140 ; troops in, 92 ; visitation in, 250

Maitland, Col. John, correspondence, 2I

Maitland, Sir Peregrine, letters of, 30, 97, I02

Malartic, letters of, I35

Malden, capture of schooner, 167

Malinda, schooner, 294

Malles, Jean Bte., grant to, 209

Mallet, 2 I 2

Nalou, Father P., 230, 253; faculties for, 254; intrigues against, 254 ; letter to, 232

Manach, Abbé, 225

Manilles, Bay of, inhabitants of the, 222

Manitoba, archives of, 276 ; census, I36; records of, I 50

Mann, Col. Gother, letter of, I6; Memoranda and Conjectures Relative to Part of the Boundaries, etc., 23

Manning, W. R., 28I

Manuscript Documents, Catalogue of, I93

Maps, I32, I37, I92

Marchand, $A b b e ́$ J. B., letter to, 236, 269

Marcoux, $A b b \dot{c}$ Joseph, letter to, 238

Marcoux, Abbé Louis, charge to, 227

Marcy, Gov. Wm. L., circulars from, 59; message, I49

Mareau, Joseph, 220

Maréchal, Archbishop (Ambrose), 267, 268, 269 ; bulls for, 249 ; letter to, 232 ; reception in Rome, 268

Maria, ship, 89,300

Marianne, ship, 296

Mariaucheau d'Esglis, Bishop Louis Philippe, letters to, 243

Maricadouy, River, land on the, 216

Maritime Provinces, 202; documents on, IO3, IO4

Markham, Ont., I I

Marmette, Joseph, investigation of Canadian history, 33,34

Maron, correspondence, I35

Marquette, diocese, 255

Marriages, 238, 239, 24I $242,243,244,250,258$; certificates, I I 4 ; mixed, $243,246,25^{8}$

Mars, ship, 296

Marsh, John, report of, I54

Martial law, I6I

Martin, sloop, 289

Maryland, 249; Amherst's suggestions, II9; boundary, I2I, I45; encroachments, I2I; indentured servants in, I 6 ; list of persons naturalized. I47; papers relating to, I33; settlers upon the Ohio from, I7

Mascarene, Gov. J. P., letter of, 195
Mason, Gov. Stevens T., attitude toward prosecution of Hastings, 49 ; letter of, 170

Massachusetts, I24, I4I ; arms, application for, 75 ; boundary of, 80, II $3,133,200$; charter of, 80 ; claim of, I39; encroachments by, I30; government, papers of, I94; land agents, I4I; list of persons naturalized, I47 ; map, I92; memorial from agent of, I94; plans to obtain men for army, 76 ; records, 202 ; subscribers for lands, 202

Massachusetts, steamship, 88

Massachusetts Historical Society, 146, 192

Massey, Eyre, letters of, 202, 289

Masson, L. R., Les Bourgeois de la Compagnie du Nord-Ouest, 28I

Masters, J., $28_{5}$

Mathews, $M a j$. R., diary of, 274

Mathews, Capt. Robert, letters of, Io7

Matignon, Fathcr, 249; letters of, 25 I

Mattingly, Mrs., 255

Maubec, Abbé, 225

Maule, Fox, letter of, I62

Maurice, 225

Mayrand, Rev. J. A., 229; letters to, 239

Mazeppa, vessel, 60, 94

Meares, Lieut. John, correspondence, 28I

Meloche, Pierre, 208; letter of, 2I3

Memehic River, 216

Memorials, military and provincial, I26

Memphremagog, Lake, 74 ; obstruction of, 96 ; overflow of, 96,97

Menou, Charles d'Aulnay de, see Aulnay

Mercantile vessels, United States, list of, I5

Merchandise, confiscation of, 212 ; duty on, 210 ; prices, $2 \mathrm{I} 8$; order relating to, $2 \mathrm{I} 3$

Merchants, petitions, I45; shipping, I34; society of, $294,295,296$

Mercier, Rev. F. X., letter to, 237

Mercier, François, 22 I

Mercier, $A b b e ́$ J. B., letter to, 236

Mercury, packet, $29 \mathrm{I}$

Mermaid, H. M. S., I46

Merritt, Hamilton, correspondence of, 60

Messenger, brig, 208

Metcalfe, Sir Charles, commission, I35; letters of, 7I, 93

Methodists, I74; influence, decrease of, 263 ; missions, 259, 263; preachers, 46

Meurin, Father P., 24I ; correspondence, 236, $242,243,241$

Neusnier, Jean, land grant of, 216

Mexican War, 93

Miami country, documents on, 27 I

Miami Rapids, council at, I79

Miamis River, Harrison's position at, 28 ; Procter's attempt at, 25 ; provisions found at, 27 ; see also Great Miamis

Miamis tribe, 24I

Michel, Sir John, despatches, 95, I83; letter of, 73

Michigan, IO3, 255; boundary, 74; British rule in, 27; Confederaie attacks on, 77 ; hostile preparations in, 22 ; imprisonment of Canadians in, 76 ; land, prices of, 72 ; relations of Upper Canada with, 20, 49 
Michigan, Lake, navigation of, I5, 68

Michigan Pioneer and Historical Collections, I 5 I

Michilimackinac, Mich., 222, 243, 244, 245; affairs in, I79; capture of, 25; church goods, $24 \mathrm{I}$; events about, 27, I20; garrison at, 27, 99; Indian affairs, I79; merchants, 213; notes on, 3I ; restoration of, 39; situation at, 25, 26; supplies, I6; see also Mackinac Michilimackinac Co., seizure of goods of the, I 77

Midland district, buying of cattle in, 16; disaffection in, I7I

Mignault, $A b b e ́$ P. M., letter to, 238

Military affairs, II7, I23, I24, I25, I46, I84, I98; correspondence, 23, 39, II 4, 202; despatches, I03 ; expeditions, I35; papers relating to, I4-3I; preparations for war, 24, I43; stores for British provinces, 64

Military posts, I2I, I25; attitude of Illinois tribes toward, I20; building of, II9; capture of, II8; events about, I20

Militia, bill, 64; Canadian, 40, I46; conduct of, 26 ; documents on, I80; United States, 40

Militia and Defense, Department of, 6 , I53, I8o

Miller, Garret, correspondence, I3I

Miller, I., 287

Milwaukee, Bishop of, letter to, 235

Mines, 260

Mingoes, details relative to, II

Ministère des Affaires Etrangères (Paris), records of, 34,180

Minnesota, Sioux Indians in, 76

Minnesota, brigantine, 57

Miscellany, 256

Missionaries, 239, 24I, 242, 259; correspondence, 225,239 ; distribution of, 266 ; relations with Hudson's Bay Co., 239; United States, I32

Missions, 34, 226-270; attitude of Hudson's Bay Co. toward, 265; Catholic and Protestant, 259, 260 264, 265; Indian, 252, 26I, 264, 266; Methodist, 259, 264, 265; Pacific, 265; property, 259; see also names of places

Missisquoi Bay, navigation on, 55

Missisquoi frontier, memorial, 55 ; outrages on, 4I, 43, 92, 97

Missisquoi River, 2I7

Mississippi, vessel, I98

Mississippi River, 222; British forces on, III Canadian traders on, I03; disorders along, 236 ; documents on, $27 \mathrm{I}$; explorations along, 273; exports from, I59; fur-trade. I2I ; information from, I9; navigation of, 157, 159; plan to remove Indians to, 20; Spanish and French posts on, I22; survey of, 99 ; trade on, 122,158 ; voyage of Capt. Gordon, I2I

Mississippi territory, 224; claims of British subjects, II 3 ; missions, 269,270 ; sale of lands in, I85; seizure of property, 99; trade, 207 ; traders, information through, I9

Missouri, fugitives from, 62 ; see also Louisiana Missouri River, Upper, explorations along, 273
Mitchell, John, map by, I28

Mobile, Ala., expedition to Illinois country from, I24; material on, I20; possession of, I20; registers at, 154 ; $34^{\text {th }}$ Regiment at, I3

Mocquier, François, land grant of, 2 I6

Moffat, H., letter-book, 282

Mohawk Indians, 136

Molasses, see under Trade

Molesworth, Sir William, letters of, 59, 88, 197

Monasteries, 257

Monck, Gov.-Gen. Charles S. R., correspondence, $72,73,76,77,87,94$; despatches, 73 , 95, 183; telegram, I7

Monckton, Brig.-Gen. Robert, despatches, II7; instructions to, I3; letters of, I35

Monk, J., case of, $22 \mathrm{I}$

Monk, Maria, 258, 262 ; calumnies, 250

Mondelet, J., letter of, I 78

Monforton, William, register of, I05

Monroe, James, letters of, $26,27,28,73$, I34, I35, $25 \mathrm{I}$

Montagnais Indians, 255

Montagu, Rear-Adm. John, letters of, 288, 289, 290 ; orders, 288

Montana, 280

Montauban, 249; letters of, 222

Montbeillard, letters of, I35

Montcalm, Louis Joseph, Marquis de, correspondence, IIO, I I7, I33, I35, 2 I 8

Montforton, 242

Montgolfier, Father, letters of, 266-267

Montgomery, $M a j .-G e n$. Richard, letter of, I56

Montreal, Que., 205, 206; archives of, 2, 5, 217, 27I, 272; Assembly, record of, I46; board of trade, 54, 59, 7I, 72; capitulation of, I, I 8,205 ; consul general, arrest of, 66; correspondence, 29, 222, 225; courts, 146 , 217,220 ; diocese of, 229-230 ; foreign merchandise in, 212 ; frontier, 39 ; government, 218; officers, I26; preparations at, 267; Prévoté, records of the, 217, 27I ; prisoners of war in, 3I; Prothonotary's Office, 27I ; registers, I05, I50; regulation of alien United States subjects, 24 ; roads to New York, 31; shipping, 73, 77, II4; state of, I65; United States customs at, 78; water connection with Lake Huron, 65

Montreal, schooner, 49

Moody, Lieut. James, narrative of, II I

Moore, Major-General, letter of, 297

Moore, Thomas, letters of, I63, I65

Moose Island, affairs at, I43; claims, II3, I74; military forces at, I43; right to occupy, I43; situation at, I44; surrender of, 26,27 , $\mathrm{I} 35$; to be given to the United States, 30

Moran, Jacques Campaux, père, 208

Moravian Indians, I36

Moraviantown, Proctor's defeat at, 25, 26

Mordaunt, Sir John, expedition against France, II6

Morgan, Thomas, letter of, 147 ; settlement of boundary dispute, 45

Morier, J. P., letter of, 178

Morin, Jacques, I92, 220

Morin, P. L., collection of maps, I92 
Mormons, immigration of, 60,88

Mornay, Bishop Louis François de, letters of, 269

Morrill's bill on trade relations, 78

Morris, Gov. Robert H., I98

Morse, Col. Robert, General Deseription of the Province of Nova Scotia, I33

Motz, Henry, 275

Mount St. Mary's College, 252, 253

Mowatt, Commander, R. N., letter of, 292

Muir, Major, letters of, 24,25

Muir, M., letter of, 200

Munro, W. B., The Office of Intendant in New France, 2II ; Seigniorial Régime, 215

Murdock, George, diary, I50; letters of, 70 , ror

Murray, Alexander Hunter, journal, I5I; letter of, 283

Murray, Lieut.-Gen. Sir George, letters of, 16, $4 \mathrm{I}, 46$

Murray, Lieut.-Col. J., letters of, 25

Murray, Maj.-Gen. James, correspondence, I Io; despatches, II7, II9; order-book of, 222

Murray, Maj. Patrick, 242; letters, I07, 236

Murry, Lientenant, 288

Musgrave, Sir Anthony, letters of, 9I

Muskets, see Arms

Muskingum, council at, 189

Muster-rolls, I25, I46

Mutiny Act, I2I; effect at New York, I24; 46th section of, 57

Myers, Lieut.-Col. Christopher, letters of, 24, 27

Nagot, Rev. François C., superior of seminary at Baltimore, letter of, 246

Nantucket Island, I35, 282; inhabitants, I35

Napier, Capt. Henry E., letter of, I40

Natchez, Miss., settlements, 147

National Intelligencer, Baltimore, Md., I43

Naturalization, 147; remarks upon, 46

Naturalization Act, convention under, 85

Naval forces, I34, I35

Naval officers, returns, I23

Navarre, Robert, 213, 2I4; land grant of, 216

Navigation, I22, I60, I99; laws, 60, 74, 75, 79, I 45, I 47, 287, 298, 300 ; rights, 88

Navy Island, I6I: Americans and insurgents on, 47; expulsion of pirates from, I67; forces at, 47; Mackenzie at, 42 ; possession of, I66; proposed attack upon, I67; rebel position at, 2I

Neckere, Bishop A. de, letter to, 233

Needham, Peter, case of, 66

Negroes, 196, 201, 202; disposal of, 50, 94, II3; emigration of, $62,79,93$, I02, I73; increase in western district, 98 ; laws relating to, 62; plans for sending to Jamaica, 94: refugees, I97-I9S, 20I; surrender of slaves, I66: use of in war, $5 \mathrm{I}$; see also names of places

Neilson, John, letter of, II3; papers. III

Nepean, Evan, correspondence, 28I

Nesqually, Bishop of, 230

Nesqually, 261, 264. 279, 282; missions at, 258

Nesqually House, 283
Netherlands, King of the, I3r; award of, I30; decision on boundary question, $4 \mathrm{I}$

Neutrality, circulars on, 67 ; bill, 163 ; breaches of, 94,95 ; instructions on, 64,89 ; interference, 274 ; laws, 9I, 99, II3; queen's proclamation, 63 ; treaty, 207

New Brunswick, archives, 147, 204; attorneygeneral, report of, 200 ; boundary, 40, 4I, 44 , I3I, I40, 153, 186; claims of, 69 ; depredations by inhabitants, I4I; disputes with Maine, I29; documents on, 56, I3I, 202; effect of war upon, 139; encroachments upon, 4I, I4I, I96; fisheries, 58 , I46; governors, 145, I46; imports and exports, ix; Indians, I9; land grants, I53, 204; legislature, 8I, I39; lieutenant-governor, $35,36,81$, I3I, I46, I 47, I53; military occupation of, 43: papers concerning, I37, I38, I53; plan of, I 28 ; provisional secretary, correspondence, 200; road from the St. Lawrence River, 40 ; surveyor-general, letter-book of, I53; trade, 55, I39, I40, I45, I96; vessels, admission of, I4I ; warrants of survey, I54

Newcastle, Duke of (Henry Pelham Fiennes Pelham Clinton), correspondence, 58, 62$66,83,84,88,89,90$

Newcastle district, disaffection in the, I7I; fugitives from, 9 I

New England, 287; feeling in, I43; fisheries, I59; fur-trade, 21 3 ; immigration from, I95; land, I94; order forbidding persons to go to, 2II: railway connection with Canada, 57 ; religion in, 253 ; seafaring people in, I59; traders, I36, I45; troops, I45, I95; Ursulines in, 252; see also the names of states

Newfoundland, 224; admiral-governor, correspondence of, 285; archives of, 284-301; bibliography, 285; Colonial Building Library, 284; Colonial Offices, 284; Colonial Secretary's Department, archives of, 285 ; court records, 285 ; defense of, 291 ; Department of Agriculture and Mines, archives of, 284; Department of Justice, archives of, 284; dependence on Vermont, 294; documents on, 34, I33, I8I, I82 ; emigration from, 293; Finance and Customs Department, archives of, 284 ; fisheries, 58,285 , 290, 299; Government House, archives of, 284; governor, 36, 46; House of Assembly, Joumals, 284, 285; Legislative Council, Journals, 284; lieutenant-governor, despatches of, 87 ; merchants, letters of, 295 ; non-intercourse bill affecting, 294; ports closed, I96; Post Office Department, archives of, 284; Prime Minister's Department, archives of, 284 ; provisions, 38 ; Public Works Department, archives of, 284 ; report on, II5; strangers forbidden in, 297; Supreme Court, archives of, $28_{4}$; vicar apostolic of, 249; volunteer corps, 290 Newfoundland, History of, Prowse, 285

Newfoundland Gazette, 295

New France, see France, New 
New Hampshire, authority in Indian Stream settlement, 4I, 96; boundary, 176; Catholicism in, 250; citizens of, IO2 ; convention, I5O; encroachments, I30, I3I ; governor, attitude of, 74; map, I92; papers relating to, I33; politics, I95; relations with, 27; trade, I45

New Jersey, Iı6

New Orleans, Bishop of, letters to, 232, 235

New Orleans, La., I59, 224, 257; Canadians in, 248; Capuchins and Ursulines in, 242, 243; faculties, 242,248 ; fur-trade, I2I ; provincial council at, 257

New South Wales, supreme court of, 6r

Newspapers, I49, I6I, I63

Newton, Captain, report, I35

New York, Bishop of, 228, 230, 249; letters to, 232, 235

New York, Documents relating to the Colonial History of the State of, 218

New York (city), account of fighting about, I06; British consul at, $43,149,162$; cathedral in, 249; minutes of council, I48; troubles in, 246

New York (state), 103, 124, 249; boundary, I76; Catholic diocese, 252; clergy, 253, 254; faculties, 227, 238; governor's proclamation, I57; head tax report, 70; hostile preparations in, 22; indentured servants, II6; insurgents, 22, 42; list of persons naturalized, I47; loans from, II8; map, I92; papers relating to, 133 ; plans for attacking Canada, 93 ; priests in, 252 ; purchase of islands in Niagara River, 30 ; refusal of arms to, 63; roads from Montreal, 3I ; schism in, 254; State Library, 255 ; trade, 84 ; treaties, I8; troops, I45

New York and Erie Canal, enlargement of, 65 Nez Percés, Ida., expedition, I5I

$\mathrm{Nez}$ Percés Indians, Presbyterian success among, 263

Niagara, Fort, see Fort Niagara

Niagara, N. Y., actions along the frontier, 26, $27,29,184$; Amherst's suggestions regarding, IIg; boats to be sent from Montreal, I4; British defense of, 26; commanding officer at, 14; distress at, I4; expedition, I23; general sessions, I77; Indians at, I09; meeting of tribes at. I Io; men poisoned at, I4; movements against, II8; notes upon, 3I; protection against the United States, 49

Niagara Falls, canal around, 67; description of, III

Niagara River, bad condition of boats, I4; commissariat matters along, 16 ; purchase of islands in, 30

Nichol, Lieut.-Col. Robert, report of, 26

Nicholson, Gov. Francis, I45; commission, 194; letter of, I94

Night watches, organization of, 295

Noiseux, History, 255

Nootka, inhabitants of, 222

Nootka Sound, controversy, 279, 28I

Nordiska Vänskapen, ship, 293
Norfolk, Va., British consul at, correspondence, 162, 197, 274; church in, 254

Normanby, Marquis of, despatches, 49 ; letters of, 43,49

Norta, Capt. John, 296

North, Lord (Frederick North), correspondence, 202

North America, exports and imports, I33

North American, Baltimore, Md., I43

Northay, J. M., letter of, 294

North Caledonia, missions, 264

Northeast Boundary, see Boundary, Northeast

Northwest Boundary, see Boundary, Northwest

Northwest Coast, by H. H. Bancroft, 280

Northwest Coast, history of, 283

Northwest Company, 220; account of, I37; affairs of, 275

North Western Navigation and Railway Co. of Canada, conveying of mails, 62

Northwest territory, 255, 277; correspondence relating to, $2 \mathrm{I}$

Norton, John, letters of, 20 , I9I

Norway House, journey to, 282

Notarial records, 219

Nouvelle France, Manuscrits... relatifs à l'Histoire de la, $2 \mathrm{I} 8$

Nova Scotia, 204; actions against United States fishermen, I96; affairs of, 194; archives, I45, I93-203; arrest of United States citizens, 80; assembly, journals and papers, 136, 20I ; boundary, 194, 200; census returns, 203; commercial relations, 20r ; correspondence, r37; Council, 136,198, r99, 200 ; court of vice-admiralty, 203 ; descriptions, I33; despatches of governors, I95; documents relating to, 35, 193-203; embargo of the United States, I44; fisheries, 58, 142, I46; French in, 199; governors, 145, I94, 201, 296; history of, 202 ; immigration to, 145 , I95; imperial orders relating to, 201 ; instructions, I45; invasions of, 202 ; land matters in, 187, I94; legislative council, journals, 136, 200; lieutenant-governor, correspondence of, $24,35,36,196,197$; map of ancient, 80 ; military preparations in, 195; negroes in, 203; New England troops in, 199; northwest angle of, I28; organization in, 77 ; plan of, $\mathrm{I} 28$; proclamations issued in, 2or; Public Records of the Province of, 193; reciprocity, 58, 91 ; records, 3 ; refugees in, 195 , 196, 205; regiments, enlistment in, 293 ; state papers, 136 , 138 , 142; survey of rivers in, $6 \mathrm{x}$; surveyor general, instructions from, 203 ; townships of, 202 ; trade, 58, I39, I42, 145, 196, I97, 199, 294; union with Cape Breton Island, r38; union with the United States, 78; Volunteers, 288; withdrawal of troops from, I22

Nova Scotia Historical Society, 193, 202

Nova Scotia Technical College, I93

Nugent, special agent of the United States, 90 ; report of, 89

Nuns, 239 
Oahu, 282

Oblates, 256, 257

O'Callaghan, Dr. E. B., letter to, 235

Odelltown frontier, fires on, 92

Odin, sce Audin

O'Donnel, L., letter to, 236

O'Dwyer, M., letter to, 235

Office of Intendant in New France, W. B. Munro, 2I I

Ogden, C. J., letter of, 293

Ogden, J., letter of, I 78

Ogden, Peter Skene, correspondence, I52, 283 ; trading expedition under, I 5 I

Ogdensburg, N. Y., as a Fenian centre, I5; British at, 25; expedition against, II2; vessels built at, 64,94

Ogden's River, I5I

Ohio, I03; boundary, 74; enmity against Upper Canada, 49 ; expedition against, 274; grant, I 47 ; hostile preparations in, 22

Ohio River, possession of the, II ; settlement on, I4, I7; voyage of Capt. Gordon, I2I

Oil, I59

Okanogan, Wash., I5I, 279

Olive Branch, 103

Olivier, D., letter to, 245

Onondaga County, N. Y., patriot meeting in, 50

Onondaga Indians, 136

Ontario, archives, I50; documents relating to, 273; land purchased in, I54; see also Canada, Upper

Ontario, Lake, 218; ascendancy on, 45 ; British vessels on, 26; canals to Albany and Montreal, I6; islands in, 4I ; manœuvring on, 25,26 ; naval forces on, I34, I35; plan to remove Indians from, 20; trade on, 212 ; vessels on, I5, I73

Orders in Council, 6, 7, 8, 9, 32, I88, I89

Ordnance Department, Canadian, correspondence, 126

Ordres du Gouvernement d'Angleterre, etc., 253

Oregon, I29, I30, I3I, I32, 265, 272, 279; boundary, 6o, 282; Catholicism in, 260, 266 ; conditions in, 265 ; episcopate for, 266 ; expedition to, 282; faculties, 248 ; Indian war in, 283; information concerning, 70, 7I, 93, I52; maps, 52; missions in, 258266 ; priest for, 264 ; province, 259,260 ; report on, 282 ; route to, 266 ; settlers in, I 32 ; vicariate in, 252 ; see also Columbia River Region

Oregon, by H. H. Bancroft, 280

Oregon City, Bishop of, 228; circular from, 227

Oregon City, 264

Orphans' Aid Society, 254

Oswald, Richard, correspondence, ix, I8I, I82I 83

Oswego, N. Y., burning of vessel at, I73; capture, 26 , II6; correspondence of officers, I26; British vice-consulate at, 76 ; Canadian express agent at, 55 ; expedition to, II6; killed and wounded at, I.35; military project at, II6; situation at, 32 ; vessels built at, 64

Oswego Canal, enlargement of, 76

Ottawa, Ont., II4; archives at, I-I92, 2I I, 2I4, 2I8, 279; made permanent capital, 3 ; transcripts from, I93

Ottawa Fifty Years Ago, II 4

Ottawa Indians, 136; speeches, 19, 126, 189

Ottawa River, canal connecting Lake Huron with, 65

Ottawa valley, commerce of, 72

Otter Creek, 216, 217

Oudiette, Nicolas, 207

Oumas, 2 I8

Outlaw, John, 220

Ouynouski (Winooski) River, 216

Owen, David, letters of, I40; petition of, 139

Owen, Commodore G. W., circular to captains of British vessels, $2 \mathrm{I}$; letter of, 2 I

Pacific Mail Steam Ship Co., 89

Page, Mrs. Maria, pass to, 295

Page, Thomas Otway, exploits during war, I6

Painchaud, $M$., letter of, 252

Pakington, Sir John Somerset, see Hampton, Lord

Palliser, John, Act of, 287 ; orders, 286, 287

Palmerston, Lord (Henry John Temple, third Viscount), claims against United States, 49; correspondence, I32; despatches, 44, I30, I3I; legal report sent to, 47 ; opinions, 44, I66; protocol signed by, 57

Pambrun, P. C., letter of, 266

Pamphlets, transmission from United States, I 49

Panet, Archbishop (Bernard Claude), correspondence, 250, 252, 253, 254, 255, 270

Panis (Pawnees), 2 I I

Papal bulls, 225

Papineau, Louis J., aid given to, I02; correspondence, 43 ; negotiations, 74 , I64; obtains rifles, 174

Papineau-Neilson papers, 149

Paragon, vessel, 282

Paris, archives in, 218; letters from, 222; transcripts from, 4, 33-34

Paris, Guide to the Materials for American History in the Archives of, 33

Parish registers, I03

Parkman collection, I46, I48, I92

Parliament (Canadian), acts of, 201 ; library of, I92; petition relative to collection of public records, 3

Parliament, Catalogue of the Library of, 34, 192

Parliamentary papers, English, I32

Parr, Gov. John, I45; letters of, 198,202

Parrtown, N. B., lots in, 204

Parsons, Catherine, letter of, 207

Pasley, T., letter of, 290

Passamaquoddy Bay, boundary, 200; islands in, 30, I I $3,128,135,139,140,144,185,187$, 200 ; situation in, It+

Passamaquoddy Indian mission, 248, 249, 252 
Passports, for British subjects, 64; regulations, $67,76,77,79,87,94,103$

Patriot, New York, 149

Patriot organizations, decline of, 79 ; intentions against Canada, 50; reports concerning, 75

Patriots, I68, I69; attack on Lake Erie, 70; meeting in Onondaga County, N. Y., 50; proceedings of, 82, 172; see also Rebellion of $1837-1838$

Payet, Father, 24I ; letters of, 242, 245

Peacock, sloop, I84

Pean, Hugues Jacques, grant to, 209, 216

- Pearson, Licut.-Col. Thomas, letters of, 24

Pecaudy, François Antoine de, grant to, 209

Pecaudy, Pierre de, grant to, 209

Peel, Sir Robert, correspondence, 39,58 , I 36

Peel's River, 283

Pecrless, steamer, 63, 94

Pelée, Pointe, 22I

Pellegrin, letters of, I35

Pelletier, François, order respecting beavers, $2 \mathrm{I} 2$

Pelly, Sir John, 282

Pelly, J. W., correspondence, 152

Pemberton, Augustus, diary of, 283

Pembina, Dakota Ty., II4; military garrison at, 2I

Peñalver y Cardenas, Bishop, 224

Pennsylvania, Amherst's suggestions, I19; attitude of legislature toward colonial struggle, 10; boundary, I21, 145; documents on, I82; encroachments, I2I ; immigration into, I2I; indentured servants in, II6; loans from, i 18 ; list of persons naturalized, i47; papers relating to, 133 ; troops from, 145

Penobscot River, 5I, 78

Pensacola, Fla., fortification at, 122 ; 35th Regiment at, I3

Pentagouet, 216

Pepperrell. Sir W., letters of, I I6, 195

Perley, Moses H., British commissioner, correspondence, ix, 62

Perrault, procureur, 22I

Perrault. Quebec merchant, letters of, 222

Perry, Com. Oliver Hazard, 198 ; victory on Lake Erie. 26

Peterson, Captain, 298

Peters, John, jr., survey by, I86

Philadelphia, Bishop of, bulls for, 249

Philadelphia, Pa., British consul at, letters of, 274; British minister at, letters of, I43; Catholics in, 249; diocese, 248; collection for, 252; episcopal succession in, 246; faculties, 227; pamphlets, 268; troubles in, 246; trustees in, 252, 254, 269; Ursulines in, 252

Philbricke, James, 220

Philipps, Go\%. Richard, I45; letter of, I94

Philipsburg, raids at, I77

Philis, 208

Phillibert, sexton, letter of, 244

Phillips, Isaac, bond, 287

Phillips, Wadsworth, commission of, 27

Philpotts, Licutenant-Colonel, report concerning Welland Canal, 43
Phips, Lieut.-Gov. Spencer, correspondence, 199

Picard, Antoine, journey of, 210

Pichon, papers, I47

Pickering, Timothy, letters of, I8, 143, 179; speech of, 18

Pickmore, Gov. Sir Francis, 285 ; letters of, 298

Picquet, mission of, 269

Pièces d'Ecriture de toutes sortes, 220

Pierce County, Wash., 282

Pierre, Jacques, land grant of, 217

Piers, Harry, I93

Pigeon River, encroachments of U. S. on, 94

Pillet, Ignace, 221

Pinkney, Col. Ninian, letters of, 26

Pinney, letter of, 29I

Pinson, letter of, 300

Pirates, expulsion of, 167

Pitch, see under Trade

Piteasewa, speech of, 189

Pitt, William, earl of Chatham, raising of troops by, 119

Pittsburgh, Pa., despatches relating to, I20

Pin, Sr. J., 237

Pius IX., letter of, 255

Placentia, Newfoundland, $284,287,288$

Planta, Joseph, letters of, I4I

Plantation captains, 287

Plantation crews, lawlessness of, 286

Plantations, boundaries, 136 ; correspondence, 285

Plaster of Paris, see under Trade

Plattsburg, British raid upon, 25; expedition, 20 ; losses at, 16

Plessis, Archbishop (Joseph O.), 211 ; charges to, 227; death of, 250; Journal d'un Voyage en Europe, 228, 245; letters to, 245, $246,247,248-258,267,268,270$; memoir to, 254 ; testimony of, 254

Pluto, ship, 293

Poinsett, J. R., letters of, 163

Pointe Coupée, I47

Pointe de la Chevelure, victory at, 105

Pointe Pelee Island, Americans captured at, 48, 167; United States sympathizers at, 161

Pole, W. W., letter of, 143; license of, 293

Police matters, 210

Politics, 39, I13, 159

Polley, John, journal of, 154

Polly, schooner, 301

Pontbriand, Bishop (Henri Marie du Breil de), letters of, 269

Pontiac, conspiracy of, 10, I19, I20, 178; council with, I8I

Pontiac War, I05

Pork, see under Trade

Port Angeles, British steamer at, 89

Porter, Asa, 220

Porter, John, letter of, I4I

Port Huron, fugitives from justice at, 65

Portland, Duke of (William Henry Cavendish Bentinck), letters of, 45, 103, 293

Portland, Me., British consul at, correspondence, 42, I3I, I53; catastrophe, 256 ; diocese, 255 
Portland, ship, 29I

Portland-Montreal railway, 53

Port regulations, 8I

Port Royal, capitulation of, I94; expedition, I45. I94; registers of, I04; siege of, I94; see also Annapolis

Portugal, trade with, I34

Postal matters, I37, I48, I49, I97, 198, 200; arrangement of $\mathbf{1} 849,72$; between England, Canada, and the United States, 53, 55, 56, 6I, 62; British Columbia, 90; colonial correspondence, II5; contract between Canada and the United States, I48; correspondence on, 62; Heriot's account, I49; improvements, I48; mail routes, 2 I, I 49 ; rates, 69 ; refusal to carry mail, 91 ; service from California to British Columbia, 67, 89, 90 ; with San Francisco, 90

Postmaster General, letter from, 6I ; report of, 69

Post-office, Canadian, I48; General, convention of, 69 ; letter from, $6 \mathrm{I}$

Posts, see Military posts

Post Vincennes, see Vincennes

Potash, see under Trade

Pothier, Toussaint, observations on capture of Michilimackinac, 25

Potier, Father, 260; estate of, 242; letter of, 242

Potomac River, British expedition up, 25

Potter, John F., 66

Potts, William, communications from, I07

Pouchot, letters of, I35

Powder, purchase of, 99

Powell, Mrs., letters of, 274

Powell, Judge W. Dummer, 242; collection of, 275 ; letter to, 236

Power, Father, letters of, 254

Power, John, letter to, 232

Pownall, John, I92

Pownall, Gov. Thomas, correspondence, II7. I 47, I99

Poynter, Rev. William, 229; letters of, 267-269

Prairie du Chien, news of. I79: Robert Dickson at, 20 ; see also Fort McKay

Preble, William P., protest against boundary decision, 4I

Preish, Rolland, 220

Prentice, Capt. Charles, journal of, 275

Prescott, Ont., attacks on, 2I, 22, 43, 49, I 49 , I6 г, I69, I77; steamer fired on at, I72

President of United States, message to Congress Dec. 3, I838, I63; proclamations, I63. I69; speech of, 189 ; see also the names of presidents.

President, vessel, I45

Preston, Capt. Thomas, trial of, I22

Prevost, Sir George, agreement relating to prisoners, I77; letters of, $26,29,96$, I09. I I0, I34, I35, I43, I44-I45; Plattsburg campaign, 29; proclamation to United States citizens, 3I ; speech of, I9o; trade instructions, I45

Price, David, letter of, I9
Priests, 257; Canadian, 256; dearth of, 255; in Boston and New York, 25I, 252

Prince, Colonel, case of, I72; conduct toward prisoners, 49, I70; report of, I69

Prince Edward Island, 274; address to the queen, 83 ; archives, I45; assembly of, 63 , I 37 ; bonds on shipments to, 87 ; breadstuffs imported, 69 ; defense of, 82 ; documents relating to, ix, 35 , II4, 202; drilling of fugitives in, Ior ; Executive Council, minutes of, I 37 ; fisheries, $58,69,83,85,87$; governors, commissions to, I46; Legislative Council, journals of, I37; legislature, 87 ; lieutenantgovernor, 36, 86; Loyalists in, I I4; orders relating to, 36 ; parliamentary publications of, 36 ; reciprocity, 58,84 ; shipping in ports of, 83 ; state papers, I37, I4I ; trade, 83 ; vice-admiralty court of, 83 ; visit of committee of United States House of Representatives, 84 ; wreck of British vessel at, 42

Prince Society, i I5

Prineess Elizabeth, ship, 298

Princess Mary, H. M. S., I46

Princess Royal, ship, 296

Principes de la Langue des Sauvages, 255

Pring, Capt. Daniel, letters of, 26,28

Pringle, Chief-Engineer, steps taken to fortify places, 290

Prisoners of war, I26, I69, I70, 200, 29I ; at Fort William Henry, II7; at Montreal, 31 ; at Prescott, I70; at Quebec, 24 ; attitude of Americans, 39; at Windsor, I70 ; correspondence relative to, 23 ; exchange of, I25. I77, I78; execution of, 49 , I7 I ; held by Indians, 20, II3; Indian, 88; in Canada, 267 ; in Michigan, 76 ; list of, 31 , 96 ; naval, I34; pardon of, 49 ; pass for, 295 ; punishment of, I6I, I68; release of, 49, I7I; transportation of, I70; treatment of, 24 , 49,98 , I 56 ; trial of, 28

Privateers, I99; American, I I3, 288; destroyed, I34

Privy Council of Canada, orders of, $6,7,8,9$, $32,188,189$; papers of, 6-9

Privy Council of Great Britain, Committee of, see Trade and Plantations, Committee for

Procter, Brig.-Gen. Henry, attempt against Fort Stephenson, 25; attempt at the Miamis, 25; defeat at Moraviantown, 25, 26; defeat of Winchester, 29; letters of, 24, $25,26,27$; relations with citizens of Detroit, 25

Propaganda, Que., 260

Propaganda, Rome, 259 ; letter of, 268

Propaganda, Society of the, 259

Propagation of the Gospel, Corporation for, 20 Protestant college, 266

Protestants, 243, 259; calumnies, 258

Proteus, prison ship, 201

Proulx, Rev. L. A., letter to, 237

Provencher, Bishop (Jean N.). 232, 237 ; correspondence, $235,239,259,260,262$

Providence, 9th Regiment at, I3

Provinces, southern, I2.4 
Provincial Archives, $193-283$
Provincial forces, letter relative to raising, etc., I I

Provincial Marine, Records of the, 28

Provisions, importation of, 29, 38, I77, 295, 298; prices of, 296

Prowse, D. W., History of Newfoundland, 285 , 286

Prowse, G. F. R., 284 n.

Public Archives, see Canada, Public Archives

Public Archives Act, 7

Public debt, 158

Public Record Office (London), transcripts from 3, 4, I15, I34, I37, I54-174, I93, 194, 280,282

Puget Sound, fortification of, 90 ; railroad from Lake Superior, 60

Puget Sound Agricultural Co., affairs of, 152; claims, 282 ; historical manuscripts of, 282 ; origin of, $282 ; v s$. Pierce County, 282

Puhnan [Putnam], Hugh, 220

Puisaye papers, I33

Pulby, T. A., letters of, II3

Purcell, Archbishop (John B.), letters of, 255, 268

Pyke, George, 220

Quebec, Archbishop of, 224, 258, 269

Quebec (city), I04, 2I5; administrative records, 206; annual reports of the chief agent at, 81; archives of, I-2, I3, I50, 2I I, 224-270; bishopric, history of, 224, 224 n., 225 ; bishops, 262, 268; board of trade, 3I n., 32, 59, 64,72 ; churches, 148, 222, 243, 245; clergy, $226,227,236,252$; court of, 220 ; diocese of, 225, 226-227; English prisoners in, 21 ; evacuation by Americans, 226; expedition against. II7; maps, I38; Marine and Emigrant Hospital, 57; military council, I 6 ; missions, 255 ; provisions, 38 ; provost, IO3, I46, 217 ; relief of, I54; seminary, 225, 236, 242,244 ; sieges of, III, I46, I99, 222, 270 ; surrender to the English, 269; teacher for, $25 \mathrm{I}$; Ursulines in, 250

Quebec (province), 179; boundaries, I33; cession of, I83; civil archives, 205-223; Court of Common Pleas, I54; court records, 217; criminal registers, 206 ; crimping for United States service, 67; English régime, 205; French régime, 205; grants and warrants, I34; immigrants, 245; land records, 2I4; legislative council, minutes, I23, I54; map of, I92; militia, condition of, I47; minutebooks, 206; ordinances of, I78; political situation in, I76; proclamations, 178; Provincial Archives, 206-219; public records of, 205 ; registers, 206, 207; Secretary and Registrar, Report of the, 216, 217, 27I ; sovereign councils of, 206 ; trade, 16,40 , 106, 291, 295, 297; United States consular agents for, 64 ; Ursulines, correspondence, 228,229

Québec, Histoire du Palais Episcopal de, by Mgr. H. Têtu, $225 \mathrm{n}$.
Québcc, Mandements, Lettres Pastorales, etc., de, edited by Mgrs. H. Têtu and C. O. Gagnon, 225

Quebec Act, 1774, documents on, 133

Quebec and St. Andrews railroad, protest of U. S., $4 \mathrm{I}$

Quebec Land Book, 32

Quebec Literary and Historical Society, 2I7

Queen Charlotte, vessel, I34

Queen Charlotte Island, American adventurers at, 87

Queen's Rangers, 274

Queenston Heights, battle of, I78, I84

Quinte, Bay of, grant to Six Nations, 108

Quiquischeoubeugouet River, 216

Raby, Abbé Louis, letter to, 226

Radford, Gwyn Owen, memorial of, i7

Radisson, Pierre Esprit, journal of, II5; letters for, 207

Raids, border aggressions, 22, 67, 103, 164; in the United States, 73, 167; losses through, 49; measures respecting, 49; upon Canada, I68

Railroads, from Lake Superior to Puget Sound, 60; Pcrtland to Montreal, 53; Quebec to St. Andrews, 74, 97; United States transcontinental, despatch relating to, 60

Railways and Canals, Department of, concentration of documents recommended, 6

Raimbault, Pierre, commission to, $211,212,213$; land grant to, 209, 216

Raisin River, 184; battle at, 25 ; mission at, $24 \mathrm{I}$

Ramea Islands, 300

Rancourt, Sicur, 237

Randell, lawyer, 252

Randolph, E., letter of, I 36

Rappe, Bishop (Louis), letters of, 256

Rawson, R. W., letters of, IOI

Raymond, Archdeacon W. O., collection of, 127, I86; documents obtained from, I86; notes by, 186

Ready, J., letter of, I00

Réaume, Sr. Pierre, 218; land grant of, 217

Rebel Invasion of Canada, Minutes of the, 106

Rebellion of I837-1838, 6; aftermath, 97; attitude of United States government, 42 ; correspondence relating to, $2 \mathrm{I}$; documents on the, 166 ; in Upper Canada, 70; material on, 30; outbreak, I49; United States citizens in, 42

Rebellion Papers, I77, I78

Rebels, plots of, 22 ; route of, 14

Recherches Historiques, Bulletin des, 244, 245

Reciprocity, 183, I93, 200, 202, 203; bill to establish, 56 ; conference, 84 ; documents on, 93 ; negotiations on, $58,198,200$; promotion by Israel D. Andrews, 59; sentiment toward, 91 ; with Canada, 55, 56, 57

Reciprocity treaty, $63,64,66,67,71,72,76,78$, 87 ; abrogation of, 62 ; act to carry into effect, 58 ; agitation over, 62 ; correspondence relating to, 83,84 ; despatches relating to, 86.94 ; extension of $60,6 \mathrm{I}, 88$; instructions, I97; proclamation relative to, 58 ; remarks 
on, 59, 197; termination of, 68, 95; trade Rideau and Welland canals, documents on hisunder, 86 ; with United States, 84 ; work- tory of, 6 ; navigation of, 68 ; see also ings of, 72,94

Records Branch, see State, Department of the Secretary of, and Archives

Records of the American Catholic Historical Society, 248

Recruits, at Buffalo, N. Y., 60; for United States army, $63,66,67,94,95$, Ior ; for eigners, 59; from British provinces, 76 ; in the United States, 59, I97, I98

Redemptorists, 247

Redpath, answer to, 63

Red River, I5I, 239; journey to the, 260

Red River Journal, II4

Red River settlement, 47, 60, I87; annexation of, II 4 ; boundary, 60 ; census, I36; condition of, 64

Rees, William, letter of, $6 \mathrm{r}$

Reeves, John, Governor of Newfoundland, 285

Refugees, colored, I40; in Nova Scotia, I96; in the United States, 42

Registre pour les Arrêts du Roy, du Conseil Supérieur, Ordonnances et Congés, 210

Registres des Jugements du Conseil, 215, 216

Réglements des Limites, 34

Reid, Capt. H., letter of, 2 I

Reid, John A., 278

Religion, 147; ceremonies, 264; progress of, 258; state of, 256, 257; see also Missions and names of places

Religious orders, declaration of the king concerning, 209

Remigny, correspondence, I 35

Renwick, James, letters of, 82

Repealers, fusion with Hunters' Lodges, II3; invasion by, II3

Repentigny, Chev. de, correspondence, I35; land grant of, 217

Reprints of English works, 4I

Resin, see under Trade

Resolution, 289

Restook, see Aroostook

Retallach, Francis, letter of, Ior

Revenue cutters, for Great Lakes, 6I

Reymond, Tom, letter of, I7

Rhea, Major, company of, 108

Rhode Island, Amherst's suggestions, IIg; boundary dispute, II 3 ; papers relating to, I33; troops from, I45

Riall, Sir Phinehas, letters of, 26

Rice, letter of, 47

Richard, Edouard, investigation of Canadian history, 33

Richard, Father Gabriel, charge to, 227 ; correspondence, 232,247

Richardson, John, letters of, 20, 154, 176, 177

Richelieu River, 216, 218; navigation on, 55; plan of forts on, 2 IS

Riclimond, Duke of (Charles Lennox), governor-general, letters of, 96, 145

Richmond, H., letter of, I39

Rideau, Que., Methodist meetings, I48; registry of baptisms, $\mathbf{I} 48$

Welland Canal

Riel Rebellion, 276

Right of search, exercise of, 23

Rimini, Madonnas of, 253

Rio Grande region, 256, 257

Rivers, survey of, $6 \mathrm{I}$

Roberts, Capt. Charles, communications from, 25 ; letters of, $20,24,27$; stores captured at Mackinac, 24

Robertson, Daniel, letters from, I07

Robertson, J. P., 276

Robinson, Maj.-Gen. Sir Frederick P., letters of, 27

Robinson, G. R., application for letter of marque, 295

Robinson, Chief Justice Sir John Beverley, letter of, $\mathbf{I 7 2}$

Robinson, Thomas, 221

Robinson, Sir William C. F., correspondence, 86,87

Rocher, Louis Joseph, land grant of, 216

Rochers, Marsac des, 208

Rochester, N. Y., 53

Rochford, Earl of, letters of, I47

Rocky Mountains, 229; boundary along 49th parallel to, 60 ; missionary of the, 266

Roe, Capt. T., 296

Rogers, A. W., 283

Rogers, Maj. James, I25 ; corps of, 126, I27

Rolph, Dr. Thomas, letters of, II2, I72, I73

Romagné, 248

Rome, correspondence with, $225,268,269$; intervention in, 254; intrigues at, 267 ; Irish faction in, 268; memoirs sent to, 254; Philadelphia affairs at, 268

Rommey, sent to sea, 290

Roquemairie, letters of, I35

Rosati, Bishop (Joseph), correspondence, 232, $234,245,248,26$ I

Ross, letter of, 298

Rottenburg, Major-General de, 24, 25

Rottot, killing of, $22 \mathrm{I}$

Roupe, $A b b e ́$ J. B., letters to, 238

Rouse's Point, bridge across Lake Champlain at, 55,57

Rousseau, ordination of, 240

Roussel, Jacques, fils, 2I 3

Rousselet, L. de, letter of, 252

Routh, R., commissary-general, letters of, 16 , 292

Rouville, raid of, 194

Roux, $A b b e ́$ J. H. A., letters to, 230, 238

Rowley, Captain, letter of, 299

Roxbury, Mass., Ursuline convent, 250

Roy, J. Edmond, 205; Rapport sur les Archives de France relatives à l'Histoire du Canada, $33 \mathrm{n}$.

Royal Fencible Americans, 288, 289

Royal George, vessel, I7

Royal Highland Emigrants, I25, 287, 288

Royal Institution, transcripts from, 193

Royalists, see Loyalists 
Royal Regiment of New York, II2; musterrolls, 125

Royal Society of Canada, Transactions, 205

Rulaud, Father, letter of, 247

Rum, see under Trade

Russel, D., 287

Russell, James, 287

Russell, Lord John, 164, 166; correspondence, 43-45, 49-5I, 59, 62, 66, 67, 79, I02, I32, I72, 196, 197 ; despatches, 51,62 , 165

Russell, Capt. Peter, correspondence of, Io9; journal of, 275

Russia, policy on northwest coast, I6 $\mathrm{r}$

Russian agencies in the U. S., I72

Russian establishment at the north, 263

Russian plots, 75

Rutherford, captivity among the Indians, I05

Ryan, John, petition of, 297

Ryan, P., memorial for register from, 292

Ryland, H. W., letters of, 99, 100, I76, I77

\section{Sable Island, II5}

Sabrevois, 212

Sackett's Harbor, attack on, 26, 131 ; ship-building at, 26; United States forces at, 23

Sackville, Viscount (George Sackville Germain), 290; letters of, 82, I24, 202

Sacs, movements of the, I79

Safare, Etienne, grant to, 209

Sainsbury, W. N., catalogue of American documents, I93

St. Albans, Vt., raid on, $67,73,77,94,183$

St. Anara River, 217

St. André, Sister, letter of, 256

St. Ange, journey of, 210

Ste. Anne de Fredericton, church register, 137

St. Antoine, registers of baptism, etc., in, I04

St. Armand, letters from officers at, $3 \mathrm{I}$

St. Aubin, père, 208

St. Aubin, Pierre, fils, 208

St. Bernard's Seminary, Rochester, N. Y., 224

St. Castin, Sieur de, 207

St. Clair, Gen. Arthur, I59; campaign against, I08; communication from, 107; council with the Indians, I89; defeat of, I07; movements of, 158

St. Clair County, Ill., 245; emigration of Indians to, IoI

St. Croix, boundary, 186

Ste. Famille, mission, 244

St. Francis de Sales, 245

St. Gabriel de la Louisiane, parish, register, I37

St. George, Lieut.-Col. Thomas B., letters of, 24

St. George, Sister, correspondence, 232, 233, 252

St. John, N. B., chamber of commerce, 140, 166; fire and famine in, 298; lots in, 204; Loyalists' lands in, IIo; provisions in, 297

St. John, island of, see Prince Edward Island

St. John River, 216; land on, I53, 216; military forces ordered to, 43 ; posts on the, 166 ; rafting logs, 146; settlements on the, 202, 203; sketch of the, 80; United States troops at the, 82
St. John's, Newfoundland, 286, 287, 288, 289; collector of customs at, 99 ; merchants of, 292, 294, 300

St. Joseph, notes on, 3I

St. Joseph River, land grants on, 216

St. Lawrence, Gulf of, fishing in, 74, I42; trade, $29 \mathrm{I}$

St. Lazurence, vessel, 49, 50

St. Lawrence River, boundary, 52, 93; islands in, $40,4 \mathrm{I}$; naval force on, 69 , 134 ; navigation of, $15,40,46,57,58,68,72,93,94$, rOI ; road to New Brunswick, 40; survey of, 40; trade of the, 79; United States schooners on, 55

St. Leger, Licut.-Col. Barry, army of, 267

St. Louis, Bishop of, letter to, 235

St. Louis, Mo., 257 ; faculties for, 248 ; registers of baptisms, etc., I04

St. Malo, archives of, 106

Ste. Marie, commandant, letter of, 244 ; registers of baptisms, etc., I04

St. Mary's, Newfoundland, 289; United States adventurers at, 47

St. Mary's Bay, 245

St. Mary's College, archives of, Iro

St. Petersburg, British chargé d'affaires at, 90

St. Pierre, Lake, 218; trade, 286

St. Regis, conduct of American residents at, 23; Indians of, 230, 267; parish of, register, 105

St. Sacrement, Lake, events at, I I I

St. Thomas, Sister, letter of, 257

St. Vallier, Bishop (Jean B. de Lacroix Chevrières de ), 236; letters of, 269,270

St. Vincent, Sieur de, land grant of, 208, 216

Salaberry, Lieut.-Col. Charles de, ix

Salières, Carignan, 218

Salmon, see Fisheries; Trade

Salmon Bay, United States consul at, 72

Salt, see under Trade

Salt Springs, Venango, Amherst urges an attempt to surprise enemy at, II

Sampson, Lieut. Henry, letter of, I3

Samuel and Sarah, transport, 28

Sandom, Captain, letters of, 22, I64; report on Welland Canal, 5I

Sandwich, Ont., attack near, I64; execution of prisoners near, 49

Sandwich Bay, fisheries in, 300

Sandwich Islands, 250, 26I ; Catholicism in the, $26 \mathrm{I}$; inhabitants of, 222 ; parish, $24 \mathrm{I}$; persecution in, 263

Sandy Creek, British repulse at, 26

San Francisco, Cal., diocese, 255 ; steam communication with Hongkong, 90

San Juan Island, I36; Americans in, 90, 9I ; British troops on, 89; dispute over, 9I; jurisdiction in, 88; land in, 65 ; occupation of, 88,89 ; water boundary, 279

Saratoga, N. Y., convention, I24; exchange of prisoners, 125

Sarnia, Ont., situation at, 32

Saskatchewan, 277, 278; archives of, 151 ; condition of, 64

Sault Ste. Marie, 7I, 2 I7 
Saumarez, Thomas, letters of, I40, 297

Saunders, Vice-Adm. Sir Charles, despatches, II7

Saunders. W., letter of, 290

Savannah, Ga., British vessels at, 84

Sawyer, Vice-Adm. Sir Herbert, despatches, I34

Scamon, Marie, naturalization for, 209

Schiefflin, letters of, I08

Scholarships for students in research work, 9

Scholefield, E. O. S., archivist, 279

Schools, Catholic and Protestant, 259

Schooners, see Ships

Scorpion, schooner, 27, I 2

Scotland, emigrants from, 39

Scott, Brig.-Gen. Winfield, alleged connection with the patriots, I72; attitude of, I6I; correspondence, I3I, I72; energy of, I64; name used by insurgents, 79 ; relations with

Scouts, is the patriots, 70 ; letters of, 2 I

Sea-cows, 287

Seamen, British, in United States ships, 95, I44

Seaton, Baron (John Colborne), letters of, II 3

Secret agent, 63

Secretary of State, American, correspondence, 74,75, I 30, I3I, I32, I 85

Secretary of State, British (Colonies), II5, 280 ; despatches, I95, I97, 20I, 280, 283

Secretary of State, Canadian, 5, 6, I88; papers of, 175 -180

Secret committees to aid Canadian insurgents, 42

Seed potatoes, used for food, 296

Seguin, F. H., notes taken to Terrebonne, III

Seguin, Jacques, grant to, 209

Seigneuries, Cadastres abrégés des, 206

Seigniorial Régime, Munro, 215

Seigniorial Tenure, Titles and Documents relating to the, 206, 216

Seine-et-Oise, archives of, I92

Selby, Prideaux, I06; letters of, I8, 108, I79; papers of, Io9

Selkirk, Lady, letter to, 237

Selkirk papers, I 87

Semple, Robert, 283

Seneca Indians, I20, 136; instructions to watch, I4; treaty with, IOI

Sessional Papers, see British Columbia

Seven Years' War, III, I35, I93, I98; Bouquet collection relating to, Io; material on, I2, I3; Montcalm's share in, IIO, III ; records, 285; see also French and Indian War

Sewall, S., letter of, 223

Seward, Gov. William Henry, despatch from, 63 ; letters of, 82 ; notes from, 73, 84; reply relative to John G. Shaver, 64

Seymour, Gov. Frederick, of British Columbia letters, 9 I

Seymour, Vice-Adm. Sir Michael, letters of, 83; memorandum on convention of I8I8, 58; suggestions respecting fisheries, 58

Shank, Maj. David, letter of, I9

Shanley, Abbé, 232

Shannon, ship, I34

Shark, H. M. S., 292
Sharpe, Gov. Horatio, correspondence, II7; part taken by, Io; requested to meet Amherst at Pliiladelphia, Io

Shaver, John G., arrest of, 94 ; case of, 65, 72, 75 ; claim of, 64

Shawnee Indians, I79; deputation from, I77; expedition of Bouquet against, I20; reply from, 107; speeches, I26, I89

Shea, criticism of, 255

Sheaffe, Maj.-Gen. R., armistice with Van Rensselaer, 25 ; letters of, 16, I7, 24, 25, 27

Sheffield, memorials from corporation of, 65

Shelburne, Earl of (William Petty, first marquis of Lansdowne), correspondence, I2I, I8I, I82 ; instructions relating to settlement upon the Ohio, I7; observations on Indian administration, $\mathrm{I} 8 \mathrm{I}$; papers, $\mathrm{x}, \mathrm{I} 80$

Shenandoah, vessel, 67,89 , I83

Sheppard, W., 287

Sherbrooke, Sir John, correspondence of, 17 , $24,25,27,28,30$; trade instructions, 145

Sherbrooke County, boundary survey, 74 ; land in, 96 ; meeting at, 160

Sheridan, Abbé, 235

Sheubenacadie Canal, N. S., papers relating to, I I 4

Shiffner, report of, 299

Ship building, 94, 96 ; decay of, I 59

Shipping, report on, 62

Ships, American, 28I, 286, 294; admission to New Brunswick ports, I4I; British seamen in, I42; capture of, 286, 292; dollars found on, 296; duties on, 97, 98, 140, 301 ; fishing, 298, 299; ill-treatment of, I42 ; in Labrador, 298; list boarded and warned, 299 ; regulations, I00, I96; release of, 299

Ships, armed, I39; built at Montreal, 73; captured, I34; duties on, 83: in Canadian waters, 95; licenses, I34; list of arrivals, 223; movements, I34; obtaining supplies, 86 ; registration of foreign-built, $65,72,75$; returns, I23; war, 66

Shirley, Gov. William, I98; expedition, II5; letters of, II6, I23, I94, I99

Short Hills, raid at, I77

Shortt, Prof. Adam, I 83

Shortt, W. T. P., Journal of the siege of Quebec, 146

Shuldham, Lord (Adm. Molineux Shuldham), orders and instructions, 287

Sidyme, Bishop of, see Turgeon

Sierra Leone, removal of negroes to, 203

Signay, Archbishop Joseph, 252, 255, 259; charges to, 227; correspondence, 23I, 238, $250,252,255,256,259,260,26 \mathrm{I}-264,266$

Silver, value of, 299

Silvy, 225

Simcoe, Lieut.-Gov. J. Graves, I53; letters of, I8, I08, I09, I47, I79, I9I; papers, 218; speeches of, 108

Simple, Father, 269

Simpson, Sir George, correspondence, 7I, I37, $229,230,240,259,262,265$; report, 282

Sioux Indians, outrages in Minnesota, 76 ; refugees in Canada, 76 
Sir Archibald Campbell, vessel, 43, 83

Sir Robert Peel, vessel, 21, 42, 48, 51, 52, 53, 75, I68, I72

Sisterhoods, 246

Sisters of Charity, 246

Sitka, Alaska, 282

Six Nations, I57, I89; Bay of Quinte, grant to the, I08; land cession by, I9I; letter-book relating to, I9I ; migration to Canada, I9I ; reply of, I79; speeches to, I26; treaties with, I8, I90; see also Five Nations and Iroquois

Skeena River, 28I

Skeensborough, camp at, 106

Skin Book, of the Beaver and Llama, 282

Slavery, I 54

Slaves, claims for, 43 ; fugitive, $45,47,49$, I69; in Louisiana, I5I ; marriages of, 243 ; seized by English, 43; trade, suppression of, 65 , 75

Sleighs, at St. Johns, 99

Sloane Manuscripts, I94

Smith, Lieut.-Gov. Charles Douglas, correspondence, 85 ; despatch from, I42

Smith, Robert, Address to the People of the United States, I45

Smith, Roswell, note from, 220

Smith, Capt. Thomas, letters of, Io\&, Igo

Smith, William, letter of, 262

Smith, W. P., case of, 49 , I70

Smuggling, 99, I00, I38, I42, I 57, I 59, I65, 166, I72, 2II, 3OI

Smyth, Brig.-Gen. Alexander, letters of, 28; proclamation, I35

Smyth, Maj.-Gen. George Stracey, letters of, I39, I40

Snake River, expeditions, I5I

Snyder, Adelaide, 245

Snyder, A. W., 245

Society of Jesus, see Jesuits

Soldiers, see Troops

Somers, Charles, license to, 293

Somers, transport, 28

Somerset, Lord Fitzroy, letter of, I62

Sorel, Que., correspondence of officers, I26; lands at, 20

South Carolina, dispute with Georgia, I23; law regarding negroes, $59-60$; list of persons naturalized, I47; Loyalists from, 202; trouble with Cherokees, II9

Southern Confederacy, missions from, 63

Southern States, laws relating to negroes, 62

South Side Fort, 290

Spain, cession of East Florida to, 82 ; disposition of Kentucky to join, I57; rupture with, I22; settlements, I43; situation in, I89; trade with, I34

Spaniards, I59; in America, I22 ; influence on trade, I2I; information relative to, $I_{5}$; rebels, 24I; relations with, I2I

Spirits, see under Trade

Sproule, George, plan by, I28

Spurrier and Co., licenses to arm ships for, 296 Squatters from United States, 64

Stamp Act, I20, I2I ; effects of, I20, I24, I47
Stanley, Lord, see Derby, Earl of

Stanstead, 96

Stanwix, Col. John, correspondence, II7 ; despatches, II9

State Books, 31, 32

State matters, I23

State of the Expedition, I Io

Stayner, T. A., correspondence, I49

Steele, Captain, letter of, I90

Stephen, Adam, memorial, I I9

Stephen, James, letter of, I49

Stephen Girard, vessel, 50, I7I

Stevenson, Andrew, note of, 48

Stiele, Capiain, communications from, Iog

Stirling peerage, I33

Stockton, memorials from corporation of, 65

Stoney Creek, fight at, 25

Stout, Thomas, 286

Strachey, Sir Henry, correspondence, ix, I8I

Strangways, W. Fox, letter of, I69

Stroud, Gilles, naturalization for, 209

Stuart, Archibald, letter of, 289 ; memoir of, I3o

Stuart, John, journal, I 52, 28I ; letters to, 28I

Subercase, $M$. de, letters of, 194

Sugar, see under Trade

Sullivan, James, report of, I68; statement of, I86

Sunderland, H. M. S., I46

Superb, H. M. S., I46

Superior, Lake, I29; boundary west of, 72 ; copper mines, 2I3; fisheries, 60, 72; railroad to Puget Sound, 60

Supreme Court, decision, 252

Surprise, H. M. S., 290

Surratt, John H., passport, 78

Susquehanna River, Connecticut claims to lands on, II9

Sutherland, D., correspondence, I49

Sutherland, Thomas J., case of, 48 , I69; trial of, 167

Swan Creek, council at, I9I

Swanston, letters of, 88

Swanton, Vt., insurgents from, $4 \mathrm{I}$

Sybil, H. M. S., 290

Sydenham, Lord (Charles Poulett Thomson), address to, 37; correspondence, 43-45, 9I, I32, I64, I65, I66; despatches from, 91 ; trip to New Brunswick, 44

Sydney, Lord (Thomas Townshend), despatches from, I74; letters of, ix, 82

Sydney, C. B. I., I38

Symmes, John Cleves, address of, Io)

Tabeau, M., 237

Tagus, ship, 296

Talbot, Thomas, letter of, 18

Tallmadge, James, I I3

Tamarois Indians, 236,243 ; evangelization of, 227 ; faculties for, 236 ; missions among the, 236,270

Tapin, 248

Tar, see under $\mathrm{T}$ rade

Tariff, 55, r47, 298; address of Home League, II 3 ; see also Customs

Tariff act, despatches upon, 75 
Taschereau, Cardinal Archbishop (Elzéar A.), Tod, John, journal, I52 letter to, 256

Taylor, of Niagara, letters of, 107

Taylor, Maj. George, letters of, 25

Taylor, S., diary, I5I

Taylor, Abbé W., 249, 250, 255; administrator, $25 \mathrm{I}$; correspondence, 232, 25I, 254; opposed, $25 \mathrm{I}$

Taylor, Gen. Zachary, force of, 56

Tchactas, 2 I 8

Tea, destruction of, 124 ; duty on, 172 ; importation of, 70, 79; smuggling of, 92, I4I ; trade, 165, I73

Te Deum, letter concerning, 226

Telegraph, steamboat, 22

Telegraph lines, across British Columbia, 9o; construction of, 89 , 9I ; from California to British Columbia, 67

Temperance, 258

Tennessee, plans for attacking Canada, 93

Terrain de la Pointe, plan of, 2 I8

Terreneuve, see Newfoundland

Tessier, J., correspondence, 23I, 246

Têtu, Mgr. H., Histoire du Palais Episcopal de Québec, 225 n.; Journal d'un Voyage en Europe par Mgr. Plessis, 245; Mandements, Lettres Pastorales, etc., edited by, 225; Visites Pastorales par Mgr. Plessis, $249,25 \mathrm{I}$

Texas, religion in, 257

Thames River, skirmishes on, 26

Thayer, Rev. John, information regarding, 270

Théberge, Father A., 229

Theller, Edward Alexander, case and trial of, I67

Thibaudeau, Pierre, land grant of, 216

Thisbé de Belcour, correspondence, I 35

Thomas, Thomas, 220

Thompson, David, letters of, 7I, 93, I36, I53; maps of, 52 ; papers, 273

Thompson's River Post, journal of, 282

Thomson, Charles Poulett, see Sydenham, Lord

Thomson, James, journals of, 150, 222; letters of, IO 7

Thornton, Sir Edward, signs protocol on treaty of Washington, 85

Thousand Islands, mill of the manor of, 2I I

Three Rivers, Que., 205, 206, 229; correspondence of officers, I26; court of, 220 ; government of, 222; papers relating to, II4; Prévôté of, registers of the, 217 ; records at, 2, I05; vicars-general of, correspondence, 225

Through the Ranks for a Commission FiftyThree Years ago, II4

Tiarks, Dr. J. L., letters of, I86; map by, I28

Tichenor, Gov. Isaac, request of, 95

Ticonderoga, defeat of Abercrombie at, II7; forces at, 156; movements against, I I8

Tigress, schooner, 27 , II 2

Timber, see under Trade

Tippecanoe, battle at, 19

Tipton, Capt. Jacob, infantry of, 108

Tithes, 243

Tobacco, see under Trade

Tolmie, John, 283

Tolmie, Dr. William Fraser, correspondence, I 52,283 ; diary of, 283 ; journals, I 52

Tombigbee River, 120

Tonicas, 218

Tonty, Alphonse de, 212, 22 I

Tonty, Henri de, 207, 219

Toronto, attack on, I66; board of trade, 60 ; observatory, 52; Public Library, 274; see also York

\section{Townsend, Micah, 150}

Townsend, William, case of, I4I

Townshend, Gen. George, correspondence, I35; papers, I 49

Townshend, Thomas, see Sydney, Lord

Townside, brig, 290

Tracy, Prouville de, commission of, 207

Trade, acts of, I45, 293; American, III, I40, 292 ; anthracite coal, 66, 76, I02; ashes, 71 ; beavers, 208, 2II, 2I2, 2I 3 ; cereals, 285; coasting, 64,66 ; colonial, 46, I39; competition, 266 ; contraband, I39, I 40 ; convention, II3; cotton, 46; diplomatic correspondence on, 54 ; documents on, 88 , 9I, 94, I I9, I20, I37, I44, I47, I54, I60, I85, I89, I93, 195, I98, I99, 201, 202, 203; duties on, 98; fish, 87, I 42, I45, 293; fish-oil, 85,87 , I42 ; foreign, 166, 208; free, 86, 200; grindstones, I38; hay, 6I ; hops, 6I ; illicit, II9, 286, 294; improvement of, 60 ; Indian, II9 ; instructions on, I45; internal, I47; leather, 40, 54; molasses, 293, 294; on lakes, 94; pitch, 294; plaster of Paris, 23, II3, I38, I39, I40; pork, 294; potash, 99 ; regulations, 40, 52, IOI, I42, 200 ; resin, 66 ; restrictions, 84, 103; routes, 2I, I93; rum, 82; salmon, 287; salt, 209; salted provisions, 95, I40, 294; spirits, $46,240,24 \mathrm{I}, 243,263,265$; sugar, I4I ; tar, $285,293,294$; timber, 54 , I4I, I46; tobacco, $46,159,174,218,294$; turpentine, 66, 285, 293, 294; wampum, 95; western, 96, 122; wheat, $44,52,53,54,70,71,93$, IOI, I65; whisky, 212; wines, 166; see also Agricultural products; Corn; Flour; Live Stock; Reciprocity; Tea; names of countries, colonies, and places

Trade and Plantations, Board of, despatches and reports of, II9, I33, I48, 179, I91, 195, 275 ; Board of (modern), 61, 62; Committee of Privy Council for, 47; Lords Commissioners for, 136

Traders, comments on, 95 ; robbing of, $\mathrm{I} 4$

Trading expeditions, see names of persons and places

Trading posts, visit to, 265

Trahan, 246

Trappists, 257,258

Traveller, steamboat, I7I

Travers, John, II 3

Treasury, Lords of the, report of, 49

Treasury documents, I30

Treaties, announcement of, I88; between United States and Indians, 20 
Treaty of 1783,185 ; papers concerning, ix, 45 , I 58, I 85, I 86

Treaty of 1794 , I86; remarks on, I6

Treaty of I8I4, II0, I86, I9I

Treaty of 1817 , abrogation of the, 67

Treaty of 1818,300 ; breach of, 83

Treaty of 1842,52, I I 4

Treaty of 1854 , abrogation of the, 67 ; expenses of the, IIO

Tremblay, Monsieur, letter to, 270

Tremlett, C. J., letter of, 293

Trent affair, 64

Trepassey, merchants of, 290

Trial, together with Dr. Gallagher's Answer to Wharton, formerly a Catholic Priest but now an Episcopalian Minister, 255

Trinidad Island, governor of, correspondence, 102 ; negroes in, 50, I02, I73, I96, 197

Trinity, Newfoundland, 288

Trinity Bay, 300

Troops, I45; American, 259; British, I22, I23, I24, I26; disbanded, 202 ; movements, I2I ; New England, I99; provincial, I26; quartering of, I2I, I23, I24

Troy, J. T., letter of, 268

Truth, communication on postage rates, 149

Tuckalatchee, speech delivered at, Igo

Tucker, C. J., letter of, 30 I

Tucker, R. A., letters of, 50

Turgeon, Archbishop (Pierre F.), correspondence, 250, 25I, 253, 255, 256, 257, 258, 259, 260, 261, 263-266; Sketch of the History of the Church in the United States, 253

Turnbull, Capt. George, letter to, 242

Turner, Joseph, 220

Turnpike to Montreal, 99

Turpentine, see under Trade

Tuscarora Indians, I36

Tyler, United States deputy marshal, 72

Ulloa, Don, I3

Undill, W., letter of, 246

Uniacke, Richard John, letters of, I42

United Empire Loyalists, see Loyalists

United Kingdom, mails, 55

United States, agreement with Puget Sound Agric. Co., 282; attitude regarding Rebellion of $1837-1838,42$; barges, 16 ; boundary, $4 \mathrm{I}, 72$, I27, I3I, I32 ; cessation of hostilities, 73; circular to British captains, $2 \mathrm{I}$; citizens, 3I, 42, 45 ; claims, 2I, 40, 46, 49; commanders, 2I, 30; Congress, 245; conspiracy against, 68, I69; constitution, I I4, I55; consular agents, 64 ; convention with, I64; correspondence with military posts, 45; dioceses of, 225 ; disputes with, I03; embargoes, I42, I43; encroachments, I39; events in, I99; fisheries, 85, I38, 300, 301; French plots, Io3; fugitive slaves from, 45; government, correspondence, 83 ; harbor defense, 76 ; history, I 56,224 ; hostile movements, 49 ; House of Representatives, committee of, 86 ; immigration and emigration, $45,46,47,85,96,142,164,201,203$; Indians, 20,40 ; infantry, British prisoners as host- ages for, 15 ; invasion of, $66,84,168$; jurisdiction upon the Great Lakes, 69; land, right to hold, 45 ; material relating to, I5; military preparations, I57; miners in, 88; minister at London, 59; missions, 63; navy, $28,42,71,73,76,84$; passage of subjects from Great Britain, 82 ; political situation in the, I43; prisoners, see Prisoners of war; prospects of war with, I77; pursuit of enemies on foreign territory, 47; Quebec and St. Andrews railroad, protest against, $4 \mathrm{I}$; refusal to lend arms to the, 63 ; relations with Canada in regard to the westward country, 20; relations with Great Britain, 95, 99; relations with, documents relative to, 22 ; religion in, 254 ; reprisals, 39 ; restoration of posts to, 29,30 ; restoration of territory, etc., I74; river defense, 76; Secretary of State, correspondence, 74, 75, I30, I3I, I32, I85; sentiments toward Canada, I6I; ships and shipping, I5, 20, 30, $39,40,4 \mathrm{I}, 45,54,55,57,63,74,76,20 \mathrm{I}$; sympathizers, 55, I60; tariff, 55; trade, 39, 40, $4 \mathrm{I}, 46,47,53,55,56,82,83,84,86,93,100$, I 3 , I36, I38, I42, I44, I52, I65, I72, I73, I78, 195, I96, I97, I99, 20I, 292, 298; treaty with Six Nations, I90; troops, complaints against, 2 I

United States, steamer, 50, I7I, I73

United States Military Academy at West Point, I53

Univers, $L$ ', 236, 253

Urbain, Father, correspondence, 257

Ursulines, 230, 232-234, 242, 243, 246, 247, 249, $250,25 \mathrm{I}, 252,256,257$; convent, 245 ; correspondence, 228, 229, 252; in New Orleans, 244

Utah, I5I

Vail, Aaron, mission to Canada, 42, 48, 162, 167, 168

Vallerand, L. P., 2I8

Vancouver, Capt. George, despatclies, I33; expedition of, I33; letters of, $28 \mathrm{r}$

Vancouver, B. C., 279; missionaries, 230 ; trading expeditions, $15 \mathrm{I}$

Vancouver Island, 283; archives, 280 ; exploration, 283 ; extension of reciprocity treaty to, 88; governor, despatches, letters, etc., 36, 280; House of Assembly, journals, papers, etc., I36, I52, 280; Lighthouse Board, correspondence, 280 ; records of, 279; register of baptisms, 263; Treasurer, letter-book of, 280

Vandalia, I47

Van Diemen's land, pardon of prisoners in, 53

Van Rensselaer, Maj.-Gen. Stephen, armistice with Sheaffe, 25; letters of, 27

Vanslyke, Albert, instructions to, I89

Van Staphorst, house of, I59

Varlet, $A b b e ́$ D. M., letters to, 236

Varlo, Capt. Charles, letter of, I3

Vaudreuil-Cavagnal, Marquis de (Pierre François de Rigaud), letters of, II7, I35; provisions for, 210 
Vaughan, Sir Charles R., despatches from, I29, Wales, Prince of (Albert Edward), II4 I30; letters of, 46 , I30

Vaultier, 225

Vavasour, Lieut. M., expedition, 7I, 282 ; mission to the Columbia River, I37

"Verax", letters from, I29

Verchères, situation at, I05

Vergennes, Comte de, letters of, I8o, I8I, I82

Verhaegen, Father, S. J., letter of, 248

Vermont, I03; boundary, I76; correspondence relating to, 150; council, minutes of, 150 ; emigration to, 293; frontier, I6I ; governor, correspondence with, 163 ; legislative committee, articles of union, I50; legislature, acts of, I50; negotiations with, I2; overflows in, 74 ; projects in, 103; protection of shad and whitefish, 78 ; Radford's relations with, I7; raids, I6, I63; relations with, documents concerning, 23,27 ; roads from Montreal to, $3 \mathrm{I}$; violation of territory, 92

Verreau, Abbé Hospice, investigation of Canadian history, 33

Vessels, see Ships

Vetch, Gov. Samuel, I45; journal of, I94; letters of, I94

Vezina, 246

Vialars, Antoine, letters of, 222

Viana, Juan de, correspondence, 28I

Victoria, B. C., Cathedral records, 283 ; Office of Registrar of Deeds, 283

Viger, Capt. Jacques, orderly book of, I to

Viger papers, I 49

Vigilant, H. M. S., I46

Vilarrasa, Brother F. Sadoc, O. P., letter of, 256

Villeclaire, fief of, 216

Vincennes, Bishop of, letter to, 234

Vincennes, Post, 244, 245; Catholics of, 24I ; Clark's movements about, I57; Gibault's visit, 243; register of, 104

Vincent, Col. John, letters of, I7, 25, 26

Vinyes, Brother V., O. P., letter of, 256

Virginia, attitude of legislature toward colonial struggle, Io; boundary, I45; emigrants from, I2I ; encroachments, I2I ; list of persons naturalized, I47 ; outrages by Creeks, I3; settlers upon the Ohio from, I7; trade, 59, 197

Visitation, Sister Ste. Marie de, letter of, 256

Visites Pastorales par Mgr. Plessis, 249, $25 \mathrm{I}$

Volume détaché des Édits, Declarations et Arrêts, etc., 210

Volunteers, Nova Scotia, 288; organization of, 295

Vulture, ship, 296

Wabash River. I59, I77; settlement on, I4

Wackitumekie, speech delivered at, I 89

Waldegrave, Rear-Adm. William, letters of, 292, 293

Walden, Howard de, see Howard de Walden, Lord

Waldo, Brig. Samuel, plan for taking Louisburg, II5

Waldron, J., letter of, 292

Walker, Col. Benjamin, character of, I58; journey to London, I6o

Walker, Capt. Charles, 296

Walker, Adm. Sir Hovenden, expedition of, I94

Wallamette, 258, 259; population, 260 ; religion in, 258, 259, 260, 261 ; schools, 263, 266

Walla-Walla, Bishop of, circular from, 227

Walla-Walla, 260; collection for, 264 ; faculties of vicar-general for, 264 ; oblates for, 264

Waller, C., 264 ; deposition of, 299

Walpole, Thomas, letters of, I82; memorial, I47

Walsh, Robert A., letters of, 263

Walshe, Rev. Mr., charges of, 72 ; letter of, 72

Wampum, see under Trade

War, American declaration of, 295

Ware, Orlando, case of, 55

War of ISI2, 6, I5, I I2, I42, I56, I79, I89, I93, $201,202,203,274$; claims, I6 ; correspondence, I7; despatches relating to, I74; documents on, $21,23,28,176,184,273$; losses, I6, I 36 ; records of the, 23 ; side-lights, I 36

War Office, correspondence of, I7, 21 ; negotiations relative to military papers, I5; papers, I03, 125

Warre, Licut. Henry I., expedition, 7I, I37, 282

Warren, Sir J. B., correspondence, 28, I44, I95, 199; despatches, 134; petition of, 293; squadron, I34; steps taken by, I43

Warships, United States, 67

Washington, George, account of Braddock's defeat, II6; capture of, 267 ; letter of, I58; memorial, II9; speech of, ios

Washington, D. C., diplomatic negotiations at, I73; general situation at, 28

Washington (state), 279

Washington Territory, duties charged in, 91; Indian war in, 283 ; money lent to, 89,90 ; Supreme Court, judgment of, 282 ; see also Columbia River Region

Washington, Treaty of (I842), boundary under, 52, I32; tenth article of, 52, 93

Washington, Treaty of (I87I), 87; act to make effective, 85 ; correspondence and protocol on, 85

Washington, vessel, 197, I98

Washington, Idaho, and Montana, by $\mathrm{H} . \mathrm{H}$. Bancroft, 280

Watson, John, passport for, 78

Wayne, Capt. William, campaign of, I90; expedition of, I8, I09; letter of, I9; speeches, I8, I90

Webb, Maj.-Gen. Daniel, capture of Fort William Henry, I23; despatch from, II6; letters of, II 5 , II 7

Webster, Daniel, information from, 75 ; letter of, 83 ; on extradition, II 4 ; on surrender of criminals, 52

Welbank, G., letters of, I08, I89

Welch, beavers found in possession of, 2 I I

Well, Father, letter to, 252

Welland Canal, 50, 7I; block-houses on, 79; navigation of, $46,68,79,8 \mathrm{I}$; records on, I6I, I80; reports on, 43, 5I ; see also Rideau 
Welland Canal Co., letter from, II3

Wentworth, Sir John, despatches, I42; letters of, I38, I42, I43, I94, I95

Wesley, John, A Calm Address to our American Colonies, 137

West, Charles, letters of, 163

West, the, operations in, 27,29

Westchester, Loyalists from, 202

Western Islands, see Azores

Western posts, 12

West Indies, company, establishment of, 207; confiscation of merchandise, 212 ; events in, I99; expedition to, 20I ; French molasses from, 294; fur-trade, 210; governors, 46, 65 ; letters relative to, 28 ; order favoring, 213 ; ports closed, I96; rights of, 207 ; salted fish in, 294; trade, 82, I 34, I42, I96, 208, 294

Whale fisheries, see Fisheries

Wharton, S., letters of, I47, I8I

Wheat, see under Trade

Whisky, see under Trade

White, Dr. Elijah, 262, 263 ; intrigues of, 259

White Cliffs, I 47

Whitehead, George, letters of, 50

Whitman, Dr. Marcus, intrigues against Catholics, 264

Whitmore, Brig.-Gen. Edward, despatches, II7, I20

Widdrington, Major-General, letter of, 20

Wiggin, United States commissioner, 6I Wilberforce, settlement of colored persons at,
47

Wilcocks, Robert, 22 I

Wild Cat, privateer, 290

Wildes, Dixey, journal, 282

Wilis, Marie, naturalization of, 208

Wilkin, Capt. Robert, company of Loyalists, 135

Wilkinson, Gen. James, account of army, 3I; movements of United States forces under, 26 ; note from. I9; operations of, 223 ; proclamation to Canadians, 26

Willcocks, Lewis, letters of, 247, 254; suit against, 254

William Henry, Prince (aft. William IV.), plot to capture, I Io

William Henry (Sorel), Loyalists at, 20

Williams, Gen. J., despatches, 94 ; letters of, I7, 26, 87, I09

Williams, Rev. Stephen, journal, I46

Wilmot, John, report of, I 54

Wilson, prisoner, rescue of, 50

Wilson, John, correspondence, 96
Wilson, Lieut.-Col. Joseph, Indian council held by, Igo

Wilson, William, letters of, 108

Winchester, defeat of, 29, I84

Windham, Lieut.-Gen. Sir Charles A., letter of, I5

Windham, William, correspondence, 294

Windsor, Ont., capture and execution of prisoners at, 22, $17 \mathrm{I}$; raids at, $21,22,49,169$, I70, I72

Wine, see under Trade

Winnebago Indians, deputation from, I77

Winooski River, 2 I6

Winslow, Col. John, journal of, 202

Wisconsin, legislative building, burning of, I60; memorial from, 60

Wolfe, Maj.-Gen. James, despatches, II7; letters of, I23; orders, I37

Wood, Sir Charles, letter of, I64

Wood, Archbishop (James Frederick), letter of, 252

Wood, Samuel, deposition of, 70

Wood, Col. William, Logs of the Conquest of Canada, 146

Woodward, Judge A. B., letters of, 24, 25, 27

Wool, Maj.-Gen. John Ellis, attitude of, I6I

Work, John, 282 ; journals of, I5 I ; letters of, I52

IV. P. Johnson, ship, 297

Wyandot Indians, speeches to, 126

Wyllis, Major, I59

Yates, James, 283

Year Book, I5I

Yellow fever, 248

Yeo, Sir James, letters of, 28, I34; despatches, I34, I35

York, capitulation of, 25 ; disaster at, 45 ; Indian speeches at, 20; landing of troops, 25; losses at, I6; see also Toronto

York, Fort, council-book of, I5o

York County, N. B., ancient epitaphs, I47

York Harbor, 287

Young, Maj. Plomer, letter of, 2I ; report on defeat of invaders, I6I

Young, W., letters of, 200

Yukon, Alaska, boundary, 279; exploration in, I5I

Yukon River, 283

Zocchi, Father N., 237 ; letter to, 23I

Zwierlein, Prof. Frederick J., 224, 226 



: 


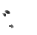




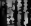

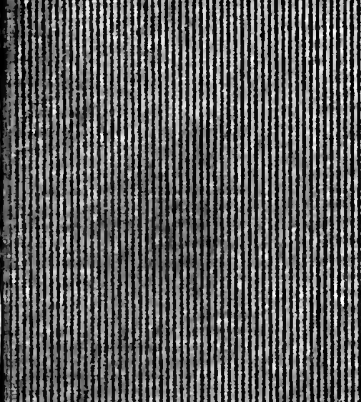

|. | | | | | | | | | | | | |

I.

m. m. m. m.

(I)

m...

m.

-

Im)

X)

X)

Y)

'P.

|. |

(2)

 Im m. 

m. . 